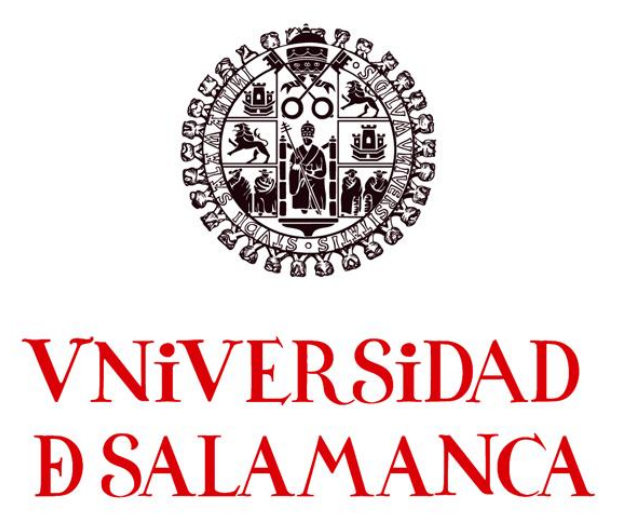

TESIS DOCTORAL

SOBREENDEUDAMIENTO DEL CONSUMIDOR.

REMEDIOS PREVENTIVOS Y DE SANEAMIENTO. ÁMBITOS Y PROCEDIMIENTOS DE ACTUACIÓN

PRESENTADA POR:

MARÍA BELÉN JAPAZE

DIRECTOR:

EUGENIO LLAMAS POMBO

SALAMANCA-2015 



\section{SOBREENDEUdAMIENTO DEL CONSUMIDOR \\ REMEDIOS PREVENTIVOS Y DE SANEAMIENTO. ÁMBITOS Y PROCEDIMIENTOS DE ACTUACIÓN}

\section{Sumario:}

\section{INTRODUCCIÓN}

\section{Primera Parte}

I.- El fenómeno del sobreendeudamiento del consumidor

A.- Planteamiento de la problemática

B.- La denominación del fenómeno: distintas expresiones

C.- El contexto de mercado y la situación de sobreendeudamiento

D.- Sobreendeudamiento: conceptualización. Diferencia con la insolvencia

E.- Sobreendeudamiento activo y pasivo.

\section{II.- Causas del sobreendeudamiento del consumidor}

A.- Causas vinculadas a las crisis de los sistemas económicos

B.- Causas vinculadas a las características del mercado y del consumo moderno

C.- Causas vinculadas a situaciones personales del consumidor

III.- Efectos del sobreendeudamiento del consumidor

\section{Segunda Parte:}

IV.- La problemática del sobreendeudamiento del consumidor en el Derecho Comparado:
A.- En el ámbito de la Unión Europea.
B.- En el Derecho interno de los países europeos: tres modelos
1.- Francia
2.- Alemania
3.- Italia
C.- Tratamiento particular de la problemática en la legislación española
1.- Justificación del tratamiento diferenciado del caso español
2.- Descripción del fenómeno regulatorio en España
D.- En el Derecho norteamericano

\section{V.- La problemática del sobreendeudamiento del consumidor en Argentina.}

A.- Herramientas legales vigentes de contenido sustancial.

1.- Código Civil de Vélez Sarsfield: institutos previstos en la teoría general

de las obligaciones y en la teoría general del contrato

2. En el Código Civil y Comercial unificado vigente desde 2015

3. En la Ley $\mathrm{N}^{\circ} 24.240$ de Defensa del Consumidor 
B.- Herramientas legales vigentes de contenido instrumental o procedimental

\section{Tercera Parte}

\section{VI.- La propuesta de regulación del sobreendeudamiento del consumidor en Argentina}

A.- Regular o no regular. Necesidad de una regulación integral y sistematizada. Fundamentación

B.- Emplazamiento de la regulación. Dónde regular: ésa es la cuestión?

C.- Contenido de la regulación. Cómo regular: ¡ésa es la cuestión!

1.- Ámbito de aplicación:

a.- Elemento objetivo

b.- Elemento subjetivo

b.1.-La figura del consumidor. La categoría del subconsumidor

b.2.- El requisito de la buena fe del consumidor sobreendeudado.

2.- Principios que deben inspirar esta regulación particular

a.- Protección de la dignidad personal: un nuevo paradigma

b.- Tutela de la confianza

c.- Principio de préstamo responsable

3.- Medidas para la prevención del sobreendeudamiento

a.- Justificación

b.- Diseño de políticas activas. Implementación

b.1.- La educación en el consumo de crédito

b.2.- El control de las prácticas empresarias

b.2.1.- Control de situaciones abusivas

b.2.2.- Control de cláusulas abusivas en la contratación

c.- Consagración de derechos y deberes en la relación jurídica

c.1.- En la etapa precontractual

c.1.1- Actividad publicitaria transparente y leal. Contenido informativo básico

c.1.2.-Deber de información veraz, adecuada y suficiente

c.1.3.- Deber de asesoramiento del proveedor

c.1.4.- Deber de mantener la oferta: carácter vinculante

c.2.- En la etapa de celebración y ejecución del contrato de crédito

c.2.1.- Deber de información a cargo del proveedor

c.2.2.- Imposición de formalidades al contrato

c.2.3.- Imposición de un contenido mínimo al contrato

c.2.4.- Imposición de un desembolso inicial

c.2.5.- Derecho de desistimiento del deudor

c.2.6.- Derecho al pago y amortización anticipada

4.- Medidas de saneamiento del sobreendeudamiento

a.- Renegociación de la deuda

b.- Exoneración del pasivo pendiente de cumplimiento 
c.- Escenarios de actuación y vías para la instrumentación de las

c.1.- Procedimiento extrajudicial.

medidas de saneamiento

c.2.- Procedimiento judicial

c.3.-Los proyectos de ley presentados al Congreso en Argentina

\section{ConClusiones}

\section{Bibliografía}




\section{INTRODUCCIÓN}

La justificación del tema objeto de esta investigación resulta de toda evidencia.

La situación de sobreendeudamiento de los consumidores constituye una preocupación actual prioritaria para el operador jurídico. La constatación de esta realidad creciente y de gravedad extrema impone el diseño de políticas públicas y su implementación, a través de normas sustanciales y procedimentales eficaces.

Los efectos del endeudamiento excesivo se proyectan en la economía doméstica del deudor, comprometiendo principalmente el salario y la vivienda del particular afectado. Pero el sobreendeudamiento objeto de esta investigación excede la situación personal del consumidor, impactando en su grupo familiar, con costes adicionales -patrimoniales y no patrimoniales- que deben ser de urgente atención. El estado de sobreendeudamiento y la insolvencia consecuente colocan al deudor a su familia en un status de marginalidad y exclusión social, negándoles el acceso a los bienes y el goce de derechos esenciales.

Las causas del sobreendeudamientos son de índole variada y se impone el estudio de las mismas, distinguiendo sus categorías. Este análisis permite adecuar la búsqueda de soluciones adecuadas a la naturaleza de los factores que propician, condicionan, desencadenan o agravan la situación de endeudamiento de las economías domésticas. Entendemos que sólo así es posible diseñar medidas de prevención -anticipatorias del riesgo que puede suponer la operatoria de crédito en el mercado actual- así como medidas correctivas o de saneamiento, frente a una situación de endeudamiento excesivo consumado, que urge superar.

El mandato constitucional de proteger los derechos del consumidor y entre ellos, el acceso a los bienes y la tutela de sus intereses económicos, impone al Estado el deber de dictar normas de intervención. Razones diversas justifican la regulación del fenómeno. Por un lado se invocan razones de mercado, dado el rol que los consumidores cumplen en el sistema. Son los consumidores lo que estimulan la producción y la comercialización de bienes y servicios; son los que movilizan los recursos y las economías; sin consumidores no hay crecimiento ni desarrollo posible. Por otra parte, y más importantes, son las razones de índole humanitaria y social que hacen innegable e impostergable una política integral en materia de sobreendeudamiento y el dictado de normas de contenido sustancial y procedimental destinadas a la prevención y curación de este mal particular y social. 
Existe consenso en la doctrina respecto de que, sin perjuicio de las valiosas herramientas existentes en el ordenamiento jurídico español y argentino, las mismas siguen mostrando insuficiencia o inadecuación. El abordaje de esta compleja problemática, sin previsión particular en la legislación argentina, impone el diseño de un modelo regulatorio que de modo integral y sistemático, asuma el tratamiento del tema. En España, la reciente reforma introducida a la legislación concursal por el Real Decreto-Ley 1/2015, consagra el mecanismo de segunda oportunidad o "exoneración del pasivo insatisfecho", extendiéndolo a un nuevo destinatario (el deudor persona natural), tal como la doctrina venía reclamando. El modelo de regulación propuesto, a escasos meses de andar, ya muestra virajes y contramarchas.

Con esta investigación y sus propuestas, pretendo contribuir al diseño de un modelo propio para Argentina. Urge movilizar al legislador. Proponemos un emplazamiento para la regulación a dictarse y definimos el ámbito de aplicación a efectos de precisar quiénes son los destinatarios de la regulación, y bajo qué condiciones, así como el supuesto de hecho que tornaría operativas las soluciones ofrecidas. Explicitamos el paradigma de abordaje y los principios jurídicos que, a nuestro juicio, deben inspirar las soluciones normativas particulares. Insistimos en el diseño de soluciones preventivas, de carácter prioritario, y en la previsión de medidas de saneamiento eficaces, frente a la situación de sobreendeudamiento consumado. Asumimos un análisis crítico de los escenarios alternativos disponibles para la implementación de los mecanismos de saneamiento, relevando los procedimientos que ofrecen los modelos de regulación existentes. Consideramos importante capitalizar la experiencia de aquellos ordenamientos que ya han fijado posición y han puesto en marcha procedimientos de superación de la crisis y de rehabilitación del consumidor afectado. Pero estamos persuadidos de la necesidad de un diseño propio, sin forzar adaptaciones.

Hemos asignado relevancia en la observación de la problemática (el endeudamiento excesivo de los consumidores como fenómeno creciente y el impacto de esta situación en su grupo familiar y en su economía doméstica), a los informes que proporcionan fuentes confiables (organismos internacionales con competencia específica, órganos comunitarios, gobiernos, universidades y entidades relevantes). Hemos compulsado el tratamiento del tema en la legislación comunitaria, en el derecho interno de los países de la Unión Europea, 
con particular referencia al ordenamiento español, para analizar finalmente, el estado de la cuestión en Argentina.

La investigación parte de un desarrollo descriptivo de doble orientación. Por un lado, analizamos el fenómeno del sobreendeudamiento (sus causas, manifestaciones y efectos) y el tratamiento de tema en la legislación vigente. Todo ello, para justificar la hipótesis de trabajo referida a la necesidad de una regulación que asuma de modo integral y sistemático el abordaje del problema y sus posibles soluciones alternativas. Concretamente en Argentina, donde el legislador está incurso en mora y debe purgarla.

Superado este desarrollo descriptivo, abrimos paso al capítulo prescriptivo proponiendo como prioritarias las soluciones de corte preventivo tendientes a neutralizar aquellos factores que propician, condicionan o agravan el endeudamiento excesivo. Proponemos dispositivos de contenido sustancial que contemplen la totalidad de la operatoria de crédito (etapa precontractual, de celebración y de ejecución del contrato), con especial referencia al control -y autocontrol- de la actividad publicitaria (para resguardar su transparencia), a la imposición de deberes recíprocos de información veraz, adecuada y suficiente, al deber de asesoramiento del proveedor, al deber de mantener la oferta con su carácter vinculante, a la imposición de formalidades mínimas al contrato, a la previsión de un desembolso inicial obligatorio, al reconocimiento del derecho de arrepentimiento del deudor -desistimiento del contrato u operatoria-, el derecho al pago y a una amortización anticipada del crédito, entre otros. El relevamiento de estas soluciones ya incorporadas al ordenamiento español en una normativa especial de vinculación directa con la problemática aquí estudiada (nos referimos a la ley de crédito al consumo), que en Argentina no tenemos, nos permitirá evaluar su eficacia y ofrecer una reformulación propia.

Frente al sobreendeudamiento ya consumado, la investigación nos impone un repaso de las medidas de saneamiento admitidas en los modelos existentes y su análisis crítico. Nuevamente en este tópico hemos de asumir la tarea de un diseño propio que contemple las soluciones posibles. La renegociación de la deuda con los acreedores (acudiendo a resortes intermedios tales como prórrogas de plazos, quitas, condonación de deudas, modificación de otras condiciones de cumplimiento, suspensión acordada de ejecuciones, etc.) es una solución que, de ser viable, debe ser alentada, asistida y acompañada. Ahora bien, frente a la inexistencia de activos o liquidación del patrimonio del deudor, regular el llamado 
"derecho a una segunda oportunidad" o derecho a la "exoneración del pasivo insatisfecho", como se ha denominado en la más reciente legislación española, es impostergable. Asi lo proponemos.

Resulta decisiva la definición de los escenarios de actuación y vías para la instrumentación de las medidas antes mencionadas, donde propondremos las alternativas posibles (procedimiento extrajudicial -administrativo o preconcursal- y judicial), ponderando ventajas e inconvenientes y a la luz de la tradición cultural y principios que imperan en cada sistema jurídico. Fijamos posición y damos fundamentos.

La investigación del tema parte del análisis de informes y documentos de organismos internacionales y de la compulsa de bibliografía principalmente española y argentina. El cotejo de modelos regulatorios nos ha llevado a bucear también en bibliografía de autores franceses, italianos, alemanes y norteamericana, aunque en menor medida. Hemos accedido a bases de datos para la confrontación de la normativa legal y de la jurisprudencia que sobre la materia. La escasez de precedentes jurisprudenciales, de vinculación directa al tema, explica que no acudamos a esta fuente como soporte relevante de la investigación, aunque se podrá apreciar que hemos recogido doctrina judicial para el análisis de temas periféricos.

Sirva esta investigación como modesto aporte para despertar del letargo al legislador argentino. En situación de marginalidad y exclusión social, los consumidores sobreendeudados y sus familias, no tienen presente ni futuro. Esperan ser visualizados y recibir ayuda para reinsertarse al sistema. No hay tiempo para miradas esquivas. 


\section{Primera Parte}

\section{I.- El fenómeno del sobreendeudamiento del consumidor}

\section{A.- Planteamiento de la problemática}

La preocupación por la problemática del sobreendeudamiento ha superado el escenario natural de sociólogos y economistas para instalarse como tema prioritario del operador jurídico.

"El fenómeno del sobreendeudamiento tiene una relevancia esencial de primerísimo orden en todo el mundo occidental... hasta el punto de haberse constituido como uno de los principales problemas de la sociedad de nuestros días" ". Se ha dicho que constituye una preocupación social e incluso sanitaria $^{2}$ y que el diseño de políticas públicas y su implementación a través de normas y procedimientos eficaces, constituye un imperativo constitucional en todo Estado democrático moderno ${ }^{3}$.

La dimensión global del fenómeno y el impacto social y económico de la problemática motivaron una reacción que debía ser encauzada de modo eficiente. De allí que, sin perjuicio de las respuestas adoptadas por los gobiernos en cada Estado, se ha entendido que la eficacia de los remedios también dependerá de su diseño comunitario y bajo principios y reglas comunes ${ }^{4}$.

\footnotetext{
1 GutiérRez de CABIEDES, Pablo, El sobreendeudamiento doméstico: prevención y solución. Crisis económica, crédito, familias y concurso, Aranzadi, Pamplona, 2009, pág. 71. El Dictamen del Comité Económico y Social Europeo sobre "Protección de los consumidores y tratamiento adecuado del sobreendeudamiento para evitar la exclusión social" aprobado en sesión del 29 de abril de 2014, expresa que "no se puede seguir considerando el sobreendeudamiento como un problema individual derivado de los impulsos y las pasiones', puesto que en la actualidad es el reflejo de una crisis social y de sociedad" (punto 2.3).

2 Álvarez Vega, María Isabel, Protección jurídica del consumidor sobreendeudado e insolvente, Cívitas, Pamplona, 2010, pág. 95.

${ }^{3}$ GutiérRez de CABIEDES, Pablo, El sobreendeudamiento doméstico..., cit., pág. 41.

${ }^{4}$ El Dictamen del Comité Económico y Social Europeo sobre "El crédito y la exclusión social en la sociedad de la abundancia" aprobado en sesión del 25 de octubre de 2007, señala que "una acción a escala comunitaria sobre esta cuestión no sólo es posible y deseable, sino necesaria e imprescindible” (punto 6.2.1). Destaca asimismo, que "a falta de una orientación comunitaria, los distintos Estados miembros han desarrollado sus
} 


\section{B.- La denominación del fenómeno: distintas expresiones}

Coincidimos con quienes señalan que el vocablo sobreendeudamiento es la alocución más adecuada para referirnos a la problemática del endeudamiento excesivo ${ }^{5}$. Adherimos también a quienes marcan la dificultad que supone delimitar el concepto de sobreendeudamiento ${ }^{6}$ y el ámbito subjetivo de la regulación que se reclama.

La doctrina destaca la disparidad de expresiones que se utilizan para referirse a la problemática.

En efecto, se habla del sobreendeudamiento de los hogares, de las familias, de las economías domésticas, de los consumidores, de los particulares o de las personas físicas. Para algunos, ofrecer una definición concreta y delimitar los beneficiarios de la regulación a cierta categoría de sujetos, implica una toma de decisión cargada de sentido, reveladora de la filosofía subyacente, marcada por paradigmas propios y por los principios que

propios sistemas jurídicos nacionales de prevención, tratamiento, recuperación y acompañamiento de los ciudadanos y familias en situación de endeudamiento excesivo" (punto 1.1), que es necesario "abrir de nuevo el debate público sobre esta cuestión (punto 1.2) y propiciar "un estrecho diálogo con la sociedad civil organizada, en la que estén representadas las principales partes interesadas en este tema (familias, trabajadores, consumidores, instituciones financieras, etc.) (punto 1.6). Se exhorta finalmente al Parlamento Europeo y al Consejo a que hagan suyas estas preocupaciones ... y las incluyan entre las prioridades de sus respectivas agendas políticas (punto 1.8).

5 "Utilizo la palabra sobreendeudamiento por no encontrar otra más adecuada en la lengua castellana...Tómesela como un neologismo, aún no aceptado en el diccionario de la Real Academia Española...formada por dos vocablos: 'sobre', que indica exceso, acumulación (del inglés, 'over') y 'endeudamiento", advirtiendo que es la misma terminología que se utiliza en Francia (surendettement), en Italia (sovraindebitamento) y en los países de lengua portuguesa (superendividamento). Ver KEMELMAJER DE CARLUCCI, A. "El sobreendeudamiento del consumidor y la respuesta del legislador francés", en Anales, Año LIII, Segunda Época, $N^{\circ}$ 46, La Ley- Academia Nacional de Derecho y Ciencias Sociales de Buenos Aires, Junio/2008.

${ }^{6}$ Álvarez Vega, María Isabel, Protección jurídica del consumidor..., cit., pág. 50; Fernández CARRÓN, Clara., El tratamiento de la insolvencia de las personas físicas, Thomson-Aranzadi, Pamplona, 2008, pág. 17; TRUjILlo DíEZ, Iván J., El sobreendeudamiento de los consumidores (Estudio jurídico en el marco de la colaboración entre la Dirección General de Consumo de la Junta de Comunidades de Castilla-La Mancha y el Centro de Estudios de Consumo de la Universidad de Castilla-La Mancha), Comares, Granada, 2003, pág. 10. 
caracterizan tales normas de intervención ${ }^{7}$. Para otros, "cada una de esas expresiones, todas ellas concernientes al referente subjetivo de este fenómeno, acentúa matices o facetas distintas (ciertas y útiles) de una realidad en gran medida similar, pero no plenamente coincidente, siendo en muchas de ellas más una cuestión de énfasis, que una diferencia esencial..."

Se advierte ${ }^{9}$ que si bien el hogar no es quien asume el rol de tomador del crédito, la expresión sobreendeudamiento de los hogares enfatiza el impacto que la situación de endeudamiento provoca, fundamentalmente cuando se trata de un crédito para la adquisición de la vivienda. Cuando se habla de sobreendeudamiento de las familias, la mirada se centra en el grupo humano que sufre las derivaciones del endeudamiento excesivo. Quienes se refieren a sobreendeudamiento de las economías domésticas, utilizan una alocución genérica (compresiva de la economía privada no vinculada necesariamente a la noción de familia) para evidenciar que son éstas y no las de las empresas, quienes precisan un específico tratamiento legal de la problemática. "Cuando la referencia es propiamente subjetiva, y no a un conjunto (patrimonial o humano), se alude a menudo al sobreendeudamiento de los consumidores”, y aquí entra en escena la impronta tuitiva de esta rama del Derecho y la advertencia de que los beneficiarios del sistema protectorio son aquellos que pertenecen a la categoría aludida. Desde esta perspectiva, "otros prefieren hablar de sobreendeudamiento de los particulares, término más amplio que da cuenta de que se trata de personas físicas... quienes se hallan en esta situación” y que son estas

\footnotetext{
${ }^{7}$ Dice RoJo FERNÁNDEZ-Río: "El sobreendeudamiento plantea muchos y variados problemas. En primer lugar, si es necesario regularlo o no. Si la respuesta es afirmativa, el debate ha de centrarse en el cómo. Si se opta por regularlo como sobreendeudamiento de los consumidores, el interés protegido, es dígase lo que se diga, estrictamente capitalista. Por el contrario, si la preferencia decanta por su regulación como sobreendeudamiento de las familias, entonces el interés protegido es muy distinto" (RoJo FERNÁNDEZ-Río, Á., "Problemas y cuestiones en torno al sobreendeudamiento e insolvencia de las familias españolas", en Tomillo Urbina, J. (Dir.)-Álvarez Rubio, J. (Coord.), El futuro de la protección jurídica de los consumidores, Thomson-Cívitas, Pamplona, 2008, pág. 251-273).

${ }^{8}$ GutiÉrRez de Cabiedes, Pablo, El sobreendeudamiento doméstico..., cit., pág. 24. En igual sentido, FERnÁNDEZ CARRón, Clara., El tratamiento de la insolvencia..., cit., pág. 18.

${ }^{9}$ GutiÉRREZ de CABIEDES, Pablo, El sobreendeudamiento doméstico..., cit., pág. 25.
} 
últimas a quienes se considera necesario dispensar la específica protección que la problemática genera ${ }^{10}$.

\section{C.- El contexto de mercado y la situación de sobreendeudamiento.}

Oportuno es señalar que el fenómeno se emplaza en un contexto de mercado similar en todas las latitudes.

Es frecuente que el endeudamiento excesivo y generalizado vaya precedido por la implementación de políticas de acceso al crédito y gran estímulo al consumo, ante una aparente bonanza económica.

En ese escenario de mercados estables y endeudamiento regular, y luego de un tiempo, los actores sociales y económicos se ven sorprendido por la paralización de amplios sectores de la actividad productiva. Sobreviene la crisis económica y financiera y con ella irrumpen medidas de emergencia que los gobiernos y las empresas se ven compelidos de adoptar.

Ello deriva, generalmente, en el achicamiento de las estructuras y los presupuestos, la supresión de puestos de trabajo, el recorte de salarios que afectan la integridad de los ingresos o restringen la disponibilidad de los mismos, la precarización de las condiciones laborales, el trabajo en negro. Esas medidas provocan necesariamente un incremento del nivel de morosidad en los compromisos asumidos, la alteración de la cadena de pagos y situaciones de incumplimiento insuperable ${ }^{11}$.

\footnotetext{
${ }^{10}$ Aún admitiendo que la noción de consumidor involucra también a las personas jurídicas y que, según los casos, podrían serlo hasta las pequeñas empresas, reiteramos una vez más que son los consumidores- personas físicas, los que motivan el desvelo de los operadores y que, a su respecto, se considera insuficiente e inadecuada la regulación existente.

${ }^{11}$ El Dictamen del Comité Económico y Social Europeo sobre "Protección de los consumidores y tratamiento adecuado del sobreendeudamiento para evitar la exclusión social” aprobado en sesión del 29 de abril de 2014, expresa que "el sobreendeudamiento afecta todos los Estados miembros, aunque en diferente medida" (punto 2.7). Menciona que no obstante impactar en todas las "categorías de personas" (punto 2.10), "en la actualidad el sobreendeudamiento resulta más preocupante, puesto que afecta a los trabajadores pobres, a los parados, que han acumulado facturas no abonadas de servicios indispensables como la energía, el agua, los seguros y de telefonía, así como retrasos en el pago del alquiler..." (punto 2.8); y que "engloba otra categoría sociológica: las personas de clase media que han perdido su empleo y que tienen una carga hipotecaria considerable por su vivienda y sin perspectivas a corto plazo de encontrar un empleo" (punto 2.9).
} 
Coinciden asimismo los doctrinarios en señalar la uniformidad de efectos graves, derivados de esta situación de endeudamiento que comprometen las economías personales y familiares, con una innegable proyección en el conjunto social ${ }^{12}$.

\section{D.- Sobreendeudamiento: conceptualización. Diferencia con la insolvencia}

Sin perjuicio de los puntos de contacto innegables, cabe destacar que sobreendeudamiento e insolvencia son términos que califican situaciones diversas ${ }^{13}$. Distintas pueden ser sus causas y sus consecuencias, al igual que la naturaleza de las soluciones que el ordenamiento jurídico debe ofrecer al regular tales fenómenos ${ }^{14}$.

Se ha dicho que "el sobreendeudamiento hace referencia a un mero hecho o situación financiera y por ende económica (grado de endeudamiento, esto es, nivel de deuda en relación con el activo), sin necesidad de proyectarse en la actualidad o no del estado jurídico-legal de insolvencia .... El hecho de sobreendeudamiento es conceptual y temporalmente previo a la insolvencia aunque pueda terminar constituyendo su causa y desembocando en ese estado jurídico (que es, de hecho, una de las cosas que se deben evitar). La insolvencia, por tanto, hace referencia a una situación o estado jurídico de imposibilidad de cumplimiento regular de las obligaciones de pago",15.

\footnotetext{
12 Álvarez Vega, María Isabel, Protección jurídica del consumidor..., cit., pág. 50.; FernándeZ CARRÓN, Clara., El tratamiento de la insolvencia..., cit., pág. 15.; GUTIÉRREZ DE CABIEDES, Pablo, El sobreendeudamiento doméstico..., cit., pág. 18; LIMA MARQUES, Claudia.- LunARDELli CAVALlAZI, Rosangela., Direitos do consumidor endividado. Superrendividamento e crédito, Biblioteca de Direito do Consumidor, 29, Editora Revista Dos Tribunais, Sao Paulo, 2006, pág. 23-38; LORENZETTI, Ricardo L., Consumidores, Rubinzal Culzoni, Santa Fe, 2009, pág. 75.; TRUjILlo DíEZ, El sobreendeudamiento de los consumidores..., cit., pág. 1 y sgtes.

${ }^{13}$ Ver ANCHÁvAl, Hugo, Insolvencia del consumidor, Editorial Astrea, Buenos Aires, 2011, pág. 31.

${ }^{14}$ QuinTANA CARLO, Ignacio, "El sobreendeudamiento de los consumidores”, en TOMILlo UrbinA, J. (Dir.)Álvarez Rubio, J. (Coord.), El futuro de la protección jurídica de los consumidores, Thomson-Civitas, Pamplona, 2008, pág. 2257-2269; Álvarez VegA, María Isabel, Protección jurídica del consumidor ..., cit., pág. 299; ANCHÁVAL, Hugo, Insolvencia del consumidor, cit., pág. 31.

${ }^{15}$ GutiÉRREZ De CABIEDES, Pablo, El sobreendeudamiento doméstico..., cit., pág. 28. No participa de la idea de distinguir los conceptos, José María De la Cuesta Rute: "No puede dudarse de que una situación de endeudamiento no significa sin más la insolvencia. Ni siquiera de suyo la preludia. Si tiene sentido hablar de endeudamiento entonces es porque sus características o circunstancias es muy alto el riesgo de que no pueda
} 
En el objetivo de definir los contornos de la problemática, existe otra dificultad adicional: establecer cuándo el endeudamiento deja de ser una práctica regular que propicia el acceso a los bienes de consumo para convertirse en una situación no deseada, perniciosa para el propio deudor y para el sistema ${ }^{16}$.

salir el deudor de esa situación. En este sentido, se puede decir que el deudor se encuentra en una situación patrimonial crítica de acuerdo con lo que antes he dicho sobre el particular. Ahora bien, si es crítica la situación es porque el endeudamiento resulta excesivo; en realidad la situación a que ahora hago referencia se suele mencionar como sobreendeudamiento. Pero para poder estimar su exceso es preciso contar con un punto de referencia respecto del que pueda ser medido. Excusado es decir que dicha medida la proporciona en términos generales el conjunto de bienes y derechos integrantes del activo patrimonial. El sobreendeudamiento supone un pasivo excesivo respecto del activo. Mas esta conclusión no nos presenta aquel fenómeno como algo distinto de la insolvencia, de modo que si hemos de destacarlo como algo singular hemos de circunstanciar el puro dato del exceso de deudas" (DE LA CUESTA RUTE, José María, "Persona física y consumidor", Ponencia presentada al $\mathrm{I}^{\circ}$ Congreso Internacional Sobreendeudamiento del consumidor e insolvencia familiar, celebrado en la Facultad de Derecho UCM en noviembre de 2008. http://eprints.ucm.es/8761/1/06.04.09.Persona_f\%C3\%ADsica_y_consumidor.pdf (fecha de consulta: 7/7/2015).

${ }^{16}$ Durante siglos, el crédito al consumo se redujo a los préstamos de empalme. En estas operaciones de crédito, el objetivo del tomador del crédito era superar estados de crisis coyunturales. Pero poco a poco, la operatoria crediticia deja de ser solamente la tabla de salvación para salir a flote en situaciones críticas o de excepción y pasa convertirse en una herramienta eficaz de crecimiento y desarrollo económico. Ya no se concibe al crédito como una vía de escape de las dificultades pasadas o presentes; se instala la idea de que es un inmejorable instrumento para construir el futuro. De un crédito originariamente pensado para la supervivencia, se transita a otro, que tiende a mejorar nivel de vida del trabajador y su núcleo familiar. Lo que antaño constituía un último recurso para superar una situación de conflicto de coyuntura, se trasforma en una llave de acceso natural y regular al mercado de bienes. Se pasa a considerar que, para los asalariados, la toma de créditos para el consumo es un modo de administración razonable del ingreso, en tanto contribuye a organizar la asignación de los recursos personales y familiares. La difusión de la operatoria de crédito impacta en la economía individual y familiar: supone el acceso del público a la sociedad de consumo y/o al mejoramiento del nivel de vida, alienta el esfuerzo por conservar y mejorar el empleo y el salario, permite una programación de sus gastos, etc.) pero su suerte está estrechamente ligada a la estabilidad del empleo y al crecimiento económico. Cuando estas premisas se ven amenazadas, el individuo y la sociedad en su conjunto pagan un alto precio por los comportamientos optimistas y hasta eufóricos de la bonanza precedente. Ver JAPAZE, María Belén, "Crédito al consumo y protección del consumidor. La impostergable necesidad de una regulación protectoria”, en JA 2010-IV, Revista del 3/11/2010. 
Se ha dicho que "no únicamente el concepto de endeudamiento plantea dificultades, pues también la forma de cuantificarlo, es fuente de divergencia" $"$.

Resulta claro que el acceso a los bienes y el mejoramiento de la calidad de vida encuentran en la operatoria crediticia un instrumento inmejorable ${ }^{18}$. Es asimismo evidente que los consumidores no están obligados al ahorro previo ni condicionados a la disponibilidad de efectivo para adquirir tales bienes ${ }^{19}$. La financiación, como rampa de acceso al consumo, es afortunadamente ofrecida, comprensiblemente alentada y eficazmente instalada.

\footnotetext{
${ }^{17}$ Así lo señala el Dictamen del Comité Económico y Social Europeo sobre "El crédito y la exclusión social en la sociedad de la abundancia” de 2007 en su punto 3.2.2. Ver ÁlvAREZ VEGA, María Isabel, Protección jurídica del consumidor..., cit., pág. 53. Plantea también esta dificultad, Trujlllo DíEZ, Iván Jesús, El sobreendeudamiento de los consumidores..., cit., pág. 11 y sgtes.

${ }^{18}$ Desde otra perspectiva, se dice que "la remuneración dineraria -como insumo de la producción- será siempre menor a la cantidad y calidad del trabajo de su portador (trabajador), con lo cual será insuficiente para obtener los bienes que el mismo produce", lo que se ve reforzado por otro dato de la realidad, cual es "la diversificación y obsolencia de los bienes y servicios". De allí que "toda remuneración en el sistema de producción, por lógica, es insuficiente para convertirse en un consumo adecuado y sostenido que genere una economía de felicidad y el auto-sustento (sin endeudamiento) para el consumidor/usuario". Se sostiene que éste, "tarde o temprano afrontará la necesidad técnica de un crédito y, por ende, un endeudamiento, con incertidumbre de pago, porque dependerá de la estabilidad del empleo y de la remuneración de la empresa...y de una diversidad de situaciones extra como la crisis, la depreciación de su moneda..." (cfr. GHERSI, Carlos A., "Endeudamiento y sobreendeudamiento desde el análisis económico del derecho", $L L$ 2015-B, diario del 20/3/2015). En el citado trabajo, el autor concluye señalando que "el endeudamiento es una necesidad o una premisa propia del sistema económico de acumulación y el sobreendeudamiento es una contingencia probable...".

${ }^{19}$ En la sociedad americana, el proceso evolutivo muestra una inversión en los conceptos que se entendían como tradicionales. Mientras en un primer momento, la lógica imponía ahorrar previamente para consumir después, a partir de la segunda mitad del siglo XX, la regla comenzó a ser inversa: se decidía la contratación primero, y luego se imponía ahorrar para afrontar los pagos mensuales que exigía el cumplimiento de la obligación asumida. Seguramente los factores socioeconómicos y la impronta cultural propia contribuyeron a la notable evolución, anticipada en el tiempo, que tuvo en América del Norte la operatoria de crédito, su instrumentación y sus técnicas, con relación al resto de las sociedades contemporáneas. Para un desarrollo de estos temas, ver Gelpi, Rosa M., y Julien-LabruYére, Historia del crédito al consumo. Doctrinas y prácticas, Península, Barcelona, 1998, pág. 233.
} 
La discusión se plantea al querer establecer cuándo la toma de crédito y el consiguiente endeudamiento dejan de ser prácticas razonables, proporcionadas, prudentes y cruzan el umbral del sobreendeudamiento, como actos perniciosos, excesivos, inconvenientes y no deseados ${ }^{20}$.

De los modelos propuestos ${ }^{21}$, la llamada fórmula objetiva es la que recibe más adeptos. Es la que propone tener por configurada una situación de sobreendeudamiento a partir de poner en relación la deuda total y la renta neta del deudor. Se computa el porcentaje de deuda en relación con la renta disponible, con la totalidad de activos, para así concluir respecto de la configuración del supuesto y establecer el grado del endeudamiento $^{22}$.

En el ámbito de la Unión Europea se señala con énfasis, y desde hace tiempo, la necesidad de contar con un concepto único de endeudamiento excesivo. Con sólidos fundamentos se expresa que "el esfuerzo de armonización debe hacer hincapié, sin lugar a dudas, en la definición del concepto y de los parámetros cualitativos y cuantitativos del fenómeno, para permitir una adecuada información y observación de las realidades sociales subyacentes, de manera comparable en toda Europa (y sería deseable que en todo el mundo), basándose en la recogida y el tratamiento de datos estadísticos comparables"23.

\footnotetext{
${ }^{20}$ GutiÉRreZ de CABIEDEs, Pablo, El sobreendeudamiento doméstico..., cit., pág. 19.

${ }^{21}$ Álvarez Vega, María Isabel, Protección jurídica del consumidor sobreendeudado..., cit., pág. 53.

${ }^{22}$ GutiÉRREZ DE CABIEDES, Pablo, El sobreendeudamiento doméstico..., cit., pág. 19.

${ }^{23}$ Dictamen del Comité Económico y Social Europeo sobre "El crédito y la exclusión social en la sociedad de la abundancia" aprobado en sesión del 25 de octubre de 2007, puntos 6.31, 6.3.1.1 y 6.3.1.2. El aludido Dictamen expresa que "hablar de endeudamiento excesivo o de sobreendeudamiento es hacer referencia a situaciones en las que el deudor se ve en la imposibilidad, de forma duradera, de pagar el conjunto de sus deudas, o expuesto a una amenaza seria de no poder hacerles frente en el momento en que sean exigibles. No obstante, los términos precisos de esta noción difieren considerablemente en cada Estado miembro, y su definición a nivel europeo está todavía pendiente. Por eso, se acoge con satisfacción la reciente iniciativa de la Comisión Europea de encargar un estudio con este fin" (punto 3.2.1). En ese documento el CES advierte que "una de las principales dificultades que plantea la evaluación de la amplitud del fenómeno del sobreendeudamiento en Europa es la falta de estadísticas fiables o la imposibilidad de proceder a comparaciones con los datos existentes, dadas las diferentes metodologías, conceptos e intervalos de medida utilizados" (punto 3.2.3). Por ello, consideró ineludible "promover la realización de un estudio ampliado a
} 
Con acierto se advierte que la eficacia de los remedios a diseñar dependerá necesariamente de una definición coincidente del fenómeno problemático, sus contornos y aristas ${ }^{24}$.

En su Dictamen de $2014^{25}$, el CESE reitera que "no hay consenso sobre la definición de sobreendeudamiento puesto que los conceptos divergen entre países”, aunque "existen determinados elementos subyacentes comunes que pueden servir como base general". De allí que se propone la elaboración de una "definición operativa común de sobreendeudamiento" que considere necesariamente los siguientes elementos:

- el hogar como unidad de medida pertinente para cuantificar el sobreendeudamiento;

- los compromisos financieros adquiridos, entre los que se incluyen los créditos hipotecarios, el crédito al consumo, las facturas de telefonía, de comunicación electrónica y de servicios básicos (agua, calefacción, electricidad, salud, etc.), los alquileres y los gastos comunes (alimentación, transporte, escolaridad, etc.);

- los compromisos informales adquiridos por la familia o la comunidad...;

- la incapacidad de pago...;

- el sobreendeudamiento estructural (se trata de un criterio temporal destinado a cubrir los problemas financieros persistentes y continuados);

- un nivel de vida digno (el hogar debe poder respetar los compromisos financieros adquiridos e informales sin reducir sus gastos mínimos vitales para mantener su nivel de vida);

- la insolvencia (el hogar no puede solucionar la situación financiera por medio de sus activos financieros y de otro tipo".

\footnotetext{
todo el territorio comunitario, que permita determinar con exactitud la dimensión económica y social del endeudamiento excesivo".

${ }^{24}$ El Dictamen del Comité Económico y Social Europeo sobre "Protección de los consumidores y tratamiento adecuado del sobreendeudamiento para evitar la exclusión social” de 2014 vuelve sobre la necesidad alcanzar un concepto armonizado, al expresar que “...si no se cuenta con una definición que analice con precisión este fenómeno múltiple, las medidas públicas podrían no tener repercusión alguna".

${ }^{25}$ Así emerge del Dictamen del Comité Económico y Social Europeo sobre "Protección de los consumidores y tratamiento adecuado del sobreendeudamiento para evitar la exclusión social” aprobado en sesión del 29 de abril de 2014 (puntos 3.1, 3.5 y 3.6)
} 


\section{E.- Sobreendeudamiento activo y pasivo:}

Al profundizar el estudio del fenómeno y en el afán de desbrozar el concepto, la doctrina suele distinguir el llamado sobreendeudamiento activo del sobreendeudamiento pasivo $^{26}$.

El sobreendeudamiento activo se refiere a una situación de base, originaria. El particular acude al financiamiento y se endeuda en exceso. El deudor contrae más obligaciones de las que puede afrontar. Esta especie comprende tanto a aquéllos que incurren en esta práctica de modo deliberado y hasta doloso -computando la posibilidad de transitar un procedimiento de insolvencia posterior- como a aquéllos que de modo irreflexivo, sin hacer las debidas previsiones, sin asesorarse y hasta en forma negligente, asumen obligaciones que exceden su capacidad de pago $^{27}$. Subyace en este subtipo, un juicio de reproche sobre la conducta desplegada por el deudor.

El sobreendeudamiento pasivo es el que se desencadena como consecuencia de acontecimientos sobrevenidos al nacimiento de las obligaciones asumidas por el deudor y por causas no imputables al particular afectado. Entre ellos, se ha considerado conveniente distinguir, a su vez ${ }^{28}$, los sucesos directos (la pérdida del empleo, la jubilación, el fallecimiento de un miembro de la familia cuyo aporte era indispensable para la economía familiar, la enfermedad del deudor o la de uno de los integrantes del grupo familiar -que altera las previsiones presupuestarias-, el divorcio del deudor, el nacimiento de hijos no esperados -especialmente los casos de partos múltiples-, etc.) de los llamados sucesos

\footnotetext{
${ }^{26}$ Álvarez Vega, María Isabel, Protección jurídica del consumidor..., cit., pág. 52; GuTIÉRREZ DE CABIEDES, Pablo, El sobreendeudamiento doméstico...”, cit., pág. 30.; TrujILlo DíEZ, Iván Jesús, El sobreendeudamiento de los consumidores..., cit., pág. 1; entre otros.

${ }^{27}$ Algunos autores mencionan en la casuística de esta subespecie, los casos de ludopatía, adicción al consumo o la tendencia a la prodigalidad (RoJo FERNÁNDEZ-Río, Ángel, "Problemas y cuestiones en torno al sobreendeudamiento...", cit., pág. 258, mientras que otros consideran que en estos supuestos no puede hablarse "con propiedad" de sobreendeudamiento, por lo que prefieren "dejar fuera" estos ejemplos (TAMAYO HAYA, Silvia, "El sobreendeudamiento de los consumidores", en TOMILlo UrbinA, Jorge (Dir.)-ÁlvarEZ RuBIO, Julio (Coord.), El futuro de la protección jurídica de los consumidores, Thomson-Civitas, Pamplona, 2008, pág. 346 y sgtes.).

${ }^{28}$ Rojo FERNÁNDEZ-Río, Ángel, "Problemas y cuestiones en torno al sobreendeudamiento...”, cit., pág. 259.
} 
indirectos (el otorgamiento de garantías a familiares o afines que luego se ejecutan, afectando la economía doméstica del particular, etc.).

Desde esta perspectiva, "algunas opiniones sostienen que existe una política común para instaurar legislativamente un principio general que la doctrina viene denominando fuerza mayor social" que, a diferencia del concepto tradicional, "es adoptado para situaciones ordinarias pero, como aquéllas, son ajenas a la voluntad del deudor que se ampara en ellas y traen aparejada una grave alteración en la solvencia del deudor,"29.

Esta clasificación binaria del endeudamiento -activo y pasivo- simplifica el esquema causal sin reparar en que el consumidor cae, con mucha frecuencia, en esa situación de exceso de deuda por una retroalimentación entre ambos subtipos. Con acierto se señala que "es justamente la correlación entre una y otra hipótesis lo que desencadena muy a menudo el endeudamiento no deseado" $"$.

${ }^{29}$ ANCHÁval, Hugo, Insolvencia del consumidor, cit., pág. 38. Con cita de ZAMUDIO y CAMICHA expresa: "He allí la configuración específica del presupuesto objetivo del concursamiento del consumidor no comerciante, cuyo régimen especial debe ser aplicado bajo cuatro requisitos: 1) el deudor debe estar afectado por alguna especial circunstancia tal como un cambio desfavorable en su salud (física o mental), trabajo (despido, reducción laboral, huelga o lockout) o familiar (divorcio, muerte o grave enfermedad de un mimbro de la familia primaria). Esta enumeración no debe ser considerada exhaustiva sino indicativa y otras situaciones pueden ser homologadas por el juez. 2) debe existir una unión o nexo causal entre la circunstancia inesperada y las dificultades en el cumplimiento de la obligación a cargo del deudor. Si la especial situación enunciada en el punto anterior no afecta la capacidad de pago del deudor porque dispone de otras fuentes de ingresos, el principio no puede ser invocado. 3) la situación configurativa de la fuerza mayor social no puede haber sido prevista por el deudor al tiempo de contratar, de lo contrario no podría excepcionarse en este principio. 4) tampoco puede haber sido causada por el deudor, si lo fuera no podría ser una defensa atendible".

${ }^{30}$ ANCHÁval, Hugo, Insolvencia del consumidor, cit., pág. 65. A causa de un suceso posterior y fortuito, como puede ser el despido del deudor o de alguno de los aportantes a la economía doméstica, la muerte de alguno de ellos, la enfermedad del deudor o de algún miembro de su familia que obliga a asumir costes no previstos, su divorcio, o cualquier otra situación que compromete las previsiones presupuestarias originariasel afectado puede verse empujado a la toma de un empréstito inconveniente, a refinanciar con el acreedor originario en condiciones muchas veces inaceptables, a hacer un uso distorsivo de la tarjeta de crédito, etc. Un análisis simplista impondría denegar el acceso a los remedios de saneamiento a este deudor que acudió al crédito de modo irreflexivo o negligente o bien, seleccionar pasivos que se verán amparados por beneficios de liberación, dejando otros al margen de los mismos. 
Más allá de estas precisiones conceptuales que casi todos los autores mencionan al analizar el concepto de sobreendeudamiento, la pregunta ineludible es si aquella distinción entre endeudamiento activo y pasivo incide o debe incidir en la regulación de la problemática.

Nos preguntamos, en efecto, si aquellas variables vinculadas a las causas del endeudamiento excesivo -culpable o fortuito/inculpable- deben condicionar la decisión del legislador. Pensamos si acaso sólo merece la atención de los operadores jurídicos aquel consumidor sobreendeudado por causas sobrevenidas y ajenas a su voluntad o si las políticas públicas y la regulación del fenómeno han de contemplar también al consumidor que cae en esta situación de modo irreflexivo y hasta deliberado ${ }^{31}$.

Adelantamos, desde ahora, una primera opinión. Coincidimos con quienes expresan que "una política integral contra el sobreendeudamiento debe hacer frente a los distintos aspectos de este fenómeno; y que no es la misma realidad la que se combate con medidas preventivas (que no tienen por presupuesto el acaecimiento concreto de adversidades imprevistas ni la buena o mala fe, lo cual concierne al aspecto subjetivo del concepto) que con medidas reparadoras o solutivas de éste (que sí lo tienen)”32.

En otros términos, creemos que sin perjuicio de distinguir objetivos y las herramientas para alcanzarlos, la regulación integral de la problemática impone no excluir situaciones de endeudamiento excesivo en función de las causas que las generan.

El resguardo de las buenas prácticas en el mercado es de interés prioritario y las desviaciones que se detecten en el comportamiento o actividad de cualquiera de los actores (proveedores y consumidores) debe ser objeto de análisis y abordaje.

Consideramos que los dispositivos que se diseñen para prevenir el sobreendeudamiento deben tener al consumidor y a su familia, como destinatarios, sin restricciones, y que las medidas de saneamiento y rehabilitación especiales -y cuyo diseño se propugna- estarán destinadas a aquellos que justifiquen el merecimiento de las mismas.

Entendemos que el tratamiento diferenciado de las herramientas legales -conforme su naturaleza y finalidad- permite un doble efecto benéfico. Por un lado, la regulación

\footnotetext{
31 Destaca este aspecto de la reflexión, TAMAYO HAYA, Silvia, "El sobreendeudamiento de los consumidores...”, cit., pág. 348 .

${ }^{32}$ GutiÉRreZ de CABIEDES, Pablo, El sobreendeudamiento doméstico..., cit., pág. 31.
} 
aportaría a la prevención y evitación del fenómeno, buscando neutralizar algunas de las causas del sobreendeudamiento (aquéllas que generalmente afectan a los más débiles del mercado y comprometen su regular funcionamiento). Y, por otra parte, se dejan a resguardo los estímulos de conducta responsable, que es dable esperar de los protagonistas del intercambio.

Pero consideramos que se impone formular alguna precisión adicional. No se trata de simplificar el razonamiento y sostener que sólo merecen una segunda oportunidad los deudores en situación de sobreendeudamiento pasivo. Como se dijo, el sobreendeudamiento activo presenta matices y de allí que resulte obligado considerar situaciones particulares.

Creemos que el saneamiento y la rehabilitación del consumidor sobreendeudado no sólo habrá de ofrecerse al deudor de buena fe (presupuesto contemplado en los modelos europeos) o al deudor "honesto pero desafortunado" (alocución norteamericana) sino también a aquellos deudores en los que la justificación es ajena a un reproche subjetivo de su conducta. Un consumidor puede acudir al crédito sin asesoramiento, endeudarse en exceso y en condiciones de contratación no recomendables pero ese proceder poco cuidadoso no debiera restringir per se el acceso al régimen de saneamiento analizado. En muchos supuestos, el merecimiento de la segunda oportunidad estará justificado en la lógica de la operatoria de crédito, en las asimetrías que le son propias, en las particularidades del mercado de que se trata, en el juego de balances y en el paradigma protectorio que debe inspirar la solución de los derechos e intereses en tensión ${ }^{33}$.

Se habla de consumidores (y subconsumidores) víctimas de la industria de crédito. Se habla de créditos abusivos o de exceso de crédito. Y no se trata de postulados trasnochados.

\footnotetext{
${ }^{33}$ Con agudeza señala ANCHÁvAl que conviene distinguir al deudor de mala fe -que contrae obligaciones a sabiendas de su impotencia patrimonial- de otros que no lo son. Señala: "un consumidor puede sobreendeudarse activamente como consecuencia de recurrir al sistema de préstamos periféricos, tales como agencias de crédito que pululan en toda la Argentina, donde con sólo llevar un recibo de sueldo entregan sumas de dinero que van desde los \$1000 a los \$10000 (según las épocas y los ciclos económicos) sin ningún control o estudio del deudor, imponiendo tasas usurarias de interés. Estas empresas son responsables de la liberalidad de su crédito y seguramente el consumidor que ha recurrido a ellas, por no poder acceder a un crédito formal, debe ser liberado de parte de esa deuda. Se trata de una especie de créditos subprime a la argentina" (ANCHÁVAL, Hugo, Insolvencia del consumidor, cit., pág. 34).
} 
El elenco de situaciones es amplio. Los mercados y los actores involucrados -los dadores de crédito y los consumidores- proponen particularidades propias. Se impone, por tanto, acudir a un razonamiento más sofisticado a la hora de definir el modelo de regulación, sus presupuestos, requisitos y efectos.

\section{II.- Causas del sobreendeudamiento del consumidor}

Las causas del sobreendeudamientos son de índole variada. Así lo refleja el Dictamen emitido por el Comité Económico y Social Europeo sobre "El crédito y la exclusión social en la sociedad de la abundancia", aprobado el 2 de octubre de 2007 que dedica al tema extensas consideraciones ${ }^{34}$.

Por su parte, el Dictamen del Comité Económico y Social Europeo sobre "Protección de los consumidores y tratamiento adecuado del sobreendeudamiento para evitar la exclusión social”, aprobado el 29 de abril de 2014, destaca que aún cuando no ha sido posible aún proponer una definición uniforme del fenómeno (punto 2.20), sí existe cierto consenso sobre las principales causas del sobreendeudamiento (punto 2.18) ${ }^{35}$.

Abocados al estudio del tema, consideramos conveniente distinguir categorías de causas. Entendemos que esta categorización facilitará la búsqueda de soluciones adecuadas a la naturaleza de los factores que propician, condicionan, desencadenan o agravan la situación de endeudamiento de las economías domésticas.

Consideramos que sólo un análisis discriminado de las causas, permitirá diseñar medidas de prevención -anticipatorias del riesgo que puede suponer la operatoria de crédito en el mercado actual- así como medidas correctivas, de saneamiento o reparadoras, frente a una situación de endeudamiento excesivo consumado, que urge superar y revertir.

\section{A. Causas vinculadas a las crisis de los sistemas económicos}

\footnotetext{
${ }^{34}$ Las reflexiones y conclusiones vertidas en el mencionado Dictamen son desarrolladas al tratar los antecedentes normativos del problema en el ámbito de la Unión Europea, ut infra.

${ }^{35}$ Remitimos al lector interesado, aquí también, al capítulo en el que trataremos los antecedentes normativos del fenómeno en el ámbito de la Unión Europea.
} 
Bajo este título corresponde mencionar las situaciones de crisis económicofinancieras por las que atraviesan en forma cíclica los países en todas las latitudes, aunque unos con más frecuencia que otros ${ }^{36}$.

Se ha dicho que "las crisis sistémicas son grandes productoras de diversas catástrofes sociales, entre las que se encuentra el endeudamiento y el empobrecimiento de la población ${ }^{37}$. Y a nadie escapa que la crisis del sistema económico y financiero muchas veces impacta en la juridicidad y la vida institucional "hasta cernirse en amenaza cierta y concreta de la paz social" 38 .

Las crisis económico financieras aludidas obligan a los Gobiernos y al sector empresario a la adopción de medidas de emergencia, que golpean las economías particulares con directa incidencia en las previsiones presupuestarias preexistentes, en la disponibilidad de los recursos de los particulares, en su capacidad de gestión frente del riesgo sobreviniente, en la conservación del ahorro y en el regular cumplimiento de los compromisos asumidos con anterioridad.

Se señala con acierto que en este cuadro de situación, "el fenómeno se autoabastece, ${ }^{, 39}$. La crisis del sector productivo y de distribución impacta negativamente en las economías domésticas que, por estar sobreendeudadas, se ven obligadas a reducir el consumo o, muchas veces, a cortar la cadena de pagos; y este efecto contagio, determina que la enfermedad de las empresas esté también condicionada a que los consumidores recuperen su buena salud económica.

\footnotetext{
${ }^{36}$ Ver, NicOLAU, Noemí L., conferencia pronunciada en el Seminario sobre "Impacto de las crisis económicas en las instituciones del Derecho privado", organizado por la Maestría en Derecho Privado con motivo de su $10^{\circ}$ aniversario, Rosario, noviembre de 2008. El texto me fue proporcionado por la autora.

37 AnCHÁval, Hugo, Insolvencia del consumidor, cit., pág. 183. En igual sentido reflexiona Julio César Rivera (RIVERA, Julio César, "Insolvencia de las personas físicas (especialmente de los consumidores)", en Revista de Derecho Comercial del Consumidor y de la Empresa, Año 1, N², La Ley, noviembre de 2010, pág. 3-7.

38 BARREIRO, Rafael F., "Precisiones acerca de concursos pequeños, crisis sistémicas y consumidores endeudados en demasía”, en Truffat, D.-BArReiro, M.-AnTONi PiosseK, C.- NiCASTRo, R. (Coord.), Libro Homenaje al Doctor Osvaldo Maffía, Lerner Editora, Córdoba, 2008, pág. 567-576.

${ }^{39}$ ANCHÁvAL, Hugo, Insolvencia del consumidor, cit., pág. 183 y sgtes.
} 
Como se dijo, la crisis lleva a implementar una política de austeridad que se traduce en medidas varias. Mencionaremos algunas, por su directa vinculación al tema analizado, en tanto se mencionan como factores que desencadenan la situación de sobreendeudamiento:

- la supresión de empleos en el sector público y privado (lo que a su vez provoca una creciente desocupación o paro, en niveles muchas veces alarmantes)

- la modificación de las condiciones laborales (precarización, proliferación del trabajo informal, etc.);

- la reducción o recorte de salarios;

- la imposición de condicionamientos a la disponibilidad del dinero y/o de bienes de los particulares (restricciones en la operatoria de las cuentas bancarias, en la compra de divisas extranjeras y en las transacciones habituales, incautación de activos, etc.);

- la implementación de políticas monetarias y cambiarias que afectan el poder adquisitivo de la moneda.

- la imposición de prohibiciones y/o restricciones en las importaciones (con la consiguiente incidencia en la producción y comercialización desarrolladas en el sector privado);

\section{B.- Causas vinculadas a las características del mercado y del consumo moderno ${ }^{40}$}

\footnotetext{
${ }^{40}$ Recordábamos en un trabajo anterior que "la producción de bienes en serie, y a escala, llevó al sector empresario a desarrollar técnicas de colocación y distribución. Las nuevas industrias se vieron obligadas a generar una demanda proporcional a su capacidad productiva, ideando nuevas técnicas para comercializar también en masa En el nuevo contexto del mercado, instalar un producto o servicio exigía renovados esfuerzos por parte de los proveedores, que se vieron precisados de diseñar herramientas para captar al público consumidor, instalar el deseo, generar la necesidad de la adquisición o contratación y facilitarles el acceso a dichos bienes. En este nuevo escenario, cobró protagonismo una disciplina autónoma, la mercadotecnia, que puso en escena a una nueva categoría de expertos, a los que parece ineludible acudir en el mercado postindustrial. El marketing se convirtió en la vedette del mercado: ya no resultaba posible concebir la actividad empresaria sin un segmento de gestión a cargo de un equipo profesional que realizara un estudio de mercado, del consumidor potencial, de los productos o servicios requeridos o apetecibles, de los sistemas de distribución más eficientes y de los canales de comunicación idóneos para la promoción publicitaria... Pero el derrotero de esfuerzos no termina ahí para el proveedor. Parece evidente que no basta con detectar las necesidades del consumidor (o pensar en cómo generarlas). Tampoco alcanza con diseñar y crear el mejor producto o servicio. Puede ser igualmente insuficiente, concebir una eficaz estrategia publicitaria. No
} 
A modo de síntesis, y sin perjuicio de un desarrollo más minucioso en los capítulos que correspondan, mencionamos los siguientes fenómenos:

-el llamado marketing crediticio actual ${ }^{41}$.

Para explicarlo en pocas líneas, señalamos que en el afán de colocar bienes y servicios en el mercado, los proveedores ofrecen la financiación correspondiente; y para

garantiza el éxito de la comercialización, el haber ideado los instrumentos jurídicos idóneos para la formalización del vínculo contractual. Existen dificultades relacionadas con la financiación de esa adquisición o contratación que muchas veces, por insuperable para el consumidor, dejan en carpeta a las más prometedoras de las campañas de promoción de un producto o servicio. No podía ser sino el empresario proveedor quien asumiera como parte de su estrategia de colocación, la gestión de este segmento de la comercialización. Propiciar y conceder financiación produce un doble efecto beneficioso: facilita la adquisición del producto o la contratación de servicios al consumidor y garantiza mejores condiciones de comercialización al empresario proveedor. Inicialmente la financiación fue promovida y ofrecida por quienes operaban en la distribución de los productos. El propio proveedor actuaba como financiador de las operaciones de consumo. Estaba principalmente dirigida a quienes se interesaban en adquirir los bienes durables que aparecían en el mercado. En esta etapa, que va desde los comienzos de la revolución industrial hasta el inicio de la Primera Guerra Mundial, era el propio proveedor quien mediante un aplazamiento del pago, financiaba las operaciones de adquisición de bienes. El vendedor era el encargado de satisfacer las necesidades de crédito de sus clientes, ya que no existía otro agente de financiación posible en el mercado... A partir de la década de 1960, se produce una diversificación significativa de los productos y servicios y se profesionalizan más aún los distintos segmentos productivos y de comercialización. La aparición de bienes de alto costo y la necesidad de que dejaran de ser bienes de lujo reservados sectores pudientes para convertirse en productos de consumo masivo, determinó la irrupción de nuevos actores en el mercado del crédito. Los proveedores no podían ya asumir la financiación de la operación pues les era indispensable compensar inmediatamente los costes de producción para así mantener el volumen de la misma y potenciar el nivel de distribución. Se hacía necesario, por otra parte, que un profesional especializado, con capacidad económica suficiente, soportara la carga de dicha financiación. La asunción de este rol financiador por los especialistas del crédito en el mercado permitió a los proveedores de bienes y servicios recuperar su función típica, optimizando la producción y la estrategia de colocación. Aparece así la figura del tercero financista de la operación de crédito que, en un primer momento, eran sociedades creadas con ese fin y usualmente vinculadas a las empresas proveedoras de bienes y servicios; y, en una etapa posterior, las entidades bancarias irrumpen en el mercado del financiamiento al consumo". Ver JAPAZE, María Belén, "Crédito al consumo...,", cit).

${ }^{41}$ RIVERA, Julio C., "Insolvencia de las personas físicas...", cit., pág. 3/7. 
ello despliegan estrategias empresarias sostenidas en publicidad inductiva y en políticas de acceso al crédito. Se aligeran los requisitos para la toma del empréstito, se conceden plazos de pago extensos con una aparente licuación de la deuda, se ofrece una tasación inicial generosa de los bienes propuestos en garantía, se bancariza el sistema de pagos (con el consiguiente manejo de la deuda por el acreedor), etc;

-las prácticas calificadas como exceso de crédito.

Bajo este título, hacemos referencia al otorgamiento de financiación con políticas de acceso amplia, soslayando la capacidad real de pago o solvencia del consumidor.

-la ausencia de una regulación del crédito para el consumo (es el caso de Argentina) que contemple sus diferentes modalidades, el regular funcionamiento de la operatoria y la responsabilidad de los sujetos involucrados frente al incumplimiento de las obligaciones asumidas, etc.

-la ausencia de control eficaz respecto de la operatoria de crédito por parte de la autoridad de aplicación ${ }^{42}$.

\section{Causas vinculadas a situaciones personales del consumidor}

Bajo esta hipótesis causal, cabe mencionar situaciones diversas por las que puede atravesar el consumidor y que determinan la imposibilidad de hacer frente a las obligaciones asumidas con anterioridad.

A título de ejemplo, nos referimos a supuestos tales como:

- la enfermedad sobreviniente del deudor o de un integrante de su grupo familiar, que compromete el salario y demás ingresos, o la disponibilidad originaria de los mismos;

- jubilación del consumidor;

- divorcio;

- nacimiento imprevisto de un hijo o de varios (partos múltiples o no);

\footnotetext{
${ }^{42}$ Nos referimos, por una parte, a las deficiencias en el control administrativo vinculado a la aprobación de las condiciones generales que permiten formalizar la financiación para el consumo, así como la falta de seguimiento de la ejecución de esos contratos. Nos preocupa, por otro lado, el escaso control de la actividad puesto en evidencia por la proliferación de entidades dadoras de crédito que operan en paralelo a los bancos y entidades financieras, principalmente abocadas a ofrecer financiamiento a sectores de bajos recursos.
} 
- fracaso de un intento de establecerse como autónomo o quiebra de negocios familiares pequeños;

- garantías otorgadas a terceros que luego son ejecutadas;

- mala gestión del presupuesto familiar. Pueden presentarse situaciones diversas, motivadas en comportamientos tales como adicción al consumo ${ }^{43}$, endeudamiento irreflexivo, uso distorsivo de las tarjetas de crédito, toma de préstamos para reembolsar otros créditos, etc.

\section{III.- Efectos del sobreendeudamiento del consumidor}

La dimensión del sobreendeudamiento, enfocada desde la perspectiva de sus consecuencias, ha sido motivo de un análisis particular especial en el Dictamen del Comité Económico Social Europeo del año $2007^{44}$.

Ahora bien, el sobreendeudamiento analizado no es una situación estrictamente personal del consumidor individual. Se proyecta e impacta en su grupo familiar, con costes adicionales -patrimoniales y no patrimoniales- que deben ser de prioritaria atención ${ }^{45}$.

El estado de sobreendeudamiento y la insolvencia consecuente colocan al consumidor y a su familia en un status de marginalidad, de innegable exclusión social, que puede dejarlos fuera del escenario del mercado, negándoles el acceso a los bienes y el goce

\footnotetext{
${ }^{43}$ Para un desarrollo de esta interesante arista del problema, ver ARIAS CAU, Esteban-BAROCELLI, Sebastián, "Sobreendeudamiento y adicción al consumo", Ponencia presentada en las XXIV ${ }^{\circ}$ Jornadas Nacionales de Derecho Civil celebradas en la Facultad de Derecho de la Universidad de Buenos Aires entre los días 21 y 23 de setiembre de 2013. Asimismo, Aravena, Patricia-Herrera, Viviana-Poblete, Pedro-Vera, Daniel, "Consumo patológico: compra impulsiva y compulsiva” Documento presentado para la asignatura Psicología Económica a cargo de la profesora Doctora MARIANEL DENEGRI, de la Universidad de La Frontera, Chile.

${ }^{44}$ Este documento comunitario, al igual que otros antecedentes normativos, serán objeto de un análisis minucioso ut infra, por su gran significación institucional y por la riqueza de su contenido.

45 Ver las profundas reflexiones que esboza el autor en, ALEGRÍA, Héctor, "Aspectos humanos no patrimoniales en la insolvencia”, LL 2008-F, 1134. Dice ALEGRÍA: "no puede dudarse que en una situación de crisis provocada por la insolvencia, la estabilidad emocional y el impacto psicológico consiguiente son significativos". El citado jurista relaciona esta preocupación con la temática de los derechos humanos, al entender que el endeudamiento y sus vicisitudes no deben comprometer el derecho a la vida, a la salud y a gozar de un medioambiente sano. Advierte que el impacto personal y familiar derivado de la insolvencia no puede ser ignorado por el legislador pues se trata del "entorno humano y social que integra el mundo en que se desenvuelve la situación de crisis y su resolución”.
} 
de derechos esenciales. Los efectos del endeudamiento excesivo se hacen ver en la economía doméstica del deudor que, con el salario comprometido, con la vivienda familiar en riesgo, sin recursos adicionales y sin crédito, no tiene presente ni futuro.

Sin perjuicio de un desarrollo más extenso en otro capítulo, no podemos sino señalar que el tratamiento de la problemática impone una perspectiva de análisis particular, vinculada a la lógica argumental de la teoría de los derechos humanos. Los organismos internacionales vienen advirtiendo que el sistema económico que impulsa el crecimiento de la producción y la distribución pero empobrece a crecientes sectores de la población constituye una masiva y flagrante violación de derechos humanos ${ }^{46}$, en tanto se desentiende del derecho que se reconoce a todos y a cada uno, a alcanzar un nivel de vida digno y a participar en un desarrollo económico (art. 25 de la Declaración Universal de los Derechos Humanos; art. 11 del Pacto Internacional de Derechos Económicos, Sociales y Culturales; art. 1 de la Declaración sobre Derecho al Desarrollo adoptada por Resolución 41/128 de la Asamblea General de las Naciones Unidas).

Parafraseando a LORENZETTI, diremos que las catástrofes económicas suelen conducir a tragedias sociales y que la superación de estas crisis impone una mirada global puesto que no pueden ser resueltas en un esquema de razonamiento que no contemple el sistema, sus causalidades complejas y las responsabilidades plurales y diversas ${ }^{47}$.

El Dictamen del Comité Económico Social Europeo del año 2014 insiste en que el sobreendeudamiento de los consumidores no debe ser enfocado desde una perspectiva simplista, como un problema individual, "puesto que en la actualidad es el reflejo de una crisis social y de sociedad" (punto 2.3). En esa línea de razonamiento, se señala que "la

\footnotetext{
${ }^{46}$ DESPOUY, Leandro, "Informe final sobre los derechos humanos y la extrema pobreza" presentado ante la Comisión de Derechos Humanos del Consejo Económico y Social de las Naciones Unidas (file:///C:/Documents\%20and\%20Settings/Belen/Escritorio/DERECHOS\%20HUMANOS.pdf) Fecha de consulta 6/7/2015).

presentado sucede con los efectos de las crisis económicas, que generalmente afectan de inmediato y con mayor vigor a las capas más desposeídas de la población

47 Conferencia pronunciada por el Presidente de la Suprema Corte de Justicia de la Nación, Ricardo LORENZETTI, en el $\mathrm{VI}^{\circ}$ Congreso de la Red Latinoamericana de Ministerios Públicos Ambientales celebrado el 4 de Diciembre de 2014 en la Facultad de Derecho y Ciencias Sociales de la Universidad de Buenos Aires. El título de la disertación fue "Catástrofes ambientales y tragedias sociales".
} 
lucha contra el sobreendeudamiento de los consumidores y la prevención de la exclusión social son un enfoque holístico. Este fenómeno no puede combatirse de manera eficaz con medidas aisladas y no coordinadas a escala europea. Resulta indispensable que los consumidores, las administraciones públicas y las empresas cooperen en mayor grado, a fin de poner en marcha métodos más creativos y eficaces" (punto 7.3). 


\section{Segunda Parte:}

\section{IV.- La problemática del sobreendeudamiento en el Derecho Comparado}

\section{A.- En el ámbito de la Unión Europea:}

En el ámbito de la Unión Europea, la preocupación por el tema no es nueva. Pero pese a la innegable decisión de encarar la tarea y a que se ha transitado ya un camino ${ }^{48}$, sigue siendo un anhelo el dictado de una regulación comunitaria especial vinculada a la problemática sobreendeudamiento de las personas físicas ${ }^{49}$.

El Consejo de la Unión Europea, mediante la Resolución del 13/7/92 sobre "futuras prioridades del desarrollo de la política de protección de los consumidores", se pronunció por primera vez, señalando como una necesidad prioritaria, la investigación sobre el endeudamiento excesivo. En su dictamen del 26/11/92, el Comité Económico Social ya señalaba que pese a "la dimensión comunitaria de la problemática", las cuestiones vinculadas al sobreendeudamiento del consumidor...no han dado lugar aún a iniciativas legislativas comunitarias".

Recién en mayo de 1999, y de la mano del propio CES, se planteó un nuevo debate sobre el tema, mediante la elaboración de un documento informativo sobre el sobreendeudamiento de los hogares.

El Consejo de Ministros, celebrado en Luxemburgo el 13/4/2000, propuso una discusión sobre la problemática del endeudamiento excesivo, motivo por el cual la Comisión ordenó la elaboración de un estudio estadístico del fenómeno y un relevamiento y análisis de las legislaciones que en materia de endeudamiento, existían en los Estados

\footnotetext{
${ }^{48}$ Dice Clara FERNÁNDEZ CARRÓN: "Nada impide afirmar que existe a nivel comunitario una política concreta para combatir este problema... aunque basada en declaraciones pragmáticas que no se han visto plasmadas por el momento, en ninguna regulación global concreta" (FERNÁNDEZ CARRón, Clara, El tratamiento de la insolvencia..., cit., pág. 21).

49 Ver el prolijo desarrollo que del tema hace TRUJILlo DíEZ, Iván Jesús, El sobreendeudamiento de los consumidores ..., cit., pág. 25 y sgtes. Ver asimismo, AlvÁrez VEGA, María Isabel, Protección jurídica del consumidor..., cit., pág. 56 y sgtes., y GuTIÉRREZ DE CABIEDES, Pablo, El sobreendeudamiento doméstico..., cit., pág. 65 y sgtes.
} 
miembros. Los resultados de ambos estudios significaron una valiosa contribución para los documentos comunitarios posteriores.

El Comité Económico Social emitió en el año 2002 un primer dictamen ${ }^{50}$, en el que se concluyó que:

“a) el fenómeno del sobreendeudamiento se ha generalizado en todos los países de la Unión Europea y está ya presente en los países en vías de adhesión, teniendo tendencia a agravarse con la cobertura de las fronteras y el comercio transfronterizo;

b) la mayoría de los países de la Unión Europea ha concebido y aplicado, a escala nacional, sistemas de prevención y rectificación de las situaciones de sobreendeudamiento diferentes, divergentes, incluso contradictorios, tanto en términos de derecho sustancial como de procedimientos judiciales y administrativos;

c) estas diferencias constituyen barreras al desarrollo del crédito transfronterizo y a la realización misma del mercado único, en la medida en que no contribuyen a garantizar la confianza necesaria de los protagonistas económicos en las potencialidades y los beneficios del mercado interior; d) por ello, es deseable realizar un esfuerzo de armonización de los aspectos jurídicos vinculados al sobreendeudamiento...".

En mérito a estas conclusiones, el CESE formula las recomendaciones que a continuación se transcriben, por su gran importancia:

-a la Comisión:

“a) proceder a la divulgación oficial inmediata de los estudios que encargó sobre los aspectos estadísticos y al lanzamiento de un nuevo concurso para la elaboración de un estudio relativo al derecho comparado que regula el sobreendeudamiento en Europa;

b) preparar, cuanto antes, un Libro Verde que analice las consecuencias de la situación actual en la perspectiva de la realización del mercado interior;

c) proponer medidas de armonización del marco legal de prevención y rectificación de las situaciones de sobreendeudamiento, tanto desde el punto de vista del derecho

\footnotetext{
${ }^{50}$ El 13/7/2000, de conformidad con el apartado 3 del art. 23 de su Reglamento Interno, el Comité Económico y Social decidió elaborar un dictamen sobre "El sobreendeudamiento de los hogares". La Sección de Mercado Único, Producción y Consumo, encargada de preparar los trabajos sobre este asunto, aprobó dicho dictamen el 8/4/2002 y en el Plenario celebrado los días 24 y 25 de abril/2002, el Comité Económico y Social sometió a votación con por 78 votos a favor, 6 en contra y 8 abstenciones. Su publicación en el Diario Oficial de la Unión Europea es del día 21/6/2002.
} 
sustancial como de los procedimientos, con arreglo a los principios de subsidiaridad y proporcionalidad...;

d) definir y establecer una red de intercambios de información entre los Estados miembros y sus servicios que permita seguir la evolución del fenómeno del sobreendeudamiento de los hogares ... con el fin de crear un observatorio europeo del sobreendeudamiento;

e) prestar una especial atención a los posibles efectos, en términos de creación o agravación de situaciones de sobreendeudamiento de los hogares, de la aprobación de medidas en distintos ámbitos de las políticas comunitarias, en particular, lo que se refiere al crédito al consumidor, y al hipotecario, a las comunicaciones comerciales, a la publicidad y a la comercialización y prácticas comerciales".

-a los Estados miembros:

“a) proseguir su acción...hasta la definición de un marco legal para un enfoque comunitario de la cuestión del sobreendeudamiento de los hogares;

b) prever la posibilidad de inscribir en un Reglamento paralelo al que definió el régimen de insolvencia para las empresas, determinados aspectos jurídicos del sobreendeudamiento (de las economías domésticas;

c) pedir a la Comisión que ... estudie y presente propuestas de armonización de la información que debe darse a los consumidores en los contratos de crédito, de la utilización de los datos relativos a la insolvencia, del papel de los intermediarios de crédito o las sociedades financieras, del régimen procesal de las ejecuciones en caso de fallo y de los procedimientos especiales de recaudación de créditos;

f) promover, desde la edad escolar, acciones de información y educación tendientes a la prevención del sobreendeudamiento".

-al Consejo y al Parlamento Europeo:

“a) asumir de forma clara e inequívoca la necesidad de llevar a cabo iniciativas, a escala de la Unión Europea, dirigidas a armonizar aspectos jurídicos del régimen de sobreendeudamiento...;

b) prever y poner a disposición los medios presupuestarios indispensables para habilitar a la Comisión a continuar el seguimiento del fenómeno del sobreendeudamiento y 
la realización de las iniciativas necesarias para la adopción de las medidas de armonización legislativa antes citadas".

Por su relevancia en el plano político, merece destacarse la Resolución del Consejo de Europa adoptada por los Ministros de Justicia Europeos, del 8/4/2005, relativa a la "búsqueda de soluciones jurídicas a los problemas de endeudamiento en una sociedad de crédito". Luego de expresar la preocupación por la problemática, se exhorta a la elaboración de un "instrumento apropiado que incluya medidas legislativas y administrativas y proponga soluciones prácticas".

La $26^{\circ}$ Conferencia del Consejo de Europa reunida en Helsinki entre los días 7 y 8 de abril del año 2005 convocada bajo el título de "Aspectos sociales de la Justicia", emitió una "Resolución relativa a la búsqueda de soluciones jurídicas al problema del endeudamiento en la sociedad de crédito", poniendo el acento en algunas de sus causas, en las manifestaciones del fenómeno y en el impacto que provoca en los diferentes los sectores sociales.

En el año 2007, el CESE emitió un segundo dictamen" ${ }^{51}$ sobre "El crédito y la exclusión social en la sociedad de la abundancia" en el que "se insta al Parlamento Europeo y al Consejo a que hagan suyas las grandes preocupaciones de la sociedad civil...y las incluya entre las prioridades de sus respectivas agendas políticas" (punto 1.8 del apartado 1 de Conclusiones y Recomendaciones).

Se reitera la conveniencia de crear "un observatorio europeo del endeudamiento que permita seguir la evolución del fenómeno a escala europea, que pueda funcionar como un diálogo de todos los interesados y que proponga, coordine y evalúe el impacto de las medidas adoptadas para prevenirlo y controlarlo” (punto 1.5 del citado apartado).

El punto 1.6 ratifica la necesidad del diálogo y el consenso "con la sociedad civil organizada en la que estén representadas la principales partes interesadas (familias, trabajadores, consumidores, instituciones financieras, etc.).

\footnotetext{
${ }^{51}$ El 16 de febrero de 2007, de conformidad con el apartado 2 del artículo 29 de su Reglamento Interno, el Comité Económico y Social Europeo decidió elaborar un dictamen sobre "El crédito y la exclusión social en la sociedad de la abundancia" que fue aprobado en Plenario del 2/10/2007 por 59 votos a favor, ninguno en contra y 1 abstención. Su publicación en el Diario Oficial de la Unión Europea es del día 16/2/2008.
} 
Nuevamente se recuerda la iniciativa de publicar "un Libro Verde que define e identifique los términos de la cuestión, en el que se le de voz a todos los interesados mediante una amplia consulta política (punto 1.7).

Este Dictamen asume el abordaje de aspectos relevantes del problema: se delinean algunos conceptos básicos, se señalan las causas principales del sobreendeudamiento, se esbozan algunas de sus consecuencias (las llamadas "dimensiones del problema") y se proponen medidas para la prevención y tratamiento.

El Dictamen mencionado asume la tarea de definir el sobreendeudamiento, advirtiendo que "el concepto no es unívoco y su definición no está exenta de dificultades" (punto 3.2.2). Expresa que el sobreendeudamiento hace referencia a "situaciones en las que el deudor se ve en la imposibilidad, de forma duradera, de pagar el conjunto de sus deudas, o expuesto a una amenaza seria de no poder hacerles frente en el momento en que sean exigibles" (punto 3.2.1).

Se pone especial énfasis en la necesidad de establecer un "concepto único de endeudamiento excesivo" a escala comunitaria, expresando que "el esfuerzo de armonización debe hacer hincapié ... en la definición del concepto y de los parámetros cualitativos y cuantitativos del fenómeno, para permitir una adecuada información y observación de las realidades sociales subyacentes, de manera comparable en toda Europa (y sería deseable que en todo el mundo), basándose en la recogida y el tratamiento de datos estadísticos comparables que permitan la definición de un modelo económico para la cuantificación del fenómeno".

Siguiendo estudios sociológicos encarados en distintos Estados miembros, el Dictamen menciona las principales causas del endeudamiento excesivo (punto 4). Se advierte que el catálogo propuesto no responde a ningún criterio de clasificación sino que se presenta como un menú de situaciones disparadoras del sobreendeudamiento que se puntualizan in concreto ${ }^{52}$.

\footnotetext{
${ }^{52}$ Se menciona: "a) el desempleo y el deterioro de las condiciones laborales; b) las modificaciones de la estructura del agregado familiar, como, por ejemplo, el divorcio, la muerte de un cónyuge, el nacimiento imprevisto de un hijo, la obligación inesperada de prestar apoyo a personas mayores o discapacitadas, una enfermedad o un accidente; c) fracaso de un intento de establecerse como autónomo y quiebra de pequeños negocios familiares para los que se prestaron garantías personales; d) incentivos excesivos al consumo y al recurso a créditos fáciles, a los juegos de azar y a la inversión en bolsa, así como la promoción de un
} 
El Dictamen dedica un apartado especial al tema de la "dimensión del problema" (punto 3), mencionando entre las consecuencias más relevantes y preocupantes, a la exclusión social, "que empuja al individuo hacia los márgenes de la sociedad y alimenta sentimientos de rechazo y autoexclusión" ${ }^{, 53}$.

Luego de reseñar las medidas adoptadas en algunos de los Estados miembros, tanto para la prevención como para el saneamiento del endeudamiento doméstico, insiste en establecer en "términos legislativos" y de "manera autónoma y armonizada", cuáles serían las medidas de acción a desplegar en el ámbito comunitario.

Entre las medidas de prevención (cfr. punto 6.3.2.1), recomienda atender a los siguientes aspectos:

a) información exhaustiva previa al contrato, ...y acompañamiento postventa;

b) corresponsabilidad en la concesión del crédito, basada en la doble asunción de obligaciones: la obligación que incumbe al solicitante de informar con veracidad al otorgante del crédito sobre su situación; y la obligación por parte de este último de hacer todo lo posible por evaluar correctamente la solicitud y aconsejar cabalmente al primero; c) posibilidad de transferir los créditos sin gastos;

determinado tren de vida en la publicidad y la comercialización; e) el aumento de los tipos de interés, cuyo efecto negativo se hace sentir, sobre todo, en los créditos a largo plazo como el crédito hipotecario; f) mala gestión del presupuesto familiar; g) ocultación deliberada por parte del cliente de información importante para que las instituciones financieras puedan evaluar su solvencia; h) recurso excesivo a la tarjeta de crédito, al crédito renovable y a las modalidades de crédito personal concedido por sociedades financieras con tipos de interés elevados; i) obtención de créditos en el mercado informal, sobre todo por personas con bajos ingresos, tipos de interés usurarios; j) créditos utilizados para reembolsar otros créditos; k) la circunstancia de que las personas con discapacidades y socialmente aisladas o con las facultades cognitivas limitadas pueden convertirse fácilmente en víctimas de entidades de crédito agresivas; 1) la falta de voluntad de determinadas instituciones financieras para renegociar con los consumidores de menos ingresos el pago de las deudas en situaciones de dificultad financiera”.

${ }^{53}$ El punto 3.1.4 dice: "La amplitud y las formas que puede adoptar la exclusión social dependen, en cada país, de distintas variables, como el sistema de seguridad social, el comportamiento del mercado de trabajo, el funcionamiento de la justicia y las redes informales de solidaridad. Los inmigrantes, las minorías étnicas, las personas mayores, los niños menores de quince años, las personas con rentas bajas y bajo nivel de escolaridad, las personas con discapacidad y los parados son algunos de los grupos más vulnerables al riesgo de pobreza y exclusión social”. 
d) supervisión de la publicidad, la mercadotecnia y las comunicaciones comerciales relativas al crédito al consumo;

e) parámetros del sistema de calificación del riesgo crediticio y prohibición de decisiones adoptadas por métodos exclusivamente automatizados;

f) garantía de un servicio bancario básico y de la universalidad de la cuenta bancaria y su transferibilidad, así como de la utilización de medios electrónicos para movimientos de cuentas (tarjetas de débito);

g) definición de parámetros para el microcrédito y otros tipos de crédito social y fomento de instituciones financieras alternativas que trabajen en estos sectores del mercado;

h) detección y sanción de prácticas comerciales desleales y de cláusulas abusivas relacionadas específicamente con la concesión de créditos;

i) derecho a retractarse; j) delimitación de la exigencia de garantías personales colaterales;

k) normas sobre las comisiones;

1) régimen de los intermediarios de crédito;

m) refuerzo de las competencias y las medidas de supervisión de las autoridades nacionales competentes en el ámbito de los servicios financieros;

n) fijación de parámetros para la definición de los niveles de usura;

o) incluir en la Directiva sobre el crédito al consumo una disposición mediante la que se obligue a los bancos a responder, en un plazo determinado, a las reclamaciones".

Con especial rango de importancia recomienda "a largo plazo ... elaborar normativas sobre los siguientes aspectos: a) sistema uniforme de seguros de carácter social; b) garantía de sostenibilidad de los regímenes de pensiones y su aplicación uniforme en todos los Estados miembros; c) definición de un sistema único de ficheros de crédito, con una garantía total de protección de los datos personales, incluida la delimitación de quién puede acceder y a qué fines se destina la información (exclusivamente para la concesión de créditos)".

Con idéntica finalidad preventiva, se recomienda a la Comisión: “a.- estimular las buenas prácticas en la materia, fomentado la adopción de códigos europeos de conducta, con sistemas de autorregulación o de corregulación, en el marco de un régimen jurídico coercitivo bien definido y efectivamente aplicado; b.- "desarrollar, en colaboración con los Estados miembros, programas específicos de información, acciones de educación centradas 
específicamente en aspectos prácticos de la utilización del crédito y experiencias de acompañamiento y de asesoramiento sobre este tema".

Respecto de las medidas de tratamiento y recuperación del sobreendeudamiento (punto 6.3.3.1), destaca que "habida cuenta de la diversidad de los sistemas creados a nivel nacional, con orígenes, principios y métodos diferentes, el esfuerzo de la Comisión deberá centrarse prioritariamente no en un intento de armonización, sino más bien en la definición de un marco de referencia y un conjunto de principios fundamentales...”.

Conforme el punto 6.3.3.2 del Dictamen, los principios a seguir son:

- "soluciones rápidas y próximas a las partes, sin costes o con costes mínimos;

- medidas que tengan en cuenta los intereses legítimos de los acreedores, pero también su responsabilidad en el nivel de endeudamiento de las familias;

- soluciones que favorezcan el consenso y la celebración de acuerdos extrajudiciales voluntarios de pago que en la medida de lo posible permitan la conservación de los bienes fundamentales para el bienestar de la familia, como la vivienda;

- medidas flexibles que permitan, en los casos más graves, optar por la liquidación de los bienes pignorables, junto con la condonación de las deudas no pagadas, y que tengan la debida consideración de la situación de terceros que hayan actuado como garantes de los deudores;

- acompañamiento especializado de los deudores durante la etapa de cumplimiento de los planes de pago posterior a la quiebra, a fin de evitar la reincidencia y ayudarles a modificar sus modelos de consumo y de endeudamiento...”.

La Directiva 2008/48/CE, de contratos de crédito al consumo, significó un aporte relevante para el tratamiento de la problemática a nivel comunitario ${ }^{54}$.

\footnotetext{
54 En el ámbito de la Unión Europea se dictó la Directiva 87/102 CEE, del 22/12/86, orientada a la armonización de las disposiciones legales, reglamentarias y administrativas de los Estados miembros, en materia de crédito al consumo. Las recomendaciones emanadas de la Directiva significaron un eficaz impulso para que los Estados miembros diseñaran políticas de tutela de los consumidores y dictaran leyes que se ocuparan de la problemática del crédito para el consumo. Sin embargo, no fueron pocos los que alzaron su voz para poner en evidencia que la Directiva, si bien perseguía una finalidad loable, su eficacia protectoria podía verse comprometida. Es que la norma comunitaria delegaba en los Estados miembros (art 11.2), la tarea de precisar los requisitos que debía satisfacer el consumidor para el ejercicio de los derechos allí reconocidos y la extensión de los mismos. El desarrollo y evolución de la operatoria del crédito al consumo,
} 
Pese a tratarse de una normativa comunitaria abocada a la regulación de una arista particular del sobreendeudamiento, por vía de la misma los Estados miembros se ven impuestos de adoptar medidas de acción, fundamentalmente de carácter preventivo, que venían siendo reclamadas con insistencia.

Con el objeto de armonizar las disposiciones legales y sus alcances, el legislador comunitario consideró conveniente ofrecer definiciones que delimitaran el ámbito de aplicación y crearan consenso sobre ciertos conceptos básicos.

El art. 3 de la Directiva 2008/47/CE define, entre otras, las figuras del "consumidor", "prestamista", "contrato de crédito" e intermediario de crédito", así como lo que debe entenderse por "coste total del crédito", "importe total adeudado", tasa anual equivalente", "tipo deudor", "tipo deudor fijo", “importe total del crédito", "soporte duradero", "contrato de crédito vinculado", etc.

El Capítulo II de la Directiva está dedicado a la "información y prácticas previas a la celebración del contrato de crédito" y en ese marco, el art. 4 establece cuál es la "información básica que deberá figurar en la publicidad"

así como la necesidad de evaluar los resultados de las políticas diseñadas y la eficacia de la legislación dictada en su consecuencia, impulsaron un casi inmediato proceso de revisión. Teniendo en cuenta las modificaciones que debían introducirse a la Directiva 87/102/CEE, como consecuencia de la evolución de la operatoria y el surgimiento de nuevas aristas problemáticas referidas al crédito al consumo, se entendió que aquélla debía derogarse y sustituirse por una nueva. La Directiva 2008/48 del 23 de abril de 2008 (BOE del 22/5/2008) imparte pautas renovadas, corrigiendo algunos puntos débiles marcados al modelo precedente. Para un desarrollo de los antecedentes y aporte de la norma comunitaria analizada, ver JAPAZE, María Belén, “Crédito al consumo ...," cit..

55 Dice el citado art. 4: "Información básica que deberá figurar en la publicidad 1. Toda publicidad relativa a los contratos de crédito que indique un tipo de interés o cualesquiera cifras relacionadas con el coste del crédito para el consumidor deberá incluir la información básica indicada en el presente artículo. Esta obligación no se aplicará a los casos en que la legislación nacional requiera la tasa anual equivalente en la publicidad de contratos de crédito que no indique un tipo de interés o cualesquiera cifras relacionadas con cualquier coste del crédito para el consumidor en el sentido del párrafo primero. 2. La información básica especificará los elementos siguientes de forma clara, concisa y destacada mediante un ejemplo representativo: a) tipo deudor, fijo y/o variable, junto con información sobre los recargos incluidos en el coste total del crédito para el consumidor; b) el importe total del crédito; c) la tasa anual equivalente; en el caso de los contratos de crédito indicados en el artículo 2, apartado 3, los Estados miembros podrán decidir que no es necesario estipular la tasa anual equivalente; d) en su caso, la duración del contrato de crédito; e) en el caso de 
"información precontractual que el prestamista debe proporcionar, "con la debida antelación y antes de que el consumidor asuma cualquier obligación en virtud de un contrato u oferta de crédito", ofreciendo un detalle de la misma ${ }^{56}$.

los créditos en forma de pago aplazado de un bien o servicio en particular, el precio al contado y el importe de los posibles anticipos, y f) en su caso, el importe total adeudado por el consumidor y el importe de los pagos a plazos. 3. Si la celebración de un contrato relativo a un servicio accesorio vinculado con el contrato de crédito, en particular un seguro, fuera obligatoria para obtener el crédito o para obtenerlo en las condiciones ofrecidas, y el coste de ese servicio no pudiera determinarse de antemano, dicha obligación deberá mencionarse de forma clara, concisa y destacada, junto con la tasa anual equivalente".

${ }^{56}$ La norma expresa que se "deberá especificar: a) el tipo de crédito; b) la identidad y la dirección geográfica del prestamista así como, en su caso, la identidad y la dirección geográfica del intermediario del crédito implicado; c) el importe total del crédito y las condiciones que rigen la disposición de fondos; d) la duración del contrato de crédito; e) en caso de créditos en forma de pago diferido por un bien o servicio y de contratos de crédito vinculados, el producto o servicio y su precio al contado; f) el tipo deudor y las condiciones de aplicación de dicho tipo, y, si se dispone de ellos, los índices o tipos de referencia aplicables al tipo deudor inicial, así como los períodos, condiciones y procedimientos de variación del tipo deudor. Si se aplican diferentes tipos deudores en diferentes circunstancias, la información arriba mencionada respecto de todos los tipos aplicables; g) la tasa anual equivalente y el importe total adeudado por el consumidor, ilustrado mediante un ejemplo representativo que incluya todas las hipótesis utilizadas para calcular dicha tasa; cuando el consumidor haya informado al prestamista sobre uno o más componentes de su crédito preferido, como por ejemplo la duración del contrato de crédito y su importe total, el prestamista deberá tener en cuenta dichos componentes; si el contrato de crédito prevé diferentes formas de disposición de fondos con diferentes tasas o tipos de préstamo, y el prestamista se acoge al supuesto contemplado en la parte II, letra b), del anexo I, deberá indicar que, para ese tipo de contrato de crédito, la tasa anual equivalente podría ser más elevada con otros mecanismos de disposición de fondos; h) el importe, el número y la periodicidad de los pagos que deberá efectuar el consumidor y en su caso el orden en que deben asignarse los pagos a distintos saldos pendientes sometidos a distintos tipos deudores a efectos de reembolso; i) cuando proceda, los gastos de mantenimiento de una o varias cuentas si fuera necesario para registrar a la vez las operaciones de pago y de disposición del crédito, salvo que la apertura de la cuenta sea facultativa, los gastos relativos a la utilización de un medio de pago que permita efectuar a la vez las operaciones de pago y de disposición del crédito, así como cualquier gasto derivado del contrato de crédito y las condiciones en que dichos gastos podrán modificarse; j) cuando proceda, la existencia de costes adeudados al notario por el consumidor al suscribir el contrato de crédito; k) la obligación de suscribir cualesquiera servicios accesorios vinculados con el contrato de crédito, en particular una póliza de seguros, cuando la celebración de un contrato relativo a tales servicios sea obligatoria para obtener el crédito o para obtenerlo en las condiciones ofrecidas; 1) el tipo de interés de demora así como las modalidades para su adaptación y, cuando proceda, los gastos por impago; L 133/74 ES 
Destacamos como norma de interés, que en el apartado 4 del citado art. 5, se impone al proveedor del crédito, facilitar gratuitamente al consumidor, una copia del proyecto del contrato de crédito; dispositivo que contribuye a la eficacia preventiva de la norma en análisis.

En esa misma línea protectoria, se inscribe el apartado 6 de la norma analizada, que consagra una obligación de informar reforzada, casi emparentada con el deber de asesoramiento, orientada a asistir al consumidor en la toma de su decisión de contratar ${ }^{57}$.

El art. 6 cierra este menú de deberes vinculados al deber de informar, estableciendo "requisitos de información precontractual para determinados contratos de crédito".

Centrados ya en la etapa de celebración y ejecución del contrato de crédito, la Directiva dedica varias normas a reforzar el débito informativo impuesto al agente financiero. Prueba de ello son los arts. 10 (referido a la "información que debe mencionarse en los contratos de crédito") y 11 (vinculado a la "información del tipo deudor").

Como medidas complementarias, destinadas a la prevención del riesgo que la toma del crédito pueda suponer para los intereses del consumidor, el art. 12 consagra el derecho a

Diario Oficial de la Unión Europea 22.5.2008 m) una advertencia sobre las consecuencias en caso de impago; n) cuando proceda, las garantías exigidas; o) la existencia o ausencia de derecho de desistimiento; p) el derecho de reembolso anticipado y, en su caso, información sobre el derecho del prestamista a una compensación y sobre la manera en que se determinará esa compensación con arreglo al artículo 16; q) el derecho del consumidor a ser informado de forma inmediata y gratuita del resultado de la consulta de una base de datos para la evaluación de su solvencia, conforme al artículo 9, apartado 2; r) el derecho del consumidor a recibir gratuitamente, previa solicitud, una copia del proyecto del contrato de crédito. Esta disposición no se aplicará cuando el prestamista no esté dispuesto, en el momento de la solicitud, a celebrar el contrato de crédito con el consumidor, y s) cuando proceda, el período de tiempo durante el cual el prestamista queda vinculado por la información precontractual”.

${ }^{57} \mathrm{El}$ art. 5.6 establece: “6. Los Estados miembros velarán por que los prestamistas y, cuando proceda, los intermediarios de crédito faciliten al consumidor las explicaciones adecuadas para que este pueda evaluar si el contrato de crédito propuesto se ajusta a sus necesidades y a su situación financiera, si fuera preciso explicando la información precontractual que se facilitará conforme a lo dispuesto en el apartado 1, las características esenciales de los productos propuestos y los efectos específicos que pueden tener sobre el consumidor, incluidas las consecuencias en caso de impago por parte del consumidor. Los Estados miembros podrán adaptar el modo de prestación de esta asistencia y su alcance, así como la identidad de la parte que se hará cargo de ella, a las circunstancias particulares de la situación en que se ofrece el contrato de crédito, la persona a quien se ofrece y el tipo de crédito ofrecido". 
"poner fin gratuitamente y en cualquier momento, por el procedimiento habitual, a un contrato de crédito de duración indefinida", estableciendo las condiciones de ejercicio del mismo. Regula asimismo, el ejercicio de idéntica facultad conferida al prestamista, evitando que se sorprenda al consumidor con prácticas irregulares lesivas de sus derechos ${ }^{58}$.

Otro valioso dispositivo preventivo llega de la mano del art. 14, que consagra el derecho al desistimiento del consumidor y regula las condiciones de su ejercicio ${ }^{59}$.

58 Reza el art. 13: "Contratos de crédito de duración indefinida 1. El consumidor podrá poner fin gratuitamente y en cualquier momento, por el procedimiento habitual, a un contrato de crédito de duración indefinida, a menos que las partes hayan convenido en un plazo de notificación. El plazo de preaviso no podrá exceder de un mes. Si así lo dispone el contrato de crédito, el prestamista podrá poner fin por el procedimiento habitual a un contrato de crédito de duración indefinida dando al consumidor un preaviso de dos meses como mínimo, notificado mediante documento en papel o en otro soporte duradero. 2. Si así lo dispone el contrato de crédito, el prestamista podrá, por razones objetivamente justificadas, poner fin al derecho del consumidor a disponer de cantidades de un contrato de crédito de duración indefinida. El prestamista informará al consumidor de la terminación, indicando las razones de la misma mediante notificación en papel u otro soporte duradero, en la medida de lo posible antes de la terminación y, a más tardar, inmediatamente después de ella, a menos que la comunicación de tal información esté prohibida por otro acto jurídico comunitario o sea contraria a objetivos de orden público o de seguridad pública”.

${ }^{59}$ Art. 14: "Derecho de desistimiento 1. El consumidor dispondrá de un plazo de 14 días civiles para desistir del contrato de crédito sin indicar el motivo. Este plazo de desistimiento se iniciará: a) en la fecha de suscripción del contrato de crédito, o bien b) en la fecha en que el consumidor reciba las condiciones contractuales y la información recogida en el artículo 10, si esa fecha fuera posterior a la indicada en la letra a) del presente apartado. 2. Para los contratos de crédito vinculados tal y como se definen en el artículo 3, letra n), cuando la legislación nacional ya prevea, en el momento de la entrada en vigor de la presente Directiva, que los fondos no pueden ponerse a disposición del consumidor antes del término de un período determinado, los Estados miembros podrán excepcionalmente establecer que el plazo señalado en el apartado 1 del presente artículo se reduzca a dicho período determinado a petición expresa del consumidor. 3. Si el consumidor ejerce su derecho de desistimiento, deberá: a) para que el desistimiento surta efecto, antes de que expire el plazo previsto en el apartado 1, notificárselo al prestamista ateniéndose a la información facilitada por este último de acuerdo con el artículo 10, apartado 2, letra p), por medios que puedan ser probados de conformidad con la legislación nacional. Se considerará que se ha respetado el plazo si la notificación se ha enviado antes de la expiración del plazo, siempre que haya sido efectuada mediante documento en papel o cualquier otro soporte duradero a disposición del prestamista y accesible para él, y b) pagar al prestamista el capital y el interés acumulado sobre dicho capital entre la fecha de disposición del crédito y la fecha de reembolso del capital, sin ningún retraso indebido a más tardar a los 30 días de haber enviado la notificación de desistimiento al prestamista. Los intereses adeudados se calcularán sobre la base del tipo deudor acordado. 
Por otra parte, el art. 16.1 de la Directiva reconoce el derecho al reembolso anticipado del crédito. Establece que "que el consumidor tendrá derecho a liquidar en todo momento, total o parcialmente, las obligaciones derivadas del contrato de crédito. Dispone que, en caso de hacerlo, el consumidor tendrá derecho a una reducción (equitativa) del coste total del crédito, que comprende los intereses y costes correspondientes a la duración del contrato que quede por transcurrir. En el apartado 2 del art. 16 determina que, de producirse tal reembolso anticipado, el prestamista tiene derecho a una compensación justa por los costes derivados del ejercicio de esta facultad por parte del consumidor ${ }^{60}$.

Merece destacarse el art. 15 de la Directiva, dedicado a los "contratos de crédito vinculados" pues la norma prevé soluciones para diversas hipótesis de conflicto que la

El prestamista no tendrá derecho a reclamar al consumidor ninguna otra compensación en caso de desistimiento, excepto la compensación de los gastos no reembolsables abonados por el prestamista a la administración pública. 4. En caso de que un prestamista o un tercero proporcione un servicio accesorio relacionado con el contrato de crédito sobre la base de un acuerdo entre ese tercero y el prestamista, el consumidor dejará de estar vinculado por dicho servicio accesorio si ejerce su derecho de desistimiento respecto del contrato de crédito conforme a lo dispuesto en el presente artículo. 5. Si el consumidor tiene derecho de desistimiento con arreglo a los apartados 1, 3 y 4, no se aplicarán los artículos 6 y 7 de la Directiva 2002/65/CE ni el artículo 5 de la Directiva 85/577/CEE del Consejo, de 20 de diciembre de 1985, referente a la protección de los consumidores en el caso de contratos negociados fuera de los establecimientos comerciales. 6. Los Estados miembros podrán disponer que los apartados 1 a 4 del presente artículo no se apliquen a los contratos de crédito que, por imperativo legal, se celebren ante notario, siempre que el notario confirme que se garantizan al consumidor los derechos previstos en los artículos 5 y 10. 7. El presente artículo se entenderá sin perjuicio de cualquier disposición de Derecho interno que establezca un plazo antes de cuyo vencimiento no pueda comenzar la ejecución del contrato".

${ }^{60}$ La Directiva 2008/48/CE define las pautas de esa compensación, ciñéndola a los costes directamente derivados del reembolso (art. 16.2) y sólo cuando el reembolso anticipado se haya producido en un período en el que el tipo deudor sea fijo (pues en los créditos de tipo deudor variable, los costes de reembolso anticipado se repercuten en gran parte en el tipo de interés). Expresa que la determinación de su importe deberá ajustarse criterios objetivos, limitados cuantitativamente (art 16.2 segundo párrafo). Establece que si el reembolso anticipado se ha adelantado en más de un año a la terminación acordada del contrato de crédito: la compensación no podrá ser superior al $1 \%$ del importe del crédito reembolsado anticipadamente; mientras que si se ha anticipado en menos de un año, la compensación no podrá ser superior al 0,5\% del importe del crédito reembolsado anticipadamente. Por lo demás, se explicita el límite lógico de que la compensación nunca podrá exceder del importe del interés que el consumidor habría pagado si no hubiera existido cancelación o amortización anticipada. 
operatoria de crédito al consumo presenta ${ }^{61}$. Por un lado, establece que "si el consumidor ha ejercido su derecho de desistimiento conforme al Derecho comunitario respecto a un contrato de suministro de bienes o servicios, dejará de estar obligado por un contrato de crédito vinculado" (art. 15.1). Por otra parte, frente al supuesto de incumplimiento total o parcial del proveedor, dispone: "si los bienes o servicios estipulados en un contrato de crédito vinculado no son entregados, o lo son sólo en parte, o no son conformes con el contrato de suministro de bienes o servicios, el consumidor tendrá derecho de recurso contra el prestamista siempre que haya recurrido contra el proveedor y no haya obtenido de él la satisfacción a que tiene derecho con arreglo a lo dispuesto por la ley o por el contrato de suministro de bienes o servicios. Los Estados miembros establecerán en qué medida y bajo qué condiciones se podrá ejercer dicho derecho". El art. 15.3, deja a salvo "las disposiciones nacionales que asignen al prestamista una responsabilidad solidaria respecto de cualquier reclamación del consumidor contra el proveedor cuando la adquisición a este de bienes o servicios se haya financiado mediante un contrato de crédito".

${ }^{61}$ La preocupación por los riesgos que el consumo financiado y el funcionamiento de la operatoria puede suponer para los intereses del consumidor es recurrente en la doctrina autoral. Ver, MARÍn LÓPEZ, Manuel J., La compraventa financiada de bienes de consumo, Aranzadi, Elcano, 2000, pág. 55; GAVIDIA SÁNCHEZ, Julio V., El crédito al consumo (cesión y contratos vinculados), Tirant lo Blanch, Valencia, 1996, pág. 33; EsCUIN IBÁÑEZ, Irene, Las adquisiciones financiadas en el crédito al consumo, Comares, Granada 2002, pág. 22; Alvarez MARTínez, Georgina Ivón, Los grupos de contratos en el crédito al consumo, texto de la tesis doctoral de la autora, publicada en La Coruña, 2008, pág. 21; PrAT AlBEnTOSA, Lorenzo, Préstamo de consumo. Crédito al consumo, Tirant lo Blanch, Valencia, 2001, pág. 37; REYES LóPEZ, María J., "La ley de crédito al consumo”, en Derecho de consumo, Tirant lo Blanch, Valencia, 2000, pág. 213; MARTínEZ RODRÍGUEZ, Nieves, "Protección del consumidor a crédito frente al financiador", en Revista Actualidad Civil, N 17, Madrid, 1era. Quincena de octubre de 2004, pág. 2005-2032; BERGEL, Salvador D., y PAOLANTONIO, Martín R., Responsabilidad civil de las entidades financieras en las operaciones de crédito al consumo, cit., pág. 281; Bergel, Salvador D., y PAOLANTONio, Martín R., "Las letras de consumo y su problemática jurídica”, en RDCO, T. 1991-B,7; ToBÍAS, José W.., Los contratos conexos y el crédito al consumo, LL 1999-D, 992; LAGUINGE, Esteban, Los contratos de crédito ante la ley de defensa del consumidor, Ábaco, Buenos Aires, 2001, pág. 14; Weingarten, Celia-GHERSI, Carlos, "Los contratos conexados. Autofinanciamiento y compraventa”, LL. 1997-F,1348; ZENTNER, Diego H., “Operaciones de crédito al consumo", Derecho del Consumidor, № 7, pág. 87, Juris, Santa Fé, 1996; JAPAZE, María Belén, "Crédito al consumo...", cit. 
El art. 17, por su parte, contempla el supuesto de cesión de los derechos del prestamista, al sostener que "Cuando los derechos del prestamista en virtud de un contrato de crédito o el propio contrato sean cedidos a un tercero, el consumidor podrá hacer valer ante el nuevo titular las mismas excepciones y defensas que ante el prestamista original, entre ellas el derecho a una compensación si está autorizada en el Estado miembro afectado" (art. 17.1). Dispone asimismo que "se informará al consumidor de la cesión indicada en el apartado 1, excepto cuando el prestamista original, de acuerdo con el nuevo titular, siga prestando los servicios relativos al crédito al consumidor" (art. 17.2).

Como bien lo destaca GuTIÉRREZ DE CABIEDES ${ }^{62}$, pese a que no se hace declaración expresa del principio de crédito responsable, "la Directiva 2008/48/CE ... tiene como leit motiv el promover en el ámbito comunitario, prácticas responsables en todas las fases de la relación crediticia, para lo cual establece el deber de los Estados de tomar las medidas adecuadas, teniendo en cuenta las peculiaridades de cada mercado crediticio"63.

La Directiva prevé dispositivos que traducen en deberes y derechos particulares, el enunciado principio, del que constituyen una innegable aplicación.

El art. 8 es una clara muestra de la consagración normativa del principio de crédito responsable, al imponer al prestamista el deber de evaluar la solvencia del consumidor con carácter previo al otorgamiento del crédito $^{64}$ y aún luego de la celebración del contrato

\footnotetext{
62 GutiÉRREZ DE CABIEDES, Pablo, El sobreendeudamiento doméstico..., cit., pág. 71.

${ }^{63}$ En efecto, el Considerando 26 de la Directiva expresa "es importante que los prestamistas no concedan préstamos de forma irresponsable o sin haber evaluado previamente la solvencia del prestatario, y que los Estados miembros lleven a cabo el control necesario para evitar tales comportamientos, así como los medios necesarios para sancionar a los prestamistas en caso de que ello ocurra".

${ }^{64}$ El art. 8 establece: “Obligación de evaluar la solvencia del consumidor. 1. Los Estados miembros velarán por que, antes de que se celebre el contrato de crédito, el prestamista evalúe la solvencia del consumidor, sobre la base de una información suficiente, facilitada en su caso por el consumidor y, cuando proceda, basándose en la consulta de la base de datos pertinente. Los Estados miembros cuya legislación exija que los prestamistas evalúen la solvencia del consumidor sobre la base de una consulta de la base de datos pertinente deben poder mantener esta obligación. 2. Los Estados miembros velarán por que, si las partes acuerdan modificar el importe total del crédito tras la celebración del contrato de crédito, el prestamista actualice 1 a información financiera de que disponga sobre el consumidor y evalúe su solvencia antes de aumentar significativamente el importe total del crédito".
} 
originario. La misma norma compromete a los Estados a velar por el estricto cumplimiento de la mencionada obligación.

Complementa la medida antes citada, la previsión del art. 9 que se refiere al "acceso a bases de datos", impartiendo directivas que hacen a la obtención de la información que servirá para evaluar la solvencia del consumidor, a sus eventuales restricciones, a la confiabilidad de la misma, y al deber de comunicar al consumidor los resultados de la consulta cuando ella motive la denegatoria de la solicitud del crédito ${ }^{65}$.

En sesión del 28 de abril de 2010, el CESE aprobó un nuevo Dictamen sobre "Acceso al crédito para los consumidores y las familias: prácticas abusivas" de gran relevancia por la agudeza de los planteos y la firme exhortación a dar respuestas.

En dicho Dictamen se expresa que "la crisis financiera ha dado lugar a la consiguiente crisis económica que está generando graves pérdidas de puestos de trabajo, actividad económica e ingresos individuales y familiares" y que "en tal contexto se produce un aumento de las situaciones de exclusión social y financiera, así como de la pobreza".

El CESE destaca que "para los consumidores y las familias, el crédito es un instrumento importante que les permite hacer frente a compras indispensables para una vida normal y ordenada. En este sentido, el acceso al crédito, con un coste razonable, es un instrumento esencial para la inclusión social. No obstante, el crédito no debe considerarse ni presentarse como sustituto ni como complemento de los ingresos de los consumidores y las familias". Y de allí que "el mayor reto de la política económica, fiscal y social es garantizar el acceso responsable al crédito, sin crear situaciones de dependencia”.

\footnotetext{
${ }^{65}$ Dice el art. 9: "Acceso a bases de datos. 1. Cada Estado miembro garantizará que los prestamistas de los demás Estados miembros tengan acceso a las bases de datos utilizadas en su territorio para la evaluación de la solvencia de los consumidores. Las condiciones de acceso deberán ser no discriminatorias. 2. Si la denegación de una solicitud de crédito se basa en la consulta de una base de datos, el prestamista informará al consumidor inmediata y gratuitamente de los resultados de dicha consulta y de los pormenores de la base de datos consultada. 3. La información deberá facilitarse a menos que esté prohibido por otras disposiciones de la legislación comunitaria o sea contrario a objetivos de orden público o de seguridad pública. 4. El presente artículo se entenderá sin perjuicio de la aplicación de la Directiva 95/46/CE del Parlamento Europeo y del Consejo, de 24 de octubre de 1995, relativa a la protección de las personas físicas en lo que respecta al tratamiento de datos personales y a la libre circulación de estos datos".
} 
El Dictamen menciona que "para conseguir este objetivo es necesario un marco normativo que impida actividades irresponsables de concesión y aceptación de préstamos".

En pos de ese objetivo, "el Dictamen pretende examinar el actual marco normativo para reconocer las lagunas que permiten que se produzcan esas situaciones de abuso y sugerir posibles soluciones a las autoridades públicas europeas y nacionales".

El CESE “invita a la Comisión Europea y a los Estados miembros a analizar con más profundidad los fenómenos de las prácticas ilegales y delictivas en el ámbito del crédito, con especial atención a las prácticas abusivas y usureras".

Recomienda "definir una norma específica europea que abarque los distintos tipos de intermediarios crediticios en la que se detallen las definiciones, requisitos y obligaciones de actuación, con independencia del producto comercializado y de que la actividad crediticia desarrollada sea de naturaleza principal o secundaria". Insiste en la necesidad de "una norma específica para la supervisión de las actividades, prácticas y actuaciones de quienes desarrollan la actividad de intermediación junto con otras actividades de diversa índole, como los agentes comerciales".

El CESE "pide que los requisitos para el registro de los distintos intermediarios financieros y crediticios en una red europea de registros nacionales se definan en referencia a una norma operativa europea de profesionalidad, prudencia y ética que, además, incluya disposiciones comunitarias de exclusión de determinados sujetos por conductas que perjudiquen a los consumidores o supongan prácticas abusivas o ilegales".

Se llama la atención respecto de ciertas prácticas empresarias que urge modificar y/o desterrar.

El CESE observa que "en el marco normativo actual para los contratos de crédito no existe ninguna obligación de adecuar la oferta a las necesidades de los consumidores". Esta falta de regulación ha permitido situaciones de abuso en las que los productos que se ofrecen a los consumidores resultan en ocasiones inadecuados a sus necesidades". Se piensa que "una respuesta podría ser la introducción en el mercado europeo de gamas apropiadas de productos crediticios certificados o estandarizados, que podrían completar la oferta disponible. De esta forma, los consumidores podrían encontrar más fácilmente el producto más conveniente y adaptado a sus necesidades". El Dictamen considera que esta medida permitiría "poner en marcha un sistema europeo de alerta rápida para detectar la 
introducción en el mercado financiero y crediticio europeo de productos financieros y crediticios tóxicos".

Se señala que "sería importante revisar la responsabilidad de los proveedores de crédito, a fin de limitar los productos inadecuados para las necesidades de los consumidores. Para ello se considera necesario introducir procedimientos comunes de ámbito europeo para las situaciones de sobreendeudamiento que sirvan de base para acciones públicas de asistencia y ayuda a las personas que se encuentren en situación de sobreendeudamiento a consecuencia de las prácticas abusivas seguidas por los proveedores".

Desde otro enfoque, y luego de mencionar que no en todos los países de la Unión Europea existe una regulación eficaz contra la usura, se expresa que estudios recientes han demostrado ello permitiría alcanzar "tener efectos positivos en la lucha contra la exclusión social y la pobreza".

Consideramos de particular relevancia la exhortación, a la sociedad civil, a involucrarse en la defensa de un mercado transparente y leal. El Dictamen señala que "la sociedad civil, en especial las asociaciones de consumidores y las organizaciones caritativas, ha de desempeñar un papel importante a la hora de determinar, estudiar y vigilar los problemas derivados de las prácticas abusivas e ilegales en la concesión de créditos a consumidores y familias". Se considera “importante crear y promover, en cooperación con las autoridades públicas, redes de la sociedad civil para el estudio, la asistencia y la supervisión de situaciones de exclusión social y de pobreza asociadas al crédito y sobreendeudamiento".

La gravedad de la crisis económica y financiera, agudizada a partir del año 2008, planteó un escenario más dramático aún para el conjunto social. El sector empresario y las economías domésticas se vieron altamente impactadas.

En las distintas geografías, los gobiernos adoptaron medidas propias de la situación de emergencia y el sector empresario ajustó su desenvolvimiento a la nueva realidad de crisis, implementando remedios de extrema dureza, en su intento por sobrevivir y mantenerse. Las economías particulares sufrieron las consecuencias de de aquellas medidas de emergencia y se les imponía el desafío de resistir pese a la desaparición de sus fuentes de trabajo, a la precarización del empleo, a la reducción de los salarios, etc. 
En 2013, un relevamiento del el Banco Central Europeo dio cuenta de que más de la mitad de la población de la zona del euro tenía deudas con los establecimientos financieros ${ }^{66}$, señalando con gran preocupación el particular impacto de ese endeudamiento en las economías personales y familiares.

En sesión del 29 de abril de 2014, el CESE aprobó un nuevo dictamen sobre "Protección de los consumidores y tratamiento adecuado del sobreendeudamiento para evitar la exclusión social”.

Destacó el Comité que si bien en varios Estados miembros se han puesto en marcha dispositivos de prevención destinados a gestionar las situaciones de sobreendeudamiento, resultan heterogéneos. Y de allí que deba "ponerse en marcha un procedimiento adecuado y uniforme, basado en el artículo 38 de la Carta de los Derechos Fundamentales, el artículo 114 del TFUE, o el artículo 81 del TFUE, en todos los Estados miembros, de conformidad con los principios generales propuestos por la Comisión en una propuesta de directiva, que demuestre de manera concreta el interés del Parlamento por resolver los problemas de los ciudadanos europeos". Se recomienda instrumentar procedimientos caracterizados por la rapidez y la gratuidad, con suspensión de los procesos judiciales una vez iniciado el trámite destinado a poner fin al sobreendeudamiento, la verificación de los créditos, la conservación de la vivienda principal, el tratamiento en pie de igualdad de los acreedores ordinarios, la posibilidad de cancelar la deuda en los casos más graves y la obligación de dejar a la persona sobreendeudada un mínimo para vivir suficiente para satisfacer de modo digno las necesidades de la vida diaria”.

Se hace explícita la idea de que el objetivo de estos procedimientos de saneamiento del endeudamiento excesivo, debe ser "reintegrar rápidamente al consumidor en la vida económica y social".

Consideramos de gran importancia lo considerado en el punto 4.1.1, al decir que la superación del sobreendeudamiento "no se puede lograr exclusivamente a través de la puesta en marcha de un dispositivo legislativo".

El CESE propone el diseño de políticas públicas de prevención, con particular énfasis en la educación. Expresa su deseo de que la Unión Europea ponga en marcha un

\footnotetext{
${ }^{66}$ Cfr. Banco Central Europeo, "Encuesta del Eurosistema sobre la situación financiera y el consumo de los hogares: resultados de la primera ola”, en Statistics Paper Series, abril de 2013, pág. 57 y sgtes.
} 
sistema de educación financiera que se implemente en los Estados miembros tanto por personal docente como en el marco de asociaciones públicas/privadas, incorporado a los programas de enseñanza escolar.

En esa misma línea, el Dictamen insiste en que "deben reforzarse las campañas de información y de divulgación en materia financiera". Se cree que "los diferentes actores socioeconómicos, las autoridades públicas, las ONG, las federaciones profesionales y las asociaciones de consumidores pueden ocuparse de la organización de dichas campañas. De hecho, se trata de aprovechar la complementariedad de las diferentes fuentes de información para el interés general”.

Sin eufemismos, el CESE recomienda "prevenir el sobreendeudamiento favoreciendo el préstamo responsable e imponiendo sanciones disuasorias en caso de incumplimiento de las obligaciones de información que tienen los profesionales”. Reitera la idea de que se debe evitar el sobreendeudamiento mediante la regulación del crédito y mediante el control del sector profesional del crédito a los particulares (puntos 4.2. y 4.3).

Vuelve el CESE a reclamar, en esta oportunidad, la regulación uniforme y el control de la usura.

En sesión plenaria del 15 de octubre de 2014, el CES aprobó otro dictamen, esta vez referido a "La fragilidad de los consumidores frente a las prácticas comerciales en el mercado único".

El Comité reitera una vez más su preocupación por la existencia de prácticas empresarias que, en la situación de crisis imperante, agravan las consecuencias lesivas para los consumidores.

"Se señala que "la reducción progresiva del poder adquisitivo ... de todos los consumidores ... y las dificultades financieras que atraviesan pequeñas y medianas empresas para seguir subsistiendo han llevado, en el marco de la rigidez de beneficios en el clima empresarial actual, a revisar muchas de las prácticas comerciales habituales en el mercado". "las distorsiones que las prácticas desleales introducen en el mercado han propiciado la emergencia de consumidores cautivos de su situación económica sobrevenida" sin libertad de decisión y con graves dificultades para hacer valer sus derechos". 
Ello explica que se insista la adopción de "medidas tanto de índole preventiva y de protección, como de mitigación y recuperación" (cfr. el desarrollo del apartado 1.5).

Se singular importancia es, en este marco de crisis, la Recomendación de la Comisión Europea de 12 de marzo de 2014 "sobre un nuevo enfoque frente a la insolvencia y el fracaso empresarial" (2014/135/UE).

En los considerandos se deja planteado el mapa de situación que justifica la Recomendación, al expresar que:

“...(2) Las normas nacionales en materia de insolvencia difieren considerablemente en cuanto a los procedimientos de que disponen los deudores con dificultades financieras para reestructurar sus empresas. Algunos Estados miembros tienen una serie limitada de procedimientos en los que las empresas solo pueden reestructurarse en una fase relativamente tardía, en el marco de los procedimientos formales de insolvencia. En otros Estados miembros, la reestructuración es posible en una fase más temprana pero los procedimientos disponibles no son tan eficaces como deberían o implican formalidades variables, especialmente en lo que respecta al recurso a los procedimientos extrajudiciales".

“(3) Del mismo modo, las normas nacionales que ofrecen una segunda oportunidad a los empresarios, en particular la condonación de las deudas contraídas en el curso de la actividad empresarial, varían en lo que respecta a la duración del período de condonación y las condiciones en que esta puede concederse".

“(4) Las divergencias entre los marcos nacionales de reestructuración, y entre las normas nacionales que ofrecen una segunda oportunidad a los empresarios honrados hacen que aumenten los costes y la incertidumbre a la hora de evaluar los riesgos de invertir en otro Estado miembro, fragmentan las condiciones de acceso al crédito y dan lugar a diferentes tasas de recuperación para los acreedores. Estas divergencias hacen más difícil la concepción y la adopción de planes de reestructuración coherentes para los grupos de empresas transfronterizos. En general, las divergencias pueden actuar como desincentivos para las empresas que desean establecerse en distintos Estados miembros".

“(11)... es necesario fomentar una mayor coherencia entre los marcos nacionales de insolvencia a fin de reducir las divergencias y las ineficiencias que obstaculizan la reestructuración temprana de empresas viables con dificultades financieras y la posibilidad 
de una segunda oportunidad para los empresarios honrados y, de este modo, reducir el coste de la reestructuración, tanto para los deudores como para los acreedores"

“(12) ... la eliminación de los obstáculos a la reestructuración efectiva de empresas viables con dificultades financieras contribuye a preservar puestos de trabajo y beneficia también a la economía en general. Facilitar a los empresarios una segunda oportunidad también haría que aumentaran las tasas de actividad por cuenta propia en los Estados miembros. Además, unos marcos de insolvencia eficientes permitirían evaluar mejor los riesgos de las decisiones sobre préstamos y empréstitos, y facilitarían la adaptación de las empresas sobreendeudadas al reducir al mínimo los costes económicos y sociales derivados de sus procesos de desapalancamiento".

Conforme el apartado I. 1, "el objetivo de la presente Recomendación es animar a los Estados miembros a establecer un marco que permita la reestructuración eficiente de las empresas viables con dificultades financieras, y ofrecer una segunda oportunidad a los empresarios honrados, con el fin de fomentar el espíritu empresarial, la inversión y el empleo, y contribuir a reducir los obstáculos para el buen funcionamiento del mercado interior".

Bajo el título "Marco de reestructuración preventiva" (apartado III), la Recomendación dispone: "6. Los deudores deberían disponer de un marco que les permita reestructurar sus empresas a fin de evitar la insolvencia. Dicho marco debería contener los siguientes elementos:

a) el deudor debería ser capaz de realizar la reestructuración en una fase temprana, tan pronto como sea evidente la probabilidad de insolvencia;

b) el deudor debería mantener el control de la gestión corriente de su actividad;

c) el deudor debería tener la posibilidad de solicitar la suspensión temporal de las acciones de ejecución individuales;

d) un plan de reestructuración adoptado por la mayoría prevista en la legislación nacional que sea vinculante para todos los acreedores, siempre que el plan sea confirmado por un órgano jurisdiccional;

e) la nueva financiación necesaria para la ejecución de un plan de reestructuración no debería ser declarada nula, anulable o no ejecutable como un acto perjudicial para el conjunto de los acreedores. 
El punto 7 del mismo apartado dispone: "El procedimiento de reestructuración no debería ser largo ni costoso, y debería ser flexible para permitir la adopción de medidas extrajudiciales. La intervención del órgano jurisdiccional debería limitarse a lo necesario y ser proporcionada, a fin de salvaguardar los derechos de los acreedores y de otras partes interesadas que resulten afectadas por el plan de reestructuración”.

En el punto 10 la Comisión recomienda: "Los deudores deberían tener derecho a solicitar al órgano jurisdiccional la suspensión temporal de las acciones de ejecución individuales (en lo sucesivo, «la suspensión») presentadas por los acreedores, incluidos los acreedores preferentes y con garantía, que podrían de otro modo ensombrecer las perspectivas del plan de reestructuración. La suspensión no debería interferir en la ejecución de los contratos en curso".

Dado que se trata de una de las ideas eje de la Recomendación, la Comisión dedica un desarrollo particular a la salida consensuada de la crisis (planes de reestructuración de deuda):

“15. Los Estados miembros deberían garantizar que los órganos jurisdiccionales confirmen los planes oportunamente $y$, en principio, mediante procedimiento escrito. Los Estados miembros deberían establecer disposiciones claras y específicas sobre el contenido de los planes de reestructuración. Los planes de reestructuración deberían contener una descripción detallada de los elementos siguientes:

a) la identificación clara y completa de los acreedores que resultarían afectados por el plan;

b) los efectos de la reestructuración propuesta sobre las deudas individuales o categorías de deudas;

c) la postura adoptada por los acreedores afectados sobre el plan de reestructuración;

d) en su caso, las condiciones para la nueva financiación;

e) las posibilidades de que el plan evite la insolvencia del deudor y garantice la viabilidad de la actividad empresarial".

Respecto de los efectos del plan de reestructuración se recomienda en el punto 25 : "Los planes de reestructuración que se adopten por unanimidad de los acreedores afectados deberían ser vinculantes para todos ellos". En el punto 26 se agrega: "Los planes de reestructuración que hayan sido confirmados por un órgano jurisdiccional deberían ser vinculantes para cada uno de los acreedores afectados e identificados en el plan". 
Como se anticipara, el reconocimiento de una segunda oportunidad, merced a la liberación del pasivo insatisfecho, constituye otro de los pilares de la Recomendación.

En el punto 30, se expresa que "Los efectos negativos de la insolvencia para los empresarios deberían limitarse a fin de darles una segunda oportunidad. A los empresarios se les deberían condonar totalmente las deudas incursas en la insolvencia en un plazo máximo de tres años a partir de:

a) en el caso de un procedimiento que concluya con la liquidación de los activos del deudor, la fecha en que el órgano jurisdiccional decidió, previa petición, iniciar el procedimiento de insolvencia;

b) en el caso de un procedimiento que incluya un plan de reembolso, la fecha en que se inició la aplicación del plan de reembolso;"

“31. Al expirar el período de condonación, a los empresarios se les deberían condonar de sus deudas sin necesidad, en principio, de volver a recurrir a un órgano jurisdiccional".

“32. La condonación total tras un breve plazo no siempre es conveniente. Por ello, los Estados miembros deberían tener la posibilidad de mantener o introducir disposiciones más exigentes que resulten necesarias para: a) disuadir a los empresarios que han actuado de forma deshonesta o de mala fe, tanto antes como después de la iniciación del procedimiento de insolvencia; b) disuadir a los empresarios que no se adhieran a un plan de reembolso o a cualquier otra obligación jurídica prevista para garantizar los intereses de los acreedores, o c) garantizar los medios de subsistencia del empresario y su familia al permitirle conservar determinados activos".

Al finalizar, la Comisión lanza su exhortación, al expresar en el punto 35: "Se ruega a los Estados miembros que apliquen los principios establecidos en la presente Recomendación”.

Esta Recomendación es de gran relevancia "no sólo por lo que representa en orden a una armonización del Derecho Europeo de insolvencias, sino porque, además, recoge lo que parece constituir un nuevo paradigma en materia de insolvencia empresarial, ... que será determinante de un nuevo sistema y que parece estructurarse en torno a dos ideas 
básicas: prevalencia de soluciones precontractuales y contractuales de reestructuración y mecanismos de segunda oportunidad para el empresario persona física" ${ }^{\text {}}$.

Se espera el impacto de esta Recomendación en el Derecho interno de los Estados Miembros, especialmente en aquellos que arrastran asignaturas pendientes por ausencia de regulación o por no ajustarse a los estándares recomendados,

El punto 36, al cierre del instrumento analizado, prevé: "La Comisión evaluará la aplicación de la presente Recomendación en los Estados miembros a más tardar el 14 de septiembre de 2015. En este contexto, la Comisión evaluará su impacto en el rescate de empresas con dificultades financieras y en la segunda oportunidad que se da a los empresarios honrados, su interacción con otros procedimientos de insolvencia en otros aspectos como los plazos de condonación para las personas físicas que no ejerzan una actividad comercial, industrial, artesanal o profesional, su impacto en el funcionamiento del mercado interior, en las pequeñas y medianas empresas y en la competitividad de la economía de la Unión. La Comisión también evaluará la necesidad de proponer nuevas medidas para consolidar y reforzar el enfoque adoptado en la presente Recomendación”.

\section{B.- En el Derecho interno de los países europeos: tres modelos}

Nos proponemos en este apartado, detener la mirada en sólo algunos de los modelos de regulación propuestos en los países europeos.

No se trata de pasar revista por las distintas geografías a modo de turismo jurídico ${ }^{68}$ sino de poner sobre la mesa de trabajo, para su análisis crítico, aquellos productos

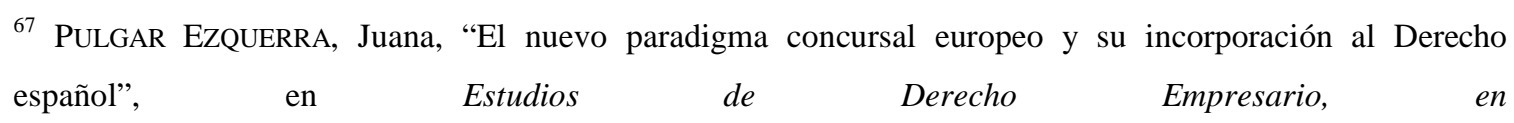
http://revistas.unc.edu.ar/index.php/esdeem/article/view/8812 (fecha de consulta: 10/2/2015). En opinión de Pulgar Ezquerra, "el planteamiento del tema en la Recomendación de 14 de marzo de 2014 es innovador y progresista, frente al tradicional planteamiento de los mecanismos de condonación por los que se ha optado en los países europeos, que hasta este momento han introducido estos mecanismos. En efecto, en la Recomendación parece que se endurecen las condiciones personales exigidas no sólo para el acceso al beneficios de los mecanismos exoneratorios (test de discharge), sino también para su mantenimiento (de empresarios deshonestos o con mala fe tanto antes como después de la insolvencia se habla en el $n^{\circ} 32$ de la Recomendación), pero a la vez se amplían y flexibilizan notablemente las deudas comprendidas bajo el ámbito de la exoneración, así como el período de concesión de dicha condonación”. 
legislativos que resultan más representativos dentro de las opciones regulatorias del fenómeno del sobreendeudamiento en general, y del consumidor en particular.

Una corriente de opinión sostiene que la visión europea originaria, considera al sobreendeudamiento de los consumidores como un problema social y no esencialmente de mercado. De allí que se entendiera que las soluciones a la exclusión y marginalidad derivadas, debían ajustarse al modelo propio del Estado de bienestar. Conforme este enfoque, la regulación del problema debía estar vinculada a programas de asistencia social, para sostener a las personas afectadas y procurarles la satisfacción de sus necesidades básicas y prioritarias ${ }^{69}$. En mérito a esta perspectiva, el sistema europeo no asumió de inicio, un criterio aperturista tratándose de procesos de insolvencia para las personas físicas. $\mathrm{Y}$ en sus previsiones legales, el saneamiento y superación del sobreendeudamiento se diseñó con procedimientos de reestructuración de deuda en los que se imponía la negociación del deudor con sus acreedores y el tránsito por planes de pago obligatorios ${ }^{70}$, como requisitos necesarios.

Se señala que la mora en el abordaje de mecanismos de liberación de deuda en sentido estricto por parte del legislador, se explica -entre otros factores- en la apreciación de que las prestaciones del Estado social de bienestar han sido notablemente superiores en los países europeos -respecto de los Estados Unidos, por ejemplo- y que ello permitió al consumidor sortear en mejores condiciones una situación económica adversa ${ }^{71}$. Se

${ }^{68}$ Expresión que acuña el Profesor Juan Ignacio PEINADO GRACIA cuando cuestiona el sinsentido de esta práctica, si no luce justificada.

${ }^{69}$ ANCHÁVAL, Hugo, Insolvencia del consumidor, cit., pág. 26 y 88.

${ }^{70}$ NIEMI-KIESILÄINEN, Johanna, "Construcciones de acreedores y deudores en la quiebra del consumidor" $L a$ quiebra del consumidor en perspectiva global, Hart Publishing, 2003, pág. 41 y sgtes.

${ }^{71}$ Pulgar EZQuerRa, Juana, "Concurso y consumidores en el marco del Estado Social del Bienestar" en Revista de Derecho Concursal y Paraconcursal, № 9, Sección Estudios, segundo semestre de 2007, pág. 43 y sgtes. "Los Estados Unidos han ofrecido históricamente a sus ciudadanos necesitados económicamente una asistencia gubernamental menos generosa, comparada con la mayoría de las democracias occidentales. Al mismo tiempo, la normativa concursal estadounidense ha sido relativamente más generosa que la de sus países homólogos, lo que constituye una paradoja que no es una simple coincidencia" (SENENT MARTínEZ, Santiago, Exoneración del pasivo insatisfecho y concurso de acreedores, tesis doctoral inédita, cit., pág. 261; http://eprints.ucm.es/28133/1/T35661.pdf) (Fecha de consulta: 20/4/2015). Para un desarrollo de estas ideas, ver las interesantes consideraciones de LAWLESS, Robert, y WARREN, Elizabeth., "Los cambios de la 
interpreta que "las normas sobre concurso de consumidores son una parte crítica de una red más amplia de seguridad social ${ }^{72}$ " y que para compensar en parte el mezquino nivel de asistencia pública, algunos Estados ofrecen una mayor apertura de las normas concursales, propiciando en el marco de sus procedimientos, la descarga del pasivo que afecta sus economías particulares (como sería el caso de Estados Unidos).

La elección de los ordenamientos europeos analizados no es azarosa. Consideramos que el modelo francés y el alemán, corporizados en sus respectivas legislaciones, traducen un paradigma regulatorio propio, ponen en ejecución políticas de gobierno particulares y proponen un plan de acción concreto y diferenciado. Todo ello, sin perjuicio de los puntos de contacto innegables. La referencia a la regulación italiana nos permite constatar la transferencia de esos modelos y la recepción de su evolución dada su consagración posterior.

No ignoramos la existencia de otras regulaciones en países europeos que presentan matices de interés pero en esta propuesta de revista, nos permitimos seleccionar aquellas que, por su carácter representativo y por su actualidad en el proceso evolutivo, sirven principalmente al objetivo propuesto.

La regulación francesa se construye como un capítulo del Código de Consumo, fragmenta el supuesto de hecho y ofrece escenarios de actuación diferenciados. El tránsito por el procedimiento en sede administrativa caracteriza el diseño de sus remedios frente al sobreendeudamiento de las personas físicas no comerciantes. Y lo combina, en su caso, con el procedimiento judicial previsto al efecto, con notas típicas y diferenciadas. La regulación alemana, emplaza sus respuestas en la ley falencia y las enmarca en el proceso judicial respectivo. Se amplía el supuesto de hecho y prevén mecanismos directos e indirectos de liberación de deuda, con particularidades que merecen ser analizadas en concreto.

La revisión de estos modelos y sus sistemas regulatorios nos permitirá indagar acerca de sus fundamentos, analizar el modo en que el legislador de cada país diseñó los

normativa concursal estadounidense en 2005: reduciendo parte de la red de seguridad", Revista de Derecho Concursal y Paraconcursal, nº 6, 2007, pág. 405-412. Asimismo, LAWLESS, Robert, "La Ley concursal estadounidense de 2005. Cómo llegamos a ella y hacia dónde vamos”, Revista de Derecho Concursal y Paraconcursal, 2008, pág. 99-111.

72 SENENT MARTÍNEZ, Santiago, Exoneración del pasivo insatisfecho y concurso de acreedores, tesis doctoral inédita, Universidad Complutense de Madrid, cit., pág. 261. 
dispositivos de prevención y saneamiento y, en su caso, constatar si la praxis de implementación resulta satisfactoria.

\section{1.- Francia $^{73}$ :}

El Derecho francés ha asumido la tarea de regular el fenómeno del sobreendeudamiento de los consumidores y lo ha hecho bajo un modelo propio ${ }^{74}$.

Frente al sobreendeudamiento constatado, el ordenamiento francés ofrece vías y procedimientos de saneamiento diferentes según el tipo de deudor afectado.

Por un lado, los comerciantes, artesanos, agricultores y profesionales independientes, en situación de endeudamiento excesivo, deberán transitar el procedimiento judicial establecido en el art. L.643.11 del Código de Comercio, a partir de la reforma concursal de la Ley 2005/845, de 26 de julio de $2005^{75}$. Esta ley y sus modificatorias posteriores diseñaron un procedimiento de salvaguardia al que el deudor -de las condiciones antes mencionadas- puede acudir si se encuentra atravesando una situación de sobreendeudamiento. Esta regulación se ha constituido en un microsistema que podría calificarse como "derecho de empresas en crisis" claramente orientado a rescatar a los emprendedores, profesionales y empresas de la situación de ahogo económico y financiero para su rehabilitación en el mercado.

Esta vía de saneamiento, de tramitarse con éxito, permitirá al profesional o empresario o compañía deudora, reorganizar la actividad comercial o productiva, contar con un escenario de conciliación con los acreedores, acordar con ellos la cancelación del

\footnotetext{
${ }^{73}$ Para un análisis de la propuesta del legislador francés y de las soluciones ofrecidas por ese modelo, ver KeMElMAJER DE CARLUCCI, Aída, "El sobreendeudamiento del consumidor...", cit..

${ }^{74}$ Entre los más recientes estudios del tema, ver SENENT MARTínEZ, Santiago, Exoneración del pasivo insatisfecho..., cit., pág. 274 y sgtes. Resultan de interés, asimismo, los trabajos de CuENA CASAS, Matilde, "Concurso y consumidores...", cit., pág. 43; SAINT-AlARY-HouIN, Corinne, "El tratamiento de las dificultades financieras de los particulares en Francia”, en CuENA CASAS, Matilde-Colino MediaviLla, José Luis (Coord.), Endeudamiento del consumidor e insolvencia familiar, Civitas, Pamplona, 2009, pág. 401 y sgtes. Ver, asimismo PAISANT, Gilles, "La insolvencia de los consumidores en el Derecho francés", en Tomillo Urbina, Jorge (Dir.)-Álvarez Rubio, Julio (Coord.), El futuro de la protección jurídica de los consumidores, Thomson-Civitas, Pamplona, 2008, pág. 237 y sgtes.

${ }^{75}$ Es la Loi de Sauvegarde des Entreprise en difficulté.
} 
pasivo y mantener las fuentes de trabajo. En el marco de ese procedimiento, se admite al empresario individual, la exoneración de deudas aunque de forma implícita al decretar con carácter general la imposibilidad de que los acreedores recuperen el ejercicio de las acciones individuales tras el cierre de la liquidación judicial, por insuficiencia de activo ${ }^{76}$.

La buena fe emerge como presupuesto evidente en la regulación del beneficio pues por un lado, se excluyen de las acciones que los acreedores no recuperarán (al cierre del procedimiento) a aquellas en las que subyace un comportamiento reprochable del deudor ${ }^{77}$; y por otra parte, el juez ejerce un control referido a las causas generadoras de este estado de endeudamiento excesivo en la declaración de quiebra ${ }^{78}$.

${ }^{76}$ Dentro del procedimiento de liquidación judicial, el art. L 643-11 del Código de Comercio francés. Se
prevé: "I. - La resolución de cierre de la liquidación judicial por insuficiencia de activo no hará recuperar a los
acreedores el ejercicio individual de sus acciones contra el deudor, salvo si el crédito se derivara de: $1^{\circ}$ Una
condena penal del deudor; $2^{\circ}$ Derechos vinculados a la persona del acreedor. II.- Sin embargo, el fiador o el
codeudor que haya pagado en lugar del deudor podrá ejercitar acciones judiciales contra este último. III. - Los
acreedores recuperarán su derecho a reclamar el pago de su crédito a título individual en los siguientes casos: $1^{\circ} \mathrm{El}$ deudor ha sido declarado en quiebra personal; $2^{\circ} \mathrm{El}$ deudor ha sido reconocido culpable de bancarrota; $3^{\circ} \mathrm{El}$ deudor o una persona jurídica de la que haya sido dirigente ha sido sometido a un procedimiento de liquidación judicial concluido por insuficiencia de activos en los cinco años anteriores al procedimiento en el que esté incurso; $4^{\circ} \mathrm{El}$ procedimiento ha sido abierto como un procedimiento territorial, en el sentido del párrafo 2 del artículo 3 del Reglamento (CE) n 1346/2000 del Consejo de 29 de mayo sobre procedimientos de insolvencia. IV. - Además, en caso de fraude a uno o varios acreedores, el Tribunal autorizará el ejercicio de acciones judiciales contra el deudor por parte del acreedor. El Tribunal se pronunciará durante el cierre del procedimiento, tras oír o citar en debida forma al deudor, al liquidador y a los interventores. Podrá pronunciarse asimismo posteriormente al mismo, a petición de cualquier persona interesada, con arreglo a las mismas condiciones. V. - Los acreedores que recuperen el ejercicio individual de sus acciones en aplicación del presente artículo podrán, si sus créditos hubieran sido admitidos, obtener un título ejecutivo por auto del presidente del Tribunal o, si sus créditos no hubieran sido verificados, obtenerlo en con arreglo a las condiciones de Derecho común”.

77 Sotillo Martí, Antonio, "Segunda oportunidad y Derecho Concursal", Seminario Interdisciplinar Facultad de Derecho celebrado el 30 de octubre de 2013 en Valencia, http://www.uv.es/seminaridret/sesiones2013/concursal/ponenciasotillo.pdf (fecha de consulta 1/7/2015)

78 SENENT MARTínEZ, Santiago, Exoneración del pasivo insatisfecho..., cit., pág. 286. El autor citado menciona que "a la quiebra personal se refiere el art. L 653-1 C. Commerce y se aplica de un lado, a las personas físicas que ejerzan la profesión de comerciante, de agricultor o que estén inscritas en el Registro Central de Artesanos, así como a cualquier persona física que ejerza una actividad profesional autónoma, 
En el caso de los consumidores, la liberación se regula, también de modo indirecto, como conclusión del procedimiento diseñado en el Code de la Consommation. En este cuerpo normativo se incorporó un título especial dedicado al tratamiento de la situación de endeudamiento de los particulares (Libro III, Título III, arts. 331-1 a 333-8), donde se consagran soluciones encaminadas al saneamiento de su situación de endeudamiento excesivo.

Esta regulación fue diseñada por la Ley No 89-1010, de 31 de diciembre de 1989 y ha sido modificada por las Leyes $\mathrm{N}^{\circ}$ 95-125, de 8 de febrero de 1995; $\mathrm{N}^{\circ}$ 98-657, de 29 de julio de 1998; $\mathrm{N}^{\mathrm{o}}$ 2003-710, de 1 de agosto de 2003; $\mathrm{N}^{\mathrm{o}} 2005-845$, de 26 de julio de 2005; $\mathrm{N}^{\mathrm{o}}$ 2007-290, de 21 de marzo de 2007; $\mathrm{N}^{\circ} 2010-737$ de 1 de julio de 2010; $\mathrm{N}^{\circ} 2010-1609$, de 22 de diciembre de 2010 y N$^{\circ} 2013-672$, de 26 de julio de 2013.

incluyendo una profesión liberal, sujeta a un estatuto legal o reglamentario o cuyo título esté protegido; de otro, a las personas físicas, dirigentes de hecho o de derecho de personas jurídicas; y finalmente a las personas físicas, representantes permanentes de personas jurídicas, dirigentes de las personas jurídicas definidas en el apartado $2^{\circ}$ ". $\mathrm{Al}$ analizar los requisitos de la declaración de quiebra personal, advierte que "a diferencia de lo que pueda aplicarse a los administradores y dirigentes de personas jurídicas, a las personas físicas que ejerzan la profesión de comerciante, de agricultor o que estén inscritas en el Registro Central de Artesanos, así como a cualquier persona física que ejerza una actividad profesional autónoma, incluyendo una profesión liberal, podrá declarársele en quiebra personal cuando según el art. L 653-3 haya cometido alguno de los siguientes actos: haber continuado injustificadamente una explotación deficitaria que sólo podía conducir a la insolvencia; haber desviado u ocultado la totalidad o parte del activo, o haber aumentado fraudulentamente su pasivo". Agrega que "según el art. L 653-4 se aplicará a los casos en que cualquiera de ellos haya realizado los siguientes actos: $1^{\circ}$ Haber ejercido una actividad comercial, artesanal o agrícola o una función de dirección o de administración de una persona jurídica, infringiendo una prohibición prevista por la Ley; $2^{\circ}$ Haber realizado compras para una reventa por debajo de su precio o empleando métodos ruinosos para procurarse fondos con la intención de evitar o retardar la apertura del procedimiento de saneamiento judicial o de liquidación judicial; $3^{\circ}$ Haber suscrito, por cuenta ajena, sin contrapartida, obligaciones consideradas demasiado importantes en el momento de su conclusión en atención a la situación de la empresa o de la persona jurídica; $4^{\circ}$ Haber pagado o mandado pagar, tras la declaración de insolvencia y con conocimiento de causa de esta, a un acreedor en perjuicio de los demás acreedores; $5^{\circ}$ Haber obstaculizado su buen desarrollo absteniéndose voluntariamente de cooperar con los órganos del procedimiento; $6^{\circ}$ Haber hecho desaparecer documentos contables, no haber llevado ninguna contabilidad infringiendo la normativa aplicable, o haber llevado una contabilidad ficticia manifiestamente incompleta o irregular con respecto a las disposiciones legales". 
La regulación del Code de la Consommtion se sitúa frente a la hipótesis del endeudamiento excesivo ya consumado y encara vías alternativas se superación y rehabilitación.

El código define su ámbito de aplicación a partir de requisitos subjetivos y objetivos.

Las soluciones legales están diseñadas para atender a la situación de determinados sujetos, que son los beneficiarios de las mismas. Debe tratarse de una persona física (excluyendo, a las personas jurídicas) y deudor de buena $\mathrm{fe}^{79}$. Desde lo subjetivo, se define también en sentido negativo. No debe ser ni comerciante, ni artesano, ni profesional, salvo que se trate de un endeudamiento que proceda de pasivos ajenos a esa actividad productiva o profesional ${ }^{80}$.

Los requisitos objetivos se centran en la noción de sobreendeudamiento, que la ley caracteriza como "la imposibilidad manifiesta de hacer frente al conjunto de deudas no profesionales exigible y a vencer..."

Este cuadro de situación puede presentar alternativas diversas y diferentes serán también las soluciones previstas por la ley. El deudor en situación remediable tendrá determinadas herramientas a su alcance y el deudor en una situación irremediablemente comprometida, otras mucho más acotadas.

La normativa francesa de tratamiento de las situaciones de sobreendeudamiento contenida en el Code de Consomation establece dos procedimientos diversos:

1.- El redressement es un procedimiento al que puede acudir el deudor se encuentra en una situación remediable, a desarrollarse en el ámbito administrativo y por ante la Comisión de

\footnotetext{
${ }^{79} \mathrm{Al}$ comentar la imposición del requisito de la buena fe, se señala que "el problema es que ni la ley ni el tribunal de casación de ese país han entregado un concepto claro de la misma, por lo cual se ha producido una serie de discusiones acerca de la amplitud de dicha exigencia" (DEL FIERRo ElGART, Alfonso, "El Derecho de la insolvencia de los consumidores: una reforma pendiente en el Derecho Concursal chileno”, Boletín Jurídico/Publicación $\quad \mathrm{N}^{\circ} \quad 3, \quad \underline{\text { http://www.superir.gob.cl/wp-content/uploads/2014/09/boletin-juridico- }}$ publicacion-n3-1.pdf (fecha de consulta 1/7/2015) .

${ }^{80}$ SENENT MARTínEZ, Santiago, Exoneración del pasivo insatisfecho..., cit., pág. 278.

${ }^{81}$ Así lo define el art. 330-1.
} 
Sobreendeudamiento creada a ese fin $^{82}$. En ese marco y bajo la conducción del organismo mencionado se ofrece un escenario de actuación propicio para la búsqueda de soluciones ajustadas a la concreta situación del particular afectado. El procedimiento diseñado prevé un trámite en el que se abren puertas sucesivas. La Comisión de Sobreendeudamiento verifica los requisitos del caso, declara la apertura del procedimiento ${ }^{83}$, dispone la notificación de los acreedores, hace una estimación del porcentual necesario para la manutención del grupo familiar del deudor, convoca para informar acerca del estado patrimonial del deudor y crea las condiciones para arribar a una solución consensuada sobre la base de un plan de pagos. En caso de que esta propuesta no alcance el consenso deseable entre consumidor y acreedores, se abre una nueva alternativa. La Comisión de Sobreendeudamiento está habilitada, ante el fracaso de la instancia conciliadora, a formular recomendaciones o disponer la adopción de medidas tales como la suspensión de las ejecuciones (salvo alimentarias), escalonar el pago de la deuda o parte de ella, imputar pagos al capital primero y luego a los intereses, reducir la tasa de interés acordada, etc., y el juez $^{84}$ procederá a analizar las medidas peticionadas y el plan de pagos propuesto para rechazarlo o bien homologarlo. En esta última hipótesis el plan de saneamiento resulta obligatorio para los acreedores denunciados por el consumidor y para los que sin haber sido denunciados, fueron notificados y convocados por la Comisión de Sobreendeudamiento.

\footnotetext{
${ }^{82}$ Se trata de un órgano de naturaleza administrativa, de composición mixta (art. L 331-1), en el que están presentes un representante del Estado en el Departamento (que actúa como Presidente), un tesorero-pagador general, un representante de los servicios fiscales, (es decir, de la Administración tributaria), otro del Banco de Francia (que actúa como Secretario) y dos, respectivamente, de entidades de crédito e inversión y de asociaciones familiares y de consumidores (escogidos ambos por el representante del Departamento de entre los propuestos por éstas). En cada Departamento existe al menos una Comisión, siendo competente territorialmente para conocer de este procedimiento la sita en el domicilio del deudor.

83 "En principio, la sola presentación de la solicitud no producirá efecto alguno sobre los procedimientos ejecutivos que se encuentren en tramitación a la fecha, salvo, como se mencionó anteriormente, que la misma Comisión solicite su suspensión al juez de ejecución, esto siempre y cuando se cuente con razones fundadas, siendo finalmente el tribunal, al sopesar los antecedentes, quien decidirá si procede o no" DEL FIERRO ElGART, Alfonso, "El Derecho de la insolvencia ...", cit.

${ }^{84}$ El Juez de la ejecución será el competente para conocer sobre los recursos que puedan interponerse contra las decisiones de la Comisión de Sobreendeudamiento, evaluar las medidas propuestas por ésta y aprobar el plan de pagos diseñado para satisfacer a los acreedores.
} 
2.-El retablissement personel del deudor es un procedimiento que tramita en el ámbito judicial, por ante un juez de ejecución, destinado al deudor que se encuentre en una situación irremediablemente comprometida. Está previsto por la ley para el supuesto en que resulta imposible o ineficaz transitar el procedimiento administrativo ${ }^{85}$. Esta vía judicial regulada en los arts. 332-5 a 332-12, que tiene por finalidad la liquidación del patrimonio personal del deudor. Recibida la solicitud, el tribunal tiene un mes de plazo para citar al deudor y sus acreedores a efectos de ofrecer la información necesaria y dar inicio al procedimiento. Esta resolución implicará la suspensión inmediata de los juicios ejecutivos individuales que estuvieran en trámite, con la sola excepción de aquéllas ejecuciones destinadas a obtener el cumplimiento de deudas provenientes de obligaciones alimenticias. El juez interviniente deberá avaluar los bienes y determinar el pasivo del deudor en un período máximo de 4 meses. Con los antecedentes aportados, el juez podrá decretar la liquidación de la totalidad de los bienes embargables, designando un martillero para ello. Entre los bienes exentos, o de carácter inembargable, destacan las cosas muebles que integran el hogar y que se estimen necesarios para el diario vivir del deudor y los bienes necesarios para el desempeño de su profesión u oficio. Si los fondos obtenidos con el proceso son suficientes para realizar el pago de las obligaciones, el juez resolverá cerrar el procedimiento. No obstante resultar insuficientes para cubrir el pasivo, si lo estimara procedente -a la luz de la buena fe del deudor-, el juez también puede declarar la clausura del procedimiento y la exoneración de las deudas insatisfechas, con excepción de las expresamente previstas ${ }^{86}$.

${ }^{85}$ El procedimiento puede ser solicitado por el deudor, si intentó sin éxito previamente un plan de recuperación convencional o recomendado, o residualmente, si hubieran transcurrido nueve meses desde la solicitud presentada ante la Comisión de Sobreendeudamiento y ésta no hubiera decidido sobre la resolución a esta situación. Puede asimismo la Comisión, solicitar la resolución de un procedimiento de recuperación si considera que se dan los supuestos de apertura de del procedure de rétablissement personnel.

86 "Cuando, tras la realización de las operaciones de liquidación acordadas por el Juez y llevadas a cabo por el liquidador nombrado al efecto, art. L 332-8 C. Consom. la masa activa realizada sea insuficiente para desinteresar a los acreedores, o cuando el deudor sólo posea el mobiliario necesario para la vida cotidiana y bienes no profesionales indispensables para el ejercicio de su actividad profesional, el juez dictará la clausura del procedimiento por activo insuficiente. La clausura entraña la desaparición de todas las deudas no profesionales del deudor, con la excepción de aquéllas cuyo precio hubiera sido pagado por un tercero a nombre del deudor, por razón de garantía o de solidaridad tal y como dispone el art. L 332-9. No obstante, el 


\section{2.- Alemania ${ }^{87}$ :}

En Alemania, los mecanismos de tutela del consumidor sobreendeudado y el reconocimiento de un beneficio a efectos de la liberación de deudas tienen reconocimiento en el ordenamiento jurídico a partir de la Insolvenzordnung de 1994, que entró en vigencia el 1de enero de 1999.

La exoneración del pasivo pendiente fue uno de los objetivos de la InsO, tal como se evidencia en la exposición de motivos ${ }^{88}$. El legislador alemán atendió tempranamente a

efecto no se extenderá a los créditos a que se refiere el art. L 333-1C. Consom., por lo que salvo acuerdo del acreedor, se excluyen de toda quita, reestructuración o supresión: $1^{\circ}$ Las deudas alimenticias; $2^{\circ}$ Las reparaciones pecuniarias debidas a las víctimas con motivo de una condena penal; $3^{\circ}$ Las multas dictadas con motivo de una condena penal será excluidas de toda quita, reestructuración o supresión” (SENENT MARTÍNEZ, Santiago, Exoneración del pasivo insatisfecho..., cit., pág. 282).

87 El modelo alemán es objeto de un estudio exhaustivo en TruJILlo DíEZ, Iván Jesús, El sobreendeudamiento de los consumidores..., cit., pág. 129. Ver asimismo el estudio de la propuesta legislativa alemana y su confrontación con otros modelos, en ALVÁREZ VEGA, María Isabel, Protección jurídica del consumidor ..., cit., pág. 126 y sgtes.; ZABALETA DíAZ, Marta, "La condonación de las deudas pendientes en el Derecho concursal alemán”, en Estudios sobre la Ley Concursal. Libro Homenaje a Manuel Olivencia, T. I, Madrid, 2005, pág. 885 y sgtes.; KOHTE, Wolfhard, "Las proyectadas modificaciones de la normativa concursal alemana sobre consumidores", en Revista de Derecho Concursal y Paraconcursal, Anales de doctrina, praxis, jurisprudencia y legislación, No. 19, 2013, pág. 415-416; FERRÉ, Juan, La liberación de deudas en el concurso del consumidor (un apunte de derecho alemán)», Anuario de Derecho Comercial, núm. 7, Aranzadi, 2006, pág. 205 y sgtes. De especial interés es la crítica esbozada en SCHMIDT, Karsten, "El Derecho alemán. Una comedia de equivocaciones", en CuEnA CASAS, Matilde-Colino MediaviLla, José Luis (Coord.), Endeudamiento del consumidor e insolvencia familiar, Civitas, Pamplona, 2009, pág. 417 y sgtes.

${ }^{88}$ Recuerda Marta Zabaleta Díaz que “en el Derecho concursal anterior a la Ordenanza de Insolvencia de 1994, y concretamente en el parágrafo 164 de la Ley de Quiebras de 1877 ... los créditos que no hubieran resultado total o parcialmente satisfechos en el procedimiento concursal, podrían ser ejecutados una vez concluido el mismo, constituyendo una lista de acreedores, un título ejecutivo a tales efectos. El plazo de prescripción de la acción de los acreedores no satisfechos era de treinta años ... lo que suponía en la práctica una condena de por visa para el deudor persona física...”. Comenta la autora, con cita de Schmidt, que la doctrina alemana hacía referencia a esta situación con la figura "torre de deudores" puesto que "al igual que en la Edad Media, quedaba encerrado en una torre sin posibilidades del volver a llevar una existencia digna" (ZABALETA DíAZ, Marta, “La condonación...”, cit., pág. 888). 
esta preocupación por la situación de endeudamiento excesivo, diseñando remedios y carriles apropiados para su implementación.

La regulación propone tres procedimientos. Por un lado, un trámite aplicable a las personas jurídicas; otro, al que pueden acogerse todas las personas físicas tras liquidar su patrimonio; y un tercero, denominado Restschulddefreiung, específico para los consumidores, que pueden acceder a la exoneración del pasivo pendiente dentro del procedimiento concursal, conforme lo establecido en los arts. 286 a 303 de la InsO.

Conforme lo expuesto en la Ordenanza de Insolvencia, la liberación del pasivo pendiente puede alcanzarse como consecuencia de la aprobación de un plan de insolvencia, cuya regulación presenta matices según el tipo de deudor.

La condonación de deudas insatisfechas mediante la implementación de esta reestructuración del pasivo y propuesta de pago constituye una de las "piezas angulares del Derecho Concursal alemán"89 (el Insolvenzplan), regulado en los parágrafos 217 a 253 InsO.

En el trámite general o común, esta vía de saneamiento se presenta como una alternativa a la liquidación, cuando en interés de los acreedores, resulte aconsejable el mantenimiento de la empresa y su continuidad sea viable. Si ese plan de pagos con liberación de pasivo pendiente propuesto es votado favorablemente por los acreedores, se privilegia la autonomía de la voluntad allí expresada, y se admite la liberación de las deudas sin necesidad de transitar el procedimiento previsto en los parágrafos 286 y sgtes ${ }^{90}$. Se trata de la única vía por la que las personas jurídicas en crisis podrían acceder a la liberación de deudas respecto de sus acreedores.

Para las personas físicas, por el contrario, la Ordenanza de Insolvencia diseña un procedimiento de condonación de deudas general (Allgemeines Insolvenzverfahren y un procedimiento simplificado para los consumidores (Verbraucherinsolvenzverfahren,) cuya estructura presenta sustanciales diferencias con el primero ${ }^{91}$.

\footnotetext{
${ }^{89}$ ZABALETA DíAZ, Marta, “La condonación ...”, cit., pág. 890.

${ }^{90}$ ZABALETA DíAZ, Marta, "La condonación...”, cit., pág. 891.

${ }^{91}$ Resulta de interés la reseña contenida en el "Informe sobre segunda oportunidad. Situación actual y perspectivas de mejora", Economistas. Consejo General, Febrero de 2015, en http://s01.s3c.es/imag/doc/2015-02-11/XXInformeCGE_SegundaOpotunidad.pdf (fecha de consulta: 1/7/2015).
} 
Dado que el Restschulddefreiung ofrece al consumidor un procedimiento particular, resulta relevante determinar a quién se considera beneficiario de esa regulación. Para ello acudimos a las previsiones de los arts. 304 a 314 de la Insolvenzordnung, que define la figura en sentido negativo, al decir que consumidor es aquella persona física que no desarrolla ni ha desarrollado ninguna actividad económica (un empleado, un funcionario, un jubilado, una ama de casa, etc.). Resulta irrelevante la importancia de su patrimonio dado que el acento está puesto en la ausencia de una actividad económica independiente por parte del sujeto. La persona física que desarrolla una actividad autónoma, el pequeño comerciante, el profesional, etc. deben acudir, en el régimen vigente, al procedimiento de liberación de deudas general pues se reserva el abreviado exclusivamente para los consumidores $^{92}$

Conforme la regulación particular (art. 305.1.1 InsO), se impone al consumidor que pretende transitar este procedimiento judicial o simplificado, acreditar -al peticionar la apertura del concurso- que con carácter previo intentó una salida consensuada con sus acreedores, con resultado adverso ${ }^{93}$. A tal fin, el deudor debe acompañar a la solicitud de apertura del procedimiento de insolvencia, una certificación expedida por persona u oficina habilitada en la que conste que en un plazo de hasta 6 meses anteriores a la solicitud de apertura del concurso, procuró arribar, sin éxito, a un acuerdo extrajudicial con los acreedores. En esa oportunidad deberá expresar las razones que impidieron esa solución o concordato.

\footnotetext{
92 Hasta la reforma del año 2001, la ley concursal también legitimaba para acceder al procedimiento abreviado, a las personas físicas que desarrollaran una actividad económica autónoma, siempre que no fuera significativa o que no precisara una organización profesional de empresa. Pero dada la dificultad para establecer pautas objetivas que permitieran distinguir con certeza entre empresas y pequeños comerciantes, el legislador alemán optó por reservar el procedimiento abreviado a los consumidores y derivar al procedimiento general de condonación de deudas, a las personas físicas que actuaran como pequeños comerciantes (ZABALETA DÍAZ, Marta, “La condonación...”, cit., pág. 893).

${ }^{93} \mathrm{Se}$ señala que los convenios que presentan normalmente los deudores no contienen una propuesta de pago o que, en su caso, se ofrecen sumas insignificantes, por lo que, en la práctica, casi la totalidad de las propuestas son ignoradas por los acreedores o desestimadas (FERRÉ, Juan, La liberación de deudas..., cit., pág. 205 y sgtes.).
} 
Se impone asimismo al deudor, acompañar a la solicitud una descripción y resumen patrimonial, detalle de ingresos y un informe pormenorizado con indicación de los acreedores, cuantía de las deudas, naturaleza de esos créditos, discriminación de intereses y todo otro detalle pertinente. Deberá presentar asimismo, un plan de pago que resulte razonable desde el punto de vista del interés de los acreedores y de la situación económica y familiar del deudor.

Presentada la solicitud de apertura del concurso por parte del deudor, juntamente con la petición de liberación de deudas, se abre la fase de tramitación de convenio con los acreedores (arts. 306-310 InsO), bajo la supervisión del juez interviniente. A partir de ese momento, el juez articulará ciertos instrumentos orientados a procurar que los acreedores acepten el plan propuesto por el deudor. En el caso de aceptación, el plan tiene la eficacia de una transacción judicial y la resolución que lo homologa constituye título de ejecución forzosa, habilitándose la clausura del procedimiento. Por el contrario, si los acreedores rechazaran la propuesta de pagos del deudor, se abrirá el procedimiento de insolvencia simplificado.

Oportuno es señalar que la tramitación de este acuerdo con los acreedores en sede judicial es facultativa, puesto que el juez, ante la posición previamente mantenida por los acreedores y las demás circunstancias del caso, puede considerar innecesario promover esta nueva instancia de negociación.

Iniciado el procedimiento propiamente de insolvencia (arts. 311-314 InsO), se impone la designación de un fiduciario (Treuhänder), que administrará los bienes del deudor, informará sobre su situación económica, sobre las causas de la insolvencia y sobre la concurrencia de los requisitos para la obtención de la liberación de deudas, debiendo asimismo reconocer los créditos que le sean comunicados.

El procedimiento legal dispone la celebración de dos juntas de acreedores. La primera de ellas (Prüfungstermin) tiene como finalidad principal el reconocimiento de los créditos denunciados; y segunda, (Schlusstermin), destinada a comunicar a los acreedores la opinión del fiduciario sobre la solicitud de exoneración de deudas. Es la oportunidad en que los acreedores pueden oponerse, indicando los motivos por los que dicha petición debería ser rechazada. 
El procedimiento concluye con el dictado de la resolución del Juzgado que puede conceder provisionalmente el beneficio de liberación de deudas o bien rechazarlo en caso de que concurra algún motivo que allí debe explicitarse ${ }^{94}$. La resolución judicial concediendo provisionalmente la exoneración de deudas da lugar al inicio del trámite específico dirigido a obtener tal liberación con carácter definitivo.

Cuando el deudor sea una persona natural que no haya podido acudir al procedimiento simplificado previsto para los consumidores, puede obtener la condonación de las deudas pendientes transitando una procedimiento alternativo. Pensando en el empresario individual, se diseñó un trámite a instar una vez concluido el procedimiento ordinario de insolvencia.

Este procedimiento de liberación de deudas se regula en los arts. 286 a 303 InsO y ha sido objeto de reformas recientes ${ }^{95}$.

Conforme su regulación, la tramitación debe superar dos fases.

La primera fase se inicia con la solicitud de liberación de deudas del deudor que se presenta junto con la petición de apertura del concurso, correspondiendo al juez resolver la admisión preliminar de la solicitud, que tiene carácter provisional ${ }^{96}$.

La segunda fase presenta carácter específico y solo se inicia si la resolución judicial admite provisionalmente la solicitud de liberación de deudas. Esta etapa se estructura sobre la base de un periodo de buena conducta supervisado por el fiduciario, que se extiende por un periodo de seis años y que concluirá, en su caso, con la resolución definitiva reconociendo el beneficio de la liberación de deudas o Restchuldbefreiung.

La reforma al régimen originario recientemente en vigencia, se orientó precisamente a propiciar la reducción de la duración del procedimiento de liberación de deuda (Gesetz zur Verkürzung des Restschuldbefreiungsverfahrens und zur Stärkung der Gläubigerrechte

\footnotetext{
${ }^{94}$ Se señala que la experiencia demuestra que la concesión del beneficio concursal tiene un carácter prácticamente automático (FerRÉ, Juan, La liberación de deudas..., cit., pág. 205 y sgtes.). Lo destaca, asimismo, SEnENT MARTíneZ, Santiago, Exoneración del pasivo insatisfecho ..., cit., pág. 315.

${ }^{95}$ Cfr. KoHTE, Wolfhard, "Las proyectadas modificaciones...", cit., pág. 415-416.

${ }^{96}$ En el caso del procedimiento común la decisión judicial, reconociendo o denegando el beneficio, se adopta tras el Schlusstermin (arts. 289.1 y 291 InsO), que supone, asimismo, la conclusión del procedimiento concursal. En el caso del concurso simplificado del consumidor, la resolución judicial también coincide con la resolución de cierre del procedimiento concursal.
} 
Bundesgesetzblatt) entrando en vigor el 1 de julio de 2014, para solicitudes posteriores a dicha fecha.

La nueva regulación permite a los deudores dar por concluido, antes de los seis años, el procedimiento de exoneración de deuda, contemplándose su conclusión tras tres años, si abonaron -en el plazo indicado- un porcentaje del treinta y cinco por ciento de los créditos concursales, o en cinco años si, como mínimo, asumen los costes del procedimiento. En los restantes casos, se mantiene el plazo de buena conducta de seis años. La norma introduce así un sistema de incentivos del que pueden sacar provecho tanto el deudor como los acreedores ${ }^{97}$.

Los arts. 290.1 y 314.3 de la InsO contemplan supuestos en los que el deudor no podrá pretender el acceso al beneficio de la exoneración del pasivo pendiente ${ }^{98}$.

La norma citada menciona como causas, a las siguientes: que el deudor haya sido condenado por un delito de insolvencia de los previstos en los artículos 283-283c StGB (Strafgesetzbuch o Código Penal) (art. 290.1.1 InsO); haber ofrecido una información incorrecta o incompleta sobre su situación económica y patrimonial (art. 290.1.2 InsO); haber obtenido o solicitado la liberación de deudas en un período de diez años anterior a la petición de apertura del concurso (art. 290.1.3 InsO); llevar un modo de vida despilfarrador, haber incumplido las obligaciones de información y de cooperación (art. 290.1.5 InsO); haber presentado listas de sus acreedores, de su patrimonio o de sus ingresos que sean incorrectas o incompletas (art. 290.1.6 InsO); o, por último, haber incumplido la obligación de pago que, en relación con el fiduciario, está prevista para el deudor en el artículo 314.3,f 2 de la Insolvenzordnung.

Destaca ZABALETA DíAZ que el legislador alemán -al regular los requisitos a los que se condiciona la procedencia de la exoneración- centra su atención en aquellas conductas reprochables del deudor que lo excluirían del beneficio pero omite considerar requisitos de carácter objetivo -como exigir la existencia de un determinado activo- con lo que "no se garantiza a los acreedores un grado mínimo de satisfacción de sus créditos"99.

\footnotetext{
${ }^{97}$ Senent MartíneZ, Santiago, Exoneración del pasivo insatisfecho ..., cit., pág. 327. Asimismo, FerRÉ, Juan, "La liberación de deudas ...", cit., pág. 205 y sgtes.).

${ }^{98}$ ZABALETA DíAZ, Marta, “La condonación ...”, cit., pág. 897.

${ }^{99}$ ZABALETA DíAZ, Marta, “La condonación ...”, cit., pág. 899.
} 
Como se dijo, la liberación de deudas puede ser controvertida por parte de los acreedores o por el profesional encargado administrar el patrimonio del deudor. Ahora bien, si en la junta de cierre ninguno de los sujetos habilitados para formalizar la oposición lo hace, el Juzgado dictará un auto concediendo la liberación de las deudas.

La obtención definitiva del beneficio está condicionada a la superación del referido período de buena conducta. Es, precisamente, la previsión de ese período de buena conducta y la imposición de las obligaciones al deudor durante el mismo, una de las notas distintivas del modelo de exoneración diseñado por el Derecho alemán.

Durante el mencionado período de buena conducta el deudor debe observar una serie de obligaciones contenidas en el artículo $295 \mathrm{InsO}$, de singular importancia para la justificación del beneficio que el modelo alemán propone.

Por un lado, se propugna que el deudor se desempeñe o lleve adelante una actividad que le permita tener ingresos propios y, en caso de que estar desempleado, que busque trabajo o no rechace las ofertas que reciba.

Por otra parte, y como una nota distintiva del modelo de regulación, se le impone la cesión al fiduciario de la parte embargable de su salario y la entrega al mismo de la mitad de las cantidades que el deudor reciba en concepto de herencia o similar.

Está asimismo obligado a informar al juzgado y al fiduciario de cualquier modificación de su domicilio o su situación laboral, así como de su situación patrimonial. Debe estar dispuesto a proporcionarles la información que le sea solicitada, en cualquier tiempo.

Finalmente, es obligación ineludible hacer todos los pagos a los acreedores a través del fiduciario, sin prestar un trato especial a ningún acreedor ${ }^{100}$.

Transcurrido el período previsto para la liberación de las deudas, se celebrará la correspondiente junta de acreedores, con asistencia del fiduciario (art. 300.1 InsO) y en caso de que no exista ninguna objeción de alguno de ellos, el Juez concederá automáticamente la liberación definitiva de las deudas pendientes ${ }^{101}$.

El auto del Tribunal, que deberá ser objeto de publicación, podrá ser recurrido por aquellos acreedores con fundamento en las causas establecidas en el artículo 303 InsO.

\footnotetext{
${ }^{100}$ SenENT MARTínEZ, Santiago, Exoneración del pasivo insatisfecho ..., cit., pág. 320.

${ }^{101}$ Sotillo Martí, Antonio, "Segunda oportunidad ...", cit.
} 
Con la reforma vigente a partir de 2014 , se faculta a que los acreedores en cualquier momento del procedimiento de insolvencia, puedan presentar una solicitud escrita de denegación de la liberación de deudas, conforme a cualquiera de las causas del art. 290. Ha sido modificado también con esta última reforma, el catálogo de causas de denegación de la liberación de deudas (se añade una nueva causa en el apartado $7^{\circ}$ del art. 290 para el caso en que el deudor incumpla la obligación de agotar las posibilidades de obtener ingresos conforme al art. $287 \mathrm{~b}$ de la InsO.).

En cuanto a los efectos del beneficio y su extensión, cabe señalar que la declaración de condonación de deudas vincula a todos los acreedores del deudor, incluidos aquellos que no hubiesen insinuado sus créditos en el procedimiento de insolvencia previo. La obtención del beneficio también libera al deudor concursal frente a sus deudores solidarios y fiadores, quienes no podrán repetir en su contra los desembolsos que hubieran tenido que afrontar frente a los acreedores del deudor ${ }^{102}$.

Resultan ajenos a la exoneración "los créditos derivados de la responsabilidad del deudor por actos ilícitos perpetrados con dolo, las multas u obligaciones similares, tales como recargos o intereses, así como los créditos derivados de préstamos sin intereses concedidos al deudor para sufragar los costes del procedimiento concursal" ${ }^{, 103}$, tal como dispone el art. 302 InsO. La reforma vigente a partir de 2014, introduce nuevas excepciones a la liberación de deudas, quedando excluidas las reclamaciones por alimentos ya devengados, que el deudor obligado no haya liquidado, y las deudas fiscales cuando el deudor haya sido condenado por sentencia firme.

Cabe señalar que la reforma también se vio impulsada por la necesidad de desvincular el trámite de liberación de deudas del procedimiento de insolvencia. Ello así, a fin de que la no apertura de este último por ausencia de masa activa, no implicara la imposibilidad de apertura del procedimiento de condonación.

Para este supuesto particular, la reforma propone asegurar el pago de una cantidad simbólica por parte del deudor, asumiendo el Estado el coste que demanden los honorarios del fiduciario.

\footnotetext{
${ }^{102}$ No obstante ello, lo acreedores del deudor, mientras no hayan sido resarcidos, sí conservarán sus derechos frente a deudores solidarios y fiadores, sobre la base de lo establecido en el art. $301 \mathrm{InsO}$.

${ }^{103}$ SENENT MARTínEZ, Santiago, Exoneración del pasivo insatisfecho..., cit., pág. 325.
} 
Se señala que "de este modo se esperaba cumplir dos objetivos: conseguir un procedimiento de liberación de deudas más sencillo y abaratar sustancialmente los costes del procedimiento" $" 104$.

3.- Italia:

La doctrina especializada advertía hasta hace unos pocos años, que el ordenamiento italiano era especialmente rico en procedimientos, instrumentos y mecanismos de composición y solución de las crisis económico financieras pero con la mirada centrada en "un solo punto de referencia: la empresa"105.

La exoneración de deudas o Esdebitazione quedó regulada en el Capítulo IX de la Legge Fallimentare, arts. 142 a 144, introducidos en la reforma del año 2006. Este emplazamiento del beneficio en el marco de la ley falencial acota su aplicación, por tanto (y por una parte), a los sujetos sometidos al fallimento, ${ }^{106}$ excluyéndose a la persona física que no ejerza una actividad comercial, incluso el empresario individual que ejerza una actividad de reducidas dimensiones; pero también excluye como destinatarios del beneficio, a los empresarios personas jurídicas, por considerar que estos últimos gozan de una regulación particular que les otorga otros beneficios en orden al resguardo de su responsabilidad patrimonial por deudas empresarias ${ }^{107}$.

Este mecanismo de liberación de deudas de la ley falencial está diseñado, en definitiva, para el empresario persona física de cierta importancia. La exclusión del ámbito

104 KOHTE, Wolfhard, "Las proyectadas modificaciones...", cit., pág. 415-416; SCHMIDT, Karsten, "El Derecho alemán...”, cit., pág. 417.

105 NIGRO señala: "el sistema está caracterizado por la previsión de regulaciones expresas e institutos específicos sólo para las crisis de las empresas...y ni siquiera para todas las categorías de empresas sino únicamente para las de una categoría especial...la empresas comerciales; y ni siquiera para todas las empresas comerciales sino sólo para las empresas comerciales no pequeñas" (NIGRO, Alessandro, "La insolvencia de las familias en el Derecho italiano”, en TOMiLlo URbinA, Jorge (Dir.)-Álvarez Rubio, Julio (Coord.), $E l$ futuro de la protección jurídica de los consumidores, Thomson-Civitas, Pamplona, 2008, pág. 211 y sgtes.).

106 Sotillo MARTí, Antonio, "Segunda oportunidad...", cit. La exclusión del pequeño empresario y del consumidor fue motivo de debate.

${ }^{107}$ SANTORO, Vittorio, "La liberación de deudas (esdebitazione) en el Derecho italiano", Revista de Derecho concursal y Paraconcursal, 2010, pág. 411-424. Cfr. http://hdl.handle.net/11365/9446 (fecha de consulta 1/7/2015). 
de aplicación del pequeño empresario así como del consumidor, "es fruto de una elección consciente del legislador" italiano ${ }^{108}$.

El art. art. 142 L. Fall., dispone que: "El quebrado persona física tiene derecho al beneficio de la liberación de deudas restantes no satisfechas respecto a los acreedores concursales, a condición de que: 1) Haya cooperado con los órganos del procedimiento, proporcionando toda la información y documentación útil para el aseguramiento del pasivo y trabajado para el correcto desarrollo del procedimiento; 2) no haya en modo alguno retrasado o contribuido a retrasar el procedimiento; 3) no haya violado las disposiciones del artículo 48; 4) no se haya beneficiado de otra liberación de deudas en los diez años anteriores a la solicitud; 5) no haya ocultado el activo, indicado pasivo inexistente, provocado o agravado la insolvencia, en particular mediante la alteración o la ocultación de documentación de tal manera que no sea posible conocer la composición del patrimonio o los negocios en los que hubiera intervenido o haya recurrido abusivamente al crédito; 6) haya sido condenado por sentencia firme por delitos de quiebra fraudulenta o contra la hacienda pública, industria y comercio y otros delitos cometidos en relación con el ejercicio de los negocios, excepto que en relación a esos delitos haya sido rehabilitado. Si se estuviera tramitando un proceso penal por cualquiera de estos delitos, el Tribunal suspenderá el proceso hasta la resolución del proceso penal.

La liberación de deudas no podrá concederse si no hubieran sido satisfechos, al menos parcialmente, los acreedores concursales".

\footnotetext{
${ }^{108}$ Se piensa que "la opción de política legislativa del legislador italiano estaría fundada en la consideración de que sólo la crisis de la empresa exige regulaciones específicas, específicos instrumentos del gobierno, porque sólo estas crisis constituyen un elemento de perturbación, de carácter general, sobre el tejido de las relaciones económicas y jurídicas, sea porque pueden comportar, a su vez, la crisis de aquellos otros, normalmente otras empresas, que hayan tenido relaciones con la empresa en dificultades, sea porque inmovilizan improductivamente factores que podrían ser utilizados de modo más provechoso en otro lugar, elemento este de perturbación que debería ser eliminado en aras de la tutela del sistema económico y de la propia lógica del mercado. Por otra parte, la crisis del sujeto privado no empresario, tiene repercusiones más limitadas y circunscritas, lo que no justifica, en términos de coste, la utilización de instrumentos complejos y articulados como aquellos proporcionados en el caso de las crisis empresariales" (SENNET MARTínEZ, con cita de Santoro en (SENENT MARTínEZ, Santiago, Exoneración del pasivo insatisfecho..., cit., pág. 295).
} 
Siguiendo el análisis de SENENT MARTíneZ, podemos decir que los requisitos para la obtención del beneficio de la liberación de deudas se explican bajo criterios diversos. De un lado, se exige la colaboración del deudor en la tramitación del procedimiento, previendo que sea el mismo quebrado quien información acabada acerca de la composición de su patrimonio y de las actividades que puedan ser objeto de ejecución por parte de los acreedores $^{109}$ (art. 142.1). Por otra parte se condiciona la liberación a la no concurrencia de actos o comportamientos que puedan calificarse como oportunistas, abusivos o fraudulentos (art. $142 \cdot 2^{\circ} \cdot 3^{\circ} \cdot 4^{\circ} \cdot 5^{\circ}$ y $6^{\circ}$ ). Finalmente la norma impone como requisito, la satisfacción parcial de los acreedores ${ }^{110}$.

El art. 143, por su parte, establece que: "El Tribunal, con el Decreto de conclusión de la quiebra o por solicitud del deudor presentada dentro del año siguiente, verificadas las condiciones contempladas en el artículo 142 y teniendo en cuenta el comportamiento de colaboración del mismo, oídos el curador y el Comité de acreedores, declarará inexigibles las deudas concursales frente al deudor ya declarado en quiebra no satisfechas en su totalidad".

El pasivo exonerable surge de interpretar, a contrario, el enunciado contenido en el art. 142.3 conforme al cual "Quedan excluidas de la liberación de deudas: a) las obligaciones de mantenimiento y de alimentos y cualesquiera obligaciones relacionadas

\footnotetext{
109 Destaca SENNENT MARTínEZ que la ley “subordina la liberación del deudor a la transparencia tanto informativa como, más concretamente, documental (art. 142, nº 1, L. Fall). Además, la información debe acompañarse de un comportamiento correcto y coherente del quebrado tendente a colaborar activamente con los órganos del procedimiento, por ejemplo, facilitando la recuperación de bienes o de créditos del quebrado que estén en manos de terceros o en el extranjero; asimismo, el quebrado no debe tener una conducta, incluso pasiva, que tienda directa o indirectamente a retrasar el procedimiento (art. 142, no . 2, L. Fall.). El legislador presume, en particular, que no colabora el quebrado que no cumpla con su obligación de entregar su correspondencia, en la actualidad también la electrónica, al curador (art. 142, nº 3, que reenvía al art. 48 L. Fall.)". (SENENT MARTíNEZ, Santiago, Exoneración del pasivo insatisfecho..., cit., pág. 299).

${ }^{110}$ Respecto de este último requisito, se destaca que "no se admite que el quebrado intente demostrar que no dispone de bien alguno (concurso sin masa), ... el legislador presume que en estos supuestos sería responsabilidad del quebrado la de haber diferido la apertura del procedimiento hasta el punto de que los bienes, de los que no podía no hacer uso para el ejercicio de la empresa, se hubieren perdido, por lo que como consecuencia a la conclusión de la quiebra no logra la liberación. (SENENT MARTínEZ, Santiago, Exoneración del pasivo insatisfecho..., cit., pág. 300).
} 
ajenas al ejercicio de la empresa; b) las obligaciones por daños y perjuicios derivadas de daño ilícito extracontractual, así como las sanciones penales y administrativas de carácter pecuniario que no sean accesorias a la deuda extinguida".

El mismo precepto advierte la extensión de los efectos de esa liberación, al establecer que "Quedan a salvo los derechos contraídos por los acreedores frente a los coobligados, el fiador del deudor y los obligados en vía de regreso".

Ante la falta de regulación de la problemática del sobreendeudamiento de los consumidores y la decisión de excluirlos al consagrar el beneficio de la liberación de deudas en la ley falencial, comenzó una intensa actividad en pos de concretar el tratamiento del tema y la ley tan esperada. Con el dictado del Decreto Legislativo 141/2010, la Ley 3/2012, el Decreto Legislativo 179/2012 y finalmente, la Ley 221/2012 se consagra un régimen que ofrece las soluciones particulares que se reclamaban ${ }^{111}$.

Se introduce por vía de una ley especial (o una sucesión de productos legislativos), una regulación pormenorizada de lo que se ha dado en llamar Procedimento di composizione della crisi da sovraindebitamento e di liquidazione del patrimonio destinado a los profesionales, consumidores, pequeños empresarios y demás sujetos excluidos del procedimiento concursales $^{112}$.

Esta regulación prevé dos procedimientos distintos.

Por un lado, un acuerdo de reestructuración de las deudas con la presentación de un plan de pagos, en el que puede preverse todas las medidas conducentes a lograr la composición de los intereses involucrados. El Juez recibe la propuesta de pagos y bloquea las acciones individuales, las ejecuciones y los embargos. La regulación impone que para

\footnotetext{
${ }^{111}$ Ver el relevamiento informado en QUIJANO GONZÁLEZ, Jesús, "El sobreendeudamiento de los particulares y del consumidor. Sistemas jurídicos europeos a debate", Revista de Derecho Concursal y Paraconcursal, $\mathrm{N}^{\circ}$ 22, Sección Recensión, segundo semestre de 2014, Editorial La Ley; asimismo http://www.academia.edu/5851665/_EUROPE_El_sobreendeudamiento_de_los_particulares_y_del_consumi dor._Sistemas_jur\%C3\%ADdicos_europeos_a debate (fecha de consulta 1/7/2015).

${ }^{112}$ Resulta de interés la compulsa del "Informe sobre segunda oportunidad. Situación actual y perspectivas de mejora”, Economistas. Consejo General, Febrero de 2015, en http://s01.s3c.es/imag/doc/2015-0211/XXInformeCGE_SegundaOpotunidad.pdf (fecha de consulta: 1/7/2015).
} 
conseguir el acuerdo es necesaria una mayoría del $70 \%$ de los créditos. En caso de obtenerse, el Juez homologa el acuerdo que obliga a todos los acreedores anteriores ${ }^{113}$.

Por otra parte, a solicitud del propio deudor o en caso de no alcanzar el acuerdo de reestructuración o incumplirse el mismo, la normativa prevé un procedimiento de liquidación del patrimonio del deudor. La liquidación tiene por objeto la realización de los bienes embargables o ejecutables del deudor para dar satisfacción a los acreedores. El inicio del trámite de liquidación impide iniciar acción ejecutiva alguna contra los bienes del deudor y se paralizan las que estuvieran en marcha. Con el decreto de apertura, el Juez nombrará un liquidador que realizará el inventario de los bienes y procederá a la realización de los mismos y pago a los acreedores.

La esdebitazione -o il beneficio della liberazione dei debiti residui non soddisfattiqueda emplazo como fase final del proceso liquidatorio del que resulta pasivo insatisfecho (art. 14 terdecies, Ley 3/2012 y modificatorias).

Se destaca, con acierto, que la regulación ofrecida es similar a la consagrada en la ley falencial. Así, "el deudor persona física tiene derecho al beneficio de la liberación de deudas restantes no satisfechas respecto a los acreedores concursales, siempre que haya cooperado para el correcto desarrollo del procedimiento, proporcionando toda la información y documentación útil; no haya en modo alguno retrasado o contribuido a retrasar el procedimiento; no se haya beneficiado de otra liberación de deudas en los ocho años anteriores a la solicitud; no haya sido condenado por sentencia firme por alguno de los delitos comprendidos en el art. 16, relativos a la realización de falsedad documental o actos fraudulentos para el acceso al proceso de reestructuración de deudas, ocultando su real situación de solvencia, o durante el procedimiento realice pagos no previstos en el acuerdo, o tras el mismo y durante el periodo de su vigencia agrave intencionadamente su posición deudora, o intencionadamente no cumpla el acuerdo. Así mismo, debe haber realizado, en los cuatro años a los que se refiere el art. 14 undecies una actividad productiva adaptada a sus capacidades o, en todo caso, haber intentado una ocupación y no ha rechazado, sin

\footnotetext{
${ }^{113}$ SOTILlO MARTí, Antonio, “Segunda oportunidad ...”, cit.
} 
razón justificada, ofertas del empleo. Además, han de haber sido satisfechos, al menos parcialmente, los acreedores concursales"114.

No llamará la atención que en este paralelo regulatorio, se imponga al deudor que pretenda obtener el beneficio de la exoneración del pasivo pendiente, el cumplimiento de requisitos moralizantes y que sólo en caso de superar este test de discharge, se lo considere merecedor de la liberación ${ }^{115}$.

Estos requisitos son casi coincidentes con los de la quiebra, añadiéndose la referencia a las infracciones específicas del art. 16 y a la obligación de realizar una actividad productiva o al menos haberlo intentado. Se mantiene, con la misma indefinición que en la quiebra, el requisito del pago parcial de las deudas concursales, sin especificar qué porcentaje debe haberse satisfecho, lo que probablemente, de lugar a problemas interpretativos en orden a la concesión del beneficio.

Respecto del pasivo exonerable, se constatan nuevas coincidencias con la regulación de la ley falencial puesto que la condonación no opera respecto de las deudas por alimentos, ni en relación a las obligaciones derivadas de la responsabilidad extracontractual, las sanciones penales y administrativas de carácter pecuniario que no sean accesorias de deudas exoneradas, ni ciertas deudas fiscales.

Cumplido el trámite de ley y a petición del deudor -deducida dentro del año siguiente a la conclusión de la liquidación- el juez dará intervención a los acreedores; y constatado el cumplimiento de los requisitos legales, se pronunciará por el otorgamiento del beneficio.

La resolución que dictase el juez interviniente puede se recurrida por los acreedores que no hayan visto íntegramente satisfechos sus créditos.

La esdebitazione puede ser revocada a instancia de los acreedores en cualquier tiempo, si se invoca y justifica la concurrencia de las circunstancias previstas en el apartado 2 b) del art. 14 terdecies (cuando el deudor, en los cinco años anteriores la apertura de la

\footnotetext{
${ }^{114}$ SenEnT MARTínEZ, Santiago, Exoneración del pasivo insatisfecho..., cit., pág. 308 y sgtes.

${ }^{115}$ No se concederá el beneficio cuando el sobreendeudamiento sea imputable al deudor que accede del crédito de forma irresponsable al crédito asumiendo un pasivo desajustado a su capacidad patrimonial. Se prevé que tampoco podrá pretender acceder al mismo cuando en los cinco años anteriores la apertura de la liquidación o en el curso la misma, el deudor ha realizado maniobras en fraude de sus acreedores, pagos u otros actos dispositivos sobre su patrimonio.
} 
liquidación o en el curso la misma, ha realizado actos dispositivos en fraude y perjuicio de sus acreedores, pagos u otros actos dispositivos sobre su patrimonio, o simulado un título de prelación para favorecer algunos acreedores al daño de otras; así como en los casos en los que con dolo o culpa grave haya aumentado o disminuido su pasivo, haya distraído u ocultado una parte relevante de su activo o haya simulado una actividad inexistente).

\section{C.- Tratamiento particular de la problemática en la legislación española}

1.- Justificación del tratamiento diferenciado del caso español:

Hasta muy poco, España y Argentina compartían una preocupación común en relación a la problemática del sobreendeudamiento de los consumidores. En ambos países se denunciaba la falta de una regulación sistemática que asumiera el abordaje del fenómeno. Y se reclamaba como tarea impostergable, el diseño de políticas públicas y una regulación que ofreciera dispositivos de carácter preventivo y de saneamiento de esta grave situación.

Si bien varios países europeos ofrecían ya modelos regulatorios con particularidades propias y diferenciadas - precedentemente reseñadas- España optó por proponer productos legislativos sucesivos que, focalizados en aristas problemáticas concretas, aportaban remedios parciales, sustanciales e instrumentales, frente al endeudamiento excesivo y la insolvencia.

Nos se nos escapa que el derrotero transitado por España en la materia, estuvo marcado por la crisis desatada a partir del año 2008 y que fueron las aristas problemáticas más urgentes y preocupantes las que impulsaron su tratamiento legislativo. Advertimos que las soluciones propuestas en orden al saneamiento de la situación de crisis fueron objeto de permanentes revisiones y que la interpretación del cortejo normativo -con sus marchas y virajes- no es tarea fácil.

Tenemos presente también que la preocupación del legislador español estuvo mayormente centrada en la crisis y el endeudamiento del sector empresario aunque como derivación necesaria, dio a luz varias de las herramientas que venían siendo reclamadas para tutelar especialmente a los consumidores sobreendeudados. 
Precisamente porque en Argentina la regulación anhelada sigue haciéndose esperar, es que nuestra atención está centrada con particular interés en el camino transitado por España. En esta sucesión de esfuerzos por dar respuestas, constatamos la existencia de normas de distinto rango, de naturaleza diversa (sustancial y procedimental), y con finalidades también diferenciadas (preventivas y de saneamiento). Advertimos, asimismo, que muchos de esos dispositivos jurídicos lucen como de pura emergencia -con sus notas de excepcionalidad y transitoriedad- y otros que llegaron con vocación de permanencia, para aportar a la reconstrucción del sistema general.

A sabiendas de la complejidad del fenómeno a regular, de los condicionamientos que cada escenario impone a quien diseña las políticas públicas y construye el andamiaje legal y del contexto de crisis en el que se enmarca la regulación a analizar, nos proponemos describir la regulación propuesta por el legislador español.

Por la afinidad de muchos de nuestros problemas y por participar de una cultura jurídica común es que nos interesa seguir el paso a paso de España y sacar provecho de esa experiencia. Del acierto o desacierto de los dispositivos legales ut infra reseñados, hemos de aprender en Argentina.

Es éste un capítulo descriptivo. Dejaremos para un momento posterior, el análisis crítico de las soluciones propuestas a fin de trazar algunas líneas que orienten el diseño de un modelo propio para Argentina, que sigue en deuda.

\section{2.- Descripción del fenómeno regulatorio en España:}

España -al igual que Argentina- no cuenta con una regulación particular del fenómeno del sobreendeudamiento del consumidor. En efecto, no existe un cuerpo normativo que de modo sistemático, organice medidas de prevención del endeudamiento excesivo de los consumidores, ni cuente con dispositivos orientados al saneamiento de esta situación concreta, en caso de constatarse su efectiva existencia.

La doctrina española ha marcado en forma coincidente su preocupación por la mora del legislador nacional y la impostergable necesidad de una regulación sistemática de la problemática. Se ha señalado la insuficiencia de los dispositivos de contenido sustancial 
existentes y la inadecuación de los procedimientos previstos en la normativa legal ${ }^{116}$; deficiencias que subsisten pese a las previsiones adoptadas y a las sucesivas reformas en materia concursal. Aún luego de los dispositivos previstos en el Real Decreto-Ley 1/2015.

${ }^{116}$ Alvarez Vega, María Isabel, Protección jurídica del consumidor..., cit., pág. 531 y sgtes; AlvarEZ VEGA, Isabel, "El concurso del consumidor en España”, en TOMILlo URBINA, Jorge (Dir.)-AlVAREZ RUBIO, Julio (Coord.), El futuro de la protección jurídica de los consumidores, Thomson-Civitas, Pamplona, 2008, pág. 299 y sgtes; AlONSO LEDESMA, Carmen, "Endeudamiento del consumidor e insolvencia familiar: propuestas de regulación en el procedimiento concursal”, en CuENA CASAS, Matilde-ColinO MEDiAviLla, José Luis (Coord.), Endeudamiento del consumidor e insolvencia familiar, Civitas, Pamplona, 2009, pág. 459 y sgtes.; CUENA CASAS, Matilde, "Algunas deficiencias de la ley concursal ante la insolvencia de la persona física”, en http://eprints.ucm.es/9714/1/Cuena_Deficiencias_LC.pdf (Fecha de consulta: 13/8/2014); BELTRÁN SÁNCHEZ, Emilio, "El concurso de acreedores del consumidor", en CuENA CASAS, Matilde-COLINO Mediavilla, José Luis (Coord.), Endeudamiento del consumidor e insolvencia familiar, Civitas, Pamplona, 2009, pág. 119 y sgtes.; BELTRÁn SÁNCHEZ, Emilio, "Insolvencia de las familias en la ley concursal española”, en Tomillo Urbina, Jorge (Dir.)-Álvarez Rubio, Julio (Coord.), El futuro de la protección jurídica de los consumidores, Thomson-Civitas, Pamplona, 2008, pág. 199 y sgtes.; Colino MediAvILLA, José Luis, "Concurso de consumidor", en Convergencias y paralelismos en el Derecho de Sociedades y en el Derecho Concursal en el marco Estados Unidos-Unión Europea. III Seminario Harvard-Complutense de Derecho de los negocios, 2007, pág. 375-388, http://eprints.ucm.es/7848/1/conccons2007publicHarv2006eprint.pdf (fecha de consulta 3/7/2015); COLINO MEDIAVILLA, José Luis, “Tratamiento de la crisis patrimonial del consumidor: ¿Procedimiento colectivo extrajudicial preconcursal, procedimiento colectivo preventivo, o procedimiento concursal especial?", en CUENA CASAS, Matilde-COLINO MEDIAVILLA, José Luis (Coord.), Endeudamiento del consumidor e insolvencia familiar, Cívitas, Pamplona, 2009, pág. 429 y sgtes.; FERnÁNDEZ SEIJO, José María, "Concurso de personas físicas: sobreendeudamiento familiar y situación de los consumidores en el marco del procedimiento concursal”, en TOMILLO URBINA, Jorge (Dir.)Álvarez Rubio, Julio (Coord.), El futuro de la protección jurídica de los consumidores, Thomson-Civitas, Pamplona, 2008, pág. 257 y sgtes.; FERnÁNDEZ CARRÓN, Clara, El tratamiento de la insolvencia..., cit., pág. 51 y sgtes.; GuTIÉRreZ DE CABIEDES, Pablo, El sobreendeudamiento doméstico..., cit., pág. 33 y sgtes.; GOZALO LÓPEZ, Vicente Gonzalo, “La protección de los consumidores en el procedimiento concursal”, en Tomillo Urbina, Jorge (Dir.)-Álvarez Rubio, Julio (Coord.), El futuro de la protección jurídica de los consumidores, Thomson-Civitas, Pamplona, 2008, pág. 283 y sgtes.; RoJo FernÁndEZ-Río, Ángel, "Problemas y cuestiones ...", cit., pág. 251 y sgtes.; PEÑAS MOYANO, Benjamín, “Concurso de consumidores" en Revista de Derecho Concursal y Paraconcursal, № 8, Sección Comunicaciones, Primer semestre de 2008, pág. 229; PUlgar EZQUERRA, Juana, “Concurso y consumidores ...”, cit., pág. 43 y sgtes.; TAMAYo Haya, Silvia, "El sobreendeudamiento de los consumidores...", cit., pág. 346 y sgtes.; TRUJILLO DíEZ, Iván Jesús, El sobreendeudamiento de los consumidores..., cit., pág. 49 y sgtes. 
Se señala que el Código Civil español carece de una sistematización propia de la tutela patrimonial del derecho de crédito y que los dispositivos existentes se encuentran dispersos en el articulado ${ }^{117}$. Pero no caben dudas de que frente al supuesto de lesión del derecho de crédito $^{118}$, es allí donde encontramos los remedios consagrados por el ordenamiento para satisfacer el interés del acreedor afectado ${ }^{119}$. El diseño de los dispositivos allí existentes responde -como es lógico- a la filosofía y a los principios imperantes al momento de la codificación civil y ello explica la centralidad que adquiere la tutela de la libertad y la autodeterminación de la persona, el resguardo de su libre querer, la fuerza vinculante de la voluntad y el principio de responsabilidad patrimonial, como rasgos definitorios de la protección institucional del derecho de crédito ${ }^{120}$.

${ }^{117}$ Orduña MoReno, Francisco Javier-TAMAYo Haya, Silvia, La protección patrimonial del crédito, T. I, Aranzadi, Cizur Menor, 2006, pág. 19.

${ }^{118}$ DÍEZ- PICAZO expresa que "en la doctrina existe un concepto muy amplio de incumplimiento" conforme al cual "el deudor incumple o no-cumple, siempre que infringe los deberes jurídicos que le atañen"; criterio en el que "está explícita o implícita la necesidad de un examen valorativo de la conducta del deudor". Ahora bien, advierte que "la valoración de la conducta del deudor puede ser importante para determinar la responsabilidad por el incumplimiento pero no lo es para definir el incumplimiento mismo" y de allí que prefiera "cargar el acento en la perspectiva de la satisfacción o de la violación del derecho de crédito, preguntándonos en qué medida ha quedado o no satisfecho, lo que, en línea de principio, es independiente de la valoración que deba atribuirse al comportamiento del deudor y que es en si mismo un hecho perfectamente objetivo". Agrega: "El análisis debe dirigirse, ante todo, a establecer una tipología de las perturbaciones del proyecto de prestación y de la objetiva insatisfacción del derecho del acreedor. Sólo después podrán ponerse en conexión tales hechos con una valoración del comportamiento de los intervinientes para deducir una especial imputabilidad de responsabilidad” (DíEZ- PICAZO, Luis, Fundamentos del Derecho Civil Patrimonial, II, Civitas, Madrid, 1996, pág. 568 y sgtes.).

${ }^{119}$ Resulta de particular interés el enfoque de LLAMAS POMBO, al señalar que los diferentes supuestos de lesión del derecho de crédito (mora, inejecución de la prestación, prestación defectuosa, prestación devenida imposible por causas imputables al deudor e incluso el daño causado con motivo del contrato en otros intereses del acreedor) tienen sus correlativos remedios, conforme la tipología de intereses del acreedor afectado Llamas POMBO, Eugenio, Cumplimiento por equivalente y resarcimiento de daños al acreedor, Entre la aestimatio rei y el id quod interest, Trivium, Madrid, 1999, pag. 153 y sgtes. Ver asimismo, el desarrollo del tema en DíEZ- PiCAZO, Luis, Fundamentos ..., cit., pág. 673 y sgtes.

${ }^{120}$ ORduÑa Moreno, Francisco Javier-TAMAYo Haya, Silvia, La protección patrimonial..., cit., pág. 24 y sgtes. 
No obstante ello, el propio Código Civil español contiene algunos dispositivos que atienden la situación del deudor y hacen aplicación del principio favor debitoris en relación al cumplimiento de las obligaciones ${ }^{121}$. Y, frente al corset impuesto por la regulación en materia de contratos, singular ha sido el aporte de la doctrina y de la jurisprudencia al momento de proponer soluciones referidas a su revisión, rescisión y resolución, donde se imponía resguardar la situación del obligado ${ }^{122}$.

La Ley de Enjuiciamiento Civil, por su parte, suma disposiciones encaminadas a resguardar al deudor del poder de agresión patrimonial del acreedor que ejecuta su crédito, mediante normas de reconocida eficacia ${ }^{123}$.

La ley de condiciones generales de la contratación y la ley general para la defensa de los consumidores y usuarios incorporaron nuevas herramientas de tutela para el consumidor deudor. Estos mecanismos responden -como es sabido- a nuevos paradigmas,

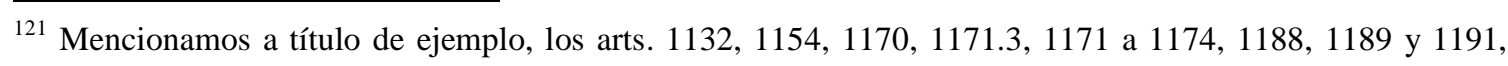
1753 y 1754 del Código Civil español.

${ }^{122}$ Señalaba CASTÁN VAZQUEZ que "en el Derecho español se carece de normas generales en que apoyar la resolución o revisión del contrato por agravación de las circunstancias para una de las partes. Conocida es la prudencia con que el Tribunal Supremo ha aplicado la doctrina de la cláusula rebus sic stantibus y demás fórmulas ideadas para mitigar equitativamente en ciertos casos el rigor de la contratación. La aplicación de la doctrina de la onerosidad excesiva no es fácil. Como observan nuestros autores, el Código civil no contiene una norma de aplicación general que permita la resolución o revisión de una relación obligatoria por haber sobrevenido un exceso de onerosidad a la prestación, y el juez no puede hacer uso como regla general de su arbitrio para conseguir una adecuación más justa de la norma a las circunstancias del caso. El favor debitoris no tiene, pues, en esta materia clara base legal. Sin embargo, es de notar que en la legislación civil española moderna se advierte una tendencia a valorar las circunstancias sobrevenidas al contrato para acudir a mitigar la suerte del obligado. Sin embargo, es de notar que en la legislación civil española moderna se advierte una tendencia a valorar las circunstancias sobrevenidas al contrato para acudir a mitigar la suerte del obligado" (CASTÁn VAzQuez, José María, "El favor debitoris en el Derecho Español", Anuario de Derecho Civil, 1961IV, pág. 835). Ver asimismo, Rogel VIDE, Carlos, Favor debitoris. Análisis crítico, Editorial Zavalía, Buenos Aires, 2010, pág. 41 y sgtes. Para un desarrollo de la doctrina de la cláusula rebus sic stantibus y de la doctrina de la imprevisión, y su impacto en el Derecho español, ver DíEZ- PICAZo, Luis, Fundamentos..., cit., pág. 885 y sgtes. Para el análisis de la rescisión por lesión, DíEZ- PICAZO, Luis, Fundamentos..., cit., pág. 507 y sgtes.

${ }^{123}$ El beneficio de competencia, la inembargabilidad de ciertos bienes del deudor, etc. son algunas de las medidas previstas en el ordenamiento procesal. 
impuestos por la constatación de un quiebre en los presupuestos tradicionales del intercambio y por la irrupción de un nuevo modelo de contratación entre proveedores y consumidores $^{124}$.

Otras leyes especiales aportaron también soluciones normativas vinculadas a la problemática del endeudamiento excesivo de los consumidores, muchas de ellas, de gran relevancia. Destacamos, en particular, la Ley 16/2011 de Contratos de Crédito al Consumo y sus modificatorias.

Ahora bien, a falta de una regulación particular que asumiera la problemática del endeudamiento excesivo de los consumidores, al momento de instar soluciones concretas de saneamiento, la mirada estuvo centrada en las normas contenidas en el régimen general de insolvencia y en los procedimientos previstos en la ley de concursos y quiebras ${ }^{125}$.

La crisis económica que irrumpió en el año 2008 hizo sentir su impacto tanto en el sector empresario como en las familias españolas. Y en este escenario de recesión, con parálisis de las actividades productivas, despidos e incremento creciente del desempleo y precarización de las condiciones laborales, hubo que adoptar medidas propias de una situación de emergencia. El legislador español se abocó al tratamiento de las cuestiones que iban presentándose como de urgencia impostergable y fue ofreciendo soluciones parciales y específicas.

El Real Decreto-Ley 3/2009, significó una importante modificación de la Ley Concursal $^{126}$, que lucía impotente -en la coyuntura- para viabilizar procedimientos de

${ }^{124}$ Como es sabido, al amparo de este régimen protectorio se diseña un cortejo de normas que parte de presupuestos inversos al modelo tradicional. La relación jurídica de consumo enfrenta a sujetos desiguales, donde uno de ellos (el proveedor de bienes y servicios) ostenta el poderío que le confiere su condición de experto en materia negocial y el reconocimiento de un rol preponderante en el establecimiento de las condiciones contractuales, mientras que la otra parte (el consumidor) -en situación de clara asimetría informativa, técnica y económica- se limitará a adherir o no, conforme decida contratar con el primero o no hacerlo.

${ }^{125}$ Para un desarrollo de los antecedes legislativos vinculados a los remedios y procedimientos de superación de la insolvencia, ver HERNÁNDEZ RODRÍGUEZ, María del Mar, La segunda oportunidad. La superación de las crisis de insolvencia, Lefebvre-El Derecho, Madrid, 2015, pág. 35 y sgtes.

${ }^{126}$ La Exposición de Motivos explica que "con respecto a la legislación concursal, la vigente ley se dictó en el año 2003 en un entorno económico completamente distinto al actual, y no ha sido hasta que la crisis financiera internacional se ha trasladado a las empresas cuando se ha podido comprobar la inadecuación de 
superación eficaces, ante ahogo provocado por la crisis. Nuevamente aquí, el foco de atención fue en endeudamiento del sector empresario.

Pese a que en la práctica, el primer esfuerzo de salida de la crisis económico financiera se encaminaba a renegociar el pasivo existente en forma privada, los procesos extrajudiciales de refinanciación de deuda no estaban regulados en el régimen de insolvencia. Más aún, hasta esa fecha la Ley Concursal suponía un freno a los mismos, entre otras razones, porque los acuerdos de refinanciación podían ser rescindidos en caso de que sobreviniera un procedimiento formal de insolvencia ${ }^{127}$.

La saturación de los Juzgados de lo Mercantil -abarrotados de concursos- y la práctica generalizada de los acuerdos de refinanciación extrajudiciales llevaron a promulgar este Real Decreto-Ley, que tiene entre sus principales objetivos facilitar la reestructuración de las deudas empresarias.

La normativa analizada define expresamente los acuerdos de refinanciación ${ }^{128} \mathrm{y}$ estimula su celebración siempre que respondan a un "plan de viabilidad" que permita la continuidad de la actividad del deudor en el corto y medio plazo. Asimismo y para sortear dificultades antes existentes, en caso de sobrevenir un procedimiento concursal, se establece la inatacabilidad de los negocios, actos, pagos y garantías constituidas en desarrollo de la refinanciación, siempre que se cumplan ciertos requisitos ${ }^{129}$. En la misma

algunas de sus previsiones. Sin perjuicio de que en el futuro sea necesario revisar en profundidad la legislación concursal a la luz de la intensa experiencia vivida en los tribunales como consecuencia de la crisis, en este momento es preciso acometer ya una serie de reformas en aquellos aspectos concretos cuyo tratamiento normativo se ha revelado más inconveniente. Las modificaciones contenidas en el presente Decreto-ley pretenden facilitar la refinanciación de las empresas que puedan atravesar dificultades financieras que no hagan ineludible una situación de insolvencia, además de, agilizar los trámites procesales, reducir los costes de la tramitación, y mejorar la posición jurídica de los trabajadores de empresas concursadas que se vean afectados por procedimientos colectivos".

${ }^{127}$ Ver DíaZ EChEGARAY, José Luis, Los acuerdos de refinanciación, Cívitas Thomson Reuters, 2015, pág. 31.

${ }^{128}$ Son "los alcanzados por el deudor en virtud de los cuales se proceda al menos a la ampliación significativa del crédito disponible o la modificación de sus obligaciones, bien mediante la prórroga de su plazo de vencimiento, bien mediante el establecimiento de otras obligaciones contraídas en sustitución de aquéllas".

${ }^{129}$ Ellos son: 1.- Suscripción por parte de acreedores que representen al menos el $60 \%$ del pasivo del deudor; 2.- Informe de un experto independiente que avale la razonabilidad del plan de viabilidad así como la 
línea, a diferencia de lo que ocurría antes (cualquier acreedor podía impugnar estos acuerdos subsidiariamente a la administración concursal), el nuevo Decreto-Ley indica que, una vez declarado el concurso, sólo la administración concursal puede impugnar dichos acuerdos. Asimismo, y como estímulo, se racionalizan y reducen los costes de las escrituras públicas de formalización de los acuerdos de refinanciación.

La nueva regulación incentiva también las propuestas anticipadas de convenio flexibilizando los requisitos de acceso y facilitando el alcance de las adhesiones, el quórum necesario para la aprobación y el trámite del procedimiento.

Ambas figuras constituyeron el germen de los institutos preconcursales, orientados a propiciar soluciones de consenso que resultaran inmunes en caso de concurso posterior.

El legislador asume que las salidas consensuadas entre las partes constituyen la primera herramienta en pos de superar la situación de endeudamiento y propiciar la continuidad de la actividad productiva y del giro empresario ${ }^{130}$.

adecuación de las condiciones pactadas y la proporcionalidad de las garantías conforme a las condiciones de mercado en el momento de firmar el acuerdo; 3.- Formalización en instrumento público (notarización).

${ }^{130}$ SENENT MARTÍNEZ explica que la superación de la situación de insolvencia del deudor puede lograrse por vías alternativas y que transitadas éstas, la liberación de las deudas puede alcanzarse por medios también diversos. En su tesis menciona que además de los mecanismos propios (donde la exoneración del pasivo se producirá ex lege, un segundo bloque abarcaría los mecanismos impropios de liberación de deudas que producen un efecto equivalente pero bien de modo indirecto, "como es el caso de la extinción de la persona jurídica en caso de conclusión de concurso con pasivo insatisfecho, o por medio de un instituto jurídico distinto a la discharge, como es el convenio con quita, que sobre un sustrato negocial, produce un efecto novatorio sobre la deuda originaria". Explica que "en la evolución histórica del derecho concursal la figura del convenio se concibe en un primer momento como una alternativa a la quiebra, siempre que a través del arreglo negociado los acreedores consigan una satisfacción de sus créditos superior de la que obtendrían si se procediera a la realización de los bienes del deudor (acuerdos extrajudiciales). En una segunda fase, el convenio deja de ser solo una alternativa solutoria a la quiebra, para configurarse como una alternativa al propio procedimiento de quiebra, evitándose así su declaración al configurarse como un procedimiento autónomo y alternativo al de quiebra, continuando, no obstante la satisfacción de los acreedores como la finalidad prioritaria del procedimiento (convenios judiciales solutorios de quiebra). El nacimiento de las grandes empresas marca un tercer momento de la evolución del derecho concursal y, en consecuencia, del convenio, dado que la crisis de éstas lleva aparejados unos graves efectos y consecuencias que trascienden a los intereses privados de los acreedores ... se ven afectados intereses públicos que justifican el abandono de la visión privatística de los convenios concursales tal y como venían concibiéndose hasta ese momento 
La Ley 13/2009, de Reforma de la Legislación Procesal para la implantación de la nueva oficina judicial, modificó luego 49 preceptos de la Ley Concursal. Estas normas abrían paso a un proceso de reforma más amplio y ambicioso de la legislación sobre la materia. Con el objetivo mencionado, se constituyó en el Ministerio de Justicia, en el seno de la Comisión General de Codificación, una Sección especial compuesta por todos los sectores implicados (judicatura, catedráticos, economistas y abogados), cuyo trabajo sirvió de base a la reforma que se concretaría luego por Ley 38/2011, de 10 de octubre.

La Ley 38/2011 profundiza en las alternativas al concurso o los denominados institutos preconcursales, que conforme la Exposición de Motivos, ofrecen "a las empresas una solución más ágil y económica a sus crisis"131.

La reforma permitió corregir el diseño de las figuras ya existentes y aspectos concretos del trámite previsto en la ley anterior ${ }^{132}$.

La ley diseñó dos tipos diferentes de acuerdos ${ }^{133}$. Por un lado, los llamados acuerdos típicos, que debían ajustarse a los requisitos establecidos en el art. 71.6 -luego

surgiendo así las limitaciones a la autonomía de la libertad de las partes ex art. 1255 CC e incorporándose la reorganización de la empresa como fin de política jurídica perseguido a través de los procedimientos concursales. Esta tendencia conservativa y reorganizativa seguirá expandiéndose progresivamente .... En la actualidad, no obstante, puede sostenerse que en la generalidad de modelos de derecho comparado el derecho concursal sigue siendo un modelo mixto, en el que la satisfacción de los acreedores aparece como finalidad prioritaria del procedimiento de insolvencia, pero no como contrapuesto a la finalidad de conservación de la empresa, si bien ésta se vincula a la viabilidad" (SENENT MARTínEZ, Santiago, Exoneración del pasivo insatisfecho..., cit., pág. 65 y sgtes.

${ }^{131}$ Se ha dicho que la reforma introducida por el real Decreto-Ley 3/2009 resultó un "absoluto y completo fracaso en su aplicación” (AZNAR DINER, Eduardo, Refinancianción de deuda, acuerdos extrajudiciales de pago y concurso de acreedores, Tirant lo Blanch, Valencia, 2014, pág. 33) y "el hecho de que cuando apenas habían transcurrido dos años desde su promulgación hubiera de reformarse nuevamente, parece confirmar este aserto o cuando menos, que no se reguló adecuadamente (DíAZ ECHEGARAY, José Luis, Los acuerdos de refinanciación, cit., pág. 37 y sgtes.).

${ }^{132}$ DíAZ EchegarAY, José Luis, Los acuerdos de refinanciación, cit., pág. 37 y sgtes..

${ }^{133}$ Para un análisis profundizado del tema y su tratamiento legislativo, ver PULGAR EzQUERRA, Juana, Preconcursalidad y acuerdos de refinanciación. Adaptado a la Ley 38/2011 de 10 de octubre de 2011 de reforma a la ley concursal, Ed. La Ley, Madrid, 2012; Asimismo, PUlGAR EZQUERRA, Juana, “Acuerdos de refinanciación, escudos protectores y garantías reales”, en http://www.mjusticia.gob.es/cs/Satellite/Portal/1292347817007?blobheader=application\%2Fpdf\&blobheader 
derogado por el Real Decreto-Ley 4/2014- que se beneficiaban de los llamados escudos protectores. En esta categoría, y considerando los sujetos habilitados a participar, se presentaban dos alternativas. De los acuerdos de refinanciación generales, participaba toda clase de acreedores y el deudor común, mientras que los acuerdos de refinanciación particulares, estaban reservados a sólo un sector de los acreedores (las entidades financieras), siendo necesaria además, la homologación judicial de la Disposición Adicional $4^{\text {a }}$ de la Ley, luego modificada también por el Real Decreto-Ley 4/2014. De otro lado, la regulación analizada consagraba a los llamados acuerdos de refinanciación atípicos, que al no ajustarse a los requisitos legales, eran producto de la autonomía de la voluntad de las partes (conf. art. 1255 del Código Civil), ajenos a la protección de los llamados escudos protectores y sujetos al régimen rescisorio general del art. 71 de la Ley Concursal.

La ley prevé la comunicación formal de que existen negociaciones con los acreedores (con sus efectos favorables), contempla con detalle los deberes de las partes que negocian el acuerdo y establece la homologación judicial de tal acuerdo que, en consecuencia y dentro de ciertos límites, se extiende a los acreedores disidentes.

Por otra parte, y frente a la necesidad inexorable de transitar el procedimiento concursal, la reforma introducida procura "que la solución de la insolvencia no se retrase en el tiempo" puesto que ello "no hace sino perjudicar al concursado y a sus acreedores, al minorar el valor de sus bienes de cuya realización depende su cobro, eliminar posibilidades de garantizar su viabilidad y aumentar los costes".

Con este objetivo, se regula un verdadero concurso abreviado, ofreciendo soluciones simples, rápidas y económicas cuando concurran determinadas circunstancias (la situación de la empresa en crisis, el número de trabajadores, las negociaciones que la

name $1=$ Content -

isposition\&blobheadervalue $1=$ attachment\%3B+filename\%3DPonencia_de_Juana_del_Pulgar_Ezquerra.PDF. (fecha de consulta: 21/4/2015). Cfr., asimismo, PÉREZ BENÍTEZ, Jacinto José, "La nueva regulación de los acuerdos de refinanciación", consulta 22/4/2015). 
empresa pudiera haber iniciado para su venta o la modificación estructural de la sociedad deudora). Se considera que este procedimiento especial ofrece al deudor un incentivo concreto puesto que si logra alcanzar con sus acreedores un convenio anticipado -siempre que no sea especialmente gravoso- escapa a formar la sección de calificación.

Considera el legislador que la anticipación de la liquidación, tal como queda regulada, es también una herramienta útil para tramitar de manera más ágil aquellos concursos en los que el deudor solicite dicha liquidación en los primeros momentos del procedimiento.

A igual propósito de estímulo responde la consideración expresa de que los créditos nacidos tras la aprobación judicial del convenio han de ser, en caso de apertura posterior de la fase de liquidación, créditos contra la masa. La novedosa figura del fresh money tiende a favorecer la concesión de crédito a una empresa en fase de convenio, contribuyendo a la continuidad de su actividad.

Por otra parte, esta reforma a la ley concursal "ha incidido con especial intensidad" en la regulación de los llamados concursos sin masa, con "modificaciones ... numerosas y de calado" $" 134$. Se destaca la incorporación de nuevo art. 176 bis.

Sobre el particular, lo relevante es que, si se dan los requisitos enunciados en este precepto $^{135}$, en el mismo auto de declaración de concurso el juez puede acordar su

\footnotetext{
134 GarCíA-VILlarrubia, Manuel, "La conclusión del concurso por inexistencia de bienes y el llamado concurso express", en El Derecho, Revista de Derecho Mercantil, $\mathrm{N}^{\circ} \quad 4$, en http://www.uria.com/es/publicaciones/buscador-publicaciones.html?id=3645\&pub=Publicacion (fecha de consulta 20/4/2015).

${ }^{135} \mathrm{El}$ art. 176 bis establece: "Especialidades de la conclusión por insuficiencia de masa activa. 1. Desde la declaración del concurso procederá la conclusión por insuficiencia de la masa activa cuando, no siendo previsible el ejercicio de acción de reintegración, de impugnación o de responsabilidad de terceros ni la calificación del concurso como culpable, el patrimonio del concursado no sea presumiblemente suficiente para la satisfacción de los créditos contra la masa, salvo que el juez considere que estas cantidades estén garantizadas por un tercero de manera suficiente.....4. También podrá acordarse la conclusión por insuficiencia de masa en el mismo auto de declaración de concurso cuando el juez aprecie de manera evidente que el patrimonio del concursado no será presumiblemente suficiente para la satisfacción de los previsibles créditos contra la masa del procedimiento ni es previsible el ejercicio de acción de reintegración, de impugnación o de responsabilidad de terceros".
} 
conclusión por insuficiencia de masa...con consecuencias diferentes según el deudor sea persona física o jurídica ${ }^{136}$.

En el marco de la crisis imperante, el legislador español advirtió que pese a las sucesivas reformas y al aggiornamiento del régimen general de insolvencia, se imponía ofrecer soluciones adicionales a quienes resultaban afectados de modo particularmente dramático. Ello explica que, en paralelo, se dictaran leyes destinadas a mejorar el sistema con vocación de permanencia (remozando la ley concursal y otras leyes regulatorias del mercado de crédito), por un lado, y que por otra parte surgieran propuestas legislativas de coyuntura, con las notas típicas de la legislación de emergencia.

${ }^{136}$ Explica GARCÍA VILLARRUBiA que tratándose de personas físicas o naturales, conforme el art. 178.2 LC, “el deudor quedará responsable del pago de los créditos restantes. Los acreedores podrán iniciar ejecuciones singulares, en tanto no se acuerde la apertura del concurso o no se declare nuevo concurso" y que "no se trata de otra cosa que de una expresión del principio de responsabilidad patrimonial universal del deudor consagrado en el artículo 1911 del Código Civil". Y agrega que "la situación cambia -al menos en aparienciaen el supuesto del deudor persona jurídica porque, según el artículo 178.3 LC, "la resolución judicial que declare la conclusión del concurso por liquidación o por insuficiencia de la masa activa del deudor persona jurídica acordará su extinción y dispondrá la cancelación de su inscripción en los registros públicos que corresponda, a cuyo efecto se expedirá mandamiento conteniendo testimonio de la resolución firme" (GARCÍA-Villarrubia, Manuel, "La conclusión del concurso...”, cit.. Señala SENENT MartíNEZ que "la extinción de la persona jurídica por conclusión del concurso por inexistencia de bienes ha supuesto un efecto depurador de numerosas sociedades formalmente vigentes por tener aún abierta su hoja registral, pero sin actividad alguna, que de otro modo no se hubiera podido producir, lo que constituye un argumento más a favor de la necesidad de declarar el concurso aun en caso de inexistencia de masa. Sin embargo, precisamente, ese efecto, comporta que el principio de subsistencia de la responsabilidad, vinculado a la responsabilidad patrimonial universal del art. 1911 del Código Civil (LA LEY. 1/1889), no opere del mismo modo en el caso de las personas jurídicas y de las personas físicas. En el caso de persona jurídica la resolución judicial que declare la conclusión del concurso por inexistencia de bienes según dispone el art. 178.3 de la Ley concursal acordará su extinción y dispondrá el cierre de su hoja de inscripción en los registros públicos, lo que equivale a una tácita condonación del pasivo insatisfecho tras la conclusión del concurso, por haberse extinguido el titular de dicho pasivo. En el caso de la persona física, sin embargo, la conclusión del concurso por inexistencia de bienes, no determina su extinción, por lo que subsiste su responsabilidad. Para un desarrollo de este aspecto de la reforma a la ley concursal, cfr. SENENT MARTínEZ, Santiago, "Concurso sin masa y protección de los consumidores", en Revista de Derecho Concursal y Paraconcursal, № 15, Sección Ponencias, Segundo semestre de 2011, pág. 133 y sgtes. 
El Real Decreto-Ley 6/2012 ${ }^{137}$, sobre "Medidas urgentes de protección de deudores hipotecarios sin recursos" es un producto legislativo mixto puesto que propuso soluciones que hacen a la estructura del régimen general de insolvencia pero, además, impulsó la adopción de medidas particulares y de excepción, caracterizadas también por la transitoriedad.

Haciéndose cargo de un foco problemático especialmente grave, dispuso la implementación de mecanismos tendientes a "permitir la restructuración de la deuda hipotecaria de quienes padecen extraordinarias dificultades para atender su pago, así como la flexibilización de la ejecución de la garantía real" "138. De la Exposición de Motivos se extrae que los beneficiarios de las medidas allí establecidas eran las personas que se encontraran "en situación profesional y patrimonial que les impida hacer frente al cumplimiento de sus obligaciones hipotecarias y a las elementales necesidades de subsistencia" dentro del "denominado umbral de exclusión".

Por otra parte, impulsó la elaboración de un Código de Buenas Prácticas al que, voluntariamente, podían y pueden adherirse las entidades de crédito. El legislador

${ }^{137}$ La Exposición de Motivos da cuenta del contexto en que se dictó la norma analizada, al señalar que "España atraviesa una profunda crisis económica desde hace cuatro años, durante los cuales se han adoptado medidas encaminadas a la protección del deudor hipotecario que, no obstante, se han mostrado en ocasiones insuficientes para paliar los efectos más duros que sobre los deudores sin recursos continúan recayendo. Resulta dramática la realidad en la que se encuentran inmersas muchas familias que, como consecuencia de su situación de desempleo o de ausencia de actividad económica, prolongada en el tiempo, han dejado de poder atender el cumplimiento de sus obligaciones derivadas de los préstamos o créditos hipotecarios concertados para la adquisición de su vivienda. Tal circunstancia y la consiguiente puesta en marcha de los procesos de ejecución hipotecaria están determinando que un segmento de la población quede privado de su vivienda, y se enfrente a muy serios problemas para su sustento en condiciones dignas. El Gobierno considera, por ello, que no puede demorarse más tiempo la adopción de medidas que permitan aportar soluciones a esta situación socioeconómica en consonancia con el derecho a disfrutar de una vivienda digna y adecuada, consagrado en el artículo 47 de la Constitución española, que ha de guiar la actuación de los poderes públicos de conformidad con el artículo 53.3 de la misma. Así lo exige, igualmente, el mandato incluido en el artículo 9.2 de la Norma Fundamental".

${ }^{138}$ Para un análisis profundizado de las medidas allí dispuestas, ver CUENA CASAS, Matilde, "Insolvencia de la persona física y sobreendeudamiento hipotecario", en Revista de Derecho Concursal y Paraconcursal, $\mathrm{N}^{\circ}$ 17, Sección Varia, Segundo semestre de 2012, pág. 97 y sgtes. 
interpretó que con ello, se involucraba al sector financiero español en el esfuerzo que requiere aliviar la difícil situación económica y social de muchas familias.

En el citado Código de Buenas Prácticas se prevén tres fases de actuación en pos de la mayor protección de los deudores afectados. Mediante la primera, se procura la reestructuración viable de la deuda hipotecaria. Para ello, se propone aplicar a los préstamos una carencia en la amortización de capital y una reducción del tipo de interés durante cuatros años, ampliando asimismo el plazo total de amortización. En caso de no resultar suficiente la reestructuración anterior, las entidades podrán, en su caso, y con carácter potestativo, ofrecer a los deudores una quita sobre el conjunto de su deuda. Y, ante la inviabilidad de las medidas anteriores, prevé la posibilidad de que los deudores hipotecarios soliciten, y las entidades deban aceptar, la dación en pago como medio liberatorio definitivo de la deuda ${ }^{139}$. La normativa contempla que en este último supuesto, "las familias podrán permanecer en su vivienda durante de un plazo de dos años satisfaciendo una renta asumible".

La disposición legal dispuso asimismo, la moderación de los tipos de interés moratorios aplicables a los contratos de crédito o préstamo hipotecario con el objeto de disminuir la carga financiera generada en casos de incumplimiento, cuando se trate de los deudores aquí protegidos.

La persistencia de la crisis económica y financiera, sumada al dato incontrastable de una tasa de desempleo alarmante, trajo nuevas manifestaciones de preocupación. El incumplimiento de las obligaciones asumidas por los deudores ante las entidades de crédito, determinó la ejecución masiva de las garantías hipotecarias con el resultado final de pérdida de la vivienda por parte de las familias endeudadas. Y ello motivó la adopción de nuevas medidas legislativas.

Esta vez, el objetivo fue puntual y concreto puesto que con el Real Decreto Ley 27/2012, de “medidas urgentes para reforzar la protección a los deudores hipotecarios", se dispuso la suspensión de los desahucios de las viviendas habituales durante dos años.

139 SENENT MARTínEZ destaca la importancia del Real Decreto-Ley analizado, al introducir "de modo limitado la dación en pago de la vivienda como mecanismo exoneratorio de la deuda garantizada" (SENENT MARTínEZ, Santiago, Exoneración del pasivo insatisfecho..., cit., pag. 356). 
Como bien se advierte, esta normativa está claramente marcada por su "carácter de excepción, en todos los sentidos: no sólo de emergencia...sino también de cariz meramente paliativo, con un enfoque de mínimos, limitado objetiva, subjetiva y temporalmente, ... de carácter sobremanera restrictivo y no exento de cierto arbitrio en su determinación y por sobre todo ello, insuficiente como solución efectiva (real y positiva) al verdadero problema de fondo, que trasciende con mucho, social y económicamente, a esto" ${ }^{\text {140 }}$.

Como acción complementaria, se aprobó la Ley 1/2013, de "Medidas para reforzar la protección a los deudores hipotecarios, reestructuración de deuda y alquiler social”. Allí se prevé la suspensión inmediata y por un plazo de dos años de los desahucios de las familias que se encuentren en una situación de especial vulnerabilidad y riesgo de exclusión $^{141}$.

${ }^{140}$ GutiÉRREZ DE CABIEDES, Pablo, "El Real Decreto-Ley 27/2012, de 15 de noviembre, de medidas urgentes para reforzar la protección a los deudores hipotecarios", en Revista de Derecho Concursal y Paraconcursal, No. 18, 2013, pág. 479 y sgtes.

${ }^{141}$ Conforme se explica en la Exposición del Motivos de la normativa analizada, "para que un deudor hipotecario se encuentre en este ámbito de aplicación será necesario el cumplimiento de dos tipos de requisitos. De un lado, los colectivos sociales que van a poder acogerse son las familias numerosas, las familias monoparentales con dos hijos a cargo, las que tienen un menor de tres años o algún miembro con discapacidad o dependiente, o en las que el deudor hipotecario se encuentre en situación de desempleo y haya agotado las prestaciones sociales o, finalmente, las víctimas de violencia de género. Asimismo, en las familias que se acojan a esta suspensión, los ingresos no podrán superar el límite de tres veces el Indicador Público de Renta de Efectos Múltiples. Este límite se eleva respecto de unidades familiares en las que algún miembro sea persona con discapacidad o dependiente o que conviva con personas con discapacidad o dependientes. Además, es necesario que, en los cuatro años anteriores al momento de la solicitud, la unidad familiar haya sufrido una alteración significativa de sus circunstancias económicas, en términos de esfuerzo de acceso a la vivienda". Allí se precisa que "la inclusión en el ámbito de aplicación pasa por el cumplimiento de otros requisitos, entre los que se pueden destacar que la cuota hipotecaria resulte superior al 50 por ciento de los ingresos netos que perciba el conjunto de los miembros de la unidad familiar, o que se trate de un crédito o préstamo garantizado con hipoteca que recaiga sobre la única vivienda en propiedad del deudor y concedido para la adquisición de la misma”. 
Por otra parte, la ley introduce mejoras en el mercado hipotecario a través de la modificación de las leyes regulatorias del sistema hipotecario, con medidas de gran relevancia $^{142}$.

Esta herramienta legal introdujo medidas protectorias vinculadas a la abusividad en la contratación de mutuos hipotecarios. En efecto, prevé en la venta extrajudicial, la posibilidad de que el notario pueda suspender la misma cuando las partes acrediten que se ha solicitado al órgano judicial competente que dicte resolución decretando la improcedencia de dicha venta, por existir cláusulas abusivas en el contrato de préstamo hipotecario (conf. lo previsto en el art. 129 de la Ley Hipotecaria), o su continuación, sin la aplicación de las cláusulas abusivas. Por otra parte, la normativa faculta expresamente al notario para que advierta a las partes que alguna cláusula del contrato puede ser abusiva.

En este instrumento legal se recogen diferentes modificaciones a la Ley de Enjuiciamiento Civil, destinadas a garantizar que la ejecución hipotecaria se realiza resguardando adecuadamente los derechos del deudor hipotecario, flexibilizando el procedimiento de ejecución ${ }^{143}$.

${ }^{142}$ Para las hipotecas constituidas sobre vivienda habitual, la normativa dispone la limitación de los intereses de demora que pueden exigir las entidades de crédito a tres veces el interés legal del dinero. Además, se prohíbe expresamente la capitalización de estos intereses y se establece que, en caso de que el resultado de la ejecución fuera insuficiente para cubrir toda la deuda garantizada, dicho resultado se aplicará en último lugar a los intereses de demora, de tal forma que se permita en la mayor medida posible que el principal deje de devengar interés. Adicionalmente se fortalece en la Ley Hipotecaria el régimen de venta extrajudicial de bienes hipotecados. De particular relevancia es el dispositivo que refuerza la independencia de las sociedades de tasación respecto de las entidades de crédito.

En la venta extrajudicial se introduce la posibilidad de que el Notario pueda suspender la misma cuando las partes acrediten que se ha solicitado al órgano judicial competente, en la forma prevista por el artículo 129 de la Ley Hipotecaria, que dicte resolución decretando la improcedencia de dicha venta, por existir cláusulas abusivas en el contrato de préstamo hipotecario, o su continuación sin la aplicación de las cláusulas abusivas. Además, se faculta expresamente al Notario para que advierta a las partes de que alguna cláusula del contrato puede ser abusiva. Dichas modificaciones se adoptan como consecuencia de la Sentencia del Tribunal de Justicia de la Unión Europea de 14 de marzo de 2013, dictada en el asunto por el que se resuelve la cuestión prejudicial planteada por el Juzgado de lo Mercantil n. ${ }^{o} 3$ de Barcelona respecto a la interpretación de la Directiva 93/13/CEE del Consejo, de 5 de abril de 1993

${ }^{143}$ La normativa contempla la posibilidad de que deudor participe de la eventual revalorización futura de la vivienda ejecutada, facilita el acceso de postores a las subastas y se rebajan los requisitos que se imponen a 
La Exposición de Motivos destaca en particular, como medida de gran relevancia, que "se establece la posibilidad de que si tras la ejecución hipotecaria de una vivienda habitual aún quedara deuda por pagar, durante el procedimiento de ejecución dineraria posterior se podrá condonar parte del pago de la deuda remanente, siempre que se cumpla con ciertas obligaciones de pago".

En este capítulo, la ley recoge también la modificación del procedimiento ejecutivo a efectos de que, de oficio o a instancia de parte, el órgano judicial competente pueda apreciar la existencia de cláusulas abusivas en el título ejecutivo y, como consecuencia, decretar la improcedencia de la ejecución o, en su caso, su continuación sin aplicación de aquéllas consideradas abusivas ${ }^{144}$.

La normativa modifica el Real Decreto-Ley 6/2012, tanto en lo que afecta al ámbito de aplicación, como en lo relativo a las características de las medidas que pueden ser $\operatorname{adoptadas}^{145}$.

los licitadores, de modo que, por ejemplo, se disminuye el aval necesario para pujar del 20 al 5 por cien del valor de tasación de los bienes. Asimismo se duplica, en idéntico sentido, el plazo de tiempo para que el rematante de una subasta consigne el precio de la adjudicación. Se introducen determinadas mejoras en el procedimiento de subasta, estableciéndose que el valor de tasación a efectos de la misma no podrá ser inferior al 75 por cien del valor de tasación que sirvió para conceder el préstamo. Anteriormente no existía ningún límite para el tipo de subasta. Además, en caso de que la subasta concluyera sin postor alguno, se incrementan los porcentajes de adjudicación del bien. En concreto, se elevaría del 60 por cien hasta un máximo del 70 por cien, siempre para los supuestos de vivienda habitual.

${ }^{144}$ Esta modificación se adopta como consecuencia de lo resuelto por el Tribunal de Justicia de la Unión Europea, en fecha 14 de marzo de 2013, en referencia a la cuestión prejudicial planteada por el Juzgado de lo Mercantil n. ${ }^{\circ} 3$ de Barcelona respecto a la interpretación de la Directiva 93/13/CEE del Consejo, de 5 de abril de 1993.

${ }^{145}$ Al modificar varias normas del articulado se deja establecido que conforme el nuevo art. 3: "1. Se considerarán situados en el umbral de exclusión aquellos deudores de un crédito o préstamo garantizado con hipoteca sobre su vivienda habitual, cuando concurran en ellos todas las circunstancias siguientes: a) Que el conjunto de los ingresos de los miembros de la unidad familiar no supere el límite de tres veces el Indicador Público de Renta de Efectos Múltiples. A estos efectos se entenderá por unidad familiar la compuesta por el deudor, su cónyuge no separado legalmente o pareja de hecho inscrita y los hijos, con independencia de su edad, que residan en la vivienda, incluyendo los vinculados por una relación de tutela, guarda o acogimiento familiar. El límite previsto en el párrafo anterior será de cuatro veces el Indicador Público de Renta de Efectos Múltiples en caso de que alguno de los miembros de la unidad familiar tenga declarada discapacidad superior 
al 33 por ciento, situación de dependencia o enfermedad que le incapacite acreditadamente de forma permanente para realizar una actividad laboral, o de cinco veces dicho indicador, en el caso de que un deudor hipotecario sea persona con parálisis cerebral, con enfermedad mental o con discapacidad intelectual, con un grado de discapacidad reconocido igual o superior al 33 por ciento, o persona con discapacidad física o sensorial, con un grado de discapacidad reconocido igual o superior al 65 por ciento, así como en los casos de enfermedad grave que incapacite acreditadamente, a la persona o a su cuidador, para realizar una actividad laboral. b) Que, en los cuatro años anteriores al momento de la solicitud, la unidad familiar haya sufrido una alteración significativa de sus circunstancias económicas, en términos de esfuerzo de acceso a la vivienda, o hayan sobrevenido en dicho período circunstancias familiares de especial vulnerabilidad. A estos efectos se entenderá que se ha producido una alteración significativa de las circunstancias económicas cuando el esfuerzo que represente la carga hipotecaria sobre la renta familiar se haya multiplicado por al menos 1,5; salvo que la entidad acredite que la carga hipotecaria en el momento de la concesión del préstamo era igual o superior a la carga hipotecaria en el momento de la solicitud de la aplicación del Código de Buenas Prácticas. Asimismo, se entiende que se encuentran en una circunstancia familiar de especial vulnerabilidad: $1 .^{\circ} \mathrm{La}$ familia numerosa, de conformidad con la legislación vigente. $2 .^{\circ}$ La unidad familiar monoparental con dos hijos a cargo. $3 .^{\circ} \mathrm{La}$ unidad familiar en la que alguno de sus miembros tenga declarada discapacidad superior al 33 por ciento, situación de dependencia o enfermedad que le incapacite de forma permanente, de forma acreditada, para realizar una actividad laboral. $4 .^{\circ}$ La unidad familiar de la que forme parte un menor de tres años. c) Que la cuota hipotecaria resulte superior al 50 por cien de los ingresos netos que perciba el conjunto de los miembros de la unidad familiar. Dicho porcentaje será del 40 por cien cuando alguno de dichos miembros sea una persona en la que concurren las circunstancias previstas en el segundo párrafo del apartado a). A efectos de las letras a) y b) anteriores, se considerará que presentan una discapacidad en grado igual o superior al 33 por ciento los pensionistas de la Seguridad Social que tengan reconocida una pensión de incapacidad permanente en el grado de total, absoluta o gran invalidez, y a los pensionistas de clases pasivas que tengan reconocida una pensión de jubilación o de retiro por incapacidad permanente para el servicio o inutilidad. 2. Para la aplicación de las medidas complementarias y sustitutivas de la ejecución hipotecaria a que se refieren los apartados 2 y 3 del Anexo, será además preciso que se cumplan los siguientes requisitos. a) Que el conjunto de los miembros de la unidad familiar carezca de cualesquiera otros bienes o derechos patrimoniales suficientes con los que hacer frente a la deuda. b) Que se trate de un crédito o préstamo garantizado con hipoteca que recaiga sobre la única vivienda en propiedad del deudor o deudores y concedido para la adquisición de la misma. c) Que se trate de un crédito o préstamo que carezca de otras garantías, reales o personales o, en el caso de existir estas últimas, que carezca de otros bienes o derechos patrimoniales suficientes con los que hacer frente a la deuda. d) En el caso de que existan codeudores que no formen parte de la unidad familiar, deberán estar incluidos en las circunstancias a), b) y c) anteriores. Conforme el nuevo art. 4: "1. En todos los contratos de crédito o préstamo garantizados con hipoteca inmobiliaria en los que el deudor se encuentre situado en el umbral de exclusión, el interés moratorio aplicable desde el momento en que el deudor solicite a la entidad la aplicación de cualquiera de las medidas del código de buenas prácticas y 
Finalmente, esta ley incluye un mandato al Gobierno "para que emprenda inmediatamente las medidas necesarias para impulsar, con el sector financiero, la constitución de un fondo social de viviendas destinadas a ofrecer cobertura a aquellas personas que hayan sido desalojadas de su vivienda habitual por el impago de un préstamo hipotecario". La Exposición de Motivos hace explícito el objetivo de que este fondo movilice "un amplio parque de viviendas, propiedad de las entidades de crédito, en beneficio de aquellas familias que sólo pueden acceder a una vivienda en caso de que las rentas se ajusten a la escasez de sus ingresos".

La reforma introducida por la Ley 1/2013 al Real Decreto Ley 6/2012 apunta también al Código de Buenas Prácticas, ampliando el espectro de las medidas concebidas de origen.

En efecto, conforme la nueva redacción del anexo en cuestión, la "reestructuración de deudas hipotecarias" -prevista con carácter previa a la ejecución - adopta contornos más flexibles. Los deudores comprendidos en el ámbito de aplicación quedan habilitados a "solicitar y obtener de la entidad acreedora la reestructuración de su deuda hipotecaria con el objeto de alcanzar la viabilidad a medio y largo plazo de la misma". Se prevé que en el término de un mes desde la presentación de la solicitud -con la documentación legalmente prevista-, la entidad deberá notificar y ofrecer al deudor un plan de reestructuración en el que se concreten la ejecución y la aplicación conjunta de las medidas aquí previstas ${ }^{146}$. Sin perjuicio de lo anterior, el deudor podrá presentar en todo momento una propuesta de plan

acredite ante la entidad que se encuentra en dicha circunstancia, será, como máximo, el resultante de sumar a los intereses remuneratorios pactados en el préstamo un 2 por cien sobre el capital pendiente del préstamo. 2. Esta moderación de intereses no será aplicable a deudores o contratos distintos de los regulados en el presente Real Decreto-ley".

${ }^{146}$ Se mencionan: “i. Carencia en la amortización de capital de cinco años. El capital correspondiente a las cuotas de ese periodo podrá o bien pasarse a una cuota final al término del préstamo o bien prorratearse en las cuotas restantes, o realizarse una combinación de ambos sistemas. ii. Ampliación del plazo de amortización hasta un total de 40 años a contar desde la concesión del préstamo. iii. Reducción del tipo de interés aplicable a Euribor + 0,25 por cien durante el plazo de carencia". Se hace constar asimismo que "No conllevará costes por compensación la amortización anticipada del crédito o préstamo hipotecario solicitada durante los diez años posteriores a la aprobación del plan de reestructuración". 
de reestructuración, que deberá ser analizada por la entidad que, en caso de rechazo, deberá comunicar al deudor los motivos en que se fundamente.

Se advierte que "en el plan de reestructuración la entidad advertirá, en su caso, del carácter inviable del plan ... o que, de resultar dicho plan inviable, se podrán solicitar las medidas complementarias previstas en el siguiente apartado". Al referirse a las mismas, el anexo menciona que: “a)...podrán solicitar una quita en el capital pendiente de amortización en los términos previstos en este apartado, que la entidad tendrá facultad para aceptar o rechazar en el plazo de un mes a contar desde la acreditación de la inviabilidad del plan de reestructuración ${ }^{147} ;$... c) Esta medida también podrá ser solicitada por aquellos deudores que se encuentren en un procedimiento de ejecución hipotecaria en el que ya se haya producido el anuncio de la subasta..."

Para el supuesto en que la reestructuración y las medidas complementarias, en su caso, no resulten viables queda establecido conforme el nuevo texto, que los deudores podrán solicitar la dación en pago de su vivienda habitual..."148 y que "en estos casos la entidad estará obligada a aceptar la entrega del bien hipotecado por parte del deudor, a la propia entidad o tercero que ésta designe, quedando definitivamente cancelada la deuda ${ }^{149}$.

${ }^{147}$ Se expresa que "a estos efectos, se entenderá por plan de reestructuración inviable aquel que establezca una cuota hipotecaria mensual superior al 50 por cien de los ingresos que perciban conjuntamente todos los miembros de la unidad familiar". A continuación se precisa que para "determinar la quita, la entidad empleará alguno de los siguientes métodos de cálculo y notificará, en todo caso, los resultados obtenidos al deudor, con independencia de que la primera decida o no conceder dicha quita: i. Reducción en un 25 por cien. ii. Reducción equivalente a la diferencia entre capital amortizado y el que guarde con el total del capital prestado la misma proporción que el número de cuotas satisfechas por el deudor sobre el total de las debidas. iii. Reducción equivalente a la mitad de la diferencia existente entre el valor actual de la vivienda y el valor que resulte de sustraer al valor inicial de tasación dos veces la diferencia con el préstamo concedido, siempre que el primero resulte inferior al segundo".

${ }^{148}$ Para un análisis profundizado del tema, cfr. LACRUZ MANTECón, Miguel L., "La moderna dación en pago", en Revista de Derecho Civil, vol. I, núm. 3 (julio-septiembre, 2014), Ensayos, pág. 89 y sgtes. http://nreg.es/ojs/index.php/RDC (fecha de consulta 15/1/2015).

${ }^{149}$ Dispone la normativa que "la dación en pago supondrá la cancelación total de la deuda garantizada con hipoteca y de las responsabilidades personales del deudor y de terceros frente a la entidad por razón de la misma deuda". Agrega que "las entidades podrán pactar con los deudores la cesión de una parte de la plusvalía generada por la enajenación de la vivienda, en contraprestación por la colaboración que éste pueda prestar en dicha transmisión", advirtiendo que "esta medida no será aplicable en los supuestos que se 
Resulta de singular importancia que "el deudor, si así lo solicitara en el momento de pedir la dación en pago, podrá permanecer durante un plazo de dos años en la vivienda en concepto de arrendatario, satisfaciendo una renta anual del 3 por cien del importe total de la deuda en el momento de la dación. Durante dicho plazo el impago de la renta devengará un interés de demora del 10 por cien".

La Ley 14/2013, “de Apoyo a los emprendedores y su internacionalización”, suma nuevas herramientas contra la crisis económica, orientadas de modo directo a beneficiar a uno de los sectores afectados -los empresarios-, aunque señalando que las medidas allí establecidas procuraban un efecto indirecto de singular importancia, como la generación y mantenimiento del empleo.

El Título preliminar -«Disposiciones generales»- establece el objeto de la regulación (art. 1), delimita el ámbito de aplicación (art. 2) y la define la figura de emprendedor (art. 3) ${ }^{150}$. El Título I -“Apoyo a la iniciativa emprendedora”-contiene una serie de medidas orientadas a incentivar la cultura emprendedora y facilitar el inicio de actividades empresariales y el desarrollo de las mismas ${ }^{151}$.

encuentren en procedimiento de ejecución en los que ya se haya anunciado la subasta, o en los que la vivienda esté gravada con cargas posteriores".

${ }^{150} \mathrm{El}$ concepto de emprendedor se define de forma amplia, como "aquellas personas, independientemente de su condición de persona física o jurídica, que van a desarrollar o están desarrollando una actividad económica productiva". Se deja establecido que "esta Ley tiene por objeto apoyar al emprendedor y la actividad empresarial, favorecer su desarrollo, crecimiento e internacionalización y fomentar la cultura emprendedora y un entorno favorable a la actividad económica, tanto en los momentos iniciales a comenzar la actividad, como en su posterior desarrollo, crecimiento e internacionalización".

${ }^{151}$ Se estimula la constitución de sociedades ofreciendo opciones que suponen abaratar el coste inicial de formación y otras medidas que "flexibilizan las exigencias de contabilidad de las empresas de menor dimensión". Como dispositivos de fomento se proponen normas de "simplificación de cargas administrativas" y otras tendientes a "eliminar obstáculos al acceso de los emprendedores a la contratación pública". En es misma línea, la ley dispone diversas medidas fiscales y en materia de Seguridad Social de apoyo al emprendedor. Se crea la figura del "Emprendedor de Responsabilidad Limitada", que permite a las personas físicas evitar que la responsabilidad derivada de sus deudas empresariales afecte a su vivienda habitual, bajo determinadas condiciones. Se advierte que el empresario es libre de constituirse en emprendedor de responsabilidad limitada, pero si lo hace deberá cumplir las obligaciones establecidas en el nuevo marco jurídico. Se acompaña esta nueva figura con garantías para los acreedores y para la seguridad jurídica en el tráfico mercantil. La operatividad de la limitación de responsabilidad queda condicionada a la inscripción y 
En lo que aquí más nos interesa, la Ley 14/2013 modifica la Ley Concursal en varias de sus normas ${ }^{152}$ con el objeto de mejorar el funcionamiento de figuras tales como el

publicidad a través del Registro Mercantil y el Registro de la Propiedad. Se prevé asimismo, la creación de una nueva figura de sociedad, la Sociedad Limitada de Formación Sucesiva (SLFS), sin capital mínimo, cuyo régimen será idéntico al de las Sociedades de Responsabilidad Limitada, excepto ciertas obligaciones específicas tendientes a garantizar una adecuada protección de terceros

${ }^{152}$ El art. 21 de la Ley 14/2013 dispone la modificación de la Ley 22/2003, Concursal. Se modifica el apartado 1 del artículo 3 que queda redactado de la siguiente manera: "1. Para solicitar la declaración de concurso están legitimados el deudor, cualquiera de sus acreedores y el mediador concursal cuando se trate del procedimiento regulado en el Título $\mathrm{X}$ de esta Ley. Se modifican los apartados 1, 3 y 4 del artículo 5 bis que quedan redactados de la siguiente manera: "1. El deudor podrá poner en conocimiento del juzgado competente para la declaración de su concurso que ha iniciado negociaciones para alcanzar un acuerdo de refinanciación o para obtener adhesiones a una propuesta anticipada de convenio en los términos previstos en esta Ley. En el caso en que solicite un acuerdo extrajudicial de pago, una vez que el mediador concursal propuesto acepte el cargo, el registrador mercantil o notario al que se hubiera solicitado la designación del mediador concursal deberá comunicar, de oficio, la apertura de las negociaciones al juzgado competente para la declaración de concurso...3. El secretario judicial, sin más trámite, procederá a dejar constancia de la comunicación presentada por el deudor o, en los supuestos de negociación de un acuerdo extrajudicial de pago, por el notario o por el registrador mercantil...4. Transcurridos tres meses de la comunicación al juzgado, el deudor, haya o no alcanzado un acuerdo de refinanciación, un acuerdo extrajudicial de pagos o las adhesiones necesarias para la admisión a trámite de una propuesta anticipada de convenio, deberá solicitar la declaración de concurso dentro del mes hábil siguiente, a menos que ya lo hubiera solicitado el mediador concursal o no se encontrara en estado de insolvencia. Se modifica el primer párrafo del apartado 3 del artículo 15 que queda redactado de la siguiente manera: "3. Una vez realizada la comunicación prevista en el artículo 5 bis y mientras no transcurra el plazo de tres meses previsto en dicho precepto, no se admitirán solicitudes de concurso a instancia de otros legitimados distintos del deudor o, en el procedimiento previsto en el Título X de esta Ley, distintos del deudor o del mediador concursal". Se modifica el número $2 .^{\circ}$ del apartado 6 del artículo 71, que pasa a tener la siguiente redacción: " $2 .^{\circ} \mathrm{El}$ acuerdo haya sido informado favorablemente por un experto independiente, que cumpla las condiciones del artículo 28, designado por el registrador mercantil del domicilio del deudor. Si el acuerdo de refinanciación afectara a varias sociedades del mismo grupo, el informe podrá ser único y elaborado por un solo experto, designado por el registrador del domicilio de la sociedad dominante, si estuviera afectada por el acuerdo o en su defecto por el del domicilio de cualquiera de las sociedades del grupo. El informe del experto contendrá un juicio técnico sobre la suficiencia de la información proporcionada por el deudor, sobre el carácter razonable y realizable del plan en las condiciones definidas en el párrafo primero y sobre la proporcionalidad de las garantías conforme a condiciones normales de mercado en el momento de la firma del acuerdo. Cuando el informe contuviera 
acuerdo de refinanciación, el acuerdo extrajudicial de pagos y la propuesta anticipada de convenio. Pone de resalto la doctrina que "el legislador no esperó a que transcurrieran dos años (desde la Ley 38/2011, que modificara normas centrales de la ley de concursos), para acometer una nueva reforma de la reforma ${ }^{153}$.

La nueva fisonomía de estas figuras revela la intención de redoblar la apuesta respecto de algunas estrategias. Se insiste en la idea de que para superar la crisis, el primer esfuerzo debe estar orientado a renegociar privadamente -acreedores y deudores- el pasivo existente.

Entre las novedades relevantes mencionamos especialmente la contenida en el Capítulo V, dedicado al "Acuerdo extrajudicial de pagos”, donde se prevé un mecanismo de negociación extrajudicial de deudas de empresarios, ya sean personas físicas o jurídicas, similar al existente en otros ordenamientos.

La ley incorpora un novedoso Título X a la Ley Concursal ${ }^{154}$, titulado "El acuerdo extrajudicial de pagos", y el art. 231 establece los presupuestos de la figura allí delineada: “1. El empresario persona natural que se encuentre en situación de insolvencia con arreglo a lo dispuesto en el artículo 2 de esta Ley, o que prevea que no podrá cumplir regularmente con sus obligaciones, podrá iniciar un procedimiento para alcanzar un acuerdo extrajudicial de pagos con sus acreedores, siempre que aportando el correspondiente balance, justifique que su pasivo no supera los cinco millones de euros. A los efectos de este Título se considerarán empresarios personas naturales no solamente aquellos que tuvieran tal condición de acuerdo con la legislación mercantil, sino aquellos que ejerzan actividades profesionales o tengan aquella consideración a los efectos de la legislación de la Seguridad Social, así como los trabajadores autónomos”. El punto 2 amplía el catálogo de sujetos habilitados, al establecer que "2. También podrán instar el mismo acuerdo cualesquiera personas jurídicas, sean o no sociedades de capital, que cumplan las siguientes condiciones: a) Se encuentren en estado de insolvencia. b) En caso de ser declaradas en concurso, dicho

reservas o limitaciones de cualquier clase, su importancia deberá ser expresamente evaluada por los firmantes del acuerdo".

${ }^{153}$ DíAZ EchegARAY, José Luis, Los acuerdos de refinanciación, cit., pág. 42.

${ }^{154}$ Cfr. el análisis crítico en PUlgar EzQUERRA, Juana, "Refinanciación de deuda, emprendedores y segunda oportunidad”, en Diario La Ley, No 8141, Sección Doctrina, 4 Sep. 2013, Año XXXIV, Editorial La Ley. 
concurso no hubiere de revestir especial complejidad en los términos previstos en el artículo 190 de esta Ley. c) Que dispongan de activos líquidos suficientes para satisfacer los gastos propios del acuerdo. d) Que su patrimonio y sus ingresos previsibles permitan lograr con posibilidades de éxito un acuerdo de pago en los términos que se recogen en el apartado 1 del artículo 236".

En el punto 3 se mencionan supuestos de exclusión, al disponer que: “3. No podrán formular solicitud para alcanzar un acuerdo extrajudicial: 1..$^{\circ}$ Quienes hayan sido condenados en sentencia firme por delito contra el patrimonio, contra el orden socioeconómico, de falsedad documental, contra la Hacienda Pública, la Seguridad Social o contra los derechos de los trabajadores. $2 .^{\circ}$ Los sujetos a su inscripción obligatoria en el Registro Mercantil que no figurasen inscritos con antelación. 3..$^{\circ}$ Las personas que en los tres ejercicios inmediatamente anteriores a la solicitud, estando obligadas legalmente a ello, no hubieren llevado contabilidad o hubieran incumplido en alguno de dichos ejercicios la obligación del depósito de las cuentas anuales. $4 .^{\circ}$ Las personas que, dentro de los tres últimos años, hubieran alcanzado un acuerdo extrajudicial con los acreedores, hubieran obtenido la homologación judicial de un acuerdo de refinanciación o hubieran sido declaradas en concurso de acreedores".

Ampliando el capítulo de las exclusiones, el punto 4, advierte: "No podrán acceder al acuerdo extrajudicial de pagos quienes se encuentren negociando con sus acreedores un acuerdo de refinanciación o cuya solicitud de concurso hubiera sido admitida a trámite". Agrega el punto 5: "Tampoco será posible iniciar el acuerdo extrajudicial si cualquiera de los acreedores del deudor, que necesariamente debieran verse vinculados por el acuerdo, hubiera sido declarado en concurso......No podrán acudir al procedimiento previsto en este Título las entidades aseguradoras y reaseguradoras".

Conforme el Preámbulo, la regulación propone un procedimiento de formato de apariencia simple y deseable flexibilidad ${ }^{155}$ que debe sustanciarse extrajudicialmente, “en

\footnotetext{
${ }^{155}$ Dispone el art. 232 de la Ley Concursal aquí incorporado: "Solicitud de acuerdo extrajudicial de pagos. 1. El deudor que pretenda alcanzar con sus acreedores un acuerdo extrajudicial de pagos solicitará el nombramiento de un mediador concursal. Si el deudor fuere persona jurídica, será competente para decidir sobre la solicitud el órgano de administración o el liquidador. 2. La solicitud se hará mediante instancia suscrita por el deudor, en la que el deudor hará constar el efectivo los activos líquidos de que dispone, los bienes y derechos de que sea titular, los ingresos regulares previstos, una lista de acreedores con expresión de
} 
brevísimos plazos, ante funcionarios idóneos por su experiencia y cualificación como son el registrador mercantil o el notario" 156 .

Se señala que "es responsabilidad del negociador impulsar los trámites de un procedimiento harto sencillo en que, al menos, se discipline mínimamente la convocatoria de todos los acreedores del deudor común, a quienes se incentiva la asistencia a la reunión" 157 . Se prevé que reunidos los sujetos involucrados, "a la vista de una propuesta avanzada por el negociador, se discuta el plan de pagos o el eventual acuerdo de cesión de bienes en pago de deudas" ${ }^{\prime 58}$. Entre las medidas de negociación de la deuda, la ley

la cuantía y vencimiento de los respectivos créditos, una relación de los contratos vigentes y una relación de gastos mensuales previstos. Esta lista de acreedores también comprenderá a los titulares de préstamos o créditos con garantía real o de derecho público sin perjuicio de que puedan no verse afectados por el acuerdo.

156 El art. 232.3 establece: "En caso de que los deudores sean empresarios o entidades inscribibles, se solicitará la designación del mediador al Registrador Mercantil correspondiente al domicilio del deudor mediante instancia que podrá ser cursada telemáticamente, el cual procederá a la apertura de la hoja correspondiente, en caso de no figurar inscrito. En los demás casos, se solicitará la designación al notario del domicilio del deudor". Por su parte, el art. 233 regula los requisitos y el procedimiento de designación del mediador concursal.

${ }^{157}$ De conformidad al art. 234, referido a la convocatoria a los acreedores, “1. En los diez días siguientes a la aceptación del cargo, el mediador concursal comprobará la existencia y la cuantía de los créditos y convocará al deudor y a los acreedores que figuren en la lista presentada por el deudor, siempre que puedan resultar afectados por el acuerdo, a una reunión que se celebrará dentro de los dos meses siguientes a la aceptación, en la localidad donde el deudor tenga su domicilio. Se excluirá en todo caso de la convocatoria a los acreedores de derecho público. 2. La convocatoria se realizará por conducto notarial, por cualquier medio de comunicación, individual y escrita, que asegure la recepción. Si constara la dirección electrónica de los acreedores por haberla facilitado éstos al mediador concursal en los términos que se indican en el apartado 4 del artículo 235, la comunicación deberá realizarse a la citada dirección electrónica. 3. La convocatoria deberá expresar el lugar, día y hora de la reunión, la finalidad de alcanzar un acuerdo de pago y la identidad de cada uno de los acreedores convocados, con expresión de la cuantía del crédito, la fecha de concesión y de vencimiento y las garantías personales o reales constituidas. 4. Una vez recibida la convocatoria, los acreedores titulares de créditos con garantía real que voluntariamente quisieran intervenir en el acuerdo extrajudicial deberán comunicárselo expresamente al mediador en el plazo de un mes".

${ }^{158}$ El art. 236 está dedicado al "plan de pagos" y dispone: "1. Tan pronto como sea posible, y en cualquier caso con una antelación mínima de veinte días naturales a la fecha prevista para la celebración de la reunión, el mediador concursal remitirá a los acreedores, con el consentimiento del deudor, un plan de pagos de los créditos pendientes de pago a la fecha de la solicitud, en el que la espera o moratoria no podrá superar los tres 
menciona la posibilidad de pactar "quitas de hasta el veinticinco por ciento de los créditos y esperas de hasta tres años".

La ley regula las condiciones de la reunión de acreedores en el art. $237^{159}$, los requisitos necesarios para arribar a ese acuerdo extrajudicial en el art. $238^{160}$ y las causas y trámite establecido en caso de impugnación del mismo ${ }^{161}$.

años y en el que la quita o condonación no podrá superar el 25 por ciento del importe de los créditos. El plan de pagos se acompañará de un plan de viabilidad y contendrá una propuesta de cumplimiento regular de las nuevas obligaciones, incluyendo, en su caso, la fijación de una cantidad en concepto de alimentos para el deudor y su familia, y de un plan de continuación de la actividad profesional o empresarial que desarrollara. El plan de pagos incluirá necesariamente una propuesta de negociación de las condiciones de los préstamos y créditos así como copia del acuerdo o solicitud de aplazamiento de los créditos de derecho público o, al menos, de las fechas de pago de los mismos, si no van a satisfacerse en sus plazos de vencimiento. 2. La propuesta podrá consistir también en la cesión de bienes a los acreedores en pago de las deudas. 3. Dentro de los diez días naturales posteriores al envío de la propuesta de acuerdo por el mediador concursal a los acreedores, éstos podrán presentar propuestas alternativas o propuestas de modificación. Transcurrido el plazo citado, el mediador concursal remitirá a los acreedores el plan de pagos y viabilidad final aceptado por el deudor". 4. El mediador concursal deberá solicitar de inmediato la declaración de concurso de acreedores si, dentro del plazo mencionado en el apartado 3 de este artículo, decidieran no continuar con las negociaciones los acreedores que representasen al menos la mayoría del pasivo que necesariamente pudiera verse afectado por el acuerdo, excluidos los créditos con garantía real cuyos titulares no hubiesen comunicado su voluntad de intervenir en el mismo o cualquier acreedor de derecho público.

159 Artículo 237. La reunión de los acreedores. 1. Los acreedores convocados deberán asistir a la reunión, salvo los que hubiesen manifestado su aprobación u oposición dentro de los diez días naturales anteriores a la reunión. Con excepción de los que tuvieran constituido a su favor garantía real, los créditos de que fuera titular el acreedor que, habiendo recibido la convocatoria, no asista a la reunión y no hubiese manifestado su aprobación u oposición dentro de los diez días naturales anteriores, se calificarán como subordinados en el caso de que, fracasada la negociación, fuera declarado el concurso del deudor común. 2. El plan de pagos y el plan de viabilidad podrán ser modificados en la reunión, siempre que no se alteren las condiciones de pago de los acreedores que, por haber manifestado su aprobación dentro de los diez días naturales anteriores, no hayan asistido a la reunión".

160 Dispone en art. 238: "El acuerdo extrajudicial de pagos. 1. Para que el plan de pagos se considere aceptado, será necesario que voten a favor del mismo, acreedores que sean titulares, al menos, del 60 por ciento del pasivo. En el caso de que el plan de pagos consista en la cesión de bienes del deudor en pago de deudas, dicho plan deberá contar con la aprobación de acreedores que representen el setenta y cinco por ciento del pasivo y del acreedor o acreedores que, en su caso, tengan constituida a su favor una garantía real sobre estos bienes. En ambos supuestos, para la formación de estas mayorías se tendrá en cuenta 
Como un modo de estimular este procedimiento, la ley puntualiza que al alcanzar el acuerdo extrajudicial, el deudor resulta beneficiado por los efectos que del mismo se derivan. El art. 240 dispone que "ningún acreedor afectado por el acuerdo podrá iniciar o continuar ejecuciones contra el deudor por deudas anteriores a la publicación de la apertura del expediente"162 y que "los créditos quedarán aplazados y remitidos conforme a lo pactado"163. Dispone la citada preceptiva que "en caso de cesión de bienes a los acreedores, los créditos se considerarán extinguidos en todo o en parte, según lo acordado".

No obstante los efectos reseñados, se advierte que "los acreedores conservarán las acciones que les correspondan por la totalidad de los créditos contra los obligados solidarios y los garantes personales del deudor" ${ }^{\text {,164. }}$.

La preceptiva legal analizada destaca el activo rol que cabe al mediador concursal en las distintas etapas del procedimiento. Ello explica que aceptado el plan de pagos, por

exclusivamente el pasivo que vaya a verse afectado por el acuerdo y a los acreedores del mismo. 2. Si el plan fuera aceptado por los acreedores, el acuerdo se elevará inmediatamente a escritura pública, que cerrará el expediente que el notario hubiera abierto. Para los abiertos por el registrador mercantil, se presentará ante el Registro Mercantil copia de la escritura para que el registrador pueda cerrar el expediente Asimismo, publicará la existencia del acuerdo en el Boletín Oficial del Estado y en el Registro Público Concursal por medio de un anuncio que contendrá los datos que identifiquen al deudor, incluyendo su Número de Identificación Fiscal, el registrador o notario competente, el número de expediente de nombramiento del mediador, el nombre del mediador concursal, incluyendo su Número de Identificación Fiscal, y la indicación de que el expediente está a disposición de los acreedores interesados en el Registro Mercantil o Notaría correspondiente para la publicidad de su contenido...".

${ }^{161}$ El supuesto de impugnación del acuerdo al que se hubiera arribado en la reunión de acreedores, está contemplado en el art. 239, que reza: “1. Dentro de los diez días siguientes a la publicación, el acreedor que no hubiera sido convocado o no hubiera votado a favor del acuerdo o hubiera manifestado con anterioridad su oposición en los términos establecidos en el artículo 237.1 podrá impugnarlo ante el juzgado que fuera competente para conocer del concurso del deudor. 2. La impugnación no suspenderá la ejecución del acuerdo y solo podrá fundarse en la falta de concurrencia de las mayorías exigidas para la adopción del acuerdo teniendo en cuenta, en su caso, a los acreedores no convocados, en la superación de los límites establecidos por el artículo 236.1 o en la desproporción de la quita o moratoria exigidas...”.

${ }^{162}$ La misma norma señala que "el deudor podrá solicitar la cancelación de los correspondientes embargos del juez que los hubiera ordenado" (art. 240.1 de la LC).

163 Art. 240.2 de la LC.

${ }^{164}$ Art. 240.3 de la LC. 
aplicación del art. 241.1, "el mediador concursal deberá supervisar el cumplimiento del acuerdo". La misma norma prevé que "2. Si el plan de pagos fuera íntegramente cumplido, el mediador concursal lo hará constar en acta notarial que se publicará en el Boletín Oficial del Estado y en el Registro Público Concursal” y que "3. Si el acuerdo extrajudicial de pagos fuera incumplido, el mediador concursal deberá instar el concurso" del deudor incumplidor.

Se considera que el procedimiento fracasa cuando no se alcanza un acuerdo -sea porque las partes deciden no continuar las negociaciones ${ }^{165}$ o porque la propuesta es rechazada ${ }^{166}$ - o cuando se constata el incumplimiento del plan de pagos acordado. Es relevante destacar que en todos estos supuestos, la ley impone al mediador concursal la carga de instar sin dilaciones el concurso del deudor afectado y al juez del caso, declarar la apertura del procedimiento correspondiente (art. 238.3 y art. 241.3 de la LC).

El art. 242 está dedicado al llamado "concurso consecutivo" -porque es consecuencia del fracaso del procedimiento de acuerdo extraconcursal- que presenta particularidades propias ${ }^{167}$. La especialidad del mismo resulta de las notas diferenciales contenidas en los diferentes apartados del citado art. 242.

Se deja establecido que "salvo el supuesto de insuficiencia de masa activa en los términos previstos en el artículo 176 bis de la Ley, se abrirá necesaria y simultáneamente la fase de liquidación..." y "en el caso de deudor empresario persona natural, si el concurso se calificara como fortuito, el juez declarará la remisión de todas las deudas que no sean

\footnotetext{
${ }^{165}$ El art. 236.4 prevé que "el mediador concursal deberá solicitar de inmediato la declaración de concurso de acreedores si, dentro del plazo mencionado en el apartado 3 de este artículo, decidieran no continuar con las negociaciones los acreedores que representasen al menos la mayoría del pasivo que necesariamente pudiera verse afectado por el acuerdo, excluidos los créditos con garantía real cuyos titulares no hubiesen comunicado su voluntad de intervenir en el mismo o cualquier acreedor de derecho público”.

${ }^{166} \mathrm{El}$ art. 238.3 establece que "si el plan no fuera aceptado, y el deudor continuara incurso en insolvencia, el mediador concursal solicitará inmediatamente del juez competente la declaración de concurso, que el juez acordará también de forma inmediata. En su caso, instará también del juez la conclusión del concurso por insuficiencia de masa activa en los términos previstos en el artículo 176 bis de esta Ley”.

${ }^{167}$ Precisa el art. 242.1 que "Tendrá la consideración de concurso consecutivo el que se declare a solicitud del mediador concursal, del deudor o de los acreedores por la imposibilidad de alcanzar un acuerdo extrajudicial de pagos o por incumplimiento del plan de pagos acordado. Igualmente tendrá la consideración de concurso consecutivo el que sea consecuencia de la anulación del acuerdo extrajudicial alcanzado".
} 
satisfechas en la liquidación, con excepción de las de Derecho público, siempre que sean satisfechos en su integridad los créditos contra la masa y los créditos concursales privilegiados" (art. 242.1 y $242 \cdot 2 \cdot 1^{\mathrm{a}}$ y $5^{\mathrm{a}}$ ).

Desde otra perspectiva, la reforma introducida por esta ley, abre paso a una figura nueva, de singular importancia: la exoneración del pasivo insatisfecho ${ }^{168}$.

El Preámbulo anuncia con gran expectativa que tiene su desembarco en la legislación española, la "exoneración de deudas residuales en los casos de liquidación del patrimonio del deudor que, declarado en concurso, directo o consecutivo, no hubiere sido declarado culpable de la insolvencia, y siempre que quede un umbral mínimo del pasivo satisfecho".

Destacamos entonces, la modificación del apartado 2 del art. 178, que con motivo de la reforma introducida por la Ley 14/2013, dispone: “2. La resolución judicial que declare la conclusión del concurso del deudor persona natural por liquidación de la masa activa declarará la remisión de las deudas insatisfechas, siempre que el concurso no hubiera sido declarado culpable ni condenado por el delito previsto por el artículo 260 del Código Penal o por cualquier otro delito singularmente relacionado con el concurso y que hayan sido satisfechos en su integridad los créditos contra la masa, y los créditos concursales privilegiados y, al menos, el 25 por ciento del importe de los créditos concursales ordinarios. Si el deudor hubiere intentado sin éxito el acuerdo extrajudicial de pagos, podrá

\footnotetext{
${ }^{168}$ Destaca SENNET MARTínEZ que "hasta la fecha de la aprobación de la citada Ley 14/2013, la ausencia de soluciones en nuestro derecho concursal al problema que planteaba la insolvencia de las personas físicas había motivado diversas resoluciones judiciales en virtud de las cuales, concluido el concurso de acreedores, se exoneraba en menor o mayor medida al deudor de sus deudas", señalando que "aunque coincidamos con las citadas resoluciones en la detección del problema y la falta de soluciones legales, ... el principio de seguridad jurídica no permite radicar la concesión o denegación del beneficio de la liberación de deudas en la discrecionalidad judicial..." (SENENT MARTínEZ, Santiago, Exoneración del pasivo insatisfecho..., cit., pág. 493). Para un desarrollo de esta cuestión, ver, CUENA CASAS, Matilde, "Conclusión del concurso de acreedores de persona física y exoneración del pasivo pendiente (a propósito del auto del Juzgado Mercantil №3 de Barcelona de 26 del octubre de 2010)", Revista de Derecho Bancario y Bursátil, $\mathrm{N}^{\circ}$ 125, EneroMarzo, 2012, pág. 289 y sgtes. Cfr. asimismo, la referencia a otro precedente en sentido concordante, CORDERO, Encarna, "La adjudicación al acreedor hipotecario extingue la deuda restante. Auto de la A.P. de Navarra de 17 diciembre 2010”, Notas Jurisprudenciales, Centro de Estudios de Consumo, en https://www.uclm.es/centro/cesco/pdf/notasJurisprudencia/financiacion/23.pdf (fecha de consulta 20/4/2015)..
} 
obtener la remisión de los créditos restantes si hubieran sido satisfechos los créditos contra la masa y todos los créditos concursales privilegiados"169.

La doctrina ha puesto énfasis en sostener que con esta reforma, hace pie en la legislación española, un mecanismo de exoneración del pasivo pendiente propio, conectado a la conclusión del concurso y previa liquidación del patrimonio del deudor ${ }^{170}$

${ }^{169}$ PUlgar EzQUERRA ha sostenido que por vía de la normativa analizada "se proyectan dos mecanismos exoneratorios, respecto de deudores distintos y con presupuestos diferentes ... de un lado, al deudor empresario natural o empresario persona jurídica en determinadas condiciones y, de otro, al deudor persona natural, sin referencia a su condición empresarial. En efecto, de un lado, en el proyectado art. 242.2.5. , se contempla una exoneración conectada necesariamente a un concurso consecutivo declarado por la imposibilidad de alcanzar un acuerdo extrajudicial de pagos o por incumplimiento del plan de pagos acordado y a la que, por tanto, pueden acceder los mismos sujetos que pueden hacerlo al acuerdo extrajudicial, que conforme al art. 231 proyectado, esto es, conforme al apartado 1 de este artículo, sería el «empresario persona natural» ... en situación de insolvencia actual o inminente, conforme al art. 2 LC, cuyo pasivo no supere los cinco millones de euros, así como cualquier persona jurídica sean o no sociedades de capital, respecto de las que no se contiene referencia alguna a su objeto social, en las que concurran las condiciones recogidas en el art. 231.2, recogiéndose a continuación, como se ha analizado, cuestionables prohibiciones para formular solicitud de acuerdo extrajudicial. Pues bien, este mecanismo exoneratorio para pequeños empresarios personas físicas o jurídicas, concedido bajo el mismo control registral que caracteriza el acuerdo extrajudicial, admite los denominados «planes cero» en los que no se prevé un porcentaje del pasivo ordinario que debe ser satisfecho y se condiciona a la calificación fortuita del concurso y al pago de deudas privilegiadas y contra masa con exclusión de las deudas de Derecho público .... De otro lado, en virtud de la nueva redacción del art. 178 LC ... se introduce también un mecanismo exoneratorio, esta vez previsto para la persona natural, sin referencia alguna al desarrollo por ésta de una actividad empresarial o emprendedora y conectado no a un previo acuerdo extrajudicial, y por tanto no sometido a los condicionantes subjetivos de que éstos se rodean, sino a la conclusión del concurso del deudor persona natural por liquidación, siempre que, como en el caso anterior, el concurso no sea culpable y además como requisito añadido no contemplado en el art. 242.2.5. ${ }^{\circ}$ el deudor no hubiere sido condenado por el delito ex art. 260 CP o por cualquier otro delito relacionado con el concurso. En este marco, se exige además que de haber sido satisfechos los acreedores privilegiados y contra masa, sea satisfecho al menos el 25\% del importe de los créditos ordinarios, excluyéndose por tanto en relación a la persona física que no es empresario, frente al supuesto anterior los denominados planes cero, añadiéndose que si el deudor hubiere intentado sin éxito el acuerdo extrajudicial de pagos, podrá obtener la remisión de los créditos restantes, referencia ésta cuestionable al parecer aludir a un supuesto de difícil concreción práctica, dado que, si se intentó sin éxito un acuerdo extrajudicial, estaríamos dentro del ámbito del concurso consecutivo y, por tanto, en el marco de la exoneración ex art. 242.2.5. ${ }^{\circ}$ que se proyecta introducir en la LC” (PULGAR EZQUERRA, Juana, "Refinanciación de deuda...”, cit.). 
Con el Real Decreto-Ley 4/2014 posterior, de Medidas urgentes en materia de refinanciación y reestructuración de deuda empresarial", el Gobierno español reformuló el diseño de soluciones concursales existentes.

Calificada doctrina, ha considerado que este nuevo instrumento legal constituyó "un paso más decisivo e innovador en relación a la regulación de los acuerdos de refinanciación"

La Exposición de Motivos comienza señalando que "con frecuencia, empresas realmente viables desde un punto de vista operativo (es decir susceptibles de generar beneficios en su negocio ordinario) se han tornado en inviables desde un punto de vista financiero" y que "ante esta situación existen dos alternativas: o bien liquidar la empresa en su conjunto, o bien sanearla desde un punto de vista financiero, con el fin de que la deuda remanente sea soportable, permitiendo así que la empresa siga atendiendo sus compromisos en el tráfico económico, generando riqueza y creando puestos de trabajo". Advierte que "la dificultad para alcanzar acuerdos entre deudor y acreedores financieros deriva no tanto de la falta de voluntad de las partes, sino de ciertas rigideces ... en la normativa concursal y preconcursal".

Se destaca que "la fase preconcursal resulta verdaderamente determinante para la reestructuración financiera de las empresas" y de allí que la reforma impulsada se centra en la mejora del marco legal preconcursal de los acuerdos de refinanciación, "por constituir una de las áreas estratégicamente más relevantes" dado que fruto del consenso entre el deudor y los acreedores, se procura la maximización del valor de los activos -evitando el concurso de la entidad- y la reducción o aplazamiento de los pasivos.

Se recuerda que los acuerdos colectivos de refinanciación y su homologación judicial otorgan protección legal a los acuerdos alcanzados por una mayoría suficiente de acreedores de modo que, en el eventual supuesto de un concurso, las operaciones en él

\footnotetext{
${ }^{170}$ SENENT MARTínEZ, Santiago, Exoneración del pasivo insatisfecho..., cit., pág. 432.

171 Pulgar EzQUeRRA, Juana, "El nuevo paradigma concursal europeo y su incorporación al Derecho español", en Estudios de Derecho Empresario, en http://revistas.unc.edu.ar/index.php/esdeem/article/view/8812 (fecha de consulta 20/4/2015).
} 
incorporadas no estén sujetas a rescisión y, en su caso, pueden extender determinados efectos a acreedores disidentes o no partícipes.

Destaca la Exposición de Motivos que "la presente reforma se centra en la mejora del marco legal preconcursal de los acuerdos de refinanciación" puesto que "se han detectado una serie de limitaciones..., las cuales están cercenando la eficacia y seguridad jurídica necesarias para acometer reestructuraciones financieras en las empresas". Se señala que "las modificaciones ... buscan en definitiva la finalidad de mejora de la posición patrimonial del deudor", poniendo énfasis en sostener que "los acuerdos que reúnan los requisitos previstos en este real decreto-ley no se verán sometidos al riesgo de rescindibilidad, que tanto ha retraído hasta ahora la actuación de las partes en fase preconcursal".

Se modifican varios preceptos de la Ley 22/2003 Concursal ante la constatación de que el procedimiento y las soluciones de consenso allí previstas -pese a su constante aggionamiento- resultaban impotentes para propiciar la continuidad de la actividad empresaria en crisis ${ }^{172}$.

La reforma del art. 5 bis se orienta a fomentar una negociación eficaz sin acelerar la situación de insolvencia del deudor por razón de una precipitada ejecución de garantías sobre determinados bienes. A tal fin, la nueva redacción de la norma citada permite que la presentación de la comunicación de iniciación de negociaciones para alcanzar determinados acuerdos pueda suspender, durante el plazo previsto para llevarlas a efecto, las ejecuciones judiciales de bienes que resulten necesarios para la continuidad de la actividad profesional o empresarial del deudor. También se permite la suspensión del resto de ejecuciones singulares promovidas por los acreedores financieros a los que se refiere la disposición adicional cuarta, siempre que se justifique que un porcentaje no inferior al $51 \%$ de acreedores de pasivos financieros han apoyado expresamente el inicio de las negociaciones encaminadas a la suscripción del correspondiente acuerdo de refinanciación ${ }^{173}$.

\footnotetext{
${ }^{172}$ PÉREZ BENÍTEZ, Jacinto José, “La nueva regulación...”, cit.

${ }^{173}$ Quedan excluidos de la suspensión, en todo caso, los procedimientos que tengan su origen en créditos de derecho público.
} 
De particular importancia es la modificación del art. 56, para limitar los supuestos de suspensión de ejecución de bienes dotados de garantía real a aquellos que resulten necesarios para la continuidad de su actividad profesional o empresarial.

La Ley Concursal vuelve a la sistemática original regulando íntegramente en el artículo 71 las denominadas acciones de reintegración. Lo que hasta ahora había sido recogido en el apartado 6 de dicho artículo como supuesto de no rescindibilidad, se recoge separadamente en el artículo 71 bis junto con un nuevo supuesto ${ }^{174}$. Se configura de este modo una posibilidad más de acuerdo entre deudor y acreedor que es más restrictiva que la del apartado 1 del mismo artículo en cuanto a los supuestos pero más laxa en cuanto a los intervinientes $^{175}$.

Al no ser rescindibles, los acuerdos que reúnan las condiciones del artículo 71 bis no estarán sometidos a las presunciones de los apartados 2 y 3 del artículo 71 aun cuando impliquen actos de disposición de activo. Además, la legitimación para el ejercicio de la acción rescisoria (que sólo podrá basarse en el incumplimiento material de los requisitos del artículo 71 bis por los acuerdos acogidos aparentemente al mismo) sigue estando

${ }^{174}$ En el apartado 1, se mantiene en lo esencial la regulación de lo hasta entonces previstos en el apartado 6 del art. 71, si bien se clarifica su extensión, que comprenderá los negocios, actos y pagos, cualquiera que sea su naturaleza, que permitan la ampliación significativa del crédito o la modificación o extinción de obligaciones. Advierte la Exposición de Motivos que "dentro de ellos están incluidas, tal y como se ha venido reconociendo en numerosos pronunciamientos judiciales, las cesiones de bienes y derechos en pago o para pago". Adicionalmente, se elimina la necesidad de informe de experto independiente, sustituyéndola por certificación del auditor de cuentas acreditativa de la concurrencia de las mayorías exigidas para su adopción. En el apartado 2 se introduce un nuevo supuesto en el cual los acuerdos alcanzados se declaran no rescindibles, sin necesidad de alcanzar determinadas mayorías de pasivo, constituyéndose en consecuencia un puerto seguro que permita la negociación directa del deudor con uno o más acreedores, siempre que signifiquen simultáneamente una mejora clara de la posición patrimonial del deudor, es decir, que no conlleven una merma de los derechos del resto de acreedores no intervinientes.

${ }^{175}$ En efecto, si en el apartado 1 se exige la concurrencia de los tres quintos del pasivo pero se habla de forma más genérica de la mejora de condiciones de financiación, en el apartado 2, a cambio de no requerirse mayoría concreta de pasivo, se exigen requisitos muy estrictos para que los acuerdos no sean tampoco rescindibles por causas distintas al incumplimiento de las condiciones que el propio artículo establece. Sirva de ejemplo la letra c) que implicará en muchos casos por parte del acreedor interviniente la liberación de garantías (susceptibles de facilitar nueva financiación), que no resulta necesariamente exigible en el caso de los acuerdos colectivos de refinanciación. 
restringida al administrador concursal y limitada a la ausencia de condiciones reguladas, respectivamente, en los dos primeros apartados del artículo 71 bis. También se limita al administrador concursal la legitimación para el ejercicio de las demás acciones de impugnación.

Relacionado con el régimen de acuerdos de refinanciación, la ley encara una revisión del régimen de homologación judicial regulado en la disposición adicional cuarta. En particular, se amplía el ámbito subjetivo, extendiéndose la posibilidad de suscribir este acuerdo a todo tipo de acreedores de pasivos financieros, excluidos los acreedores por operaciones comerciales y los acreedores de derecho público. Se posibilita asimismo, la extensión a los acreedores disidentes o no participantes no solo de las esperas, sino también, mediante un porcentaje de pasivo superior, de otras medidas acordadas en el seno del acuerdo de refinanciación, como es el caso de las quitas, capitalización de deuda y cesión de bienes en pago o para pago.

Respecto de los acreedores que dispongan de garantía real, se introducen algunas innovaciones. Advierte la Exposición de Motivos que "hasta ahora se partía de una distinción entre deudor con garantía real y deudor sin garantía real, siendo el primero prácticamente inmune a los acuerdos homologados salvo en lo que pudiera afectar a esperas de duración limitada o suspensión de ejecuciones. Pero lo cierto es que no todos los acreedores con garantía real son de la misma condición"176. Y de allí que lo relevante "no es tanto realizar una distinción subjetiva, sino una distinción objetiva entre la parte de deuda que está cubierta por el valor real de la garantía y aquélla que no lo está, anticipando en cierta medida lo que podría ocurrir en caso de liquidación concursal"177. La segunda novedad consiste en dar mayor relevancia y nitidez a la distinción entre obligación

\footnotetext{
${ }^{176}$ Se explica que "a veces tal circunstancia es un puro nominalismo, puesto que la garantía de la que se dispone es de un rango posterior a otras preferentes o puede recaer sobre un activo de muy escaso valor que cubre una pequeña parte de la deuda, o pueden producirse ambas situaciones simultáneamente".

${ }^{177}$ De este modo, el concepto determinante es el de valor real de la garantía que se define de forma simple en el apartado 2 de la disposición adicional cuarta en unos términos totalmente coherentes con la realidad jurídica y económica de la referida garantía. A partir de ahí el tratamiento de la parte de créditos no cubiertos por la garantía es el mismo que se atribuye a los acreedores sin garantía real.
} 
principal y obligación accesoria ${ }^{178}$. Por ello, si la deuda principal puede ser afectada en caso de no tener cobertura de garantía real por el acuerdo de una mayoría muy cualificada de otros acreedores, la deuda cubierta con garantía real debe poder ser también afectada" ${ }^{\circledR 179}$,

En concordancia con lo anterior, se prevé la posibilidad de extender los efectos del acuerdo a determinados acreedores con garantía real y se simplifica el procedimiento de homologación, en el que el juez conoce directamente de la solicitud, en aras a garantizar la celeridad y flexibilidad buscada en esta fase preconcursal y en el que únicamente tendrá que comprobar la concurrencia de las mayorías exigidas para acordar la homologación. En cualquier caso, y con el fin de no perjudicar el valor de la garantía en caso de incumplimiento por parte del deudor, se establecen reglas especiales de atribución del resultante al acreedor.

El Real Decreto-Ley 11/2014, de "Medidas urgentes en materia concursal" intenta garantizar la plena coherencia del conjunto de la normativa concursal después de las novedades introducidas en el régimen de los acuerdos de refinanciación por el Real Decreto-Ley 4/2014.

Esta reforma introduce modificaciones respecto al convenio concursal ${ }^{180}$ para unificar la regulación de la figura a las que se consideran premisas básicas.

\footnotetext{
${ }^{178}$ Se señala que "ha ocurrido en el tráfico jurídico y económico que, a pesar de ser una obligación accesoria, la garantía ha adquirido un valor hasta cierto punto abstraído de la obligación principal, debido a su progresiva espiritualización, a su intangibilidad y a la posibilidad de transmisión del objeto de la garantía sin merma de la misma" pero "no puede perderse de vista que la garantía lo es siempre de una obligación principal y que, aunque el valor de la segunda dependa, también y entre otros, del valor de la primera, cada una conserva su esencia y características propias”.

179 Todo sin perjuicio de que se exige que el acuerdo mayoritario se adopte -en este caso- con mayorías cualificadas aún más elevadas, pero computadas sobre el total de las garantías, es decir, por titulares de deuda garantizada que se encuentren en una situación similar a la del disidente o no participante en el acuerdo.

${ }^{180} \mathrm{Se}$ introducen, en primer lugar, previsiones análogas a las de la disposición adicional cuarta de la Ley Concursal (en redacción dada por el Real Decreto-ley 4/2014, de 7 de marzo) relativas a la valoración de las garantías sobre las que recae el privilegio especial (artículos 90 y 94 de la Ley Concursal). Se amplía además, el quórum de la junta de acreedores, atribuyendo derecho de voto a algunos acreedores que hasta ahora no lo tenían (acreedores que hubiesen adquirido sus derechos de crédito con posterioridad a la declaración de concurso, exceptuando a los que tengan una vinculación especial con el deudor, para lo que se reforma no solamente el artículo 122 sino también el 93 para hacer un listado más amplio de personas especialmente
} 
La regulación analizada dispone la creación de una Comisión de seguimiento de prácticas de refinanciación y reducción de sobreendeudamiento, con funciones de verificación del cumplimiento de las medidas adoptadas por este Real Decreto-Ley que, por otra parte, elevará propuestas de modificaciones normativas para facilitar la reestructuración preconcursal o concursal de deuda de empresas económicamente viables.

La ley 17/2014 la Ley 17/2014, de "medidas urgentes en materia de refinanciación y reestructuración de deuda empresaria”, convalida en lo esencial, el Real Decreto-Ley $4 / 2014^{181}$.

vinculadas con el deudor que, por esta razón, tendrán la condición de acreedores subordinados y carecerán en consecuencia de voto en la junta de acreedores). Se introducen determinadas previsiones adicionales respecto a los efectos del convenio en el artículo 100. Se señala que los acuerdos de aumento de capital requeridos cuando se trate de capitalización se adoptarán con las mismas mayorías previstas en la disposición adicional 4. ${ }^{a}$. También se efectúa una remisión al régimen general de transmisión de unidades productivas a lo dispuesto en el artículo 146 bis, lo que implica, con determinadas excepciones, su adquisición libre de obligaciones preexistentes impagadas. Por otra parte, se facilita la cesión en pago de bienes con determinadas cautelas destinadas a evitar comportamientos fraudulentos. Se introducen modificaciones respecto de las votaciones y mayorías en el convenio y a la ampliación de la capacidad de arrastre de los acreedores disidentes en determinadas circunstancias. Se levanta la limitación general que con anterioridad existía para los efectos del convenio (quitas del 50 por ciento y esperas de cinco años), exigiéndose un mayoría reforzada del 65 por ciento para superar dichos límites. Se introduce la regla ya aprobada respecto a los convenios preconcursales en lo referente a las mayorías máximas exigibles para los pactos de sindicación, que será del 75 por ciento (artículo 121.4). Se introduce una previsión novedosa (nuevo artículo 134.3), sobre la posibilidad de arrastre de determinados créditos con privilegio general o especial, incluso en la parte cubierta por el valor de la garantía, aunque para ello se exige un doble requisito: además de unas mayorías aún más reforzadas, el que el acuerdo sea adoptado por acreedores de la misma clase. Para ello se distinguen cuatro clases de acreedores: los acreedores de derecho laboral; los acreedores públicos; los acreedores financieros; y finalmente, el resto (entre los cuales deberán incluirse de forma principal a los acreedores comerciales). Al igual que en el apartado 11 de la disposición adicional cuarta y con el fin de respetar en la mayor medida posible el verdadero valor de la garantía, se establece en el artículo 140 que si, llegado el caso, el acreedor con privilegio (que hubiera votado a favor de un convenio o se hubiera visto arrastrado por él) tiene que ejecutar la garantía, se hará con el montante total obtenido que no exceda del crédito originario.

181 "Podemos afirmar, sin temor a equivocarnos que, si exceptuamos la legitimación de cualquier acreedor que haya suscrito el acuerdo de refinanciación para solicitar su homologación, esta reforma se la limitado a ligerísimas modificaciones de estilo" (DíAz ECHEGARAY, José Luis, Los acuerdos de refinanciación, cit., pág. 46). 
Finalmente, llega el Real Decreto-Ley 1/2015 del 27 de febrero, de "Mecanismo de segunda oportunidad, reducción de carga financiera y otras medidas de orden social", que incorpora diferentes dispositivos vinculados a la problemática analizada ${ }^{182}$.

Nuevamente el legislador español revisa el diseño del acuerdo extrajudicial de pagos (AEP), ratificando su convicción respecto de la eficacia de las salidas de consenso y la necesidad de alentar el tránsito por estas vías preconcursales.

La Exposición de Motivos señala que con la reformulación del instituto del acuerdo extrajudicial de pagos se busca una ampliación del ámbito de aplicación, flexibilizar su contenido y expandir sus efectos ${ }^{183}$.

Se reforma el procedimiento previsto originariamente para el acuerdo extrajudicial de pagos, en la creencia de que de ese modo se mejora la propuesta de saneamiento ${ }^{184}$.

182 Señala SANCHEZ-CALERO GUILARTE: "Estamos ante una nueva reforma de la Ley Concursal (LC), convertida ya de manera habitual en una norma de oportunidad, es decir, que disciplina el régimen legal en atención a la coyuntura económica, de profunda crisis hasta hace poco...". Advierte que "una legislación coyuntural nace con una obvia vocación temporal (aunque esto nos enseña la historia legislativa que no siempre sucede)" y “que si se confirma la recuperación económica, no faltarán voces que reclamarán un giro de la LC". Y agrega: "Es deseable que tantos cambios, adiciones y cambios de los cambios no perjudiquen la coherencia sistemática de la LC. Esta supuso un paso histórico en favor de un mejor Derecho de la insolvencia y lo que no debiera suceder es que el carrusel de cambios y adiciones debilite la calidad de esa legislación" (SANCHEZ-CALERO GuILARTE, Juan, "Segunda oportunidad...”, cit.

${ }^{183}$ Para un análisis minucioso del tratamiento legislativo del acuerdo extrajudicial de pago en el régimen del Real Decreto-Ley 1/2015, ver el prolijo desarrollo de FERnANDEZ SEIJO, José María, La reestructuración...cit.. Cabe señalar sobre el punto, que la figura analizada ha sido objeto de un nuevo reajuste por Ley 25/2015 de 28 de julio, al que haremos referencia en tanto resulte pertinente.

${ }^{184}$ La regulación del AEP en la Ley 14/2013 ha sido duramente criticada. La reforma introducida por el RDL 1/2015, pretende contribuir al objetivo originario de desjudicializar determinados supuestos de crisis. Oportunamente se diseñó un procedimiento alternativo al concurso, a fin de que el deudor alcance un acuerdo con sus acreedores -con base en la propuesta elaborada por el mediador concursal- y procure solventar el pasivo fuera de un procedimiento judicial. "Pero en aquel momento no se incluyó a los consumidores o personas físicas, trabajadores y trabajadoras, que son precisamente los más perjudicados" (Cfr. "Análisis del Real Decreto-Ley 1/2015", UGT, Secretaría de Acción Sindical, Coordinación Área Externa, Gabinete Técnico Confederal, Informe del 11 del marzo de 2015 http://www.ugt.es/Publicaciones/informe_analisis_real_decreto_ley_1_2015_segunda_oportunidad.pdf, (fecha de consulta: 25/4/2015). 
Calificada doctrina destaca la vocación aperturista de la reforma en tanto el nuevo régimen permite el acceso al procedimiento, de toda persona física o natural, con independencia de su carácter empresario ${ }^{185}$, además de las personas jurídicas ${ }^{186}$. Se amplía el ámbito de aplicación del acuerdo extrajudicial de pagos, desapareciendo la injustificable exclusión que la regulación anterior establecía para el consumidor, a quien le estaba vedada la posibilidad de utilizar la figura para renegociar el pasivo con los acreedores, fuera del concurso $^{187}$.

El remozado art. 231 de la ley concursal dispone ahora: "Presupuestos. 1. El deudor persona natural que se encuentre en situación de insolvencia con arreglo a lo dispuesto en el artículo 2 de esta Ley, o que prevea que no podrá cumplir regularmente con sus obligaciones, podrá iniciar un procedimiento para alcanzar un acuerdo extrajudicial de pagos con sus acreedores..... A los efectos de este título se considerarán empresarios personas naturales no solamente aquellos que tuvieran tal condición de acuerdo con la legislación mercantil, sino aquellos que ejerzan actividades profesionales o tengan aquella consideración a los efectos de la legislación de la Seguridad Social, así como los trabajadores autónomos...”.

Agrega el precepto que "En el caso de deudor persona natural empresario, deberá aportarse el correspondiente balance".

No obstante su vocación aperturista, la reforma deja en claro que este procedimiento alternativo al concurso, destinado al deudor persona natural (empresario y no empresario), mantiene algunas barreras de acceso. Así pues, el propio art. 231 expresa que el deudor

${ }^{185}$ IrIaRte Ibarguren, Ainoa, "Las 10 claves sobre la Segunda Oportunidad, Reducción de la Carga Financiera y Otras Medidas de Orden Social (Real Decreto Ley 1/2015, de 27 de febrero BOE de 28 de febrero de 2015)", Redacción Wolters Kluwer, http://lighthouse9901news.blogspot.com.ar/2015/03/las-10claves-sobre-la-segunda.html (fecha de consulta: 22/4/2015).

${ }^{186} \mathrm{El}$ art 231.2 dispone: "2. También podrán instar el mismo acuerdo cualesquiera personas jurídicas, sean o no sociedades de capital, que cumplan las siguientes condiciones: a) Se encuentren en estado de insolvencia.

b) En caso de ser declaradas en concurso, dicho concurso no hubiere de revestir especial complejidad en los términos previstos en el artículo 190 de esta Ley. c) Que dispongan de activos suficientes para satisfacer los gastos propios del acuerdo".

187 Cuena CASAS, Matilde, "A propósito del Real Decreto-Ley 1/2015 ¿Un régimen de segunda oportunidad?" en El Notario del Siglo XXI, Nㅜ 60, marzo/abril 2015, pág. 10 y sgtes. 
"podrá iniciar un procedimiento para alcanzar un acuerdo extrajudicial de pagos con sus acreedores, siempre que la estimación inicial del pasivo no supere los cinco millones de euros". Y agrega que "No podrán formular solicitud para alcanzar un acuerdo extrajudicial de pagos: $1 .^{\circ}$ Quienes hayan sido condenados en sentencia firme por delito contra el patrimonio, contra el orden socioeconómico, de falsedad documental, contra la Hacienda Pública, la Seguridad Social o contra los derechos de los trabajadores en los 10 años anteriores a la declaración de concurso. $2 .^{\circ}$ Las personas que, dentro de los cinco últimos años, hubieran alcanzado un acuerdo extrajudicial de pagos con los acreedores, hubieran obtenido la homologación judicial de un acuerdo de refinanciación o hubieran sido declaradas en concurso de acreedores (art. 231.3). Y agrega que tampoco podrán acceder al trámite "quienes se encuentren negociando con sus acreedores un acuerdo de refinanciación o cuya solicitud de concurso hubiera sido admitida a trámite (art. 231.4).

Los beneficios de transitar el procedimiento analizado se hacen explícitos en el art. 235, que pasa a tener nueva redacción ${ }^{188}$. Así, por un lado, el citado art. 235 enuncia los "efectos de la iniciación del expediente", precisando que "una vez solicitada la apertura del expediente, el deudor podrá continuar con su actividad laboral, empresarial o profesional" aunque "desde la presentación de la solicitud, el deudor se abstendrá de realizar cualquier acto de administración y disposición que exceda los actos u operaciones propias del giro o tráfico de su actividad" (art. 235.1). En el mismo precepto se advierte que "desde la comunicación de la apertura de las negociaciones al juzgado competente para la declaración del concurso, los acreedores que pudieran verse afectados por el posible acuerdo extrajudicial de pagos: a) no podrán iniciar ni continuar ejecución judicial o extrajudicial alguna sobre el patrimonio del deudor mientras se negocia el acuerdo extrajudicial hasta un plazo máximo de tres meses ${ }^{189}$ (art. 235.2.a).

\footnotetext{
${ }^{188}$ Para un análisis de los efectos del acuerdo extrajudicial de pago, ver el interesante desarrollo en FERNANDEZ SEIJO, José María, La reestructuración ..., cit., pág. 64 y sgtes.

${ }^{189}$ Se hace constar expresamente que "Se exceptúan los acreedores de créditos con garantía real, que no recaiga sobre bienes o derechos que resulten necesarios para la continuidad de la actividad profesional o empresarial del deudor ni sobre su vivienda habitual. Cuando la garantía recaiga sobre los bienes citados en el inciso anterior, los acreedores podrán ejercitar la acción real que les corresponda frente a los bienes y derechos sobre los que recaiga su garantía sin perjuicio de que, una vez iniciado el procedimiento, quede paralizado mientras no hayan transcurrido los plazos previstos en este apartado" (art. 235.2.a). Por otra parte,
} 
La norma dispone otro efecto benéfico para el deudor en situación de impotencia patrimonial, al disponer que "practicada la correspondiente anotación de la apertura del procedimiento en los registros públicos de bienes, no podrán anotarse respecto de los bienes del deudor instante, embargos o secuestros posteriores a la presentación de la solicitud del nombramiento de mediador concursal, salvo los que pudieran corresponder en el curso de procedimientos seguidos por los acreedores de derecho público". Además, "durante el plazo de negociación del acuerdo extrajudicial de pagos y respecto a los créditos que pudieran verse afectados por el mismo, se suspenderá el devengo de intereses" (art. $235.3)^{190}$

Relevante es para el sujeto afectado, la previsión de cierre de la norma aludida, conforme la cual "el deudor que se encontrase negociando un acuerdo extrajudicial no podrá ser declarado en concurso, en tanto no transcurra el plazo previsto en el artículo 5 bis.5" (art. 235.5)

El art. 236, reformado también por el real Decreto-Ley 1/2015, contiene una nueva regulación de la propuesta de acuerdo extrajudicial de pagos en cuanto a los plazos, el rol del mediador (cuando así corresponda), contenido y medidas que la integren ${ }^{191}$. La norma el art. 235.4 prevé que "El acreedor que disponga de garantía personal para la satisfacción del crédito podrá ejercitarla siempre que el crédito contra el deudor hubiera vencido. En la ejecución de la garantía, los garantes no podrán invocar la solicitud del deudor en perjuicio del ejecutante".

${ }^{190}$ Ello, “de conformidad con lo dispuesto por el artículo 59" de la ley concursal.

${ }^{191}$ Reza el art. 236 .1: "La propuesta podrá contener cualquiera de las siguientes medidas: a) Esperas por un plazo no superior a diez años. b) Quitas. c) Cesión de bienes o derechos a los acreedores en pago o para pago de totalidad o parte de sus créditos. d) La conversión de deuda en acciones o participaciones de la sociedad deudora. En este caso se estará a lo dispuesto en el apartado 3.ii) 3. ${ }^{\circ}$ de la disposición adicional cuarta. e) La conversión de deuda en préstamos participativos por un plazo no superior a diez años, en obligaciones convertibles o préstamos subordinados, en préstamos con intereses capitalizables o en cualquier otro instrumento financiero de rango, vencimiento o características distintas de la deuda original. Solo podrá incluirse la cesión en pago de bienes o derechos a los acreedores siempre que los bienes o derechos cedidos no resulten necesarios para la continuación de la actividad profesional o empresarial y que su valor razonable, calculado conforme a lo dispuesto en el artículo 94.2, sea igual o inferior al crédito que se extingue. Si fuese superior, la diferencia se deberá integrar en el patrimonio del deudor. Si se tratase de bienes afectos a garantía, será de aplicación lo dispuesto por el artículo 155.4. En ningún caso la propuesta podrá consistir en la liquidación global del patrimonio del deudor para satisfacción de sus deudas ni podrá alterar el orden de prelación de créditos legalmente establecido, salvo que los acreedores postergados consientan expresamente". 
citada prevé que el plan de pagos propuesto deberá incluir un detalle de los recursos previstos para su cumplimiento y que el plan de viabilidad que lo respalde, deberá contemplar una propuesta de cumplimiento regular de las nuevas obligaciones. En el mismo precepto se impone proponer asimismo, un plan de continuación de la actividad profesional o empresarial.

$\mathrm{El}$ art. 238, reformado por este Real Decreto-Ley, dispone ahora que para que el acuerdo extrajudicial de pagos se considere aceptado, serán necesarias nuevas mayorías, calculadas sobre la totalidad del pasivo que pueda resultar afectado por el acuerdo ${ }^{192}$ (art. 238.1). Agrega que "si la propuesta fuera aceptada por los acreedores, el acuerdo se elevará inmediatamente a escritura pública, que cerrará el expediente que el notario hubiera abierto. Para los abiertos por el registrador mercantil o la Cámara Oficial de Comercio, Industria, Servicios y Navegación, se presentará ante el Registro Mercantil copia de la escritura para que el registrador pueda cerrar el expediente. Por el notario, el registrador o la Cámara Oficial de Comercio, Industria, Servicios y Navegación se comunicará el cierre del expediente al juzgado que hubiera de tramitar el concurso" (art. 238.2) ${ }^{193}$.

192 Reza el nuevo art. 238.1: "Para que el acuerdo extrajudicial de pagos se considere aceptado, serán necesarias las siguientes mayorías, calculadas sobre la totalidad del pasivo que pueda resultar afectado por el acuerdo: a) Si hubiera votado a favor del mismo el 60 por ciento del pasivo que pudiera verse afectado por el acuerdo extrajudicial de pagos, los acreedores cuyos créditos no gocen de garantía real o por la parte de los créditos que exceda del valor de la garantía real, quedarán sometidos a las esperas, ya sean de principal, de intereses o de cualquier otra cantidad adeudada, con un plazo no superior a cinco años, a quitas no superiores al 25 por ciento del importe de los créditos, o a la conversión de deuda en préstamos participativos durante el mismo plazo. b) Si hubiera votado a favor del mismo el 75 por ciento del pasivo que pudiera verse afectado por el acuerdo extrajudicial de pagos, los acreedores cuyos créditos no gocen de garantía real o por la parte de los créditos que exceda del valor de la garantía real, quedarán sometidos a las esperas con un plazo de cinco años o más, pero en ningún caso superior a diez, a quitas superiores al 25 por ciento del importe de los créditos, y a las demás medidas previstas en el artículo 236”.

193 Añade la norma que "Igualmente se dará cuenta del hecho por certificación o copia remitidas a los registros públicos de bienes competentes para la cancelación de las anotaciones practicadas. Asimismo, publicará la existencia del acuerdo en el Registro Público Concursal por medio de un anuncio que contendrá los datos que identifiquen al deudor, incluyendo su Número de Identificación Fiscal, el registrador o notario competente o la Cámara Oficial de Comercio, Industria, Servicios y Navegación, el número de expediente de nombramiento del mediador, el nombre del mediador concursal, incluyendo su Número de Identificación Fiscal, y la indicación de que el expediente está a disposición de los acreedores interesados en el Registro 
A fin de superar algunas de las críticas que la versión anterior de la figura despertó, el art. 238.4 dispone ahora que: "Los acuerdos extrajudiciales de pagos adoptados por las mayorías y con los requisitos descritos en este Título no podrán ser objeto de rescisión concursal en un eventual concurso de acreedores posterior".

Otra de las novedades incorporadas en pos del objeto perseguido, es la contenida en el art. 238 bis, que bajo el título "Extensión subjetiva", dispone: "1. El contenido del acuerdo extrajudicial vinculará al deudor y a los acreedores descritos en el apartado 1 del artículo precedente. 2. Los acreedores con garantía real, por la parte de su crédito que no exceda del valor de la garantía, únicamente quedarán vinculados por el acuerdo si hubiesen votado a favor del mismo. 3. No obstante, los acreedores con garantía real que no hayan aceptado el acuerdo, por la parte de sus créditos que no excedan del valor de la garantía, quedarán vinculados a las medidas previstas en las letras a) y b) del apartado 1 del artículo anterior, siempre que las mismas hayan sido acordadas, con el alcance que se convenga, por las siguientes mayorías, calculadas en función de la proporción del valor de las garantías aceptantes sobre el valor total de las garantías otorgadas: a) Del 65 por ciento, cuando se trate de las medidas previstas en el apartado 1 a) del artículo anterior. b) Del 80 por ciento, cuando se trate de las medidas previstas en el apartado 1 b) del artículo anterior" ${ }^{, 194}$.

La eficacia de la herramienta legal analizada se pone de manifiesto en el también remozado art. 240, que al regular los efectos del acuerdo sobre los acreedores, hace explícitas las consecuencias favorables que del mismo se derivan ${ }^{195}$. En efecto, la norma dispone ahora que:

\footnotetext{
Mercantil, Notaría o Cámara Oficial de Comercio, Industria, Servicios y Navegación correspondiente para la publicidad de su contenido".

${ }^{194} \mathrm{Si}$ bien a partir de la reforma, el acuerdo extrajudicial de pagos puede extenderse a los acreedores con garantía real -aunque no hayan consentido- pero exigiendo que una mayoría del 65 o $80 \%$ de esta clase de acreedores vote en favor del acuerdo, se ha dicho que este requisito "constituye un imposible, porque en la insolvencia del deudor consumidor es lo más probable que sólo exista un acreedor con garantía real, por lo que no podrá formarse en su contra una mayoría dentro de las misma clase" (CARRASCO PERERA, Ángel, "El mecanismo de segunda oportunidad ... para consumidores insolventes en el RDL 1/2015: realidad y mito", en http://www.uclm.es/centro/cesco/pdf/trabajos/mecanismosegundaoportunidad.pdf).

${ }^{195}$ La doctrina considera un acierto el nuevo texto del precepto pues se cie que "la reforma procede a una mejor sistematización de los efectos" del AEP (CABANAS TREJO, Ricardo, "El nuevo régimen legal de la
} 
“1. Ningún acreedor afectado por el acuerdo podrá iniciar o continuar ejecuciones contra el deudor por deudas anteriores a la comunicación de la apertura del expediente. El deudor podrá solicitar la cancelación de los correspondientes embargos del juez que los hubiera ordenado".

“2. Por virtud del acuerdo extrajudicial, los créditos quedarán aplazados, remitidos o extinguidos conforme a lo pactado".

“3. Los acreedores que no hubieran aceptado o que hubiesen mostrado su disconformidad con el acuerdo extrajudicial de pagos y resultasen afectados por el mismo, mantendrán sus derechos frente a los obligados solidariamente con el deudor y frente a sus fiadores o avalistas, quienes no podrán invocar la aprobación del acuerdo extrajudicial en perjuicio de aquellos".

"4. Respecto de los acreedores que hayan suscrito el acuerdo extrajudicial, el mantenimiento de sus derechos frente a los demás obligados, fiadores o avalistas, dependerá de lo que se hubiera acordado en la respectiva relación jurídica".

El Real Decreto-Ley 1/2015 introduce un nuevo art. 242 bis a la ley concursal ${ }^{196}$, en el que se prevé un procedimiento de acuerdo extrajudicial de pagos para personas naturales no empresarios (consumidores) con notas propias ${ }^{197}$, orientadas a simplificar el trámite y darle agilidad.

exoneración del pasivo concursal y del acuerdo extrajudicial de pagos (Real Decreto-Ley 1/2015, de 27 de febrero)" en Diario La Ley, $N^{\circ}$ 8505, Sección Doctrina, 23 de Marzo de 2015, Ref. D-111, Editorial La Ley). ${ }^{196}$ El precepto citado lleva el título Especialidades del acuerdo extrajudicial de pagos de personas naturales no empresarios.

${ }^{197}$ Señala CABANAS TREJo que "el AEP de la persona natural no empresario ha de discurrir forzosamente según este sistema, y en los otros casos deber aplicarse el general, sin especialidades". Consecuentemente advierte que "por eso se ha de tener en cuenta que el concepto de empresario es muy amplio a efectos del AEP, y que basta con tener la condición de empresario a los efectos de la SS, o con ser trabajador autónomo, para quedar fuera del especial. Siendo así, un particular por el mero hecho de tener una empleada de hogar quedaría fuera de este último, aunque no desempeñe actividad económica alguna ... Otro tanto ocurre con el familiar de un trabajador autónomo, pues también entra en la categoría cuando realice trabajos para el mismo de forma habitual y no tengan la condición de trabajador por cuenta ajena .... Bastará con que concurra alguna de estas circunstancias para que el notario no pueda aceptar su tramitación especial, con independencia de que la mayor parte del pasivo no guarde relación con la actividad, o esta ni siquiera exista (empleador en el servicio doméstico). Sostiene que "así como en el pasado la aplicación extensiva de aquella noción servía para 
Para propiciar el acceso al AEP, se diseña un procedimiento exclusivamente notarial. La norma deja establecido que la solicitud de inicio del trámite deberá ser presentada por el deudor ante un notario que corresponda a su domicilio.

Resultan aplicables las previsiones de los apartados 2 y 3 del art. 232 (reformados por este Real Decreto-Ley), que contienen precisiones orientadas a simplificar el acceso al procedimiento ${ }^{198}$. En efecto, se indica que "la solicitud se hará mediante formulario normalizado ${ }^{199}$ suscrito por el deudor" que "incluirá un inventario con el efectivo y los activos líquidos de que dispone, los bienes y derechos de que sea titular y los ingresos regulares previstos". Se impone asimismo la carga de acompañar "una lista de acreedores, especificando su identidad, domicilio y dirección electrónica, con expresión de la cuantía y vencimiento de los respectivos créditos, en la que se incluirán una relación de los contratos vigentes y una relación de gastos mensuales previstos"200.

De conformidad a lo allí establecido, una vez constatada la suficiencia de la documentación aportada y la procedencia de la negociación del acuerdo extrajudicial de pagos, el notario deberá -de oficio- comunicar la apertura de las negociaciones al juzgado competente para la declaración del concurso.

Establece el dispositivo que el notario impulsará las negociaciones entre el deudor y sus acreedores, salvo que designase, si lo estimase conveniente, un mediador concursal. El nombramiento del mediador concursal deberá realizarse en los cinco días siguientes a la recepción por el notario de la solicitud del deudor, debiendo el mediador aceptar el cargo en un plazo de cinco días. Las actuaciones notariales o registrales previstas en el art. 233

dar entrada en el AEP a un mayor número de personas, quizá convendría con la nueva regulación una cierta flexibilidad, pero en sentido contrario, al objeto de permitir una tramitación del AEP más acorde con la verdadera situación personal del instante. De ser así, deberán incluirse todas las deudas, pues no hay separación entre las personales y las generadas por razón la actividad” (CABANAS TREJO, Ricardo, "El nuevo régimen legal ...", cit.

${ }^{198}$ Cfr. CABANAS TREJO, Ricardo, "El nuevo régimen legal...”, cit.

199 La norma analizada menciona que "el contenido de los formularios normalizados de solicitud, de inventario y de lista de acreedores, se determinará mediante orden del Ministerio de Justicia”.

${ }^{200}$ Se establece en el misma dispositiva, que "esta lista de acreedores también comprenderá a los titulares de préstamos o créditos con garantía real o de derecho público sin perjuicio de que puedan no verse afectados por el acuerdo. Para la valoración de los préstamos o créditos con garantía real se estará a lo dispuesto en el artículo 94.5." 
(referido al nombramiento del mediador concursal) no devengarán retribución arancelaria alguna.

A fin de imprimir agilidad al trámite, se establece que el plazo para la comprobación de la existencia y cuantía de los créditos y para realizar la convocatoria de la reunión entre deudor y acreedores será de quince días, a contar desde la notificación al notario de la solicitud o de diez días desde la aceptación del cargo por el mediador, en su caso. La reunión de las partes deberá celebrarse en un plazo de treinta días desde su convocatoria (art. 242 bis 1.5).

Para propiciar el análisis previo y la evaluación del contenido, se establece que la propuesta de acuerdo deberá ser remitida con una antelación mínima de quince días naturales a la fecha prevista para la celebración de la reunión, pudiendo los acreedores formular propuestas alternativas o de modificación dentro de los diez días naturales posteriores a la recepción de aquél. Dispone la norma que "la propuesta de acuerdo únicamente podrá contener las medidas previstas en las letras a), b) y c) del artículo 236.1 de la LC" (es decir, esperas por un plazo no superior a diez años, quitas o cesión de bienes o derechos a los acreedores en pago o para pago de totalidad o parte de sus créditos).

Resulta relevante señalar que la dispositiva analizada hace referencia expresa a la suspensión de las ejecuciones del art. 235 (ejecución hipotecaria sobre la vivienda habitual), estipulando que el plazo de la misma será de dos meses desde la comunicación de la apertura de las negociaciones al juzgado salvo que, con anterioridad, se adoptase o rechazase el acuerdo extrajudicial de pagos o tuviese lugar la declaración de concurso (art. 242 bis. 1.8).

Si al término del plazo de dos meses el notario o, en su caso, el mediador, considera que no es posible alcanzar un acuerdo, instará el concurso del deudor en los diez días siguientes, remitiendo al juez un informe razonado con sus conclusiones (art. 242 bis. 1.9). Estas medidas contribuyen a la eficacia del dispositivo legal, evitando dilaciones innecesarias cuando se advierte que no será éste el procedimiento adecuado para sanear la situación del sujeto afectado. 
La norma prevé que en este caso, "el concurso consecutivo se abrirá directamente en la fase de liquidación" (art. 242 bis. 1.10) ${ }^{201}$, medida que supone acotar las etapas y acelerar del procedimiento posterior.

El Real Decreto-Ley 1/2015 dispone además, la modificación del Real Decreto-Ley 6/2012, de "Medidas urgentes de protección de deudores hipotecarios sin recursos".

A fin de ampliar el ámbito de aplicación de las medidas protectorias, deja establecido en el nuevo art. 3.1 que: "se considerarán situados en el umbral de exclusión aquellos deudores de un crédito o préstamo garantizado con hipoteca sobre su vivienda habitual, cuando concurran en ellos todas las circunstancias siguientes:

a) Que el conjunto de los ingresos de los miembros de la unidad familiar no supere el límite de tres veces el Indicador Público de Renta de Efectos Múltiples anual de catorce pagas. A estos efectos se entenderá por unidad familiar la compuesta por el deudor, su cónyuge no separado legalmente o pareja de hecho inscrita y los hijos, con independencia de su edad, que residan en la vivienda, incluyendo los vinculados por una relación de tutela, guarda o acogimiento familiar. El límite previsto en el párrafo anterior será de cuatro veces el Indicador Público de Renta de Efectos Múltiples anual de catorce pagas en caso de que alguno de los miembros de la unidad familiar tenga declarada discapacidad superior al 33 por ciento, situación de dependencia o enfermedad que le incapacite acreditadamente de forma permanente para realizar una actividad laboral, o de cinco veces dicho indicador, en el caso de que un deudor hipotecario sea persona con parálisis cerebral, con enfermedad mental, o con discapacidad intelectual, con un grado de discapacidad reconocido igual o superior al 33 por ciento, o persona con discapacidad física o sensorial, con un grado de discapacidad reconocido igual o superior al 65 por ciento, así como en los casos de enfermedad grave que incapacite acreditadamente, a la persona o a su cuidador, para realizar una actividad laboral.

b) Que, en los cuatro años anteriores al momento de la solicitud, la unidad familiar haya sufrido una alteración significativa de sus circunstancias económicas, en términos de esfuerzo de acceso a la vivienda, o hayan sobrevenido en dicho período circunstancias

${ }^{201}$ Conforme el art. 242.2.1 ${ }^{\circ}$ LC también reformado por el Real Decreto-Ley 1/2015, tratándose de una persona natural empresario, la solicitud de concurso instada por el mediador concursal, deberá acompañarse de una propuesta anticipada de convenio o un plan de liquidación. 
familiares de especial vulnerabilidad. A estos efectos se entenderá que se ha producido una alteración significativa de las circunstancias económicas cuando el esfuerzo que represente la carga hipotecaria sobre la renta familiar se haya multiplicado por al menos 1,5; salvo que la entidad acredite que la carga hipotecaria en el momento de la concesión del préstamo era igual o superior a la carga hipotecaria en el momento de la solicitud de la aplicación del Código de Buenas Prácticas".

c) Que la cuota hipotecaria resulte superior al 50 por cien de los ingresos netos que perciba el conjunto de los miembros de la unidad familiar. Dicho porcentaje será del 40 por cien cuando alguno de dichos miembros sea una persona en la que concurren las circunstancias previstas en el segundo párrafo del apartado a). A efectos de las letras a) y b) anteriores, se considerará que presentan una discapacidad en grado igual o superior al 33 por ciento los pensionistas de la Seguridad Social que tengan reconocida una pensión de incapacidad permanente en el grado de total, absoluta o gran invalidez, y a los pensionistas de clases pasivas que tengan reconocida una pensión de jubilación o de retiro por incapacidad permanente para el servicio o inutilidad".

Precisa la nueva normativa que “...se entiende que se encuentran en una circunstancia familiar de especial vulnerabilidad: $1 .^{\circ}$ La familia numerosa, de conformidad con la legislación vigente. $2 .^{\circ}$ La unidad familiar monoparental con dos hijos a cargo. $3 .^{\circ} \mathrm{La}$ unidad familiar de la que forme parte un menor de tres años. $4 .^{\circ}$ La unidad familiar en la que alguno de sus miembros tenga declarada discapacidad superior al 33 por ciento, situación de dependencia o enfermedad que le incapacite de forma permanente, de forma acreditada, para realizar una actividad laboral. $5^{\circ}$ El deudor mayor de 60 años, aunque no reúna los requisitos para ser considerado unidad familiar según lo previsto en la letra a) de este número" (supuesto este último, incorporado en esta reforma).

La modificación de los apartados 2 y 3 del art. 5 de la ley concursal resulta de gran interés puesto que supone también una ampliación del ámbito de aplicación del Código de Buenas Prácticas al que las entidades de crédito pueden adherir ${ }^{202}$.

\footnotetext{
${ }^{202}$ Dispone el art. 5.2: "La aplicación del Código de Buenas Prácticas se extenderá a las hipotecas constituidas en garantía de préstamos o créditos, cuando el precio de adquisición del bien inmueble hipotecado no exceda en un $20 \%$ del que resultaría de multiplicar la extensión del inmueble, por el precio medio por metro cuadrado para vivienda libre que arroje el Índice de Precios de la Vivienda elaborado por el
} 
También se introduce por vía del Real Decreto-Ley 1/2015, una modificación de la Ley 1/2013, de "Medidas para reforzar la protección a los deudores hipotecarios, reestructuración de deuda y alquiler social".

Una de las principales disposiciones es la de extender hasta el año 2017 el plazo de suspensión de lanzamientos sobre viviendas habituales de los colectivos especialmente vulnerables.

Haciéndose cargo de la persistencia de la situación de crisis y de las urgencias de los sujetos y familias afectadas, se modifican los apartados 1, 2 y 3 del art. 1 de la Ley 1/2013, con el objeto de ampliar el catálogo de sujetos beneficiarios de las medidas allí establecidas:

"1. Hasta transcurridos cuatro años desde la entrada en vigor de esta Ley, no procederá el lanzamiento cuando en un proceso judicial o extrajudicial de ejecución hipotecaria se hubiera adjudicado al acreedor, o a persona que actúe por su cuenta, la vivienda habitual de personas que se encuentren en los supuestos de especial vulnerabilidad y en las circunstancias económicas previstas en este artículo.

2. Los supuestos de especial vulnerabilidad a los que se refiere el apartado anterior son: a) Familia numerosa, de conformidad con la legislación vigente. b) Unidad familiar monoparental con dos hijos a cargo. c) Unidad familiar de la que forme parte un menor de tres años. d) Unidad familiar en la que alguno de sus miembros tenga declarada discapacidad superior al 33 por ciento, situación de dependencia o enfermedad que le incapacite acreditadamente de forma permanente para realizar una actividad laboral. e) Unidad familiar en la que el deudor hipotecario se encuentre en situación de desempleo y haya agotado las prestaciones por desempleo. f) Unidad familiar con la que convivan, en la

Ministerio de Fomento para el año de adquisición del bien inmueble y la provincia en que esté radicada dicho bien, con un límite absoluto de 300.000 euros. Los inmuebles adquiridos antes del año 1995 tomarán como precio medio de referencia el relativo al año 1995. No obstante, solo podrán acogerse a las medidas previstas en el apartado 3 del Código las hipotecas constituidas en garantía de préstamos o créditos concedidos, cuando el precio de adquisición del bien inmueble hipotecado no exceda del que resultaría de multiplicar la extensión del inmueble, por el precio medio por metro cuadrado para vivienda libre que arroje el Índice de Precios de la Vivienda elaborado por el Ministerio de Fomento para el año de adquisición del bien inmueble y la provincia en que esté radicada dicho bien, con un límite absoluto de 250.000 euros. Los inmuebles adquiridos antes del año 1995 tomarán como precio medio de referencia el relativo al año 1995”. 
misma vivienda, una o más personas que estén unidas con el titular de la hipoteca o su cónyuge por vínculo de parentesco hasta el tercer grado de consanguinidad o afinidad, y que se encuentren en situación personal de discapacidad, dependencia, enfermedad grave que les incapacite acreditadamente de forma temporal o permanente para realizar una actividad laboral. g) Unidad familiar en que exista una víctima de violencia de género, conforme a lo establecido en la legislación vigente, en el caso de que la vivienda objeto de lanzamiento constituya su domicilio habitual. h) El deudor mayor de 60 años.

3. Para que sea de aplicación lo previsto en el apartado 1 deberán concurrir, además de los supuestos de especial vulnerabilidad previstos en el apartado anterior, las circunstancias económicas siguientes: a) Que el conjunto de los ingresos de los miembros de la unidad familiar no supere el límite de tres veces el Indicador Público de Renta de Efectos Múltiples anual de catorce pagas. Dicho límite será de cuatro veces el Indicador Público de Renta de Efectos Múltiples anual de catorce pagas en los supuestos previstos en las letras d) y f) del apartado anterior, y de cinco veces dicho indicador en el caso de que el ejecutado sea persona con parálisis cerebral, con enfermedad mental o con discapacidad intelectual, con un grado de discapacidad reconocido igual o superior al 33 por ciento, o persona con discapacidad física o sensorial, con un grado de discapacidad reconocido igual o superior al 65 por ciento, así como en los casos de enfermedad grave que incapacite acreditadamente, a la persona o a su cuidador, para realizar una actividad laboral. b) Que, en los cuatro años anteriores al momento de la solicitud, la unidad familiar haya sufrido una alteración significativa de sus circunstancias económicas, en términos de esfuerzo de acceso a la vivienda. c) Que la cuota hipotecaria resulte superior al 50 por cien de los ingresos netos que perciba el conjunto de los miembros de la unidad familiar. d) Que se trate de un crédito o préstamo garantizado con hipoteca que recaiga sobre la única vivienda en propiedad del deudor y concedido para la adquisición de la misma”.

Pero la vedette del Real Decreto-Ley 1/2015 es, sin dudas, la modificación del régimen de la llamada segunda oportunidad o exoneración del pasivo insatisfecho oportunamente diseñada por la Ley $14 / 2013^{203}$.

\footnotetext{
${ }^{203}$ Señalaba SENENT MARTínEZ que la Ley 14/2013 había introducido en el ordenamiento jurídico español la figura de la exoneración del pasivo insatisfecho pero sin regular un procedimiento específico para
} 
La reforma incorpora a la ley concursal un nuevo art. 178 bis, bajo el título "Beneficio de la exoneración del pasivo insatisfecho") y modifica el art. 178.

En su versión anterior al Real Decreto-Ley 1/2015, el art. 178.2 de la ley concursal establecía que la resolución judicial que resolviera la conclusión del concurso del deudor persona natural por liquidación de la masa activa, declararía la remisión de las deudas insatisfechas, siempre que el concurso no hubiera sido declarado culpable (...) y que se hubieran satisfecho en su integridad los créditos contra la masa, y los créditos concursales privilegiados $\mathrm{y}$, al menos, el 25 por ciento del importe de los créditos concursales ordinarios. Asimismo, si el deudor hubiere intentado sin éxito el acuerdo extrajudicial de pagos, podría obtener la remisión de los créditos restantes si hubieran sido satisfechos los créditos contra la masa y todos los créditos concursales privilegiados.

El Real Decreto-Ley 1/2015 da una nueva redacción al precepto y establece ahora que fuera de los supuestos previstos en el artículo siguiente (178 bis incorporado), en los casos de conclusión del concurso por liquidación o insuficiencia de masa activa, la regla es que el deudor persona natural quedará responsable del pago de los créditos restantes ${ }^{204}$.

consumidores, lo que constituía una asignatura pendiente que urgía concretar (SENENT MARTíNEZ, Santiago, Exoneración del pasivo insatisfecho..., cit.

204 HERNÁNDEZ RODRÍGUEZ señala que la reforma del instituto "reconoce la primacía del principio de responsabilidad personal universal del art. 1911 del Código Civil, al devolver a la ley concursal la regla según la cual el deudo persona natural quedará responsable del pago de los créditos restantes, esto es, no satisfechos en el seno del concurso concluido por liquidación o insuficiencia de la masa activa". Recuerda que "esta regla había sido excluida de la redacción del art. 178.2 con la reforma operada por la Ley 14/2013 a partir de la cual se refería exclusivamente a la exoneración de pasivos y los requisitos legales para ello, de manera que la responsabilidad universal por las deudas pendientes había de extraerse a sensu contrario, lo que fue fuente de numerosas críticas” (HERnÁNDEZ RodRíGUEZ, María del Mar, “La segunda oportunidad en el Real DecretoLey1/2015, publicación del 1 de abril de 2015, http://www.elderecho.com/tribuna/mercantil/segundaoportunidad-Real-Decreto-Ley_11_790930003.html) (Fecha de consulta: 20/4/2015). BENAVIDES VELASCO recuerda que desde hace tiempo la doctrina venía reclamando la necesidad de introducir al ordenamiento jurídico español, un mecanismo de liberación de deudas para la persona física, tal como ya existía en países del entorno y señala que el legislador fue reacio a su incorporación "quizá por el arraigo y potencia que en nuestra sociedad posee el contenido del art. 1911 del Código Civil” (BENAVIDES Velasco, Patricia G., Masa activa del concurso y bienes gananciales, cit., pág. 262). 
El beneficio de exoneración del pasivo insatisfecho de las personas físicas se regula autónomamente ahora en el art. 178 bis, lo que puede considerarse un acierto del legislador. En apoyo de esta conclusión se expresa que la consagración de la figura modifica de manera sustancial el régimen de la responsabilidad patrimonial universal y que ello justifica de manera sobrada esta regulación separada ${ }^{205}$.

El remozamiento del instituto constituye -como se dijo- la novedad introducida a la ley concursal ${ }^{206}$.

El nuevo diseño de la figura lo presenta como un beneficio que debe ser solicitado por el deudor que pretenda prevalerse del $\operatorname{mismo}^{207}$ (a diferencia del régimen anterior,

\footnotetext{
${ }^{205}$ HERNÁNDEZ RodRÍGUEZ, María del Mar, “La segunda oportunidad en el Real Decreto-Ley1/2015, cit.

${ }^{206}$ El nuevo art. 178 bis dispone bajo el título "Beneficio de la exoneración del pasivo insatisfecho", lo siguiente: “1. El deudor persona natural podrá obtener el beneficio de la exoneración del pasivo insatisfecho en los términos establecidos en este artículo, una vez concluido el concurso por liquidación o por insuficiencia de la masa activa. 2. El deudor deberá presentar su solicitud de exoneración del pasivo insatisfecho ante el Juez del concurso dentro del plazo de audiencia que se le haya conferido de conformidad con lo establecido en el art. 152.3. 3. Solo se admitirá la solicitud de exoneración de pasivo insatisfecho a los deudores de buena fe. Se entenderá que concurre buena fe en el deudor siempre que se cumplan los siguientes requisitos: $1^{\circ}$ Que el concurso no haya sido declarado culpable. $2^{\circ}$ Que el deudor no haya sido ni condenado en sentencia firme por delitos contra el patrimonio, contra el orden socioeconómico, falsedad documental, contra la Hacienda Pública y la Seguridad Social o contra los derechos de los trabajadores en los 10 años anteriores a la declaración de concurso. Si existiera un proceso penal pendiente, el juez del concurso deberá suspender su decisión respecto a la exoneración del pasivo hasta que exista sentencia penal firme. $3^{\circ}$ Que, reuniendo los requisitos establecidos en el art. 231, haya celebrado o, al menos, intentado celebrar un acuerdo extrajudicial de pagos. $4^{\circ}$ Que haya satisfecho en su integridad los créditos contra la masa, y los créditos concursales privilegiados y, si no hubiera intentado un acuerdo extrajudicial de pagos previo, al menos, el 25 por ciento del importe de los créditos concursales ordinarios. $5^{\circ}$ Que, alternativamente al número anterior: i) Acepte someterse al plan de pagos previsto en el apartado 6. ii) No haya incumplido las obligaciones de colaboración establecidas en el art. 42. iii) No haya obtenido este beneficio dentro de los diez últimos años. iv) No haya rechazado dentro de los cuatro años anteriores a la declaración de concurso una oferta de empleo adecuada a su capacidad. v) Acepte de forma expresa, en la solicitud de exoneración de pasivo insatisfecho, que la obtención de este beneficio se hará constar en la sección especial del Registro Público Concursal con posibilidad de acceso público, por un plazo de cinco años...”.

207 Señala CARRASCO PERERA que no existe ya una declaración necesaria de remisión o exoneración del pasivo sujeta a las condiciones materiales del art 178.2 antiguo, sino que su concesión parece potestativa del juez del concurso, frente a la solicitud expresa del concursado. Plantea dudas a partir de la expresión
} 
donde el beneficio era aplicable de oficio), siempre que se cumplan una serie de requisitos adicionales a los que establecía la regulación anterior.

La petición de exoneración sólo puede formularse ante el juez del concurso, ${ }^{208}$ en caso de que éste haya concluido por liquidación ó por falta de bienes, o insuficiencia de masa activa, quedando pasivo insatisfecho (conf. art. 178 bis. 1 LC) ${ }^{209}$.

contenida en el texto legal del nuevo art. 178 bis ("El deudor persona natural podrá obtener el beneficio de la exoneración del pasivo insatisfecho...”), dado que pareciera existir "un elemento de libre valoración del juez, aún cumplidas las condiciones materiales del apartado 3...”. Admite, no obstante, que podría interpretarse que "la posibilidad no es más que un elemento descriptivo del tipo, indicativo de que la remisión se obtendrá si se cumplen las condiciones objetivas materiales". Concluye que cumplidos los requisitos legales, "el juez no dispone de discrecionalidad para conceder o no la remisión" aunque el propio art. 178 bis -en su apartado 8, al referirse a la resolución definitiva del beneficio-, menciona que el juez habrá de ponderar las circunstancias del caso, en determinado supuesto (cuando el deudor "que no hubiese cumplido en su integridad el plan de pagos pero hubiese destinado a su cumplimiento, al menos, la mitad de los ingresos percibidos durante dicho plazo que no tuviesen la consideración de inembargables"). Ver CARRASCO PERERA, Ángel, "El mecanismo de segunda oportunidad para consumidores insolventes en el RDL 1/2015: realidad y mito”, en http://www.uclm.es/centro/cesco/pdf/trabajos/mecanismosegundaoportunidad.pdf (Fecha de consulta: 20/4/2015).

${ }^{208}$ Atento a que la regulación del beneficio prevé que se haya tramitado el concurso del deudor y declarado su conclusión por las causas contempladas en el art. 178 citado, la remisión de deudas no puede sino peticionarse y obtenerse en ese marco procesal. En este modelo regulatorio, la exoneración del pasivo pendiente no puede solicitarse en otro procedimiento administrativo. Sin perjuicio de las quitas que puedan acordarse conforme al nuevo art. 236 de la ley concursal, la remisión de pasivo insatisfecho tampoco puede ser motivo de previsión en el acuerdo extrajudicial de pagos, ante la eventualidad de su incumplimiento.

${ }^{209}$ La doctrina destaca que la nueva regulación contempla la posibilidad de acceder al beneficio de la remisión del pasivo pendiente no solamente en el supuesto de conclusión del concurso por liquidación sino que se añade el de la conclusión del concurso por insuficiencia de la masa activa, al que no se refería el art. 178.2 de la ley concursal conforme la reforma introducida por la Ley 14/2013. Se señala asimismo, que no podrá acogerse a este beneficio el deudor cuando el concurso haya concluido por cualquier otra causa, "lo cual constituye una lógica del sistema puesto que en el resto de los supuesto no surge la necesidad de proteger a un deudor merecedor de una segunda oportunidad ya que el procedimiento concursal habrá cumplido su fin, esto es, que los acreedores vean satisfechos sus créditos (vía convenio o por el pago o consignación de todas las deudas) o los acreedores habrán renunciado a sus créditos o desistido del concurso, o habrá concluido el concurso por circunstancias anormales derivadas de la falta de concurrencia de los requisitos para su declaración” (HERNÁNDEZ RODRíGUEZ, María del Mar, "La segunda oportunidad en el Real Decreto- 
Se deja claramente establecido que el beneficio presupone acreedores insatisfechos frente a la inexistencia o insuficiencia de bienes del deudor -declarada por el juez como causa de la clausura del proceso concursal- o porque pese a la liquidación de la totalidad del patrimonio, subsiste un pasivo pendiente. En este último caso, recién luego de la liquidación, y dentro del plazo de audiencia que se le haya conferido al deudor y al resto de las partes para formular oposición a la conclusión del concurso, puede el deudor solicitar la concesión del beneficio al juez interviniente ${ }^{210}$.

Para acceder a la exoneración del pasivo insatisfecho, la norma menciona que debe tratarse de un deudor de buena fe. Se trata de un presupuesto o requisito central, singularmente regulado en el art. 178 bis.3.

Ahora bien, la buena fe - a efectos de la figura analizada- constituye un concepto normativo y no valorativo ${ }^{211}$, diferente del acuñado por las normas civiles ${ }^{212}$. El texto

Ley1/2015, cit.). Destaca este aspecto positivo, BenAVIDEZ Velasco, Patricia G., Masa activa del concurso y bienes gananciales, cit, pág. 265.

${ }^{210}$ Dispone el art. 178 bis.2: "El deudor deberá presentar su solicitud de exoneración del pasivo insatisfecho ante el Juez del concurso dentro del plazo de audiencia que se le haya conferido de conformidad con lo establecido en el artículo 152.3".

${ }^{211}$ CARRASCo PERERA, Ángel, "El mecanismo de segunda oportunidad para consumidores insolventes en el RDL 1/2015: realidad y mito", cit. En igual sentido se pronuncia Matilde CUENA CASAS al decir que la buena fe exigida "se deduce de la concurrencia de una serie de requisitos que exceden al evaluación de la conducta del deudor" mencionando las condiciones que emergen de los modelos o alternativas posibles contenidas en el citado art. 178 bis CuEna CASAS, Matilde, “A propósito del Real Decreto-Ley 1/2015 ¿Un régimen de segunda oportunidad?” en El Notario del Siglo XXI, $\mathrm{N}^{\circ}$ 60, marzo/abril 2015, pág. 10 y sgtes.). Sobre el punto, HERNÁNDEZ RODRÍGUEZ destaca con tono crítico que algunos de los requisitos que definen este concepto normativo en los distintos ordinales del art. 178 bis, "poseen remota relación con la buena fe del deudor" y señala que "ninguna exigencia contiene el precepto vinculada con la conducta del deudor en el momento de generación de la situación de insolvencia o de endeudamiento". La autora citada se plantea "si es posible admitir la solicitud del deudor que, a pesar de no cumplir algunos de los requisitos especificados en $\operatorname{los} n^{\circ} 1^{\circ}$ a $5^{\circ}$ del apartado 3 , se presenta como un claro deudor de buena fe y su situación de insolvencia ni en su origen ni en su agravación se encuentra vinculada con el requisito incumplido sino en circunstancias ajenas" y se pronuncia en sentido positivo a la luz de una "interpretación finalista" del precepto analizado. Entiende que "en estos supuestos será necesaria una fundamentación y justificación reforzada de la solicitud, de la que sea posible extraer, con carácter inicial, la apariencia de buena fe del deudor concursado por encima del cumplimiento de las exigencias específicas" para examinar "si el deudor, a pesar de no cumplir todos los 
legal establece que "Sólo se admitirá la solicitud de exoneración de pasivo insatisfecho a los deudores de buena fe", advirtiendo que se entenderá satisfecho el requisito aludido cuando se verifiquen los extremos allí establecidos.

De inicio, la ley considera que el deudor es de buena fe siempre que se verifiquen los recaudos del apartado $3^{\circ}$ de la norma analizada: "1.- Que el concurso no haya sido declarado culpable" (art. 178 bis.3.1 $\left.{ }^{\circ}\right)^{213}$ y "2.- Que el deudor no haya sido condenado en específicos requisitos, puede ser calificado como deudor honesto pero desafortunado". Agrega que "hubiera sido más acorde al espíritu de la exoneración de deudas, seguir el sistema del merecimiento que siguen otros ordenamientos, en los que se parte de analizar si el deudor, por su conducta, es merecedor o no del reconocimiento de esta segunda oportunidad..." (HERnÁNDEZ RODRíGUEZ, María del Mar, La segunda oportunidad...., pág. 106 y sgtes.).

${ }^{212}$ Enseña DíEZ-PICAZo que la buena fe "expresa la confianza o la esperanza en una actuación correcta de otro", referido a "un modelo de comportamiento...que vive en las creencias y en la conciencia social y al que deben ajustarse los comportamientos individuales" (DíEZ-PiCAZO, Luis, Fundamentos de Derecho Patrimonial, T. I, Introducción a la Teoría del Derecho, Ed. Civitas, Madrid, 1996, pág. 48). Marca esta diferencia conceptual con la buena fe a la que alude el Real Decreto-Ley 1/2015, FERNÁNDEZ SEIJO, al señalar que "el beneficio de exoneración del pasivo sólo se permite a aquellos deudores que previamente hayan acreditado actuar de buena fe, estableciendo el art. 178 bis un concepto de buena fe a los efectos concursales que no coincide con el concepto de buena fe que de ordinario se utiliza en el Código Civil" (FERnÁndeZ SEIJo, José María, La reestructuración de las deudas en la Ley de Segunda Oportunidad, cit., pág. 205).

${ }^{213}$ Esta primera exigencia, reveladora de la buena fe del deudor, impone una necesaria correlación del precepto analizado con otras normas del subsistema. Recuerda Fernández Seijo que "Es la sección sexta del proceso concursal la que se destina a indagar sobre las causas que han generado la insolvencia o que hayan agravado la misma en orden a la posible calificación del concurso como culpable -artículo 163 y siguientes LC-...La sección de calificación del procedimiento concursal responde a una necesidad lógica, la de evaluar cuáles han sido las causas que ha llevado al deudor a una situación de insolvencia, comprobar si las circunstancias que el deudor describió en la memoria que acompañaba al concurso -artículo 6 LC- se corresponden con la realidad, si el deudor ha actuado con lealtad al informar de esas causas, si ha sido puntual en la solicitud del concurso, si ha aportado la documentación precisa y exacta para el que juzgado y los acreedores puedan conocer la situación de la concursada...Sólo los comportamientos más graves, aquéllos en los que el deudor haya actuado con dolo o culpa grave que genere insolvencia o agrave la misma, tendrán el reproche de la calificación del concurso como culpable. Si no se observa ese dolo o culpa grave el concurso se calificará como fortuito". Destaca el citado autor que "Para facilitar las tareas de calificación...la ley concursal establece una serie de presunciones tanto de culpa del concurso -artículo 164.2 LC- como de dolo o culpa grave del concursado o de su entorno más cercano -artículo 165 LC-” (cfr. FERNÁNDEZ SEIJO, José 
sentencia firme por delitos contra el patrimonio, contra el orden socioeconómico, falsedad documental, contra la Hacienda Pública y la Seguridad Social o contra los derechos de los trabajadores en los 10 años anteriores a la declaración de concurso" (art. 178 bis.3. $2^{\circ}$ ).

Pero todavía más. La doctrina menciona que con el Real Decreto-Ley 1/2015, el concepto de buena fe se ensancha pues para reconocerle esta calidad, el deudor debe observar condiciones materiales adicionales ${ }^{214}$. La redacción del art. 178 bis, apartado 3, puntos $3^{\circ}, 4^{\circ}$ y $5^{\circ}$, así lo evidencia.

Se exige asimismo, que el deudor "reuniendo los requisitos establecidos en el artículo 231, haya celebrado o, al menos, intentado celebrar un acuerdo extrajudicial de pagos" (art. 178 bis.3.3 ${ }^{\circ}$ ), interpretándose que "sin duda...el hecho de que un deudor haya iniciado los trámites extrajudiciales previstos en el Título X, pone de manifiesto su buena

María, La reestructuración de las deudas en la ley de segunda oportunidad, cit., pág. 209). Cabe destacar que la Ley 25/2015 de 28 de julio, modificó el precepto agregando que "No obstante, si el concurso hubiera sido declarado culpable por aplicación del artículo 165.1.1. ${ }^{\circ}$ el juez podrá ... conceder el beneficio atendidas las circunstancias y siempre que no se apreciare dolo o culpa grave del deudor". Esta modificación ha sido criticada por CUENA CASAS por considerar que el retraso en la declaración de concurso es no es un fallo leve. Entiende que "declararse tarde en concurso puede hacer inviable el acuerdo y que el concurso se vea abocado a la liquidación y al perjuicio de los intereses de los acreedores". La autora citada expresa que "se amplía la puerta de entrada al sistema, dulcificándose el requisito de la buena fe del deudor" y que el cambio resulta "poco afortunado" (CUENA CASAS, Matilde, "Una segunda oportunidad para la persona física insolvente: cambios de última hora", en http://www.legaltoday.com/practica-juridica/mercantil/concursal/una-segundaoportunidad-para-la-persona-fisica-insolvente-cambios-de-ultima-hora) (Fecha de consulta: 27/9/2015).

${ }^{214}$ CARRASCO PERERA considera un absurdo que las condiciones contenidas en los diferentes modelos "se sigan caracterizando como determinaciones necesarias de la buena fe" del deudor. Entiende que "es un error introducir la condición de buena fe, si luego va a ser totalmente normativizada por medio de elementos fácticos y estándares de conducta que nada tienen que ver" con esa calidad. Sostiene que "bastaría haber dicho que la remisión (del pasivo pendiente) está sujeta al cumplimiento de las condiciones legalmente establecidas. "La normativa concursal configura un concepto de buena fe que no coincide con el concepto de buena fe que inspira otras instituciones civiles o mercantiles" y que esa conceptualización "incluye tanto requisitos de carácter objetivo como requisitos de carácter formal” (cfr. FERNÁNDEZ SEIJO, José María, La reestructuración de las deudas en la ley de segunda oportunidad, cit., pág. 208). 
voluntad inicial, vinculada a su deseo de llegar a un acuerdo con sus principales acreedores",215.

Bajo esta premisa -haber celebrado o haber intentado celebrar un acuerdo extrajudicial de pagos- el art. 178 bis.3 analizado, prevé dos alternativas de exoneración del pasivo.

En el primero de estos modelos (art. 178 bis. $3.4^{\circ}$ ), el legislador español impone que el deudor, haya satisfecho un umbral de pasivo mínimo con carácter previo, para pretender la liberación de la deuda restante. La norma contempla dos supuestos dentro del tipo, que deben ser analizados separadamente:

a.- Deudor persona física que haya celebrado o, al menos, intentado celebrar un acuerdo extrajudicial de $\operatorname{pagos}^{216}$. En ese caso, para acceder a la exoneración del pasivo

${ }^{215}$ FERNÁNDEZ SEIJO, José María, La reestructuración de las deudas en la ley de segunda oportunidad, cit., pág. 240. HERNÁNDEZ RODRíGUEZ considera que "el tenor del art. 187 bis apartado 3 refleja el cambio de criterio del legislador que ha pretendido que todo deudor legitimado para ello intente un acuerdo extrajudicial de pagos de manera previa a acudir a la vía concursal, potenciando con ello la solución alternativa al concurso" y destaca que a partir del uno de marzo de 2015 la legitimación para presentar una solicitud de acuerdos extrajudiciales de pago se amplía de manera sustancial, lo que se corresponde con el requisito que analizamos. En principio, cualquier deudor persona física o jurídica puede ahora intentar un acuerdo extrajudicial de pagos, por lo que si pretende verse beneficiado por la exoneración del pasivo insatisfecho en un ulterior concurso deberá previamente utilizar o intentar la vía del acuerdo extrajudicial. Únicamente estarían exonerados de este requisito aquellos deudores que carecen de legitimación para intentar un acuerdo de refinanciación...Con ello se está potenciando la solución extraconcursal, al constituir un claro incentivo para el deudor persona natural la posible exoneración del pasivo insatisfecho de frustrase el acuerdo y devenir necesario el concurso de acreedores". Advierte como criticable "este nuevo requisito común" puesto que "el carácter forzado del intento de un acuerdo extrajudicial de pagos genera el riesgo de que sea empleado como un mero cauce formal para una posible exoneración de deudas en un concurso ulterior, especialmente en supuestos en los que la falta de activo haga en la práctica inviable un posible acuerdo con los acreedores por la vía de los arts. 231 y siguientes de la Ley Concursal y les aboque a un concurso que concluya en el momento de su declaración por insuficiencia de la masa activa al amparo del art. 176 bis apartado 4. Por ello, no puede considerarse como garante de la solución extraconcursal ni, en todo caso, su ausencia puede entenderse como ausencia de buena fe" (HERNÁNDEZ RODRÍGUEZ, María del Mar, La segunda oportunidad. La superación.., cit., pág. 90 y sgtes.).

${ }^{216}$ A propósito del tema, recuerda CUENA CASAS que el art. 231 de la ley concursal impone algunos requisitos que restringen el acceso a este procedimiento de salida convencional de la crisis (dado que, por ejemplo, no pueden transitar esta vía los deudores cuyo pasivo supere los 5 millones de euros). Añade que, por otra parte, 
insatisfecho, en el marco de la liquidación y con la realización de los activos que no tengan la consideración de bienes inembargables, el deudor debe haber satisfecho en su integridad, los créditos contra la masa y los créditos privilegiados;

b.- Deudor persona física no haya intentado un acuerdo extrajudicial de pagos ${ }^{217}$. En tal caso, para obtener la remisión del pasivo pendiente, en la liquidación y con el producido de la misma, además de todos los créditos contra la masa y todos los privilegiados, el deudor debe haber satisfecho al menos, el $25 \%$ del importe de los créditos concursales $\operatorname{ordinarios}^{218}$.

pese a haber intentado arribar al acuerdo, el mismo puede fracasar en la etapa de negociación, puede lograrse pero luego ser incumplido, o bien puede anularse luego de su celebración, supuestos éstos que parecieran ser los contemplados en el modelo analizado (CUENA CASAS, Matilde, "A propósito del Real Decreto-Ley...", cit.). En igual sentido, FERNÁNDEZ SEIJO menciona que el deudor puede haber iniciado el trámite del acuerdo extrajudicial de pagos pero esa solicitud puede haber sido inadmitida por defectos formales o ausencia de la documentación necesaria o bien pueden presentarse circunstancias tales como la inasistencia de los acreedores a la reunión oportunamente convocada, falta de quórum y mayorías, voto contra en acuerdo, impugnación y procedencia de la misma, incumplimiento del acuerdo, etc. (cfr. FernÁndEZ SeIJo, José María, La reestructuración..., cit., pág. 241).

${ }^{217}$ Este subtipo contempla la posibilidad de que el deudor no haya intentado un acuerdo extrajudicial de pagos -porque no quiso o porque no pudo- no obstante lo cual podrá acceder al beneficio previsto en el régimen legal, siempre que logre abonar las deudas no exonerables sin un plan de pagos (CUENA CASAS, Matilde, "A propósito del Real Decreto-Ley...”, cit.).

${ }^{218}$ Interpreta CABANAS TREJO que "el umbral de deuda pagada, cuando no se haya intentado previamente un AEP (art. 178 bis. $3.4^{\circ}$ ), se fija, igual que antes, en la totalidad de los créditos contra la masa y de los concursales privilegiados, más el $25 \%$ de los ordinarios. Ahora bien, cuando se haya intentado un AEP (art. 178 bis. $3.3^{\circ}$ ), bastará con los créditos contra la masa y con los privilegiados, aunque nada se haya pagado de los ordinarios. El recurso previo a un AEP es una circunstancia que podrá darse o no, pero su falta sólo incrementa dicho umbral". Agrega que el requisito del AEP del apartado 3.3, "está mal coordinado con el del número siguiente (4. ${ }^{\circ}$ )" pues "vuelve a referirse al AEP cuando fija el umbral de deuda pagada, pero lo hace como alternativa a otro supuesto, que sólo puede ser la ausencia de un intento previo de AEP. No se puede ser en un apartado un requisito imperativo (3. ${ }^{\circ}$ ), y en el otro presentarse como una alternativa (4. ${ }^{\circ}$ )". Entiende que "el redactor del Real Decreto-Ley ... se ha hecho un pequeño lío, y lo que debería ser una circunstancia añadida y posible, sólo para rebajar el umbral de deuda, se presenta como un requisito obligatorio para todos los deudores. La cuestión no es baladí, pues puede haber una auténtica avalancha de expedientes de AEP para acceder después a la exoneración, si la interpretación que finalmente se impone es que este requisito es autónomo y resulta ineludible. Creemos que debe rechazarse tal interpretación, pues este apartado no 
En ambos supuestos del apartado $4^{\circ}$, el art. 178 bis.3, parece considerar que la buena fe pasa por haber satisfecho ese umbral de pasivo, con los pisos aludidos al analizar los supuestos contenidos en el citado ordinal.

Oportuno es reiterar que el mecanismo de exoneración previsto impone haber concluido las operaciones de liquidación y la realización de la totalidad del patrimonio embargable. La solicitud de condonación de deuda sólo puede ser planteada cuando ya no queda patrimonio realizable, cualquiera fuera el resultado de esa liquidación ${ }^{219}$. A efectos de acreditar el cumplimiento del requisito mencionado -satisfacción del umbral mínimoresultará imprescindible contar con el informe definitivo del administrador concursal, con el que quedará establecida la situación de los créditos antes aludidos.

En el segundo modelo (art. 178 bis. 3, $5^{\circ}$ ), el legislador contempla el supuesto en que el deudor puede ser considerado de buena fe pero no alcanza el umbral de pago del pasivo necesario para acceder a la exoneración ${ }^{220}$.

En la hipótesis mencionada, para acceder a la remisión del pasivo, el deudor persona natural debe proponer un plan de pagos de las deudas no exonerables -que el juez deberá autorizar- y someterse al cumplimiento del mismo durante los cinco años siguientes a la conclusión del concurso.

En esta variante, "la satisfacción de determinadas deudas no será ya un presupuesto de la remisión",221. No se exige que el deudor haya satisfecho con carácter previo una

constituye un requisito independiente y se ha de poner en conexión con el siguiente" (cfr. CABANAS TREJO, Ricardo, "El nuevo régimen legal ...", cit., pág. 260.

${ }^{219}$ FERNÁNDEZ SEIJO, José María, La reestructuración..., cit., pág. 259.

${ }^{220}$ Según FERNÁNDEZ SEIJO, se trata de deudores "que han sido declarados en concurso, previo intento de acuerdo extrajudicial de pago, que han visto liquidado su patrimonio embargable en el ámbito de la liquidación concursal y que, concluida la liquidación, sin embargo no han podido satisfacer los créditos contra la masa, los créditos concursales privilegiados y, en caso de no haber intentado al acuerdo extrajudicial, no hayan podido tampoco satisfacer al menos el $25 \%$ del crédito ordinario". Señala que "es importante advertir que para poder optar a los mecanismos de esta regla $5^{\circ}$ es necesario que previamente se haya intentado un acuerdo extrajudicial de pagos" puesto que "la regla $5^{\circ}$ es una alternativa a la regla $4^{\circ}$, lo que determina que no pueda eximirse al deudor del cumplimiento de los requisitos de las tres primeras reglas del artículo 178 bis.3 LC” (FERNÁNDEZ SEIJO, José María, La reestructuración..., cit., pág. 263 y sgtes.).

221 Así lo entiende CARRASCO PERERA, quien en su análisis crítico sostiene con énfasis que "no se trata necesariamente de condiciones suspensivas de cumplimiento previo (cfr. CARRASCO PERERA, Ángel, "El 
parte de sus deudas sino que precisamente por esa eventualidad, deberá aceptar el sometimiento a un plan de pagos -durante el plazo legalmente establecido- y observar su cumplimiento, para así poder peticionar y obtener el otorgamiento del beneficio.

Cabe destacar que el plan de pagos habrá de proponerse en el marco de un procedimiento concursal de liquidación en el que esas operaciones han concluido, sin que quede patrimonio embargable. La administración concursal habrá fijado ya el pasivo en su informe definitivo, del que emergerá el crédito contra la masa y el crédito concursal no exonerable. Y dado que este modelo de exoneración impone al deudor asumir un compromiso de cumplimiento del plan de pago, se ha señalado que el mismo deberá afrontarse con los escasos recursos disponibles (bienes inembargables que por permanecer en manos del deudor pueden ser realizables, elementos de la masa activa que no se han podido vender durante el concurso, rentas e ingresos del deudor, préstamos o ayudas del entorno familiar o social del deudor, etc. ${ }^{222}$.

Es oportuno señalar que si bien la exoneración de pasivo insatisfecho es regulada en el marco del trámite de liquidación -art. 178 bis, que remite al 152.3 LC-, con la reforma introducida por el Real Decreto-Ley 1/2015, se autoriza a solicitar el beneficio al deudor, también en los supuestos de insuficiencia de masa activa, donde el procedimiento concursal concluye sin necesidad de abrir la liquidación, al verificarse los presupuestos y requisitos de la figura contenida en el art. 176 bis (modificado por la ley analizada). La citada preceptiva establece que la declaración de insuficiencia de masa activa no impedirá que el deudor mantenga la propiedad de bienes legalmente inembargables o desprovistos de valor de mercado o cuyo coste de realización sea manifiestamente desproporcionado respecto de su previsible valor venal; bienes que podrían servir al deudor para afrontar el plan de pagos que prevé el art. 178 bis. 3 ordinal $5^{\text {2223. }}$.

mecanismo de segunda oportunidad..., cit.). En igual sentido, destaca CABANAS TREJO que este modelo alternativo "constituye una importante novedad" puesto que el deudor "aunque no hubiera pagado un solo euro, puede aspirar todavía al beneficio de la exoneración” (CABANAS TREJO, Ricardo, "El nuevo régimen legal..., cit.).

${ }^{222}$ FERNÁNDEZ SEIJO, José María, La reestructuración... cit., pág. 265 y sgtes.

${ }^{223}$ FERnÁNDEZ SEIJO, José María, La reestructuración... cit., pág. 311 y sgtes. Dadas las particularidades que presenta la implementación del beneficio de la exoneración del pasivo insatisfecho en este supuesto - 
Al comentar este modelo de exoneración del pasivo insatisfecho, algún sector doctrinario señala que se "relajan los requisitos vinculados a la satisfacción de los créditos" (comparándolo con el modelo del art. 178 bis. $3.3^{\circ}$ y $4^{\circ}$ ) aunque admitiendo que el deudor que no ha atendido al pasivo previamente, deberá observar requisitos adicionales estrictos y comprometerse en un plan de pagos posterior, de las deudas no exonerables ${ }^{224}$.

Desde otro enfoque, un sector de opinión considera que el legislador adopta un criterio mas riguroso en este segundo modelo ${ }^{225}$ pues exige que el deudor que propone el plan de pagos, no haya incumplido obligaciones de colaboración del art. 42 LC, que no haya obtenido el beneficio de exoneración del pasivo pendiente dentro de los diez últimos años y que no haya rechazado dentro de los cuatro años anteriores a la declaración de concurso, una oferta de empleo adecuada a su capacidad. Se destaca que, por otra parte, debe aceptar que conste en el Registro Público Concursal durante cinco años, que se acogió a un régimen de segunda oportunidad ${ }^{226}$.

conclusión del procedimiento por insuficiencia de la masa activa- resulta de ineludible lectura el capítulo que el autor citado dedica a la problemática, con su meduloso análisis.

${ }^{224}$ HERNÁNDEZ RODRÍGUEZ, María del Mar, "La segunda oportunidad ...", cit. La autora interpreta que la redacción de la norma legal evidencia "por un lado, un aparente endurecimiento de los requisitos relativos a la conducta exigible del deudor y, por otro, la aminoración de los requisitos vinculados con la atención del pasivo".

${ }^{225}$ Calificada doctrina señala que "parece exigirse un plus de buena fe" (CUENA CASAS, Matilde, "A propósito del Real Decreto-Ley...", cit., pág. 10 y sgtes.).

${ }^{226}$ Destaca CUENA CASAS que el deudor que acepta someterse al plan de pagos con la pretensión de obtener la exoneración del pasivo pendiente, está impuesto de aceptar que conste en el Registro Público Concursal durante cinco años, que se acogió a un régimen de segunda oportunidad y que este dato negativo "le provocará a buen seguro exclusión financiera imposible de limpiar porque no se regulan los ficheros de solvencia positivos...". La jurista interpreta que con esta norma se pretende disuadir al deudor de solicitar el beneficio analizado (CuENA CASAS, Matilde, “A propósito del Real Decreto-Ley...”, cit, pág. 10 y sgtes.). CARRASCO PERERA lanza una dura crítica sobre este aspecto, al señalar que "con toda seguridad, para poder encarrilar su vida de nuevo, el deudor necesitará crédito y nadie se lo dará, por mucho que se instaure la ficción de que es un "hombre nuevo" ... Ya ni siquiera hará falta acudir a los registros de morosos. En el propio Registro Público Concursal se hallará la huella del pasado. No hay aquí derecho al olvido. Y, aunque lo hubiera, ningún acreedor olvida" (CARRASCo PererA, Ángel, "El mecanismo de segunda oportunidad...", cit.). Estas críticas al precepto, vinculadas a la estigmatización del deudor, determinaron que en la reforma introducida por la Ley 25/2015, se incorporara a la norma un párrafo nuevo conforme al cual 
Resulta de particular interés mencionar cuáles son -en el modelo analizado- las deudas comprendidas en el plan de pagos al que deberá someterse el deudor que decida transitar esa vía de remisión del pasivo pendiente. En efecto, se distinguen los llamados créditos exonerables (que serán objeto de la liberación) de los créditos no exonerables (comprendidos en el plan de pagos que el deudor deberá observar, por ser deudas ajenas a la remisión del pasivo) ${ }^{227}$.

Siguiendo la distinción de CUENA CASAS, son créditos exonerables: a.-los créditos ordinarios y subordinados a la fecha de conclusión del concurso, aunque no hubieran sido comunicados; b.- el remanente que quede insatisfecho tras la ejecución de los créditos garantizados con hipoteca o prenda sin desplazamiento, sobre los bienes o derechos hipotecados o pignorados (art. 90.1 LC), siempre que tal remanente tenga la categoría de crédito ordinario o subordinado. Por otra parte, son créditos no exonerables: los créditos contra la masa, privilegiados, el crédito público (sea ordinario o subordinado) y los créditos por alimentos.

Se destaca que la regulación emergente del Real Decreto-Ley 1/2015 propone una diferencia de régimen jurídico respecto de los créditos exonerables y no exonerables conforme los distintos modelos de segunda oportunidad, lo que según CuENA CASAS

\footnotetext{
"Únicamente tendrán acceso a esta sección las personas que tengan interés legítimo en averiguar la situación del deudor, entendiéndose en todo caso que tienen interés quienes realicen una oferta en firme al deudor ya sea de crédito o de cualquier otra entrega de bienes o prestación de servicios, que tenga que ser remunerada o devuelta por éste y que esté condicionada a su solvencia, así como las Administraciones Públicas y órganos jurisdiccionales habilitados legalmente para recabar la información necesaria para el ejercicio de sus funciones. La apreciación de dicho interés se realizará por quién esté a cargo del Registro Público Concursal”. La doctrina considera que si bien se mejora el texto anterior, esta publicidad adicional de la situación del deudor resulta innecesaria y que "bastaría que el dato negativo constase en los ficheros de solvencia patrimonial (cuyo acceso está regulado en el art. 42 del Reglamento de protección de datos) y en la CIRBE que gestiona el Banco de España" (CUENA CASAS, Matilde, "Una segunda oportunidad para la persona física insolvente: cambios de última hora", en http://www.legaltoday.com/practica-juridica/mercantil/concursal/unasegunda-oportunidad-para-la-persona-fisica-insolvente-cambios-de-ultima-hora) (Fecha de consulta: 27/9/2015).

${ }^{227}$ CUEnA CASAS, Matilde, “A propósito del Real Decreto-Ley..., cit, pág. 10 y sgtes.).
} 
“carece de toda justificación”,228. En efecto, se señala que a diferencia del modelo que prevé el sometimiento al plan de pagos (art. 178 bis. $3.5^{\circ}$ LC), "si el deudor se acogió a la opción A -abono de umbral de pasivo mínimo- no aparece excepcionado de la exoneración, y será por tanto exonerable, el crédito público subordinado y los créditos por alimentos (art. 178 bis. 3.4 LC)".

Coincide la doctrina en la dura crítica a la decisión del legislador, de excluir al crédito público del bloque de deuda no exonerable (salvo el crédito público subordinado, en el modelo contenido en el art. 178 bis. $3.4^{\circ}$ LC antes mencionado $)^{229}$.

El apartado 5 del art. 178 bis analizado deja expresamente establecido que "El beneficio de la exoneración del pasivo insatisfecho concedido a los deudores previstos en el número $5^{\circ}$ del apartado 3 se extenderá a la parte insatisfecha de los siguientes créditos:

$1^{\circ}$ Los créditos ordinarios y subordinados pendientes a la fecha de conclusión del concurso, aunque no hubieran sido comunicados, y exceptuando los créditos de derecho público y por alimentos.

$2^{\circ}$ Respecto a los créditos enumerados en el art. 90.1, la parte de los mismos que no haya podido satisfacerse con la ejecución de la garantía quedará exonerada salvo que quedara incluida, según su naturaleza, en alguna categoría distinta a crédito ordinario o subordinado".

${ }^{228}$ CuEna CASAS, Matilde, “A propósito del Real Decreto-Ley...”, pág. 10 y sgtes.). Así lo destaca también el documento elaborado en la sesión de debate celebrada el 25 de marzo de 2015 en la Fundación para la Investigación sobre el Derecho y la Empresa (Fide). Las conclusiones allí contenidas, mencionan con espíritu crítico el desigual tratamiento del pasivo exonerable en función del modelo al que el deudor se acoja (http://www.insolnet.es/wp-content/uploads/2015/04/RDL-1_2015-Segunda-oportunidad.pdf) (Fecha de consulta 20/4/2015).

229 Se dice por un lado que "la demagogia del legislador se reduce a predicar y no dar trigo" puesto que las deudas públicas (fiscales y de seguridad social seguirán gravando al deudor persona física ya que "no se perdonan ni antes (cfr. nuevos arts. 231.5 II y 235.2.a) II) ni después de abierto y cerrado el concurso (cfr. art. 178 bis.3.4 y 178bis.5.1)" (CARRASCO PERERA, Ángel, "El mecanismo de segunda oportunidad...", cit.). CUENA CASAS pone de resalto que el tratamiento de la deuda pública contenido en el régimen de segunda oportunidad español, "incumple de forma flagrante las recomendaciones del FMI” y se aparta de la posición fijada por el Banco Mundial, cuando sostiene que "el Estado debe soportar el mismo tratamiento que los demás acreedores para así apoyar el sistema de tratamiento de la insolvencia” (CUENA CASAS, Matilde, "A propósito del Real Decreto-Ley...”, cit, pág. 10 y sgtes.). 
Al regular los efectos de la figura, la norma contempla la situación del concursado casado en régimen de gananciales ${ }^{230}$, consagrando una solución particular ${ }^{231}$. Al analizar el texto legal, CABANAS TREJo explica con "cierta perplejidad", que "la exoneración se extiende al cónyuge del concursado cuando se trate de créditos que sean responsabilidad del patrimonio común", señalando que ello conduce a "un resultado que simplemente nos parece inaudito, pues de esas deudas, que son de ese cónyuge, y no del concursado, por mucho que estén incluidas en su pasivo concursal, también debía responder el deudor con sus bienes privativos, que súbitamente quedan liberados"232.

Al explicar el desarrollo del trámite, el art. 178 bis dispone que si el deudor reúne los requisitos legales - conforme los diferentes modelos (pago previo de un umbral de deuda o sometimiento a un plan de pagos)- y no existe oposición de los acreedores, el juez interviniente concederá con carácter provisional el beneficio de la exoneración del pasivo insatisfecho, concluyendo el concurso (apartado 4$)^{233}$.

La Exposición de Motivos menciona que la exoneración de las deudas se realizará automáticamente de cumplirse los requisitos establecidos. Y, como bien lo advierte HERNÁNDEZ RODRÍGUEZ, “aunque de manera expresa no se prevé tal carácter reglado en el

\footnotetext{
${ }^{230}$ Para un estudio profundizado del tema, en sus aristas particulares, ver BENAVIDES VELASCO, Patricia G., Masa activa del concurso..., cit., pág 223.

${ }^{231}$ Dispone la norma analizada: "Si el concursado estuviera casado en régimen de gananciales u otro de comunidad y no se hubiera procedido a la liquidación del régimen económico conyugal, el beneficio de la exoneración del pasivo insatisfecho se extenderá al cónyuge del concursado, aunque no hubiera sido declarado su propio concurso, respecto de las deudas anteriores a la declaración de concurso de las que debiera responder el patrimonio común".

${ }^{232}$ Cfr. CABANAS TREjo, Ricardo, "El nuevo régimen legal...", cit.

${ }^{233} \mathrm{El}$ art. 178 bis.4 establece: “4. De la solicitud del deudor se dará traslado por el Secretario Judicial a la Administración concursal y a los acreedores personados por un plazo de cinco días para que aleguen cuanto estimen oportuno en relación a la concesión del beneficio. Si la Administración concursal y los acreedores personados muestran su conformidad a la petición del deudor o no se oponen a la misma, el Juez del concurso concederá, con carácter provisional, el beneficio de la exoneración del pasivo insatisfecho en la resolución declarando la conclusión del concurso por fin de la fase de liquidación. La oposición solo podrá fundarse en la inobservancia de alguno o algunos de los requisitos del apartado 3 y se le dará el trámite del incidente concursal. No podrá dictarse auto de conclusión del concurso hasta que gane firmeza la resolución que recaiga en el incidente reconociendo o denegando el beneficio".
} 
artículo 178 bis ..., el trámite para la concesión previsto en el apartado 4 permite concluir que el legislador ha querido otorgar dicho carácter automático ... a la concesión del beneficio, de no formularse oposición" 234 .

Resulta de particular relevancia la previsión contenida en el apartado 5, párrafos 4 y 5 del citado art. 178 bis, en cuanto dispone que respecto de las deudas exoneradas, los acreedores no podrán iniciar ningún tipo de acción contra el deudor, aunque sí podrán hacerlo contra los obligados solidariamente con el concursado y frente a los fiadores y $\operatorname{avalistas}^{235}$.

\footnotetext{
${ }^{234}$ HeRnÁNDEZ RodRíGUEZ, María del Mar, "La segunda oportunidad...", cit.

${ }^{235}$ Reza la norma mencionada: "Los acreedores cuyos créditos se extinguen no podrán iniciar ningún tipo de acción dirigida frente al deudor para el cobro de los mismos. Quedan a salvo los derechos de los acreedores frente a los obligados solidariamente con el concursado y frente a sus fiadores o avalistas, quienes no podrán invocar el beneficio de exoneración del pasivo insatisfecho obtenido por el concursado". HERNÁNDEZ RODRÍGUEZ formula una crítica sobre este aspecto de la regulación señalando que "llama la atención que el legislador se refiera de manera exclusiva a los deudores previstos en el número $5^{\circ}$ del apartado 3 . Sin embargo, nada se establece sobre los efectos en relación al deudor que haya procedido al pago de los créditos contra la masa, los créditos privilegiados y, en su caso, el $25 \%$ de los créditos ordinarios, esto es, el del número $4^{\circ}$ del apartado 3 . En principio, por la propia definición del beneficio que se contienen en el apartado cuatro, se produce la exención de todo el pasivo insatisfecho, que por definición y contraste con el requisito cumplido por el deudor, podrá ser el pasivo subordinado y todo o parte del pasivo ordinario, según los casos. Sin embargo nada se dice en relación con los créditos de derecho público y los alimentos ni respecto a la extensión de la exoneración con relación a terceros. En cuanto a lo primero, entiendo que la exoneración es total, de la misma manera que acontecía hasta la reforma, sin que podamos aplicar de manera analógica lo dispuesto expresamente para los deudores que no han satisfecho el mínimo de créditos previstos con carácter general para la obtención del beneficio. Mayores dudas surgen en relación a los efectos respeto a terceros responsables. Ante la falta de regulación expresa, habría que acudir a las reglas generales del Código Civil EDL 1889/1- (artículos 1143 y 1847) según las cuales, en principio, se extendería los efectos de la exención a estos terceros acreedores solidarios y fiadores. Si se pretendía equiparar los efectos de la exoneración frente a terceros para los acreedores de los números $4^{\circ}$ y $5^{\circ}$ del apartado 3 , hubiera sido deseable que el legislador se refiera a estos dos efectos como comunes evitando con ello las no deseables dudas interpretativas que generan inseguridad jurídica y pueden ser fuente de conflictos judiciales en una materia especialmente sensible" (cfr. HERNÁNDEZ RodRíGUEZ, María del Mar, "La segunda oportunidad...", cit.; ver asimismo, el desarrollo posterior de estas cuestiones en HERNÁNDEZ RODRíGueZ, María del Mar, La segunda oportunidad..., cit, pág. 136 y sgtes.).
} 
Dado que la deuda exonerable es remitida respecto del deudor que accede al beneficio y que, no obstante ello, subsiste respecto de los coobligados solidarios y de quienes prestaron fianza o avales, la doctrina considera un acierto que ello se traduzca en una disposición normativa expresa. CUENA CASAS destacó que "precisamente por la accesoriedad que caracteriza a las garantías personales, era necesario que expresamente la ley las excepcionara, al igual que sucede en otros ordenamientos" pero lamentaba que no quedara claro en la norma qué es lo que sucede con la acción de reembolso (art. 1838 del CC) que le corresponde al fiador contra el deudor una vez que haya cumplido la prestación" ${ }^{236}$. Recogiendo el guante, el legislador modificó el precepto analizado mediante la Ley 25/2015 de 28 de julio, y con el añadido un inciso al art. 178 bis 5 LC, deja aclarado que los fiadores u obligados solidarios no podrán "subrogarse por el pago posterior a la liquidación en los derechos que el acreedor tuviese contra aquél, salvo que se revocase la exoneración concedida". Luego de la reforma, "queda claro que el fiador o codeudor solidario que paga no puede ejercitar la acción de reembolso contra el deudor. De esta forma, se salvaguarda la esencia de las garantías personales (ejercitables para los casos de insolvencia del deudor principal) y además se mantiene la eficacia de la exoneración del pasivo pendiente frente al deudor principal ${ }^{237}$.

La exoneración definitiva del pasivo insatisfecho se produce recién tras un período de 5 años, conforme la regulación legal del beneficio.

En caso de haber accedido a la remisión del pasivo por el modelo contenido en el art. 178 bis. $3,3^{\circ}$ y $4^{\circ}$ (pago previo de un umbral de pasivo mínimo), el plazo de 5 años opera a efectos de permitir la eventual revocación del beneficio, si concurrieran las causales previstas en el aparado $7^{238}$.

\footnotetext{
${ }^{236}$ Cuena CASAS, Matilde, “A propósito del Real Decreto-Ley..., cit, pág. 10 y sgtes., cit. La autora citada lamentaba en este trabajo, la falta de previsión al respecto y recuerda que la legislación alemana expresamente contempla este supuesto al disponer que "el deudor resulta liberado frente al deudor solidario, al fiador o ante cualquier otro derecho de retorno en idéntica medida a la que resulta liberado frente a los acreedores de la insolvencia" (parágrafo 301).

${ }^{237}$ CuEna CASAS, Matilde, "Una segunda oportunidad...", cit..

${ }^{238}$ Dispone el art. 178 bis.7: "Cualquier acreedor concursal estará legitimado para solicitar del juez del concurso la revocación del beneficio de exoneración del pasivo insatisfecho cuando el deudor, durante los cinco años siguientes a su concesión: a) Incurriese en alguna de las circunstancias que conforme a lo
} 
En caso de haberse acogido al segundo modelo (sometimiento a un plan de pagos), el pasivo no exonerable debe abonarse durante esos 5 años por disposición legal, salvo que algunas de esas deudas tengan un vencimiento posterior ${ }^{239}$.

El plazo quinquenal adoptado por el legislador español se aparta de la Recomendación de la Comisión Europea de 12 de marzo de 2014 sobre "Un nuevo enfoque frente a la insolvencia y el fracaso empresarial" ${ }^{240}$. Al analizar la cuestión, el Considerando 20 señala que "se deben adoptar medidas para reducir los efectos negativos de la insolvencia para los empresarios, mediante disposiciones que prevean la plena condonación de deudas después de cierto plazo máximo" y en el apartado IV (referido a "Una segunda oportunidad para los empresarios"), se postula que "a los empresarios se les deberían condonar totalmente las deudas incursas en la insolvencia en un plazo máximo de tres años..."241.

establecido en el apartado 3 hubiera impedido la concesión del beneficio de la exoneración del pasivo insatisfecho. b) En su caso, incumpliese la obligación de pago de las deudas no exoneradas conforme a lo dispuesto en el plan de pagos c) Mejorase sustancialmente la situación económica del deudor de manera que pudiera pagar todas las deudas pendientes sin detrimento de sus obligaciones de alimentos, o d) Se constatase la existencia de ingresos, bienes o derechos ocultados. La solicitud se tramitará conforme a lo establecido en la Ley de Enjuiciamiento Civil para el juicio verbal. En caso de que el Juez acuerde la revocación del beneficio, los acreedores recuperan la plenitud de sus acciones frente al deudor para hacer efectivos los créditos no satisfechos a la conclusión del concurso".

${ }^{239}$ Establece el art. 178 bis.6: "Las deudas que no queden exoneradas conforme a lo dispuesto en el apartado anterior, deberán ser satisfechas por el concursado dentro de los cinco años siguientes a la conclusión del concurso, salvo que tuvieran un vencimiento posterior. Durante los cinco años siguientes a la conclusión del concurso las deudas pendientes no podrán devengar interés. A tal efecto, el deudor deberá presentar una propuesta de plan de pagos que, oídas las partes por plazo de 10 días, será aprobado por el juez en los términos en que hubiera sido presentado o con las modificaciones que estime oportunas. Respecto a los créditos de derecho público, la tramitación de las solicitudes de aplazamiento o fraccionamiento se regirá por lo dispuesto en su normativa específica".

${ }^{240}$ Lo destaca el documento elaborado en la sesión de debate celebrada el 25 de marzo de 2015 en la Fundación para la Investigación sobre el Derecho y la Empresa (Fide) (http://www.insolnet.es/wpcontent/uploads/2015/04/RDL-1_2015-Segunda-oportunidad.pdf).

${ }^{241}$ Cabe destacar que conforme el Considerando 15, "aunque el sobreendeudamiento y la insolvencia de los consumidores no entran en el ámbito de aplicación de la presente Recomendación, se insta a los Estados 
La nueva regulación prevé la posibilidad de que el beneficio de la exoneración concedido en forma provisoria, sea revocado durante el plazo de 5 años antes mencionado, por concurrencia de las causas previstas en el art. 178 bis.7 LC (incurrir en alguna de las circunstancias que conforme a lo establecido en el apartado 3 hubiera impedido la concesión del beneficio, incumplir el plan de pagos, constatar la existencia de ingresos, bienes o derechos ocultados, ó mejorar sustancialmente la situación económica ${ }^{242}$ ). Se legitima a cualquier acreedor concursal para instar la revocación del beneficio y "no sólo aquellos afectados por la remisión",243.

Esta última previsión legal -la posibilidad de revocar la exoneración provisionalmente otorgada con fundamento en que el deudor beneficiado mejoró "sustancialmente su situación económica”- generó las más airadas críticas y un marcado consenso respecto su desacierto.

Se ha expresado que esta causa de revocación desnaturalizaba la institución diseñada, en tanto contrariaba la finalidad expresada por el legislador en la Exposición de Motivos. Se señaló el contrasentido de sostener que la ley otorga una segunda oportunidad al deudor, para propiciar su recuperación económica, y luego prever que en caso de que ello

miembros a estudiar la posibilidad de aplicar estas recomendaciones también a los consumidores, ya que algunos de los principios recogidos en la presente Recomendación también les pueden ser aplicables”.

${ }^{242}$ Se señala que bajo esta hipótesis, el legislador contempla circunstancias posteriores que deriven en un incremento patrimonial del deudor que pueda calificarse como significativo; "mejor fortuna que puede vincularse a que el deudor empiece a trabajar -si estaba de paro- cambie a un trabajo mejor remunerado, sea ascendido o se incrementen sus retribuciones,... haya recibido una herencia,... o haya tenido un golpe de suerte en juegos de azar. También en aquellos supuestos en los que el deudor inicie una actividad empresarial exitosa o haya realizado inversiones con resultado positivo. También podrá considerarse ...si se revaloriza su patrimonio o si el deudor se viera beneficiado patrimonialmente por una resolución judicial que se hubiera dictado con posterioridad a la conclusión del procedimiento concursal". Se advierte que "este conjunto de circunstancias deben ser probadas por quien las alegue" (FERNÁNDEZ SEIJO, José María, La reestructuración..., cit., pág. 298).

${ }^{243}$ CARRASCO PARERA señala que "no deja de ser curioso que un acreedor afectado por la exoneración pueda pedir la revocación de este beneficio si el deudor incumple la obligación de pago de una deuda que no está exonerada” y se pregunta “¿cuál es el interés legítimo para tal pretensión?” (CARRASCO PERERA, Ángel, “El mecanismo de segunda oportunidad...”, cit.). Ver asimismo, FERNÁNDEZ SEIJO, José María, La reestructuración..., cit., pág. 291. 
ocurra, los acreedores podrán peticionar el cese del beneficio y recobrar la acción para reclamar el cumplimiento de las deudas exoneradas. Con razón se ha dicho que la norma operará como "un claro desincentivo para que el deudor vuelva a su actividad negocial o productiva", comprometiendo la eficacia del dispositivo legal, que será "una mera ilusión"244.

CuEna CASAS ha sostenido que esta posibilidad de revocación prevista en el régimen jurídico analizado, convierte a la herramienta en un mero pactum de non petendo $^{245}$, sin antecedentes en el Derecho comparado.

Las críticas mencionadas fueron receptadas por el legislador, que mediante Ley 27/2015, de 28 de julio (de Mecanismo de segunda oportunidad, reducción de carga financiera y otras medidas de orden social), que modifica el texto del art. 178 bis.7 LC y autoriza la revocación del beneficio en el plazo previsto pero concreta las causas de la aludida mejora de fortuna. En efecto, dispone el art. 178.7 en esta última versión que "Cualquier acreedor concursal estará legitimado para solicitar del juez del concurso la revocación del beneficio de exoneración del pasivo insatisfecho... si durante el plazo fijado para el cumplimiento del plan de pagos: ...c) Mejorase sustancialmente la situación económica del deudor por causa de herencia, legado o donación; o juego de suerte, envite o azar, de manera que pudiera pagar todas las deudas pendientes sin detrimento de sus obligaciones de alimentos".

En opinión de CUENA CASAS, se trata de la modificación más relevante de las contenidas en la Ley 25/2015 puesto esta causal de revocación prevista originariamente que el deudor mejorara sustancialmente su situación económica- "constituía un auténtico despropósito que desnaturalizaba la presunta exoneración”. Y de allí que la autora citada celebre la modificación de la norma en cuestión en tanto neutraliza "los efectos adversos de un planteamiento legal que sólo podía calificarse de ridículo"246.

\footnotetext{
${ }^{244}$ Cfr. Documento elaborado en la sesión de debate celebrada el 25 de marzo de 2015 en la Fundación para la Investigación sobre el Derecho y la Empresa (Fide) (http://www.insolnet.es/wpcontent/uploads/2015/04/RDL-1_2015-Segunda-oportunidad.pdf).

${ }^{245}$ Cuena CASAS, Matilde, “A propósito del Real Decreto-Ley..., cit., pág. 10 y sgtes., cit.

${ }^{246}$ CUENA CASAS, Matilde, "Una segunda oportunidad...", cit..
} 
El aparatado 8 del art. 178 bis dispone que "transcurrido el plazo previsto en el apartado anterior sin que se haya revocado el beneficio, el Juez del concurso, a petición del deudor concursado, dictará auto reconociendo con carácter definitivo la exoneración del pasivo insatisfecho en el concurso".

Una primera lectura de la preceptiva analizada permite sostener que para obtener la remisión definitiva, es necesario: que transcurra el plazo quinquenal dispuesto por la ley, que durante el mismo no haya sido revocado el beneficio provisional otorgado, que el deudor peticione el reconocimiento del beneficio con carácter de definitivo ${ }^{247}$ y que siendo así, el juez del concurso dicte una resolución favorable a dicha petición.

La redacción del precepto lleva a concluir que verificada la concurrencia de los presupuestos antes citados, el juez está impuesto de acoger la petición del deudor interesado y acordar el carácter definitivo de la exoneración del pasivo pendiente ${ }^{248}$.

Se señala acertadamente que aunque el deudor hubiera cumplido el plan de pago antes de los cinco años, es necesario respetar el plazo, ya que si durante el transcurso del mismo aquél mejorara sustancialmente su situación económica, tal extremo podría eventualmente justificar el pedido de revocación del beneficio por parte de los acreedores $^{249}$.

La regulación prevé la hipótesis de incumplimiento del plan de pagos, cuando sea ésta la modalidad a la que se acogió el deudor al solicitar la remisión del pasivo

\footnotetext{
${ }^{247}$ Destaca FERNÁNDEZ SEIJO que "la decisión sobre la exoneración definitiva no la acuerda el juez de oficio sino sólo a instancias del deudor". Y agrega: "Nada establece la LC, pero parece razonable que se le exijan ciertas formalidades a dicha petición: 1) Deberá formularla por escrito. 2) Ese escrito deberá cumplimentar en cuanto a representación y defensa los mismos requisitos que tuviera cualquier otro escrito del deudor en sede concursal. 3) Deben haber transcurrido 5 años desde que se dictó la resolución en la que se acordó la exoneración provisional. ... 4) En función de los escenarios referidos en el punto anterior, el deudor deberá acreditar: - Si cumplió ya con los umbrales del 178 bis $3.4^{\circ}$ LC antes de la conclusión, no debe acreditar el cumplimiento de ningún pago más. - Si estaba sometido a un plan de pagos conforme a la regla $5^{\circ}$, debe acreditar haber cumplido con el plan de pagos. - Si sometido al plan de pagos no ha podido cumplirlo, deberá acreditar haber aplicado al pago la mitad de sus ingresos en los términos que prevé el artículo 178 bis 8.III". (FERNÁNDEZ SEIJO, José María, La reestructuración..., cit., pág. 305).

${ }^{248}$ HERNÁNDEZ RodRÍGUEZ, María del Mar, "La segunda oportunidad...”, cit.

${ }^{249}$ Cfr. CABANAS TREJo, Ricardo, “El nuevo régimen legal...”, cit.
} 
insatisfecho. Ahora bien, por un lado cabe recordar que este incumplimiento autoriza a que los acreedores reclamen la revocación del beneficio pero puede transcurrir el plazo de 5 años sin que éstos peticionen al juez el cese del mismo. En este caso, pareciera que el legislador deja en manos del juez la verificación del cumplimiento del plan de pagos que, como regla, debe observarse íntegramente para acceder a la exoneración definitiva.

No debemos olvidar que el juez del concurso es el custodio de la ley y que debe velar por la armonización de todos los intereses comprometidos. Y en resguardo de los derechos de los acreedores involucrados en el plan de pagos, debe exigir que éste se encuentre cumplido en el plazo establecido (aún cuando el acreedor afectado no haya denunciado el incumplimiento y solicitado la revocación del beneficio provisionalmente reconocido).

Esta interpretación guarda relación con lo establecido en el apartado 8 del art. 178 bis, que en la versión originaria disponía: "también podrá (el juez), atendiendo a las circunstancias del caso $^{250}$ y previa audiencia de los acreedores, declarar la exoneración definitiva del pasivo insatisfecho del deudor que no hubiese cumplido en su integridad el plan de pagos pero hubiese destinado a su cumplimiento, al menos, la mitad de los ingresos percibidos durante dicho plazo que no tuviesen la consideración de inembargables". Con la reforma introducida al mismo apartado por la Ley 25/2015 de 28 de julio, el legislador añade una posibilidad más de acceder a la exoneración del pasivo pendiente cuando el deudor no hubiese cumplido en su integridad el plan de pagos pero hubiese destinado a su cumplimiento "la cuarta parte de los ingresos percibidos durante aquel plazo y concurriesen las circunstancias previstas en el artículo 3.1, letras a) y b), del Real Decreto-ley 6/2012, de 9 de marzo, de medidas urgentes de protección de deudores hipotecarios sin recursos, respecto a los ingresos de la unidad familiar y circunstancias familiares de especial vulnerabilidad".

\footnotetext{
${ }^{250}$ Advierte HERNÁNDEZ RODRÍGUEZ que "nada se concreta en relación a qué circunstancias habrán de ser examinadas" pero entiende que "deberá valorarse si el deudor ha efectuado un esfuerzo positivo para atender las deuda pendientes y cumplir el plan de pagos o, en otros términos, no ha llevado a cabo una conducta obstaculizadora a dicho incumplimiento. Se trata en definitiva de valorar si el deudor ha actuado con buena fe en el sentido objetivo ya expuesto" (HERNÁNDEZ RoDRíGUEZ, María del Mar, La segunda oportunidad..., cit, pág. 173..
} 
La norma admite un margen de discrecionalidad del juez del concurso y lo habilita a disponer la remisión definitiva del pasivo, pese al cumplimiento parcial del plan de $\operatorname{pagos}^{251}$, y luego de ponderar los extremos que a criterio del legislador justificarían la eventual liberación del deudor con más las restantes circunstancias del caso. Todo ello, en observancia de trámite procesal previo impuesto por la preceptiva analizada (convocar a audiencia a los acreedores conforme allí se indica, eventual apertura a prueba, resolución).

El efecto fundamental de la resolución a dictar por el juez es reconocer el carácter definitivo la exoneración del pasivo insatisfecho en el concurso ${ }^{252}$. De allí que sería deseable que el juez indique que la resolución despliega todos sus efectos respecto del pasivo concursal no pagado, con expresa mención de las deudas comprendidas, "más que nada para salvaguardar al deudor frente a posibles reclamaciones individuales de esos acreedores sí, por ejemplo, no estaban personados en el concurso y no estaban informados de la exoneración"253.

El apartado 8 del art. 178 bis analizado cierra su texto señalando que la resolución que dispone la exoneración definitiva del pasivo pendiente se publicará en el Registro Público Concursal y que contra ella "no cabrá recurso alguno". Pero, con la reforma introducida por la Ley 25/2015 de 28 de julio, a renglón seguido se incorpora una párrafo conforme al cual "No obstante, la exoneración definitiva podrá revocarse cuando concurra la causa prevista en el párrafo primero del apartado anterior". La aludida causal de

\footnotetext{
${ }^{251}$ HERNÁNDEZ RODRÍGUEZ plantea la duda sobre si resulta exigible el pago de un mínimo del pasivo no exonerado, dado que el precepto alude a que no se haya cumplido íntegramente el plan de pagos. Señala que "a contrario sensu podríamos entender que si el incumplimiento es total no cabría esta exoneración definitiva" pero a renglón seguido interpreta que "no está pensando en eso la norma y si por circunstancias extraordinarias el deudor no ha podido atender en modo alguno sus deudas, no ha obtenido ingresos que superen el umbral del art. 1 del Real Decreto-Ley 8/2001 y se aprecia buena fe en su conducta, sería posible exonerar de manera definitiva al deudor (HERNÁNDEZ RoDRíGUEZ, María del Mar, La segunda oportunidad..., cit, pág. 173).

252 "Es interesante el matiz de la norma ya que no se establece la declaración, sino el reconocimiento del carácter definitivo de la exoneración” (FERNÁNDEZ SEIJO, José María, La reestructuración..., cit., pág. 306).

253 FERNÁNDEZ SEIJO considera que "en caso de no reflejar expresamente esos pasivos, el auto deberá hacer referencia a los pasivos contenidos en el informe definitivo de la administración concursal" (FERNÁNDEZ SEIJO, José María, La reestructuración..., cit., pág. 307).
} 
revocación del beneficio definitivo es la prevista en el en el art. 178 bis.7 LC, es decir, cuando se constatara que el deudor ha ocultado la existencia de ingresos, bienes o derechos.

Al comentar esta novedad legislativa, se interpreta que el estímulo de buen comportamiento del deudor resulta positivo pero la eventualidad de esta revocación precariza un beneficio ya acordado por el juez concursal con carácter definitivo ${ }^{254}$.

\section{D.- En el Derecho norteamericano ${ }^{255}$ :}

El modelo americano original se sustenta en la idea de que el crédito promueve el crecimiento económico y propicia el bienestar de los particulares. El modelo de fresh start o volver a empezar pone el énfasis en esta segunda oportunidad, que debe serle ofrecida al consumidor sobreendeudado para así recuperarlo lo antes posible para la actividad económica y de consumo. Se considera que una función básica de los procesos de quiebra es atender a los mercados de crédito, propiciando que el acceso sea fácil y abierto, al igual que la salida de los mismos ${ }^{256}$.

Como bien señala CUENA CASAS, "la liberación del pasivo pendiente constituye el eje fundamental de la política de insolvencia en USA, hasta el punto que se ha llegado a

\footnotetext{
${ }^{254}$ Expresa CUENA CASAS que esta revocación sólo podrá solicitarse dentro de los cinco años posteriores a la exoneración definitiva y de allí que considere "excesiva la provisionalidad de la que dota el legislador español al régimen de segunda oportunidad. El deudor estará diez años en barbecho porque esta causa de revocación se prolonga 10 años después de la declaración de exoneración provisional” Por otra parte se señala con acierto que "si en los cinco años que dura la exoneración provisional no se ha logrado probar la ocultación de ingresos, bienes o derechos del deudor" resulta improbable "que vaya a descubrirse dentro de los cinco años posteriores a la exoneración definitiva” (CUENA CASAS, Matilde, “Una segunda oportunidad ...”, cit. ${ }^{255}$ Ver sobre el tema, especialmente la crítica a las últimas reformas del sistema americano, Gross, Karen, "La insolvencia de los consumidores en el Derecho de los Estados Unidos", en TOMILlo URBINA, Jorge (Dir.)-Álvarez Rubio, Julio (Coord.), El futuro de la protección jurídica de los consumidores, ThomsonCivitas, Pamplona, 2008, pág. 229 y sgtes. Asimismo, JACOBY, Melissa-WARD, George R., "Perspectivas empíricas y de política jurídica sobre el concurso de los consumidores en los Estados Unidos”, en CUENA Casas, Matilde-Colino Mediavilla, José Luis (Coord.), Endeudamiento del consumidor e insolvencia familiar, cit., pág. 381 y sgtes. Para una visión del modelo americano y su paradigma, en confrontación con otros modelos, ver Alvárez VegA, María Isabel, Protección jurídica del consumidor..., cit., pág. 102 y sgtes.
}

${ }^{256}$ AlvÁrez VEGA, María Isabel, Protección jurídica del consumidor..., cit., pág. 105. 
decir que una legislación concursal sin discharge es inimaginable". Con cita de doctrina especializada en el país de referencia, sostiene que la liberación de deudas es la pieza clave y sobre la que gira todo el sistema concursal americano ${ }^{257}$.

El régimen legal originario ofrecía a los deudores individuales, precisados de acceder a un procedimiento de insolvencia, dos alternativas de opciones consagradas en sendos capítulos del US Bankruptcy Code (el Chapter 7 y el 13) ${ }^{258}$. De ahí que se haya dicho que el sistema concursal estadounidense para consumidores se caracterice como un "sistema de doble procedimiento"

En el primero de ellos (Capítulo 7, de la liquidación), el deudor que lo promueve, debe presentarse ante el juez correspondiente, peticionar la apertura del procedimiento,

${ }^{257}$ CuEna CASAS, Matilde, “Fresh start...", cit. Señala la autora citada que desde sus inicios en la ley de 1898, se concibe a la discharge como un instrumento de política económica. A pesar de que a priori parece que el sistema absorbe la mala suerte del deudor, particularmente sus acreedores, se entiende que toda la sociedad se beneficia de la liberación del deudor, en tanto, exonerado de su pasivo pendiente, ésta recupera un miembro que puede ser productivo para la sociedad. Es la denominada teoría de la utilidad social o teoría humanitaria. Cuando un hombre honesto tiene mala suerte y quiebra financieramente, la sociedad no gana nada manteniéndolo hundido y, sobre todo, ello no beneficia a los acreedores puesto que de igual manera no van a ver satisfechos sus créditos por cuanto la supervivencia de sus derechos de crédito bloquea la capacidad productiva del deudor y por tanto, la posibilidad de cobro por parte de aquéllos. El sistema nace, pues, con un planteamiento claro: la rehabilitación del deudor honesto, lo cual contrasta con la mayoría de los sistemas europeos en los que como gráficamente se ha señalado "la filosofía anti-deudor prevalece". Con cita de BLUM, sostiene que "por el contrario, la política concursal en USA que viene a ser complemento de la política social estatal dirigida a proteger al deudor, a los trabajadores, a la comunidad en su conjunto, evitando que se generen situaciones de exclusión social". Predomina la idea de que la legislación concursal debe tender a la recuperación económica del deudor y su reintegración en el proceso productivo.

${ }^{258}$ La normativa concursal norteamericana se ofrece en el título 11 de las leyes federales norteamericanas (U.S. Code). Se trata de un régimen unificado, abarcativo de todas las soluciones frente a la insolvencia, sea que afecten a los particulares y sus economías domésticas o al sector empresario. Concretamente, respecto de las personas físicas, la regulación propone cuatro tipos de procedimientos bajo el U.S. Bankruptcy Code: a.- el capítulo 7 relativo a la liquidación; b.- el capítulo 11, relativo a la reorganización de los créditos; c.- el capítulo 12, relativo a las explotaciones agrarias o pesqueras familiares con ingresos regulares; y d.- el capítulo 13 relativo a personas físicas con ingresos regulares. No obstante el catálogo de opciones, los capítulos 7 y 13 fueron siempre las alternativas transitadas por los particulares en crisis por deudas propias del consumo moderno. Resulta de sumo interés el valioso informe y el desarrollo propuesto en JACOBY, Melissa B., “Perspectivas Empíricas...”, cit., pág. 389. 
indicar con precisión su estado patrimonial -con detalle de sus bienes y deudas-, beneficiándose automáticamente con la paralización de todas las acciones de cobro que se hubieran promovido en su contra. Esta suspensión incluye aún a los acreedores que cuentan con una garantía real. Los titulares de tales acreencias podrán eventualmente obtener la autorización del juzgado interviniente para continuar con la ejecución o iniciar otras acciones judiciales.

Se produce el desapoderamiento de los bienes del deudor (con excepción de los exentos que la ley de cada Estado determina) que se liquidan a fin de que las sumas obtenidas sean objeto de distribución entre los acreedores, conforme las reglas de preferencias legalmente establecidas.

Verificado el desapoderamiento de los bienes no exentos, incorporado el producido de tales activos al patrimonio del concurso y cumplido el procedimiento de distribución entre los acreedores, el deudor queda liberado de toda responsabilidad. En mérito a la operatividad del beneficio de condonación de deudas al que accede, el deudor persona física queda habilitado para retomar su actuación en el mercado y el comenzar de nuevo (lógica del llamado fresh start).

Pese a la simpleza aparente, la normativa impone al deudor que pretende acceder a este beneficio, superar un estricto test de discharge, regulado en el art. 727 del US Code. Subyace aquí, como es evidente, la idea de que la exoneración del pasivo pendiente debe propiciarse en razón de un merecimiento del deudor, de buena fe. Y de allí que la preceptiva elabore un catálogo de conductas o situaciones reprochables o censuradas que impedirán el reconocimiento del beneficio analizado.

Las causas de exclusión hacen referencia a conductas relacionadas con la ocultación o alzamiento de bienes, a la ocultación o falseamiento de información y documentación relativo a la situación financiera y comercial del deudor dentro o fuera del procedimiento concursal, así como a la realización de actos al margen de los órganos del concurso. En general la realización de cualquier actuación tendente a perjudicar a los acreedores comporta la exclusión del deudor del procedimiento del capítulo $7^{259}$.

\footnotetext{
${ }^{259}$ SENENT MARTíneZ, Santiago, Exoneración del pasivo insatisfecho..., cit., pág. 266.
} 
Una causa de exclusión particular, impuesta por la regulación especial, es el haber obtenido el beneficio de la discharge de acuerdo con lo previsto en este capítulo o en la Sección 14, 371, o 476 del Bankruptcy Act en un procedimiento iniciado dentro de los ocho años anteriores a la petición, o haber obtenido el beneficio en el ámbito de los capítulos 12 y 13 dentro de las secciones 1228 o 1328, o en el marco de la Sección 660 o 661 de la Bankruptcy Act en un caso iniciado dentro de los seis años anteriores a la solicitud, a no ser que se hayan realizado los pagos que se relacionan en el art. 727, o el no haber completado el curso de asesoramiento financiero legalmente previsto en el art. 111.

El fiduciario o cualquier acreedor puede invocar la concurrencia de las causas de exclusión ante el Tribunal y peticionar la denegación del beneficio. Frente a la denuncia de alguno de estos extremos, se ordenará al fiduciario la investigación correspondiente (art. 727 c), y en su caso, el beneficio de la discharge será revocado por el Tribunal en los términos del art. 727 d, hasta un año después de su concesión.

La decisión vinculada a la revocación del beneficio debe adoptarse a instancia de parte y previa audiencia de los interesados.

La segunda vía de acceso a la liberación del pasivo es la prevista en el Capítulo 13. El inicio de este procedimiento supone que el deudor encuentre un escenario de negociación con sus acreedores a fin de acordar un plan de pagos con su consiguiente cronograma de cumplimiento, que será afrontado con todos sus ingresos disponibles y luego de dejar establecida la cuantía necesaria para solventar sus gastos personales y familiares. A partir de la solicitud de apertura del procedimiento y por tres años o cinco años -dependiendo del nivel de ingresos del deudor-, la totalidad de los mismos -menos lo necesario para su manutención- es gestionada por el administrador concursal (el bankrupty trastee). Este modelo permite al deudor mantener la propiedad de sus bienes.

El procedimiento del capítulo 13 (del plan de pagos) requiere que se trate de personas físicas con ingresos regulares, que concurra buena fe en el solicitante y que sus deudas vencidas y líquidas se encuentren por debajo de un límite legal ${ }^{260}$. Cabe destacar

\footnotetext{
${ }^{260}$ El límite para deudas con garantía real es de un millón de dólares y de casi trescientos cincuenta mil dólares para las deudas sin garantía, ajustándose este límite, como sucede con otras cifras monetarias presentes en el Bankruptcy Code, cada tres años.
} 
que para la regulación americana no es necesario que la deuda sea principalmente derivada del consumo para que una persona física pueda acogerse a este procedimiento ${ }^{261}$.

Transcurrido el tiempo legalmente establecido, el deudor que cumple el plan de pagos accede al beneficio de la liberación de deudas, con excepción de los derechos de garantía que recaen sobre los bienes afectados ${ }^{262}$.

Al momento de marcar las diferencias entre las opciones propuestas por el legislador americano, SENNET MARTíNEZ expresa: "si el deudor quiere empezar de cero (fresh start), puede entregar todos sus bienes no exentos, y empezar de nuevo, solicitando el chapter 7. Si pretende conservar sus bienes, sin embargo, deberá acomodar su solicitud al chapter 13 y esperar durante tres años o cinco años, pudiendo volver a empezar de cero, saldando las deudas restantes, aunque esta "puesta a cero" se pospone ${ }^{, 263}$.

Esta característica del sistema relativa a la elección de la vía a la que acudir, que quedaba en manos del deudor, se ha visto limitada considerablemente, como veremos, por la reforma llevada a cabo en el año 2005.

En el año 2005, se aprobó en EEUU una significativa modificación en el régimen legal de insolvencia, hasta entonces vigente, contenido en el Título XI del US Bankruptcy Code $^{264}$.

La ley concursal aprobada en $2005^{265}$ tuvo el apoyo de los dos partidos políticos mayoritarios pero el trámite parlamentario estuvo signado por marcadas tensiones y algunas opiniones críticas que aún se hacen escuchar ${ }^{266}$.

\footnotetext{
${ }^{261}$ JACOBY, Melissa B., “Perspectivas Empíricas...”, cit., pág. 390.

${ }^{262}$ Para un estudio riguroso del procedimiento y de su funcionamiento, ver HIERRO ANIBARRO, Santiago, "Estudio de una jurisdicción conflictiva. Los tribunales concursales de los Estados Unidos de América”, en Estudios sobre la ley concursal. Libro Homenaje a Manuel Olivencia, V. I, Madrid, 2005, pág. 747 y sgtes..

${ }^{263}$ SENEnt MartíneZ, Santiago, Exoneración del pasivo insatisfecho..., cit., pág. 269. El autor remite a un interesantísimo trabajo de PотTOw, que ilustra acerca de las variantes entre los modelos de la ley americana (PotTow, John A. E., "Un primer estudio de los cambios de la ley concursal estadounidense de 2005", Revista de Derecho Concursal y Paraconcursal, Anales de doctrina, praxis, jurisprudencia y legislación, $\mathrm{N}^{\mathrm{o}}$ 3, 2005, pág. 355-363).

${ }^{264}$ Ver las interesantes consideraciones sobre el proceso de reforma, contenidas en JACOBY, Melissa B., "Perspectivas Empíricas ...”, cit., pág. 395. Asimismo, Del FIERRo ElgarT, Alfonso, "El Derecho de la insolvencia...", cit.
} 
Frente al notable incremento de las solicitudes de concurso y de liberación del pasivo insatisfecho, el diagnóstico de las entidades financieras fue tan contundente como simplista: el sistema legal vigente y las praxis consecuente, propiciaban abusos intolerables ${ }^{267}$. El uso distorsivo del procedimiento concursal y de sus remedios, se erigió en argumento central de la reforma, sin tener en cuenta, que el incremento de las declaraciones de concurso fue paralelo al incremento brutal y progresivo del crédito al consumo $^{268}$. Se sostuvo que los consumidores incurrían en un endeudamiento irresponsable para luego buscar el auxilio del proceso concursal ${ }^{269}$. "La denuncia reiterada por parte de la industria del crédito, sustentada por estadísticas gubernamentales...produjo un gran movimiento liderado por el lobby crediticio decidido a persuadir al congreso norteamericano"270 y fue así que la Bankrupty Abuse Prevention and Consumer Protection Act entró en vigor el 17/10/2005 271 , "a pesar de las advertencias de los académicos, jueces y abogados especializados en el sector" 272 .

${ }^{265}$ La citada ley de reforma del sistema es conocida como la Bankrupty Abuse Prevention and. Consumer Protection Act (BAPCPA).

${ }^{266}$ Recoge esa visión crítica, GROSs, Karen, "La insolvencia de los consumidores...”, cit., pág. 229 y sgtes..

${ }^{267}$ Cuena CASAS, Matilde, "Fresh start...", cit.. Ver asimismo, Pulgar EzQUERRA, Juana, "Concurso y consumidores...", cit., pág. 43 y sgtes.

${ }^{268}$ LAWLESS, Robert, "La Ley concursal estadounidense de 2005. Cómo llegamos a ella y hacia dónde vamos", Revista de Derecho Concursal y Paraconcursal, 2008, pág. 99-111.

${ }^{269}$ Las estadísticas de concursos de persona física en USA parecían revelar que tal abuso se estaba produciendo, pues no paraban de crecer progresivamente los números de insolvencias al margen de la coyuntura económica. El incremento no se interrumpía ni siquiera en época de bonanza económica. El relevamiento realizado por expertos muestra que se pasa de 287 concursos en el año 1980 a 1.563 .111 en el año 2004 En el año 2005 se llega a los 2.039,214 concursos, aumentando un 31 por ciento (www.abiworld.org American Bankruptcy Institute). Se informó asimismo que en las dos semanas anteriores a la entrada en vigor de la ley, 600 deudores se declararon en concurso, lo cual supuso un notable incremento si se tiene en cuenta que usualmente eran 30 las declaraciones de concurso semanales.

${ }^{270}$ AlváREZ VegA, María Isabel, Protección jurídica del consumidor..., cit., pág. 107.

${ }^{271}$ Para un desarrollo de las dificultades que tuvo que afrontar el trámite legislativo, ver, LAWLESS, Robert M.-WARREN, Elizabeth, "Los cambios en la normativa concursal estadounidense en 2005", en Revista Concursal y Paraconcursal, $N^{\circ}$ 3, 2007, pág. 406 y sgtes.

${ }^{272}$ Alvárez VEGA, María Isabel, Protección jurídica del consumidor..., cit., pág. 107. 
La reforma del año 2005 determinó la imposición de nuevos requisitos formales al procedimiento de insolvencia. Se imponen asimismo, nuevos requisitos sustanciales tanto para el acceso como para la salida del mismo.

Uno de los requisitos incorporados en la reforma, que condiciona el acceso al procedimiento, está vinculado a la obligatoriedad de un asesoramiento financiero previo.

Antes de la reforma de 2005, la persona física que pretendía acogerse al procedimiento de condonación de deuda, podía consultar un abogado, completar los formularios previstos para el inicio del trámite, pagaba una tasa correspondiente y solicitaba la apertura del procedimiento concursal. Luego de la reforma, ese mismo consumidor debe someterse a un asesoramiento crediticio (credit counseling) dentro de los 180 días anteriores a la solicitud, para poder ser declarado en concurso. El asesoramiento crediticio debe ser proporcionado por un asesor de la lista que a tal efecto confecciona y aprueba el Ministerio de Justicia. El deudor no puede acceder al procedimiento concursal si no acredita con la certificación correspondiente, que ha recibido tal asesoramiento crediticio $^{273}$.

'Declarada la apertura del proceso y durante su desarrollo, el deudor debe recibir formación crediticia adicional pues de no mantener esta suerte de educación en el crédito, podrá denegársele la exoneración de las deudas pendientes ${ }^{274}$.

La imposición de un nuevo requisito condiciona también la libre elección del procedimiento. El llamado test de recursos (Means Test) es un mecanismo que permite establecer qué deudor puede acogerse a los distintos modelos de discharge previstos en la legislación concursal. Se acude a una complicada fórmula que somete a prueba la capacidad

\footnotetext{
${ }^{273}$ Se menciona que el asesoramiento crediticio puede obtenerse a través de Internet y los proveedores de esos servicios aseguran que viene a durar unos 20 minutos y tiene un coste de unos 50 dólares (LAWLESS, Robert, y WARREN, Elizabeth., "Los cambios de la normativa concursal estadounidense en 2005: reduciendo parte de la red de seguridad”, Revista de Derecho Concursal y Paraconcursal, nº 6, 2007, pág. 405-412).

274 “En USA además del asesoramiento previo, el deudor que se ha beneficiado de una exoneración de deudas debe también llevar a cabo con posterioridad al proceso concursal, un curso de educación financiera que deberá certificar una agencia de asesoramiento crediticio acreditada. Estos cursos deben ser financiados por el deudor y tienen un coste aproximado entre 50 y 100 dólares. Si el deudor no lleva a cabo el asesoramiento crediticio que le impone la ley, pierde el derecho a liberar el pasivo pendiente, al margen de las circunstancias del caso concurrentes". CUENA CASAS, Matilde, "Fresh start ...", cit.
} 
patrimonial del consumidor para el pago de sus deudas ${ }^{275}$ y por la que se procura incrementar el tránsito por el capítulo 13 (cumplimiento de un plan de pagos para recién alcanzar la exoneración del pasivo). Esta disposición opera como barrera de acceso al mecanismo de discharge del capítulo 7 (por el que se libera al deudor de sus deudas pendientes con cesión de la totalidad del patrimonio no exento y no sujeto a derechos de garantía) $^{276}$.

Si bien ya con la legislación anterior a la reforma, el deudor que presentaba su solicitud de apertura del procedimiento debía someterse a este examen previo, con las sucesivas modificaciones y especialmente con la del año 2005, el means test se convirtió en una valla de acceso más dura de sortear. Con el objetivo de evitar la abusividad en el acceso al beneficio de liberación de deudas, la nueva regulación incorporó requisitos objetivos (nivel de ingresos y gastos, cuantía del pasivo, composición del patrimonio, garantías sobre bienes, progresión de cumplimiento, comparación con estándares) y endureció el criterio ${ }^{277}$.

275 "Este nuevo test de recursos cuestiona, primero, si el deudor tiene ingresos por encima o por debajo de la media para las unidades familiares del mismo tamaño en el estado del deudor. Si el deudor está por debajo de la media, se acaban ahí las averiguaciones y el deudor puede solicitar el concurso bajo el Chapter 7. Para los deudores con ingresos por encima de la media, el test de recursos se transforma entonces en una compleja fórmula para determinar si el deudor tiene ingresos suficientes como para elaborar un plan del Chapter 13. Esta fórmula se apoya en los estándares elaborados por el Internal Revenue Service (la autoridad fiscal federal) para determinar si se transige con el deudor con relación a sus deudas fiscales" (SENENT MARTíNEZ, Santiago, Exoneración del pasivo insatisfecho..., cit., pág. 270).

${ }^{276}$ Ver JACOBY, Melissa B., "Perspectivas Empíricas...”, cit., pág. 395 y sgtes.

277 "Con la Bankruptcy Abuse Prevention and Consumer Protection Act de 2005 (BAPCPA), se implementaron grandes cambios en este tema, fruto de un arduo debate, pues finalmente el Means Test tiene la posibilidad de impedir a un deudor aplicar una solicitud de quiebra; y en caso de no fijarse un punto justo para prevenir los abusos, se corre el riesgo de no permitir a un consumidor obtener el alivio que implica el procedimiento y el fresh start proveniente del discharge $\mathrm{y}$, con ello seguir siendo un miembro activo otorgando impulsos económicos a la sociedad. En ese marco, la mencionada acta introduce los siguientes cambios: i. Si un deudor tiene capacidad económica para enfrentar el pago a sus acreedores sin garantías, es suficiente antecedente para determinar inmediatamente la presencia de un abuso. Con esto se acerca bastante a una exigencia de una situación patrimonial desmerecida de insolvencia, o al menos cercana a la misma. ii. Al considerar la capacidad de pago del deudor, sus gastos se limitarán a los referidos a un nivel medio razonable, el cual será determinado por el Internal Revenue Service iii. Se amplió a los sujetos capaces de solicitar se deseche la solicitud de quiebra en base al Means Test que, en general, según la sección 707(b) del 
Esta nueva cara del means test $\mathrm{o}$ test de recursos procuraba orientar decididamente, en su caso, el tránsito por el capítulo 13 (por sobre el capítulo 7) que por su modalidad, se consideraba más satisfactorio de los intereses de los acreedores (plan de pagos) y mantenía por otra parte, el estímulo de las actividades productivas del deudor, que conserva la propiedad y gestión de sus bienes.

Se advierte, por otra parte, que la reforma impuso cargas muy significativas a los abogados puesto que con la nueva ley, el asesor letrado del deudor se ve obligado a asegurar al tribunal que, ha investigado el caso y que no tiene razones para creer que esa información proporcionada por el deudor sea incorrecta, asumiendo una responsabilidad personal $^{278}$.

Bankruptcy Code, se le otorga a cualquier parte o autoridad que participe del procedimiento. iv. Finalmente, la solicitud se presume como abusiva por parte del deudor, cuando éste falla el Means Test, presunción que únicamente podrá desvirtuarse demostrando posteriores e inevitables cambios que implicaron, o una reducción de su activo, o un aumento en sus gastos. Ahora bien, junto con incorporar estos cambios, este examen finalmente determinará si el deudor puede o no acogerse al procedimiento de quiebras del Capítulo 7. El examen consta de dos partes, la primera valla a superar a superar consiste en comparar los ingresos anuales promedio del deudor con la media de su correspondiente estado.516 Si el ingreso anual es menor a la media, la barrera está superada y el Means Test, aprobado. En caso contrario, viene la segunda barrera a superar para aprobar, la cual implica reducir ese ingreso, restando los gastos normales de un sujeto medio, donde se realizará una proyección a 5 años, para ver si en ella tendría ingresos suficientes para pagar a sus acreedores. Si el ingreso mensual promedio, deducidos los gastos de mantención del deudor, familia y dependientes, multiplicado por los 5 años (60 meses) es mayor a 10.000 USD, el abuso es inmediatamente presumido. Si, en cambio, oscila entre 6.000 y $10.000 \mathrm{USD}$, se presumirá también el abuso, siempre y cuando dicho monto sea suficiente para pagar el $25 \%$ de los créditos que no gozan de garantía. Se puede esquematizar el segundo paso del Means Test, que determinará si existe abuso de la siguiente manera: (Ingresos mensuales - gastos mensuales permitidos) x 60 es igual o superior a 10.000 USD, o (Ingresos mensuales - gastos mensuales permitidos) x 60 es igual a 6.000 a 10.000 USD, si esa suma cubre el 25\% o más de los créditos sin garantía)". Ver el desarrollo explicativo en Del FIERRo ElgarT, Alfonso, "El Derecho de la insolvencia de los consumidores: una reforma pendiente en el Derecho Concursal chileno", Boletín Jurídico/Publicación $\mathrm{N}^{\circ}$ 3, http://www.superir.gob.cl/wp-content/uploads/2014/09/boletinjuridico-publicacion-n3-1.pdf (fecha de consulta 1/7/2015).

278 "Con anterioridad, los abogados no podían remitir informes falsos con su conocimiento en el procedimiento concursal, pero la responsabilidad primaria de la corrección de esos informes recaía sobre el consumidor. Ahora, el abogado debe responder de qué sea correcto y ha de adoptar una actitud de sospecha hacia el cliente, estando sujetos los abogados que contravengan estas previsiones legales a sanciones pudiendo 
Se produce una importante limitación en el ámbito de discrecionalidad del juez, que antes gozaba de amplias facultades. Con la reforma, el sistema se sostiene en la aplicación estricta de normas que no ofrecen margen de flexibilidad. Se ha señalado que la nueva ley “deposita la confianza en los acreedores del mercado de crédito, en los legisladores y en los actores particulares (los consultores de deuda y las agencias de formación de deudores). La reforma exuda desconfianza hacia los sujetos que antes gozaban de credibilidad: abogados, jueces e incluso académicos"279.

\section{V.- La problemática del sobreendeudamiento del consumidor en Argentina.}

Un relevamiento de los remedios previstos en el ordenamiento jurídico argentino nos servirá para justificar la conclusión que, desde ya, adelantamos. Los dispositivos existentes y en vigencia resultan insuficientes e inadecuados para hacer frente a la problemática que nos desvela. Les reconocemos valor y eficacia respecto de aquella realidad para la que fueron diseñados.

Pero estamos persuadidos. La complejidad del fenómeno del sobreendeudamiento del consumidor exige nuevas herramientas legales y escenarios de actuación particulares.

Los nuevos males imponen remedios actuales.

\section{A.- Herramientas legales vigentes de contenido sustancial}

1.- Código Civil de Vélez Sarsfield: institutos previstos en la teoría general de las obligaciones y en la teoría general del contrato

En la dogmática tradicional del Código Civil argentino, el contrato es considerado el resultado de un acuerdo concertado entre sujetos con idéntico poder de negociación, donde cada uno pone a disposición del otro una porción de su libertad y se compromete a observar un comportamiento determinado, ajustado al plan prestacional convenido.

Como consecuencia de esta autonomía privada reconocida al individuo, la regulación civil debía orientarse a resguardar el libre querer de los particulares, para que

verse obligados a pagar las costas procesales de los acreedores" (SENENT MARTínEZ, Santiago, Exoneración del pasivo insatisfecho..., cit., pág. 272).

${ }^{279}$ GROSS, Karen, "La insolvencia de los consumidores...", cit., pág. 229 y sgtes. 
todos pudieran decidir por sí, la entrada y salida del contrato y las condiciones bajo las que quisieran obligarse. Para garantizar el ejercicio de estas libertades parecía necesario que el Estado se abstuviera de dictar normas de intervención y se impidiera a los jueces intromisiones indebidas. Era convicción generalizada entre los juristas del liberalismo que cualquier intervención encubría la posibilidad de una dictadura y de allí, que los tribunales debieran respetar lo acordado por las partes, aún cuando se considerara que sus intereses podrían haberse negociado de un modo más satisfactorio. El juez no estaba llamado a imponer criterios de eficiencia autorreguladora.

No obstante ello, el principio de autonomía de la voluntad no fue aplicado con rigor absoluto, ni siquiera por los mismos códigos que lo consagraron ${ }^{280}$. Ni bien se admite la consagración del principio de libertad contractual como sustrato de la autonomía privada, la doctrina enuncia ineludiblemente, los límites institucionales ${ }^{281}$ que definen el campo de actuación de los particulares. Los propios códigos liberales asumieron la necesidad de establecer restricciones a la libertad contractual para asegurar por un lado, la coordinación de los intereses librados a la regulación particular y por otro, resguardar los intereses reservados a la regulación pública, excluidos del campo de actuación privada.

Sin que por ello se alteraran las premisas que inspiraron al modelo tradicional, irrumpe en el escenario contractual la noción de orden público, que se plasma en normas jurídicas de carácter institucional que poseen el grado de generalidad necesario para sentar el estándar al que debe ajustarse la conducta particular ${ }^{282}$. Estas restricciones a la autonomía privada se presentan como la contracara de aquéllas razones que justificaron el

\footnotetext{
${ }^{280}$ Alterini, Atilio A., Contratos Civiles, Comerciales, de Consumo, Abeledo Perrot, Buenos Aires, 1998, pág. 68.

${ }^{281}$ LOREnZETTI, Ricardo L., Tratado de los Contrato. Parte General, Rubinzal Culzoni, Santa Fe, 2004, pág. 90. El autor señala que la relación entre el contrato y las instituciones en que se desenvuelve, ha sido poco estudiada por la teoría contractual y que ello se explica por las características del modelo tradicional. Entiende que la dogmática contractual clásica -el contrato basado en el consentimiento- se construye sobre la base de una perspectiva individualista, con un sujeto aislado de su contexto, al que debe garantizarse autonomía y la no intervención estatal, con un régimen legal ajustado a un marco de estricta bilateralidad y ajeno por tanto, a la referencialidad pública de las normas privadas.

${ }^{282}$ LORENZETTI, RiCARDO L., Tratado de los Contratos, cit., pág. 94 y sgtes.
} 
reconocimiento de la libertad contractual ${ }^{283}$. Se entiende que el ejercicio de la libertad supone la posibilidad de decidir sin condicionamientos externos pero que no se trata de decidir sin límites, puesto que éstos existen y son derivados de los derechos de otros y de los bienes públicos ${ }^{284}$.

Estas normas de intervención se orientan a compatibilizar los propósitos e intereses particulares, con los valores y bienes colectivos ${ }^{285}$. Se traducen por lo general, en fórmulas amplias que corporizan principios axiológicos a los que las partes deberán ajustar el ejercicio de su poder de autonormación. Es precisamente esta función armonizadora, la que explica su denominación: son normas de intervención enroladas en la noción de orden público de coordinación. Como ejemplo de esta modalidad de intervención contractual, podemos mencionar a las normas referidas a la licitud del objeto ${ }^{286}$ (adecuación a la ley, a la moral y a las buenas costumbre) y a la licitud de la causa de la obligación y del contrato $^{287}$.

La constatación de la desigualdad innegable de las partes eventualmente involucradas en la contratación abrió cauce para el desarrollo de una nueva función del orden público. En razón de esas asimetrías ${ }^{288}$ irrumpen normas de intervención que inspiradas en la noción de orden público de protección, intentan restablecer el desequilibrio

\footnotetext{
${ }^{283}$ Alterini, Atilio A., Contratos Civiles..., cit., p. 68. Desde esta perspectiva, las normas de intervención atienden la situación de los restantes intereses que puedan resultar comprometidos por la regulación contractual de los particulares directamente involucrados.

${ }^{284}$ LORENZETTI, RICARDO L. Las normas fundamentales de Derecho Privado, Rubinzal Culzoni, Santa Fe, 2005, pág. 432.

${ }^{285}$ Cfr. LORENZETTI, RiCARDO LUIS, Las normas fundamentales..., cit., pág. 476. Del mismo autor, ver asimismo el desarrollo realizado en Tratado de los Contratos..., pág. 94 y sgtes.

${ }^{286}$ En el CCiv, ver arts. 953, 1167 y concordantes.

${ }^{287}$ En el CCiv, arts. 502, 1167 y concordantes.

${ }^{288} \mathrm{Al}$ justificar la vulnerabilidad del consumidor en sus diferentes manifestaciones, se pone particular énfasis en destacar la asimetría informativa. Es la que define de modo irrefutable el desnivel cognoscitivo entre el proveedor y el consumidor; es la que pone en evidencia el carácter de experto del poseedor de la información y lo profano de quien se ve precisado de ella. Ver LORENZETTI Ricardo L., Consumidores, cit., pág. 39 y sgtes.; pág. 64 y sgtes.
} 
de los extremos involucrados, mediante la imposición de obligaciones en cabeza de los fuertes y en favor de los débiles ${ }^{289}$.

El legislador advierte que no puede permanecer impasible frente al escenario que propicia el mercado ${ }^{290}$ y en una labor de ingeniería jurídica, diseña las normas que habrán de orientar las conductas de los protagonistas del intercambio, evitando distorsiones y abusos en esa relación de desequilibrio.

Como señalábamos ut supra, la preocupación por la situación del deudor, en tanto sujeto débil en la relación jurídica obligacional, no es nueva ${ }^{291}$. El Código Civil argentino, al igual que muchos otros, se ocupó de diseñar herramientas para prevenir y corregir las situaciones de inequidad o abuso que podían presentarse. Entre ellas, mencionamos los siguientes institutos:

\footnotetext{
${ }^{289}$ LORENZETTI marca la distinción entre las normas que se inspiran en el orden público de dirección dirigidas al conjunto social, preocupadas por obtener efectos distributivos, interesada en la problemática de la externalidades derivadas del intercambio particular, de contenido variable y cambiante- de aquellas otras normas, que llevan la impronta del orden público de protección, inspiradas en principios de justicia conmutativa, preocupadas por las partes contractualmente vinculadas y su desigualdad, dirigidas a una clase de sujetos a los que considera precisados de tutela, que apuntan a problemas estructurales y por ello, más durables en el tiempo. Ver por todos, LoREnZetTI, Ricardo L., Consumidores, cit., pág. 24 y sgtes.. Para un desarrollo del tema, cfr. LORENZETTI, Ricardo L., Normas fundamentales..., cit., pág. 427.

${ }^{290}$ Ver Stiglitz, G. A., Reglas para la defensa de los consumidores y usuarios, Juris, Santa Fe, 1998, pág. 111 y sgtes.

291 Alterini Y LÓPEZ CABANA decían hace tiempo: "La noción de orden público como fenómeno desequilibrante de la autonomía de la voluntad, sirvió para paliar la vulnerabilidad de quienes se veían perjudicados por 'los hechos contrarios al Derecho y a la moral'... En el Código (Civil) argentino como en los demás códigos del siglo XIX, campean las exigencias de moralidad, licitud y congruencia para el acto jurídico y su finalidad, la repulsa al enriquecimiento sin causa, la admisión de beneficio de competencia ... y un cierto criterio interpretativo favorable al deudor". Destacan asimismo estos autores que la reforma al CCiv del año 1.968 -al igual que otras reformas a los códigos decimonónicos- introdujeron institutos que reforzaron la protección de la vulnerabilidad y así pueden citarse mecanismos diversos: la figura de la lesión, la imprevisión, el abuso del derecho, la reductibilidad de la cláusula penal, la atenuación de la indemnización por razones de equidad y la explicitación del rico principio de la buena fe (ALTERINI, Atilio. A.-LÓPEZ CABANA, Roberto., "La debilidad jurídica en la contratación contemporánea”, en Derecho de Daños, La Ley, Buenos Aires, 1992, pág. 85-103).
} 
- El régimen de nulidad de los actos jurídicos por vicios en el consentimiento ${ }^{292}$;

- El instituto de la lesión ${ }^{293}$;

- El instituto de la imprevisión ${ }^{294}$;

- El pago a mejor fortuna ${ }^{295}$;

- El pago con beneficio de competencia ${ }^{296}$;

- La facultad judicial de reducir los intereses $\operatorname{pactados}^{297}$;

- La reprobación de la usura ${ }^{298}$;

${ }^{292}$ Llambías, Jorge. J., Tratado de Derecho Civil-Parte General, T. II, Abeledo Perrot, Buenos Aires, 1997, pág. 411; BordA, Guillermo. A., Tratado de Derecho Civil-Parte General, Tomo II , Ed. La Ley, Buenos Aires, 2008, pág. 297.

${ }^{293}$ Art. 954 del CCiv. Ver Belluscio, A. (Dir.)-ZAnnoni, E. (Coord.), Código Civil y leyes complementarias comentado, T. IV, Astrea, Buenos Aires, 1988, pág. 354; BuERES, A. J. (Dir.)-Highton, E. (Coord.) Código Civil y Normas Complementarias, T. II B, Hammurabi-José Luis Depalma Editor, Buenos Aires, 1998, pág. 597; Rivera, J. C.-Medina, G. (Dir.), Código Civil Comentado.., Rubinzal Culzoni, Santa Fe, 2007, pág. 363; Cifuentes, S. (Dir.)-Sagarna, F. (Coord,), Código Civil Comentado, T. I, La Ley, Buenos Aires, 2008, pág. 149.

294 Art. 1198, 2do. párrafo, del Cód. Civil. Ver Belluscio, Augusto (Dir.)-Zannoni, Eduardo (Coord.), Código Civil..., T. 5, cit., pág. 896 y sgtes.; Bueres, Alberto J. (Dir.)-HiGHTON, Elena, Código Civil ..., T. 3 C, cit., pág. 47; Mosset ItUrRaspe, Jorge-PiedeCASAs, Miguel A. (Dir.), Código Civil Comentado, Contratos-Parte General, pág. 395 y sgtes.; Cifuentes, Santos (Dir.)-SaGARna, Fernando (Coord,), Código Civil..., T. I, cit., pág. 93 y sgtes.

295 Arts. 620 y 752 del Cód. Civil. Ver Belluscio, Augusto (Dir.)-ZannONi, Eduardo (Coord.), Código Civil ..., T. 3, cit., pág. 114 y sgtes., y pág. 523 y sgtes.; Bueres, Alberto J. (Dir.)-Highton, Elena, Código Civil..., T. 2 B, cit., pág. 110 y sgtes.; Trigo RePresas, Alberto-CompagnuCCi DE Caso, Rubén (Dir.), Código Civil Comentado, T. II, pág. 276 y sgtes.; Cifuentes, Santos (Dir.)-SAGARnA, Fernando (Coord,), Código Civil Comentado, T. I, pág. 611 y sgtes. y pág. 752, La Ley, Buenos Aires, 2008.

${ }^{296}$ Art. 799 del Cód. Civil. Ver Belluscio, Augusto (Dir.)-Zannoni, Eduardo (Coord.), Código Civil... T. 3, cit., pág. 646 y sgtes.; Bueres, Alberto J. (Dir.)-Highton, Elena, Código Civil..., T. 2 B, cit., pág. 216 y sgtes.; Trigo Represas, Alberto-CompagnuCCI De CASo, Rubén (Dir.), Código Civil ..., T. II, pág. 401 y sgtes.; Cifuentes, Santos (Dir.)-Sagarna, Fernando (Coord.), Código Civil ..., T. I, cit., pág. 801 y sgtes. ${ }^{297}$ Ver Belluscio, Augusto (Dir.)-Zannoni, Eduardo (Coord.), Código Civil..., T. 3, cit., pág. 115 y sgtes.; Bueres, Alberto J. (Dir.)-Highton, Elena, Código Civil..., T. 2 A, pág. 472 y sgtes.; Trigo RePresas, Alberto-Compagnucci de Caso, Rubén (Dir.), Código Civil..., T. I, cit., pág. 489. 
- La facultad judicial de revisar la cláusula penal inserta en el contrato ${ }^{299}$;

- La inembargabilidad de ciertos bienes del deudor;

- El instituto del bien de familia ${ }^{300}$;

- La figura de la prodigalidad ${ }^{301}$.

Los remedios enunciados han sido de innegable utilidad pero fueron diseñados para el contrato que responde a la lógica de la contratación tradicional, paritaria, entre iguales. En muchos de los casos de trata de soluciones para hipótesis de excepción, que imponen acreditar presupuestos y requisitos cuya configuración se juzga con carácter restrictivo. En otros supuestos, se trata de beneficios que suponen la adopción de previsiones incompatibles con la operatoria aquí analizada o cuyo goce está condicionado a la tramitación de un procedimiento complejo, que insume tiempo o puede imponer altos costes.

La complejidad de la problemática del sobreendeudamiento -por la condición de los sujetos involucrados, por la naturaleza de los bienes y derechos involucrados y por el impacto que ese endeudamiento excesivo provoca en el regular funcionamiento del mercado- impone la previsión de soluciones particulares De allí que exista consenso

\footnotetext{
298 Alterini, Atilio A.-Ameal, Oscar-LóPEZ CABANA, Roberto, Derecho de Obligaciones, Abeledo Perrot, Buenos Aires, 1998, pág. 473; WAYAR, Ernesto, Derecho Civil-Obligaciones, Lexis Nexis, Buenos Aires, 2002, pág. 538.

${ }^{299}$ Art. 656 del Cód. Civil. Ver Belluscio, Augusto (Dir.)-Zannoni, Eduardo (Coord.), Código Civil..., T. 3, cit., pág. 213 y sgtes.; Bueres, Alberto J. (Dir.)-Highton, Elena, Código Civil..., T. 2 A, cit., pág. 559 y sgtes.; Trigo RePresas, Alberto-CompagnuCCi DE CASO, Rubén (Dir.), Código Civil..., T. II, cit., pág. 27 y sgtes.; Cifuentes, Santos (Dir.)-Sagarna, Fernando (Coord.), Código Civil..., T. I, cit., pág. 646 y sgtes.

${ }^{300}$ Ley N ${ }^{\circ}$ 14.394. Ver, GuASTAVInO, Elías, Derecho de Familia-Bien de Familia (3era. Edición actualizada por Eduardo Molina QUIROGA con la colaboración de Sandra FodOR, Lucía E. GUASTAVINO y Gabriel N. E. GuAstavino), Ed. La Ley, Buenos Aires, 2010.

${ }^{301}$ Art. 152 bis del Cód. Civil. Ver Belluscio, Augusto (Dir.)-Zannoni, Eduardo (Coord.), Código Civil..., T. 1, cit., pág. 584 y sgtes.; Bueres, Alberto J. (Dir.)-Highton, Elena, Código Civil..., T. 1 B, cit., pág. 744 y sgtes.; Rivera, Julio César (Dir.), Código Civil..., cit., pág. 614 y sgtes.; Cifuentes, Santos (Dir.)Sagarna, Fernando (Coord.), Código Civil ..., T. I, cit., pág. 154 y sgtes.
} 
respecto de que resulta inaceptable forzar la aplicación de correctivos diseñados en otros tiempos y para situaciones conflictivas diferentes ${ }^{302}$.

2.- En el Código Civil y Comercial unificado vigente desde 2015:

El nuevo Código Civil y Comercial unificado sienta principios y consagra reglas sintetizando las medidas de tinte protectorio respecto de aquéllos a quienes se considera débiles jurídicos, revigorizando institutos ya existentes e incorporando nuevos dispositivos, que constituyen una contribución relevante a la tutela aquí analizada.

Ya desde el Título Preliminar se imparten directivas concretas referidas al ejercicio de los derechos (Capítulo 3), con expresa referencia al principio de buena $\mathrm{fe}^{303}$ y al abuso del derecho ${ }^{304}$, de directa aplicación a los casos en conflicto que nos desvelan. Por su parte, en el Libro I destinado a la Parte General, el Título III referido a los Bienes, contiene normas de gran interés. En el Capítulo 2, el art. $242^{305}$ (dedicado a la "garantía común”) dispone que los bienes del deudor están afectados al cumplimiento de las obligaciones contraídas por éste ${ }^{306}$ y el articulado del Capítulo 3 (arts. 244 a 256) regula con detalle la situación del inmueble destinado a la vivienda del deudor, lo que revela la preocupación particular del codificador por esta temática sensible. El Título IV dedicado a los Hechos y Actos Jurídicos reproduce con una sistemática depurada, herramientas tradicionales tales

\footnotetext{
${ }^{302}$ En España, coincide la doctrina en señalar la inadecuación, por insuficiencia e ineficacia, de las soluciones contenidas en el Código Civil y en algunas otras normas de contenido sustancial de Derecho Privado. Ver Álvarez Vega, María Isabel, Protección jurídica del consumidor..., cit., pág. 139 y sgtes.

${ }^{303}$ Art. 9.

${ }^{304}$ Art. 10.

305 Art. 242: “Garantía común. Todos los bienes del deudor están afectados al cumplimiento de sus obligaciones y constituyen la garantía común de sus acreedores, con excepción de aquellos que este Código o leyes especiales declaran inembargables o inejecutables. Los patrimonios especiales autorizados por la ley sólo tienen por garantía los bienes que los integran".

${ }^{306}$ La preceptiva del art. 242 antes citada entra en diálogo con el principio de responsabilidad patrimonial universal ahora consagrado expresamente en el art. 743 del nuevo Código Civil y Comercia. Reza el aludido art.743: "Bienes que constituyen la garantía. Los bienes presentes y futuros del deudor constituyen la garantía común de sus acreedores. El acreedor puede exigir la venta judicial de los bienes del deudor, pero sólo en la medida necesaria para satisfacer su crédito. Todos los acreedores pueden ejecutar estos bienes en posición igualitaria, excepto que exista una causa legal de preferencia".
} 
como la regulación de los vicios de la voluntad (arts. 265 a 278) y de los actos jurídicos (arts. 332 a 342$)^{307}$.

En el Libro III dedicado a los Derechos Personales, encontramos normas orientadas a proteger al deudor en la relación jurídica obligacional (Título I, referido a las Obligaciones en General) y en los contratos en general (Título II, referido a los Contratos en General), así como dispositivos de tutela del consumidor en la relación y en los contratos de consumo (Título III, dedicado a los Contratos del Consumo y Título IV, referido a Modalidades Especiales), que servirían para auxiliar a nuestro consumidor sobreendeudado, ante la ausencia de un régimen particular.

Se mantienen, en general, los remedios tradicionales oportunamente consagrados en el régimen de los actos jurídicos, en la teoría general de la obligación y en la teoría general del contrato, aunque con figuras remozadas y resistematizadas. Pero además, se incorpora al Código Civil y Comercial unificado la regulación de los contratos celebrados por adhesión a cláusulas generales predispuestas, con el aporte de soluciones propias, de gran utilidad en orden a la prevención de situaciones lesivas (requisitos impuestos a esta modalidad de contratación ${ }^{308}$, previsión de cláusulas particulares ${ }^{309}$, reglas de interpretación $^{310}$, régimen de las cláusulas abusivas ${ }^{311}$, etc.). Es igualmente relevante, por su eventual aplicación respecto de la materia en estudio, la regulación del fenómeno de la conexidad contractual en el nuevo Código. En efecto, contamos ahora con tres normas particulares referidas a la definición del fenómeno ${ }^{312}$, a reglas de interpretación de los contratos conexos $^{313}$ y la previsión de sus efectos ${ }^{314}$.

Por otra parte, como se dijo, tiene desembarco en el nuevo Código una nueva categoría contractual -la de los contratos de consumo- y allí se emplazan dispositivos

\footnotetext{
${ }^{307} \mathrm{El}$ art. 332 regula el instituto de la lesión al que algunos doctrinarios aluden al momento de insistir respecto de la existencia de mecanismos de solución idóneos en el Código Civil.

${ }^{308}$ Art. 985.

${ }^{309}$ Art. 986.

${ }^{310}$ Art. 987.

${ }^{311}$ Arts. 988 y 989.

${ }^{312}$ Art. 1073.

${ }^{313}$ Art. 1074.

${ }^{314}$ Art. 1075.
} 
especiales referidos a las prácticas abusivas en las relaciones de consumo $^{315}$, a la información $^{316}$ y publicidad ${ }^{317}$, a las cláusulas abusivas ${ }^{318}$ y a ciertas modalidades especiales de contratos de consumo ${ }^{319}$ para las que se diseñan, mecanismos de protección reforzada que pueden sumar soluciones a la problemática del sobreendeudamiento del consumidor aquí analizada ${ }^{320}$. A ello cabe agregar que en el Capítulo 12 (dedicado a los contratos bancarios) dentro del Título IV (destinado a los contratos en particular), contiene dispositivos de marcada impronta protectoria y cuya aporte a la problemática que nos convoca, es innegable. En la sección $1^{\circ}$ del mencionado capítulo, el parágrafo $1^{\circ}$ ofrece normas referidas a la transparencia de las condiciones contractuales (arts. 1378 a 1383) y el parágrafo $2^{\circ}$, bajo el título "Contratos bancarios con consumidores y usuarios", suma previsiones adicionales de contribución directa (arts. 1384 a 1389); disposiciones que serán objeto de análisis particular ut infra.

\section{3.- En la Ley $\mathrm{N}^{\circ} 24.240$ de Defensa del Consumidor:}

La Ley 24.240 contiene una sola norma referida a la problemática del consumo financiado y regula sólo algunas de sus aristas más conflictivas.

$\mathrm{Si}$ bien las reformas al texto originario del art. 36, introducido por las Leyes $\mathrm{N}^{\circ}$ 26.361 (2008) y № 26.993 (2014), amplían el contenido del dispositivo legal, quedan sin resolver los problemas más acuciantes.

La preceptiva analizada se ocupa, en su primera parte, de establecer los requisitos formales que debe observar el contrato de crédito para el consumo. Del texto surge la imposición de la forma escrita y de un contenido mínimo en el instrumento que formaliza la

\footnotetext{
${ }^{315}$ Art. 1096.

${ }^{316}$ Art. 1100.

${ }^{317}$ Art. 1101.

${ }^{318}$ Arts. 1117 a 1122.

${ }^{319}$ Se trata de los contratos celebrados fuera de los establecimientos comerciales (art. 1104), los celebrados a distancia (art. 1105) y aquellos en los que se utilizan medios electrónicos (arts. 1106 a 1109).

${ }^{320}$ Por su importancia, se destaca el acogimiento de una figura ya consagrada en la ley de defensa del consumidor (art. 34), el llamado derecho de arrepentimiento o revocación, que puede ser ejercido por el consumidor, en las condiciones y con los alcances allí previstos. En el Código Civil y Comercial unificado, el aludido derecho de revocación está regulado en los arts. 1110 a 1116.
} 
operatoria. Ese clausulado base allí establecido, traduce el cumplimiento de la carga informativa impuesta por la ley al proveedor del crédito.

El art. 36 consagra un deber de información particular, en vistas de las características del contrato de que se trata y en atención a los riesgos que puede suponer para el consumidor, la celebración de la operatoria ${ }^{321}$.

El legislador imparte directivas concretas en relación al comportamiento informativo que el proveedor del crédito debe observar ${ }^{322}$, al establecer un catálogo de ítems que puntualizan la información a suministrar, como piso por debajo del cual el objeto de este deber no se entenderá satisfecho ${ }^{323}$.

Al prever las consecuencias del incumplimiento de este deber de información impuesto al proveedor del crédito -por omisión de los datos mencionados por la ley- la norma menciona la pena de nulidad. Advierte con acierto la doctrina que la nulidad es una

${ }^{321}$ Luego de imponer un genérico deber de informar en el art. 4 de la ley, el legislador particulariza dicha
obligación, como un modo de destacar que existen situaciones especiales, que justifican una información
concreta, reforzada o diferencial. Se trata de supuestos en los que se ha entendido necesario acudir en auxilio
del consumidor, a efectos de resguardar de un modo particular, los derechos o intereses que puedan resultar
afectados. Para un desarrollo de este tema, ver JAPAZE, María Belén, "El deber de información", Capítulo V,
en RusCONI, Dante (Coord.), Manual de Derecho del Consumidor, Abeledo Perrot, Buenos Aires, 2015, pág. 221-267.

${ }^{322}$ Conforme la norma analizada, el agente financiero debe consignar en el contrato, los siguientes datos: "a) La descripción del bien o servicio objeto de la compra o contratación, para los casos de adquisición de bienes o servicios; b) El precio al contado, sólo para los casos de operaciones de crédito para adquisición de bienes o servicios; c) El importe a desembolsar inicialmente -de existir- y el monto financiado; d) La tasa de interés efectiva anual; e) El total de los intereses a pagar o el costo financiero total; f) El sistema de amortización del capital y cancelación de los intereses; g) La cantidad, periodicidad y monto de los pagos a realizar; h) Los gastos extras, seguros o adicionales, si los hubiere". La propia preceptiva establece que "cuando el proveedor omitiera incluir alguno de estos datos en el documento que corresponda, el consumidor tendrá derecho a demandar la nulidad del contrato o de una o más cláusulas", advirtiendo que "cuando el juez declare la nulidad parcial simultáneamente integrará el contrato, si ello fuera necesario”. Si la información omitida es la tasa de interés efectiva anual, el propio precepto prevé que "su omisión determinará que la obligación del tomador de abonar intereses sea ajustada a la tasa pasiva anual promedio del mercado difundida por el Banco Central de la República Argentina vigente a la fecha de celebración del contrato”.

${ }^{323}$ Cuando nos referimos al objeto de la obligación de informar nos preguntamos sobre el quid de este deber jurídico: ¿qué se debe informar? 
sanción grave y que hubiera sido deseable que el legislador precisara los alcances de la misma. En efecto, la nulidad del contrato de crédito puede no ser una solución ajustada a los intereses del consumidor, que procura acceder a la financiación para adquirir bienes o contratar servicios y no verse privado de ella. Por otra parte, si como entendemos, la norma se refiere a la nulidad del instrumento que formaliza el contrato, habrá que concluir que ante la invalidez de éste último, la relación jurídica entablada entre las partes habrá de regirse por las disposiciones, usos y prácticas más favorables al consumidor. Consideramos que es la conclusión que compatibiliza la aplicación del principio de conservación del negocio (buscado por el consumidor) con la necesidad de rescatarlo en condiciones que lo dejen a resguardo ${ }^{324}$.

La norma dispone que el consumidor puede demandar la nulidad del contrato o de una o más cláusulas. Esta alternativa guarda relación con la acción de nulidad del contrato prevista en el art. 37 de la misma ley ${ }^{325}$. El dispositivo advierte que si el juez declara la nulidad parcial simultáneamente integrará el contrato, si ello fuera necesario".

${ }^{324}$ FARINA, Juan M., Defensa del consumidor y del usuario. Comentario exegético de la ley 24.240 y del decreto reglamentario 1798/94, Astrea, Buenos Aires, 2008, pág. 390; MosSET ITURRASPE, JorgeWajnTRAub, Javier H., Ley de Defensa del Consumidor. Ley 24.240, Rubinzal Culzoni, Santa Fé, 2008, pág. 199; SAuX, Edgardo. I.-Muller, Enrique C., Comentario al art. 36 de la Ley 24240, en PiCASSO, Sebastián.VÁZQUEZ FERREYRA, Roberto (Dir.), Ley de Defensa del Consumidor comentada y anotada, La Ley, Buenos Aires, 2009, pág. 425-439.

${ }^{325}$ La ley establece en el art. 37 que "en caso de que el oferente viole el deber de buena fe en la etapa previa a la conclusión del contrato o en su celebración, o transgreda el deber de información..., el consumidor tendrá derecho a demandar la nulidad del contrato, o la de una o más cláusulas...”. La acción de nulidad aquí prevista, aligera los presupuestos y requisitos de la acción de nulidad tradicional, cualquiera fuera ésta, aún confrontándola con la que exhiba un parentesco más cercano. Se exige demostrar el incumplimiento del deber de informar que pesaba en cabeza del proveedor, sin necesidad de acreditar la existencia un vicio en el consentimiento, en el sentido tradicional y con los recaudos impuestos por la norma civil. A tenor de la norma citada, no es necesario indagar acerca de la efectiva afectación de la voluntad del consumidor o usuario, que para el legislador se presumiría. Se trata de una solución legal que armoniza con el fundamento y la finalidad de la obligación de informar impuesta al proveedor de bienes y servicios. Como se advierte, el criterio adoptado ofrece un correctivo notoriamente más ventajoso para el consumidor. No obstante las observaciones que pudiéramos formular en relación a la naturaleza de la acción reconocida al consumidor por vía del citado precepto legal, confrontándolas con las soluciones que el propio art. 37 de la ley prevé, lo cierto 
El objetivo perseguido por la norma -propiciar una suerte de consentimiento informado- se instrumenta entonces, recurriendo a tres herramientas: el establecimiento de un deber de información particular al proveedor de crédito, la imposición de formalidades al contrato que corporiza la relación jurídica entre el agente financiero y el consumidor y la sanción de nulidad en caso de infracción.

Con la reforma introducida al art. 36 por la Ley $\mathrm{N}^{\circ} 26.361$ en el año 2008, el precepto incorpora a su regulación una nueva previsión, de singular importancia. Se trata del contrato de consumo vinculado a un contrato de crédito. La norma traduce en un dispositivo particular la regla de la accesoriedad, al establecer que la existencia y operatividad del contrato de consumo estará condicionada al efectivo otorgamiento de la financiación.

Reza el precepto analizado: "La eficacia del contrato en el que se prevea que un tercero otorgue un crédito de financiación quedará condicionada a la efectiva obtención del mismo. En caso de no otorgamiento del crédito, la operación se resolverá sin costo alguno para el consumidor, debiendo en su caso restituírsele las sumas que con carácter de entrega de contado, anticipo y gastos éste hubiere efectuado".

Si bien se trata de un dispositivo aislado, la doctrina ha recibido con beneplácito que la ley contemple esta arista problemática del tema ${ }^{326}$, caracterizada por la irrupción de un tercero que actúa como agente financiero y posibilita la adquisición de bienes y la contratación de servicios con el proveedor.

Como bien lo advierte FARINA ${ }^{327}$, ya la doctrina venía pregonando desde hace tiempo, la necesidad de profundizar el estudio de la conexidad contractual para justificar la aplicación de correctivos adecuados frente a las diferentes hipótesis de conflicto que pueden presentarse en el contrato de crédito para el consumo ${ }^{328}$.

es que el consumidor cuenta con remedios o correctivos propios, adecuados a la naturaleza de los derechos afectados y a la impronta del sistema.

${ }^{326}$ SAuX, Edgardo I.-Muller, Enrique C., Comentario al art. 36..., cit., pág. 428.

${ }^{327}$ FARINA, Juan M., Defensa del consumidor..., cit., pág. 391.

${ }^{328}$ Ver SOzZO, G., "Interpretación y otros efectos de la complejidad negocial (¿Para qué puede servir vincular los contratos?", en Revista de Derecho Privado y Comunitario, 2007-2, Rubinzal Culzoni, Santa Fé, 2007, pág. 311-337.; LoRENZETTI, Ricardo L., Tratado de los contratos, T. I, cit., pág. 42 y sgtes.; LORENZETTI, Ricardo L., "Redes contractuales: conceptualización jurídica, relaciones internas de colaboración, efectos 
Aunque la jurisprudencia ya aludió en algunos precedentes a la situación de conflicto analizada ${ }^{329}$, resulta saludable la previsión normativa expresa. Como lo señalan SAUX y MULLER ${ }^{330}$, "la ley de defensa del consumidor no abordaba las cuestiones de coligación más usuales" y "la cuestión adquiere relevancia dado que con frecuencia, para acceder a bienes o servicios en el mercado, se le impone al consumidor la necesidad de recurrir a la asistencia financiera de un sujeto distinto del proveedor, generalmente una entidad crediticia indicada por éste en virtud de un acuerdo de colaboración suscripto entre ellos".

La consagración de esta solución legal deja, de todas formas, sin precisar algunas cuestiones que pueden poner en riesgo la aplicación del dispositivo.

La norma establece que en caso de conexidad, la eficacia del contrato de consumo estará condicionada al efectivo otorgamiento del crédito. Ahora bien, puede que ello se haya previsto expresamente en el contrato pertinente y, en ese supuesto, no existirá riesgo de conflicto alguno. Pero la conexidad contractual puede no resultar explícita y aquí es donde se avizoran los problemas. Consideramos que aunque el texto legal menciona que la solución allí consagrada está prevista para el supuesto en que esta vinculación contractual "se prevea", la disposición no debe ser interpretada en un sentido literal. En primer lugar, porque si las partes han condicionado expresamente la existencia o eficacia del contrato de consumo a la obtención del crédito con un tercero, no hacía falta un dispositivo legal que así lo reconociera. En segundo lugar, porque el criterio propiciado sólo se explica en función de los principios que sustentan la teoría de la conexidad contractual y la noción de frente a terceros", Revista de Derecho del Consumidor, No 28, pág. 22/29; LORENZETTI, Ricardo L., "Cuál es el cemento que une las redes de consumidores, de distribuidores o de paquetes de negocios? (aproximación a la conexidad contractual como fundamento imputativo)", LL 1995-E,1013; LORENZETTI, Ricardo L., "Redes Contractuales, contratos conexos y responsabilidad"; en Revista de Derecho Privado y Comunitario, No 17 , Rubinzal Culzoni, Santa Fe, 1998, pág. 207-261; MosSET ITURRASPE, Jorge, Contratos Conexos, Grupos y redes contractuales, Rubinzal Culzoni, Santa Fe, 1999; ToBÍAS, José W.- De Lorenzo, Miguel F., "Complejo de negocios unidos por un nexo (el ligamen negocial)", $L L-\mathrm{D}, 1387$; WEINGARTEN, Celia-GHERSI, Carlos A.., "Los contratos conexados", en LL 1997-F-1348.; entre otros.

${ }^{329}$ C. Cont. Adm. y Trib. Ciudad De Buenos Aires, Sala 2, sentencia N 918 del 23/4/2002, “Comisión Municipal de la Vivienda c/Sazatornil, Vanesa Carina s/Aut adm.” (cfr. http://www.infojus.gob.ar/docsf/dossier-f/defensa_del_consumidor.pdf, Fecha de consulta: 26/8/2015).

${ }^{330}$ SAuX, Edgardo I.-Muller, Enrique. C., Comentario al art. 36..., cit., pág. 431. 
causa del negocio. Y en esa línea de interpretación es que siempre que se pueda demostrar la existencia de una operación global o un negocio único, -más allá de los contratos que lo instrumenten y de los sujetos que intervengan- deberá entenderse que las vicisitudes del contrato de crédito incidirán en la esfera del contrato de consumo y a la inversa ${ }^{331}$.

No podemos sino lamentar que esta previsión particular del art. 36, referida a los contratos de crédito vinculados a los de consumo, haya quedado a medio camino. Son varias las aristas problemáticas a resolver en los contratos de crédito para el consumo y urge dar respuesta a las mismas. Las sucesivas reformas al art. 36 de la Ley $\mathrm{N}^{\circ} 24.240$ dejaron pasar la oportunidad de cumplir una de las asignaturas pendientes, referidas a las demás situaciones de conflicto derivadas de la conexidad contractual en la materia. Sigue sin existir una solución legal para la hipótesis de incumplimiento total o parcial del proveedor de bienes y servicios y la incidencia de este supuesto en el contrato de crédito vinculado. Lamentamos que no se han recogido aún las valiosas propuestas del Derecho Comparado $^{332}$ y que los aspectos regulados ofrezcan soluciones insuficientes para satisfacer la protección que se reclama ${ }^{333}$.

Advertimos, sin embargo, que la regulación del fenómeno de la conexidad contractual en el Código Civil y Comercial unificado (art. 1073 a 1075) ofrece ahora la riqueza de su contenido y permite dar respuesta a muchos de los problemas que pueden presentarse en la operatoria del crédito al consumo ${ }^{334}$. Las soluciones allí establecidas

\footnotetext{
331 JAPAZE, MARÍA BELÉN, María Belén, “Crédito al consumo ...”, cit.

${ }^{332}$ Sólo por citar un ejemplo, mencionamos a la Ley 16/2011 de Contratos de Crédito al Consumo española.

${ }^{333}$ Este tema es objeto de análisis en JAPAZE, María Belén, "Crédito al consumo..., cit.

334 Dentro del Libro III referido a los Derechos Personales, el Título II está dedicado a los Contratos en General; y en su desarrollo, el Capítulo 12 regula "Los contratos conexos". Son tres las normas que lo integran. Dispone el art. 1073: "Definición. Hay conexidad cuando dos o más contratos autónomos se hallan vinculados entre sí por una finalidad económica común previamente establecida, de modo que uno de ellos ha sido determinante del otro para el logro del resultado perseguido. Esta finalidad puede ser establecida por la ley, expresamente pactada, o derivada de la interpretación, conforme con lo que se dispone en el artículo 1074". Por su parte, el art. 1074 establece: "Interpretación. Los contratos conexos deben ser interpretados los unos por medio de los otros, atribuyéndoles el sentido apropiado que surge del grupo de contratos, su función económica y el resultado perseguido". Finalmente, el art. 1075 reza: "Efectos. Según las circunstancias, probada la conexidad, un contratante puede oponer las excepciones de incumplimiento total, parcial o defectuoso, aún frente a la inejecución de obligaciones ajenas a su contrato. Atendiendo al principio de la
} 
aportan todo su caudal, integrándose al sistema protectorio en una muestra más de la pluralidad de fuentes que lo integran ${ }^{335}$.

No obstante las lagunas antes mencionadas, el art. 36 analizado contiene aspectos positivos tales como la ya citada imposición de formalidades al instrumento que formaliza el crédito para el consumo, la previsión de cargas informativas especiales al proveedor del crédito, la regulación de algunos aspectos de la conexidad contractual y la consagración de un deber de control de cumplimiento de las disposiciones de la norma analizada al Banco Central de la República Argentina ${ }^{336}$.

Destacamos como positivo que, en el último párrafo del citado art. 36, el legislador haya definido una cuestión conflictiva, vinculada al juez competente para decidir las controversias que puedan suscitarse con motivo de los contratos de crédito al consumo. La disposición legal define la suerte de las cláusulas contractuales que disponen una prórroga de la jurisdicción, pretendiendo que las acciones judiciales fundadas en estos contratos se diriman por ante el juez del domicilio del proveedor. Con esta cláusula inserta en el contrato, se imponía a los consumidores litigar en extraña jurisdicción desalentando los reclamos que pudieran formular a los proveedores y agentes financieros; y en caso de ser los consumidores los demandados, debían soportar los costes personales y económicos que supone llevar adelante la defensa de sus intereses en una jurisdicción distinta a la de su domicilio.

Con el agregado introducido al final del precepto, se deja establecido que "será competente para entender en el conocimiento de los litigios relativos a contratos regulados

\footnotetext{
conservación, la misma regla se aplica cuando la extinción de uno de los contratos produce la frustración de la finalidad económica común".

${ }^{335}$ Invitamos al lector interesado a analizar la riqueza de la regulación de los contratos conexos contenida en el nuevo Código Civil y Comercial. Ver HeRnÁndez, Carlos A., en LoREnZETTI, Ricardo L. (Dir.), Código Civil y Comercial de la Nación Comentado, T. VI, Rubinzal-Culzoni, Santa Fe, 2015, pág.153-162; Alterini, Jorge (Dir.), Código Civil y Comercial Comentado. Tratado exegético, T. V, La Ley, Buenos Aires, 2015, pág. 643-655; RIVERA, Julio César-MEDINA, Graciela (Dir.), Código Civil y Comercial de la Nación Comentado, T. III, La Ley, Buenos Aires, 2014, pág. 627-631.

${ }^{336}$ Dispone en su texto el art. 36 citado: "El Banco Central de la República Argentina adoptará las medidas conducentes para que las entidades sometidas a su jurisdicción cumplan, en las operaciones a que refiere el presente artículo, con lo indicado en la presente ley".
} 
por el presente artículo, en los casos en que las acciones sean iniciadas por el consumidor o usuario, a elección de éste, el juez del lugar del consumo o uso, el del lugar de celebración del contrato, el del domicilio del consumidor o usuario, el del domicilio del demandado, o el de la citada en garantía. En los casos en que las acciones sean iniciadas por el proveedor o prestador, será competente el tribunal correspondiente al domicilio real del consumidor, siendo nulo cualquier pacto en contrario".

En mérito a lo dispuesto por la norma transcripta, cuando el consumidor sea el accionante, podrá optar entre distintas sedes para demandar al proveedor; pero cuando sea demandado por éste, sólo será competente el juez que corresponda al domicilio del consumidor. El criterio legal impuesto constituye una eficaz herramienta para desbaratar prácticas lesivas de los intereses de los consumidores, históricamente cristalizadas en cláusulas que fueron calificadas como abusivas y que ha costado remover.

\section{B.- Herramientas legales vigentes de contenido instrumental o procedimental}

El Derecho concursal cuenta con principios, instituciones y reglas que justifican la autonomía del sistema. El proceso concursal diseñado por el legislador es el cauce en el que se incardinan las soluciones propuestas para el abordaje de la problemática de la insolvencia.

El tradicional debate vinculado a si debe existir un proceso concursal único para cualquier tipo de deudor (empresario o no empresario) o regímenes diferenciados, es de larga data. En nuestro país, el sistema normativo concursal está unificado y no obstante algunas voces críticas, existe un marcado consenso respecto de la conveniencia de esta modalidad. El régimen comprende a toda la gama de deudores en estado de insolvencia: personas jurídicas (sociedades comerciales, asociaciones sin fines de lucro, entidades mutuales, etc.) y personas físicas (empresarios y no comerciantes, cuentapropistas y asalariados, jubilados, amas de casa, etc.).

En lo que aquí interesa, la ley concursal dedica dos normas específicas a una figura (la de los "Pequeños Concursos y Quiebras") que es, en el sistema argentino, el único cauce posible para la superación de la situación de insolvencia de los consumidores, que aquí nos ocupa. 
Dice el art. 288: "Concepto. A los efectos de esta ley se consideran pequeños concursos y quiebras aquellos en los cuales se presente, en forma indistinta, cualquiera de estas circunstancias:

1- que el pasivo denunciado no alcance la suma de CIEN MIL PESOS (\$100.000.-);

2- que el proceso no presente más de VEINTE (20) acreedores quirografarios;

3- que el deudor no posea más de VEINTE (20) trabajadores en relación de dependencia”.

Agrega el art. 289: "Régimen aplicable. En los presentes procesos no serán necesarios los dictámenes previstos en el artículo 11, incisos 3 y 5, la constitución de los comités de acreedores y no regirá el régimen de supuestos especiales previstos en el artículo 48 de la presente ley. El controlador del cumplimiento del acuerdo estará a cargo del síndico en caso de no haberse constituido comité de acreedores. Los honorarios por su labor en esta etapa serán del 1\% (uno por ciento) de lo pagado a los acreedores".

Pese a que en este Capítulo IV de la Ley de Concursos y Quiebras se ha diseñado un proceso concursal sujeto a reglas especiales -dadas las particularidades de la situación del deudor- resulta evidente que las normas citadas, luego de definir su ámbito de aplicación, poco o nada dicen sobre el trámite que justificaría la especialidad del mismo. Estos pequeños concursos terminan siendo más de lo mismo. De allí que la crítica de los autores no se haya hecho esperar.

MAFFíA ${ }^{337}$ marca con ironía esta paradoja, al decir que la ley de concursos y quiebras argentina en sus arts. 288 y 289, determina cuáles son los casos de pequeñas quiebras y de pequeños concursos, pero "se limitó a bautizarlos [...] sin fijar un procedimiento que aligerase los pasos que hacen al trámite común en materia concursal”. Advierte "que por pequeña que sea una quiebra, tramitará como las adultas; por pequeño que sea un concurso preventivo, padecerá de la inmodificada y aún acrecida pesantez del régimen anterior".

JUNYENT BAS y MOLINA SANDOVAL señalan que las diferencias en el trámite, esbozadas en el art. 289 de la LCQ, no son significativas por lo que "la duración del proceso, los requisitos de presentación, la publicación edictal, el régimen de insinuación y

\footnotetext{
${ }^{337}$ MAfFIA, Osvaldo J., La ley de concursos comentada, T. II, Lexis Nexis, BA, Buenos Aires, 2002, pág. 373. El autor desarrolla esta ideas en el Capítulo LVIII de la obra citada, bajo el título "Procedimiento especial (sólo que sin procedimiento especial) para los pequeños concursos".
} 
revisión de créditos, sus accesorios (imposición de costas, gastos, intereses, etc.), los principios concursales, las tasas tributarias, los funcionarios concursales y sus honorarios, el mecanismo de obtención de mayorías, los supuestos de quiebra indirecta, el régimen de los hipotecarios y muchísimos otros institutos tienen aplicación similar, sin distinguir entre pequeños y grades concursos" ${ }^{, 338}$.

En igual sentido se ha expresado que las "nimias diferencias" de trámite consagradas por el art. 289, "no alcanzan para tener por configurado un trámite sustancialmente diferente [...] pues ni la secuencia procesal de los actos por cumplirse ni la estructura general del proceso aparecen alteradas" ${ }^{339}$.

Un sector de la doctrina ha calificado al pequeño concurso como un trámite caracterizado simplemente por "diferencias cosméticas" respecto del proceso concursal ordinario, lamentando la "oportunidad perdida" para asumir un tratamiento serio y eficaz de la problemática del endeudamiento excesivo de las personas físicas ${ }^{340}$.

Desde otro enfoque, una opinión crítica advierte que tampoco "se trata de un problema de tamaño y de procedimiento" sino más bien de la falta de un tratamiento acorde para la problemática del sobreendeudamiento del consumidor ${ }^{341}$.

KEMELMAJER DE CARLUCCI destaca que esa insatisfacción generalizada coincide en reclamar un cambio en el sistema vigente pero a renglón seguido advierte que esas voces críticas impulsan tales cambios, por motivos y con objetivos diversos ${ }^{342}$.

Por una parte, los impulsores de las reformas persiguen el nuevo diseño de la figura de los pequeños concursos sin que entorpezca el trámite del proceso concursal general u ordinario, ni la labor de los fueros: se habla de "descongestionar el trabajo judicial, de

\footnotetext{
338 Junyent Bas, Francisco.-Molina SAndoval, Carlos. A., Facultades del juez concursal, Advocatus, Córdoba, 2004, pág. 280.

${ }^{339}$ BARREIRO, Rafael, "Precisiones acerca de concursos pequeños...”, cit., pág. 567 y sgtes.

340 Fragapane, Héctor R.-GAMES, Fernando Gabriel, "Juguemos a los concursos", en TrufFAt, DanielBarreiro, Marcelo-Antoni PiosseK, Carlos Roberto- NicAStro, Ramón Vicente (Coord.), Libro Homenaje al Doctor Osvaldo Maffía, Lerner Editora, Córdoba, 2008, pág. 597-608.

341 ANCHAVAL, Hugo., "Sobreendeudamiento de consumidores y responsabilidades subyacentes", en Truffat, D.-Barreiro, M.-Antoni Piossek, C.- Nicastro, R. (Coord.), Libro Homenaje al Doctor Osvaldo Maffía, Lerner Editora, Córdoba, 2008, pág. 619/627.

${ }^{342}$ KEMELMAJER DE CARLUCCI, Aída, “El sobreendeudamiento del consumidor..., cit.
} 
aliviar la carga de trabajo que pesa sobre la jurisdicción y la sindicatura, de evitar trámites complejos y económicamente dispendiosos, de acelerar los procesos, de realizar rápidamente los bienes para facilitar el cobro de las acreencias y de terminar rápidamente un concurso que a nadie beneficia". Y de allí que "las propuestas pasan por abreviar los plazos de publicación de edictos, o publicar menos edictos para abaratar los costos, simplificar la verificación, eliminar la verificación tardía y el recurso de revisión, eliminar la sindicatura, restringir aún más la apelabilidad o que todas las apelaciones sean resueltas en forma conjunta en no más de tres oportunidades que la ley debe determinar, prever que la clausura del procedimiento produzca la caducidad de todas las deudas anteriores cuyos titulares no se hubiesen presentado a verificar, que la clausura pueda disponerse aún cuando no se haga distribución alguna, etc." ${ }^{343}$.

Desde otro enfoque, se reclama que la problemática del sobreendeudamiento del consumidor tenga un tratamiento propio, especial y diferenciado. Esta corriente de opinión exhibe dos vertientes. Por un lado, se propugna diseñar un capítulo dentro de la misma ley concursal, distinguiendo categorías de sujetos endeudados (empresas, personas físicas/consumidores) y procedimientos para cada caso, en un todo de acuerdo a los objetivos perseguidos en cada supuesto, esto es, satisfacer prioritariamente el interés de los acreedores o priorizar el rescate del consumidor endeudado y la protección de su familia) ${ }^{344}$. Por otra parte, se propone la regulación de la problemática bajo la impronta

\footnotetext{
${ }^{343}$ Con cita de los autores que formulan esas propuestas, lo expresa KEMELMAJER DE CARLUCCI, Aída, "El sobreendeudamiento del consumidor y la respuesta del legislador francés”, en Anales, Año LIII, Segunda Época, cit..

344 Ver los valiosísimos trabajos de AlEGRía Héctor, "Los llamados pequeños concursos. Concursos de personas físicas, consumidores, patrimonios reducidos”, en ANAYA, Jaime-ALEGRíA, Héctor (Dir.), Derecho Comercial-Doctrinas Esenciales-Concursos y Quiebras, T. I, La Ley, Buenos Aires, 2008, pág. 787 y sgtes.; RIVERA, Julio César, "Insolvencia de las personas físicas..., cit., pág. 4; BARREIRO, Marcelo-LORENTE, JAVIER A.-TRUfFAT, E. Daniel, "Del traje de confección al de medida: los procesos concursales deben tener una regulación diversa según su magnitud", Ponencia presentada en el IV $^{\circ}$ Congreso Iberoamericano de Derecho Concursal; Barreiro, Marcelo-LOREnTE, JAVIER A.-TrufFAT, E. Daniel, "Proyecto de ley que regula el concurso mínimo", Ponencia presentada en el IV ${ }^{\circ}$ Congreso Iberoamericano de Derecho Concursal. En esta línea, el VII ${ }^{\circ}$ Congreso Nacional de Derecho Concursal y V Congreso Iberamericano de la Insolvencia desarrollado en octubre de 2009 en Mendoza, cuya Comisión $\mathrm{N}^{\circ} 1$ se abocó al tema del "concurso del consumidor", recomendó: la previsión de soluciones alternativas de justicia privada, como el arbitraje, la
} 
tutelar, dentro de la ley general de defensa de los consumidores y usuarios o bien ley especial mediante, donde las soluciones se encaminen prioritariamente a la prevención, y con medidas de saneamiento para aquellas situaciones de endeudamiento excesivo irreversiblemente constatadas.

Entre ambos extremos, alzan sus voces quienes propugnan asumir el tratamiento de la situación recurriendo a cauces y métodos alternativos de resolución de controversias, señalando las bondades de esta opción para la superar la crisis del sobreendeudamiento del consumidor $^{345}$.

conciliación, la mediación o concordato administrativo ante el órgano de defensa al consumidor; y ante el fracaso de estas variantes, transitar la una instancia judicial, mediante la previsión de un procedimiento abreviado y dinámico. Se propuso: el funcionamiento de una justicia simple y económica, a cargo de jueces letrados o vecinales; diseñar un procedimiento análogo al acuerdo preventivo extrajudicial, pero más acotado; regular el trámite de un procedimiento especial -denominado "concurso mínimo": un proceso breve, con una única entrada, orientada a la reestructuración del pasivo y con amplias facultades judiciales; ofrecer al consumidor sobreendeudado la oportunidad de la rehabilitación.

${ }^{345}$ CRISTÓFARO, Giovanna E., "La conveniencia del uso de técnicas de resolución alternativa de conflictos por las pymes, los consumidores y los concursados”, en ANTONI PIOSSEK, C. (Dir.), Resoluciones alternativas de conflictos en la crisis de la empresa y el consumidor. Libro homenaje al Doctor Francisco Junyent Bas, Lerner Editora, Córdoba, 2010, pág. 113-129. 


\section{TERCERA PARTE}

\section{VI.- La regulación del fenómeno del sobreendeudamiento en Argentina}

\section{A.- Regular o no regular. Necesidad de una regulación integral y sistematizada. Fundamentación.}

Frente al fenómeno del endeudamiento, un sector de la doctrina se ha preguntado sobre la necesidad de su regulación ${ }^{346}$. En la actualidad, este interrogante inicial constituye un planteo superado.

Entendemos que regular o no regular, no es la cuestión. No existen alternativas a evaluar. Regular sobre la materia es una necesidad, un imperativo ${ }^{347}$.

\footnotetext{
${ }^{346}$ ROJO FERNÁNDEZ-Río, Ángel, “Problemas y cuestiones...”, cit., pág. 254.
}

${ }^{347}$ En otra oportunidad, tuvimos ocasión de expresar que las regulaciones responden a una visión crítica en cuanto al funcionamiento libre del mercado y de los intercambios voluntarios. Advertíamos que con fundamento en las fallas del mercado -y luego de la adopción de una decisión política determinada- las normas de intervención procuran modificar el desarrollo de la actividad económica. Señalamos que la nota típica de la regulación consiste en la interferencia pública, al abanico de opciones abiertas al individuo. Decíamos que el Estado no sustituye la actividad regulada sino, que desvía lo que ocurriría de otra manera, invadiendo esferas de relación de los particulares. Reflexionábamos entonces acerca del fracaso de un modelo intervencionista pero insistíamos en que el proceso desregulatorio no debía ser entendido como la abdicación de potestades estatales, encaminadas a compatibilizar los derechos e intereses individuales con los bienes colectivos y el interés general. Sosteníamos que un modelo de equilibrio exige del Estado una toma de decisión. Insistíamos en que resulta inaceptable la existencia de un Estado fugitivo, despreocupado de la tutela de los sujetos involucrados en las relaciones que propicia el intercambio moderno y, especialmente, de los hiposuficientes en materia negocial. Consideramos que el mercado no se protege dejando librado el escenario económico a sólo uno de los actores de la relación de consumo, so pretexto de "no intervenir". En esa línea de razonamiento dijimos que la economía de mercado de ningún modo se opone al deber del Estado de asumir un rol activo en la protección de los intereses involucrados por la relación de consumo. Entendemos que ésta es una falsa contradicción de quienes venden un discurso de exportación, insostenible en los países serios, que se interesan por resguardar al mercado de prácticas irregulares. Y concluíamos diciendo que "en un mercado como el que deseamos, el secreto parece estar en advertir que cada sujeto forma parte de un todo, que debe funcionar con libertades y lealtades recíprocas. Sólo protegiendo a todos (empresarios, competidores y consumidores) y no sólo a algunos de los eslabones de la cadena productiva, se protege al mercado y, con éste, el pleno ejercicio de los derechos individuales" (JAPAZE, María Belén., "El Derecho del Consumo y el 
El mandato constitucional de proteger los derechos del consumidor y entre ellos, el acceso a los bienes, a su dignidad y a sus intereses económicos (art. 42 de la Constitución Nacional; art. 51 de la Constitución Española), impone al Estado el deber de dictar normas de intervención que hagan propia la preocupación por las consecuencias derivadas del endeudamiento excesivo.

Razones diversas justifican la regulación del fenómeno. Por un lado se invocan razones de mercado, dado el rol que los consumidores cumplen en el sistema. Son los consumidores lo que estimulan la producción y la comercialización de bienes y servicios; son los consumidores los que movilizan los recursos y las economías; se ha entendido que sin consumidores no hay crecimiento ni desarrollo posible ${ }^{348}$. Por otra parte, y más importantes, son las razones de índoles humanitaria y social que hacen innegable e impostergable la necesidad de una política integral en materia de sobreendeudamiento y el dictado de normas de contenido sustancial y procedimental destinadas a la prevención y curación de este mal particular y social.

Las graves consecuencias del sobreendeudamiento definen un cuadro de situación que no puede ser consentido con la mirada esquiva y la voz silente del conjunto social; menos aún de los poderes públicos ${ }^{349}$. En esta línea de interpretación, la Corte de Casación

replanteo de algunas antinomias tradicionales", en Revista Crítica de Derecho Privado, № 5, Carlos Álvarez Editor, Montevideo, 2008, pág. 693-713).

${ }^{348}$ Cobran renovado valor las palabras pronunciadas por el Presidente de los EEUU, décadas atrás: "Los consumidores constituyen el gripo económico más importante y se hallan interesados en casi todas las decisiones económicas públicas y privadas; sus gastos representan las dos terceras partes de los gastos económicos totales. Pero sin embargo, es el único grupo en la economía que no está realmente organizado, y por eso, no es tenido en consideración" (Mensaje especial al Congreso, sobre protección de los consumidores, pronunciado por John Fitzgerald KenNEDY el 15 de marzo de 1962).

349 Señala PUlgar EzQuerRA: “...El art. 51 CE consagra constitucionalmente la protección de los consumidores imponiendo a los poderes públicos el mandato de garantizar su defensa, protegiendo mediante procedimientos adecuados, entre otro, los legítimos intereses económicos de los consumidores, entre los que se sitúa la racionalización de sus problemas económicos con arreglo a criterios de justicia y equidad, y todo ello en el marco de las prestaciones del Estado social de bienestar" (Pulgar EZquerRa, Juana, "Concurso y consumidores...", cit., pág. 43 y sgtes.). 
francesa ha calificado a la regulación del sobreendeudamiento como norma de orden público económico de protección social ${ }^{350}$.

La preocupación por la situación del deudor no es nueva, claro está. El principio de favor debitoris se asienta sobre la idea de que, como regla, el sujeto pasivo de la relación obligacional es un débil jurídico, precisado de protección ${ }^{351}$. De allí que ya los códigos civiles decimonónicos advertían que el principio de autonomía de la voluntad y la fuerza vinculante del contrato no autoriza a entender que el derecho del acreedor todo lo arrasa y que el deudor -que afronta dificultad o imposibilidad de pago- puede quedar convertido en un muerto civil ${ }^{352}$.

En la actualidad, y a la luz del principio de protectorio ya acogido por la regulación privatista, aquéllos postulados redoblan la apuesta, sosteniendo que al consumidor sobreendeudado no sólo se lo debe auxiliar a fin de sortear su situación sino que además, hay que "garantizarle, al menos, la esperanza de que su situación mejorará"353.

En Argentina, al igual que en España -hasta hace muy poco- ${ }^{354}$, la doctrina viene reclamando al Congreso Nacional, la regulación de la problemática ${ }^{355}$. Se trata de un

${ }^{350}$ Kemelmajer De CARLuCCI, Aída, Aída, "El sobreendeudamiento del consumidor..., cit.

${ }^{351}$ Ver la evolución del principio de debilidad jurídica, en los trabajos señeros de ALTERINI, Atilio AníbalLÓPEZ CABANA, Roberto M., “La debilidad jurídica...”, cit., pág. 88, ALTERINI, Atilio Aníbal- LóPEZ CABANA, Roberto M., "La debilidad jurídica en la contratación conemporánea", D.J., 1998-I-817; LÓPEZ Cabana, Roberto M., "Defensa jurídica de los más débiles”, en Revista de Direito do Consumidor $\mathrm{N}^{\circ} 28$, Editora Revista dos Tribunais, San Paulo, 1998, pág. 7/21. Asimismo, LORENZETTI, Ricardo Luis, "El Derecho Privado como protección del individuo particular", en Revista de Derecho Privado y Comunitario, N 7, Derecho Privado en la reforma constitucional, Ed. Rubinzal-Culzoni, Santa Fé, 1.994, pág. 53.

352 Lima Marques, Claudia-LunARdelli CAVAllaZZI, Rosángela, Direitos do consumidor endividado..., cit., pág. 12. Profundizaremos este tema ut infra.

353 Con cita de doctrina francesa, en Kemelmajer DE CARLuCCI, Aída, "El sobreendeudamiento del consumidor..., cit.

${ }^{354}$ Ver las agudas consideraciones que sobre el particular se formulan en ZABALETA, M., El concurso del consumidor, Anuario Facultad de Derecho, Universidad de Alcalá III, Alcalá de Henares, 2010, pág. 301/331. Asimismo, PUlgar EzQuERrA, Juana, “Concurso y consumidores ...”, cit., pág. 43 y sgtes.

355 AlegríA, Héctor, "Los llamados pequeños concursos...”, cit.; FARHI DE MonTALVÁN, Diana, "La insolvencia del consumidor: un problema social globalizado que debe preocupar a la comunidad", Ponencia presentada en el $\mathrm{IV}^{\circ}$ Congreso Iberoamericano sobre Insolvencia; BARREIRO, Marcelo, "Una aproximación al fenómeno del sobreendeudamiento del consumidor y su necesaria regulación”, Ponencia presentada en el $\mathrm{IV}^{\circ}$ 
reclamo fundado en la constatación de que los problemas derivados de la situación de sobreendeudamiento no pueden ser resueltos con los instrumentos legales disponibles en nuestro ordenamiento jurídico.

El congreso de civilistas más importante de Argentina incluyó, en la agenda de temas, la problemática mencionada; y consideró impostergable un pronunciamiento que movilizara a los operadores políticos y jurídicos. De allí que al celebrarse las $\mathrm{XXIV}^{\circ}$ Jornadas Nacionales de Derecho Civil en Buenos Aires, entre los días 26 y 28 de setiembre de 2013, se encomendara a la Comisión $\mathrm{N}^{\circ} 8^{356}$ el tratamiento y debate de las principales aristas en conflicto. Las conclusiones reflejan la preocupación por la situación, expresando que "los mecanismos regulados en la actual ley de quiebras son insuficientes para solucionar el sobreendeudamiento de los consumidores" y que "resulta necesario el dictado de una legislación especial, bajo el imperio de los principios del Derecho del Consumidor, que aborde de manera integral medidas de prevención, saneamiento, reparación y rehabilitación para los casos de sobreendeudamiento de los consumidores" (conclusión $\mathrm{N}^{\circ}$ $10)$.

Congreso Iberoamericano de Derecho Concursal sobre Crisis económica mundial y la concursalidad; TRUFFAT, E. Daniel, "Pequeños concursos: lineamientos para la regulación del concurso pequeñísimo (y en especial, el concurso del consumidor)”, Ponencia presentada en el IV $^{\circ}$ Congreso Iberoamericano de Derecho Concursal sobre Crisis económica mundial y la concursalidad; BARREIRO, Marcelo-LORENTE, JAVIER A.TrufFAT, E. Daniel, "Del traje de confección al de medida: los procesos concursales deben tener una regulación diversa según su magnitud”, Ponencia presentada en el $\mathrm{IV}^{\circ}$ Congreso Iberoamericano de Derecho Concursal; BARREIRO, Rafael, "Precisiones acerca de concursos pequeños...", cit., pág. 567 y sgtes.; JUNYENT BAS, Francisco, "El empleado público sobreendeudado y la pérdida de la fuente de trabajo", en LL 2010-B,1264; JUNYENT BAS, Francisco-IZQUIERDO, Silvina, "El consumidor sobreendeudado y el derecho a quebrar. A propósito de la búsqueda de la rehabilitación y la limpieza del pasivo preexistente", Semanario Jurídico $N^{\circ} 1734$ del 26/11/2009, pág. 757; CRISTÓFARO, Giovana E., "procedimiento especial para el sobreendeudamiento de personas físicas con ingresos fijos", Ponencia presentada en el $\mathrm{V}^{\circ}$ Congreso Iberoamericano sobre Insolvencia; entre muchos otros.

${ }^{356}$ La Comisión $\mathrm{N}^{\circ} 8$ de esas Jornadas Nacionales de Derecho Civil estuvo presidida por Gabriel STIGLITZ, Carlos A. Hernández y Celia Weingarten. En el marco del debate desarrollado en esa Comisión presentamos con coautoría con el profesor Gabriel STIGLITZ y Sebastián BAROCELLI, una ponencia titulada "Sobreendeudamiento de los consumidores. Visibilización de la problemática para su prevención, tratamiento, rehabilitación y saneamiento" que sometimos a la consideración de los presentes, recogiéndose algunos de los postulados allí desarrollados, en las conclusiones finales. 
En el ámbito mercantil, el $\mathrm{V}^{\circ}$ Congreso Iberoamericano sobre la Insolvencia y el VII $^{\circ}$ Congreso Argentino de Derecho Concursal realizados en Mendoza entre el 4 y el 7 de octubre de 2009, propusieron el tratamiento del tema en la Comisión 1, dedicada a "El sobreendeudamiento del Consumidor. Alternativas para su solución”. Un importantísimo número de ponencias destacaban la imperiosa necesidad de una regulación particular de la problemática $^{357}$. Se sucedieron numerosas convocatorias académicas en el ámbito del

${ }^{357}$ Cfr. las ponencias de ALONSO, Daniel, "El sobreendeudamiento de la persona física no comerciante frente a los procesos concursales"; ANCHAVAL, Hugo Alberto, "Ideas para una legislación sobre insolvencia del consumidor", además de "No country for de poor: a propósito del acceso de los consumidores pobres al sistema concursal" y "La regla de la liquidación de bienes en la quiebra del consumidor como minor rule"; ANTONIO, Ariel, "Procedimiento especial para el sobreendeudamiento del persona físicas con ingresos fijos"; ANTÚNEZ, María Alejandra, "Sobreendeudamiento del consumidor"; AIL, Gabriel Marcelo y MARTín, Lidia Roxana, "Tribunales arbitrales de consumo"; BARREIRO, Marcelo, "Sobre la prevención del sobre consumo" y "Pautas para la regulación de un procedimiento para los concursos mínimos"; Beltramo, Nicolás, QUIROGA, Hernán y RodRíGUEZ, Juan Manuel, "Concurso y quiebra del consumidor"; Borgarello, Luisa, "El concurso del consumidor: algunas reflexiones"; CERINI, Valentín Javier, "El uso el abuso del sistema concursal por el consumidor final"; CORTEZ, Gloria Esther y GONZÁLez MASANÉs, Pablo, "Sobreendeudamiento del consumidor. Propuesta de lege lata para su tratamiento hasta tanto se cuente con una adecuada respuesta legislativa"; CURVALE ACEVEDO, Darío, "El sobreendeudamiento del consumidor y el concurso preventivo"; DEL PinO, Silvina María, ¿Cómo solucionar el problema del sobreendeudamiento consumidor? Hacia una propuesta que propicie la eficiencia y evite el malgaste jurisdiccional"; DE CESARIS, María Cristina, Dos SANTOS FreiRe, María Betania y WeidmAnN, Gabriela, "La quiebra directa a instancia del consumidor sobreendeudado"; DuARTE, María Luisa y SCHOTT, Mateo Germán, "La corresponsabilidad de las entidades financieras en el sobreendeudamiento del consumidor"; DuARTE, María Luisa y SCHOTT, Mateo Germán, "Posibles soluciones al sobreendeudamiento pasivo"; FARHI DE MONTALbán, Diana V., "Tratamiento de la insolvencia del consumidor. Una asignatura pendiente"; FIlIzzola, Gustavo, Romero, Juan Carlos, Ruiz Vega, Ricardo y TABASCo, Carlos, "Los concursos de empleados públicos"; GARCía, Silvana Mabel: "Créditos que deberían excluirse del beneficio de liberación de deudas. Calificación como involuntarios de algunos de ellos"; GAMES, Fernando y FRAGAPANe, Héctor, "Un APE para el sobreendeudamiento de los empleados públicos y privados"; GiACOMINI, Alejandra Ethel, "Del ahorro al endeudamiento. Situación actual"; GRANADOS, Ernesto y GERBAUDO, Germán, "El sobreendeudamiento de los consumidores"; INDIANA MiCELLI, María, "La quiebra los consumidores. Entre la razonabilidad en la interpretación de la norma y su congruencia con el sistema"; LLUDGAR, María Graciela: "Propuesta para solucionar el sobreendeudamiento del consumidor"; MANDGLOD MORO, Federico Juan Manuel, "Breve interpretación económica del derecho orientada a resolver ciertas cuestiones pendientes de la LCQ, particularmente vinculadas con la implementación de los contratos financieros derivados, en un entorno de 
Derecho Comercial que volvieron sobre la problemática. En 2012, el VII ${ }^{\circ}$ Congreso Argentino de Derecho Concursal y $\mathrm{VI}^{\circ}$ Congreso Iberoamericano de la Insolvencia, celebrado en Tucumán, continuó con el reclamo de un tratamiento legislativo, aportando opiniones al debate y en la obra colectiva escrita presentada en el citado evento científico.

La Corte Suprema de la Nación, en Argentina, en el precedente "Rinaldi" expresó que "La Constitución, al tutelar a los consumidores, obliga a una interpretación coherente del principio protectorio, que en el caso se refiere, concretamente, al problema del sobreendeudamiento". Y destacó que "En muchos países se han dictado leyes especiales

consumo y crisis ponderados"; MARTín, Lidia Roxana, “Análisis económico del consumidor sobreendeudado y su afectación al instituto concursal"; MARMOL, Pablo, "Sobreendeudamiento y plan de reestructuración: conceptos que deben precisarse" y "La equidad y el arbitraje como solución para el sobreendeudamiento del consumidor”; MonTELVETTI, Cecilia Beatriz, "Crisis globalizada: ¿qué hacemos con los pequeños deudores?"; MORCECIÁn, Rubén y GACIO, Marisa, "Sobreendeudamiento del consumidor. Mecanismos para su solución en sede administrativa"; MORO, Carlos: "Una pandemia jurídica: la quiebra del consumidor"; MuJICA, Juan Ramón "Situación de la insolvencia del consumidor, ampliación de los sujetos comprendidos en el tema”; PARDUCCI, Diego Martín: ¿Por qué no es adecuada la actual legislación concursal frente al sobreendeudamiento del consumidor?; PEREYRA, Alicia Susana: "Sobreendeudamiento del consumidor. Una propuesta para desjudicializar el proceso" (parte I) y "Sobreendeudamiento del consumidor. Una propuesta para desjudicializar el proceso" (parte II); PUCCIO, Mónica y MEDINA, Emilio: Análisis críticos de los factores intervinientes en la quiebra del consumidor”; ROSON, María Teresa y PÉREZ LOZANO, Sol, "Más vale prevenir que curar"; RodRÍGUEZ PUCCETTI, Carolina, "Actualidad sobre la quiebra del consumidor. Posibles soluciones"; RUIZ, Juan Manuel y SICOLI, Silvana, "El sobreendeudamiento del consumidor. Alternativas para su solución”; SODERO, Martín, "La educación del consumidor como solución preventiva frente al sobreendeudamiento"; SOSA, Lucía, LÓPEZ, Erica y CHAVEZ, Verónica, "Un abordaje realista”; SPINA, María Laura, MuSACCHIO, Carolina y ARdOY, Victoria: ¿Están las Provincias Argentinas constitucionalmente habilitadas para dictar una ley que regule un procedimiento ante el sobreendeudamiento de los consumidores o insolvencia familiar?; TEPSICH, Carlos y MoRALES, María, Giano, Viviana Mónica María, ChamillaRd, Daniel Roberto y COLOMBO, Oscar Alfredo, "La ubicación de la eventual normativa sobre la insolvencia del consumidor: un aspecto a considerar"; TORRESI, Gloria María y HADAD, Lisandro, "Propuestas para prevenir y curar el sobreendeudamiento del consumidor"; TRUFFAT, E. Daniel, "La no deseada, pero imprescindible, posibilidad de imposición de plan de pagos en caso de concurso mínimo"; TURniAsKy, Patricia Mirta, "Reflexionando sobre la insolvencia del consumidor"; VíTOLO, Daniel Roque: "Debe legislarse en forma particular un régimen de reestructuración extrajudicial y judicial de pasivos para personas físicas no comerciantes". Tuvimos la oportunidad de compulsar todas las ponencias presentadas a este congreso, muchas de ellas de singular aporte. 
destinadas a regular el problema del sobreendeudamiento de los consumidores...que autorizan medidas vinculadas con la intervención en el contrato, otorgando plazos de gracia, estableciendo una suerte de concurso civil, o bien promoviendo refinanciación a través de terceros" ${ }^{\prime 358}$.

Sin perjuicio de las valiosas herramientas existentes en nuestro ordenamiento jurídico, existe consenso respecto de que las mismas resultan insuficientes o inadecuadas para el abordaje de esta compleja problemática. Se reclama una nueva regulación, ajustada a las particularidades de los sujetos afectados, a los factores que desencadenan, condicionan y agravan la situación de sobreendeudamiento, a sus dramáticas consecuencias.

No se nos escapa que el fenómeno del sobreendeudamiento de los consumidores no se puede gestionar ni resolver con el dictado y la puesta en marcha de un dispositivo legislativo $^{359}$. La ley a dictarse debe ser la traducción de un modelo regulatorio, construido para implementar políticas públicas en coherencia con el sistema general, a la luz de principios y valores ${ }^{360}$.

${ }^{358}$ Cfr. Voto de los Ministros LoRENZETti y ZAFFARONI en CS, 15/3/2007, "Rinaldi, Francisco A. y otro c/Guzmán Toledo, Ronal C. y otra”, LL 2007-B,413.

359 Así lo advierte el Dictamen del Comité Económico y Social Europeo aprobado el 29 de abril de 2014, tantas veces citado, el punto 4.1.1.

360 "El Derecho y la política de consumo no pueden ser estructuras pretendidamente neutras o pasivas del sistema socioeconómico. Debe, por el contrario, reflejar sus propios valores y promover la justicia social. No pueden ignorar aquella vulnerabilidad del consumidor ante dichas imperfecciones o faltas de transparencias del mercado, por la mera circunstancia de que el derecho y la política de consumo no son simplemente instrumentos de un orden social socioeconómico establecido sino vectores de cambio" (STIGLITZ, Gabriel A., Reglas para la defensa de los consumidores y usuarios, Juris, Santa Fe, 1998, pág. 114). "Se trata de orientar a los consumidores a reencontrar el rol y la influencia que la teoría económica tradicional les ha dado, sin duda, pero que el entorno socio económico real de la sociedad moderna les ha hecho perder. Tal política no limitará sus preocupaciones a reencontrar los imperativos de cualidades, de eficacia y de racionalidad exigidas por el sistema económico. Buscará, especialmente, corrigiendo las lagunas e insuficiencias que afectan al buen funcionamiento del mercado, a restablecer un cierto equilibrio entre los recursos y los poderes respectivos de los actores que participan del sistema; a devolver al consumidor su poder sobre el proceso de consumo, disminuyendo las coacciones que rodean el ejercicio de la función de consumir. La política sugerida es, en este sentido, activa, porque superando la sola corrección de las debilidades constatadas en el funcionamiento del mercado económico y la sola protección de los consumidores contra los abusos que resultan de él, tiende a ayudar al consumidor a liberarse de las coacciones del consumo, asegurar la 
Oportuno es recordar que el más alto Tribunal Nacional, con voto de los Ministros LORENZETTI y ZAFFARONI, en la citada causa "Rinaldi", conectó la problemática en debate (ejecución de un mutuo con garantía hipotecaria) con el estatuto de la persona y sus derechos fundamentales, haciendo explícita la necesidad de buscar soluciones ajustadas a los bienes en tensión ${ }^{361}$.

Por la relevancia de las consideraciones allí vertidas nos permitimos reproducir los párrafos que aportan luz al tema aquí analizado. Se dijo:

-Que "el presente caso trata de un contrato caracterizado por la vinculación con derechos fundamentales vinculados al estatuto de protección de la persona y la vivienda familiar".

-Que "la conexión con el estatuto de la persona es evidente, ya que una ejecución sin límites de lo pactado afectaría gravemente la existencia de la persona del deudor y su grupo familiar y los conduciría a la exclusión social”.

-Que "si bien la lógica económica de los contratos admite que el incumplidor sea excluido del mercado, ello encuentra una barrera cuando se trata de las personas".

-Que "todos los individuos tienen derechos fundamentales con un contenido mínimo para desplegar plenamente su valor eminente como agentes morales autónomos, que constituyen la base de la dignidad humana, que esta Corte debe proteger".

-Que "los derechos vinculados al acceso a bienes primarios entran en esta categoría y deben ser tutelados".

promoción de los aspectos cualitativos de las aspiraciones de vida de los ciudadanos y exigir el restablecimiento de los fundamentos de un sistema social marcado por ideales democráticos" (BOURGOIGNIE, Thierry, "El año del consumo", en Revista de Política del Consumidor, vol. 13, editado por Thierry Bourgoignie y Guy DelvaX, Bruselas, pág. 4-35).

${ }^{361}$ En el caso "Rinaldi, Francisco Augusto y otro c/ Guzmán Toledo, Ronal C. y otra s/ejecución hipotecaria" (CS, sentencia del 15 de marzo de 2007; LL 2007-B , 415), la Corte Suprema de Justicia de la Nación se expidió respecto de una deuda garantizada con hipoteca en la que estaba comprometida la vivienda única y familiar del deudor. Aplicó la denominada doctrina del esfuerzo compartido -receptada en las previsiones del art. 6 de la ley 26.167- que postula la distribución proporcional entre las partes de la carga patrimonial originada en la variación cambiaria, con el fin de arribar a una solución que resguarde los derechos constitucionales de las partes y logre una recomposición justa y razonable para restablecer el equilibrio de las prestaciones. 
-Que "la Constitución, al tutelar a los consumidores, obliga a sostener una interpretación coherente del principio protectorio, que en el caso se refiere, concretamente, al problema del sobreendeudamiento".

-Que "es necesario considerar ... que la finalidad perseguida por las partes mediante esta contratación, está estrechamente vinculada a la vivienda familiar, que ha sido dada en garantía y que no puede ser desconocida por el acreedor".

-Que "la incorporación de la vivienda, aun como objetivo mediato, en el territorio del contrato de mutuo, permite establecer un cerco en la buena fe con la que deben juzgarse las prestaciones. De ello se deriva que la vivienda en sí misma constituye un límite al compromiso asumido por el mutuario, y no resulta admisible que por obtener un crédito comprometa todo su patrimonio, sino exclusivamente la vivienda".

-Que esta interpretación "es coherente con el art. 14 bis de la Constitución Nacional que contempla la protección de la familia y el acceso a una vivienda digna, derechos que también son tutelados por diversos instrumentos internacionales de derechos humanos que, según la reforma de 1994, poseen rango constitucional (arts. VI de la Declaración Americana de los Derechos y Deberes del Hombre; 16, inc. 3 y 25, inc. 1, de la Declaración Universal de Derechos Humanos; 17 de la Convención Americana sobre Derechos Humanos -Pacto de San José de Costa Rica-; 10 y 11 del Pacto Internacional de Derechos Económicos, Sociales y Culturales y 23 del Pacto Internacional de Derechos Civiles y Políticos)".

Al comentar este pronunciamiento judicial, BARREIRO pone énfasis en señalar que la Corte Nacional ha reconocido un derecho a la protección del consumidor sobreendeudado, "elevándola al rango de derecho fundamental vinculado con la dignidad de la persona humana" ${ }^{362}$ y reflexiona sobre la necesidad de repensar la convivencia de los derechos en tensión.

Este leading case de la Suprema Corte de Justicia de la Nación ha impuesto un estándar de protección del consumidor sobreendeudado y lo ha hecho a partir de un conflicto particular entre el acreedor de un mutuo hipotecario y su deudor. No debe sorprender entonces que las consideraciones allí vertidas se potencien cuando se trata de diseñar políticas y dispositivos de implementación para gestionar la crisis creciente de

\footnotetext{
${ }^{362}$ BARREIRO, Rafael F., "Precisiones acerca de concursos pequeños...”, cit., pág. 567-576.
} 
sectores vulnerables en situación de sobreendeudamiento. El acceso a los bienes esenciales no puede ser negado a la persona humana sin compromiso de su dignidad, del derecho a la vida con calidad, a la salud en su más amplio sentido, a su integridad ${ }^{363}$.

La ley cuyo dictado se propugna debe adecuarse a la garantía de tutela de la dignidad personal y de la vida familiar, de base constitucional. Los operadores jurídicos "deben frente a cualquier caso, ver si habla la Constitución al respecto, y constatarán que siempre habla ... Nada del derecho vigente queda al margen de la Constitución, especialmente de sus valores y principios, y así todo el derecho se impregna de ellos o se constitucionaliza",364.

El legislador no puede soslayar que en el escenario del mercado, todos los actores tienen derecho a participar del desarrollo económico y progresar; y que ello debe ser propiciado con reglas de actuación que alienten comportamientos transparentes, leales, solidarios. La tutela de los derechos esenciales implica un compromiso del poder público y la adopción de decisiones sin las cuales resulta imposible su satisfacción.

\section{B.- Emplazamiento de la regulación. Dónde regular: ¿esa es la cuestión?}

Admitido que la regulación de la problemática es un imperativo derivado del mandato tutelar impartido desde la Constitución, y esbozadas las propuestas de regulación de los distintos sectores, nos preguntamos si existe aquí un planteo de incumbencias a resolver.

\footnotetext{
${ }^{363}$ Nos dice VIGO: "La gran misión de los jueces constitucionales y supranacionales que se implementarán en sintonía con el Estado de Derecho Constitucional, es que prevalezcan los derechos humanos o se los tomen en serio (Dworkin). No sólo hemos visto crecer las diferentes generaciones de derechos humanos, sino que ellos son visualizados como principios, mandatos de optimización o derecho concentrado, que requiere de los juristas les extraigan las respuestas jurídicas apropiadas en función de los diferentes casos. La llamada constitucionalización del derecho, equivale a su humanización en el sentido que el derecho llega a ser caracterizado como un esfuerzo institucional para hacer triunfar los derechos humanos, no sólo en relación al Estado, sino en relación a cualquier otro poder y al resto de los ciudadanos" (VIGO, Rodolfo Luis, "Del Estado de Derecho Legal al Estado de Derecho Constitucional”, Suplemento de Derecho Constitucional, La Ley, 2010 (febrero), pág. 1; LL 2010-A,1165).

${ }^{364}$ VIGO, Rodolfo Luis, “Del Estado de Derecho Legal...”, cit., pág 1170).
} 
"Es indudable que el problema del sobreendeudamiento del consumidor presenta una diagonal entre el derecho concursal y el derecho del consumidor propiamente dicho" 365 .

Voces autorizadas consideran que "el tema debe resolverse en el ámbito del Derecho concursal, atendiendo sin dudas a los particularismos del objeto de la legislación y sus necesarias influencias interdisciplinarias" ${ }^{\text {366 }}$. Se considera que el fenómeno es uno sólo -la insolvencia- y que puede presentar características particulares que justifiquen medidas específicas, dado que el consumidor es un nuevo sujeto concursal, distinto del deudor individual -clásicamente visto- "ya sea por la forma en que contrae sus obligaciones ...o por las graves implicancias sociales que resultan de ese estado de sobreendeudamiento, que trasciende el mero interés individual para convertirse en un problema social...y económico" 367 .

Se entiende que dentro del régimen general se "deben estructurar procedimientos de insolvencia para personas físicas que comprendan tanto la solución preventiva como la liquidativa" y se recuerda que "la mediación en los procesos concursales tiene actualmente aplicación en otros países y puede constituirse en una pieza importante [...]" al momento

\footnotetext{
365 ANCHÁvAL, Hugo, Insolvencia del consumidor..., cit., pág. 28.

${ }^{366}$ ALEGRÍA, Héctor, "Los llamados pequeños concursos...”, cit., pág. 787 y sgtes.

${ }^{367}$ ANCHÁvAl, Hugo, Insolvencia del consumidor..., cit., pág. 28 y sgtes. Se pronuncia en sentido contrario VÍTOLO, por considerar que "el consumidor no es -en puridad de verdad- un sujeto a quien deba referirse la normativa -en los aspectos de legitimación subjetiva- en materia de insolvencia, ni tampoco puede construirse un régimen de insolvencia particular alrededor de este concepto". Considera que "no existe una personificación jurídica del consumidor, de donde no puede hablarse del consumidor como sujeto a los efectos de un tratamiento integral de su situación patrimonial de cara a la insolvencia...el consumidor no es más que la calificación de una de las partes en los contratos y relaciones de consumo" (Vítolo, Daniel R., La insolvencia del consumidor, Ad Hoc, Buenos Aires, 2012, pág. 58 y sgtes.). El citado autor propone la regulación del fenómeno considerando como destinatario al deudor persona física no comerciante (VíTOLO, Daniel R., "Debe legislarse en forma particular un régimen de reestructuración extrajudicial y judicial de pasivos para personas físicas no comerciantes", ponencia presentada en el $\mathrm{V}^{\circ}$ Congreso Iberoamericano sobre la Insolvencia y el VII ${ }^{\circ}$ Congreso Argentino de Derecho Concursal realizados en Mendoza entre el 4 y el 7 de octubre de 2009).
} 
de ayudar al consumidor y sus acreedores a encontrar una adecuada composición de intereses $^{368}$.

Desde otro sector se reclama una regulación de corte netamente protectorio y al abrigo de los principios del Derecho del Consumidor, por considerar que la especificidad de la problemática y los bienes involucrados sólo pueden ser atendidos por quienes diseñan correctivos inspirados en la tutela de los vulnerables del mercado ${ }^{369}$. Desde este enfoque, las opciones serían emplazar la regulación de la problemática como un capítulo de la ley o código de defensa del consumidor (modelo francés y propuesta de Brasil) o bien, promover el dictado de una ley especial que incluya el diseño de dispositivos sustanciales y procedimentales ajustados al principio protectorio del microsistema.

No pretendemos negar que, desde nuestra perspectiva, el emplazamiento de la regulación reclamada, tiene gran importancia. El diseño de dispositivos orientados a la prevención y saneamiento del sobreendeudamiento de los consumidores estará inspirado en el paradigma del sistema en el que se inserte y responderá a los principios que le sean propios. Pero creemos, también, que dicho emplazamiento no es dirimente.

Despojados de preconceptos, debemos admitir que lo relevante es elaborar un cortejo de herramientas eficaces, sustanciales y procedimentales, de naturaleza preventiva y reparadora de la situación de sobreendeudamiento. Somos conscientes de que la satisfacción de operador jurídico dependerá de la eficacia de ese diseño, más allá de su pertenencia a un fundo o a otro.

Sea que la regulación reclamada se incorpore al régimen general de los concursos y quiebras, a la ley de defensa del consumidor o sea motivo de una ley especial, lo que interesa es dar respuesta eficaz a una problemática de tratamiento impostergable.

\footnotetext{
${ }^{368}$ RIVERA Julio César, “Insolvencia de las personas físicas...”, cit., pág. 5.

${ }^{369}$ Esta opinión se sustenta en la creencia de que los principios y las reglas que definen la identidad y autonomía del Derecho concursal, han justificado el diseño de soluciones normativas ajustadas a una lógica diferente, inspiradas en paradigmas incompatibles con los que marcan la impronta del Derecho del Consumidor. Proponemos al lector, la lectura del valioso trabajo del profesor español Juan Ignacio Peinado Gracia que explica con evidencia y creatividad, la lógica de muchas de las soluciones sustanciales y procedimentales del Derecho concursal. Quien bucee en las ideas allí plasmadas, no podrá sino entusiasmarse con el planteo y la lucidez del enfoque. Ver, PEINADO GRACIA, Juan Ignacio, "Cooperación y pillaje en el concurso", $A D C, 2006$, pág. 231.
} 
Adelantamos desde ya que nos inclinamos por el dictado de una ley especial que concentre los dispositivos necesarios para el abordaje del problema. La temática en análisis es compleja y exhibe gran dinamismo. Los factores que la desencadenan son múltiples y variados y las medidas a adoptar para su prevención y saneamiento deberán ser igualmente dinámicas y flexibles ${ }^{370}$.

Sin perjuicio de que la regulación esté inspirada en el paradigma propio del sistema protectorio de los consumidores, su emplazamiento en una ley particular facilitará las modificaciones que fueran necesarias para adecuar las herramientas y los procedimientos cuando su puesta a prueba y evaluación así lo demande.

Creemos, por otra parte, que la regulación de la problemática en una ley especial permitirá dedicar un capítulo particular a la prevención del fenómeno con abordaje de aspectos tales como la educación para el consumo en el mercado de crédito, la publicidad, el marketing crediticio y sus técnicas, el control de ciertas prácticas empresarias de colocación de productos financieros, el deber de información y de asesoramiento particular, las modalidades de contratación y su eventual abusividad, deber de asistencia durante la ejecución del contrato, la gestión del riesgo en caso de mora o imposibilidad de

\footnotetext{
370 "Cualquiera sea el criterio a adoptar, en tanto se preserven los criterios de protección que se buscan proporcionar a los consumidores afectados, así como un razonable grado de coherencia con los principios contenidos en la materia concursal, es relativamente indiferente el corpus donde se asienten las disposiciones legales, puesto que lo que sin duda debe preservarse es la sumatoria de protección con coherencia... Por ahora, la regulación autónoma representaría una mejor perspectiva de integración de ambos aspectos en un corpus diferenciado. Ello porque la inserción en cualesquiera de las normativas marco enunciadas no parece ser imprescindible. Tampoco parece adecuado que los principios que allí se consagren puedan utilizarse por extensión en la preceptiva exclusivamente concursal, en la cual lucirían estas previsiones como un tanto forzadas dentro de un plexo que tiene principios diferentes. En cuanto a la LDC, si bien estimamos que debería ser su lugar definitivo, tampoco parece conveniente la inclusión de un nuevo capítulo referido al sobreendeudamiento, luego de tres reformas parciales y una cuarta integral, salvo que se integre dentro de una nueva y amplia reforma que lleve a establecer un Código de Consumo, lo que es un más que deseable objetivo; pero por ahora no aparece como probable que ocurra en un mediano plazo. Todo lo cual nos hace considerar como más adecuado, para las circunstancias actuales, la solución de regulación independiente, aunque armonizada con la legislación de consumo y de concursos, en tanto esta última sea compatible (BERSTEN, Horacio L., "La regulación del sobreendeudamiento de los consumidores", en LL Suplemento Actualidad, del 30/08/2011, pág. 1).
} 
cumplimiento, etc., que en principio exceden la finalidad del régimen de insolvencia contenido en las leyes concursales y de quiebra.

\section{C.- Contenido de la regulación. Cómo regular: ¡ésa es la cuestión!}

Voces prudentes nos advierten sobre los riesgos de "imaginar inmediatamente y sin estudios previos seriamente realizados, estatutos completos, separados y diferenciales para las distintas situaciones" y por ello aconsejan que "la solución de lo urgente [...] debe considerar -en la medida de lo razonable y lo factible- lo importante",371.

Frente a la crisis económico-financiera que atravesaron y atraviesan los países centrales en Europa y Estados Unidos y, ante la lamentable pero previsible repercusión que aquélla puede supone para los países de otras latitudes (ya acostumbrados a las tormentas pero nunca preparados para recibirlas), se viene exhortando desde hace años a que en Argentina, "el Congreso asuma con la debida diligencia esta materia, teniendo en cuenta la experiencia comparada y los aportes de la doctrina" 372 .

Campea la idea de que la regulación de la problemática del sobreendeudamiento de los consumidores debe estar diseñada sobre la base de nuevos principios, que por un lado orienten la redistribución de los riesgos derivados de la insolvencia del deudor y del consiguiente incumplimiento de la obligación de pago y, por otro, no pierdan de vista que las soluciones preventivas y curativas, se ordenan tras un principal objetivo: evitar y superar las consecuencias derivadas de la situación de sobreendeudamiento del consumidor $^{373}$.

\footnotetext{
${ }^{371}$ Con el rigor que lo caracteriza, ALEGRía hace una propuesta de soluciones inmediatas y hasta tanto se defina el modelo, para todos los supuestos de concursos sin activo, con activos insuficientes, con activos reducidos, cualquiera sea el deudor insolvente, con especial atención a consumidores o personas físicas con ingresos fijos por relación de dependencia o similar, o que obtiene sus ingresos preponderantemente con su trabajo personal o de su familia (ALEGRÍA, Héctor, "Los llamados pequeños concursos...”, cit., pág. 787 y sgtes.).

${ }^{372}$ RIVERA, Julio César, "Insolvencia de las personas físicas..., cit., pág. 6). El autor propugna por una regulación que contemple "la prevención del sobreendeudamiento con medidas dirigidas también a los dadores de crédito y la generación de un procedimiento concursal abreviado en el que como paso previo, un mediador facilite el acuerdo entre el deudor y sus acreedores".

373 Dice Alberto BeRCOVITZ RODRÍGUEZ-CANO: "La institución del sobreendeudamiento se diferencia profundamente del concurso tal como está regulado en la ley concursal, porque el sobreendeudamiento no
} 
1.- Ámbito de aplicación de la regulación propuesta:

Nos preguntamos en este apartado: ¿qué situación de endeudamiento es la que nos preocupa? Asimismo: ¿cuál consumidor es el que motiva esta preocupación?

El ámbito de aplicación de la regulación que se propone está definido por dos elementos de base, subjetivo y objetivo. No se nos escapa que la delimitación de estos factores supone la adopción de un criterio, la toma de una decisión de política legislativa.

Más allá de los reclamos sociales y de la opinión de la doctrina, una vez asumida la necesidad de la regulación de la problemática, será el legislador el que delimite los contornos de las soluciones ofrecidas.

Desde una perspectiva subjetiva, se impone determinar quiénes son los sujetos amparados y bajo qué condiciones se los considera merecedores de esta tutela particular. Asimismo, corresponde establecer -desde un punto de vista objetivo- cuál situación de endeudamiento es la que, a criterio del legislador, justifica la aplicación de los dispositivos preventivos y de saneamiento que habrán de diseñarse ${ }^{374}$.

\section{a.- El elemento objetivo:}

El elemento objetivo, del que partimos para definir el ámbito de aplicación de la regulación reclamada, nos impone definir la situación problemática que justificaría la intervención del legislador.

Admitida la dificultad para definir el concepto de sobreendeudamiento (o endeudamiento excesivo), advertimos que, con matices, la doctrina mayoritaria coincide en señalar que la noción alude a una situación financiera caracterizada por la grave dificultad o

tiene por finalidad básica la satisfacción de los acreedores, sino la adopción de las medidas que permitan al particular superar la situación de endeudamiento a que se ha visto abocado, sin actuaciones que sean excesivamente traumáticas" (BERCOVITZ RODRÍGUEZ-CANO, A., "El presupuesto subjetivo del concurso. En particular, el problema del sobreendeudamiento de los consumidores", en QUINTANA CARLO, I-BONET NAVARro, Á.- GARcía CruCES-GonZÁLEZ (Dir.), Las claves de la ley concursal, Thomson-Aranzadi, Madrid, 2005, pág. 17-23).

374 Álvarez Vega, María Isabel, Protección jurídica del consumidor..., cit., pág. 55 y sgtes. 
imposibilidad del deudor para afrontar el pago de las deudas asumidas frente a sus acreedores $^{375}$.

Al momento de expresar nuestra opinión, coincidimos con GUTIÉRREZ DE CABIEDES $^{376}$ en que no es conveniente acotar esta noción al momento de delimitar el elemento objetivo y establecer, por ende, el ámbito de aplicación de la regulación que propugnamos.

El concepto de sobreendeudamiento debe estar referido a una situación de hecho en la que el deudor afronta dificultades serias para cumplir las obligaciones asumidas. Marcamos este aspecto en el afán de destacar la distinción entre sobreendeudamiento e insolvencia, entendiendo que en nuestra cultura jurídica, este último vocablo hace referencia a un status jurídico que suele ser la consecuencia del endeudamiento excesivo pero no necesariamente se identifica con él.

Insistimos, asimismo en que el particular afectado debe encontrarse seriamente comprometido para cumplir las obligaciones contraídas y no necesariamente en situación de imposibilidad de cumplir. Esta consideración tiende a reforzar la distinción entre sobreendeudamiento e insolvencia, dado que este último concepto se caracteriza por un estado de cesación de pagos que -en nuestra opinión- no debería ser un rasgo definitorio del elemento objetivo.

Señalamos que la grave dificultad para afrontar el cumplimiento, debe estar referida a obligaciones contraídas y en situación de pronta exigibilidad y no necesariamente deudas vencidas. Creemos que ello permite ampliar el catálogo de hipótesis aprehendidas en la noción de endeudamiento excesivo, ensanchando la base de este elemento objetivo. Entendemos que exigiendo el carácter de obligaciones vencidas, se niega injustificadamente la configuración del presupuesto analizado, propiciando un agravamiento de la situación del deudor que, de lo contrario, podría reclamar la aplicación de los mecanismos preventivos y correctivos a diseñar.

\footnotetext{
375 GutiérRez de CABIEdes, Pablo, El sobreendeudamiento doméstico..., cit., pág. 28; Álvarez VeGA, María Isabel, Protección jurídica del consumidor..., cit., pág. 52; FERNÁNDEZ CARRÓN, Clara, El tratamiento de la insolvencia..., cit., pág. 18; TRUJILlo DíEZ, Iván Jesús, El sobreendeudamiento de los consumidores..., cit., pág. 14; entre otros.

${ }^{376}$ GutIÉRREZ de CABIEDES, Pablo, El sobreendeudamiento doméstico..., pág. 28.
} 
El Anteproyecto de ley actualmente en estudio ${ }^{377}$, que regularía el "concurso de las personas humana que no realizan actividad económica organizada" en la ley concursal, prevé en el art. 304 que "304.- Es presupuesto para la apertura del proceso regulado en el presente capítulo que el sujeto peticionante se encuentre: 1) En estado de cesación de pagos; 2) En dificultades económicas o financieras de carácter general; o 3) Sobre endeudado. A efectos de este artículo se entenderá por sujeto sobre endeudado a aquel que presente, en su patrimonio, un desequilibrio significativo entre su activo ejecutable y las obligaciones por las cuales dicho activo deba responder".

La alocución utilizada (sobreendeudamiento) refiere, como se dijo en el capítulo de inicio, a la idea de un endeudamiento excesivo. Y como es evidente, esa calificación alude a un concepto relativo (el exceso), puesto que el límite entre la toma de deuda razonable o excesiva dependerá del patrón con el que se compare el endeudamiento. La confrontación del volumen de deuda con el activo disponible permitirá establecer el grado de endeudamiento y concluir sobre su carácter excesivo o sobre la inexistencia del mismo ${ }^{378}$. Se señala con acierto que la medida, grado o intensidad de ese endeudamiento no puede ser medido con idénticos parámetros cuando se trata de una empresa que cuando estamos en presencia de un consumidor en crisis. ANCHÁVAL menciona con agudeza que "mientras la emisión de deuda no necesariamente es considerada como una señal de insolvencia en una empresa, para un consumidor significa, en la enorme mayoría de los casos, un innegable síntoma...una empresa puede sobreendeudarse sanamente en un proyecto a largo plazo, recuperando la amortización con tiempo suficiente para esperar. Una empresa equilibrada con grandes créditos concedidos, probablemente sea una empresa en expansión. Un

\footnotetext{
${ }^{377}$ Nos referiremos al Anteproyecto en el final de esta investigación, analizando los dispositivos propuestos.

${ }^{378}$ BARREIRO propone considerar algunos indicadores de sobreendeudamiento sugeridos por organizaciones de defensa de los derechos del consumidor y menciona a título de ejemplo aquellas variables que serían reveladoras de un exceso de deuda: a.- cuando el volumen de deuda contraída es al menos tres veces superior a la renta anual; b.- cuando el toral de la deuda supera el $75 \%$ del patrimonio neto del hogar; c.- cuando el peso de la carga de su deuda supera el 35\% de los ingresos familiares mensuales (BARREIRO, Marcelo, "Sobre la prevención del sobre consumo", Ponencia presentada en el $V^{\circ}$ Congreso Iberoamericano sobre la Insolvencia y el $\mathrm{VII}^{\circ}$ Congreso Argentino de Derecho Concursal realizados en Mendoza entre el 4 y el 7 de octubre de 2009).
} 
consumidor con grandes créditos concedidos, probablemente sea un deudor con grandes deudas" 379 .

Será también tarea del legislador, determinar si algunas situaciones de endeudamiento excesivo del deudor -en función de las causas que las generaron- deben estar excluidas del ámbito de aplicación de la regulación que propugnamos.

Recordamos que la doctrina suele distinguir el llamado sobreendeudamiento activo del pasivo ${ }^{380}$ y que esas precisiones conceptuales referidas a las causas y circunstancias del endeudamiento determinarían, según algunos, que el régimen protectorio sólo se ocupe del consumidor sobreendeudado por causas sobrevenidas y ajenas a su voluntad, no así del deudor que cae en esta situación por un comportamiento originario irreflexivo y hasta deliberado $^{381}$.

Sin perjuicio de analizar esta arista del problema ut infra al tratar el elemento subjetivo del ámbito de aplicación, reiteramos aquí la apreciación antes esbozada. Insistimos en esto, porque lo consideramos de vital importancia: una política integral contra el sobreendeudamiento debe hacer frente a los distintos aspectos de este fenómeno; y la adopción de medidas preventivas -de inhibición de una situación amenazante o de atenuación del daño que ha empezado a producirse- no deben ser retaceadas con aquellos justificativos.

Entendemos que el carácter originario o sobreviniente de la causal de endeudamiento excesivo, así como la imputabilidad o ajeneidad de la situación no deben ser argumentos para negar la aplicación de las soluciones de corte preventivo que reclamamos. No obstante ello, admitimos que las medidas curativas, de saneamiento o de rehabilitación pueden considerar aquellos extremos como condicionantes para su aplicación, lo que debe ser motivo de un análisis particular ${ }^{382}$.

\footnotetext{
${ }^{379}$ ANCHAVAL, Hugo, Insolvencia del consumidor, cit., pág. 36.

${ }^{380}$ TrujILlo DíEZ, Iván Jesús, El sobreendeudamiento de los consumidores ..., cit., pág. 1.; ÁlVAREZ VEGA, María Isabel, Protección jurídica del consumidor..., cit., pág. 52; GuTIÉRREZ DE CABIEDES, Pablo, El sobreendeudamiento doméstico..., cit., pág. 30; entre otros.

381 Destaca este aspecto de la reflexión, TAMAYO HAYA, Silvia, "El sobreendeudamiento de los consumidores...”, cit., pág. 348.

382 GutIÉRREZ de CABIEDES, Pablo, El sobreendeudamiento doméstico..., cit., pág. 31.
} 
Lo reiteramos: sin perjuicio de distinguir dispositivos y requisitos para acceder a ellos, la regulación integral de la problemática aconseja no excluir situaciones de endeudamiento excesivo en función de las causas que lo generen.

Creemos firmemente que alentar las buenas prácticas en el mercado es un objetivo de primer orden y que las distorsiones en el funcionamiento del sistema o en el proceder de cualquiera de los protagonistas de la operatoria (entidades de crédito y consumidores/deudores) deben ser contempladas en esta regulación.

Propiciamos una política amplia cuando se trata de remedios de carácter preventivo: el consumidor y su familia deben ser destinatarios, sin restricciones. El mercado se verá asimismo beneficiado con medidas que favorezcan la transparencia, las buenas prácticas y la adopción de precauciones que se orienten a desterrar conductas distorsivas.

Admitimos sí, que tratándose de las medidas de saneamiento, deberán evaluarse situaciones y casos concretos, para facilitar la rehabilitación de aquellos consumidores que justifiquen el merecimiento de los beneficios que de aquéllas se deriven. Pero advertimos desde ya que, en nuestra visión particular, esta justificación estaría dada en todos aquellos supuestos en los que no pueda formularse un juicio de reproche a la conducta del particular afectado $^{383}$.

b.- El elemento subjetivo:

El elemento subjetivo, definitorio del ámbito de aplicación de la regulación, nos remite al sujeto destinatario de la regulación, al beneficiario de la misma. ¿Quién puede invocar en su favor la aplicación de los dispositivos legales cuyo diseño se propugna?

La reciente propuesta española destina sus mecanismos de liberación de deuda propios e impropios $^{384}$ al deudor persona natural (arts. 231.1 y 178 bis de la ley concursal

\footnotetext{
${ }^{383}$ Hemos de desarrollar la idea de que el requisito de buena fe del deudor, previsto en casi todos los ordenamientos que prevén mecanismos de liberación de pasivo pendiente, debe ser interpretado como ausencia de mala fe. Entendemos que esta perspectiva guarda relación con el estándar de tutela deseable y nos permite analizar con justicia, hipótesis en las que el comportamiento precipitado, poco advertido, descuidado o en apariencia irreflexivo, debe ser considerado insuficiente para formular un juicio de reproche al deudor, y excluirlo de los beneficios que propugnamos. Volveremos sobre ello.

${ }^{384}$ SENENT MARTínEZ, Santiago, Exoneración del pasivo insatisfecho..., cit.)
} 
conforme la modificación impuesta por el Real Decreto-Ley 1/2015), con lo que se admite al empresario persona física, en dicho ámbito de aplicación.

La regulación francesa se refiere al sobreendeudamiento de las personas físicas no comerciante o por deudas "no profesionales" (art. 330-1 del Código de Consumo).

El modelo alemán -conforme el Título IX, Sección 304, párrafos I y II- destina su regulación al deudor/persona física que no desarrolla ninguna actividad comercial autónoma o que habiéndola desarrollado, sea de poca envergadura.

\section{b.1.- La figura del consumidor. La categoría del subconsumidor}

En Argentina propugnamos la idea de atender al sobreendeudamiento del consumidor, sin desconocer que la utilización del concepto genera polémica e impone precisiones.

Para llamar nuestra atención sobre lo relevante de este aspecto problemático, se pregunta Aída KEMELMAJER DE CARLUCCI: “¿quién es el consumidor-deudor sujeto de estas reflexiones"? ${ }^{385} \mathrm{Al}$ hablar de sobreendeudamiento del consumidor ¿nos referimos a la figura definida en la ley ${ }^{386}$ o ese concepto debe ser reelaborado a los fines de la regulación que propiciamos?

\footnotetext{
385 KEMELMAJER DE CARLUCCI, Aída, "El sobreendeudamiento del consumidor...”, cit.

${ }^{386}$ El texto refundido de la Ley General para la Defensa de los Consumidores y Usuarios (Real Decreto Legislativo 1/2007 y su modificatoria, Ley 3/2014) establece en el art. 3: "Concepto general de consumidor y de usuario. A efectos de esta norma y sin perjuicio de lo dispuesto expresamente en sus libros tercero y cuarto, son consumidores o usuarios las personas físicas que actúen con un propósito ajeno a su actividad comercial, empresarial, oficio o profesión. Son también consumidores a efectos de esta norma las personas jurídicas y las entidades sin personalidad jurídica que actúen sin ánimo de lucro en un ámbito ajeno a una actividad comercial o empresarial”. Para un desarrollo de la evolución del concepto legal en España, ver, BerCovitz Rodríguez-CANO, Rodrigo (Coord.), Comentario del Texto Refundido de la Ley General para la Defensa de los Consumidores y Usuarios y otras leyes complementarias (Real Decreto Legislativo 1/2007), Aranzadi-Thomson Reuters, Madrid, 2009, pág. 86 y sgtes.; CÁMARA LAPUENTE, Sergio (Dir.), Comentarios a las Normas de Protección de los Consumidores, Colex, Madrid, 2011, pág. 102 y sgtes.

387 SPINA, María Laura, MuSACCHIO, Carolina y ARDOY, Victoria: ¿Están las Provincias Argentinas constitucionalmente habilitadas para dictar una ley que regule un procedimiento ante el sobreendeudamiento de los consumidores o insolvencia familiar?, Ponencia presentada en el $\mathrm{V}^{\circ}$ Congreso Iberoamericano sobre la
} 
La ley argentina define la figura del consumidor en el art. 1 de la Ley 24.240 (reformada por la Ley $\mathrm{N}^{\circ} 26.361$ de 2008 y N²6.694 de 2014, Anexo II, apartado 3.1) como "toda persona física o jurídica que adquiere o utiliza bienes o servicios en forma gratuita u onerosa como destinatario final, en beneficio propio o de su grupo familiar o social...Se considera asimismo consumidor o usuario a quien, sin ser parte de una relación de consumo, como consecuencia o en ocasión de ella adquiere o utiliza bienes o servicios como destinatario final, en beneficio propio o de su grupo familiar o social. ${ }^{388}$.

Sin perjuicio de la mayor o menor amplitud del concepto adoptado por cada ordenamiento, resulta claro que el sobreendeudamiento que nos preocupa y cuya protección nos desvela, es el endeudamiento excesivo del consumidor persona física.

Aún cuando en nuestro sistema legal, la relación de consumo reconoce fuentes diversas $^{389}$, la problemática en estudio centra su atención en la situación del consumidor contratante (el deudor tomador de crédito, comprador a plazos, usuario de un servicio contratado con financiamiento del propio proveedor o de un tercero, etc.).

Hemos justificado ya la preocupación por la situación del consumidor/persona física sobreendeudado. Su problemática excede lo estrictamente personal arrastrando la suerte del Insolvencia y el $\mathrm{VII}^{\circ}$ Congreso Argentino de Derecho Concursal realizados en Mendoza entre el 4 y el 7 de octubre de 2009.

${ }^{388}$ No es ésta la ocasión para ahondar sobre la cuestión, pero permítasenos destacar que la reforma del año 2008 permitió consolidar la amplitud del concepto de consumidor que ya era de interpretación aceptada, pese al corset que parecía imponerle la letra del art. 1 en su redacción originaria. Para un desarrollo de la noción de consumidor y su evolución en las sucesivas reformas del Derecho argentino, ver LORENZETTI, Ricardo L., Consumidores, cit., pág. 95; RuSCONI, Dante, en RuSCONI, Dante (Coord.), Manual de Derecho del Consumidor, Abeledo Perrot, Buenos Aires, 2015, pag. 192 y sgtes.; KeMELMAJER DE CARLuCCI, Aída, "El consumidor. Concepto. Modificaciones introducidas por la Ley 26.361”, en ANTONI PIOSSEK, C. (Dir.), Resoluciones alternativas de conflictos en la crisis de la empresa y el consumidor. Libro homenaje al Doctor Francisco Junyent Bas, cit., pág. 233; FRUSTAGLI, Sandra-HeRnÁNDEZ, Carlos A., "El concepto de consumidor. Proyecciones actuales en el Derecho argentino", en LL 2011-F,992; WAJNTRAUB, Javier. H., "La noción de consumidor", en Revista de Responsabilidad Civil y Seguros, Año IX, N 3, Mayo 2007. Asimismo, FARINA, Juan M., Defensa del consumidor..., cit., pág. 41; MosSET ITURRASPE, JORGEWajntraub, Javier H., Ley de Defensa del Consumidor..., cit., pág. 37; SANTARElli, Fluvio G., Comentario al art. 1, en PiCASSO, Sebastián-VÁZQUEZ Ferreyra, Roberto (Dir.), Ley de Defensa del Consumidor comentada y anotada, cit., pág. 26.

${ }^{389}$ LORENZETTI, Ricardo L., Consumidores, cit., pág. 118 y sgtes. 
grupo familiar, con graves costes adicionales que deben ser atendidos ${ }^{390}$. El deudor y su familia -el grupo humano- son los sufren las graves consecuencias del endeudamiento excesivo. "No debemos olvidar que ... cuando hablamos del sobreendeudamiento del consumidor ... también hablamos de sobreendeudamiento familiar, ${ }^{, 391}$. Ello explica el Comité Económico y Social Europeo, en su Dictamen de 2014, proponga que en la elaboración de una definición operativa común se considere "al hogar como unidad de medida pertinente ${ }^{, 392}$.

Precisamente por esta mirada del fenómeno es que se enfatiza en hablar de sobreendeudamiento de las economías domésticas. Esta alocución genérica (compresiva de la economía particular) procura destacar que son las personas físicas y no el sector empresario, quienes precisan un específico tratamiento legal de la problemática.

Las razones de esta exclusión del consumidor/persona jurídica resultan claras. Se considera que quien precisa de un régimen particular de saneamiento para superar su situación de endeudamiento excesivo, es el consumidor persona física; y que, en su caso, la persona jurídica y el empresario individual, podrán acudir a la regulación concursal vigente.

La adhesión al concepto de consumidor, dados sus elementos y contornos, excluirá del ámbito de aplicación aquí analizado, al deudor persona física cuando su situación de endeudamiento refiera a pasivos contraídos en el marco de su desarrollo empresario (aunque persona individual) o profesional; nota que marca ya un distingo con otros modelos regulatorios (el español, por ejemplo).

Será considerado consumidor -destinatario de los beneficios de la regulación que propiciamos- a aquel que acuda al financiamiento para la adquisición de bienes o la

\footnotetext{
${ }^{390}$ Como lo señala AlEgRíA, se trata del "entorno humano y social que integra el mundo en que se desenvuelve la situación de crisis y su resolución” y de allí que el impacto personal y familiar derivado de la insolvencia no puede ser ignorado por el legislador (ALEGRÍA, Héctor, “Aspectos humanos..., cit.).

391 MoRCECIÁN, Rubén y GACIO, Marisa, "Sobreendeudamiento del consumidor. Mecanismos para su solución en sede administrativa", Ponencia presentada en el $\mathrm{V}^{\circ}$ Congreso Iberoamericano sobre la Insolvencia y el $\mathrm{VII}^{\circ}$ Congreso Argentino de Derecho Concursal realizados en Mendoza entre el 4 y el 7 de octubre de 2009.

${ }^{392}$ Así emerge del Dictamen del Comité Económico y Social Europeo sobre "Protección de los consumidores y tratamiento adecuado del sobreendeudamiento para evitar la exclusión social” aprobado en sesión del 29 de abril de 2014.
} 
contratación de servicios como destinatario final, para su beneficio personal o de su grupo familiar, excluyendo los que correspondan a su actividad profesional, productiva o lucrativa ${ }^{393}$.

La definición de este aspecto del elemento subjetivo puede enfrentarnos a zonas grises. No será siempre sencillo establecer el origen de las deudas contraídas o el destino de los bienes y servicios contratados. De allí que al momento de establecer si estamos frente a una situación de endeudamiento vinculada a la actividad lucrativa del sujeto o ajena a la misma, debamos acudir a criterios de cierta flexibilidad y, en caso de duda, estar a la interpretación más favorable al consumidor.

Cuanto más rudimentaria sea la economía doméstica del consumidor, más difícil puede ser la determinación de estas aristas del pasivo. No será infrecuente que la adquisición de un bien tenga en vista usos o utilidades mixtos (personal y familiar, a la vez que profesional o de afectación a alguna actividad productiva). Ocurre lo mismo cuando se trata de bienes o servicios que pueden tener una incorporación transitoria a labores lucrativas del particular. O supuestos en los que se adquieren bienes o se contratan servicios que sólo de forma mediata se incorporan a la actividad profesional del sujeto.

La toma de créditos puede serlo, asimismo, para refinanciar deudas anteriores o para asignar partidas a obligaciones de origen diverso (profesionales y de la economía personal o familiar). El uso de la tarjeta de crédito puede ofrecer, de igual modo, dificultades para distinguir destinos en la operatoria.

Consideramos que al momento de calificar el origen de las deudas contraídas y juzgar si la situación queda aprehendida en el ámbito de aplicación de la regulación propugnada, habrán de traspolarse -en lo pertinente- los criterios adoptados para determinar la aplicación del régimen protectorio de los consumidores ${ }^{394}$.

\footnotetext{
${ }^{393}$ En este marco se propone definir al sobreendeudamiento del consumidor como "el estado financiero al que llega una persona que adquiere bienes o utiliza servicios como parte de una relación de consumo y que como consecuencia de ella o en ocasión de tal relación, no puede cumplir regularmente con las obligaciones a su cargo" (ALONSO, Daniel, "El sobreendeudamiento de la persona física..., cit.).

${ }^{394}$ Ver LoREnZETTI, Ricardo L., Consumidores, cit., pág. 101 y sgtes.; KeMELMAJER DE CARLuCCI, Aída, "El consumidor....”, cit, pág. 243 y sgtes.; RuSCONI, Dante, en RusCONI, Dante (Coord.), Manual de Derecho del Consumidor, cit., pág. 177 y sgtes.
} 
Para sortear los equívocos terminológicos, se señala la conveniencia de identificar al destinatario de la regulación como persona física no comerciante, entendiendo que esta figura se adapta mejor al menú de sujetos que transitan por el proceso concursal y pensando que las medidas de saneamiento deben emplazarse en esa regulación. Se dice que el concepto de consumidor -acuñado por el microsistema especial- excede la figura del sujeto que debe ser beneficiado por este régimen que propugnamos, y que debe ser acotado, a los fines de definir el elemento subjetivo (excluyendo al consumidor persona jurídica); mientras que, por otro lado, aquel concepto muestra estrechez al emplazarse en una relación jurídica particular (la relación de consumo). Para superar ese exceso y ese defecto, se propone utilizar la figura de la persona física no comerciante, por considerar que ello deja a resguardo la finalidad perseguida (diseñar mecanismos de saneamiento para proteger al consumidor/ persona física sobreendeudada) y se adecua mejor al régimen de insolvencia general (que contaría con un nuevo procedimiento para estos destinatarios particulares) ${ }^{395}$.

Sin perjuicio de admitir las precisiones adicionales que impone adherir al concepto de consumidor, consideramos que esta noción ofrece la sustancia necesaria que sirve de base a la regulación que propiciamos. La figura del consumidor -más allá de las discusiones que plantea su definición ${ }^{396}$ - tiene ya tradición jurídica, proporciona el bagaje conceptual, inspira el paradigma protectorio y marca un estándar de tutela.

Sobre esa base asentada, el acotamiento de la figura -a los fines de la regulación del sobreendeudamiento- lejos de ser un obstáculo, permitirá revalorizar la categoría de los subconsumidores, admitida por todos los ordenamientos, aunque no siempre visualizada con la relevancia que merece.

Así como no existe una única debilidad constatable en el plano social ${ }^{397}$, tampoco deben soslayarse las diferentes manifestaciones que la vulnerabilidad exhibe en el marco de las relaciones de consumo. Se impone ir más allá de un reconocimiento aislado de la debilidad del consumidor puesto que en el mismo contexto relacional, existen diferentes

\footnotetext{
395 ALONSO, Daniel, "El sobreendeudamiento de la persona física...", cit.

${ }^{396}$ KeMELMAJER DE CARLuCCI, Aída, “El consumidor...”, cit, pág. 234.

${ }^{397}$ Resulta ineludible transitar por las profundas reflexiones que formula CIURO CALDANI al analizar esta temática. Cfr., entre otros trabajos de inmenso valor, CIURO CALDANI, Miguel Ángel, "Desde la protección del propietario a la protección del consumidor y el usuario", en E.D. T. 159, pág. 1022 y sgtes.
} 
expresiones de esa hiposuficiencia que no deben ser desconocidas. De allí que sea necesario establecer estándares especiales de tutela no siempre admitidos jurídicamente ${ }^{398}$.

Se señala que en los comienzos del desarrollo del crédito, el sobreendeudamiento fue un problema de la clase media, entendida ésta como la que alcanza ciertos niveles de renta y activos ${ }^{399}$. Pero el fenómeno de la democratización de crédito propició el endeudamiento de grupos sociales que antes no accedían a las operatorias de financiamiento. El sobreconsumo y el endeudamiento excesivo impactan de modo diferenciado en los grupos sociales aludidos. Frente a la crisis y el embate de los acreedores, la capacidad de respuesta y el compromiso patrimonial son también distintos ${ }^{400}$.

Preocupan todas las situaciones, pero un sector de la doctrina ha puesto énfasis en estos dos aspectos: la pérdida del inmueble que sirve de base a la vivienda familiar y la afectación sustancial del salario que se destina al pago de los compromisos asumidos. En todos los casos, sobrevienen consecuencias patrimoniales y extrapatrimoniales dramáticas: la impotencia de pago, la marginación del mercado de crédito, la exclusión social, la afectación de la dignidad personal y del grupo familiar.

La atención del operador jurídico se ha centrado, en los últimos años, un supuesto particular de consumidor sobreendeudado, el que accede a créditos y toma deuda, respaldada exclusivamente en su salario ${ }^{401}$.

Cuando se agota la capacidad de descuento de ese ingreso, el patrimonio de este subconsumidor deja de ser la garantía de sus acreedores, el crédito se esfuma y comienza su

\footnotetext{
${ }^{398}$ HeRnÁNDEZ, Carlos A., "Reflexiones sobre el Derecho del consumidor (a propósito de algunos aportes del Doctor Miguel Ángel Ciuro Caldani)” en, Alterini, Atilio-Nicolau, Noemí (Dir.), El Derecho Privado ante la internacionalización, la integración y la globalización. Homenaje al profesor Miguel Ángel Ciuro Caldani, Buenos Aires. El texto de este trabajo me fue facilitado generosamente por el autor.

399 ANCHAVAL, Hugo, Insolvencia del consumidor, cit., pág. 46 y sgtes.

${ }^{400}$ Se dice que en la clase media, el activo más importante suele ser la vivienda familiar mientras que en las clases más vulnerables, el salario es el único bien del patrimonio del deudor (ANCHAVAL, Hugo, Insolvencia del consumidor, cit., pág. 48 y sgtes.

${ }^{401}$ Como es evidente, suele tratarse de un consumidor de créditos que no accedería al mercado formal por la cuantía de sus ingresos mensuales -reales o declarados por el empleador-, porque no tiene antigüedad laboral, porque tiene un empleo no registrado, porque se encuentra jubilado, porque no puede ofrecer garantías personales, etc.. Ello explica que las entidades dadoras de crédito ofrezcan a este público cautivo, empréstitos de baja calidad y altas tasas.
} 
calvario como sujeto marginal del mercado y de la sociedad. Todavía más, ciertos deudores en situación de quiebra estarían expuestos a la pérdida de sus fuentes de trabajo porque algunos estatutos conservan una causal de cesantía vinculada a ese status ${ }^{402}$, mientras otros los hace pasibles de sufrir la aplicación de ciertos dispositivos que restringen sus posibilidades adquirir estabilidad, acceder a ciertos puestos de trabajo, ser promocionados $^{403}$, ascender, etc.

${ }^{402}$ Con motivo de la reglamentación que prevé el Estatuto del Personal de la Administración Pública, una gran cantidad de trabajadores dependientes de la Provincia de Córdoba, ve amenazada su fuente de trabajo frente a la situación de endeudamiento. Así, el régimen especial establece como causal de cesantía "...ser declarado en concurso o quiebra fraudulenta", por lo que, pareciera que a este tipo de empleados les están vedados los remedios concursales. De allí los cuestionamientos de la doctrina y su afán de proteger a los trabajadores haciendo pie en principios constitucionales y en la defensa de los derechos humanos, máxime cuando el art. 104 de L.C. permite al fallido trabajar en relación de dependencia...Ahora bien, va de suyo que el aludido Estatuto del Personal de la Administración Pública, reglado por la ley 7233 del año 1985 (Adla, XLV-A, 823), es hoy "anacrónico" y virtualmente inaplicable. En efecto, adviértase que se considera causa de cesantía ser "declarado en concurso o quiebra fraudulenta", de manera tal, que la norma sancionaba, bajo el imperio de la anterior ley concursal 19.551 (Adla, XXVII-B, 1677) a aquellas personas a quienes se les "calificada la conducta" como fraudulenta. La ley 24.522 (Adla, LV-D, 4381) eliminó el régimen de calificación de conducta y la mera declaración de quiebra no acarrea sanción alguna y no puede serlo, pues el art. 104 de la ley concursal permite a todo quebrado seguir realizando tareas artesanales o en relación de dependencia. En efecto, la inhabilitación que apareja el art. 234 de L.C. se limita a las hipótesis del art. 238 de la legislación concursal tutelando la actividad mercantil, pero jamás poniendo un riesgo la fuente de trabajo; rectius: la relación de empleo que le permite al fallido seguir viviendo y enfrentando las obligaciones alimentarias, propias y de su núcleo familiar, como así también, de vivienda y de educación de sus hijos y la consiguiente cobertura social, como derechos humanos tutelados constitucionalmente, art. 14 y 14 bis de la Constitución Nacional. En una palabra, la pérdida del trabajo por encontrarse en quiebra implicaría una sanción absolutamente inconstitucional convirtiendo a la persona en un "muerto civil", categoría absolutamente inadmisible a la luz del art. 14, 14 bis de la Carta magna y de la Carta de la Organización Internacional del Trabajo y Tratados constitucionalizados, art. 75 inc. 22 de la C.N. Cabe también señalar la clausura por falta de activo y la consiguiente presunción de fraude y pase a la justicia penal tampoco implica definición alguna sobre "quiebra fraudulenta, hasta que no recaiga sentencia condenatoria en sede penal" (JUNYENT BAS, Francisco, "El empleado público sobreendeudado ..., cit.

${ }^{403}$ DE LAS MoRenAS, Gabriel Alejandro, "Reciente legislación de Mendoza sobre las consecuencias de la quiebra en los empleos públicos”, LLGran Cuyo, 2010 (julio), 503. Explica allí el citado autor que la ley 8131 es una modificación de la ley 6722 (Adla, LIX-E, 6291), que constituye el régimen general del personal policial de Mendoza, cuyos efectos se hacen extensivos a los penitenciarios. La misma introdujo 
KEMELMAJER DE CARLUCCI señala que el discurso protectorio se muestra paradojal frente a la tendencia jurisprudencial que niega la apertura del concurso y el pedido de quiebra al deudor que declara tener sólo su sueldo, a su vez afectado por embargos y descuentos voluntarios"

En término generales los precedentes jurisprudenciales señalan que: $1^{\circ}$ ) El proceso de quiebra tiene como finalidad específica liquidar los bienes del fallido, para distribuir su producido entre sus acreedores, por lo que, tratándose de un proceso de liquidación de bienes, es requisito para su apertura la existencia de bienes para liquidar; $2^{\circ}$ ) El efecto principal de la quiebra es lograr la ordenada y proporcional distribución del insuficiente patrimonio del fallido entre sus acreedores y es necesario la existencia de un patrimonio a ejecutar; $3^{\circ}$ ) El deudor puede recurrir a otros remedios previstos por la legislación concursal y por las leyes procesales; $4^{\circ}$ ) La aceptación del pedido de propia quiebra conduciría a graves consecuencias para el solicitante: la clausura por falta de activo, con su consiguiente presunción de fraude y la necesaria comunicación a la justicia penal, lo que trae aparejado en sede concursal la imposibilidad de rehabilitación del fallido hasta su sobreseimiento o absolución en sede penal ${ }^{405}$.

modificaciones en las condiciones laborales de los trabajadores de la seguridad modificando su status en función de la condición concursal en que se encuentran. El art. $1^{\circ}$ de la ley 8131 suprime el inciso $4^{\circ}$ de la ley 6722 que habilitaba una suspensión de 35 a 60 días a los policías fallidos. Seguidamente, el art. $3^{\circ}$ de la ley 8131 modifica el art. 185 inc. 8) que fija como requisito para acceder a la promoción por parte del personal policial el no encontrarse con declaración judicial de quiebra. El art. $4^{\text {o }}$ modifica el inciso 7 del art. 195, norma que fija las pautas de los órdenes de mérito para lograr ascensos en la carrera policial, y resta cinco puntos por la declaración judicial de quiebra. Finalmente, en el art. $6^{\circ}$ se recomienda que la reglamentación de la ley prevea restricciones para que concursados y fallidos desempeñen funciones que implique el manejo de fondos del Estado. De su lado, la ley 8134 introduce modificaciones generales en el régimen general del empleo público que está regulado en el dec. 560/73 (Adla, XXXIII-B, 1991). Se agrega al art. $9^{\circ}$ del estatuto del empleado público la imposibilidad de ser nombrado con carácter de permanente o no permanente a todos los agentes que se encuentren concursados o fallidos. Agrega la ley que no podrán concursar cargos, ni ascender ni cualquier otra mejora. Esta última valla de ingreso es reforzada por la modificación introducida al art. 11 inc. c del estatuto, donde se prohíbe el ingreso de los concursados a revistar en la administración.

${ }^{404}$ KEMELMAJER DE CARLUCCI, Aída, “El sobreendeudamiento del consumidor...”, cit.

${ }^{405}$ DE LAS MORENAS, reseña estos argumentos en abstracto, a partir de las consideraciones vertidas en el caso Costarelli (Juzg. de Procesos Concursales y Registro n ${ }^{\circ}$ 3, Mendoza, 28/8/2006, "Costarelli Enrique s/ Quiebra", LL, Cita Online AR/JUR/11087/2006). Cfr. DE LAS MORENAS, Gabriel Alejandro, "Rechazo de 
Un sector doctrinario crítico ha expresado que esta argumentación de base "muestra una laudable intención ... de dar coto a situaciones que entienden anómalas" pero que este afán de corregir a los deudores sin bienes, choca con la letra y el espíritu de la ley concursal. Compartir la moralización de los procesos concursales no impide distinguir posiciones que, so color de aquella, terminan cercenando el acceso jurisdiccional a quienes más lo necesitan...Privar a una persona de la quiebra o asumir el abuso por la sola ausencia de activo, equivale a condenar al sujeto a una situación falencial perenne que lo perjudica y segrega frente a sus congéneres fallidos que sí cuentan con activo" ${ }^{406}$.

quiebra voluntaria por ausencia de activos. Una polémica vigente. ¿Existe un derecho a quebrar? ¿Es ejercitable ese derecho por las personas de escasos recursos?", Suplemento Concursos y Quiebras, 2008 (octubre), 34; LL 2008-E 1346.

${ }^{406}$ Señala De LAS MoRENAS que el art. 2 de la LCQ prevé que "pueden ser declaradas en concurso las personas de existencia visible..."; que los arts. 77 (casos en que la quiebra debe ser declarada a pedido de acreedor) y 86 (quiebra a pedido del deudor), carecen de regla alguna que establezca como requisito de procedencia la existencia de bienes desapoderables en el activo; que la ausencia de activo o la escasez del mismo es una posibilidad que la propia ley contempla en el art. 232 LCQ; que la exigencia de los arts. 11 y 88 LCQ respecto del estado valorado del activo y pasivo como recaudos formales de admisión no puede llevarse al extremo de pensar que quien no tiene activo no tiene derecho a acceder; que conforme al art. $1^{\circ} \mathrm{LCQ}$, la condición antonomásica para la aplicabilidad de la ley concursal es la existencia del estado de cesación de pagos; y que más allá de la existencia o no de cierta medida de activo en el patrimonio del cesante, lo relevante para la ley concursal es su condición de tal. Señala el autor citado que aún admitiendo que la finalidad específica y el principal efecto de la quiebra es la liquidación de los bienes del deudor y su distribución ordenada entre los acreedores, este interés particular no es único, ni exclusivo. Se halla también involucrado el interés del sujeto fallido de poner fin a su estado de cesación de pagos, ya sea mediante la eliminación de la insolvencia por medio del consenso con sus acreedores, o bien, una vez rehabilitado, con la posibilidad de comenzar de nuevo. Sostiene, por otra parte, que la distribución de las pérdidas ocasionadas por la insolvencia del deudor con criterios de razonabilidad y respetando el principio paritario, es de interés público; tanto como que las personas insolventes "sean esterilizadas patrimonialmente para saldar su pasivo y prontamente vueltas al mercado, para que sean útiles a la sociedad". Afirma con contundencia, que la quiebra no sólo liquida un patrimonio sino que rehabilita un sujeto y permite una nueva oportunidad (conf. arts. 234, 235, 236, 107 y 108 párrafo $2^{\circ}$ LCQ) y que no es por tanto discutible que el fallido tiene acceso a un nuevo ciclo patrimonial una vez que se encuentra rehabilitado. Efectivamente, la clausura de la quiebra por falta de activo es mirada con recelo por la ley falencial. La denuncia penal por haber quebrado sin bienes es una imposición de la legislación concursal; y la praxis penal muestra que rara vez los fallidos en tales condiciones son citados a indagatoria, que la investigación penal queda paralizada con la sola denuncia y que suele 
Existe consenso respecto de que el pedido de quiebra voluntaria donde se ha verificado la existencia de cesación de pagos y el deudor persona física no posee activos, puede y debe ser rechazado cuando se constata abuso de derecho, fraude a la ley o comisión de ilícito, propugnándose una valoración ajustada a la complejidad del fenómeno aquí analizado (sobreendeudamiento de este subconsumidor particular) y al paradigma protectorio que se impone.

En estos casos es donde se ha puesto en evidencia y con mayor crudeza, la ausencia de previsiones legales específicas, la inadecuación de los remedios existentes y la dificultad para encontrar fórmulas adaptativas ${ }^{407}$.

Los desencuentros en la interpretación de los dispositivos legales y su aplicación a estos casos particulares han quedado registrados en los precedentes jurisprudenciales de toda la geografía del país ${ }^{408}$ y en las opiniones vertidas por la doctrina autoral ${ }^{409}$. Y ello resulta explicable.

ordenarse el archivo de las actuaciones casi inmediato por ausencia de delito. Recuerda De las Morenas que el fallido que quiebra sin bienes goza igualmente de la presunción de inocencia, de raigambre constitucional. (DE LAS MORENAS, Gabriel Alejandro, "Rechazo de quiebra voluntaria ...", cit.

${ }^{407}$ Remitimos al valioso trabajo llevado a cabo por el equipo de investigación dirigido por Aída KEMELMAJER de Carlucci y Horacio Roitman. Cfr. Kemelmajer de Carlucci, Aída-Roitman, Horacio (Dir.), “El sobreendeudamiento de la persona física en el ámbito del Poder Judicial de la Provincia de Córdoba con relación a las causas judiciales iniciadas entre el año 2006 y 2010 en el fuero de concursos y quiebras y penal económico. Consecuencias normativas, procesales e institucionales", en Investigaciones aplicadas en el ámbito del Poder Judicial de Córdoba 8, Colección Investigaciones y Ensayos, Córdoba, 2011, pág. 97-145,

https://www.justiciacordoba.gob.ar/JusticiaCordoba/files/libros/Investigaciones\%20y\%20Ensayos\%20n\%C2 \%BA\%208.pdf (Fecha de consulta: 9/7/2015).

${ }^{408}$ Cámara en lo Civil y Comercial de Necochea, 5/9/2013, "D.R.R. s/Quiebra”, elDial.com; Cámara Civil y Comercial, Rosario, 12/06/2008, "Calvo, Sabina N. s/ Quiebra”; Cámara Civil y Comercial, Rosario, 7/09/2007, “Gerlo, Rolando Antonio", LL Litoral, 2007 (diciembre), 1135; Cámara Civil y Comercial, Rosario, 27/8/2007, "Mac Guire, Daniel s/Quiebra”; Juzg. Procesos Concursales y Registro, N², Mendoza, 14/4/2008, "Oro, Olga Rosa”, Juzg. de Procesos Concursales y Registro n 3, Mendoza, 28/8/2006, "Costarelli Enrique s/ Quiebra”, LL, Cita Online AR/JUR/11087/2006; Juzg. de Procesos Concursales y Registro n 3, 3/11/1995, "Soletti”; Juzg. Civil y Comercial N³9 Nominación, Córdoba, "Depainte, Oscar Javier s/Quiebra propia simple"; Juzg. Civil y Comercial (Secretaría Concursal), III ${ }^{\circ}$ Nominación, Tucumán, 16/04/2012, “González, Edmundo José s/ Quiebra Pedida”; Juzg. Civil y Comercial (Secretaría Concursal), 
La normativa concursal se muestra impotente para resolver estos nuevos problemas porque son ajenos a las situaciones que pensaron ser resueltas con su dictado. Precisamente ese vacío legislativo o la inadecuación de los dispositivos existentes es lo que explica que el tránsito por el procedimiento vigente, luzca disfuncional y hasta pueda alentar iniciativas distorsivas y abusos ${ }^{410}$.

IV Nominación, Tucumán, 11/09/2012, "Graneros, Damiana E. s/ Quiebra pedida”; Juzg. Civil y Comercial (Secretaría Concursal), VIII ${ }^{\circ}$ Nominación, Tucumán, 5/2/2013, "Segovia, Francisco Solano s/Quiebra Pedida"; Juzg. Civil y Comercial (Secretaría Concursal), VIII ${ }^{\circ}$ Nominación, Tucumán, 6/3/2013, "Encinar, Mario H. s Quiebra Pedida"; Juzg. Civil y Comercial (Secretaría Concursal), VIII ${ }^{\circ}$ Nominación, Tucumán, 23/04/2013, "Pérez, Daniel Félix s/ Quiebra Pedida"; entre otros.

${ }^{409}$ DE LAS MORENAS, Gabriel Alejandro, "Rechazo de quiebra voluntaria...”, cit.; DE LAS MORENAS, Gabriel Alejandro, "Reciente legislación ...", cit.; JUNYENT BAS, Francisco-IZQUIERDO, Silvina., "El consumidor sobreendeudado ...", cit., pág. 757-766; JUNYENT BAS, Francisco-IZQUIERDO, Silvina., "El consumidor $\begin{array}{llllll}\text { sobreendeudado } & \mathrm{y} & \text { el } & \text { derecho } & \text { quebrar, }\end{array}$ https://www.google.com.ar/?gws_rd=ssl\#q=Junyent+Bas+Izquierdo+sobreendeudamiento+del+consumidor+ e+el+derecho+a+quebrar (Fecha de consulta 9/7/2015); JUNYENT BAS, Francisco A. - IzQUIERDO, Silvina, "¿Decoctor ergo fraudator? La quiebra de los consumidores", en Suplemento Concursos y Quiebras, 2009 (octubre), 1; LL 2009-F, 991; RIVERA, Julio César, "Insolvencia de las personas físicas...”, cit., pág. 3; BARACAT, Edgar J.- MiCELLI, María I., "La crisis del sistema ante la desnaturalización del proceso falencial", Ponencia presentada al $\mathrm{VI}^{\circ}$ Congreso Argentino de Derecho Concursal y $\mathrm{IV}^{\circ}$ Congreso Iberoamericano sobre la Insolvencia, Rosario, Libro de Ponencias, T. I, Moralización en los procesos concursales, pág. 81 y sgtes.; MicelLI, María I., "Un límite necesario al uso antifuncional de la quiebra voluntaria", LLLitoral, 2007 (diciembre), 1135; GARAGUSO, Horacio- GARAGUSO, Guillermo H., "Las pequeñas quiebras que avergüenzan a algunos juristas y jueces son necesarias para el deudor y sus acreedores", ponencia presentada en las Jornadas Nacionales de Institutos de Derecho Comercial celebradas en San Nicolás en el año 2008, en Libro de Ponencias, Fundación para la Investigación y el Desarrollo de las Ciencias Jurídicas, pág. 408 y sgtes.; PEREYRA, Alicia, "Los procesos concursales en los que el deudor manifiesta no poseer activos liquidables: sólo cuenta con su sueldo", en Revista de Derecho Concursal, Zeus, T VI, pág. 221 y sgtes.; Di LeLLA, Nicolás J., "El fenómeno de las llamadas 'quiebras sin activo' y su tratamiento en la jurisprudencia actual", La Ley Online, AR/DOC/1805/2013; entre otros.

${ }^{410}$ Entre 2007 y 2008, se presentó un fenómeno particular en jurisdicciones provinciales, caracterizado por la presentación masiva de pedidos de propia quiebra de personas físicas, que eran empleados públicos en su inmensa mayoría. Se constató que en muchos casos, poco tiempo antes de quebrar, habían contraído obligaciones que excedían notablemente de su capacidad patrimonial y se consideró evidenciado que el objetivo era peticionar la propia quiebra, denunciar el sueldo como único bien en el patrimonio, restringir la responsabilidad al límite embargable del salario por un año y una vez rehabilitado, liberarse del pasivo con un 
El sobreendeudamiento del consumidor en general y el de aquel que se encuentra en una situación de mayor vulnerabilidad (sin activos y con su salario como único bien en el patrimonio) requieren nuevas respuestas legislativas, con una lógica y fundamentos propios; y demandan del intérprete, criterios de valoración diferentes, ajustados a un nuevo paradigma de prevención, saneamiento y rehabilitación del deudor en crisis.

Es indisimulable nuestro deseo de que la regulación que reclamamos se concrete en una ley especial que -de modo integral y sistematizado- contemple remedios preventivos y de saneamiento, con dispositivos sustanciales y procedimentales.

Pero así como fijamos posición sobre la cuestión metodológica, también hemos admitido que el objetivo es ofrecer soluciones eficaces. Y si una eventual reforma a la ley concursal permite acercar de modo más inmediato, procedimientos que sirvan al saneamiento de las economías domésticas en crisis, la alentamos. No parece irrazonable que, en ese marco, el legislador deba fragmentar el supuesto de hecho (incluyendo a nuestro consumidor) y, para uniformar el lenguaje con el que se identifica a los sujetos del concurso, llame persona física no comerciante a este deudor sobreendeudado particular ${ }^{411}$.

patrimonio limpio para el futuro. Se menciona que estos deudores encontraron abogados que publicitaban sus servicios profesionales en diarios y revistas, ofreciendo asistencia para limpiar deudas, garantizando el saneamiento de esa economía particular dañada en un año, mediante el pago de una determinada suma de dinero amortizable hasta mensualmente. La reacción de los tribunales fue adversa y procedieron -al menos en algunos casos- a rechazar los pedidos de propia quiebra, argumentando que de conformidad con los hechos expuestos en la demanda, el peticionante estaría utilizando abusiva y antifuncionalmente su derecho, intentando desbaratar el derecho de sus acreedores, en contra de la regla contenida en el art. 1071 del CCiv, en tanto éste podría hallar en los remedios ordinarios —incidencia de reducción y/o levantamiento de embargos sobre sueldos - los procedimientos adecuados para abordar su endeudamiento y ajustarlos a sus ingresos.

${ }^{411}$ No se nos escapa que la adhesión a la fórmula del deudor persona física (o natural, con lo llama la ley española) y su ampliación a aquéllas que ejercen una actividad empresaria obedece en muchos ordenamientos, a la necesidad de ofrecer soluciones coyunturales frente a la crisis imperante y que esta regulación se muestra como de emergencia y con la nota de excepcionalidad que le es propia. Comprendemos que esta visión ampliada a la persona natural empresaria persigue -además del saneamiento de su economía individual y su rehabilitación- el mantenimiento de fuentes de trabajo y el estímulo para la reactivación de su actividad productiva. No nos aventuramos a señalar que el modelo adoptado por el legislador español carezca de vocación de permanencia. Decimos que, en Argentina, el destinatario de la regulación que propiciamos es el 
Avizoramos también que con la entrada en vigencia del nuevo Código Civil y Comercial de la Nación -ahora unificado- el universo de situaciones reguladas tendrá una nueva impronta. Hemos señalado ya que los paradigmas y principios allí recogidos revelan la centralidad de la persona humana en este nuevo Corpus de Derecho Privado, que acude también en nuestro auxilio para encontrar respuestas al problema del sobreendeudamiento del consumidor. Sorprende -pero no tanto- que muchas de las soluciones nacidas con vocación de ruptura, al amparo del Derecho del Consumidor, hoy exhiben un tránsito inverso y se instalan en el sistema general, ocupado de la persona humana, sin otra calificación.

b.2.- El requisito de la buena fe del consumidor sobreendeudado. Nuestra interpretación:

Siguiendo con el análisis del elemento subjetivo, cabe señalar que algunas legislaciones contemplan expresamente como requisito, la acreditación de la buena fe del deudor que pretenda prevalerse de las soluciones previstas en el régimen de sobreendeudamiento $^{412}$.

Coincidimos otra vez con GutiÉRREZ DE CABIEDES al decir que "no es una exigencia ontológica, conceptual" que defina la aplicación de la regulación. "Esta nota tiene su virtualidad sólo en determinados ámbitos o medidas insertas en el tratamiento jurídico que debe darse al fenómeno del sobreendeudamiento (en las medidas reparadoras o solutivas en el seno del procedimiento de sobreendeudamiento o insolvencia, como puede ser [...] la liberación de las deudas restantes tras la liquidación) pero no en todas las medidas, como en la mayoría de las preventivas...dado que obviamente también debe evitarse el sobreendeudamiento doloso" ${ }^{413}$.

FRUSTAGLI y HERNÁNDEZ afirman con convicción este aserto: "es indiscutible que en el plano preventivo, los instrumentos idóneos para evitar el endeudamiento excesivo de

consumidor persona física y que en esta denominación del elemento subjetivo vemos corporizada la esencia y el fundamento de aquélla.

${ }^{412}$ Así lo establece el art. L. 330-1 del Código de Consumo francés y el art. 178 bis de la ley concursal española conforme la modificación introducida por el Real Decreto-Ley 1/2015.

${ }^{413}$ GutiÉRREZ DE CABIEDES, Pablo, El sobreendeudamiento doméstico..., cit., pág. 27. 
los consumidores resultan operativos al margen de su buena o mala fe, mientras que las soluciones de índole correctivas, ... podrán -en principio- limitarse a aquellas situaciones de sobreendeudamiento objetivo o pasivo" ${ }^{\natural 14}$.

Los ordenamientos del Derecho Comparado imponen como requisito de las medidas de saneamiento y rehabilitación, la buena fe del deudor que pretender prevalerse de ellas. Y la doctrina abona esta posición. Se exige que el operador -sea en sede administrativa o en se de judicial) constate la buena fe de sujeto afectado por el endeudamiento excesivo, evaluando su concreta situación, para reconocer el beneficio del trámite particular, a aquél que justifiquen el merecimiento del mismo.

Reiteramos aquí nuestra visión particular. Concurriendo los elementos objetivo y subjetivo (graves dificultades o imposibilidad de asumir el cumplimiento de las obligaciones vencidas y a vencer y el consumidor persona física como sujeto afectado), entendemos que la buena fe de este último presumirse. El beneficio del procedimiento especial resultará justificado en todos aquellos supuestos en los que no pueda formularse un juicio de reproche a la conducta del particular afectado ${ }^{415}$.

Al analizar la concurrencia del elemento objetivo (la situación de endeudamiento excesivo y la imposibilidad de afrontar el cumplimiento de las obligaciones asumidas), quien lleve adelante el procedimiento evaluará la composición del pasivo, su origen y cuantía, confrontándolo con la renta disponible. Esa indagación le permitirá evaluar el cuadro de situación del sujeto sobreendeudado y concluir, además, respecto de esta arista concreta de la problemática.

El requisito de la buena fe del consumidor sobreendeudado debe ser interpretado, desde nuestra perspectiva, como la ausencia de mala fe. Será deudor de buena fe ni no se constata un proceder desaprensivo o de marcado menosprecio respecto de elementales normas de tutela del propio interés.

\footnotetext{
${ }^{414}$ Frustagli, Sandra-HeRNÁNDEZ, Carlos A., “Sobreendeudamiento del consumidor”, en LL 2013-E,1160.

415 Postula un criterio similar BORGARELLO, Luisa, "El concurso del consumidor: algunas reflexiones", Ponencia presentada en el $\mathrm{V}^{\circ}$ Congreso Iberoamericano sobre la Insolvencia y el VII ${ }^{\circ}$ Congreso Argentino de Derecho Concursal realizados en Mendoza entre el 4 y el 7 de octubre de 2009.
} 
Esta perspectiva de análisis guarda relación con la vulnerabilidad estructural del consumidor y las asimetrías en las que aquélla se traduce ${ }^{416}$. Nos permite considerar hipótesis en las que el comportamiento en apariencia irreflexivo, torpe, ligero o poco cuidadoso no será reprochable y, por tanto, no autorizará la exclusión de los beneficios que propugnamos.

Nos advierte MOSSET ITURRASPE ${ }^{417}$ que en la base de su concreta desigualdad, se advierte una característica propia del consumidor: su ignorancia, su no saber. Ignora la multiplicidad de productos y servicios que el mercado incorpora y ofrece de modo permanente; ignora, asimismo, el surgimiento constante de nuevas formas de contratación y comercialización de los mismos. El consumidor que nos ocupa, en la mayor parte de los casos, obra por necesidad, precisado de adquirir bienes y servicios para resolver sus dilemas cotidianos. Es un inexperto en materia negocial. Con frecuencia, son las urgencias de nuestro tiempo las que llevan al consumidor a contratar con ligereza.

Esa ligereza, torpeza, inexperiencia y estado de necesidad tipifican la figura. Pero no se trata de una debilidad inherente a la persona singular sino de su emplazamiento en las relaciones de mercado y del rol que ocupa en la sociedad de consumo ${ }^{418}$. Precisamente por el contraste con la experticidad del proveedor y el sitial protagónico que éste asume en la relación de consumo, es que se explica la aplicación del principio protectorio.

En el ámbito de la operatoria de crédito, el experto es el profesional del negocio. Nos referimos al agente financiero, a la banca, a la entidad que ofrece financiación, al proveedor de bienes y servicios, en su caso. Es éste quien diseña el producto financiero luego de un estudio de mercado, de identificar el segmento al que apunta y de fijarse metas

\footnotetext{
${ }^{416}$ Rusconi, Dante, en Rusconi, Dante (Coord.), Manual de Derecho del Consumidor, cit., pág. 12 y sgtes.

417 MOSSET ITURRASPE, Jorge, "Introducción al derecho del consumidor”, Revista de Derecho Privado y Comunitario, T. 5, Consumidores, Rubinzal Culzoni, Santa Fe, 1994, pág. 7 y sgtes.

${ }^{418}$ Nos dice RUSCONI: "Se ha intentado sin éxito, afortunadamente, desprestigiar nuestra materia diciendo entre muchas otras cosas, que ...los consumidores no eran dignos de tutela legal diferenciada simplemente porque eran los menos talentosos del mercado y que esta torpeza no podía ser justificativo para el dictado de normas especiales....si se pretendió menospreciar al consumidor, con un sesgo peyorativo, haciendo ver que la culpa de sus males radicaba en sus flaquezas personales, también quedó dicho que ellas no obedecen a factores que le sean inherentes sino al ámbito o espacio en el que habita" (RUSCONI, Dante, en RUSCONI, Dante (Coord.), Manual de Derecho del Consumidor, cit., pág. 13).
} 
de colocación. Es quien organiza la estrategia para captar la clientela, para estimularla y persuadirla, para generar su confianza, para remover los obstáculos que le impidan concretar el negocio. Es quien propondrá las reglas del juego ofreciendo los instrumentos que servirán para formalizar el empréstito. Es quien maneja la operatoria.

La profesionalidad del dador de crédito y su condición de experto justifican que, como regla, debamos presumir la buena fe de quien negocia con él. Resulta razonable pensar el consumidor no acude al crédito en un plan macabro para defraudar a quien se lo provee. No parece descaminado interpretar que el consumidor deposita su confianza en quien hace de esta actividad su modo de vida y sustento.

Tomar empréstitos con escasa información y sin asesoramiento, hacerlo en condiciones gravosas a sus intereses y acumular deuda, pueden considerarse a priori, prácticas carentes de prudencia que no merecen disimulo ni excusa. Ahora bien, tales situaciones deben merituarse en el caso concreto, conforme el mercado de que se trata, los sujetos involucrados y las modalidades en que el consumidor accedió a la operatoria y transitó la misma.

Las estrategias de colocación de crédito son intensas. El consumidor es muchas veces buscado, sustituyéndose su iniciativa por la del propio agente financiero (recibe correos postales y mails, llamados telefónicos, visitas). Se estimula el empréstito al punto de lo irresistible mediante campañas publicitarias agresivas y de alto impacto. Se facilita la entrada al contrato removiendo todos los obstáculos posibles. Se aligeran de los requisitos (documentación mínima y trámite express), se libera al tomador del crédito de un desembolso inicial ("pague la primera cuota recién a los 60 o 90 días") y se conceden plazos extensos con aparente licuación de la deuda (“50 cuotas mínimas”). En algunos casos (financiación por la adquisición de determinados bienes o la contratación de ciertos servicios) se exime de la garantía de terceros, haciendo suscribir documentos al propio deudor; en otros supuestos, se cotizan alto los bienes dados en garantía generando la sincera creencia de que el tomador cuenta con respaldo y tranquilidad en la eventual contingencia. Se ofrecen facilidades para el pago de las amortizaciones, con descuentos por planilla y de la propia cuenta sueldo ("Ud paga sin moverse de su casa. Nosotros nos ocupamos"). La contratación estandarizada genera seguridad: las condiciones han sido predeterminadas por el experto, son iguales para todos y ha sido controladas previamente por la autoridad de 
aplicación que, además, ejerce un supervisa la legalidad de la operatoria y la actividad del sector. La estructura del negocio crea una apariencia de solvencia técnica y económica. El consumidor confía pues está en manos de un profesional del negocio. La información suele ser insuficiente y el asesoramiento previo brilla por su ausencia, más aún el que pueda precisar el consumidor que ya transita la operatoria.

Algunos consumidores deciden con mayor libertad con quien contratarán, a la hora de adquirir bienes con financiación o tomar empréstitos; otros no tiene esa posibilidad de elección y acuden a sus propias cooperativas de trabajo o entidades mutuales, o acceden al crédito que ofrecen entidades que trabajan con estos sectores sociales más vulnerables (jubilados, trabajadores informales o de bajos ingresos, deudores sin garantías, etc.).

No creemos que el consumidor deba probar su buena fe para pretender los beneficios del saneamiento. El comportamiento especulativo y temerario del consumidor resultará de la indagación que el operador jurídico lleve adelante en el procedimiento previsto por la regulación a dictarse (acumulación de deuda en un plazo corto e inmediato anterior al momento de peticionar las medidas de saneamiento, adquisición de bienes suntuarios notoriamente ajenos a la realidad del adquirente ${ }^{419}$, endeudamiento sin ingresos

\footnotetext{
${ }^{419}$ No es infrecuente ver que algunas familias de escasos recursos, tienen en el hogar algunos productos que otras familias de mejores ingresos no poseen. La tecnología aplicada a los medios de comunicación, a actividades recreativas y lúdicas ha determinado la aparición de los llamados productos inteligentes (telefonía móvil altamente sofisticada, smart $t v$, dispositivos de computación, equipos de audio complejos, juegos electrónicos, etc.). Ocurre lo mismo en materia de servicios, donde los costes de la contratación lucen excesivos respecto del nivel de ingresos de sus usuarios. La adquisición de bienes o la contratación de servicios que pueden parecer de lujo y desajustados a la economía familiar deben ser juzgados también en el caso particular. Por un lado, porque en determinados supuestos existe una justificación ajena a la voluntad del consumidor (en ciertas localidades generalmente apartadas de centros urbanos -y en algunas villas emplazadas muy cerca de éstos- suelen verse viviendas muy precarias pero que cuentan con antenas parabólicas para la recepción de la señal de televisión por aire, siendo ese empresario proveedor el único que llega a esos usuarios, alejados de todo y para quienes esa contratación supone acceder a la información, a la recreación, a la cultura). Por otra parte, no menos importante, muchas veces el consumidor adquiere un producto o contrata un servicio alejado de sus necesidades o inadecuado a su realidad porque no fue debidamente informado, asesorado o aconsejado por el proveedor que lo financia o por el dador de crédito que le otorga el empréstito. El desacierto de esta contratación puede no serle entonces reprochable sino más bien a quien no arbitró las diligencias necesarias para neutralizar esa elección inconveniente o descaminada.
} 
alguno, etc.). En su caso, serán los acreedores quienes deban aportar elementos que justifiquen el ejercicio abusivo del derecho a peticionar los beneficios de la regulación reclamada.

No pretendemos negar que puedan presentarse casos en los que la viveza criolla (a la que aluden algunos pronunciamientos judiciales y cierta doctrina) lleve a algún consumidor a endeudarse en forma deliberada para luego intentar liberarse del pasivo a bajo coste, perjudicando a sus acreedores. La regulación deberá disponer mecanismos para desalentarlos pero no es este temor a supuestos de excepción -más bien excepcionalísimoslo que debe condicionar la valoración del requisito de buena fe analizado.

El criterio mencionado define los contornos del elemento subjetivo analizado. La regulación particular de la problemática estará destinada al consumidor (o subconsumidor sobreendeudado) de buena fe, entendida ésta conforme lo señalado.

La interpretación del requisito antes esbozada está en armonía con el estándar de tutela deseable. Creemos que, por otra parte, traduce en reglas concretas los principios que sostienen el sistema.

Consideramos que esta pauta de interpretación contribuye a orientar conductas responsables de todos los protagonistas de la operatoria de crédito pero especialmente de aquéllos que, por su carácter profesional, asumen el rol protagónico en el funcionamiento y desarrollo de la actividad.

2.- Principios que deben inspirar esta regulación particular:

a.- Protección de la dignidad personal: un nuevo paradigma

$\mathrm{El}$ art. 8 bis de la ley de defensa del consumidor argentina, al consagrar el derecho a un trato digno, tradujo en una norma particular del microsistema, el mandato garantista impartido desde la Constitución. El art. 1097 del nuevo Código Civil lleva al sistema general, una norma equivalente al art. 8 bis de la Ley 24240 citada, revigorizándola. El codificador iusprivatista no se limita a replicar el reconocimiento del derecho a un trato digno, imponiendo su observancia a los proveedores de bienes y servicios, sino que

Estas aristas deben ser atendidas puesto que un análisis ligero y simplista conducirá a conclusiones desacertadas, poniendo en riesgo la eficacia de la tutela que propiciamos. 
consagra el estándar de cumplimiento. En efecto, el nuevo art. 1097 establece que "la dignidad de la persona debe ser respetada conforme a los criterios generales que surgen de los tratados de derechos humanos".

El respeto de la dignidad del consumidor "constituye uno de los derechos básicos de los consumidores, en tanto principio ordenador que sirve de fundamento, base o marco de referencia teleológico de los restantes derechos" ${ }^{\text {420 }}$. Se ha señalado, que la cualidad central del ser humano es precisamente la dignidad y de allí que corresponda admitir la postulación de un principio general del derecho con la dignidad de la persona como eje, "que se expande por todo el ordenamiento jurídico, con jerarquía constitucional"

No hemos de extendernos en el desarrollo de estas ideas en este apartado. Hemos formulado ya algunas consideraciones al explicar el contexto en el que se emplazan las relaciones que propicia el mercado, en general, y la operatoria de crédito, en particular; y lo haremos al justificar la necesidad de implementar mecanismos de prevención de ciertas prácticas empresarias que colocan al consumidor en situaciones abusivas que no pueden ser consentidas (marketing agresivo, publicidad ilícita, modalidades especiales de contratación, mecanismos de cobranza, etc.).

Precisamente porque la explosión de derechos reconocidos al consumidor resulta igualmente insuficiente para neutralizar la amenaza y la conculcación de sus libertades, es que parece necesario proclamar el respeto de la dignidad con mayúsculas, que viene a completar su tutela, "con aromas de una cláusula general"

El fenómeno de la democratización de crédito ha permitido el acceso de grupos sociales que antes no accedían a las operatorias de financiamiento. Y, como es evidente, el sobreconsumo y el endeudamiento excesivo impactaron duramente en ese colectivo de sujetos y sus familias. Frente al embate de los acreedores, la capacidad de respuesta del consumidor sobreendeudado es diversa. Muchas situaciones son las que preocupan pero un sector de la doctrina ha destacado dos aristas particularmente dramáticas: la pérdida del inmueble que sirve de base a la vivienda familiar y la afectación sustancial del salario del

\footnotetext{
${ }^{420}$ GELCICH, Marcelo G.- GARCÍA VILlAREAL, Antonio-PASSARELlA, Julián Emmanuel, "La información y el crédito en la sociedad de riesgos", LL Litoral, 2010 (noviembre), 1081.

${ }^{421}$ GHERSI, Carlos Alberto, "La dignidad como principio general del derecho”, LL 2014-D, 1054.

${ }^{422}$ SANTARELLI, Fulvio Germán, "De la debilidad, sistema y paradigmas", en RCyS 2014-II, tapa.
} 
deudor en crisis. Las derivaciones son conocidas: la marginación del mercado de crédito, la exclusión social, la afectación de la dignidad personal y del grupo familiar.

Cuando el consumidor toma deuda respaldada exclusivamente en su salario y se agota la capacidad de descuento de ese ingreso, el patrimonio de este subconsumidor deja de ser la garantía de sus acreedores, el crédito deja de ser una realidad y comienza el oscuro peregrinaje de un sujeto sin futuro.

El nuevo Código Civil y Comercial de la Nación es revelador de nuevos paradigmas. Los principios allí recogidos hacen explícita la centralidad de la persona humana. En la novísima regulación privatista, la regulación de las relaciones jurídicas de consumo, echa anclas en la ética de los vulnerables ${ }^{423}$, justificando la naturaleza tuitiva de los dispositivos que integran el sistema, desde el código y fuera de él. Y como la regulación que propiciamos necesariamente habrá de integrarse a ese sistema, en diálogo con las demás fuentes, debe participar de aquellos principios y valores.

La debilidad estructural que se predica del consumidor en las relaciones del mercado, en general, encuentra en la operatoria de crédito un escenario particularmente amenazante. Esa vulnerabilidad luce extrema por la complejidad de su funcionamiento y lo sofisticado de su técnica negocial. No llamará la atención por tanto, que nuestra propuesta sea inspirar las soluciones en el respeto de esa dignidad del consumidor sobreendeudado.

Precisamente porque ese endeudamiento excesivo coloca a la persona del deudor y a la familia en situación de indignidad intolerable es que los esfuerzos deben orientarse prioritariamente, a prevenir ese mal, neutralizando los factores que contribuyen al mismo. Y frente al sobreendeudamiento constatado, el legislador debe ofrecer un camino de salida iluminado por el paradigma de la dignidad y en la ética de los vulnerables antes referida.

Los dispositivos preventivos y de saneamiento deben ajustar su diseño a la naturaleza de los bienes en juego ${ }^{424}$. No hay tiempo ya para distracciones, ni justificación para el disimulo. Atender a la situación del sobreendeudamiento de los consumidores es un deber impostergable para el legislador argentino.

\footnotetext{
${ }^{423}$ LORENZETTI, Ricardo L., "Entra en vigencia el nuevo Código Civil y Comercial de la Nación”, en La Ley, Revista del 3/8/2015, pág.2 y sgtes.

${ }^{424}$ Cfr. las ideas esbozadas en LORENZETTI, Ricardo L., "Nuevos paradigmas en el Derecho privado: el acceso a los bienes", en LL 1994-E,990.
} 


\section{b.- Tutela de la confianza}

Es indudable que la operatoria de crédito y los servicios que el sector ofrece a los usuarios del sistema, presentan notas de complejidad. En este escenario de asimetrías más agudas, contrastan con evidencia la experticia del proveedor y lo profano del consumidor. Podríamos afirmar sin temor a equivocarnos que la organización de sector empresario, su modalidad de actuación y el producto ofrecido constituyen una manifestación de los denominados sistemas expertos ${ }^{425}$. En efecto, una de las partes de esa relación de mercado es un sistema de logros técnicos con experiencia profesional, que genera confianza especial. Y esa confianza depositada en quien ostenta apariencia de solvencia técnica en el manejo del negocio, no puede ser defraudada ${ }^{426}$.

En el ámbito de la operatoria de crédito, el experto es el proveedor del crédito. Es quien diseña el producto financiero, quien organiza la estrategia para captar la clientela, quien propone las reglas del juego ofreciendo los instrumentos que servirán para formalizar el empréstito, es quien maneja la operatoria. El consumidor deposita su confianza en quien hace de esta actividad, la razón de su existencia ${ }^{427}$.

\footnotetext{
425 "La organización económico- social en una economía global tiene a configurarse como "sistema experto" en numerosas áreas, presentando entonces un supuesto de magnitud considerable y relevante. El viaje en avión, el turismo, los servicios informáticos, los bancarios, los clubes de campo, el seguro, la jubilación, los parques de diversiones, los shopping centers, las prestaciones de salud, presentan características similares en el plano organizacional: a) son sistemas, ya que el individuo no se relaciona con otro individuo, sino con un sistema de individuos; b) son expertos ya que presentan características tecnológicas inescrutables, y el individuo sólo se relaciona con su presentación externa y simplificada. Frente a este fenómeno, las conductas de los empresarios como de los consumidores cambian sustancialmente, apartándose de los modelos de elección racional que inspiraron las legislaciones codificadas" (LORENZETTI, Ricardo L., "La oferta como apariencia y la aceptación basada en la confianza”, LL 2000-D,1155).

${ }^{426}$ Cfr. las reflexiones contenidas en NiCOLAU, Noemí, "El principio de confianza en el Derecho civil actual”, en J.A. Lexis Nexis,. 2001-III-pag. 1144.

${ }^{427}$ LORENZETTI explica que "desde el punto de vista de la teoría de la acción humana, la presencia del futuro de por sí implica la necesidad de planificar, pero cuando el individuo debe actuar en contextos turbulentos y sofisticados, soporta una carga excesiva. Necesita reducirla en base a la confianza” (LORENZETTI, Ricardo L., "La oferta como apariencia..." cit.).
} 
Acudir al empréstito con escasa información y sin asesoramiento, hacerlo en condiciones gravosas y acumular deuda pueden considerarse a priori, prácticas irresponsables sin excusa que las justifique. Pero a la hora de juzgar el comportamiento de ese consumidor endeudado en exceso deben merituarse en el caso concreto ${ }^{428}$. No puede ignorarse, el contexto del mercado de que se trata, los sujetos involucrados y las modalidades en que el consumidor accedió a la operatoria y transitó la misma. Como se dijo, algunos consumidores deciden con mayor libertad a quien habrán de recurrir para adquirir bienes con financiación o tomar empréstitos pero otros no tiene esa posibilidad de elección y acuden a entidades de crédito que trabajan con estos sectores sociales más vulnerables (jubilados, trabajadores informales o de bajos ingresos, deudores sin garantías, etc.).

La confianza tiene muchos significados normativos: es un bien jurídico protegido, es una regla interpretativa y un criterio decisorio ${ }^{429}$. Cuando un régimen jurídico adopta liminarmente el principio de protección de la confianza, expresa una determinada

428 "Frente a este fenómeno, las conductas de los empresarios como de los consumidores cambian sustancialmente, apartándose de los modelos de elección racional que inspiraron las legislaciones codificadas. El consumidor o usuario actual podría ser considerado negligente si se aplicara un standard contractual clásico; porque las pruebas que realiza para verificar los datos suministrados antes de contratar son muy pocas y generalmente inicua; actúa en base a un conocimiento inductivo débil. Pero no se trata de un problema de negligencia, sino de una necesidad: si se tuviera que verificar razonablemente cada acto, sería imposible vivir, y los costos de transacción serían altísimos. La conducta individual tiende a simplificar, reduciendo los costos de transacción y el agotamiento sociológico que significaría pretender entender cada uno de los sistemas con los cuales uno se relaciona. Un ser racionalmente orientado no podría vivir, porque debería solicitar información sobre cada sistema, conocer el mismo, y luego actuar. La regla es la disminución de la información que se obtiene para actuar, derivada de su alto costo marginal y de oportunidad; disminuye la racionalidad y aumenta la fe en los sistemas complejos, lejanos, abstractos, que llega a ser casi religiosa" (LORENZETTI, Ricardo L., "La oferta como apariencia..." cit.).

${ }^{429}$ LORENZETTI, Ricardo L., "La oferta como apariencia..." cit. Para indagar, en particular, acerca de la responsabilidad civil por infracción al principio de confianza, resulta de necesaria consulta la obra de DE Castro Portugal Carneiro da Frada, Manuel Antonio, Teoría da confíanca e responsabilidade civil, Ed. Almedina, Coimbra, 2004. 
concepción de la vida social y muestra que ha decidido condenar los comportamientos contrarios a ella ${ }^{430}$.

En el tratamiento de las diferentes aristas problemáticas del fenómeno que nos desvela, hemos de explicitar los campos de aplicación directa del principio de confianza. Consideramos que las medidas de corte preventivo del sobreendeudamiento deben estar también inspiradas en la tutela de la confianza. El quiebre de este valor importa la minar las bases de la operatoria de crédito y el sustrato de la relación proveedor-consumidor. Este riesgo debe ser neutralizado por razones de mercado y por razones humanitarias. El crédito es una rampa de acceso a los bienes y a la calidad de vida. Las medidas de saneamiento deben seguir el mismo norte. La distribución del coste de la insolvencia y su absorción por los proveedores de crédito será oportunamente justificada. Pero a modo de adelanto, la liberación del pasivo pendiente será una manifestación más de la responsabilidad que necesariamente quepa al dador de crédito frente a esa situación de endeudamiento excesivo, que no le es ajena, y donde la confianza depositada en el sistema y en sus operadores, ocupa un lugar central como factor de imputación ${ }^{431}$.

c.- Principio de préstamo responsable

El INSOL, importante organismo internacional dedicado al estudio de la insolvencia, emitió ya en el mes de mayo de 2001 un informe de gran relevancia, conocido como el Consumer Debt Report ${ }^{432}$ en el que se proponían reglas para el abordaje de la problemática del sobreendeudamiento.

El citado informe concluye con una serie de recomendaciones orientadas a los diferentes sectores involucrados (legisladores, entidades públicas y privadas, dadores de crédito y asociaciones de consumidores), de singular importancia. Por su pertinencia,

430 NicOlaU, Noemí, "La teoría de la confianza en el Derecho civil actual”, en file:///D:/Mis\%20documentos/Downloads/nicolau___confianza.pdf (Fecha de consulta 20/7/2015).

${ }^{431}$ MARTORELL, Ernesto E., "Nuevos paradigmas que agravan la responsabilidad de los bancos", La Ley, Revista del 26/03/2015.

${ }^{432}$ Ver www.insol.org/pdf/consdebt.pdf 
centramos nuestra atención en las entidades financieras, proveedoras del crédito a los consumidores, a las que se les recomendaba:

- repensar la metodología de acceso al crédito ${ }^{433}$;

- mejorar la información disponible

- revisar las metodologías de cobro ${ }^{434}$.

El desembarco del principio de préstamo responsable, aunque sin consagración expresa, en la Directiva 2008/48 de Crédito al Consumo ${ }^{435}$, impide disimular distracciones. El tema quedó planteado y el debate está abierto en el ámbito de la Unión Europea. No se discute su recepción sino la eficacia de las medidas que traduzcan este principio en normas legales de aplicación concreta.

El Comité Económico Social Europeo en su Dictamen del 25 de octubre de $2007^{436}$ manifestó su preocupación al señalar que la Comisión "sólo abordó de manera episódica el tema del crédito responsable" (punto 6.1.3) e insistió en la necesidad de un mayor compromiso de las instituciones de crédito con las necesidades y la situación de sus deudores individuales, la búsqueda de un instrumento financiero más adaptado a las

${ }^{433}$ Lo decíamos páginas arriba: con el fin de captar al potencial cliente, las entidades de crédito abren sus puertas y despliegan la alfombra roja. La disponibilidad del proveedor es amplia. El profesional va la búsqueda del consumidor, se le ofrecen facilidades para el acceso a la contratación, se prescinde de los antecedentes crediticios o se disimulan sus flaquezas, se cotizan de modo generoso los bienes ofrecidos en garantía, etc. Pero cuando aparecen las dificultades de pago, el camino se estrecha y la salida al final del camino se ve oscura e incierta. Ahí comienzan las exigencias rigurosas: formalidades estrictas para la renegociación, abrupta caída de la cotización de los bienes dados en garantía, restricciones de actuación, etc.

${ }^{434}$ Como lo señaláramos, es frecuente que los agentes financieros, para facilitar la colocación del crédito, celebren convenios con empleadores o sindicatos asegurándose el reembolso de los mismos mediante la práctica del "descuento por planilla", por lo que el trabajador percibirá su salario previa deducción de la cuota destinada al pago del crédito. En otros casos, se acude a la bancarización del sistema de pago, de modo que se debitan automáticamente de las cuentas disponibles del deudor (cuenta sueldo, generalmente) las sumas correspondientes. Estos y otros mecanismos permiten el manejo de la deuda por el acreedor, sin que el deudor -titular del salario y de los restantes bienes que respaldan la deuda- pueda decidir el tiempo y el modo en que afrontará las erogaciones pertinentes. Estas prácticas han conducido, en muchos casos, a situaciones abusivas, contrarias a la dignidad personal del deudor, en tanto lesivas de su autodeterminación e intereses.

${ }^{435}$ Hemos desarrollado in extenso el contenido de esta Directiva al analizar los antecedentes normativos en el Derecho Comparado.

${ }^{436}$ Nos referimos al Dictamen sobre "El crédito y la exclusión social en la sociedad de la abundancia". 
circunstancias de cada uno, o incluso el rechazo a conceder más crédito, en caso de riesgo inminente de sobreendeudamiento (punto 5.1.i).

El Dictamen mencionado impulsa la autorregulación y la corregulación, por considerar que "la elaboración de códigos de conducta por parte de las entidades financieras ... puede contribuir a prevenir algunas prácticas abusivas y a integrar una dimensión más social en la actividad de las instituciones de crédito” (punto 5.1.k).

El Comité Económico y Social Europeo, en su Dictamen del 28 de abril de $2010^{437}$, señala que "el mayor reto de la política económica, fiscal y social es garantizar el acceso responsable al crédito" (punto 2.7) y que "para conseguir este objetivo es necesario un marco normativo que impida actividades irresponsables de concesión y aceptación de préstamos" (punto 2.8).

En este Dictamen se formulan recomendaciones reveladoras de una firme posición y de la intención genuina de implementar medidas eficaces. En efecto:

-“1.6 El CESE recomienda definir una norma específica europea que abarque los distintos tipos de intermediarios crediticios en la que se detallen las definiciones, requisitos y obligaciones de actuación, con independencia del producto comercializado y de que la actividad crediticia desarrollada sea de naturaleza principal o secundaria".

_“ 1.7 El CESE recomienda una norma específica para la supervisión de las actividades, prácticas y actuaciones de quienes desarrollan la actividad de intermediación junto con otras actividades de diversa índole, como los agentes comerciales".

-“1.8 El CESE pide que los requisitos para el registro de los distintos intermediarios financieros y crediticios en una red europea de registros nacionales se definan en referencia a una norma operativa europea de profesionalidad, prudencia y ética que, además, incluya disposiciones comunitarias de exclusión de determinados sujetos por conductas que perjudiquen a los consumidores o supongan prácticas abusivas o ilegales".

Por su parte, el Dictamen del Comité Económico Social Europeo del 29 de abril de $2014^{438}$, al referirse a la temática, expresa que "El CESE defiende el concepto de crédito

\footnotetext{
${ }^{437}$ Nos referimos al Dictamen sobre "Acceso al crédito para los consumidores y las familias: prácticas abusivas".

438 Nos referimos al Dictamen sobre "Protección de los consumidores y tratamiento adecuado del sobreendeudamiento para evitar la exclusión social”.
} 
responsable" (punto 4.2.2), entendiendo que "el comportamiento responsable de los profesionales debe ejercerse ya en las ofertas y la publicidad que difunden, así como en el asesoramiento y las explicaciones que facilitan a los consumidores en el momento de la suscripción de los créditos" (punto 4.2.1).

Este instrumento destacó con especial énfasis, que la prevención del sobreendeudamiento está estrechamente ligada a la implementación del principio de préstamo responsable (punto 4.2) y puso el acento en el rol protagónico de los profesionales del rubro. Y todavía más, dejó planteado el debate a cerca de la necesidad de considerar la imposición de "sanciones disuasorias" en caso de incumplimiento de las obligaciones a su cargo (punto 4.2 in fine).

Parece incuestionable que "hablar de préstamo responsable se erige en auténtica prioridad. Resulta esencial en orden a la prevención del sobreendeudamiento"439.

GUTIÉRREZ DE CABIEDES señala, a modo introductorio, que el principio de préstamo responsable supone, por un lado, que las partes han puesto recíprocamente a disposición información veraz, adecuada y suficiente, en la etapa precontractual ${ }^{440}$.

En esa línea, aquel principio impone que la publicidad diseñada para la colocación del crédito -más allá de su admitida finalidad persuasiva- proporcione al consumidor potencial, información completa, trasparente y comprensible; y que, en las tratativas previas concretas, aquella información guarde correspondencia con los intereses del sujeto particular que se presenta a solicitar financiamiento.

Este deber de información precontractual, debidamente cumplido, permitirá conocer y comprender efectivamente las características del crédito que se le ofrece y las condiciones de la contratación, para así valorar la posibilidad y conveniencia de hacerlo con ese agente financiero y bajo esas pautas, evaluando asimismo las exigencias que supone en relación a su capacidad de reembolso.

\footnotetext{
${ }^{439}$ CUENA CASAS, Matilde, "Préstamo responsable, información crediticia y protección de datos personales", en Revista de Derecho Concursal y Paraconcursal, $N^{\circ}$ 20, Sección Estudios, Segundo semestre de 2013, pág. 161-185. Ver, asimismo, CuENA CASAS, Matilde, "El sobreendeudamiento privado como causa de la crisis financiera y su necesario enfoque multidisciplinar", en PRAT Albentosa-Cuena CASAS (Coord.), Préstamo responsable y ficheros de solvencia, Thomson Reuters-Aranzadi, Pamplona, 2014, pág. 27-89.

${ }^{440}$ GutiÉRREZ DE CABIEDES, Pablo, El sobreendeudamiento doméstico..., cit., p. 118.
} 
En cumplimiento de aquel principio, el agente financiero indagará sobre las necesidades y posibilidades del tomador del crédito, para así suministrar información necesaria y útil, asesorar y hasta aconsejar ${ }^{441}$.

El proveedor de crédito debe analizar la particular situación del deudor y ofrecerle la financiación que satisfaga sus necesidades e intereses, y de la que se deriven obligaciones que puedan ser razonablemente $\operatorname{asumidas}^{442}$. Su ojo experto advertirá claramente el índice de riesgo de la operatoria y la suerte probable del reembolso en el caso particular.

El crédito ofrecido al consumidor debe guardar proporción con su capacidad económica. Contrariamente a lo que suele alegarse, el agente financiero es quien está en mejor situación para acceder a la información necesaria y procesarla, evaluando la situación patrimonial del interesado en acceder al crédito. Aquella información debe ser

\footnotetext{
${ }^{441}$ Hemos destacado en otra oportunidad, que "entender la estructura y el funcionamiento de un negocio puede ser insuficiente para juzgar la conveniencia de su realización en el caso concreto [...] y en muchos supuestos, se impone al proveedor el deber de añadir a la información pertinente, las sugerencias y las recomendaciones que permitan al consumidor evaluar si el negocio ofrecido se adecua a sus expectativas, necesidades o requerimientos. El asesoramiento procura que el consumidor se encuentre en las mejores condiciones para decidir la concreción o no el negocio; esto es, adquirir el bien o contratar el servicio, evaluando ventajas y desventajas y los riesgos de hacerlo en las condiciones ofrecidas. Dejando de lado aquellos supuestos en los que el asesoramiento o consejo constituye la obligación nuclear expresamente convenida, debe entenderse que la existencia de este deber accesorio y adicional en cabeza del proveedor de bienes y servicios, dependerá de las circunstancias fácticas que rodean al negocio en cuestión y a los sujetos involucrados ...en determinados supuestos, al deber de suministrar la información, se adiciona un deber de consejo que supone previamente, ayudar al consumidor a expresar sus necesidades, interpretarlas, advertir los aspectos positivos y negativos de la operación más los riesgos consiguientes, y sugerir la elección apropiada, mediante una opinión que puede ser iniciativa o disuasiva de la decisión a adoptar por quien recibe ese consejo”. Ver JAPAZE, María Belén, en RusConi, Dante (Coord.), Manual de Derecho del Consumidor, cit., pág. 198 y sgtes.

${ }^{442}$ Con un razonamiento simple, MARÍN LÓPEZ expresa que "no hay mejor medida para evitar el sobreendeudamiento que no conceder crédito a aquellos particulares que presumiblemente se van a encontrar en dificultades para cumplir sus obligaciones" (MARín LÓPEZ, "El crédito al consumidor", en http://www.ubo.cl/icsyc/wp-content/uploads/2011/09/4-Mar\%C3\%ADn.pdf (fecha de consulta 11/7/2015).
} 
obtenida a requerimiento ${ }^{443}$ y del propio consumidor ${ }^{444}$, así como de los registros y bases informativas de solvencia que ofrece el mercado de crédito ${ }^{445}$.

Parece incuestionable que las entidades crediticias deben consultar, indagar y finalmente evaluar la solvencia del potencial cocontratante para concluir sobre su efectiva capacidad de reembolso y cumplimiento ${ }^{446}$. Esta labor previa permitirá definir un cuadro de situación y adoptar una decisión estratégica referida a la concesión o denegatoria de la solicitud de crédito ${ }^{447}$. ${ }^{443}$ Sin ninguna duda, el consumidor debe proporcionar al proveedor de crédito información veraz y suficiente
sobre su estado patrimonial. Pero considero importante insistir en que el cumplimiento satisfactorio de este
deber de cooperación, está de algún modo condicionado a que el proveedor indague acerca de aquello que
procura saber al momento de evaluar las necesidades y la capacidad económica del tomador del crédito. El
status profesional del proveedor justifica que recabe la información (previa indagación y requerimiento del
deudor) conforme el criterio propio que deriva de su experticia.
${ }^{444}$ Lo reiteramos una vez más: pesa sobre el deudor un deber de colaboración que le impone ofrecer la
información que le sea requerida por el proveedor del crédito y hacerlo de buena fe, sin retaceos ni falsedades.
Pero como decimos esto, decimos lo otro: en caso de imputar reticencia o mala fe al consumidor, se deberán
acreditar tales extremos.

${ }^{445}$ Las bases de datos, cualquiera sea su modalidad tienen como objetivo habilitar un sistema -público o privado- destinado a proporcionar y compartir información destinada a empresas que operan en el sistema financiero. Sobre la justificación económica de estos registros de solvencia patrimonial, ver ÁLVAREZ VEGA, María Isabel, Protección jurídica del consumidor..., cit., pág. 377 y sgtes.

446 "Los distintos modelos de calificación del riesgo pretenden conocer, ex ante, tres circunstancias: la posibilidad de que exista pérdida, su cuantía y el momento en que se producirá. En el ámbito de la financiación a los particulares, las bases de los modelos de evaluación del riesgo contemplan la evolución de la capacidad de pago histórica del deudor, la evolución futura de la situación económica del tomador, y su relación con el entorno económico y financiero en el que se desenvuelve.... Cada modelo pone mayor énfasis en el factor que estima más fiel a los fines de una certera evaluación de las circunstancias en las que la entidad otorgará el crédito" (Bohoslavsky, Juan Pablo, Créditos abusivos. Sobreendeudamiento de Estados, empresas y consumidores, Editorial Ábaco de Rodolfo Depalma, Buenos Aires, 2009; pág. 177 y sgtes.).

447 "El conocimiento de las dificultades económicas y eventual crisis financiera del cliente coloca generalmente a las entidades de crédito ante el controvertido dilema de conceder o mantener el crédito o extinguir, en su caso, el ya existente, a la vista de la incertidumbre e inseguridad que suele presidir en un buen número de casos la valoración de su gravedad o el carácter pasajero o definitivo de la misma, hecho que sin duda dificulta la percepción de su posición real de cómplice o víctima de esta situación. Decisión por tanto no exenta en ambos casos de importantes riesgos y conflictos de carácter jurídico-económico entre todos los 
La evaluación de la situación patrimonial del tomador de crédito se lleva a cabo, como es lógico, en el interés prioritario del agente financiero ${ }^{448}$. Éste resolverá su otorgamiento y las condiciones de la financiación en función del riesgo que, conforme su perfil y estrategia empresaria, esté dispuesto a afrontar ${ }^{449}$.

No obstante ello se advierte que aún cuando las entidades de crédito debieran ser "las primeras interesadas en la concesión de préstamos responsables, ya que soportan en intereses implicados en el concurso, que evidencia en último término las siempre difíciles relaciones entre entidades de crédito y procedimiento concursal, interés a la libre actuación de estos operadores económicos e intereses públicos y privados presentes en éste — saneamiento y satisfacción de los acreedores—, y que, en consecuencia, es susceptible de generar en ciertos supuestos responsabilidad por los daños y perjuicios provocados con su ejecución como manifestaciones patológicas del ejercicio abusivo del derecho en las relaciones jurídicas financieras. En efecto, si la excesiva prudencia y reticencia en la concesión o mantenimiento del crédito o la ruptura repentina y sorpresiva del mismo puede provocar la insolvencia del deudor, necesitado urgentemente de financiación por carecer de otras fuentes alternativas, la excesiva ligereza y el reiterado e injustificado otorgamiento, más allá de las pautas que dicta la sana y prudente gestión que debe regir la actividad bancaria, conociendo o debiendo conocer la gravedad e irreversibilidad de la situación real y comprometida que atraviesa el afectado, no meramente temporal o coyuntural, puede arrojar idénticos efectos negativos" (Rubio ViCEnTE, Pedro J., "Concesión abusiva de crédito y concurso", en Revista de Derecho Concursal y Paraconcursal, $\mathrm{N}^{\circ}$ 8, Sección Comunicaciones, Primer semestre de 2008, pág. 247 y sgtes.).

448 "Dado que es de la esencia al negocio bancario que el prestamista haga una adecuada evaluación de las solvencia del deudor, no debería ser necesaria una intervención del legislador en este terreno, en tanto que las pérdidas de una inadecuada elección del deudor son soportadas por el propio prestamista. Es éste el primer interesado en que el deudor sea solvente y no parece razonable que tenga interés en conceder un crédito a una persona que no va a poder amortizarlo" (CUENA CASAS, Matilde, "Préstamo responsable...”, cit.).

${ }^{449}$ Es crucial comprender la noción de política crediticia, entendida como la estrategia comercial que la entidad decide imprimir a su cartera de préstamos. Se trata de un perfil que define su identidad propia. Aquélla decisión empresaria estratégica, la elaboración de los productos que la representan y el modo de comercializarlos es una manifestación del derecho a ejercer su industria y a comerciar, reconocidos por la norma constitucional. Ahora bien, el respeto de esas libertades y derechos no debe desconocer los límites impuestos por la necesidad de evitar perjuicios a los demás sujetos involucrados en la operatoria y costes injustificados a terceros. Se dice que la piedra de toque reside en determinar, a la luz de un criterio objetivo, cuándo el riesgo asumido es excesivo o irrazonable. Al momento de juzgar su eventual responsabilidad, el operador jurídico evaluará la conducta obrada con el parámetro propio del buen banquero y decidirá si existe un ejercicio regular de su derecho o se ve comprometida su responsabilidad profesional. (cfr. el desarrollo de estos conceptos en Bohoslavsky, Juan Pablo, Créditos abusivos..., cit., pág. 177). 
primera persona el riesgo de impago, no es menos cierto que ha quedado demostrado cómo a través de diversos mecanismos...pueden lograr la externalización del mismo, convirtiendo el riesgo individual en riesgo sistémico" 450 que, en definitiva, será soportado por el conjunto social ${ }^{451}$.

Ahora bien, en vistas de las características de la operatoria de crédito actual, se impone que el profesional del negocio aporte su experticidad y la ponga también al servicio de su contraparte en este aspecto. La directiva enunciada viene impuesta por la lógica propia de la categoría contractual en la que se emplaza. No se trata contratos paritarios o entre iguales sino de contratos que enlazan a sujetos con marcadas asimetrías cognoscitivas

450 GALlEGo SÁNCHEZ, Esperanza, "La obligación de evaluar la solvencia del deudor. Consecuencias derivadas de su incumplimiento", en PRAT Albentosa-Cuena CASAS (Coord.), Préstamo responsable y ficheros de solvencia, Thomson Reuters-Aranzadi, Pamplona, 2014, pág. 207-242.

${ }^{451}$ Explica BALBUENA RIVERA que en España, "en gran medida a resultas de la erosión en la confianza del consumidor tras el inicio de la actual crisis, se ha dado un paso más...A comienzos del año 2011, fruto del enorme crecimiento en los niveles de endeudamiento de los ciudadanos, se introduce de forma explícita ... el concepto de responsabilidad en la concesión de préstamos, siendo la promulgación de la Ley de Economía Sostenible el primer hito en la sucesión de desarrollos normativos para su efectiva implementación en el sector financiero". Destaca que su principal aportación "consistió en instaurar la obligación de evaluar la solvencia del potencial prestatario como mecanismo de protección al servicio de los usuarios financieros". Señala que la Ley de Contratos de Crédito al Consumo representa el segundo hito del proceso regulatorio de fomento de la concesión responsable de crédito puesto que en su art. 18 establece la obligación de evaluar la solvencia del consumidor, recomendándose el uso de la información disponible en distintas fuentes. Menciona asimismo, que con la promulgación de la Orden de Transparencia y Protección del Cliente de Servicios Bancarios se introducen las correspondientes obligaciones para que el sector financiero mejore los niveles prudenciales en la concesión de este tipo de operaciones, "en beneficio de los clientes y de la estabilidad del mercado” (Título III, Capítulo I, art. 18). Cita, para concluir la reseña, la Circular 5/2012 del Banco de España sobre Transparencia de los Servicios Bancarios y Responsabilidad en la Concesión de Préstamos que aspira a ser "un nuevo marco de normas de conducta que deberá regir entre las entidades de crédito y los clientes de servicios bancarios (cfr. BALBUENA RIVERA, Manuel, "Análisis del riesgo financiero de las personas físicas y su impacto en el coste crediticio", en PRAT ALBENTOSA-CUENA CASAS (Coord.), Préstamo responsable y ficheros de solvencia, Thomson Reuters-Aranzadi, Pamplona, 2014, pág. 117-179). Para un análisis crítico de la regulación española, ver PRAT ALBENTOSA, Lorenzo, "Régimen jurídico de los ficheros de solvencia", en Prat Albentosa-Cuena Casas (Coord.), Préstamo responsable y ficheros de solvencia, Thomson ReutersAranzadi, Pamplona, 2014, pág. 363-406). 
y técnicas. De allí que el sistema imponga a quien concentra el dominio del negocio, la carga de ocuparse de sí y de la otra parte, en lo que resulte pertinente ${ }^{452}$.

Al indagar sobre los antecedentes crediticios del consumidor, la entidad accederá a la información que permita establecer un cuadro de situación: empréstitos acordados, naturaleza de los mismos, nivel de endeudamiento, comportamiento crediticio, etc. Ese material informativo servirá para la elaboración de una conclusión seria -positiva o negativa- respecto de la solvencia y capacidad de pago del deudor. Pero sea cual fuere el resultado, al compartirlo con quien pretende un nuevo empréstito o ampliar el existente, lo impondrá de la actualidad de su situación: volumen de deuda contraída, bienes comprometidos en garantía, porción de salario disponible, etc. Sería deseable que esa respuesta a la solicitud de crédito, favorable o desfavorable pero en todos los casos fundada, quede documentada y se ofrezca al solicitante. De ese modo quedará evidenciado el conocimiento cierto del resultado de aquella indagación para ambas partes y a la luz del mismo se juzgarán eventualmente sus comportamientos (otorgar crédito frente a un informe negativo, insistir con otra entidad, frente al rechazo de la solicitud, etc.).

Como una contribución a la aplicación del principio de crédito responsable, se propone la creación de registros de solvencia patrimonial y/o en el mejoramiento de los sistemas de información crediticia existentes ${ }^{453}$.

El Comité Económico Social Europeo, en su Dictamen del 25 de octubre de 2007, se ocupa de este aspecto. Allí se expresa que la utilización de sistemas de calificación del riesgo crediticio permite estimar el riesgo de insolvencia mediante la evaluación de múltiples variables y la fijación objetiva de límites de endeudamiento individual y familiar (punto 5.1.e). Destaca que "la utilización de bases de datos con todos los antecedentes

\footnotetext{
${ }^{452}$ Se trata de una aplicación particular del principio protectorio.

${ }^{453}$ Suelen distinguirse dentro de los registros de crédito o solvencia, los denominados positivos y negativos. Los registros positivos son aquellos que recogen información sobre todos los créditos que un particular tiene solicitados (o ha tenido) en un determinado lapso de tiempo. Revelan el nivel de endeudamiento en un período concreto. Allí se consigna el historial de cumplimiento, el comportamiento crediticio del deudor; constan los créditos que se han satisfecho en los términos acordados. Son conocidos como "registros de información de crédito" o "registros sobre solvencia. Por su parte, los registros negativos ofrecen un perfil desfavorable del deudor pues recogen únicamente los incidentes de pago, esto es, los créditos incumplidos o con demoras en el cumplimiento. De allí que sean conocidos como "registros de morosos".
} 
financieros de los clientes (ficheros de crédito positivos) o sólo con los incidentes de reembolso (ficheros de crédito negativos), pese a los riesgos que se les reconocen, ... permite a las instituciones de crédito conocer el nivel de endeudamiento de un cliente y fundamentar mejor la decisión de conceder un préstamo (punto 5.1.j).

Para las entidades financieras significaría una medida idónea para eficientizar la tarea de obtención, procesamiento y evaluación de solvencia patrimonial de los clientes y potenciales deudores ${ }^{454}$. Su funcionamiento facilitaría el acceso a la información con ahorro de tiempo y de costes, sin tener que desarrollar complejos sistemas de análisis estadísticos de gestión de riesgos, incompatibles con la celeridad de la operatoria ${ }^{455}$.

La posibilidad de crear un sistema de registros reveladores del cuadro de situación, luce como una medida eficaz para advertir el grado de endeudamiento y el comportamiento derivado del deudor, neutralizando su configuración o el agravamiento de este exceso en el empréstito $^{456}$.

La consagración de un régimen jurídico vinculado a la obligación de evaluar la solvencia se encuentra indisolublemente unido al fortalecimiento de los sistemas de información crediticia, que también deben ser objeto de una regulación prolija y de un control riguroso por parte de la autoridad de aplicación, para su eficiente funcionamiento ${ }^{457}$.

\footnotetext{
${ }^{454}$ Coinciden con estas ideas, SosA, Lucía- LóPEZ, Erica- CHAVEZ, Verónica, "Regulación de la insolvencia: abordaje desde la realidad", Ponencia presentada en Ponencia presentada en el $\mathrm{V}^{\circ}$ Congreso Iberoamericano sobre la Insolvencia y el VII ${ }^{\circ}$ Congreso Argentino de Derecho Concursal realizados en Mendoza entre el 4 y el 7 de octubre de 2009.

${ }^{455}$ Para un desarrollo de estos objetivos y su implementación, cfr. CELENTANI, Marco, "El intercambio de información y el funcionamiento del mercado de crédito”, en PRAT AlBENTOSA-CuENA CASAS (Coord.), Préstamo responsable y ficheros de solvencia, Thomson Reuters-Aranzadi, Pamplona, 2014, pág. 93-115.

456 TRUjILlo Dítz, Iván Jesús, El sobreendeudamiento de los consumidores..., cit., pág. 55.

${ }^{457}$ Explica GERSCOVICH que la organización de una central de datos y riesgos crediticios permite la concentración de la información existente. Destaca asimismo que, en Argentina, los servicios de información financiera que brindan el Banco Central de la República Argentina y otras empresas privadas, dentro del marco de la Ley $\mathrm{N}^{\circ}$ 25.326, cumplen un rol altamente positivo en lo relativo a difusión de información financiera (Gerscovich, Carlos G., Consumidores bancarios, Abeledo Perrot, Buenos Aires, 2011, pág. 120 y sgtes.). La normativa reglamentaria, conforme al grado de cumplimiento de las obligaciones crediticias asumidas, distingue entre los deudores de cartera comercial y de cartera de consumo. De allí emergen parámetros diferentes para clasificar a uno y otro dentro de alguna de las seis categorías siguientes: "Situación
} 
La información en poder del prestamista a la hora de evaluar la solvencia es esencial ${ }^{458}$. Si la información es escasa, contradictoria entre las distintas bases o incompleta, puede dar lugar a falsos test de solvencia positivos, con las consecuencias desfavorables que de ello se derivan.

1: En situación normal (cartera comercial). El cliente atiende sus compromisos, tiene capacidad de pago alta y es puntual en el pago de sus obligaciones. Cumplimiento normal (cartera de consumo). Se encuentran incluidos los deudores de la cartera de consumo y vivienda que incurran en atrasos que no superen los 31 días. Situación normal (cartera comercial considerada juntamente con la de consumo o vivienda -no superior a \$200.000-). Situación 2: Con riesgo potencial (cartera comercial). El cliente puede atender sus compromisos pero sus flujos de fondos tienden a deteriorarse. Presenta atrasos reducidos y ocasionales. Mantiene convenios judiciales y extrajudiciales homólogos a vencer, de los cuales ha cancelado por lo menos el 35\%. Cumplimiento inadecuado (cartera de consumo). Se encuentran incluidos los deudores de la cartera de consumo y vivienda que incurran en atrasos de más de 31 días y hasta 90 días. Cumplimiento inadecuado (cartera comercial considera juntamente con la de consumo o vivienda -no superior a \$200.000-). Situación 3: Con problemas (cartera comercial). El cliente tiene problemas para atender normalmente sus compromisos; se advierte un progresivo deterioro en el flujo de fondos. Mantiene convenios judiciales y extrajudiciales homologados a vencer, de los cuales no ha cancelado el 35\%. Cuenta con refinanciaciones reiteradas de capital aun cuando abone los intereses. Cumplimiento deficiente (cartera de consumo). Incurre en atrasos de más de 90 y hasta 180 días. Cumplimiento deficiente (cartera comercial considerada juntamente con la de consumo o vivienda -no superior a \$200.000-). Situación 4: Con alto riesgo de insolvencia (cartera comercial). Es altamente improbable que el cliente cumpla con todos sus compromisos: tiene un alto nivel de endeudamiento. Ha solicitado concurso preventivo o quiebra por obligaciones iguales o superiores al $5 \%$ del patrimonio del cliente. Cuenta con refinanciaciones de capital e intereses con quitas de capital y la entidad debió aceptar bienes en pago de parte de obligaciones. De difícil recuperación (cartera de consumo). Incurre en atrasos mayores a 180 días y menores a un año. De difícil recuperación (cartera comercial considerada juntamente con la de consumo o vivienda -no superior a \$200.000-). Situación 5: Irrecuperable (cartera comercial). Las deudas se consideran incobrables. Existe suspensión de pagos, quiebra decretada o pedido de su propia quiebra. Cuenta con refinanciaciones reiteradas de capital e intereses y con financiación de gastos de explotación. Irrecuperables (cartera de consumo). El deudor incurre en atrasos superiores a un año. Irrecuperables (cartera comercial considerada juntamente con la de consumo vivienda -no superior a \$200.000-). Situación 6: Irrecuperables por disposición técnica, se trata de deudores que a su vez, son morosos de ex entidades financieras, pues registran con estas atrasos superiores a 180 días. Consecuentemente, pertenecer a una de estas categorías implica tener las puertas de acceso al crédito razonablemente aciertas o definitivamente clausuradas.

${ }^{458}$ CUENA CASAS, Matilde, "El sobreendeudamiento privado ...”, cit., pág. 82. 
La existencia de estos bancos de datos serviría, además, como medida disuasoria del incumplimiento pues la inclusión del consumidor en tales registros, por los efectos que supone, estimularía el cumplimiento diligente de las obligaciones asumidas.

Debe advertirse, no obstante, que el funcionamiento de estos registros debe estar regulado para dejar a resguardo los derechos de los deudores y evitar cualquier invasión indebida a la esfera de la intimidad de la persona así como la afectación de su honor ${ }^{459}$. La recopilación de información crediticia, el acopio de la misma y su difusión deben estar circunscriptos a datos necesarios y relevantes para la evaluación de la capacidad de pago o solvencia del potencial deudor. En esa línea de razonamiento, el requerimiento de información de estos registros debe estar estrictamente vinculado a la evaluación de la solvencia patrimonial del tomador del crédito ${ }^{460}$.

De conformidad a lo expresado, los proveedores de crédito pueden incurrir en responsabilidad si no adecuan su conducta a las obligaciones que, a la luz del principio analizado, les son propias ${ }^{461}$.

"El concepto de préstamo responsable no puede implicar un derecho al crédito si la evaluación de la solvencia es positiva, ni un impedimento al mismo si el informe es negativo. El riesgo connatural al negocio bancario no puede ser evitado en todo caso. Ahora bien, de procederse a la concesión de un préstamo tras una evaluación negativa de solvencia, las consecuencias de la imposibilidad de pago, no deben ser las mismas que ante un incumplimiento fruto de una evaluación positiva de solvencia. El prestamista no sólo padecerá los efectos del impago, sino que deben producirse efectos adicionales que tengan

\footnotetext{
${ }^{459}$ La Ley $N^{\circ} 25.326$, en Argentina, sentó el principio de licitud del tratamiento de datos personales cuando el titular hubiere prestado su consentimiento libre y expreso, pero ese consentimiento no es necesario en estos casos: a) cuando se obtengan de fuentes de acceso publico irrestricto (art. $5^{\circ}$, inc. 2.a); b) cuando se trate de operaciones que realicen las entidades financieras y de las informaciones que reciban de sus clientes, siempre que no se afecte el secreto financiero (art. $5^{\circ}$, inc. 2.e); c) cuando se trate de datos personales de carácter patrimonial relativos a la solvencia económica y al crédito, obtenidos de fuentes accesibles al publico o precedentes de informaciones facilitadas por el interesado o con su consentimiento, para la prestación de servicios de información crediticia ( art. 25 , inc. $1^{\circ}$ ); o d) cuando se trate de datos personales relativos al cumplimiento o incumplimiento de obligaciones de contenido patrimonial, facilitados por el acreedor o por quien actué por su cuneta y riesgo (art. 26 , inc. $2^{\circ}$ ).

${ }^{460}$ GutiÉRREZ DE CABIEDES, Pablo, El sobreendeudamiento doméstico..., cit., pág. 133 y sgtes.

461 Álvarez Vega, María Isabel, Protección jurídica del consumidor ..., cit., pág. 70 y sgtes.
} 
impacto en la esfera contractual del consumidor, tal y como acontece en otros ordenamientos donde el préstamo responsable es una realidad" ${ }, 42$.

TRUJILlo DíEZ sostiene que "debe trasladarse a las entidades de crédito parte de la responsabilidad en la situación de endeudamiento del consumidor, obligándoles a comprometerse en la medida que se estime adecuada, para la superación de la crisis de la economía doméstica del deudor. Siendo la morosidad y la insolvencia el riesgo típico de la actividad crediticia, incumbe principalmente a los profesionales del crédito el prevenirse frente a estas situaciones, bien aminorando el riesgo, bien aceptándolo mediante su internalización. Cargar exclusivamente al deudor con las consecuencias perjudiciales de su sobreendeudamiento supone atribuirle en exclusiva un riesgo estadístico previamente conocido y valorado. Además, ello atentaría contra la confianza que el deudor depositó en la entidad crediticia, desde el momento en que, sin prevenirle del riesgo concreto, aceptó su solicitud de crédito. Sólo haciendo al acreedor parcialmente responsable del sobreendeudamiento del consumidor, se le incentivará para que ponga mayor cuidado a la hora de conceder el crédito y en la valoración del riesgo concreto que la operación conlleve" 463 .

En esta línea de razonamiento, se ha señalado que "mediante la imposición de costos sobre los acreedores, cuando han concedido crédito a alguien que no está en condiciones de pagar, la descarga les da un incentivo adicional para evitar la extensión de crédito imprudente" ${ }^{\mathrm{4}}$.

\footnotetext{
462 CuEna CASAS, Matilde, "Préstamo responsable...", cit. Explica que "la noción de préstamo responsable entendida como obligación de evaluar la solvencia del deudor se recoge en el art. 18 de la Orden EHA/2899/2011, ... de transparencia y protección del cliente de servicios bancarios (26), y se desarrolla el art. 12 de la Circular 5/2012, de 27 de junio ... del Banco de España a entidades de crédito y proveedores de servicios de pago sobre transparencia de los servicios bancarios y responsabilidad en la concesión de crédito . También es reiterada en el art. 29 Ley de Economía sostenible ..., y recogida en el art. 14 de la Ley 16/2011, de 24 de junio ... de Crédito al Consumo" y que "a pesar de su trascendencia, la referencia a la noción de préstamo responsable en dichas normas es extraordinariamente vaga, plagada de conceptos indeterminados". Cuestiona, asimismo, que se regule la obligación de evaluar la solvencia pero sin aclarar los que acontece cuando se concede un préstamo tras una evaluación negativa.

463 TRUjILlo DíEZ, Iván Jesús, El sobreendeudamiento de los consumidores ..., cit., pág. 22.

${ }^{464}$ ANCHAVAL, Hugo, Insolvencia del consumidor, cit., pág. 84.
} 
Hemos dicho ya que conceder un préstamo al consumidor que previsiblemente no podrá devolverlo, no es una práctica prohibida por el sistema. Tan sólo se pretende que la entidad, que en ejercicio de esa libertad de empresa y del derecho a comerciar y desarrollar su industria así lo hace, asuma las consecuencias del impago que conocía o debía conocer $^{465}$.

En sentido concordante con este principio, organismos especializados vienen propugnando una justa y equitativa distribución del riesgo en los créditos para el consumo $^{466}$.

El Dictamen del Comité Económico y Social Europeo aprobado el 29 de octubre de 2011, expresa que "el objetivo perseguido por la evaluación de la solvencia del prestatario debería ser evitar el endeudamiento excesivo" y de allí que "en el caso de impago, el prestamista deberá asumir la responsabilidad, si su decisión se ha basado en una evaluación mediocre de solvencia del prestatario". Cierra esta conclusión señalando que "los costes que generan los préstamos irresponsables deben ser soportados por el prestamista" ${ }^{467}$.

Cabe destacar que en los países en que se ha desarrollado esta idea, se concibe que "la abusiva concesión de crédito comporta un perjuicio de carácter pluriofensivo" "468, pues atenta no sólo contra el patrimonio del deudor financiado en exceso sino que se afecta el interés de los acreedores concurrentes, al comprometerse la garantía patrimonial ofrecida.

Se insta, por tanto, a la consagración un régimen de responsabilidad derivado del otorgamiento abusivo del crédito, siguiendo los criterios de los modelos que han sentado ya las bases de una regulación al efecto. GUTIÉRREZ DE CABIEDES señala que "en estos ordenamientos, se ha instaurado tal responsabilidad en torno a los siguientes elementos: un comportamiento doloso o culposo dirigido a financiar a un sujeto [...] que no está en condiciones de restituir la financiación; la provocación de una retraso en la declaración de

\footnotetext{
${ }^{465}$ Cfr. el desarrollo de estas ideas en CUENA CASAS, Matilde, "El sobreendeudamiento privado...", cit., pág. 82 y sgtes.

${ }^{466}$ Es una de las reglas que emergen del Consumer Debt Report emitido por el INSOL, al que nos referimos ut supra.

${ }^{467}$ Nos referimos al Dictamen sobre la "Propuesta de Directiva del Parlamento Europeo y del Consejo sobre los contratos de crédito para bienes inmuebles de uso residencial" http://www.gerontomigracion.uma.es/index.php?q=node/337 (fecha de consulta 11/7/2015).

${ }^{468}$ GutIÉRREZ DE CABIEDES, Pablo, El sobreendeudamiento doméstico..., cit., pág. 121.
} 
concurso como resultado de esa financiación; la existencia de un daño para el conjunto de los acreedores distintos de la entidad financiera por la lesión del principio de la par conditio; y la existencia de un nexo causal entre el comportamiento de la entidad financiera y el daño" 469 .

En el afán de definir los contornos de la responsabilidad analizada, RUBIO VICENTE $^{470}$ señala que "la ausencia consciente o inconsciente de una correcta y ajustada valoración de las condiciones y circunstancias actuales y de la previsible evolución económica del deudor, así como de su efectiva capacidad de reembolso...lejos de beneficiarle, constituye un serio perjuicio no sólo para el deudor sino también para el interés económico del conjunto de acreedores”. Menciona que la concesión de créditos de cuantía elevada o el incremento de los mismos -cubiertos además con importantes y desproporcionadas garantías personales o reales o la realización de otras operaciones de ingeniería económica que aseguren su recuperación- y la correlativa asunción de gravosas obligaciones económicas - incompatibles con capacidad real de restitución o cumplimiento según sus actuales condiciones patrimoniales y perspectivas económicas- se convierte las más de las veces en la verdadera causa o causa última de la insolvencia del deudor o de la agravación de su situación. Advierte que, por otra parte, estas operaciones contribuyen a aumentar el nivel de endeudamiento, incrementar el pasivo y engrosar aún más la lista de acreedores, postergando la apertura del procedimiento concursal. Concluye que, en ese contexto, corresponderá imponer responsabilidad a la entidad otorgante "únicamente allí donde la concesión o mantenimiento de crédito se produzca inmerso ya el deudor en una situación de insolvencia definitiva e irreversible o ésta se contemple objetivamente como inevitable y no en cambio donde simplemente se evidencie como algo potencial o exista

${ }^{469}$ GutiÉRrez de CABIEDES, Pablo, El sobreendeudamiento doméstico..., cit., pág. 120 y sgtes). Para un desarrollo de los modelos en el Derecho Comparado, ver BoHOSLAVsKY, Juan Pablo, Créditos abusivos..., cit., pág. 332 y sgtes.; RuBio ViCEnTE, Pedro J., "Concesión abusiva de crédito...”, cit., pág. 247 y sgtes.; Cuena CASAS, Matilde, "Préstamo responsable...", cit; CuEna CASAS, Matilde, "El sobreendeudamiento privado...", cit.; BONHOMME, Regine, "La responsabilidad por concesión abusiva de crédito conforme la ley 2005-845 de 26 de julio de 2005. El art. L. 650-1 del CCom”, en Revista de Derecho Concursal y Paraconcursal, $N^{\circ}$ 5, Sección Reseña legislativa española y comparada, Segundo semestre de 2006, pág. 349-352).

${ }^{470}$ Rubio ViCEnTE, Pedro J., "Concesión abusiva de crédito...”, cit. 
riesgo de insolvencia, siendo aún razonable sin embargo la superación de la crisis económica".

No pasamos por alto que la morosidad y el incumplimiento de las obligaciones tornan operativos los mecanismos legal y contractualmente previstos para estas contingencias propias de la operatoria. No ignoramos que estos remedios ofrecen respuestas adecuadas para el conflicto individual. Tenemos presente que los procesos concursales ofrecen otro cauce para el supuesto de insolvencia del deudor y concurrencia de acreedores. Ahora bien, resulta innegable que cuando el estado moratorio y la situación de incumplimiento se instalan y expanden, con costes patrimoniales y no patrimoniales graves para el consumidor y su familia, aquellos dispositivos resultan inadecuados para resolver la nueva dimensión del fenómeno problemático. Por un lado, porque aquellos remedios derivan de una regulación diseñada principalmente para la tutela del crédito y sus titulares; y porque cuando se ve afectado el regular funcionamiento de la actividad económica general y de la operatoria de crédito en particular, otras deben ser las medidas para corregir aquéllas distorsiones no deseadas.

Cuando se concede crédito a manos llenas a quien no podrá devolverlo, la respuesta no debe ser la condena del deudor a la exclusión social y la impunidad absoluta del acreedor. La gravedad del problema impone "afrontarlo con valentía aunque ello suponga la pérdida de algún privilegio de los fuertes" $"$ "471.

El principio de crédito responsable debe traducirse también en un régimen de responsabilidad para las entidades crediticias cuando se constate un proceder apartado del

\footnotetext{
${ }^{471}$ CUEnA CASAS, Matilde, "El sobreendeudamiento privado..., cit., pág. 40 y 88. Admitiendo que la idea de la responsabilidad agravada de las entidades de crédito está instalada, se pregunta MARTORELL de qué modo "nuestra comunidad jurídica — siempre tan pacata a la hora de atribuír responsabilidades— habrá de recibir el cambio. Empero, y aún desde las posturas más conservadoras — siempre refractarias a todo lo que signifique agravar la responsabilidad del poderoso— será muy difícil pretender controvertir dicha mutación con argumentos de autoridad, o invocando afectación de la seguridad jurídica, precariedad o improvisación propia de naciones subdesarrolladas. Y ello porque, tanto la tendencia internacional al agravamiento (de la responsabilidad)..., como los precedentes que reflejan la aplicación a los Bancos de las multas y/o las condenas judiciales de mayor significación patrimonial, tienen su origen en los Países exportadores de capital, que son aquellos a los que — desde siempre - en la República Argentina se les ha asignado el liderazgo mundial” (MARTORELL, Ernesto E., "Nuevos paradigmas...", cit.).
} 
estándar del "buen banquero"472. Estas propuestas se asientan en la convicción de que son principalmente los dadores de crédito, por su carácter profesional y prevalente en el mercado, los que deben tomar la posta en la adopción de medidas que contribuyan a mejorar el funcionamiento de la operatoria ${ }^{473}$.

El nuevo Código Civil y Comercial unificado -vigente en Argentina desde el 1 de agosto de este año 2015- es revelador del cambio de paradigmas que mueve al Derecho Privado que, en la materia que nos ocupa, "habrá de aparejar un sensible agravamiento de las obligaciones de la banca en la República Argentina...lo que permite hablar, sin riesgo a equivocarnos, de un claro agravamiento en materia de responsabilidad de las entidades de crédito" 474 .

No existen razones para temer que la consagración del principio de préstamo responsable provoque un desincentivo de conductas diligentes por parte de los consumidores. Con acierto se ha dicho, que aquella directriz se traduce que deberes para ambas partes y que si el consumidor incurre en comportamientos reñidos con la buena fe que debe presidir las relaciones contractuales, será a la hora de pretender las medidas de saneamiento de su situación de sobreendeudamiento, que el juez evaluará su merecimiento para otorgarlas o denegarlas ${ }^{475}$.

3.- Medidas para la prevención del sobreendeudamiento

a.- Justificación:

\footnotetext{
472 Bohoslavsky, Juan Pablo, Créditos abusivos..., cit., pág. 231.

${ }^{473}$ Frente a la globalización de la crisis, no sólo es importante conocer las patologías financieras ocurridas extramuros sino, además, pensar seriamente en la internacionalización de las soluciones jurídicas aplicadas por los jueces extranjeros en materia financiera que "prácticamente en todos los casos, han pasado por el meridiano de un sensible agravamiento de la responsabilidad bancaria, por entenderse que ... aun permitiendo la sociedad capitalista la existencia de winners and loosers (ganadores y perdedores), y aceptando la legitimidad de luchar por obtener reasonable fees (ganancias razonables), la actividad bancaria y su debida regulación (tanto así como la protección del ahorrista), ... revisten interés nacional (KABAS DE MARTORELL, María Elisa- MARTORELL, Ernesto E., "Fraudes y escándalos bancarios internacionales. Experiencias para la realidad argentina", La Ley 2013-B,1151).

${ }^{474}$ MARTORELL, Ernesto E., “Nuevos paradigmas...”, cit. .

${ }^{475}$ GutiÉRREZ DE CABIEDES, Pablo, El sobreendeudamiento doméstico..., cit., pág. 124.
} 
El ya aludido Consumer Debt Report ${ }^{476}$ del INSOL del año 2001, proponía como una de sus reglas, la adopción de medidas de prevención del sobreendeudamiento, "para reducir la necesidad de intervención”.

El Dictamen del Comité Económico y Social Europeo de 2007, sobre "El crédito y la exclusión social en la sociedad de la abundancia", dedica el extenso desarrollo de su punto 5.1 a la prevención del fenómeno, destacando su importancia.

El Dictamen del 2014, sobre "Protección de los consumidores y tratamiento adecuado del sobreendeudamiento para evitar la exclusión social” de 2014, vuelve sobre el tema señalando que "en varios Estados miembros se han puesto en marcha dispositivos de prevención destinados a gestionar situaciones de sobreendeudamiento" pero muestra su preocupación por la heterogeneidad de las soluciones propuestas (punto 1.8).

El objetivo prioritario de inhibir situaciones condicionantes, y evitar el consiguiente estado de sobreendeudamiento, supone ineludiblemente la adopción de precauciones. Éstas pueden ser espontáneas pero en ausencia de esta iniciativa, deben ser estimuladas o hasta impuestas.

En un estado ideal de cosas, esperaríamos que los protagonistas del intercambio asumieran una visión de conjunto y desplegaran comportamientos solidarios frente a la dificultad o adversidad. Pero como de ordinario ello no ocurre, el operador jurídico se ve forzado a consagrar deberes que instalen prácticas tendientes a la evitación de situaciones de riesgo.

La regulación que propugnamos debería contener dispositivos de contenido sustancial, orientados a la prevención, neutralizando situaciones que propician o determinan la situación de endeudamiento excesivo.

No parece discutible ya que las soluciones preventivas se imponen por sobre remedios de otra naturaleza; y que su justificación responde a razones éticas, económicas y jurídicas $^{477}$. Los principios solidaristas exigen no desamparar al débil; y si esa

\footnotetext{
$\overline{{ }^{476} \text { Ver www.insol.org/pdf/consdebt.pdf }}$

${ }^{477}$ Resulta de lectura indispensable el desarrollo de las ideas contenidas en SEGUí, Adela M., "Prevención de los daños y tutela inhibitoria en el Derecho del Consumo", Picasso, Sebastián - VÁZquez FerReYRA, Roberto A., (dirs.), Ley de Defensa del Consumidor comentada y anotada, T. II, La Ley, Buenos Aires, 2009, pág. 661-696.
} 
hiposuficiencia tiene carácter estructural como la del consumidor, el deber de intervención viene impuesto por las circunstancias del caso. Razones de índole económica demuestran, por otra parte, que es más eficiente asumir costes de prevención que de reparación del daño causado. Finalmente, razones de justicia, imponen que en esa confrontación de intereses en juego, se priorice la situación del sujeto vulnerable apelando al esfuerzo de quien menos dificultades tiene para soportar algunas de las cargas.

La eficacia de la tutela preventiva depende en gran medida de la idoneidad de las herramientas jurídicas diseñadas por el legislador para la gobernabilidad de los riesgos propios del intercambio en el mercado ${ }^{478} \mathrm{y}$, particularmente, de los que plantea la operatoria de crédito.

b.- Diseño de políticas activas. Implementación:

Resulta innegable que la prevención del sobreendeudamiento de los consumidores está directamente vinculada al diseño de políticas públicas en la materia y a su implementación eficaz. Nos proponemos mencionar solo algunas de las líneas en las que, consideramos, debe focalizarse la atención de quien tiene a su cargo esta alta responsabilidad.

b.1.- La educación en el consumo de crédito:

Entre los organismos internacionales y la doctrina especializada, es coincidente el reclamo de políticas públicas que, entre otros aspectos, hagan centro en la educación al

\footnotetext{
${ }^{478}$ Sobre el tema de la prevención en la sociedad del riesgo, ver MÁRQUEZ, J. F., texto de la conferencia pronunciada en el $V^{\circ}$ Congreso Internacional de Derecho Privado organizado por el Núcleo de Derecho Civil, Punta del Este, Octubre de 2008). Asimismo, ver Sozzo, Gonzalo, "Introducción. Derecho y gobierno de los riesgos”, en Sozzo, Gonzalo (Coord.), El Gobierno de los riesgos, UNL Ediciones, Santa Fe, 2007, pág. 11 y sgtes.
} 
consumidor $^{479}$. Se considera que es una de las herramientas preventivas más importantes del régimen tuitivo ${ }^{480}$.

"El CESE ya ha hecho hincapié en la necesidad de desarrollar la educación para un consumo sostenible". Señala que "la educación financiera ... contribuye a la buena gestión del presupuesto personal y a la prevención del sobreendeudamiento" ${ }^{\text {"481 }}$. Y de allí que se impulse la puesta en marcha de programas nacionales de educación financiera para ser implementados en la enseñanza escolar, tanto por personal docente como por asociaciones públicas o privadas, adaptados a la edad y a los conocimientos de los destinatarios ${ }^{482}$.

Se insta a que la educación financiera sea "introducida tempranamente en los programas escolares y en otros ámbitos de la educación y la formación, en el marco de un proceso de aprendizaje a lo largo de toda la vida". Con acierto se señala que tales

${ }^{479}$ PUERTAS VILlAVICENCIO, María José, "La importancia de educar para consumidor: el Indecopi como ente protector y de promoción de los derechos de los consumidores peruanos", en TOMILlo URBINA, Jorge (Dir.)Álvarez Rubio, Julio (Coord.), La protección de los consumidores como motor de desarrollo económico, Civitas-Thomson Reuters, Pamplona, 2011, pág. 149-159.

${ }^{480}$ SÁENZ, Luis R, "Comentario al art. 60 de la Ley de Defensa del Consumidor”, en PICASSO, SebastiánVÁZQUeZ FERreyra, Roberto (Dir.), Ley de Defensa del Consumidor comentada y anotada, Ed. La Ley, Buenos Aires, 2009, pág.729-735. Gabriel STIGLIZ ha destacado enfáticamente la relevancia de este derecho, al que califica de esencial, puntualizando los deberes que el Estado debe observar a fin de resguardarlo (STIGLITZ, Gabriel A., La defensa del consumidor en Argentina. 30 años de derecho, sin políticas, Rubinzal Culzoni, Santa fe, 2012, pág. 66 y sgtes.). Ver asimismo, el análisis profundo de la temática en BRÚ, Jorge M., "Educación y formación del consumidor (reflexiones sobre la conciencia del consumidor)", en STIGLITZ, Gabriel A. (Dir.), Manual de Defensa del Consumidor, Editorial Juris, Rosario, 2004, pág. 19-51. Destaca por su parte Dante RUSCONI que las Directrices de las Naciones Unidas para la Protección del Consumidor exhortan a los Estados a mantener políticas enérgicas, respecto del derecho a la educación del consumidor" (principios, punto 3, d), advirtiendo que la redacción de los arts. 60, 61 y 62 de la ley argentina de defensa del consumidor -en su redacción actual- se aproximan a las sugerencias que sobre el punto formularan las mencionadas Directivas de Naciones Unidas (Cfr. RusConi, Dante, en RUSCONI, Dante (Coord.), Manual de Derecho del Consumidor, cit., pág. 115 y sgtes.).

${ }^{481}$ Punto 4.1.3 del Dictamen de 2014 antes citado.

${ }^{482}$ El Dictamen del CESE de 2014 dedica el punto 4 al tema de la prevención del sobreendeudamiento y en ese marco, su primer apartado se titula "Educación financiera y consumo responsable". El desarrollo de estos conceptos queda aprehendido por los puntos 4.1.1 a 4.1.6. 
programas "pueden variar ... en función de su cultura, sistema de valores, características sociodemográficas y económicas, patrones de consumo y nivel de endeudamiento"483.

"El CESE considera que deben reforzarse las campañas de información y de divulgación en materia financiera, pues debe ofrecerse educación a todos los públicos. Opina que los diferentes actores socioeconómicos, las autoridades públicas, las ONG, las federaciones profesionales y las asociaciones de consumidores pueden ocuparse de la organización de dichas campañas. De hecho, se trata de aprovechar la complementariedad de las diferentes fuentes de información para el interés general" (punto 4.1.7).

En casi todas las latitudes, las leyes de protección de los consumidores receptan expresamente el derecho a la educación en el consumo ${ }^{484}$ pero la deuda de implementación

${ }^{483}$ En este caso, se trata de una consideración contenida en el Dictamen del CESE de 2007, punto 5.1.b.

${ }^{484}$ El art. 17 del Texto Refundido de la Ley General para la Defensa de los Consumidores y Usuarios establece: "Información, formación y educación de los consumidores y usuarios. 1. Los poderes públicos, en el ámbito de sus respectivas competencias, fomentarán la formación y educación de los consumidores y usuarios, asegurarán que estos dispongan de la información precisa para el eficaz ejercicio de sus derechos y velarán para que se les preste la información comprensible sobre el adecuado uso y consumo de los bienes y servicios puestos a su disposición en el mercado. 2. Los medios de comunicación social de titularidad pública estatal dedicarán espacios y programas, no publicitarios, a la información y educación de los consumidores y usuarios. En tales espacios y programas, de acuerdo con su contenido y finalidad, se facilitará el acceso o participación de las asociaciones de consumidores y usuarios representativas y los demás grupos o sectores interesados, en la forma que se acuerde con dichos medios”. Por su parte, la Ley $\mathrm{N}^{\circ} 24.240$ de Defensa del Consumidor argentina dedica el Capítulo XVI a la "Educación al consumidor", con sus arts. 60 a 62 . El art. 60 reza: "Incumbe al Estado nacional, a la Ciudad Autónoma de Buenos Aires, a las provincias y a los Municipios, la formulación de planes generales de educación para el consumo y su difusión pública, arbitrando las medidas necesarias para incluir dentro de los planes oficiales de educación inicial, primaria, media, terciaria y universitaria los preceptos y alcances de esta ley, así como también fomentar la creación y el funcionamiento de las asociaciones de consumidores y usuarios y la participación de la comunidad en ellas, garantizando la implementación de programas destinados a aquellos consumidores y usuarios que se encuentren en situación desventajosa, tanto en zonas rurales como urbanas". El art. 61 dispone: "Formación del Consumidor. La formación del consumidor debe facilitar la comprensión y utilización de la información sobre temas inherentes al consumidor, orientarlo a prevenir los riesgos que puedan derivarse del consumo de productos o de la utilización de los servicios...”. Cierra el capítulo, el art. 62: “Contribuciones Estatales. El Estado nacional podrá disponer el otorgamiento de contribuciones financieras con cargo al presupuesto nacional a las asociaciones de consumidores para cumplimentar con los objetivos mencionados en los artículos anteriores. En todos los casos estas asociaciones deberán acreditar el reconocimiento conforme a los 
sigue pendiente. Esa mora de los poderes públicos muestra, en la operatoria de crédito, su rostro más amargo.

b.2.- El control de las prácticas empresarias:

\section{b.2.1.- Prácticas empresarias abusivas}

El diseño de políticas públicas encaminadas a neutralizar situaciones que contribuyan al endeudamiento excesivo luce impostergable. El regular funcionamiento del mercado de crédito impone el control de prácticas empresarias que puedan comprometer la transparencia del negocio y el justo equilibrio de los derechos en tensión ${ }^{485}$.

El Comité Económico y Social Europeo elaboró un Dictamen sobre "Acceso al crédito para los consumidores y las familias: prácticas abusivas", aprobado el sesión del 28 de abril de 2010, de gran relevancia. En el mismo, el CESE invita a la Comisión Europea y a los Estados miembros a analizar con más profundidad los fenómenos de las prácticas ilegales y delictivas en el ámbito del crédito, con especial atención a las prácticas abusivas y usureras y a iniciativas específicas en el espacio europeo de justicia (punto 1.5).

Se cree que la mayoría de las situaciones de abuso en el campo del crédito se producen en las relaciones entre intermediarios crediticios y consumidores (punto 4.19). De allí que para garantizar la transparencia, la fiabilidad y la profesionalidad de aquéllos, se promueva la creación de un registro de intermediarios crediticios. Este registro contaría con unos criterios vinculantes para la inscripción y estaría controlado por organismos constituidos por las asociaciones profesionales de bancos, intermediarios y mediadores financieros y asociaciones de consumidores, bajo el control de la autoridad supervisora, que deberían indicar la causa de la suspensión, cancelación o exclusión y la responsabilidad solidaria en caso de daños comprobados en un tribunal (punto 4.21).

artículos 56 y 57 de la presente ley. La autoridad de aplicación seleccionará a las asociaciones en función de criterios de representatividad, autofinanciamiento, actividad y planes futuros de acción a cumplimentar por éstas".

${ }^{485}$ Ver el interesante desarrollo de estos conceptos en BoURGOIGNIE, Thierry, "Seguridad del consumidor y vigilancia de mercado: estrategias y herramientas legales”, en TOMILlo URBINA, Jorge (Dir.)-ÁlvAREZ RUBIO, Julio (Coord.), La protección de los consumidores como motor de desarrollo económico, CivitasThomson Reuters, Pamplona, 2011, pág. 93-110. 
"El CESE pide que los requisitos para el registro de los distintos intermediarios financieros y crediticios en una red europea de registros nacionales se definan en referencia a una norma operativa europea de profesionalidad, prudencia y ética que, además, incluya disposiciones comunitarias de exclusión de determinados sujetos por conductas que perjudiquen a los consumidores o supongan prácticas abusivas o ilegales” (punto 1.8).

La Directiva 2005/29/CE del Parlamento Europeo sobre las "Prácticas Comerciales Desleales" ofrece pautas orientadoras para un adecuado control de prácticas empresarias que urge desterrar, en tanto puedan resultar amenazantes y lesivas de los derechos de los consumidores $^{486}$.

El marketing crediticio pone en evidencia el despliegue de prácticas que, sin dudas, pueden ser calificadas como abusivas. Sus manifestaciones son plurales: se aprovecha la sorpresa del consumidor, se estimula la contratación urgiendo respuestas, se facilita el acceso al consumo de crédito removiendo los obstáculos que naturalmente permiten evaluar la conveniencia del contrato, se despliegan estrategias que obstan a la concientización de las obligaciones que supone la operatoria, se condiciona el libre querer del consumidor con la oferta de productos y contratos en bloque, proliferan comportamientos de carácter engañoso.

El Anexo I de la Directiva analizada consagra una suerte de catálogo que muestra prácticas generales reprobadas, muchas de las cuales encuentran en el mercado de crédito, su mejor (o peor) escenario ${ }^{487}$.

\footnotetext{
${ }^{486}$ En el art. 5, la Directiva 2005/29/CE sienta la "prohibición de las prácticas comerciales desleales", señalando que: “2. Una práctica comercial será desleal si: a) es contraria a los requisitos de la diligencia profesional, y b) distorsiona o puede distorsionar de manera sustancial, con respecto al producto de que se trate, el comportamiento económico del consumidor ...”. Y puntualiza: “4. En particular, serán desleales las prácticas comerciales que: a) sean engañosas según lo establecido en los artículos 6 y 7, o b) sean agresivas según lo establecido en los artículos 8 y 9".

487 “Anexo I: Prácticas comerciales que se consideran desleales en cualquier circunstancia. Prácticas comerciales engañosas: 1) Afirmar el comerciante ser signatario de un código de conducta no siendo cierto. 2) Exhibir un sello de confianza o de calidad o un distintivo equivalente sin haber obtenido la necesaria autorización. 3) Afirmar que un código de conducta ha recibido el refrendo de un organismo público o de otro tipo no siendo cierto. 4) Afirmar que un comerciante (incluidas sus prácticas comerciales) o un producto ha sido aprobado, aceptado o autorizado por un organismo público o privado cuando éste no sea el caso, o hacer esa afirmación sin cumplir las condiciones de la aprobación, aceptación o autorización. 5) Realizar una
} 
invitación a comprar productos a un precio determinado sin revelar la existencia de motivos razonables que el comerciante pueda tener para pensar que no estará en condiciones de ofrecer, él mismo o a través de otro comerciante, dichos productos o productos equivalentes a ese precio durante un período y en cantidades razonables, teniendo en cuenta el producto, el alcance de la publicidad que se le haya dado y el precio de que se trate (publicidad señuelo). 6) Realizar una invitación a comprar productos a un precio determinado para luego: a) negarse a mostrar el artículo anunciado a los consumidores, b) negarse a aceptar pedidos de dicho artículo o a hacer entregas del mismo en un período de tiempo razonable, c) enseñar una muestra defectuosa del mismo, con la intención de promocionar un producto diferente (señuelo y cambio). 7) Afirmar falsamente que el producto sólo estará disponible durante un período de tiempo muy limitado o que sólo estará disponible en determinadas condiciones durante un período de tiempo muy limitado a fin de inducir al consumidor a tomar una decisión inmediata, privándole así de la oportunidad o el tiempo suficiente para hacer su elección con el debido conocimiento de causa. 8) Comprometerse a proporcionar un servicio posventa a consumidores con los que el comerciante se haya comunicado con anterioridad a una transacción en un idioma que no sea idioma oficial del Estado miembro en que esté instalado el comerciante, y que tal servicio se encuentre luego disponible únicamente en otro idioma, sin haber advertido claramente de ello al consumidor antes de que éste se comprometa a realizar la transacción. 9) Afirmar o crear por otro medio la impresión de que un producto puede ser legalmente vendido no siendo cierto. 10) Presentar los derechos que otorga la legislación a los consumidores como si fueran una característica distintiva de la oferta del comerciante. 11) Recurrir a un contenido editorial en los medios de comunicación para promocionar un producto, pagando el comerciante por dicha promoción, pero sin que ello quede claramente especificado en el contenido o mediante imágenes y sonidos claramente identificables para el consumidor (publirreportajes). Este supuesto se entenderá sin perjuicio de la Directiva 89/552/CEE (1). 12) Hacer afirmaciones materialmente inexactas en cuanto a la naturaleza y la extensión del peligro que supondría para la seguridad personal del consumidor o de su familia el hecho de que el consumidor no compre el producto. 13) Promocionar un producto similar al producto de un determinado fabricante para inducir de manera deliberada al consumidor a creer que el producto procede de ese mismo fabricante no siendo cierto. 14) Crear, dirigir o promocionar un plan de venta piramidal en el que el consumidor realice una contraprestación a cambio de la oportunidad de recibir una compensación derivada fundamentalmente de la entrada de otros consumidores en el plan, y no de la venta o el consumo de productos. 15) Afirmar que el comerciante está a punto de cesar en sus actividades o de trasladarse sin que vaya a hacerlo. 16) Alegar que los productos pueden facilitar la obtención de premios en juegos de azar. 17) Proclamar falsamente que un producto puede curar enfermedades, disfunciones o malformaciones. 18) Transmitir información materialmente inexacta sobre las condiciones del mercado o sobre la posibilidad de encontrar el producto, con la intención de inducir al consumidor a adquirirlo en condiciones menos favorables que las condiciones normales de mercado. 19) Afirmar en una práctica comercial que se ofrece un concurso o premios de promoción sin conceder los premios descritos ni algo razonablemente equivalente.

20) Describir un producto como «gratuito», «regalo», «sin gastos» o cualquier fórmula equivalente si el consumidor tiene que abonar dinero por cualquier concepto distinto del coste inevitable de la respuesta a la 
El art. 8 de la Directiva centra la atención en las prácticas agresivas que urge controlar, señalando que "se considerará agresiva toda práctica comercial que, en su contexto fáctico, teniendo en cuenta todas sus características y circunstancias, merme o pueda mermar de forma importante, mediante el acoso, la coacción, incluido el uso de la fuerza, o la influencia indebida, la libertad de elección o conducta del consumidor medio

práctica comercial y la recogida del producto o del pago por la entrega de éste. 21) Incluir en la documentación de comercialización una factura o un documento similar de pago que dé al consumidor la impresión de que ya ha encargado el producto comercializado sin que éste haya hecho el pedido correspondiente. 22) Afirmar de forma fraudulenta o crear la impresión falsa de que un comerciante no actúa a los fines propios de su actividad comercial, industrial, artesanal o profesional, o presentarse de forma fraudulenta como un consumidor. 23) Crear la impresión falsa de que el servicio posventa en relación con el producto está disponible en un Estado miembro distinto de aquel en el que se ha vendido el producto. Prácticas comerciales agresivas 24) Crear la impresión de que el consumidor no puede abandonar el local hasta haber perfeccionado el contrato. 25) Realizar visitas en persona al domicilio del consumidor, ignorando las peticiones de éste de que el comerciante abandone su casa o no vuelva a personarse en ella, salvo en las circunstancias y en la medida en que esté justificado, con arreglo a la legislación nacional, para hacer cumplir una obligación contractual. 26) Realizar proposiciones no solicitadas y persistentes por teléfono, fax, correo electrónico u otros medios a distancia, salvo en las circunstancias y en la medida en que esté justificado, con arreglo a la legislación nacional, para hacer cumplir una obligación contractual. Este supuesto se entenderá sin perjuicio del artículo 10 de la Directiva 97/7/CE y de las Directivas 95/46/CE (2) y 2002/58/CE. 27) Exigir al consumidor que desee reclamar una indemnización al amparo de una póliza de seguro que presente documentos que no puedan razonablemente considerarse pertinentes para determinar la validez de la reclamación o dejar sistemáticamente sin responder la correspondencia al respecto, con el fin de disuadirlo de ejercer sus derechos contractuales. 28) Incluir en una publicidad una exhortación directa a los niños para que compren o convenzan a sus padres u otros adultos de que les compren los productos anunciados. Esta disposición se entiende sin perjuicio de lo dispuesto en el artículo 16 de la Directiva 89/552/CEE relativa a la radiodifusión televisiva. 29) Exigir el pago inmediato o aplazado, la devolución o la custodia de productos suministrados por el comerciante, pero que no hayan sido solicitados por el consumidor (suministro no solicitado), salvo cuando el producto en cuestión sea un producto de sustitución suministrado de conformidad con lo establecido en el artículo 7, apartado 3, de la Directiva 97/7/CE. 30) Informar expresamente al consumidor de que el trabajo o el sustento del comerciante corren peligro si el consumidor no adquiere el producto o servicio. 31) Crear la impresión falsa de que el consumidor ha ganado ya, ganará, o conseguirá si realiza un acto determinado, un premio o cualquier otra ventaja equivalente, cuando en realidad:

—no existe tal premio o ventaja equivalente, — la realización de una acción relacionada con la obtención del premio o ventaja equivalente está sujeta a la obligación, por parte del consumidor, de efectuar un pago o incurrir en un gasto". 
con respecto al producto y, por consiguiente, le haga o pueda hacerle tomar una decisión sobre una transacción que de otra forma no hubiera tomado".

De gran interés resultan las pautas ofrecidas por el art. 9, al momento de calificar como abusiva, una práctica empresaria. Dispone la norma: "para determinar si una práctica comercial hace uso del acoso, la coacción, con inclusión del uso de la fuerza, o la influencia indebida se tendrán en cuenta: a) el momento y el lugar en que se produce, su naturaleza o su persistencia; b) el empleo de un lenguaje o un comportamiento amenazador o insultante; c) la explotación por parte del comerciante de cualquier infortunio o circunstancia específicos lo suficientemente graves como para mermar la capacidad de discernimiento del consumidor, de los que el comerciante tenga conocimiento, para influir en la decisión del consumidor con respecto al producto; d) cualesquiera obstáculos no contractuales onerosos o desproporcionados impuestos por el comerciante cuando un consumidor desee ejercitar derechos previstos en el contrato, incluidos el derecho de poner fin al contrato o el de cambiar de producto o de comerciante; e) la amenaza de ejercer cualquier acción que, legalmente, no pueda ejercerse".

Todas las exhortaciones resultan insuficientes cuando se trata de impulsar el control por parte de la autoridad pública. Es el Estado el principal responsable de la protección del consumidor en el mercado pues así resulta del mandato garantista impartido desde la Constitución, en casi todos los países del mundo. Voces críticas señalan el marcado contraste entre el desarrollo creciente del sistema protectorio a nivel legislativo y en la praxis judicial, por un lado, y la deuda respecto de políticas activas y su adecuada implementación ${ }^{488}$.

En materia de sobreendeudamiento de los consumidores, el control estatal de las prácticas empresarias es impostergable. El objetivo es neutralizar situaciones que constituyen factores muchas veces determinantes de la crisis de las economías domésticas.

No obstante lo expresado, cabe destacar también el rol que le cabe a la sociedad civil en este control de las prácticas empresarias lesivas de los derechos de los consumidores.

"La sociedad civil, en especial las asociaciones de consumidores, ha de desempeñar un papel importante a la hora de determinar, estudiar y vigilar los problemas derivados de

\footnotetext{
${ }^{488}$ STIGLITZ, Gabriel A., La defensa del consumidor en Argentina..., cit., pág. 10.
} 
las prácticas abusivas e ilegales en la concesión de créditos a consumidores y familias". Resulta necesario "crear y promover, en cooperación con las autoridades públicas, redes de la sociedad civil para el estudio, la asistencia y la supervisión de situaciones de exclusión social y de pobreza asociadas al crédito y sobreendeudamiento. Estas redes tienen un cometido esencial como punto de intercambio de información y buenas prácticas, y también como parte del sistema armonizado de reclamaciones" ${ }^{\text {489 }}$.

\section{b.2.2.- Control de cláusulas abusivas en la contratación:}

La preocupación del legislador por la problemática de las cláusulas abusivas -en el marco de los contratos de consumo, en general, y de los contratos de crédito, en particularexplica la reacción del sistema ${ }^{490}$. La vulnerabilidad del consumidor y la necesidad de tutelarlo emergen nuevamente como razón de ser de la intervención legislativa.

Cuando el sistema posibilita que uno de los sujetos pueda establecer normas con eficacia general, a las que necesariamente deberá adherir la contraparte, es innegable el ejercicio de un poder de predisponente, su superioridad, su señorío en este campo de actuación. Y dado que los contratos de consumo celebrados bajo este modelo involucran sectores de la economía de gran impacto social, se impone coordinar los derechos y libertades en tensión.

El ejercicio de estas prerrogativas que el mercado posibilita al empresario, no puede juzgarse sino mediante el examen de compatibilidad con los bienes públicos afectados y nociones conceptuales susceptibles de aprehender lo colectivo. Debe adoptarse un criterio particularmente estricto, adoptando el modelo de un buen legislador ${ }^{491}$ y exigiendo una

\footnotetext{
${ }^{489}$ Puntos 6.1, 6.2 del Dictamen del Comité Económico y Social Europeo sobre "Acceso al crédito para los consumidores y las familias: prácticas abusivas” de 2010.

${ }^{490}$ El tema de las cláusulas abusivas no es patrimonio exclusivo de los contratos de consumo, especialmente amparados por los microsistemas del consumidor. Sin embargo, es en este campo donde su estudio ha encontrado su desarrollo más fecundo. Es un dato de la realidad que los contratos de consumo se concretan casi en regla, por vía de contratos predispuestos, sujetos a condiciones generales prerredactadas y celebrados por adhesión; y es sin dudas el consumidor, el ejemplo paradigmático de las situaciones abusivas que tales modalidades de contratación significan para el extremo estructuralmente débil de la relación jurídica.

${ }^{491}$ LORENZETTI desarrolla estos temas, trazando un paralelo entre el abuso del derecho tradicional y la existencia de situaciones abusivas, en un enfoque enriquecedor y novedoso (Cfr. LORENZETTI, Ricardo L.,
} 
previsibilidad mayor, en la contemplación del espectro de resultados de las conductas normativas. El sujeto al que el sistema permite fijar las reglas del juego, está precisado de compaginar intereses contrapuestos. Es que si habrá de regular para sí y para otros, deberá tener una mirada global del universo a reglar y examinar las consecuencias que de tal regulación se deriven.

Con acierto se destaca ${ }^{492}$, que las soluciones jurídicas con fundamento ético coinciden con las provistas por el análisis económico, que inspiradas en el principio de eficiencia, hacen conjugar los postulados de bien común con los de la suma total de los intereses generales e individuales que enuncia el utilitarismo; coincidiendo además en que las consecuencias derivadas de una cláusula abusiva, írritas al orden jurídico, deben ser soportadas por quien estaba en condiciones idóneas para evitarlas.

"El control de incorporación, también llamado de inclusión, de consentimiento, general o abstracto de las condiciones generales (que de todas esas maneras se ha denominado) no va dirigido a examinar un determinado contrato ya perfeccionado sino a verificar las circunstancias en que se realiza el acto de predisposición en si, la comprobación de unas determinadas exigencias formales que ha de cumplir aquel profesional o empresario que propone utilizar unas determinadas condiciones generales en el ejercicio de su actividad negocial ${ }^{493}$ ". Estas consideraciones generales, aplicadas a la operatoria de crédito y al consumo financiado, encuentran justificación reforzada, no bien se advierte que el aludido control de incorporación del clausulado contractual constituye una herramienta preventiva más del fenómeno del sobreendeudamiento pero de cumplimiento ineludible.

En todos los ordenamientos, el control administrativo que debe ejercer la autoridad de aplicación respecto del modelo contractual predispuesto, para la operatoria de crédito, es una imposición de base que se complementa con precauciones legales adicionales ${ }^{494}$.

\footnotetext{
"Situaciones jurídicas abusivas lesivas de libertades del consumidor", en STIGLITZ, Gabriel (Dir.), Derecho del Consumidor, № 7, Editorial Juris, Rosario, 1996, pág. 9-16).

${ }^{492}$ Alterini, Atilio Aníbal, Contratos Civiles..., cit., pág. 387.

${ }^{493}$ Llamas POMBO, Eugenio La compraventa, Ed. La Ley, Madrid, 2014, pág. 798 y sgtes.

${ }^{494}$ El art. 38 de la Ley de Defensa del Consumidor argentina dispone: "Contrato de adhesión. Contratos en formularios. La autoridad de aplicación vigilará que los contratos de adhesión o similares, no contengan cláusulas de las previstas en el artículo anterior. La misma atribución se ejercerá respecto de las cláusulas
} 
Agrega Llamas Pombo: “de poco o nada serviría una regulación legal de las condiciones generales, si la misma quedase limitada al mero control de incorporación de las mismas al contrato. Nada se opone a que unas determinadas condiciones generales, claras y transparentemente redactadas, y perfectamente accesibles y aceptadas por el adherente, resulten en la práctica absolutamente contrarias a las exigencias de la buena fe negocial, al equilibrio de las prestaciones y a la más elemental justica contractual. Por ello es preciso el llamado control de contenido, que se ha definido en la doctrina como el conjunto de operaciones de naturaleza preeminentemente valorativa, destinadas a determinar si la regulación material recogida en las condiciones generales es o no admisible, o sea, compatible con el principio de buena fe" ${ }^{, 495}$.

Precisamente comentando la decisión del Tribunal Supremo español en un conflicto vinculado a un préstamo hipotecario ${ }^{496}$, PERTíñEZ VÍLCHEZ señala que "la obligación de transparencia impuesta a las condiciones generales "tiene un contenido dinámico que no se agota en el mero cumplimiento de los requisitos de incorporación, o en la redacción de una cláusula sin ambigüedades (art. 6.2 de la LCGC) ..." ${ }^{497}$. Y precisamente porque el control de transparencia no se limita al cumplimiento de los requisitos previstos en la normativa administrativa sobre transparencia bancaria, es que aún superada la instancia de aprobación del contrato modelo por la autoridad del sector correspondiente, tanto los organismos

uniformes, generales o estandarizadas de los contratos hechos en formularios, reproducidos en serie y en general, cuando dichas cláusulas hayan sido redactadas unilateralmente por el proveedor de la cosa o servicio, sin que la contraparte tuviere posibilidades de discutir su contenido". Por su parte, el art. 39 establece: "Modificación contratos tipo. Cuando los contratos a los que se refiere el artículo anterior requieran la aprobación de otra autoridad nacional o provincial, ésta tomará las medidas necesarias para la modificación del contrato tipo a pedido de la autoridad de aplicación”.

${ }^{495}$ LlAMAS POMBO, Eugenio La compraventa, cit., pág. 803.

${ }^{496}$ El Tribunal Supremo, mediante sentencia del 9/5/2013, se pronunció en el marco de una acción de cesación entablada por una asociación de consumidores contra distintas entidades financieras por la inclusión en sus contratos de préstamo hipotecario de límites mínimos a las variaciones del tipo de interés (cláusulas suelo). Consideró que estas cláusulas resultaban abusivas por un defecto de transparencia y no por un desequilibrio excesivo entre la cláusula suelo y el límite máximo a la variación del tipo de interés (cláusula techo), fijado normalmente en unos umbrales irracionales.

${ }^{497}$ Cfr. PeRTíñEZ VÍlChEZ, Francisco, "Falta de transparencia y carácter abusivo de la cláusula suelo en los contratos de préstamo hipotecario", en http://www.indret.com/pdf/995.pdf (Fecha de consulta: 1/10/2015). 
administrativos de defensa de los consumidores como el juez, en su caso, pueden y deben ejercer el control de legitimidad del contenido contractual, saneándolo cuando luzca teñido de abusividad ${ }^{498}$.

En esta línea de razonamiento, el codificador argentino se propone llamar la atención respecto de la relevancia de la cuestión, y al regular los "Contratos bancarios" (Libro III, Título IV, Capítulo 12) en el nuevo Código Civil y Comercial, dedica el Parágrafo $1^{\circ}$ de la Sección $1^{\circ}$, a la "Transparencia de las condiciones contractuales". El aludido parágrafo contiene 6 dispositivos referidos a aspectos concretos que hacen a la transparencia de la operatoria bancaria, resignificando el aludido principio. En lo que aquí nos ocupa, la autoridad de contralor del sector está llamada a velar por el debido cumplimiento de los recaudos y diligencias impuestos a las entidades dadoras de crédito y el operador jurídico -autoridad de aplicación de la ley de defensa de consumidores y usuarios y jueces- harán lo propio en sus respectivos escenarios de actuación.

En orden a la prevención del sobreendeudamiento, resulta ineludible un sobrevuelo en la problemática de las cláusulas abusivas y su regulación por el legislador.

No exige gran esfuerzo de argumentación sostener el postulado conforme al cual aún superado el control de incorporación y de contenido ante a la autoridad administrativa, se impone intervenir cuando aquel modelo contractual estandarizado cobra dinamismo y da operatividad al plan prestacional que constituye el débito del tomador del crédito o de quien requiere financiación para la adquisición de bienes o servicios. En esta etapa se renuevan los riesgos de agravamiento de la situación patrimonial del consumidor que procuramos neutralizar.

En el ordenamiento argentino, a diferencia de otros ${ }^{499}$, la temática de las cláusulas abusivas tuvo como primer puerto el régimen especial de protección de los

\footnotetext{
${ }^{498}$ Ello explica que al sentar las reglas del control judicial respecto de las cláusulas abusivas, el nuevo Código Civil y Comercial disponga que "la aprobación administrativa de los contratos o de sus cláusulas no obsta al control" en sede judicial (art. 1122 inc. a); previsión que ha recibido la opinión laudatoria de la doctrina (STiglitz, Rubén S.-Stiglitz, Gabriel A., Contratos por adhesión, cláusulas abusivas y protección del consumidor, 2da. edición actualizada y ampliada con la Ley 24.240 y el proyecto de Código Civil y Comercial de la Nación, La Ley, Buenos Aires 2012, pág. 321; asimismo, Alterini, Jorge H. (Dir.), Código Civil y Comercial ..., cit, T. V, La Ley, Buenos Aires, 2015, pág. 960).
} 
consumidores $^{500}$. Esta problemática, como otras tantas, fue asumida por una ley especial que nació con vocación de ruptura respecto del sistema general. No obstante ello, constatamos en la actualidad que muchas de las soluciones legales gestadas en el microsistema particular exhiben un tránsito inverso, con destino final en los códigos de fondo, para enriquecerlos y hacer más eficiente el principio de tutela que las inspira ${ }^{501}$. La

499 Para un desarrollo minucioso del tema, con particular referencia de los antecedentes legislativos y su evolución, así como del análisis de la problemática y su tratamiento en el ordenamiento español, ver LLAMAS POMBO, Eugenio La compraventa, cit., pág. 810 y sgtes.

${ }^{500}$ El art. 37 de la Ley de Defensa del Consumidor argentina dispone: "Sin perjuicio de la validez del contrato, se tendrán por no convenidas: a) Las cláusulas que desnaturalicen las obligaciones o limiten la responsabilidad por daños; b) Las cláusulas que importen renuncia o restricción de los derechos del consumidor o amplíen los derechos de la otra parte; c) Las cláusulas que contengan cualquier precepto que imponga la inversión de la carga de la prueba en perjuicio del consumidor. La interpretación del contrato se hará en el sentido más favorable para el consumidor. Cuando existan dudas sobre los alcances de su obligación, se estará a la que sea menos gravosa. En caso en que el oferente viole el deber de buena fe en la etapa previa a la conclusión del contrato o en su celebración o transgreda el deber de información o la legislación de defensa de la competencia o de lealtad comercial, el consumidor tendrá derecho a demandar la nulidad del contrato o la de una o más cláusulas. Cuando el juez declare la nulidad parcial. Simultáneamente integrará el contrato, si ello fuera necesario".

${ }^{501}$ El nuevo Código Civil y Comercial argentino, en el Libro II (Derechos Personales), Título II (Contratos en general), Capítulo 3 (Formación del consentimiento), Sección $2^{\circ}$ (Contratos celebrados por adhesión a cláusulas generales predispuestas), emplaza el art. 988 que reza: "Cláusulas abusivas. En los contratos previstos en esta sección, se deben tener por no escritas: a) las cláusulas que desnaturalizan las obligaciones del predisponente; b) las que importan renuncia o restricción a los derechos del adherente, o amplían derechos del predisponente que resultan de normas supletorias; c) las que por su contenido, redacción o presentación, no son razonablemente previsibles". El art. 989 dispone: "Control judicial de las cláusulas abusivas. La aprobación administrativa de las cláusulas generales no obsta a su control judicial. Cuando el juez declara la nulidad parcial del contrato, simultáneamente lo debe integrar, si no puede subsistir sin comprometer su finalidad". Por otra parte, el Título III titulado "Contratos de consumo", incluye en su cortejo al art. 1118 que establece: "Control de incorporación. Las cláusulas incorporadas a un contrato de consumo pueden ser declaradas abusivas aun cuando sean negociadas individualmente o aprobadas expresamente por el consumidor. El art. 1119 consagra la regla general conforme la cual "Regla general. Sin perjuicio de lo dispuesto en las leyes especiales, es abusiva la cláusula que, habiendo sido o no negociada individualmente, tiene por objeto o por efecto provocar un desequilibrio significativo entre los derechos y las obligaciones de las partes, en perjuicio del consumidor". Agrega el art. 1120: "Situación jurídica abusiva. Se considera que existe una situación jurídica abusiva cuando el mismo resultado se alcanza a través de la predisposición de 
recepción de los dispositivos diseñados para atender a la problemática de las cláusulas abusivas en el nuevo Código Civil y Comercial argentino contribuye a la salud del sistema. La regulación propuesta desde el código unificado nutre a los remedios nacidos en el seno de la ley especial, los fortalece, los hace crecer, mejora sus contornos, les proporciona vitalidad, ganan en eficiencia ${ }^{502}$.

La doctrina considera preferible, al momento de descalificar las cláusulas abusivas, el empleo de una fórmula general que desembarca en casi todas las legislaciones. Desde esta perspectiva, la directriz ha sido la idea de que aquéllas desnaturalizan las obligaciones

una pluralidad de actos jurídicos conexos". El art. 1122 establece: "Control judicial. El control judicial de las cláusulas abusivas se rige, sin perjuicio de lo dispuesto en la ley especial, por las siguientes reglas: a) la aprobación administrativa de los contratos o de sus cláusulas no obsta al control; b) las cláusulas abusivas se tienen por no convenidas; c) si el juez declara la nulidad parcial del contrato, simultáneamente lo debe integrar, si no puede subsistir sin comprometer su finalidad; d) cuando se prueba una situación jurídica abusiva derivada de contratos conexos, el juez debe aplicar lo dispuesto en el artículo 1075".

${ }^{502}$ Destaca STIGLITZ que la definición de las cláusulas abusivas en materia de contratos de consumo receptada por el Código Civil y Comercial argentino permite focalizar la esencia de la problemática de esta disposición contractual en tanto "tiene por objeto o por efecto provocar un desequilibrio significativo entre los derechos y las obligaciones de las partes, en perjuicio del consumidor" (art. 1119) y que no obstante reproducir las dos fórmulas abiertas propuestas por los incisos a y b del art. 37 de la Ley de Defensa del Consumidor, el texto legal ahora ofrecido constituye una "mejora ostensible" a la de la ley especial. Señala el destacado jurista que esta cláusula abierta o general tiene "carácter imperativo" y "tiene por objeto o por efecto el control de legitimidad directo de los preceptos de autonomía que integran los contratos". Sostiene asimismo, que la fórmula general "opera como una red de protección en tanto impide que se evadan de dicha calificación aquellas hipótesis no incluidas en los elencos de cláusulas calificadas como abusivas..." (STIGLITZ, Rubén S., en LoREnzeTti, Ricardo L. (Dir.), Código Civil y Comercial..., cit., T. V, Rubinzal Culzoni, Santa Fe, 2015, pág. 650 y sgtes.). Como un aporte adicional del nuevo Código Civil y Comercial, STIGLITZ menciona como novedad de la nueva legislación, a la hipótesis incluida en el art. 988 inc. c, que recoge como manifestación de la abusividad contractual, a las denominadas cláusulas sorpresivas, que se caracterizan por su imprevisibilidad en el contrato que las contiene. Se trata de disposiciones contractuales que "ingresan clandestinamente", que "aparecen subrepticiamente". “...El predisponente cuenta con que el adherente no las espera, por lo que su expectativa consiste en tomarlo desprevenido. Es una cláusulas que exhibe una desmesurada deslealtad" y de allí que "el ordenamiento jurídico reacciona...porque constituyen un plus por sobre la generalidad de las cláusulas abusivas" (STIGLITZ, Rubén S., en LoRENZETTI, Ricardo L. (Dir.), Código Civil y Comercial..., cit., pág. 655; En sentido similar, se comenta este precepto en ALTERINI, Jorge H. (Dir.), Código Civil y Comercial...,cit., T. V, La Ley, Buenos Aires, 2015, pág. 941). 
de las partes provocando un grave desequilibrio, que motiva la reacción del sistema e impone el saneamiento del acuerdo.

Se señala, por un lado que el Derecho dispositivo propone un modelo de regulación que el legislador considera razonable y lo ofrece a las partes a fin de que lo tomen en cuenta al contratar $^{503}$. Y de allí que una cláusula contractual que se aparta del modelo de razonabilidad sin un motivo justificado, se aleja de lo deseable, propiciando situaciones de tensión que habrán de juzgarse con rigor y severidad. La desnaturalización es entendida como un apartamiento injustificado aquel Derecho dispositivo ${ }^{504}$.

No obstante los puntos de contacto de las diversas legislaciones, corresponde a cada Derecho positivo determinar los contornos de la figura y ofrecer las pautas que permitan calificar a una cláusula contractual como abusiva. Ello explica que, sin perjuicio de la fórmula general ofrecida, algunos sistemas proponen listas negras con cláusulas prohibidas, que resultan nulas, y/o listas grises, donde las cláusulas enunciadas pueden ser invalidadas por el juez conforme las circunstancias del caso ${ }^{505}$.

La ley argentina de defensa del consumidor (art. 37) y el nuevo Código Civil y Comercial argentino (art. 1122), al igual que la regulación española (art. 83 del Texto Refundido de la Ley General para la Defensa de los Consumidores y Usuarios), adoptan el

\footnotetext{
${ }^{503}$ LORENZETTI, Ricardo L., "Tratamiento de las cláusulas abusivas en la Ley de Defensa del Consumidor", en Revista de Derecho Privado y Comunitario, № 5, Consumidores, Rubinzal-Culzoni, Santa Fe, 1994, pág. 172.

${ }^{504}$ LORENZETTI, Ricardo L., Tratado de los Contratos, T. 1, cit., pág. 165.

505 POLO, Eduardo, Protección del contratante débil y condiciones generales de los contratos, Civitas, Madrid, 1990, pág. 57 y sgtes. Resulta de particular interés el minucioso catálogo que ofrece la lista que emerge de los arts. 85 a 91 del Texto Refundido de la Ley General para la Defensa de los Consumidores y Usuarios español. Remitimos para su análisis crítico a PERTíñEZ VÍLCHEZ, Francisco en CÁMARA LAPUENTE, Sergio (Dir.), Comentarios a las Normas de Protección de los Consumidores, Colex, Madrid, 2011, pág. 788938. Ver asimismo, GonzÁlez PeCAnowsa, Isabel, en BerCovitz RodríGuez-CAnO, Rodrigo (Coord.), Comentario del Texto Refundido de la Ley General para la Defensa de los Consumidores y Usuarios y otras leyes complementarias (Real Decreto Legislativo 1/2007), Aranzadi-Thomson Reuters, Madrid, 2009, pág. 995-1180. Sugerimos aquí también bucear en el análisis que propone LLAMAS POMBO al hacer el relevamiento de la fórmula general y del catálogo de cláusulas abusivas contenidos en la ley española y concluir sobre la interpretación de sus efectos y alcances (LLAMAS POMBO, Eugenio La compraventa, cit., pág. 821 y sgtes.).
} 
criterio de tener por no convenidas, sin perjuicio de la validez del contrato, a las cláusulas abusivas. Esta solución, armonizada con los mecanismos de otorgar al consumidor la iniciativa de articular la nulidad total o parcial del contrato y al juez la potestad de integrarlo con las normas pertinentes, forman un cortejo de equilibrio en las relaciones negociales propias del mercado actual ${ }^{506}$.

Es una realidad incontrastable que los contratos que formalizan la relación consumidor-entidad/agente financiero son escenario propicio para los excesos de quien propone las reglas del juego. Existen sobradas herramientas legales para combatir la abusividad en el marco contractual ${ }^{507}$. El desafío es llevar adelante un control previo serio por parte de la autoridad administrativa y alentar un rol activo de los jueces a la hora de

${ }^{506}$ Alterini, Atilio Aníbal, Contratos Civiles..., cit., pág. 392. El art. 37 de la ley argentina expresa: "Sin perjuicio de la validez del contrato, se tendrán por no convenidas: a) Las cláusulas que desnaturalicen las obligaciones o limiten la responsabilidad por daños; b) Las cláusulas que importen renuncia o restricción de los derechos del consumidor o amplíen los derechos de la otra parte; c) Las cláusulas que contengan cualquier precepto que imponga la inversión de la carga de la prueba en perjuicio del consumidor. La interpretación del contrato se hará en el sentido más favorable para el consumidor. Cuando existan dudas sobre los alcances de su obligación, se estará a la que sea menos gravosa. En caso en que el oferente viole el deber de buena fe en la etapa previa a la conclusión del contrato o en su celebración o transgreda el deber de información o la legislación de defensa de la competencia o de lealtad comercial, el consumidor tendrá derecho a demandar la nulidad del contrato o la de una o más cláusulas. Cuando el juez declare la nulidad parcial. Simultáneamente integrará el contrato, si ello fuera necesario".

${ }^{507}$ La normativa sectorial se ocupa también de la problemática. Mediante Comunicación A 5460 del BCRA se introducen modificaciones a las normas sobre "Protección de los usuarios de servicios financieros" y en el apartado 2.3.8. sobre "Cláusulas abusivas", dispone: "En los contratos celebrados entre el usuario de servicios financieros y los sujetos obligados, se tendrán por no escritas las cláusulas que: 2.3.8.1. Desnaturalicen las obligaciones del sujeto obligado. 2.3.8.2. Importen una renuncia o restricción a los derechos del usuario de servicios financieros, o amplíen derechos del sujeto obligado. 2.3.8.3. Por su contenido, redacción o presentación no sea razonable esperar que se las incluya por no guardar conexión con la naturaleza del contrato. 2.3.8.4. Impongan obstáculos onerosos para el ejercicio efectivo de los derechos del usuario de servicios financieros. 2.3.8.5. Coloquen al usuario de servicios financieros en una situación desventajosa o desigual con el sujeto obligado. 2.3.8.6. Transfieran la responsabilidad del sujeto obligado a terceros. 2.3.8.7. Establezcan la inversión de la carga de la prueba en perjuicio del usuario de servicios financieros. 2.3.8.8. Permitan al sujeto obligado, directa o indirectamente, alterar el importe de las tasas, comisiones y/o cargos de manera unilateral, apartándose del mecanismo previsto en toda la normativa aplicable, para modificación de cláusulas contractuales". 
ponderar la legitimidad -o ilegitimidad- del clausulado que sirve de base a las obligaciones asumidas por los consumidores.

c.- Consagración de derechos y deberes en la relación jurídica.

En el marco de la relación jurídica concreta, el principal destinatario de los deberes de prevención es el proveedor del crédito, sea que se trate de entidades financieras habilitadas para el ejercicio del negocio que les es propio, así como cualquier otra empresa que otorgue financiación, aunque no sea éste su principal cometido o lo haga bajo otras modalidades (informales o alternativas) ${ }^{508}$. Hacemos extensivos estos deberes de los proveedores de bienes y servicios que ofrecen la financiación para la adquisición o contratación de aquéllos.

Existe consenso $^{509}$ en mencionar entre las medidas preventivas a considerar en la regulación, las siguientes:

\section{c.1.- En la etapa precontractual}

c.1.1. Actividad publicitaria transparente. Contenido informativo básico.

Con acierto se ha dicho que la regulación del fenómeno publicitario debe ser una prioridad de cualquier política amplia de protección del consumidor ${ }^{510}$.

La actividad publicitaria desplegada por los empresarios constituye uno de los núcleos básicos en torno a los que gira la economía y se erige como el medio idóneo para facilitar el funcionamiento del mercado. La publicidad sirve como principal arma de lucha entre los empresarios competidores y es el puente entre aquéllos y el público consumidor ${ }^{511}$.

\footnotetext{
${ }^{508}$ GutiÉRREZ DE CABIEDES, Pablo, El sobreendeudamiento doméstico..., cit., pág. 125.

509 TrujILlo DíEZ, Iván Jesús, El sobreendeudamiento de los consumidores..., cit., pág. 51; GUTIÉRREZ DE CABIEDES, Pablo, El sobreendeudamiento doméstico..., cit., pág. 124; Álvarez VegA, María Isabel, Protección jurídica del consumidor sobreendeudado..., cit., pág. 301; entre otros.

${ }^{510}$ PARDUCCI, Diego Martín, “Contratos bancarios con consumidores y usuarios”, Suplemento Especial Nuevo Código Civil y Comercial de la Nación. Contratos en particular, 2015 (abril), pág. 214.

511 Kemelmajer Del CARluCCI, Aída, "Publicidad y consumidores" en Revista de Derecho Privado y Comunitario, 5, Rubinzal Culzoni, Santa Fe, Santa Fe, 1994, pág. 63 y sgtes. En este trabajo, la autora nos
} 
Los estudios del mercado demuestran que hasta el mejor producto o servicio moriría en las carpetas de los empresarios de no ser por la publicidad que los acerca e instala en la gente $^{512}$. "La publicidad es el producto" o dicho de otro modo, "el producto es ante todo, su imagen", lo que el público ve o cree ver en aquello que se le ofrece ${ }^{513}$.

La publicidad tal como está pensada, diseñada e instrumentada, tiende a alcanzar su propósito persuasivo sobre una masa de consumidores de espectro diverso. Beneficiada por los aportes de sicólogos, sociólogos, especialistas en marketing, los llamados creativos, etc., y la fuerza potenciadora de los medios de comunicación masiva, la publicidad es ya un producto en sí mismo, que incorpora su propia sustancia al bien o servicio que promociona.

Se dice que "la persuasión está presente en la publicidad de la misma forma que lo está un iceberg: tres cuartas partes sumergidas bajo el agua" ${ }^{\text {"514 }}$. En lo que no se ve está el exhaustivo trabajo de quienes han estudiado el perfil del consumidor: sus gustos $\mathrm{y}$ preferencias, el volumen y la frecuencia con la que se consume tal o cual producto o se utiliza tal o cual servicio, las circunstancias que son ocasión para la adquisición de productos, las motivaciones individuales y sociales que determinan ese consumo, etc. Ese caudal informativo es procesado e incorporado en la etapa de elaboración, para luego dar paso a la tarea de los profesionales que diseñarán la estrategia de distribución, fundamentalmente por vía de la actividad publicitaria.

Se afirma con razón que "la publicidad se ha convertido lisa y llanamente en la industria de la persuasión" ${ }^{\text {,515. }}$.

explica con la profundidad que caracteriza sus investigaciones, el rol de la publicidad en el funcionamiento del mercado moderno.

${ }^{512}$ Kemelmajer de CARluCCI, Aída, "Publicidad y consumidores", cit., con cita de ERHARD.

513 Alterini, Atilio A., "Control de la publicidad y comercialización”, en StiglitZ, Gabriel A., Derecho del Consumidor, 5, Juris, Rosario, 1993, pág. 23 y sgtes.; AlteRinI, Atilio A., "Responsabilidad objetiva derivada de la generación de confianza", en Temas de responsabilidad civil, Ediciones Ciudad Argentina, Buenos Aires, 1995, pág. 243-255.

${ }^{514}$ Delgado Zegarra, Jaime, "Técnicas de comercialización y publicidad" en, StiglitZ, Gabriel A., Derecho del Consumidor, 5, Juris, Rosario, 1993, pág. 151 y sgtes.

${ }^{515}$ Kemelmajer De CARlucCi, Aída, "Publicidad y consumidores", cit., pág. 65. 
No obstante considerar que resulta deseable el ofrecimiento de información suficiente acerca del bien o servicio comercializado en el mensaje publicitario ${ }^{516}$, no parece ser éste el propósito que define la esencia de la publicidad.

En un estado ideal de cosas, la publicidad debería cumplir una finalidad informativa $^{517}$. Mas, si bien la información encuentra en la actividad publicitaria un canal de expresión natural, debemos admitir que responden a funciones y objetivos esencialmente diversos. La información apunta a ilustrar, a iluminar, al discernimiento, a aportar datos objetivos, veraces y suficientes al consumidor respecto de los bienes o servicios ofrecidos. La publicidad por su parte, orienta sus esfuerzos hacia la persuasión, la seducción y la captación del público. Precisamente al hacer un paralelo entre ambas nociones, la profesora KEMELMAJER DE CARLUCCI señala que "se ha comprobado que la eficacia persuasiva de la publicidad es, como regla, directamente proporcional a la escasez de información"518.

La finalidad de la publicidad es seducir, persuadir al consumidor de las bondades del bien ofrecido, captar al público para su marca y movilizarlo a fin de concretar el consumo; y tal objetivo no se satisface necesariamente con el suministro de información. En la racionalidad del marketing, lo prioritario es capturar la atención, instalar el deseo del consumidor y determinarlo a la adquisición del producto o del servicio. Se entiende que la información que necesariamente deberá suministrar tendrá otro momento, en el que la decisión de concretar el acto de consumo sea difícilmente removible.

Antes que la información, la publicidad prioriza la transmisión de valores que incidan en la decisión, por su impacto positivo o negativo pero igualmente eficaz. La belleza, el éxito, la seguridad, la eficiencia, la solvencia, la confiabilidad, etc. son valores que, asociados a un producto o servicio, generan gran adhesión. Del mismo modo, provocar una sensación de miedo a no tener el bien o no contar con el servicio, de inseguridad, de

\footnotetext{
516 Morello, Augusto M. - Stiglitz, Rubén S. - Stiglitz, Gabriel A., "Información al consumidor y contenido del contrato”, en STiGLiTZ, Gabriel A., Derecho del Consumidor, 5, Juris, Rosario, 1993, pág. 151 y sgtes.

${ }^{517}$ LORENZETTI, Ricardo L., Consumidores, cit., pág. 152.

${ }^{518}$ KeMELMAJER DE CARluCCi, Aída, "Publicidad y consumidores”, cit., pág. 66.
} 
fracaso, de marginación, de incertidumbre, de riesgo, etc., pueden ser técnicas que movilicen al consumidor a la contratación ${ }^{519}$.

La regulación necesariamente debe atender a tres centros de interés. Por un lado, se debe garantizar el derecho de expresión del empresario proveedor, en tanto la publicidad es una manifestación evidente de dicha libertad ${ }^{520}$. Se impone que, conforme los principios propios del sistema democrático y de libertad de los mercados, sea respetado el ejercicio regular de este derecho. Por otra parte, resulta inexorable que por vía de la regulación se establezcan condiciones para asegurar la transparencia del mercado, desterrando prácticas distorsivas, desleales o deshonestas. En este supuesto, existe una doble esfera de intereses: no sólo los competidores, que aspiran a una competencia leal, sino la comunidad toda, interesada en un mercado transparente, de prácticas regulares y honestas. Por último -y reservamos su mención para el cierre por ser la que más nos interesa- se impone arbitrar dispositivos legales que, bajo el paradigma tutelar, contemplen la situación de los consumidores. Precisamente porque en el campo de la actividad publicitaria es donde suelen manifestarse situaciones de desequilibrio y vulnerabilidad ${ }^{521}$.

El Estado debe permanecer alerta al desarrollo de la actividad publicitaria, atendiendo los intereses de los actores del mercado (consumidores y competidores) pero principalmente de quienes, por su debilidad estructural, requieren de la tutela diferenciada del sistema. La regulación de la actividad y el control de las prácticas comerciales

\footnotetext{
${ }^{519}$ La necesidad de acceder al goce de bienes esenciales -y no tanto- es acompañada por estímulos del deseo que la publicidad provoca mediante la explotación de valores positivos tales como el bienestar, el confort, el alivio frente a una situación de ahogo económico, el acceso a placeres sustitutivos de otros a los que probablemente el consumidor no puede acceder, el éxito, alcanzar un status laboral o social determinado, etc. Pero otras veces, la publicidad exacerba la sensación a marginación, exclusión, inseguridad, decadencia, miedo, etc., que padece quien se ve privado del uso de ciertos bienes del mercado o de servicios que hacen a la calidad de vida, al progreso, al desarrollo en plenitud.

${ }^{520}$ Nos dice LORENZETTI que por tratarse de una comunicación inspirada en fines comerciales, la publicidad constituye una subcategoría de la libertad de expresión y de allí que su protección por el ordenamiento jurídico sea "mucho más tenue" (LORENZETTI, Ricardo L., Consumidores, cit., pág. 153).

${ }^{521}$ JAPAZE, María Belén, "Publicidad y prácticas comerciales", Capítulo VII, en RUSCONI, D. (Coord.), Manual de Derecho del Consumidor, Abeledo Perrot, Buenos Aires, 2015, pág. 310 y sgtes.
} 
constituye el único modo de preservar un mercado como el que queremos: con reglas claras, transparente, honesto, con oportunidades para todos ${ }^{522}$.

En el considerando 18, la Directiva de Crédito al Consumo 2008/48 establece que los consumidores deben estar protegidos contra las prácticas desleales o engañosas por lo que resulta conveniente adoptar disposiciones específicas sobre la publicidad relativa a los contratos de crédito $^{523}$. El Capítulo II de la Directiva está dedicado a la "información y prácticas previas a la celebración del contrato de crédito" y, en ese marco, el art. 4 establece la "información básica que deberá figurar en la publicidad".

El legislador español incorporó esta dispositiva en el art. 9 de la Ley 16/2011 imponiendo esta suerte de contenido mínimo, por debajo del cual, se incurre en infracción a la ley ${ }^{524}$ con la consiguiente responsabilidad.

\footnotetext{
${ }^{522}$ Ver las interesantes reflexiones contenidas en LOVECE, Graciela, "Contrato de publicidad" en GHERSI, Carlos A.- WeIngARTEn, Celia (Dir.), Tratado de los contratos civiles, comerciales, laborales, administrativos y de consumo, T. II, La Ley, Buenos Aires, 2010, pág. 55-91.

${ }^{523}$ La Directiva de Crédito al Consumo 2008/48 relativa a los contratos de crédito al consumo fue aprobada el 23 de abril de 2008 por el parlamento Europeo, derogándose la Directiva 87/102/CEE antes vigente.

${ }^{524}$ Dispone el art. 9: "Información básica que deberá figurara en la publicidad. 1. La información básica establecida en este artículo deberá incluirse en la publicidad y comunicaciones comerciales, así como en los anuncios y ofertas exhibidos en los locales comerciales, en los que se ofrezca un crédito o la intermediación para la celebración de un contrato de crédito, siempre que indiquen el tipo de interés o cualesquiera cifras relacionadas con el coste del crédito para el consumidor. 2. La información básica especificará los elementos siguientes de forma clara, concisa y destacada mediante un ejemplo representativo: a) El tipo deudor fijo o variable, así como los recargos incluidos en el coste total del crédito para el consumidor. b) El importe total del crédito. c) La tasa anual equivalente, salvo en el caso de los contratos en los que el crédito se conceda en forma de posibilidad de descubierto y que deban reembolsarse previa petición o en el plazo de tres meses, indicados en el segundo párrafo del apartado 1 del artículo 4. d) En su caso, la duración del contrato de crédito. e) En el caso de los créditos en forma de pago aplazado de un bien o servicio en particular, el precio al contado y el importe de los posibles anticipos. f) En su caso, el importe total adeudado por el consumidor y el importe de los pagos a plazos. La información básica deberá publicarse con una letra que resulte legible y con un contraste de impresión adecuado. 3. Si se condicionara la concesión del crédito en las condiciones ofrecidas a la celebración de un contrato relativo a un servicio accesorio vinculado con el contrato de crédito, en particular un seguro, y el coste de ese servicio no pudiera determinarse de antemano, dicha condición deberá mencionarse de forma clara, concisa y destacada, junto con la tasa anual equivalente".
} 
Esta imposición de contenido publicitario impuesta por la Ley de Crédito al Consumo español, se complementa con las previsiones legales que la normativa sobre publicidad en general y sobre publicidad en materia de servicios bancarios y financieros, pueda haberse dictado antes y que se dicten en forma posterior ${ }^{525}$. En efecto, es frecuente que existan normas especiales y sectoriales de rango diverso ${ }^{526}$, que contemplen previsiones orientadas al regular funcionamiento de la actividad crediticia y, entre ellas, dispositivos referidos a la publicidad que los dadores de crédito despliegan para atraer a los consumidores e impulsarlos a tomar empréstitos o al consumo financiado.

Oportuno es señalar que conforme el Considerando 18 de la Directiva de Crédito al Consumo, antes citada, "los Estados miembros deben conservar la libertad de regular en su Derecho nacional los requisitos en materia de información en lo que respecta a la publicidad" más allá de lo que en particular ha sido objeto de previsión en ese instrumento comunitario.

Destacamos que en la regulación española, el legislador hace explícito que esa información básica de mínima -concretamente detallada- alcanza a todo tipo de mensaje publicitario, siendo indiferente el medio y soporte elegidos para su difusión ${ }^{527}$. Resulta saludable que allí se exprese que la información debe suministrarse en forma clara, concisa y destacada mediante un ejemplo representativo.

Saludable resulta que la directiva legal comprenda todo el espectro de publicidad encaminada a la oferta y colocación de crédito, que se puntualice el contenido informativo básico, que se indiquen pautas de cumplimiento concretas -claridad y precisión de la información a suministrar- y que se imponga una modalidad de instrumentación particular dar un ejemplo representativo con la información allí contenida- a fin de asegurar la comprensibilidad del mensaje publicitario a sus destinatarios. Complementa acertadamente estas previsiones, la referencia contenida en el art. 9.2 cuando dispone que "la información

\footnotetext{
${ }^{525}$ SERrano de NiCOLÁs, Ángel, en Marín LóPEZ, Manuel Jesús (Dir.), Comentarios a la Ley de Crédito al Consumo, Thomson Reuters-Aranzadi, Pamplona 2014, pág. 437-474.

${ }^{526}$ Para un detalle pormenorizado de esa regulación sectorial en España, ver ORDÁs ALONSO, Marta, Los contratos de crédito al consumo en la Ley 16/2011 de 24 de junio. Cuadernos de Aranzadi, Thomson ReutersAranzadi, Pamplona, 2013, pág. 111 y sgtes. Ver asimismo, el análisis en SERRANO DE NicOLÁs, Ángel, en MARín LóPeZ, Manuel Jesús (Dir.), Comentarios a la Ley de Crédito al Consumo, cit., pág. 440 y sgtes.

${ }^{527}$ ORDÁs AlONSO, Marta, Los contratos de crédito al consumo..., cit., pág. 110 y sgtes.
} 
básica deberá publicarse con una letra que resulte legible y con un contraste de impresión adecuado".

Este dispositivo legal tiene a la transparencia como su finalidad última ${ }^{528}$. Constituye una herramienta para contribuir a ese objetivo central del mercado de crédito $^{529}$.

El suministro de esta información básica en la publicidad, ha de propiciar la adopción de decisiones racionales por parte del consumidor. Precisamente, a fin de contribuir a esa función teleológica es que el legislador hace referencia la claridad como pauta para juzgar el cumplimiento satisfactorio de la obligación impuesta. En esa línea de razonamiento, se exige que la provisión de información se realice también en forma concisa. Se procura evitar un efecto saturación, que atente contra la finalidad iluminista que inspira al precepto. El carácter destacado de la información a suministrar se vincula a la necesidad de que la publicidad llame la atención del consumidor -le sirva de advertenciarespecto de su relevancia en el contrato.

Con acierto se ha dicho que la publicidad ha reemplazado -en el marco de los contratos de consumo, en general- a las tratativas previas, a los pour parler de la teoría clásica de los contratos. De allí que la información contenida en la publicidad cumple una finalidad esencial $^{530}$.

\footnotetext{
528 Serrano de NiCOlÁs, Ángel, en MARÍn LóPeZ, Manuel Jesús (Dir.), Comentarios..., cit., pág. 460 y sgtes.

${ }^{529}$ Ver el minucioso análisis de la normativa de transparencia para el sector bancario y directivas de implementación, en Vicente-Almazén PÉRez de Petinto, Miguel, "Normas de transparencia en la contratación bancaria de préstamos y créditos", en La protección de consumidores y usuarios en la contratación bancaria. Cuadernos de Derecho y Comercio, Consejo General del Notariado, Madrid, 2014, pág. 17-63.

${ }^{530}$ Nos dice LORENZETTI: "Un elemento decisivo para la comprensión de estos temas es que el modelo "oferta-aceptación" del contrato clásico, está elaborado sobre la base de un contratante interesado en la adquisición de un bien que no posee....Este esquema tiene como presupuesto que la demanda de los bienes y servicios es la que crea la necesidad de ellos y, por tanto, la oferta se adapta a ella. Este procedimiento cambió sustancialmente en la sociedad de consumo y, por lo tanto, muda también el modelo legal". Nos explica que en el mercado actual "la demanda es creada por la publicidad, el marketing, los atractivos como el sorteo, la conexión entre bienes de distinta naturaleza, la creación de situaciones jurídicas de cautividad. El consumidor en muchos casos no compra porque necesita ni es la necesidad la que crea la oferta; es a la inversa: la oferta crea la necesidad. Se compra porque se vio una buena publicidad, porque se desea un status particular al que
} 
Frente a este revitalizado rol de la publicidad, el jurista tiene ante sí un fenómeno de ineludible análisis y surge la necesidad de su regulación. Parece evidente que la tutela de los consumidores exige algo más que la censura de supuestos de publicidad ilícita y la previsión de las sanciones correspondientes. De allí que a ese catálogo de mandatos negativos o prohibiciones, el legislador adicione un mandato de contenido positivo, una obligación de hacer.

Con la racionalidad propia de las normas que integran el sistema de protección de los consumidores, se diseñó un nuevo dispositivo que asigna a la información un rol dinámico y la traduce en un deber de conducta orientado a morigerar las consecuencias de las asimetrías del mercado ${ }^{531}$. Pero tampoco basta con imponer al proveedor un débito informativo para que el consumidor pueda realizar elecciones fundadas y reflexivas. Ante la necesidad de imponer rigor al contenido informativo y en mérito a la remozada función de la publicidad, se consideró imprescindible establecer que lo expresado en la publicidad debía integrarse al contenido contractual, al plan prestacional ${ }^{532}$. Es que si el consumidor decide prestar su consentimiento -aún mediante la adhesión a condiciones prefijadas o prerredactadas por el empresario proveedor- es innegable la relevancia de la actividad publicidad previamente desplegada por éste ${ }^{533}$. Si en vistas de las condiciones ofrecidas, el consumidor o usuario concretó la contratación, tal contenido publicitario forma necesariamente parte de su querer, de su consentimiento, de su voluntad en el negocio $^{534}$.

va asociado el producto, porque se ganó un sorteo, porque se está en una situación cautiva que obliga a comprar; se pagan precios porque no hay otras opciones, se adquieren accesorios porque están adheridos inevitablemente a otros" (cfr. LORENZETTI, Ricardo L., Consumidores, cit., pág. 133).

${ }^{531}$ Gerscovich, Carlos G., Consumidores bancarios, cit., pág. 280 y sgtes.

532 Se ha dicho que "la publicidad cumple una función de oferta contractual y como tal, vincula obligacionalmente a quien la formula, en los términos manifestados en los anuncios. Se trata por esta vía, de proteger la confianza que los usuarios depositan en los datos consignados públicamente desde la oferta misma, en tanto se generan razonables expectativas..." (GHERSI, Carlos - WEINGARTEN, Celia (Dir.), Tratado Jurisprudencial y Doctrinario. Defensa del Consumidor, T. I, La Ley, Buenos Aires, 2011, pág. 282).

533 Pizarro, Ramón D.- Stiglitz, Rubén S. "la Publicidad como fuente heterónoma de integración del contrato", LL 2009-E, 1082.

534 Advierte LORENZETTI que en las relaciones de consumo, "la política jurídica es distinta" a la que inspira las soluciones legales de los contratos clásicos, donde hay negociación igualitaria. Aquí, el bien tutelado es la 
$\mathrm{Al}$ ofrecer información por vía de la publicidad y, como medida eficaz para imponer seriedad y rigor al anuncio publicitario, todos los ordenamientos modernos asignan virtualidad obligatoria a las precisiones allí contenidas ${ }^{535}$.

La solución legal señalada significó -por otra parte- un mecanismo preventivo eficaz contra empresarios desaprensivos que, mediante publicidad engañosa o abusiva, distorsionaban la realidad del negocio ofrecido, propiciando la celebración de un acto de consumo en base a la voluntad viciada del consumidor ${ }^{536}$.

En la operatoria de crédito, el contrato se integra y enriquece de varias fuentes ${ }^{537}$. Las obligaciones que integran el plan prestacional emergen del contrato (conforme la interpretación literal y contextual de su contenido), de la publicidad y de la ley ${ }^{538}$. También en vistas de esta eventual integración del contrato es que el legislador destina especial atención a la publicidad desplegada en este ámbito particular de los contratos de crédito o consumo financiado ${ }^{539}$.

En Argentina, ante la ausencia de una normativa que de modo sistemático asumiera el abordaje de la temática, se imponía una remisión a la regulación sectorial ${ }^{540}$. Pero con la

confianza del consumidor en la oferta pública que hace el empresario y no la negociación competitiva (LORENZETTI, Ricardo L., Consumidores, cit., pág. 135).

${ }^{535}$ Es el caso del art. 8 de la Ley de Defensa del Consumidor argentina que dispone: "Efectos de la publicidad. Las precisiones formuladas en la publicidad o en anuncios prospectos, circulares u otros medios de difusión obligan al oferente y se tienen por incluidas en el contrato con el consumidor...". El nuevo Código Civil argentino replica la preceptiva del art. 8 citado, con una ligera modificación de sus términos pero con idéntico propósito. Reza el art. 1103: "Efectos de la publicidad. Las precisiones formuladas en la publicidad o en anuncios, prospectos, circulares u otros medios de difusión se tienen por incluidas en el contrato con el consumidor y obligan al oferente".

${ }^{536}$ Ver las interesantes consideraciones vertidas en SCHIAVI, María Virginia, "Abordaje jurídico del vínculo entre la publicidad y el consumidor", LL 2011-E,678.

${ }^{537}$ MosSeT ITURRASPE, Jorge -WAJNTRAUb, Javier H., Ley de defensa del consumidor ..., cit., pág. 100.

${ }^{538}$ LOWEnROSEn, Flavio, Derecho del Consumidor. Teoría y práctica, 1, Ediciones Jurídicas, Buenos Aires, 2008, pág. 245.

${ }^{539}$ SERRANO de NiCOLÁs, Ángel, en MARÍn LóPEZ, Manuel Jesús (Dir.), Comentarios..., cit., pág.459 y sgtes. ${ }^{540}$ Se señala con acierto que el BCRA “deberá ir dictando una normativa dinámica mediante circulares, comunicaciones y resoluciones que sirvan de respuesta directa frente a supuestos que tiendan a menoscabar la protección del cliente bancario". Es así como se han dictados comunicaciones específicas sobre cuestiones de mayor interés para el usuario, tales como las comunicaciones A 2147, A 2689, A 3052, A 3123 y A 3266 
entrada en vigencia del nuevo Código Civil y Comercial, los dispositivos referidos a la publicidad en materia de contratos de consumo, en general, y de contratos bancarios con consumidores, en particular, gozan de las bondades de su emplazamiento jerarquizado.

El nuevo escenario regulatorio contribuye a la visibilidad de las directivas allí impartidas, que resultan de aplicación directa. Con ello se potencia, como es lógico, la eficacia de la función preventiva que persigue la consagración de deberes vinculados a la

relativas a la forma de declarar la tasa y hacer la publicidad; la comunicación A 2423 sobre la creación del servicio de atención al usuario del sistema financiero; etc. (cfr. PORTHÉ, Luis Ignacio, "Responsabilidad de las entidades bancarias frente al consumidor", en http://www.derecho.uba.ar/publicaciones/lye/revistas/84/09winitzky-porthe.pdf (Fecha de consulta 15/7/2015). El Banco Central de la República Argentina emitió con fecha 24 de enero de 2013, la Comunicación “A” 5388 que dispone aprobar las normas sobre "Protección de los usuarios de servicios financieros" y entre las mismas, mencionamos, por su pertinencia, el apartado 2.4., destinado a la "Publicidad de la información". Allí se establece que "Las entidades financieras y las empresas no financieras emisoras de tarjetas de crédito deberán dar cumplimiento a las siguientes condiciones en cuanto al acceso a la información por parte de los usuarios de servicios financieros que revistan el carácter de consumidores finales ...: 2.4.1. En forma personal. Todas las casas operativas de estos sujetos obligados deberán entregar a los referidos usuarios de servicios financieros que lo soliciten un detalle con las características de los productos y servicios que ofrecen, precisando especialmente la totalidad de los costos asociados a ellos. En todos los casos se deberá entregar a los usuarios de servicios financieros copia íntegra de los instrumentos que suscriben al momento de contratar productos o servicios financieros. 2.4.2. Por Internet. Estos sujetos obligados deben publicar en la página de inicio de su sitio de Internet institucional todos los costos, cargos, gastos, seguros, comisiones, tasa de interés, costo financiero total y/o cualquier otro concepto, de la totalidad de los productos y/o servicios, propios o de terceros, ofrecidos a los referidos usuarios de servicios financieros y que estos últimos deban abonar. También deberán informar las promociones y bonificaciones ofrecidas, con indicación precisa de las fechas de comienzo y de finalización, así como sus modalidades, condiciones y limitaciones. El acceso a toda esta información deberá ubicarse en un lugar destacado -en cuanto a visibilidad- y de fácil acceso en la mencionada página de Internet de inicio de estos sujetos obligados. La información debe ser íntegra, clara, discriminada por concepto y no debe remitir a otros documentos, archivos y/o sitios de Internet. Estas publicaciones obligan a estos sujetos obligados durante todo el tiempo que se encuentren disponibles en su sitio de Internet institucional y hasta tanto sean reemplazadas. Aquellos conceptos que no se encuentren publicados en el sitio de Internet de estos sujetos obligados, no podrán ser cobrados a los referidos usuarios de servicios financieros". 
publicidad; y el incumplimiento de los mismos hace evidente la operatividad de los remedios previstos para la tutela de los consumidores ${ }^{541}$.

En el Capítulo dedicado a los "Contratos Bancarios" en general (Libro II, Título IV, Capítulo 12), y dentro del Parágrafo $1^{\circ}$ titulado "Transparencia de las condiciones contractuales", el art. 1379 dispone: "Publicidad. La publicidad, la propuesta y la documentación contractual deben indicar con precisión y en forma destacada si la operación corresponde a la cartera de consumo o a la cartera comercial, de acuerdo a la clasificación que realiza el Banco Central de la República Argentina. ... Los bancos deben informar en sus anuncios, en forma clara, la tasa de interés, gastos, comisiones y demás condiciones económicas de las operaciones y servicios ofrecidos".

Por su parte, el Parágrafo $2^{\circ}$ dedicado a "Contratos bancarios con consumidores y usuarios", contiene al art. 1385 que establece: "Publicidad. Los anuncios del banco deben contener en forma clara, concisa y con un ejemplo representativo, información sobre las operaciones que se proponen. En particular deben especificar: a) los montos mínimos y máximos de las operaciones individualmente consideradas; b) la tasa de interés y si es fija o variable; c) las tarifas por gastos y comisiones, con indicación de los supuestos y la periodicidad de su aplicación; d) el costo financiero total en las operaciones de crédito; e) la existencia de eventuales servicios accesorios para el otorgamiento del crédito o la aceptación de la inversión y los costos relativos a tales servicios; f) la duración propuesta del contrato".

La norma transcripta impone el contenido informativo mínimo que debe ser incluido en los anuncios publicitarios que las entidades bancarias difundan para la colocación de las “operaciones que proponen”. Deja asimismo establecido que la información allí contenida debe ser suministrada en forma clara y concisa. Con gran acierto la norma exige que se ofrezca un "ejemplo representativo" con la información allí consignada, facilitando el acceso a la misma y su comprensibilidad por el destinatario. No se debe pasar por alto que

\footnotetext{
${ }^{541}$ BARbiER, Eduardo, en LORENZETTI, Ricardo L. (Dir.), Código Civil y Comercial de la Nación Comentado, T.VII, Rubinzal-Culzoni, Santa Fe, 2015, pág. 252.
} 
el cocontratante es un consumidor, y que precisamente por su ignorancia e inexperiencia en materia negocial, se impone el auxilio del profesional experto ${ }^{542}$.

La doctrina destaca la relevancia del dispositivo contenido en el citado art. 1385 del Código Civil y Comercial, en orden a la finalidad preventiva motivo de análisis en este apartado. Insistimos: se trata de llamar la atención del consumidor a fin de permitirle comprender el compromiso patrimonial que significará para su economía privada embarcarse en la operatoria de crédito, practicar proyecciones presupuestarias razonables y decidir en consecuencia.

Señalar BARBIER que "los montos máximos y mínimos de las operaciones consideradas individualmente facilitan una proyección de las posibilidades del interesado (inc. a), sin que quepa disociarlas de su capacidad de repago; otro tanto sucede con la información sobre la duración del contrato (inc. f), permitiéndole al cliente apreciar otras variables de su desarrollo personal o laboral y ponderar el impacto en su economía doméstica. La información sobre la exigencia de contraer compromisos adicionales por la accesoriedad funcional prevista para acceder a la operación (inc. e), da certeza sobre el real alcance del compromiso patrimonial que debe asumir el cliente. Finalmente, la información relativa a la tasa de interés y si es fija o variable (inc. b), las tarifas por gastos y comisiones con indicación de los supuestos y la periodicidad de su aplicación (inc. c) y el costo financiero total en las operaciones de crédito (inc. d) contribuyen a la representación consciente del consumidor de la ventaja o esfuerzo patrimonial que implica acceder a la operación que se propone" ${ }^{, 543}$.

c.1.2.- Deber de información veraz, suficiente y adecuada en cabeza del proveedor de crédito.

La imposición legal de este deber de información persigue una concreta finalidad, cual es, acortar las distancias, las desigualdades estructurales que existen entre los extremos de la relación. En particular, en la etapa precontractual, la obligación de informar procura

\footnotetext{
${ }^{542}$ Cfr. Alterini, Jorge H. (Dir.), Código Civil y Comercial de la Nación..., T. VII, cit., pág.42 y sgtes.

${ }^{543}$ BARBIER, Eduardo, en LoRENZETTI, Ricardo L. (Dir.), Código Civil y Comercial de la Nación..., cit., pág. 252.
} 
resguardar el consentimiento en sentido amplio ${ }^{544}$, un consentimiento auténtico ${ }^{545}$, un consentimiento pleno y reflexivo, un consentimiento lúcido ${ }^{546}$. Es el momento en que el consumidor debería conocer el producto que se le ofrece (en el caso, la operatoria financiera de que se trate) y las condiciones de contratación, para así evaluar ventajas y desventajas, comparar productos, considerar riesgos, hacer previsiones adecuadas, etc.

La amplia gama de productos y la multiplicidad de alternativas posibles en la operatoria de crédito producen una especie de sobrecarga selectiva. Cuanto más se amplía el espectro de elecciones ofrecidas al sujeto y más ardua aparece la tarea de desentrañar el objeto de la decisión, más apremiante es la necesidad de reducir la complejidad ${ }^{547}$. Se ha dicho que la sociedad moderna vive su futuro en forma del riesgo de las decisiones, con una marcada preocupación por aprehender las aristas principales del problema a resolver, por conocer sus dificultades, por prevenir las contingencias y por prever las respuestas a las mismas. En dicho contexto, la información constituye un bien preciado, que se consume como producto en sí mismo y como instrumento para acceder a otros bienes y servicios del $\operatorname{mercado}^{548}$.

El consumidor enfrenta la dificultad propia del modelo de elección racional, que condiciona la conducta del sujeto a un esquema lógico tradicional que manda discernir y recién ejecutar el acto de consumo. En el caso, parece claro que la comprensión del negocio

\footnotetext{
${ }^{544}$ OsSOLA, Federico-VAllesPinOS, Carlos G., La obligación de informar, Advocatus, Córdoba, 2001, pág. 131; En el mismo sentido, STIGLITZ, Rubén. S., "El deber de información y los vicios del consentimiento" en LL 2005-C, 1444-; STIGLITZ, Rubén S., Responsabilidad Civil- Doctrinas Esenciales, T. I, 1073).

${ }^{545}$ PÉREZ GARCÍA, Pedro A., La información en la contratación privada. En torno al deber de informar en la Ley general de Defensa de los Consumidores y Usuarios, Ministerio de Sanidad y Consumo de España, Ed. Instituto Nacional de Consumo, Colección Estudios, Madrid, 1990, pág. 26-39.

${ }^{546}$ Cfr. DíAZ AlabART, Silvia., "La forma ad luciditatem en la contratación con consumidores" en LÓPEZ CABANA, Roberto-AmEAL, Oscar (Dir.), Obligaciones y contratos en los albores del siglo XXI. Buenos Aires, Abeledo Perrot, Buenos Aires, 1997, pág. 635-639.

${ }^{547}$ IZUZQUIZA, Ignacio, Introducción a LUHMANN, Niklas, Sociedad y sistema: la ambición de la teoría, Paidos -I.C.E.-Universidad Autónoma de Barcelona, Barcelona, 1997, pág. 16; ZoLO, Danilo, Democracia y Complejidad (Un enfoque realista), Nueva Visión, Buenos Aires, 1994, pág. 20 y sgtes.

${ }^{548}$ Para un estudio profundizado de la revolución de la tecnología de la información, ver CASTELLS, Manuel, La era de la información. Economía, sociedad y cultura.: Vol. I: La sociedad red, Siglo XXI, Buenos Aires, 2005, pág. 55 y sgtes.
} 
depende en gran medida de la información que se obtenga y de la posibilidad de procesarla, antes de adoptar una decisión ${ }^{549}$.

En este contexto, la información deja de ser un concepto estático y se convierte en un deber jurídicamente impuesto al proveedor de crédito, orientado al resguardo del libre querer del consumidor. Con acierto se señala que un consumidor adecuadamente informado, consciente de las características del producto que se le ofrece y de las condiciones de la operación a realizar, tendrá la posibilidad de efectuar elecciones sustentadas en sus reales necesidades, de adquirir productos y contratar servicios adecuados a sus expectativas, necesidades y posibilidades económicas.

Ciñéndonos a la operatoria de crédito o financiamiento, la Directiva de Crédito al Consumo 2008/48 destaca en su considerando 19, que "a fin de que el consumidor pueda tomar una decisión con pleno conocimiento de causa, antes de la celebración del contrato debe recibir información adecuada, que pueda llevarse consigo para su examen, sobre las condiciones y el coste del crédito, así como sobre sus obligaciones".

El art. 5 de la mencionada Directiva, advierte sobre la relevancia de la oportunidad en el cumplimiento del débito informativo al establecer determina que la "información precontractual" debe ser proporcionada "con la debida antelación y antes de que el consumidor asuma cualquier obligación en virtud de un contrato u oferta de crédito", ofreciendo un detalle de la misma ${ }^{550}$.

\footnotetext{
${ }^{549}$ GHERSI y WEINGARTEN sostienen que "se trata de un derecho personalísimo, que se incardina en el marco más amplio de la libertad del individuo que tiene una significación instrumental pues a través de ella se posibilita el ejercicio de otros derechos estrechamente conectados entre sí, a punto tal que es imposible imaginar la vigencia alguna de ellas sin el previo aseguramiento del derecho a la información" (GHERSI, Carlos-Weingarten, Celia (Dir.), Manual de los Derechos de los Consumidores y Usuarios, La Ley, Buenos Aires, 2011, pág.72 y sgtes.).

${ }^{550}$ La norma expresa que se "deberá especificar: a) el tipo de crédito; b) la identidad y la dirección geográfica del prestamista así como, en su caso, la identidad y la dirección geográfica del intermediario del crédito implicado; c) el importe total del crédito y las condiciones que rigen la disposición de fondos; d) la duración del contrato de crédito; e) en caso de créditos en forma de pago diferido por un bien o servicio y de contratos de crédito vinculados, el producto o servicio y su precio al contado; f) el tipo deudor y las condiciones de aplicación de dicho tipo, y, si se dispone de ellos, los índices o tipos de referencia aplicables al tipo deudor inicial, así como los períodos, condiciones y procedimientos de variación del tipo deudor. Si se aplican diferentes tipos deudores en diferentes circunstancias, la información arriba mencionada respecto de todos los
} 
El apartado 4 del citado art. 5, impone al proveedor del crédito facilitar gratuitamente al consumidor, una copia del proyecto del contrato de crédito; dispositivo que contribuye a la eficacia preventiva de la norma en análisis.

El apartado 6 del precepto analizado consagra una obligación de informar reforzada, casi emparentada con el deber de asesoramiento, orientada a asistir al consumidor en la toma de su decisión de contratar ${ }^{551}$.

tipos aplicables; g) la tasa anual equivalente y el importe total adeudado por el consumidor, ilustrado mediante un ejemplo representativo que incluya todas las hipótesis utilizadas para calcular dicha tasa; cuando el consumidor haya informado al prestamista sobre uno o más componentes de su crédito preferido, como por ejemplo la duración del contrato de crédito y su importe total, el prestamista deberá tener en cuenta dichos componentes; si el contrato de crédito prevé diferentes formas de disposición de fondos con diferentes tasas o tipos de préstamo, y el prestamista se acoge al supuesto contemplado en la parte II, letra b), del anexo I, deberá indicar que, para ese tipo de contrato de crédito, la tasa anual equivalente podría ser más elevada con otros mecanismos de disposición de fondos; h) el importe, el número y la periodicidad de los pagos que deberá efectuar el consumidor y en su caso el orden en que deben asignarse los pagos a distintos saldos pendientes sometidos a distintos tipos deudores a efectos de reembolso; i) cuando proceda, los gastos de mantenimiento de una o varias cuentas si fuera necesario para registrar a la vez las operaciones de pago y de disposición del crédito, salvo que la apertura de la cuenta sea facultativa, los gastos relativos a la utilización de un medio de pago que permita efectuar a la vez las operaciones de pago y de disposición del crédito, así como cualquier gasto derivado del contrato de crédito y las condiciones en que dichos gastos podrán modificarse; j) cuando proceda, la existencia de costes adeudados al notario por el consumidor al suscribir el contrato de crédito; k) la obligación de suscribir cualesquiera servicios accesorios vinculados con el contrato de crédito, en particular una póliza de seguros, cuando la celebración de un contrato relativo a tales servicios sea obligatoria para obtener el crédito o para obtenerlo en las condiciones ofrecidas; 1) el tipo de interés de demora así como las modalidades para su adaptación y, cuando proceda, los gastos por impago; m) una advertencia sobre las consecuencias en caso de impago; n) cuando proceda, las garantías exigidas; o) la existencia o ausencia de derecho de desistimiento; p) el derecho de reembolso anticipado y, en su caso, información sobre el derecho del prestamista a una compensación y sobre la manera en que se determinará esa compensación con arreglo al artículo 16; q) el derecho del consumidor a ser informado de forma inmediata y gratuita del resultado de la consulta de una base de datos para la evaluación de su solvencia, conforme al artículo 9, apartado 2; r) el derecho del consumidor a recibir gratuitamente, previa solicitud, una copia del proyecto del contrato de crédito. Esta disposición no se aplicará cuando el prestamista no esté dispuesto, en el momento de la solicitud, a celebrar el contrato de crédito con el consumidor, y s) cuando proceda, el período de tiempo durante el cual el prestamista queda vinculado por la información precontractual".

${ }^{551} \mathrm{El}$ art. 5.6 establece: "Los Estados miembros velarán por que los prestamistas y, cuando proceda, los intermediarios de crédito faciliten al consumidor las explicaciones adecuadas para que este pueda evaluar si el 
El art. 6 cierra este menú de deberes vinculados al deber de información, estableciendo "requisitos de información precontractual para determinados contratos de crédito", por considerar que así lo exige la particular naturaleza de los mismos.

Importante es destacar que la Directiva no se desentiende de la forma en que habrá de cumplirse el débito informativo. Se impone expresamente que la información se proporcione por escrito o, en el sentido amplio, en cualquier soporte duradero.

El cumplimiento de este deber de información en la etapa precontractual es considerado estratégico por la doctrina ${ }^{552}$ y la regulación particular debe extremar recaudos para asegurar su cumplimiento.

La Ley de Contratos de Crédito al Consumo 16/2011 española dedica su art. 10 a la "Información previa al contrato" y dispone:

“1. El prestamista y, en su caso, el intermediario de crédito deberán facilitar de forma gratuita al consumidor, con la debida antelación y antes de que el consumidor asuma cualquier obligación en virtud de un contrato u oferta de crédito sobre la base de las condiciones del crédito ofrecidas por el prestamista y, en su caso, de las preferencias manifestadas y de la información facilitada por el consumidor, la información que sea precisa para comparar las diversas ofertas y adoptar una decisión informada sobre la suscripción de un contrato de crédito.

2. Esta información, en papel o en cualquier otro soporte duradero, se facilitará mediante la Información normalizada europea sobre el crédito al consumo que figura en el anexo II.

3. Dicha información deberá especificar:

a) El tipo de crédito.

contrato de crédito propuesto se ajusta a sus necesidades y a su situación financiera, si fuera preciso explicando la información precontractual que se facilitará conforme a lo dispuesto en el apartado 1, las características esenciales de los productos propuestos y los efectos específicos que pueden tener sobre el consumidor, incluidas las consecuencias en caso de impago por parte del consumidor. Los Estados miembros podrán adaptar el modo de prestación de esta asistencia y su alcance, así como la identidad de la parte que se hará cargo de ella, a las circunstancias particulares de la situación en que se ofrece el contrato de crédito, la persona a quien se ofrece y el tipo de crédito ofrecido".

552 Trujillo DíEZ, Iván Jesús, El sobreendeudamiento de los consumidores..., cit., pág. 55 y sgtes.; GutiÉRrez DE CABIEDEs, Pablo, El sobreendeudamiento doméstico..., cit., pág. 129 y sgtes.; AlvÁREZ VEGA, María Isabel, Protección jurídica del consumidor..., cit., pág. 319 y sgtes.; entre otros. 
b) La identidad y el domicilio social del prestamista, así como en su caso la identidad y el domicilio social del intermediario del crédito implicado.

c) El importe total del crédito y las condiciones que rigen la disposición de fondos.

d) La duración del contrato de crédito.

e) En caso de créditos en forma de pago diferido por un bien o servicio y de contratos de crédito vinculados, el producto o servicio y su precio al contado.

f) El tipo deudor y las condiciones de aplicación de dicho tipo, y, si se dispone de ellos, los índices o tipos de referencia aplicables al tipo deudor inicial, así como los períodos, condiciones y procedimientos de variación del tipo deudor.

Si se aplican diferentes tipos deudores en diferentes circunstancias, la información arriba mencionada respecto de todos los tipos aplicables.

g) La tasa anual equivalente y el importe total adeudado por el consumidor, ilustrado mediante un ejemplo representativo que incluya todas las hipótesis utilizadas para calcular dicha tasa.

Cuando el consumidor haya informado al prestamista sobre uno o más componentes de su crédito preferido, como por ejemplo la duración del contrato de crédito y su importe total, el prestamista deberá tener en cuenta dichos componentes.

Si el contrato de crédito prevé diferentes formas de disposición de fondos con diferentes tasas o tipos de préstamo, y el prestamista se acoge al supuesto contemplado en la parte II, letra b), del anexo I, deberá indicar que, para ese tipo de contrato de crédito, la tasa anual equivalente podría ser más elevada con otros mecanismos de disposición de fondos.

h) El importe, el número y la periodicidad de los pagos que deberá efectuar el consumidor y en su caso el orden en que deben asignarse los pagos a distintos saldos pendientes sometidos a distintos tipos deudores a efectos de reembolso.

i) En su caso, los gastos de mantenimiento de una o varias cuentas, si fuera necesario para registrar a la vez las operaciones de pago y de disposición del crédito, salvo que la apertura de la cuenta sea facultativa, los gastos relativos a la utilización de un medio de pago que permita efectuar a la vez las operaciones de pago y de disposición del crédito, así como cualquier gasto derivado del contrato de crédito y las condiciones en que dichos gastos podrán modificarse. 
j) En su caso, la existencia de costes adeudados al notario por el consumidor al suscribir el contrato de crédito.

k) Los servicios accesorios al contrato de crédito, en particular de seguro, cuando la obtención del crédito o su obtención en las condiciones ofrecidas estén condicionadas a la suscripción del servicio accesorio. Deberán también facilitarse las condiciones que alternativamente se aplicarían al contrato de crédito al consumo si no se contrataran los servicios accesorios y, en particular, pólizas de seguros.

1) El tipo de interés de demora, así como las modalidades para su adaptación y, cuando procedan, los gastos por impago.

m) Una advertencia sobre las consecuencias en caso de impago.

n) Cuando proceda, las garantías exigidas.

o) La existencia o ausencia de derecho de desistimiento.

p) El derecho de reembolso anticipado y, en su caso, información sobre el derecho del prestamista a una compensación y sobre la manera en que se determinará esa compensación con arreglo al artículo 30.

q) El derecho del consumidor a ser informado de forma inmediata y gratuita del resultado de la consulta de una base de datos para la evaluación de su solvencia, conforme al artículo 15 , apartado 2.

r) El derecho del consumidor a recibir gratuitamente, previa solicitud, una copia del proyecto del contrato de crédito, salvo que en el momento de la solicitud el prestamista no esté dispuesto a celebrar el contrato de crédito con el consumidor.

s) En su caso, el período de tiempo durante el cual el prestamista queda vinculado por la información precontractual.

4. Cualquier información adicional que el prestamista pueda comunicar al consumidor será facilitada en un documento aparte que podrá adjuntarse a la Información normalizada europea sobre el crédito al consumo.

5. Se considera que el prestamista ha cumplido los requisitos de información de los apartados 1, 2 y 3 del presente artículo y de los apartados 1 y 2 del artículo 7 de la Ley 22/2007, de 11 de julio, sobre comercialización a distancia de servicios financieros destinados a los consumidores, si facilita la Información normalizada europea sobre el crédito al consumo. 
6. En el caso de comunicación a través de telefonía vocal a que se refiere la Ley 22/2007, de 11 de julio, sobre comercialización a distancia de servicios financieros destinados a los consumidores, la descripción de las características principales del servicio financiero deberá incluir al menos los elementos considerados en el apartado 3, letras c), d), e), f), h) y k) del presente artículo, junto con la tasa anual equivalente ilustrada mediante un ejemplo representativo y el importe total adeudado por el consumidor.

7. Si el contrato se hubiera suscrito, a petición del consumidor, utilizando un medio de comunicación a distancia que no permita facilitar la información prevista en el apartado 3 , en particular en el caso contemplado en el apartado 6, el prestamista facilitará al consumidor toda la información precontractual utilizando el formulario de Información normalizada europea sobre crédito al consumo inmediatamente después de la celebración del contrato.

8. Además de la Información normalizada europea sobre el crédito al consumo, se facilitará gratuitamente al consumidor, previa petición, una copia del proyecto del contrato de crédito, salvo cuando el prestamista no esté dispuesto, en el momento de la solicitud, a celebrar el contrato de crédito con el consumidor.

9. En el caso de los contratos de crédito en que los pagos efectuados por el consumidor no producen una amortización correspondiente del importe total del crédito, sino que sirven para reconstituir el capital en las condiciones y los períodos establecidos en el contrato de crédito o en un contrato accesorio, la información precontractual deberá incluir, además, una declaración clara y concisa de que tales contratos no prevén una garantía de reembolso del importe total del crédito del que se haya dispuesto en virtud del contrato, salvo que se conceda dicha garantía".

Por su parte, el art. 12 impone un deber de información precontractual particular tratándose de determinados contratos de crédito $^{553}$. Se ha dicho que la norma limita el

\footnotetext{
${ }^{553}$ Se trata de los "contratos en los que el crédito se conceda en forma de posibilidad de descubierto y que deban reembolsarse previa petición o en el plazo máximo de tres meses” (art. 4.1, $2^{\circ}$ párrafo) y de los "contratos de crédito que prevean que el prestamista y el consumidor pueden establecer acuerdos relativos al pago aplazado o los métodos de reembolso cuando el consumidor ya se encuentre en situación de falta de pago del contrato de crédito inicial, siempre que tales acuerdos puedan evitar la posibilidad de actuaciones judiciales relativas al impago y el consumidor no se vea sometido a condiciones menos favorables que las establecidas en el contrato de crédito inicial" (art. 4.4).
} 
contenido de la información a suministrar ${ }^{554}$ teniendo en cuenta el carácter especial de estos contratos $\mathrm{y}$, en particular, el hecho de que carezcan de una relevancia transfronteriza.

\begin{abstract}
${ }^{554}$ Dispone el art. 12: "Información previa a determinados contratos de crédito. 1. El prestamista y, cuando proceda, el intermediario de crédito deberán facilitar de forma gratuita al consumidor, con la debida antelación y antes de que éste asuma cualquier obligación en virtud del contrato de crédito o una oferta relativa a los contratos de crédito previstos en el párrafo segundo del apartado 1 y en el apartado 4 del artículo 4, sobre la base de las condiciones del crédito ofrecidas por el prestamista y, en su caso, de las preferencias manifestadas por el consumidor y de la información facilitada por el mismo, la información que sea precisa para comparar las diversas ofertas y adoptar una decisión informada sobre la suscripción de un contrato de crédito. 2. Dicha información deberá especificar: a) El tipo de crédito. b) La identidad y el domicilio social del prestamista, así como, en su caso, la identidad y el domicilio social del intermediario del crédito implicado. c) El importe total del crédito. d) La duración del contrato de crédito.
\end{abstract}

e) El tipo deudor, las condiciones de aplicación de dicho tipo, los índices o tipos de referencia aplicables al tipo deudor inicial, los recargos aplicables desde la suscripción del contrato de crédito y, en su caso, las condiciones en las que puedan modificarse. f) Las condiciones y procedimiento para poner fin al contrato de crédito. g) Cuando así se contemple en los contratos de crédito a los que se refiere el párrafo segundo del apartado 1 del artículo 4, una indicación de que podrá exigirse al consumidor el reembolso de la totalidad del importe del crédito en cualquier momento. h) El tipo de interés de demora, así como las modalidades para su adaptación y, cuando proceda, los gastos por impago. i) El derecho del consumidor a ser informado de forma inmediata y gratuita del resultado de la consulta de una base de datos para la evaluación de su solvencia, conforme al apartado 2 del artículo 15. j) En los contratos de crédito a los que se refiere el apartado 1 del artículo 4, los gastos aplicables desde el momento de la celebración de dichos contratos y, en su caso, las condiciones en que dichos gastos podrán modificarse. k) Cuando proceda, el período de tiempo durante el cual el prestamista queda vinculado por la información precontractual.

3. Esta información se facilitará en papel o en cualquier otro soporte duradero, y figurará toda ella de manera igualmente destacada. Podrá facilitarse mediante la Información normalizada europea sobre el crédito al consumo que figura en el anexo III. 4. Se considerará que el prestamista ha cumplido los requisitos de información de los apartados anteriores y de los apartados 1 y 2 del artículo 7 de la Ley 22/2007, de 11 de julio, sobre comercialización a distancia de servicios financieros destinados a los consumidores, si ha facilitado la Información normalizada europea sobre el crédito al consumo. 5. En el caso de los contratos de crédito indicados en el apartado 4 del artículo 4 , la información proporcionada al consumidor conforme a los apartados 1 y 2 del presente artículo incluirá además:

a) la tasa anual equivalente ilustrada mediante un ejemplo representativo que mencione todas las hipótesis utilizadas para calcularla; b) el importe, el número y la periodicidad de los pagos que deberá efectuar el consumidor $\mathrm{y}$, cuando proceda, el orden en que deben asignarse los pagos a distintos saldos pendientes sometidos a distintos tipos deudores a efectos de reembolso, y c) el derecho de reembolso anticipado y, en su 
Aunque advierten que de ese modo, el legislador pretende lograr un equilibrio entre la garantía de un nivel adecuado de protección de los consumidores sin imponer excesivas cargas de información a los prestamistas o, en su caso a los intermediarios de crédito" ${ }^{„ 55}$.

Llama la atención lo pormenorizado de la regulación vinculada a la información en la etapa precontractual y celebramos que en España así sea. La variedad de los aspectos contemplados (sujetos obligados, información a suministrar, su adecuación a las

caso, información sobre el derecho del prestamista a una compensación y sobre la manera en que se determinará esa compensación. Sin embargo, si el contrato de crédito estuviera también comprendido en el ámbito de aplicación del párrafo segundo del apartado 1 del artículo 4, sólo serán aplicables las disposiciones mencionadas en los apartados 1 y 2 del presente artículo. 6. En el caso de las comunicaciones por telefonía vocal, y cuando el consumidor solicite disponer de la posibilidad de descubierto con efecto inmediato, la descripción de las principales características del servicio financiero incluirá al menos: a) Para los contratos de crédito indicados en el párrafo segundo del apartado 1 del artículo 4, los elementos indicados en las letras c), e) y g) del apartado 2 de este artículo; y b) para los contratos de crédito indicados en el apartado 4 del artículo 4 , los elementos indicados en las letras c) y e) del apartado 2 de este artículo, el elemento indicado en la letra a) del apartado 5 de este artículo y la especificación de la duración del contrato de crédito.

7. En el caso de los contratos de crédito concedidos en forma de facilidad de descubierto y que deban ser reembolsados en el plazo máximo de un mes, la descripción de las principales características del servicio financiero incluirá al menos los elementos indicados en las letras c), e) y g) del apartado 2. 8. Además de la información a que aluden los apartados 1 a 6 de este artículo, se facilitará al consumidor, previa petición, una copia del proyecto del contrato de crédito que contenga la información contemplada en el artículo 16, cuando este último sea aplicable.

Lo establecido en el párrafo anterior no será de aplicación cuando el prestamista no esté dispuesto, en el momento de la solicitud, a celebrar el contrato de crédito con el consumidor. 9. Cuando el contrato se hubiera suscrito, a petición del consumidor, utilizando un medio de comunicación a distancia que no permita facilitar la información prevista en los apartados 1, 2 y 5, incluidos los casos mencionados en el apartado 6, se considerará que el prestamista ha cumplido sus obligaciones con arreglo a los apartados 1 y 5 si inmediatamente después de la celebración del contrato de crédito facilita al consumidor la información contractual de acuerdo con el artículo 16, en la medida en que sea aplicable. 10. Si el prestamista vincula la obtención del crédito en las condiciones ofrecidas con la contratación de servicios accesorios, en particular un contrato de seguro, deberá informarse de esta circunstancia y de su coste, así como de las condiciones que alternativamente se aplicarían al contrato de crédito si no se contrataran los servicios accesorios y, en particular, el contrato de seguro".

${ }^{555}$ SerRano de Nicolás, Ángel, en MARín LóPEZ, Manuel Jesús (Dir.), Comentarios..., cit., pág. 552 y sgtes. Asimismo, ORDÁs Alonso, Marta, Los contratos de crédito al consumo..., cit., pág. 129 y sgtes. 
manifestaciones del consumidor, oportunidad de la provisión, gratuidad, modo de transmitir la información y soportes de la misma, hacer explícitos ciertos derechos de los consumidores, etc.) y las previsiones adoptadas satisfacen los requerimientos en relación a la temática.

Advertimos que en España, las entidades de crédito están sujetas a regulaciones de fuentes diversas ${ }^{556}$-conforme los perfiles, modalidades de la operatoria y contratos de que se trate- y que en todas ellas se asigna particular atención a la información precontractual que deben suministrar a los clientes en general y consumidores en particular ${ }^{557}$. Tales previsiones legales están llamadas a aplicarse en forma armónica y bajo la impronta de tutela de los consumidores ${ }^{558}$.

El modelo propuesto por la ley de crédito al consumo española puede servir a ordenamientos que como el argentino, no cuentan con una regulación particular. Las normas que se destinan a la información precontractual lucen atentas a las principales aristas del tema. Contemplan la información referida a los elementos esenciales del crédito que se ofrece, a la identidad de quien actúa como prestamista e intermediario, el coste total del crédito y modo de estimarlo, los gastos adicionales que pudieran agregarse, la duración

556 Sólo por citar algunas: Ley 16/2011 de Contratos de Crédito al Consumo, Ley 22/2007 sobre Comercialización a Distancia de Servicios Financieros destinados a los Consumidores, Ley 2/2009 sobre Contratación con los Consumidores de Préstamos o Créditos Hipotecarios y de Servicios de Intermediación para la celebración de Contratos de Préstamo o Crédito, Ley 7/1998 de Condiciones Generales de la Contratación, Texto Refundido de la Ley de Defensa de los Consumidores y Usuarios (aprobado por Real Decreto-Ley 1/2007), la vastísima regulación del sector, entre otras.

557 Para un desarrollo del tema, ver HERNÁNDEZ PAULSEN, Gabriel, La obligación precontractual de la entidad de crédito de informar al cliente en los servicios bancarios y de inversión, Marcial Pons, Madrid, 2014, pág. 135 y sgtes. Para un desarrollo de la información precontractual en la Ley General para la defensa de los Consumidores y Usuarios española, ver PARRA LuCÁn, María Ángeles, en CÁMARA LAPUENTE, Sergio (Dir.), Comentarios a las Normas de Protección de los Consumidores, Colex, Madrid, 2011, pág. 258-270.; Asimismo, Álvarez lata, Natalia, en Bercovitz Rodríguez-Cano, Rodrigo (Coord.), Comentario del Texto Refundido de la Ley General para la Defensa de los Consumidores y Usuarios y otras leyes complementarias (Real Decreto Legislativo 1/2007), Aranzadi-Thomson Reuters, Madrid, 2009, pág. 226250 .

558 Serrano de Nicolás, Ángel, en MARÍn LóPEZ, Manuel Jesús (Dir.), Comentarios..., cit., pág. 480 y sgtes. 
del contrato, el modo de satisfacer los pagos periódicos, las garantías exigidas, las consecuencias de la mora en el cumplimiento (aclarando el tipo de interés y su cuantía) y del incumplimiento definitivo o impago como advertencia, el derecho de desistimiento o la ausencia del mismo, el derecho al reembolso anticipado (y en su caso, la compensación a la que eventualmente tenga derecho el dador del crédito), el derecho a ser informado de forma inmediata y gratuita del resultado de la evaluación de solvencia, el derecho a recibir una copia del contrato a suscribir, el tiempo durante el cual el dador del crédito queda vinculado por esa información precontractual, etc.

Resulta de particular interés que la normativa española imponga la obligación de proveer esta información precontractual en papel o en cualquier otro soporte duradero a fin de que el consumidor interesado en acceder al crédito pueda reflexionar luego en soledad sin la presencia del intermediario o proveedor directo- o compartir el análisis del tema en familia o con algún especialista, comparar la propuesta con otras diferentes, evaluar su disponibilidad presupuestaria, proyectar las derivaciones, medir riesgos.

En Argentina, a falta de una norma que con carácter general, regule la obligación de los dadores de crédito de ofrecer información en la etapa precontractual, la remisión a la Ley de Defensa del Consumidor y -desde agosto de 2015- al nuevo Código Civil y Comercial unificado, resulta ineludible.

El art. 4 de la Ley $\mathrm{N}^{\circ} 24.240$ sienta una directiva general, en tanto impone al proveedor, el deber de suministrar al consumidor, la información relacionada con las características esenciales de los bienes y servicios que provee, así como también, lo relativo a las condiciones de su comercialización. Se trata de una fórmula amplia, congruente con la finalidad perseguida al diseñar esta herramienta jurídica: que el consumidor acceda a la información necesaria y útil para conocer el producto o servicio y las modalidades de contratación, evaluar la adecuación de la operatoria a sus necesidades y requerimientos, y la conveniencia de hacerlo con ese proveedor y en las condiciones propuestas.

En el régimen general de la Ley $\mathrm{N}^{\circ} 24.240$ citada -al igual que en todos los ordenamientos de protección de los consumidores- se establecen los requisitos que definen el objeto del débito informativo que pesa sobre el proveedor. La ley argentina impone que la información a suministrar debe ser cierta, clara y detallada (art. 4). 
En consonancia con esta disposición contenida en la regulación especial, en el Capítulo 2 (dedicado a la "Formación del consentimiento") del Título III (Contratos de Consumo), el Código Civil y Comercial unificado contiene el art. 1100, que reza: "Información. El proveedor está obligado a suministrar información al consumidor en forma cierta y detallada, respecto de todo lo relacionado con las características esenciales de los bienes y servicios que provee, las condiciones de su comercialización y toda otra circunstancia relevante para el contrato. La información debe ser siempre gratuita para el consumidor y proporcionada con la claridad necesaria que permita su comprensión"

Al decir que la información debe ser cierta, la norma impone el deber de suministrar información veraz, exacta, seria, objetiva, ajustada a la realidad, respaldada en los antecedentes particulares. Estas pautas, aplicadas a la operatoria de crédito, suponen que el proveedor ajuste la información al principio de transparencia evitando cualquier elemento que genere una imagen distorsiva de la realidad del negocio.

La veracidad de la información a suministrar por el proveedor es una cualidad que viene impuesta por el texto del art. 42 de la Constitución Nacional, que expresamente destaca este requisito a observar. Ello explica que la norma infraconstitucional haga propia la exigencia, en su texto particular.

Se exige, asimismo, que la información sea clara. Esta imposición legal supone que el caudal informativo sea comprensible para su destinatario. Satisfacer este recaudo importa la adopción de diligencias específicas por parte del proveedor, y de allí que se hayan impartido directivas concretas, para asegurar la concurrencia del mencionado requisito: que la información sea proporcionada por escrito y en idioma nacional, que resulte fácilmente legible $^{560}$, de acceso sencillo (proporcionada en un acto único o evitando remisiones,

\footnotetext{
${ }^{559}$ Para un análisis de la norma transcripta, remitimos a WAJNTRAUB, Javier H., en LORENZETTI, Ricardo L. (Dir.), Código Civil y Comercial de la Nación Comentado, T. VI, Rubinzal-Culzoni, Santa Fe, 2015, pág. 254 y sgtes.). Asimismo, cfr. Alterini, Jorge H. (Dir.), Código Civil y Comercial de la Nación..., T. V, cit., pág. 837 y sgtes.).

${ }^{560}$ Lo legible implica la posibilidad real y efectiva de leer fácilmente lo escrito y proteger de esa forma, el derecho subjetivo del consumidor a ser debidamente informado sobre la naturaleza y demás características de la relación creditoria...” (C. Civ. y Com. Córdoba, 4a, 21/06/2007, “Gama S.A. c. Ramallo, Rogelio E.”, LexisNexis 70041533). Vinculado al requisito de legibilidad, la Secretaría de Industria, Comercio y Minería (Subsecretaría de Defensa del Consumidor) dictó la Resolución $\mathrm{N}^{\circ}$ 906/98, sobre medidas en relación a los
} 
folletos anexos o complementarios, etc.), que se exprese en un lenguaje adecuado para el público al que está dirigido el producto o servicio $^{561}$ y por un medio o canal de comunicación apropiado .

Podríamos explicitar este requisito en un sentido negativo, señalando que no debe incurrir el proveedor en un lenguaje equívoco, confuso o ambiguo, ni en prácticas que desalienten la ingesta de la información (documentación voluminosa o de letra pequeña, instrumentos que remitan a otros textos anexos o que se entregan por separado o en distintos momentos, instructivos condicionados a entrevistas posteriores, etc.), pues ello pone en riesgo la finalidad iluminista del precepto. Si la norma busca echar luz, hacer conocer, facilitar la comprensión, auxiliar al consumidor, contribuir a la toma de una

contratos escritos de consumo; los textos incluidos en documentos que extiendan los proveedores, por los que se generan derechos y obligaciones para las partes y/o terceros en los términos de la Ley 24.240, y las informaciones que brinden por escrito los proveedores a los consumidores, del 30/12/98 (B.O. del 7/1/1999). Así se establece: “Art. $1^{\circ}$ : Los contratos escritos de consumo; los textos incluidos en documentos que extiendan los proveedores, por los que se generen derechos y obligaciones para las partes y/o terceros, en los términos de la Ley $\mathrm{N}^{\circ}$ 24.240, y las informaciones que por imperativo legal brinden por escrito los proveedores a los consumidores, deberán instrumentarse en idioma nacional y con caracteres tipográficos no inferiores a uno con ocho décimos $(1,8)$ de milímetros de altura. Art. $2^{\circ}$ : Los contratos y demás documentos a que se refiere el artículo anterior deberán asimismo resultar fácilmente legibles, atendiendo al contraste; formato, estilos o formas de las letras; espacios entre letras y entre líneas; sentido de la escritura, y cualquier otra característica de su impresión. Art. $3^{\circ}$ : Cuando determinados textos, informaciones o cláusulas, por imperativo legal, deban incluirse en forma destacada, notoria, ostensible o similar, deberán consignarse en negrita, con caracteres tipográficos equivalentes, como mínimo, a una vez y media el tamaño de los utilizados en el cuerpo o texto general del documento".

${ }^{561}$ La comprensibilidad del lenguaje depende en gran medida de la adecuada selección de los datos a proporcionar y del modo en que se transmite esa información. Los tecnicismos y la formalidad de las expresiones utilizadas muchas veces conspiran contra este requisito. Debe buscarse el difícil equilibrio entre la necesidad de suministrar información cierta y lo imperioso de que ésta sea accesible para su destinatario. "No puede admitirse que para negocios de la vida diaria, como es la suscripción a un sistema de tarjeta de crédito, el consumidor deba estudiar e interiorizarse de un lenguaje innecesariamente asentado en términos y expresiones ambiguas...no es razonable exigirle (al consumidor) conocimientos superiores a los de un experto contable". En el mismo pronunciamiento se consideró que el banco emisor "no anotició leal y correctamente el alcance de las obligaciones del adherente...al no informar sobre el cálculo de las tasas de interés, razón por la cual es improcedente su pretensión de cobrar los intereses predispuestos en el contrato de modo confuso e impreciso" (C. Nac. Com., Sala B, 28/4/98, “Finvercon S.A. c/Pierro, Claudia A.”, LL 1998-C-624). 
decisión razonada y reflexiva, etc., el proveedor debe omitir cualquier práctica que desnaturalice la télesis normativa ${ }^{562}$.

El precepto analizado impone asimismo que la información sea detallada, con lo cual, debe el proveedor ofrecer precisiones acerca de los ítems legalmente establecidos, evitando generalizaciones ${ }^{563}$. Al explicar este recaudo, se dice que la información debe ser pertinente $^{564}$, completa $^{565}$ y suficiente ${ }^{566}$ pues sólo de ese modo, el consumidor tendrá a su

${ }^{562}$ Se ha dicho que "el hecho de que las tasas de financiación aplicables al sistema de tarjetas de crédito se encontraran consignadas en volantes explicativos es insuficiente para desvirtuar la existencia de una infracción al art. 16 de la ley 25.065 pues el derecho que tienen los consumidores a conocerlas, no está condicionado a ninguna actividad suplementaria en cabeza de ellos, sino que deriva del correlativo deber de exhibición que impone la ley" (C. Cont. Adm. y Trib. Ciudad Bs As., Sala I, 2/3/2005, "Banco de la Nación Argentina-Suc. Pompeya c/Ciudad de Buenos Aires", LL 2005-C-805).

${ }^{563}$ Desde esta perspectiva, un tribunal confirmó la multa impuesta a una entidad financiera que otorgaba préstamos para la financiación de automotores en tanto "no informó al deudor acerca de su estado de cuenta, limitándose a manifestar que adeudaba cierta suma de dinero, sin precisar las cuotas que habían sido pagadas, omitiendo imputar los pagos ya efectuados" (C. Fed. Salta, 9/6/2008, "Volkswagen Compañía Financiera S.A.”, LL NOA 2008, noviembre, 195). Del mismo modo, al evaluar el cumplimiento del deber de informar impuesto al banco emisor de una tarjeta de crédito, se dijo que el deber consistía en "explicar claramente la exactitud de la liquidación, aportando copia de los comprobantes o fundamentos que avalen la situación". De allí que el tribunal interviniente expresara que "es procedente la multa impuesta a la entidad financiera....debido a la omisión de informar sobre los cargos de la facturación de una tarjeta denunciada como extraviada, pues no se acreditó haber ofrecido una explicación clara y exacta de la liquidación..." (C. Cont. Adm. y Trib. Ciudad Bs As, Sala II, 13/6/2008, "Malher, Israel vs.- Banco de la Nación Argentina”, LL CABA 2008 (diciembre), 323).

${ }^{564}$ LORENZETTI, Ricardo L., Consumidores, cit., pág. 169.

${ }^{565}$ La completividad exige que la información sea acabada, perfecta, integral, omnicomprensiva. En un precedente de interés, el tribunal confirmó la multa aplicada por la Secretaría de Industria y Comercio a una entidad bancaria por infracción al arts. 4 de la ley 24.240 "toda vez que la entidad no cumplió sus deberes cuando respondió la solicitud de información que hiciera el denunciante acerca de la tasa de interés aplicable al mutuo hipotecario contratado, expresando que ella resultaba de efectuar una simple operación aritmética en base al Programa de Amortización de la Operación — sistema "Francés"—, debidamente suscripto por las partes" (Trib. Superior de Justicia de la Provincia de Córdoba, sala Contencioso Adm., "Roela S.A. c. Provincia de Córdoba s/ plena jurisdicción - recurso de apelación”, 05/11/2013, LLC 2014 (abril), 313).

${ }^{566}$ La suficiencia de la información está necesariamente ligada a una valoración de los datos que cualitativa y cuantitativamente explican las características esenciales del producto o servicio y las condiciones de su comercialización. Corresponderá al proveedor -como poseedor de la información- seleccionar el contenido 
alcance los elementos necesarios y útiles para conocer, comprender, hacer una previsión de riesgos, decidir y adoptar precauciones para evitar daños. Se ha destacado que el proveedor debe transmitir toda la información que sea necesaria para la obtención de la finalidad perseguida $^{567}$, "de modo que no queden dudas" al consumidor ${ }^{568}$.

Si bien la oportunidad no es una cualidad mencionada por la ley, el proveedor debe velar por el cumplimiento tempestivo de la obligación a su cargo ${ }^{569}$. La puntualidad -en todo deber jurídico obligacional ${ }^{570}$ - es un requisito innegablemente vinculado a la obtención del objeto y a la satisfacción del interés del acreedor ${ }^{571}$. Tratándose de la etapa precontractual, es de toda evidencia que la información deberá ser ofrecida antes de la celebración del contrato y con una razonable antelación, a efectos de propiciar ese consentimiento reflexivo al que antes nos hemos referido. Precisamente, la inejecución del comportamiento informativo en el tiempo oportuno puede comprometer irremediablemente la responsabilidad del proveedor ${ }^{572}$.

de la información a suministrar, elaborar el mensaje y decidir el modo en que habrá de concretarse la conducta o comportamiento informativo (el lenguaje, el canal de comunicación, la oportunidad en que habrá de concretarse el acto de información, la frecuencia o reiteración del mensaje, etc. Luego, y en razón de juzgar el cumplimiento de la prestación y la obtención del objeto, será la autoridad de aplicación o los jueces, quienes evaluarán la eficacia o ineficacia de la conducta obrada y la eventual responsabilidad del proveedor.

${ }^{567}$ Ver OSSOLA, Federico - VALLESPINOS, Gustavo, La obligación de informar, cit., pág. 160.

568 JABIF, Hernán M. - PASTORE, Augusto O., "Relación de consumo: cajeros automáticos", en DJ $2007-$ 2,1037. En relación a los servicios bancarios, se confirmó la sanción impuesta a la entidad señalando que la información debe ser proporcionada "en forma contundente" a fin de que "se indique al usuario las condiciones del crédito que se le otorga" (C. Nac. Cont. Adm. Fed, sala V, 19/05/1999, "Banco Quilmes S.A. c. Secretaría de Comercio e Inversiones”, Albremática 110.187).

${ }^{569}$ SARCIAT, Alberto D."La asimetría de la información”, LL 2008-C. 616.

${ }^{570}$ Wayar, Ernesto C., Derecho Civil. Obligaciones, cit., pág. 417 y sgtes.

${ }^{571}$ Se entendió que "viola el deber de información previsto en la ley de defensa del consumidor 24.240 la entidad financiera que no realizó la transferencia de fondos al exterior solicitada por un cliente, aduciendo gastos adicionales, si la información exigida para que prosperase la operación -detalle de comisiones y gastos con mención de importes y porcentajes que serán debitados de la cuenta- no se brindó en tiempo oportuno; esto es, antes de firmar el contrato, ni en la forma y exhaustividad exigida..." (cfr. C. Civ. y Com. Mar del Plata., Sala I, 26/5/2005, “Alfageme, Esteban R. c/Banco Francés BBVA”, LLBA 2005(septiembre), 980).

572 Para un desarrollo de los presupuestos de la responsabilidad por incumplimiento del débito informativo y los escenarios de actuación en el Derecho argentino, ver JAPAZE, María Belén, "El deber de información", 
La eficacia del débito informativo impuesto a los dadores de crédito en esta etapa precontractual depende de la adopción de las precauciones diversas: de la adecuada selección del material informativo (de su certeza, completividad y suficiencia), del código adoptado para la elaboración del mensaje (en lo sustancial y en lo formal) y del acierto o desacierto del canal de comunicación, de la oportunidad del suministro, etc. ${ }^{573}$.

En la regulación particular de los "Contratos bancarios celebrados con consumidores y usuarios" (Libro III, Título IV, Capítulo 12), el nuevo Código Civil y Comercial acude decididamente en nuestro auxilio con las previsiones contenidas en el art. 1387. En efecto, bajo el título "Obligaciones precontractuales", el legislador establece que “Antes de vincular contractualmente al consumidor, el banco debe proveer información suficiente para que el cliente pueda confrontar las distintas ofertas de crédito existentes en el sistema, publicadas por el Banco Central de la República Argentina....”. Otro dispositivo de interés es el contenido en el art. 1389 que dispone: "Información en contratos de crédito. Son nulos los contratos de crédito que no contienen información relativa al tipo y partes del contrato, el importe total del financiamiento, el costo financiero total y las condiciones de desembolso y reembolso".

Por su parte, el art. 1382 -que integra el cortejo de normas vinculadas a la "Transparencia de las condiciones contractuales" con que se inicia el capítulo dedicado a los "Contrato bancarios" en general, impone una obligación de información periódica que

Capítulo V, en Rusconi, D. (Coord.), Manual de Derecho del Consumidor, Abeledo Perrot, Buenos Aires, 2015, pág. 221-267. En el Derecho español, ver el minucioso análisis en HERNÁNDEZ PAULSEN, Gabriel, La obligación precontractual..., cit., pág. 279 y sgtes.

${ }^{573}$ En un caso de interés, el tribunal confirmó la sanción impuesta a una entidad financiera por violación a los arts. 4 y 19 de la Ley de Defensa del Consumidor, por considerar que "quedó demostrado que no otorgó información fehaciente a un usuario de tarjeta de crédito de cómo proceder en caso de sustracción o pérdida de la misma y al ser requerido al consumidor el contrato de tarjeta de crédito, éste manifestó no poseer copia del mismo y la entidad bancaria recién la presentó al interponer el recurso de apelación, porque decía que no podía ser hallada en sus registros —en el caso, se le había debitado un cargo producido luego de la sustracción de la tarjeta y por haberse determinado que era la firma del cliente mediante una pericia privada, pues la obligación de comunicar las condiciones jurídicas aplicables a la transacción de que se trate, merece ser recalcada cuando se está en presencia de una relación profesional-consumidor" (C. Fed. de Apel. de La Plata, sala III, “Banco Credicoop c. D.N.C.I. Disp. 821/06”, 31/08/2010, LLBA 2011 (marzo), 215). 
permitirá al consumidor conocer el desenvolvimiento de la operatoria que lo involucra y controlar su evolución ${ }^{574}$.

Determinar en cada caso si la información suministrada por el proveedor satisface las directivas impuestas por el legislador, constituye una típica cuestión de hecho, que el intérprete -la autoridad de aplicación o el juez- habrán de merituar conforme las circunstancias del caso. Todo ello, sin olvidar que en caso de duda sobre el carácter satisfactorio o insatisfactorio del comportamiento informativo, habrá que estar a la interpretación que resulte más favorable al consumidor (conf. art. 3 de la ley 24.240).

\section{c.1.3. Deber de asesoramiento del proveedor}

Existe consenso en la doctrina respecto de que el proveedor en general -por su carácter profesional y la consiguiente experticidad en materia negocial- no agota con la información precontractual, su débito respecto del consumidor. Se señala que el deber de informar va acompañado de prestaciones complementarias -dar asesoramiento o consejode necesario cumplimiento. Estas consideraciones generales lucen evidentes en la operatoria de crédito, donde el deber de asesorar constituye un débito especial, recogido por la normativa particular.

Aconsejar supone que a partir de la información existente, de las opciones que se ofrecen, de las ventajas y desventajas que exhiben dichas alternativas y de las variables que inciden en la toma de decisión, el experto emitirá una opinión encaminada a orientar la conducta de la otra parte. El consejo supone expresar un parecer, un juicio, un criterio, a fin de guiar la decisión del sujeto que lo recibe. Se ha dicho que importa un plus por sobre la información, en tanto conlleva una carga subjetiva ${ }^{575}$. No se trata de una conducta neutra

\footnotetext{
${ }^{574}$ Establece el art. 1382: "Información periódica. El banco debe comunicar en forma clara, escrita o por medios electrónicos previamente aceptados por el cliente, al menos una vez al año, el desenvolvimiento de las operaciones correspondientes a contratos de plazo indeterminado o de plazo mayor a un año. Transcurridos sesenta días contados a partir de la recepción de la comunicación, la falta de oposición escrita por parte del cliente se entiende como aceptación de las operaciones informadas, sin perjuicio de las acciones previstas en los contratos de consumo. Igual regla se aplica a la finalización de todo contrato que prevea plazos para el cumplimiento".

575 STIGLITZ, Ruben - STIGLITZ, Gabriel, "La obligación precontractual y contractual de información, Deber de consejo" en $L L$ 1997-B-750.
} 
sino dotada de un sentido, encaminada a una finalidad particular: orientar, guiar, determinar, etc., el comportamiento de otro.

Pero todavía más, se ha dicho que "entender la estructura y el funcionamiento de un negocio puede ser insuficiente para juzgar la conveniencia de su realización en el caso concreto"576 y que en muchos supuestos se impone al proveedor el deber de añadir a la información pertinente, las sugerencias y las recomendaciones que permitan al consumidor evaluar si el negocio ofrecido se adecua a sus expectativas, necesidades o requerimientos.

El asesoramiento procura que el consumidor se encuentre en las mejores condiciones para decidir la toma del crédito o el consumo financiado, evaluando ventajas y desventajas, y los riesgos de hacerlo en las condiciones ofrecidas.

Se ha advertido que en determinados supuestos, al deber de suministrar la información, se adiciona un deber de consejo que supone previamente, ayudar al consumidor a expresar sus necesidades, interpretarlas, advertir los aspectos positivos y negativos de la operación más los riesgos consiguientes, y sugerir la elección apropiada mediante una opinión que puede ser iniciativa o disuasiva de la decisión a adoptar por quien recibe ese consejo ${ }^{577}$.

Emparentado con el asesoramiento o consejo, se encuentra el deber de advertencia $^{578}$, que supone comunicar y llamar la atención respecto de ciertos riesgos a los que pueda verse expuesto el consumidor con motivo de la contratación propuesta.

Se trata de un deber particular -necesariamente vinculado a la obligación de informar- pero que se orienta a poner en evidencia la eventual afectación de la indemnidad del consumidor. En el caso, el dador de crédito deberá analizar el cuadro de situación de su

\footnotetext{
${ }^{576}$ Al analizar la situación del consumidor en el mercado de capitales y la obligación de asesoramiento en cabeza de los intermediarios de la inversión, Martín Abdala nos dice que "muchos inversores necesitan no sólo inversión, sino también asesoramiento, para valorar si en el caso concreto conviene realizar la operación (ABDALA, Martín, "El consumidor en el mercado de capitales", en LORENZETTI - SCHOTZ (Directores), Derecho del consumidor, Abaco de Rodolfo Depalma-Universidad Austral, Buenos Aires, 2003, pág. 215.

${ }^{577}$ Molina QuiRogA, Eduardo, "Exigencias de la buena fe en los contratos informáticos", en LL 2008-C, 1068.

${ }^{578}$ Para profundizar el estudio y la distinción de las figuras (obligación de informar, deber de consejo y deber de advertencia) ver LLOBET I AGUADO, Joseph, El deber de información en la formación de los contratos, Marcial Pons, Madrid, 1996, pág. 33 y sgtes.
} 
eventual co-contratante y llamarle la atención respecto de los alcances del compromiso a asumir y el impacto en sus intereses económicos.

El Dictamen del Comité Económico Social Europeo sobre "El crédito y la exclusión social en la sociedad de la abundancia" de 2007 señalaba ya la necesidad de impulsar "la creación o extensión de redes de servicios de asesoramiento financiero que ayuden a los ciudadanos a administrar su presupuesto de manera equilibrada y a elegir las mejores opciones de financiación para el consumo" (punto 5.1.c), como medida de prevención del endeudamiento excesivo de las economías domésticas.

Años más tarde, en su Dictamen sobre "Protección de los consumidores y tratamiento adecuado del sobreendeudamiento para evitar la exclusión social”, de 2014, el CESE explicitó que el principio de crédito responsable impone a los profesionales del sector, un asesoramiento personalizado, facilitando a los consumidores las explicaciones necesarias para que comprendan la operatoria y los riesgos derivados de la contratación (punto 4.2.1) $)^{579}$.

En el Dictamen sobre "Acceso al crédito para los consumidores y las familias: prácticas abusivas de 2010, el CESE pone énfasis en señalar que en el marco normativo actual para los contratos de crédito no se consagra el deber de adecuar la oferta a las necesidades de los consumidores y que esta falta de regulación ha permitido situaciones de abuso que las que los productos que se ofrecen... resultan inadecuados a sus necesidades. Éste es el caso cuando se ofrece un solo tipo de crédito o cuando se ofrecen de forma indiscriminada tarjetas de crédito o débito para la compra de productos (puntos 4.7 y 4.8).

El considerando 27 de la Directiva 2008/48, de Crédito al Consumo, establece que "el consumidor puede necesitar ayuda para decidir qué contrato de crédito, de entre todos los productos propuestos, es el que mejor se ajusta a sus necesidades y su situación financiera. Por consiguiente, los Estados miembros deben asegurarse de que los

\footnotetext{
579 Señala el CESE en el punto 6.3.1 del aludido Dictamen: "El asesoramiento en materia de servicios financieros y de consumo, la obligación de asesoramiento que tienen las entidades bancarias y crediticias, así como la ayuda a la gestión del presupuesto, suelen ser insuficientes o inadecuadas para las personas endeudadas. Por lo tanto, las autoridades públicas nacionales deben poner a disposición de las personas con dificultades servicios de ayuda social capaces de ofrecerles, si lo desean, ayuda inmediata, o asistencia jurídica gratuita. A este respecto, los Estados miembros podrían apoyar y dar carácter oficial a la labor de asistencia jurídica que desempeñan las organizaciones de defensa de los consumidores”.
} 
prestamistas proporcionen dicha asistencia respecto de los productos crediticios que ofrecen al consumidor. Si fuera necesario, la información precontractual pertinente, así como las características esenciales de cada uno de los productos propuestos, deben explicarse al consumidor de forma personalizada, de manera que pueda entender qué repercusiones pueden tener sobre su situación económica. Si procede, la citada obligación de prestar asistencia al consumidor debe aplicarse también a los intermediarios. Los Estados miembros deben poder determinar en qué momento y en qué medida han de facilitarse esas explicaciones al consumidor, teniendo en cuenta las circunstancias particulares de la situación en la que se ofrece el crédito, la necesidad de asistencia del consumidor y la naturaleza de cada uno de los productos crediticios".

En el art. 5.6, la Directiva dispone: "Los Estados miembros velarán por que los prestamistas y, cuando proceda, los intermediarios de crédito faciliten al consumidor las explicaciones adecuadas para que este pueda evaluar si el contrato de crédito propuesto se ajusta a sus necesidades y a su situación financiera, si fuera preciso explicando la información precontractual que se facilitará conforme a lo dispuesto en el apartado 1, las características esenciales de los productos propuestos y los efectos específicos que pueden tener sobre el consumidor, incluidas las consecuencias en caso de impago por parte del consumidor. Los Estados miembros podrán adaptar el modo de prestación de esta asistencia y su alcance, así como la identidad de la parte que se hará cargo de ella, a las circunstancias particulares de la situación en que se ofrece el contrato de crédito, la persona a quien se ofrece y el tipo de crédito ofrecido".

La obligación de asesoramiento incumbe a la entidad financiera concedente del crédito en virtud de su experticia y consideramos que dada la particular naturaleza de la operatoria de que se trata, la asistencia, el asesoramiento y hasta el consejo, son prestaciones razonablemente esperadas por el consumidor de crédito.

En consonancia con la Directiva, la Ley 16/2011 de Contratos de Crédito al Consumo española establece en el art. 11: "Asistencia al consumidor previa al contrato. Los prestamistas $\mathrm{y}$, en su caso, los intermediarios de crédito facilitarán al consumidor explicaciones adecuadas de forma individualizada para que éste pueda evaluar si el contrato de crédito propuesto se ajusta a sus intereses, a sus necesidades y a su situación financiera, si fuera preciso explicando la información precontractual, las características 
esenciales de los productos propuestos y los efectos específicos que pueden tener sobre el consumidor, incluidas las consecuencias en caso de impago por parte del mismo.

A la luz del art. 12 citado, los deberes a cargo del prestamista y de los intermediarios de crédito se resignifican. Para un sector de opinión, este deber de asistencia es una manifestación del deber de información precontractual, constituye un modo de suministrar la información ${ }^{580}$. Para otros, a quienes adherimos, la asistencia impuesta por la ley es un débito equivalente al deber de asesoramiento: el experto aporta su saber particular no sólo para ilustrar el conocimiento ajeno con explicaciones de contenido neutro, sino que orienta su conducta con una opinión o parecer, aportando eventualmente su consejo $^{581}$. Señala gráficamente Ordás Alonso, que el contenido del débito a cargo del dador de crédito se ensancha pues no se limita a una "obligación de hacer conocer" sino que se le impone "un deber de hacer comprender" 582.

Pese a la falta de precisión sobre el punto en el texto legal, coincidimos con quien entiende que el deber de asistencia o asesoramiento debe ser satisfecho en todos los casos, haya existido o no un requerimiento de tales explicaciones por parte del consumidor ${ }^{583}$. La norma analizada consagra una obligación imperativa y de allí que resulte nula la renuncia

\footnotetext{
580 Álvarez lata, Natalia, en Marín LóPez, Manuel Jesús (Dir.), Comentarios a la Ley de Crédito al Consumo, Thomson Reuters-Aranzadi, Pamplona 2014, pág. 535.

581 MARÍn LóPEZ, Manuel Jesús, “Obligación de asesoramiento, obligación de evaluar la solvencia del consumidor y otras obligaciones precontractuales del prestamista. Su regulación en el Proyecto de Ley de Contratos de Crédito al Consumo", en www.uclm.es/centro/cesco/pdf/trabajos/6/2011/6-2011-8.pdf (Fecha de consulta: 15/7/2015). Asimismo, Álvarez Olalla, Pilar, "Crédito al consumo", en BerCovitz, Rodrigo (Coord.), Tratado de Contratos, T. II, Valencia, Tirant lo Blanch, 2009, pág. 4532.

582 ORDÁs AlOnso, Marta, Los contratos de crédito al consumo..., cit., pág. 133.

${ }^{583}$ ORDÁs Alonso, Marta, Los contratos de crédito al consumo..., cit., pág. 134. La autoriza citada advierte, con acierto que "en la medida en que dicha asistencia ha de ser individualizada, en función del nivel de conocimientos que posea el concreto consumidor en esta materia, quizá no sea preciso explicar la información precontractual, las características esenciales de los productos y los efectos específicos que puedan tener sobre el mismo". Destaca que "si bien es cierto que nos encontramos ante contratos de gran complejidad técnica, nada obsta que el consumidor sea, por ejemplo, un empleado de una entidad crediticia perfectamente familiarizado con éste y otro tipo de contratos". Ahora bien, estos supuestos de excepción no relevan al obligado de ofrecer ese espacio y tiempo de asistencia y asesoramiento, dejando a salvo su responsabilidad particular.
} 
previa del consumidor a la prestación de la asistencia por parte del prestamista o intermediario, así como la cláusula contractual por la cual éstos pretendieran eximirse de su cumplimiento $^{584}$.

El comportamiento desplegado para cumplir este deber de asistencia habrá de adecuarse a los requerimientos del consumidor. Las explicaciones se medirán, desde lo cualitativo y lo cuantitativo, conforme las necesidades del destinatario. Si bien es cierto que se espera una posición activa del consumidor, que haga explícitas sus dudas e inquietudes, corresponde al profesional del negocio, estimular sus manifestaciones, indagar acerca de sus necesidades y evaluar sus requerimientos, para así adecuar el quid del deber de asistencia legalmente impuesto.

La norma impone al dador de crédito, suministrar información precisa, en forma personalizada y con un añadido de explicaciones expertas que permitan al consumidor conocer el producto ofrecido y las condiciones de la contratación, evaluando la adecuación y conveniencia del negocio propuesto conforme su situación económica y financiera. La clave de la obligación de asistencia es "formar y ayudar a la opinión y decisión del consumidor, ${ }^{, 585}$.

El modelo analizado dedica normas expresas al deber de asesoramiento impuesto a quien ofrece financiamiento en el mercado $\mathrm{y}$, por si hiciera falta, puntualizamos que los destinatarios de la imposición legal no sólo son las entidades de créditos sino todo aquel proveedor de bienes y servicios que financia por sí o por terceros la adquisición o contratación de los mismos.

Sin perjuicio de la existencia de un régimen particular para las entidades financieras y del contralor que sobre las mismas ejerza la autoridad de aplicación correspondiente, la regulación que propiciamos debe imponer expresamente el deber de asesoramiento y definir sus contornos. Ello facilitará el juzgamiento de la responsabilidad de los sujetos obligados.

Consideramos que la imposición de esta obligación constituye una herramienta preventiva eficaz. La información y el asesoramiento por parte del experto, contribuirán a la neutralizar situaciones no deseadas. Un consumidor sin información y no asesorado

\footnotetext{
${ }^{584}$ Álvarez lata, Natalia, en Marín LóPEZ, Manuel Jesús (Dir.), Comentarios..., cit., pág. 534.

585 Álvarez lata, Natalia, en MARÍn LÓPEZ, Manuel Jesús (Dir.), Comentarios..., cit., pág. 535.
} 
difícilmente pueda hacer previsiones razonables o tomar decisiones acertadas. Asumir obligaciones sin una evaluación adecuada del impacto en sus previsiones presupuestarias puede comprometer seriamente la economía doméstica del consumidor.

\section{c.1.4. Deber de mantener la oferta: carácter vinculante.}

La Ley 16/2011 de Contratos de Crédito al Consumo española dispone en su art. 8: "Oferta vinculante. El prestamista que ofrezca un crédito a un consumidor estará obligado a entregarle antes de la celebración del contrato, si el consumidor así lo solicita, un documento con todas las condiciones del crédito en términos idénticos a lo establecido en el artículo 10 para la información previa al contrato, como oferta vinculante que deberá mantener durante un plazo mínimo de catorce días naturales desde su entrega, salvo que medien circunstancias extraordinarias o no imputables a él. Si esta oferta se hace al mismo tiempo que se comunica la información previa al contrato prevista en el artículo 10, deberá facilitarse al consumidor en un documento separado que podrá adjuntarse a la Información Normalizada Europea sobre crédito al consumo".

La norma analizada alude a aquellas tratativas preliminares que el prestamista lleva adelante con un consumidor concreto y en cuyo marco, éste solicita la entrega de un documento con las condiciones del crédito conforme lo establecido en el art. 10 (referido a la información precontractual ${ }^{586}$. El dispositivo asigna la virtualidad de oferta vinculante al supuesto particular en que concurran la solicitud -por parte del consumidor- del instrumento con la información precontractual ${ }^{587}$ y el cumplimiento de esta carga ${ }^{588}$ por parte del dador de crédito. Configurado el supuesto de hecho, la ley impone a esa oferta el carácter irrevocable durante el tiempo allí establecido.

\footnotetext{
${ }^{586}$ SerRano de NiCOLÁs, Ángel, en MARÍn LóPEZ, Manuel Jesús (Dir.), Comentarios..., cit., pág. 419.

${ }^{587}$ ORDÁs ALONSO critica esta previsión legal por entender que "supone dejar en manos del consumidor la protección que el legislador pretender otorgarle mediante la regulación de la oferta vinculante. A ello se une el hecho de que el consumidor puede desconocer tanto el derecho que le asiste a solicitar esa oferta como las implicaciones derivadas de la misma” (ORDÁs AlOnSO, Marta, Los contratos de crédito al consumo..., cit., pág. 100).

${ }^{588} \mathrm{Al}$ analizar la naturaleza de este deber jurídico impuesto al prestamista, se señala que en puridad se trata de una carga del acreedor (cfr. arg. en CABANILLAS SÁNCHEZ, Antonio, Las cargas del acreedor en el derecho civil y mercantil, Editorial Montecorvo, Madrid, 1988, pág. 342 y sgtes.).
} 
Conforme lo previsto por el legislador español, la oferta plasmada en ese documento -que ha sido entregado a requerimiento del consumidor interesado- "será vinculante para el prestamista tan pronto el prestatario muestre su incondicionada voluntad de contratar ... respecto de la información específica que se haya proporcionado" ${ }^{\text {589 }}$.

La solicitud del consumidor no está sujeta a formalidad alguna, de modo que puede formularse verbalmente, por escrito y por vías diversas (personalmente ante la entidad, por correo, por medios electrónicos, etc.). No obstante ello, a efectos de poner en evidencia la inobservancia de la entrega por parte de la entidad de crédito, conviene acudir a un requerimiento que permita su acreditación.

Aunque resulte de toda obviedad, la ley expresamente dice que el suministro del documento con la información equivalente a la referida en el art. 10 -información precontractual- a la que se le asignará virtualidad de oferta vinculante, es gratuito. Cualquier mecanismo que se intentara para cargar un coste -por mínimo que sea- en cabeza del consumidor interesado en acceder ese instrumento que corporiza la oferta vinculante, importará una infracción a la norma y hará pasible a la entidad de las sanciones correspondientes.

A efectos de cumplir con la finalidad que inspira el dispositivo, la información vinculada a las condiciones del crédito deber ser suministrada por escrito -en papel u otro soporte material duradero- y en idénticas condiciones a la denominada información precontractual (a la que se refiere el art. 10 de la ley). Esta última previsión contribuye a la transparencia impuesta a la actividad y al principio de préstamo responsable.

La regulación de esta oferta vinculante, en el modelo analizado, impone a la entidad de crédito mantenerla con carácter irrevocable durante un plazo determinado. En el caso, el legislador español modifica el término originariamente establecido (en el art. 16 de la Ley 7/1995 de Crédito al Consumo derogada) que queda fijado en 14 días corridos a contar desde la entrega del documento ${ }^{590}$. En vista de ello, resulta relevante acreditar la fecha en que se cumple con la entrega del citado instrumento para que exista certeza respecto del

\footnotetext{
${ }^{589}$ Serrano de Nicolás, Ángel, en Marín LóPEZ, Manuel Jesús (Dir.), Comentarios..., cit., pág. 430.

${ }^{590}$ Para un análisis de la correspondencia entre la ley de crédito al consumo antes vigente y la actual y la normativa del sector referida a la transparencia en el mercado de crédito español, ver ORDÁs ALONSO, Marta, Los contratos de crédito al consumo..., cit., pág. 100 y sgtes.
} 
cómputo del plazo, que resulta de interés para ambas partes. El carácter irrevocable de la oferta debe mantenerse durante ese tiempo a fin de dejar a salvo la responsabilidad por la entidad crediticia $^{591}$ y es el lapso temporal durante el cual el consumidor podrá aceptar y exigir la contratación en las condiciones allí precisadas ${ }^{592}$.

El documento con la oferta vinculante (conf. art. 8), no obstante su contenido equivalente, es un instrumento distinto de aquél que contiene la información precontractual del art. 10. "Se trata de que quede claro que son dos documentos autónomos ... pues cumplen funciones distintas" ${ }^{, 593}$. De allí que aunque pudiera incluso parecer redundante la doble entrega de esta documentación, luce justificada en el principio de transparencia aplicado a la información y en la virtualidad de cada uno: mientras la información precontractual del art. 10 es éso, la contenida en la oferta del art. 8 es vinculante durante el plazo allí establecido ${ }^{594}$.

Con la incorporación de esta norma, se persigue evitar distorsiones o abusos en la conformación de la voluntad contractual, de modo que pudiera captarse el libre querer del consumidor con propuestas de condiciones en apariencia ventajosas, que después no fueran a materializarse contractualmente.

Un dispositivo como el mencionado cumpliría una eficacia preventiva del sobreendeudamiento. El carácter vinculante de la oferta, plasmada en la información proporcionada por el proveedor y el deber de mantenerla durante el plazo de irrevocabilidad que la ley determine, permitiría que "el consumidor pueda no sólo conocer de forma fehaciente y segura el contenido del contrato, sino compararlo con otras ofertas,

\footnotetext{
${ }^{591}$ Recordamos que la propia norma prevé la extinción de la oferta vinculante o su revocabilidad cuando concurran "circunstancias extraordinarias o no imputables" al prestamista.

${ }^{592}$ Formulada la aceptación por el consumidor, deberá suscribirse el contrato de crédito al consumo -sujeto a cláusulas predispuestas a las que el interesado prestará su adhesión- que obviamente deberá ajustarse a las condiciones de contratación contenidas en la oferta y a la información precontractual allí contenida.

${ }^{593}$ Serrano de Nicolás, Ángel, en MARÍn LóPEZ, Manuel Jesús (Dir.), Comentarios..., cit., pág. 435.

${ }^{594}$ Cfr. MARÍn LÓPEZ, Manuel Jesús, "Protección del consumidor y crédito al consumo. Análisis del proyecto de ley de contratos de crédito al consumo", en Revista de Derecho Privado N $^{\circ}$ 95, marzo-abril, Edersa, Madrid, 2011, pág. 67.
} 
reflexionar sobre sus necesidades y finalmente obtener el crédito por su simple aceptación, sin alteraciones o mayores obligaciones o gravámenes en las condiciones del contrato" ${ }^{\Perp 5}$.

En Argentina, a falta de una regulación particular de la operatoria de crédito al consumo, acudimos a la Ley $\mathrm{N}^{\circ} 24240$ de Defensa del Consumidor que ofrece un dispositivo de interés, aunque su diseño responde a la adquisición de bienes y servicios en general.

El art. 7 de la ley, bajo el título "Oferta", dispone: "La oferta dirigida a consumidores potenciales indeterminados, obliga a quien la emite durante el tiempo en que se realice, debiendo contener la fecha precisa de comienzo y de finalización, así como también sus modalidades, condiciones o limitaciones. La revocación de la oferta hecha pública es eficaz una vez que haya sido difundida por medios similares a los empleados para hacerla conocer. La no efectivización de la oferta será considerada negativa o restricción injustificada de venta, pasible de las sanciones previstas en el artículo 47 de esta ley",596.

Se trata de un supuesto distinto al de la legislación española, no sólo por su generalidad (referido a la oferta en cualquier tipo de contratos de consumo) sino porque en este caso, el efecto vinculante asignado a la oferta, lo es respecto de aquella dirigida a consumidores potenciales indeterminados apartándose de la figura regulada en el modelo contractual tradicional del Código Civil (arts. 1148 del Código de Vélez; art. 972 del nuevo

\footnotetext{
${ }^{595}$ GutiÉRREZ DE CABIEDES, Pablo, El sobreendeudamiento doméstico..., cit., pág. 142 y sgtes.

${ }^{596}$ La reglamentación por vía del Decreto $N^{\circ}$ 1798/94 establece: “ a) En la oferta de bienes o servicios realizada en el lugar donde los mismos se comercializan se podrán omitir las fechas de comienzo y finalización, en cuyo caso obliga a quien la emite durante el tiempo en que se realice. La oferta realizada fuera del lugar de comercialización deberá contener siempre el plazo de su vigencia. Cuando el proveedor limite cuantitativamente su oferta de productos y servicios, deberá informar la cantidad con que cuenta para cubrirla. Cuando por cualquier causa en una oferta se hubieren incluido precisiones contradictorias, se estará siempre a la más favorable al consumidor o usuario. b) Si el proveedor de cosas o servicios no cumple la oferta o el contrato el consumidor podrá, en su caso, alternativamente y a su elección: I) exigir el cumplimiento forzado de la obligación, siempre que el incumplimiento no obedezca a caso fortuito o fuerza mayor no imputable al proveedor; II) aceptar otro producto o prestación de servicio equivalente; III) rescindir el contrato con derecho a la restitución de lo pagado y al resarcimiento por daños y prejuicios. En los casos de servicios contemplados en el art. 23 de la Ley No 24.240, y previo al ejercicio de estas opciones, deberá estarse a lo establecido en dicho artículo".
} 
Código Civil y Comercial), que se refiere a la oferta dirigida a persona determinada ${ }^{597}$. En esa misma línea de razonamiento, se expresa que "el carácter vinculante de las ofertas al público que consagra la Ley de Defensa del Consumidor importa una derogación, para el ámbito regido por esa normativa, de las exigencias contenidas en el Código Civil, en el sentido de que las ofertas deben, para considerarse tales, ser dirigidas a persona o personas determinadas o determinables"

Se ha dicho que por vía de este precepto contenido en la Ley de Defensa del Consumidor argentina, se consagra la eficacia de la oferta al público tal como lo propiciaba la doctrina moderna; recepción que hace propia el nuevo Código Civil y Comercial vigente a partir de agosto de 2015, en su art. 974, con las particularidades allí señaladas ${ }^{599}$.

Desde luego, la operatividad del dispositivo dependerá de la concurrencia de otros recaudos puesto que, como señala LORENZETTI, la normativa protectoria introduce reglas verdaderamente importantes cuando se trata de la oferta dirigida a consumidores

${ }^{597}$ Cfr. SANTARelli, Fulvio G., Comentario al art. 7, en PiCASSO, Sebastián-VÁzQuez Ferreyra, Roberto (Dir.), Ley de Defensa del Consumidor Comentada y Anotada, T. I, La Ley, Buenos Aires, 2009, pág. 97-99.

${ }^{598}$ MosSET ITURRASPE, Jorge-WAJNTRAUB, Javier H., Ley de Defensa del Consumidor..., cit., pág. 90.

${ }^{599}$ ZENTNER, Diego H., "Contratos de Consumo", Capítulo VIII, en RusCONI, Dante (Coord.), Manual de Derecho del Consumidor, Abeledo Perrot, Buenos Aires, 2015, pág. 420. El autor destaca que en el Código de Vélez, la regla era la no obligatoriedad de la oferta, por hallarse sujeta a retractación mientras que la nueva regulación propone un nuevo esquema. En efecto, el nuevo Código Civil y Comercial unificado, dentro del Título II referido a los contratos en general (el Título III es el dedicado a los contratos de consumo), contiene el art. 972 que dispone: "Oferta. La oferta es la manifestación dirigida a persona determinada o determinable, con la intención de obligarse y con las precisiones necesarias para establecer los efectos que debe producir de ser aceptada". Art. 973: "Invitación a ofertar. La oferta dirigida a personas indeterminadas es considerada como invitación para que hagan ofertas, excepto que de sus términos o de las circunstancias de su emisión resulte la intención de contratar del oferente. En este caso, se la entiende emitida por el tiempo y en las condiciones admitidas por los usos". El art. 974 establece: "Fuerza obligatoria de la oferta. La oferta obliga al proponente, a no ser que lo contrario resulte de sus términos, de la naturaleza del negocio o de las circunstancias del caso. La oferta hecha a una persona presente o la formulada por un medio de comunicación instantáneo, sin fijación de plazo, sólo puede ser aceptada inmediatamente. Cuando se hace a una persona que no está presente, sin fijación de plazo para la aceptación, el proponente queda obligado hasta el momento en que puede razonablemente esperarse la recepción de la respuesta, expedida por 1 os medios usuales de comunicación. Los plazos de vigencia de la oferta comienzan a correr desde la fecha de su recepción, excepto que contenga una previsión diferente". 
potenciales indeterminados. Así se menciona que la oferta debe ser completa, con referencia a todos los elementos esenciales -bien o servicio sobre el que versa y las condiciones de su contratación- así como respecto de aspectos secundarios que adquieren relevancia en esta categoría contractual (condiciones de pago, plazos, tasa de interés, otras circunstancias de la obligación, etc. ${ }^{600}$. Ahora bien, se habla de una completividad ampliada pues el contenido del plan prestacional resultará no sólo de la voluntad expresamente manifestada sino de aquellos deberes que se deriven de la ley y de la publicidad (conf. art. 8) ${ }^{601}$. Se advierte que si lo que faltan son elementos que no hacen a la existencia del contrato sino a la comprensión del consumidor respecto de aquéllos, habrá oferta y contrato, aunque pueda verse comprometida la responsabilidad del proveedor por incumplimiento de su deber de informar ${ }^{602}$.

En rigor, el carácter vinculante de la oferta del proveedor, se deriva de la imposibilidad de revocarla o al deber de mantenerla durante el plazo que corresponda ${ }^{603}$. De allí que se entienda que las ofertas al público en los contratos de consumo son genuinamente obligatorias mientras transcurra el lapso temporal que va entre la fecha de comienzo y finalización, cuya precisión impone la preceptiva analizada ${ }^{604}$.

La norma faculta al oferente a revocar la oferta hecha al público para lo cual deberá difundir esa revocación por medios similares a los empleados para hacerla conocer. Por ende, si el oferente decide retirar la oferta o modificar algún aspecto de la misma, deberá orientar su mensaje al público al cual fue dirigida la propuesta original recurriendo a medios equivalentes de difusión. De no cumplirse los requisitos de la ley, la oferta deberá considerarse vigente y podrá el consumidor aceptarla, configurándose el contrato en cuestión. El retiro extemporáneo de la oferta no tendrá virtualidad jurídica, y frente a la aceptación del consumidor, el oferente estará obligado al cumplimiento del contrato y, en

\footnotetext{
${ }^{600}$ GHERsi, Carlos-Weingarten, Celia (Dir.), Tratado Jurisprudencial..., cit., pág. 270.

${ }^{601}$ LORENZETTI, Ricardo L., Consumidores, cit., pág. 231 y sgtes.

${ }^{602}$ Mosset Iturraspe, Jorge-WajnTraub, Javier H., Ley de Defensa del Consumidor..., cit., pág. 91. LORENZETTI, Ricardo L., Consumidores, cit., pág. 235.

${ }^{603}$ STIGLitZ, Rubén S.- STIGLiTZ, Gabriel A., Responsabilidad precontractual, Abeledo Perrot, Buenos Aires, 1992, pág. 130.

${ }^{604}$ ZENTNER, Diego H., “Contratos de Consumo...”, cit., pág. 412.
} 
su caso, a soportar los remedios previstos para el supuesto de incumplimiento contractual conforme el régimen protectorio, con más las sanciones adicionales que correspondan ${ }^{605}$.

c.2. En la etapa de celebración y ejecución del contrato de crédito

c.2.1. Deber de información a cargo del proveedor

Centrados ya en la etapa de celebración y ejecución del contrato de crédito, la Directiva 2008/48 dedica varias normas a reforzar el débito informativo impuesto al agente financiero. Prueba de ello son los arts. 10 (referido a la "información que debe mencionarse en los contratos de crédito") y 11 (vinculado a la "información del tipo deudor").

El considerando 31 establece que "con el fin de que el consumidor pueda conocer sus derechos y obligaciones en virtud del contrato, este debe contener toda la información necesaria de forma clara y precisa".

La doctrina repite hasta el cansancio que el deber de información constituye una obligación que no sólo se impone al proveedor en la etapa precontractual y al momento de concretar la celebración del contrato sino que debe ser cumplida durante todo el íter contractual. Sólo de ese modo se satisface en plenitud, la finalidad perseguida al diseñar esta herramienta jurídica $^{606}$. Esta regla luce claramente justificada en la operatoria de crédito.

El nuevo Código Civil y Comercial argentino, al regular los contratos bancarios en general, dentro del parágrafo titulado "Transparencia de las condiciones contractuales",

\footnotetext{
${ }^{605}$ Mosset ItURRASPE, Jorge-WajnTRAub, Javier H., Ley de Defensa del Consumidor..., cit., pág. 92.

${ }^{606}$ Para que los consumidores obtengan la ejecución satisfactoria con relación a un bien o servicio contratado, el deber de información que de acuerdo a la ley 24.240 recae sobre los proveedores de servicios, debe ser previo, concomitante y posterior a la formalización del contrato, pues ello hace al leal y cabal conocimiento que el consumidor debe tener sobre los alcances de la relación jurídica que lo vincula con quien posee el poder económico de predisponer los términos contractuales" (C. Cont. Adm. y Trib. Ciudad Autónoma de Buenos Aires, sala II, 1/12/2011, "Direct TV Argentina S.A. c. Gobierno de la Ciudad de Buenos Aires”, LL Online, AR/JUR/86563/2011). Nos recuerda López Cabana que "el para qué debe contratar el consumidor con información, tiene una respuesta doble: a.- tiende a proteger el consentimiento a prestar y, b.- una vez formalizado el contrato debe ayudarlo a utilizar satisfactoriamente el producto o servicios" (LÓPEZ CABANA, Roberto M., "La información en los contratos de consumo”, en J.A. 1995-IV-800).
} 
emplaza al art. 1382, conforme al cual la entidad bancaria debe suministrar información periódica a quien se vincula contractualmente con ella. Dispone, en efecto, la norma citada: "El banco debe comunicar en forma clara, escrita o por medios electrónicos previamente aceptados por el cliente, al menos una vez al año, el desenvolvimiento de las operaciones correspondientes a contratos de plazo indeterminado o de plazo mayor a un año. Transcurridos sesenta días contados a partir de la recepción de la comunicación, la falta de oposición escrita por parte del cliente se entiende como aceptación de las operaciones informadas, sin perjuicio de las acciones previstas en los contratos de consumo. Igual regla se aplica a la finalización de todo contrato que prevea plazos para el cumplimiento”. Como ya se señalara, el dispositivo procura que el cliente haga un seguimiento del desarrollo de la operatoria, conozca su evolución, advierta la trayectoria de la misma, realice proyecciones y actúe en consecuencia.

\section{c.2.2. Imposición de formalidades al contrato: la forma escrita.}

Si se impone al proveedor el deber de entregar un modelo representativo de contrato cuya celebración se propone, y hacerlo en forma anticipada a la formalización del mismo, resulta indudable la necesidad de una norma expresa que imponga la forma escrita del contrato en cuestión.

La Directiva 2008/48 de Crédito al Consumo así lo recomienda en el art. 6.1. En efecto, dispone la norma citada: "1. Con la debida antelación, y antes de que el consumidor asuma cualquier obligación en virtud de un contrato de crédito o una oferta relativa a un contrato de crédito ... el prestamista y, cuando proceda, el intermediario de crédito, deberán facilitar al consumidor, sobre la base de las condiciones del crédito ofrecidas por el prestamista y, en su caso, de las preferencias manifestadas y de la información facilitada por el consumidor, la información que sea precisa para comparar las diversas ofertas y adoptar una decisión informada sobre la suscripción de un contrato de crédito.

La Ley 16/2011 de Contratos de Crédito al Consumo española que tomamos de modelo, dedica el art. 16 a la "Forma y Contenido de los contratos". Respecto del primer aspecto, que ahora nos ocupa, la norma dispone:

“1. Los contratos de crédito sometidos a la presente Ley se harán constar por escrito en papel o en otro soporte duradero y se redactarán con una letra que resulte legible y con un 
contraste de impresión adecuado. Todas las partes contratantes recibirán un ejemplar del contrato de crédito".

La doctrina ha destacado que el sistema de tutela de los consumidores es revelador del resurgimiento del formalismo en materia contractual, que hace excepción a la tendencia general, encaminada a aligerar la expresión del consentimiento de las partes ${ }^{607}$. En sentido concordante, se dice que la Ley de Contratos de Crédito al Consumo constituye un ejemplo más, que pone de manifiesto el renacimiento del principio formalista como mecanismo orientado a garantizar la emisión de un consentimiento pleno por parte del sujeto débil en la contratación de consumo ${ }^{608}$.

En particular, se entiende que la forma escrita impuesta al contrato de crédito al consumo por el art. 16, se encamina a asegurar que el consumidor tome conocimiento de la información que constituye ese contenido mínimo impuesto al contrato y pueda conservarla. De allí que la forma escrita deba utilizar el papel o cualquier otro soporte duradero $^{609}$.

Se considera que dada la notoria complejidad de la operatoria de crédito y de los contratos que instrumentan estos negocios, la imposición de la forma escrita es un mecanismo protectorio eficaz. "Si se toma la escritura como un indicio de seriedad (verba volant, scripta manet), la forma puede cumplir una función preventiva, porque alerta al consumidor frente a los riesgos que asume. En tal hipótesis, la forma es un requisito de conclusión del contrato: le da vida y, sin ella, el contrato es nulo"610.

El art. 21 prevé la penalización por inobservancia de la forma prevista por la ley, al establecer: "1. El incumplimiento de la forma escrita a que se refiere el párrafo primero del apartado 1 del artículo 16 dará lugar a la anulabilidad del contrato".

\footnotetext{
${ }^{607}$ TORRES GARCíA, Teodora F., "Protección del consumidor y derecho de la contratación", en Separata del Libro homenaje a ldelfonso Sánchez Mera, Europa Notario-Consejo General del Notariado, Madrid, 2002, pág. 881; ORTi VAllejo, Antonio, "Derecho a la información” en BerCovitz, Rodrigo - SAlAS, Javier, Comentarios a la ley para la defensa de los consumidores y usuarios, Civitas, Madrid, 1992, pág. 416.

${ }^{608}$ ORDÁs AlOnSO, Marta, Los contratos de crédito al consumo..., cit., pág. 163

${ }^{609}$ Arroyo Amayuelas, Esther, en Marín LóPez, Manuel Jesús (Dir.), Comentarios a la Ley de Crédito al Consumo, Thomson Reuters-Aranzadi, Pamplona 2014, pág. 650 y sgtes.

${ }^{610}$ Arroyo AmayUelas, Esther, en Marín LóPeZ, Manuel Jesús (Dir.), Comentarios ..., cit., pág. 654.
} 
La ley determina que el incumplimiento de la forma escrita provoca la anulabilidad del contrato ${ }^{611}$. La solución del art. 21, conforme la Ley 16/2011, se aparta de la norma que le sirve de antecedente pues en los arts. 6 y 7 de la Ley 7/1995 de Crédito al Consumo derogada, la inobservancia de la forma escrita se sancionaba con la nulidad del contrato; dispositivo que generó duras críticas puesto que importaba desbaratar el negocio e imponer a las partes el deber de restituirse, lo que en virtud del contrato hubieran recibido (el capital del crédito concedido, antes del plazo, por ejemplo) ${ }^{612}$.

Establece el precepto analizado que una vez formalizado el contrato, todas las partes contratantes deben recibir un ejemplar. Se trata de un deber impuesto la entidad de crédito que es quien provee el instrumento que formaliza el contrato, lo ofrece a los sujetos intervinientes (tomador del crédito, fiador, avalista, aseguradora, etc.), trabaja sobre el mismo ajustándolo -en lo pertinente- a los requerimientos particulares y gestiona el acto de suscripción. Pese a la literalidad de la norma, y a la opinión de algún sector doctrinario ${ }^{613}$, se considera que "será suficiente con la existencia de un ejemplar por cada término de la relación contractual" ${ }^{\prime 614}$. Se cree que deben recibir necesariamente un ejemplar del contrato las partes contratantes y no los restantes sujetos intervinientes que, en su caso, podrán acceder a una copia del mismo.

La norma analizada no prevé expresamente el momento en que debe concretarse la entrega del contrato aunque la lógica indica que será al momento de su conclusión y firma

\footnotetext{
${ }^{611}$ Para el análisis de la naturaleza de la forma impuesta, ver ORDÁs ALONSO, Marta, Los contratos de crédito al consumo..., cit., pág. 164 y sgtes.

${ }^{612}$ Roca GuILlamón, Juan, "Los contratos de crédito al consumo. Forma y contenido, reembolso anticipado y cobros indebidos (Ley 7/1995, de 23 de Marzo)", en NIETO CAROL, Ubaldo (Dir), Crédito al Consumo y transparencia bancaria, Civitas, Madrid, 1998, pág. 200.

${ }^{613}$ Cfr. Bernal Del Castillo, Ángel, "La Ley 7/1995, de 23 de marzo, de Crédito de Consumo”, en DE LEÓn ARCE, Alicia (Dir.), Derechos de los consumidores y usuarios”, Tirant lo Blanch, Madrid, 2007, pág. 418; Asimismo, ver las consideraciones que se formulan en atención a previsiones particulares sobre transparencia de los servicios bancarios, en ARROYO AMAYUELAS, Esther, en MARín LÓPEZ, Manuel Jesús (Dir.), Comentarios..., cit., pág. 665.

${ }^{614}$ ORDÁs Alonso, Marta, Los contratos de crédito al consumo..., cit., pág. 169.
} 
por las partes. Ello no obsta a que la entrega pueda cumplirse, sin menoscabo de los derechos del consumidor, en forma inmediata posterior ${ }^{615}$.

La ley española no prevé sanción alguna para el caso de incumplimiento del deber de entrega del ejemplar del contrato pero se entiende que el consumidor estará habilitado a ejercer la facultad de reclamar la datio del instrumento, venciendo la resistencia de la entidad de crédito. Existe consenso respecto de que ese incumplimiento no debe acarrear la anulabilidad del contrato sino generar los correctivos orientados a la satisfacción del interés concreto -acceder al ejemplar o a la copia del contrato- y a la censura de la inconducta con la sanción administrativa que corresponda ${ }^{616}$.

El nuevo Código Civil y Comercial argentino, al regular los contratos bancarios en general, dentro del parágrafo titulado "Transparencia de las condiciones contractuales", emplaza el art. 1380, que dispone: "Forma. Los contratos deben instrumentarse por escrito, conforme a los medios regulados por este Código. El cliente tiene derecho a que se le entregue un ejemplar". Y más concretamente, en el parágrafo dedicado a los "Contratos bancarios con consumidores y usuarios", la directiva impartida se refuerza con el art. 1386, que reza: "Forma. El contrato debe ser redactado por escrito en instrumentos que permitan al consumidor: a) obtener una copia; b) conservar la información que le sea entregada por el banco; c) acceder a la información por un período de tiempo adecuado a la naturaleza del contrato; d) reproducir la información archivada".

La exigencia de la forma legalmente impuesta luce satisfecha de cualquiera de los modos en que la expresión escrita puede manifestarse conforme las previsiones del mencionado código (conf. art. 286). En efecto, "puede tener lugar por instrumento público o por instrumentos privados firmados o no firmados, excepto en aquellos casos en que determinada instrumentación sea impuesta. En los instrumentos generados por medios electrónicos, el requisito de la firma queda satisfecho si se utiliza una firma digital que asegure indubitablemente la autoría e integridad del instrumento (art. 288). Con respecto al soporte instrumental, el citado art. 286 autoriza que se utilice cualquier soporte, siempre que su contenido sea representado con texto inteligible, aunque su lectura exija medios

\footnotetext{
${ }^{615}$ ARroyo Amayuelas, Esther, en Marín LóPez, Manuel Jesús (Dir.), Comentarios..., cit., pág. 666 y sgtes.

${ }^{616}$ ORDÁs AlONSO, Marta, Los contratos de crédito al consumo ..., cit., pág. 169.
} 
técnicos. En la misma línea, el art. 1106, referido a los contratos de consumo en general, establece que siempre que el código o leyes especiales exijan que el contrato conste por escrito, este requisito se debe entender satisfecho si se emplea un soporte electrónico u otra tecnología similar" ${ }^{\prime 617}$.

Celebramos la previsión expresa de la forma escrita en el nuevo Código Civil y Comercial puesto que hace explícitas las necesidades del cliente, que la formalidad impuesta procura satisfacer. Con acierto se destaca que la misma propiciará un mayor resguardo protectorio de los consumidores al permitirles "obtener una copia, conservar la información que le sea entregada por el banco, acceder a la información por un período de tiempo adecuado a la naturaleza del contrato, y reproducir información archivada...exigencias todas compatibles con la utilización de los medios electrónicos"618.

\section{c.2.3. Imposición de un contenido mínimo al contrato}

Los documentos comunitarios, desde que el debate quedó planteado, marcan la necesidad de establecer un contenido contractual mínimo y estandarizado que facilite el acceso, la obtención, la aprehensión y el aprovechamiento de la información. Así lo prevé el art. 10 de la Directiva 2008/48.

Se trata de establecer un piso mínimo de disposiciones contractuales que garanticen la transparencia y seriedad de la operatoria ofrecida a quienes buscan financiamiento para el acceso a bienes de consumo. El legislador determinará el quid y el quantum de ese contenido mínimo, que deberá ser revisado periódicamente para proceder a los ajustes que fueran necesarios.

El control de cumplimiento de este clausulado mínimo luce sencillo no bien se advierte que basta con establecer un catálogo de condiciones generales a incluir en los contratos particulares que luego serán propuestos -con sus agregados- para la aprobación concreta de la autoridad de aplicación. Ahora bien, y como se dijo, debería existir una permanente evaluación de estos contenidos a fin de agregar los que fueran necesarios, adecuarlos o corregirlos.

\footnotetext{
${ }^{617}$ Alterini, Jorge H. (Dir.), Código Civil y Comercial de la Nación..., T. VII, cit., pág. 50).

${ }^{618}$ BARBIER, Eduardo, en LORENZETTI, Ricardo L. (Dir.), Código Civil y Comercial de la Nación..., cit., pág. 254.
} 
El establecimiento de esta base contractual uniforme en todos los contratos de la misma especie, marca un piso. Este contenido minimun legalmente impuesto corporiza un estándar de protección que podrá elevarse a instancias del propio proveedor de crédito incluyendo precisiones informativas adicionales o cualquier otra previsión que contribuya al resguardo del interés del consumidor- pero no menguarse.

La uniformidad del clausulado mínimo cumplirá -como en todas las condiciones generales de contratación- una función iluminista. La estandarización del contenido base propicia su difusión, mejorando la información general disponible; y con ello, la previsibilidad del negocio. Servirá asimismo como motor de confianza en la operatoria puesto que, al menos sobre estos aspectos, se entenderá que las condiciones de contratación son serias y leales.

La Ley 16/2011 de Contratos de Crédito al Consumo española que nos sirve de modelo, dedica el art. 16 al contenido mínimo que fija el piso sobre el cual habrá de construirse el contrato ${ }^{619}$. Dispone:

“...2. Además de las condiciones esenciales del contrato, el documento deberá especificar, de forma clara y concisa, los siguientes datos:

a) El tipo de crédito.

b) La identidad y el domicilio social de las partes contratantes, así como, si procede, la identidad y el domicilio social del intermediario de crédito.

c) La duración del contrato de crédito.

d) El importe total del crédito y las condiciones de disposición del mismo.

e) En el caso de créditos en forma de pago diferido de un bien o servicio o en el caso de contratos de crédito vinculados, el producto o servicio y su precio al contado.

f) El tipo deudor y las condiciones de aplicación de dicho tipo y, si se dispone de ellos, los índices o tipos de referencia aplicables al tipo deudor inicial, así como los períodos, condiciones y procedimientos de variación del tipo deudor y, si se aplican diferentes tipos deudores en diferentes circunstancias, la información arriba mencionada respecto de todos los tipos aplicables.

${ }^{619}$ Ver del desarrollo del tema en ARroyo AMAYUELAS, Esther, en MARÍN LÓPEZ, Manuel Jesús (Dir.), Comentarios..., cit., pág. 644 y sgtes.; ORdás AlOnSO, Marta, Los contratos de crédito al consumo..., cit., pág. 170 y sgtes. 
g) La tasa anual equivalente y el importe total adeudado por el consumidor, calculados en el momento de la suscripción del contrato de crédito. Se mencionarán todas las hipótesis utilizadas para calcular dicho porcentaje.

h) El importe, el número y la periodicidad de los pagos que deberá efectuar el consumidor $y$, cuando proceda, el orden en que deben asignarse los pagos a distintos saldos pendientes sometidos a distintos tipos deudores a efectos de reembolso.

i) En caso de amortización del capital de un contrato de crédito de duración fija, el derecho del consumidor a recibir gratuitamente un extracto de cuenta, en forma de cuadro de amortización, previa solicitud y en cualquier momento a lo largo de toda la duración del contrato de crédito.

El cuadro de amortización indicará los pagos adeudados, así como los períodos y las condiciones de pago de tales importes. Este cuadro deberá contener un desglose de cada reembolso periódico que muestre la amortización del capital, los intereses calculados sobre la base del tipo deudor y, en su caso, los costes adicionales.

Cuando el tipo de interés no sea fijo o los costes adicionales puedan variar en virtud del contrato de crédito, en el cuadro de amortización figurará de forma clara y concisa la indicación de que los datos del cuadro solo serán válidos hasta la siguiente modificación del tipo deudor o de los costes adicionales en virtud del contrato de crédito.

j) Si deben pagarse recargos e intereses sin amortización de capital, una relación de los períodos y las condiciones de pago de los intereses deudores y de los gastos conexos recurrentes y no recurrentes.

k) Cuando proceda, los gastos de mantenimiento de una o varias cuentas que registren a la vez operaciones de pago y de disposición del crédito, salvo que la apertura de la cuenta sea opcional, los gastos relativos a la utilización de un medio de pago que permita efectuar tanto operaciones de pago como de disposición del crédito, así como los demás gastos derivados del contrato de crédito y las condiciones en que dichos costes pueden modificarse.

1) El tipo de interés de demora aplicable en el momento de la celebración del contrato de crédito y los procedimientos para su ajuste y, cuando proceda, los gastos por impago.

m) Las consecuencias en caso de impago.

n) Cuando proceda, una declaración que establezca el abono de gastos de notaría. 
o) Las garantías y los seguros a los que se condicione la concesión del crédito, cuya contratación se ajustará a la legislación específica de los mismos.

p) La existencia o ausencia de derecho de desistimiento y el plazo y demás condiciones para ejercerlo, incluida la información relativa a la obligación del consumidor de pagar el capital dispuesto y los intereses de conformidad con el artículo 28, apartado 2, letra b), y el importe del interés diario.

q) Información sobre los derechos derivados del artículo 29, así como las condiciones para el ejercicio de dichos derechos.

r) El derecho de reembolso anticipado, el procedimiento aplicable, así como en su caso información sobre el derecho del prestamista a una compensación y sobre la manera en que se determinará esa compensación. Para el caso de reembolso anticipado y en caso de que el contrato de crédito tenga vinculado uno de seguro, el derecho del prestatario a la devolución de la prima no consumida en los términos que establezca la póliza.

s) El procedimiento que deberá seguirse para ejercer el derecho de poner fin al contrato de crédito.

t) La existencia o no de procedimientos extrajudiciales de reclamación y recurso para el consumidor, y, en caso de que existan, la forma en que el consumidor puede acceder a ellos.

u) Las demás condiciones del contrato, cuando proceda.

v) En su caso, nombre y dirección de la autoridad de supervisión competente.

3. En el supuesto contemplado en la letra i) del apartado anterior, el prestamista deberá poner gratuitamente a disposición del consumidor un extracto de cuenta en forma de cuadro de amortización en cualquier momento a lo largo de toda la duración del contrato de crédito.

4. En el caso de los contratos de crédito en que los pagos efectuados por el consumidor no producen una amortización correspondiente del importe total del crédito, sino que sirven para reconstituir el capital en las condiciones y los períodos establecidos en el contrato de crédito o en un contrato accesorio, la información contractual exigida en virtud del apartado 2 deberá incluir una declaración clara y concisa de que tales contratos no prevén una garantía de reembolso del importe total del crédito del que se haya dispuesto en virtud del contrato de crédito, salvo que se conceda dicha garantía". 
Por su parte, el art. $21^{620}$ prevé la "Penalización por falta de forma y por omisión de cláusulas obligatorias", al establecer:

“...2. En el supuesto de que el documento del contrato no contenga la mención a la tasa anual equivalente a la que se refiere la letra g) del apartado 2 del artículo 16, la obligación del consumidor se reducirá a abonar el interés legal en los plazos convenidos.

3. En el supuesto de que el documento del contrato no contenga la mención a que se refiere la letra h) del apartado 2 del artículo 16, y siempre que no exista omisión o inexactitud en el plazo, la obligación del consumidor se reducirá a pagar el precio al contado o el nominal del crédito en los plazos convenidos.

En el caso de omisión o inexactitud de los plazos, dicho pago no podrá ser exigido al consumidor antes de la finalización del contrato.

4. En el caso de que los datos exigidos en el apartado 2 del artículo 16 y en el artículo 17 figuren en el documento contractual pero sean inexactos, se modularán, en función del perjuicio que debido a tal inexactitud sufra el consumidor, las consecuencias previstas en los apartados 2 y 3 anteriores".

El legislador argentino deberá -en la regulación que propiciamos- establecer el elenco de previsiones contractuales básicas para garantizar al consumidor, que el contrato contiene el quid del negocio, desde lo cualitativo y lo cuantitativo, ajustándose al principio protectorio.

El catálogo de contenido previsto por el art. 36 de la ley 24.240 resulta insuficiente. Se impone una regulación particular, que contemple ese contenido mínimo pero lo haga teniendo en miras el fenómeno problemático que nos ocupa: neutralizar situaciones y prácticas que sirven de causa o condición al sobreendeudamiento de los consumidores.

La entrada en vigencia del nuevo Código Civil y Comercial argentino, aporta dos normas particulares de gran importancia, que complementan el dispositivo de la aludida ley de defensa del consumidor. Al regular los contratos bancarios en general, dentro del parágrafo titulado "Transparencia de las condiciones contractuales”, encontramos al art. 1381, que dispone: "Contenido. El contrato debe especificar la tasa de interés y cualquier precio, gasto, comisión y otras condiciones económicas a cargo del cliente. Si no determina

${ }^{620}$ Para un análisis del tema, ver, ARROYO AMAYUELAS, Esther, en MARín LÓPEZ, Manuel Jesús (Dir.), Comentarios..., pág. 807-827. 
la tasa de interés, es aplicable la nominal mínima y máxima, respectivamente, para las operaciones activas y pasivas promedio del sistema, publicadas por el Banco Central de la República Argentina a la fecha del desembolso o de la imposición". Por otra parte, en el parágrafo dedicado a los "Contratos bancarios con consumidores y usuarios", el art. 1388, que reza: "Contenido. Sin perjuicio de las condiciones establecidas para los contratos bancarios en general, ninguna suma puede ser exigida al consumidor si no se encuentra expresamente prevista en el contrato. En ningún caso pueden cargarse comisiones o costos por servicios no prestados efectivamente. Las cláusulas relativas a costos a cargo del consumidor que no están incluidas o que están incluidas incorrectamente en el costo financiero total publicitado o incorporado al documento contractual, se tienen por no escritas".

La regulación de este tópico, en el nuevo Código Civil y Comercial argentino, constituye un aporte desde lo conceptual y contribuye a la eficacia de los dispositivos existentes. Por un lado, traduce en una norma legal de rango superior, una regla que no resulta sobreabundante pese a la evidencia de la directiva que contiene; esto es, la prohibición de cargar costos por servicios que no hayan sido efectivamente prestados ${ }^{621}$. De otro lado, plantea las hipótesis que pueden ser ocasión de conflicto en la operatoria de crédito y que merecían un tratamiento particular: la imposición de cargos por nuevos servicios no previstos contractualmente y la modificación de los cargos originariamente previstos.

La norma analizada consagra una regla clara conforme la cual ninguna suma puede ser exigida al consumidor, si no se encuentra expresamente prevista en el contrato. Ahora bien, la doctrina con acierto señala que la realidad de estos contratos impone distinguir situaciones y adoptar criterios de razonabilidad, ajustados a la particular naturaleza del servicio de que se trata y al conjunto de los intereses involucrados, sin descuidar la protección del sujeto que motiva nuestros desvelos. "Sucede que muchos de los contratos bancarios son celebrados por tiempo indeterminado o por largos períodos de tiempo. En estos contratos, y con motivo del incesante avance tecnológico, la mayor sofisticación de la actividad bancaria y la multiplicidad de servicios que los bancos brindan a sus clientes,

${ }^{621}$ Esta previsión ya se encontraba prevista en las normas sobre "Protección de usuarios de servicios financieros” dictada por el Banco Central de la República Argentina 
permanentemente se incorporan nuevos servicios, tal vez inexistentes al momento de la celebración del contrato, por lo que no pudieron ser previstos en él...En estos supuestos de nuevos servicios no previstos contractualmente, así como en los casos de cambios en los costos de las comisiones y cargos que se hallaban pactados, los bancos deberán cumplir con las normas ...sobre 'Protección de usuarios y servicios financieros' que ...prevén dos formas diferentes por las que se puede obtener el consentimiento del cliente. Éstas dependerán de si lo que se notifica es una modificación del costo de un concepto o, en cambio, la incorporación de uno nuevo. En el primer supuesto, el consentimiento puede ser tácito, por falta de objeción al mismo dentro del plazo establecido para ello. Más... cuando lo que se pretende es la incorporación de nuevos conceptos en calidad de comisiones y/o cargos que no hubiesen sido previstos en el contrato, se requiere obtener previamente el consentimiento expreso del cliente" ${ }^{, 622}$.

622 Alterini, Jorge H. (Dir.), Código Civil y Comercial de la Nación..., T. VII, cit., pág. 59. La Comunicación A 5460 del BCRA, en su apartado 2.3.4. referido a "Cambios de condiciones pactadas", dispone: "A fin de modificar las condiciones pactadas debe darse la totalidad de las siguientes condiciones: i) En el contrato deberán encontrarse taxativamente especificadas las condiciones que pueden ser objeto de modificación así como los parámetros o criterios objetivos para su concreción, ajustándose a lo señalado en el punto 2.3.2. Los incrementos en las tasas de interés, comisiones y/o cargos, además, deben ser justificados desde el punto de vista técnico y económico, en el marco de lo dispuesto en el punto 2.3.2.1. ii) La modificación no debe alterar el objeto del contrato ni importar un desmedro respecto de los productos o servicios contratados. iii) Consentimiento. En el caso de que el sujeto obligado pretenda incorporar nuevos conceptos en calidad de comisiones y/o cargos que no hubiesen sido previstos en el contrato o reducir prestaciones contempladas en él, deberá previamente obtener el consentimiento expreso del usuario de servicios financieros. Cuando se trate de modificaciones en los valores de comisiones y/o cargos debidamente aceptados por el usuario, su consentimiento al cambio podrá quedar conformado por la falta de objeción al mismo dentro del plazo establecido en el acápite iv). En los contratos de tarjeta de crédito el consentimiento a modificaciones en las condiciones pactadas (nuevas comisiones y/o cargos) sólo puede ser dado por el titular de la cuenta. iv) Notificaciones. Forma, plazos y efectos. El usuario de servicios financieros debe ser notificado de las modificaciones que aplicará el sujeto obligado con una antelación mínima de (60) sesenta días corridos a su entrada en vigencia. Las modificaciones que resulten económicamente más beneficiosas para el usuario -por una reducción de los valores pactados- no requieren notificación anticipada. Las notificaciones por cambios de condiciones pactadas (nuevos conceptos y/o valores o reducción de prestaciones del servicio) serán en todos los casos gratuitas para el usuario de servicios financieros. deberán efectuarse mediante documento escrito dirigido al domicilio real del usuario de servicios financieros -en 
Estas precisiones conducen a interpretar adecuadamente las disposiciones legales aplicables y respetar la necesaria coherencia del sistema. Oportuno es recordar que el Código Civil y Comercial prevé en el art. 1383, que "el cliente tiene derecho, en cualquier momento, a rescindir un contrato por tiempo indeterminado sin penalidad ni gastos, excepto los devengados antes del ejercicio de este derecho", dejando a resguardo su derecho a repensar la conveniencia de la operatoria y su permanencia en el contrato, así como decidir la salida del mismo, sin costes adicionales ni sanciones.

La previsión del art. 1388 comentado cierra su texto con una directiva de protección directa del consumidor bancario, al establecer que "Las cláusulas relativas a costos a cargo del consumidor que no están incluidas o que están incluidas incorrectamente en el costo financiero total publicitado o incorporado al documento contractual, se tienen por no escritas". Se destaca que "esta norma puede disuadir posibles artilugios o prácticas abusivas de parte de los bancos, por lo que, por una parte, se pretenda publicar o consignar un costo financiero total menor al real a fin de hacer más atractivo el crédito ofrecido, mientras que, por otro lado, se incluyan cláusulas expresas en los contratos en los que específicamente se pongan a cargo del consumidor ciertos gastos o comisiones. Al existir las mencionadas cláusulas expresas en los contratos -y de no existir la norma en comentario-, los bancos podrían alegar que, pese al error cometido al calcular el costo financiero total, igualmente tienen derecho a percibir los conceptos no incorporados o incorporados erróneamente, ya que estaría fuera de discusión que ellos fueron pactados..."623. En la interpretación propiciada, los bancos no podrán pretender el cobro de conceptos no incorporados en el costo financiero total y los incorporados incorrectamente, sólo en la medida que lo estén.

\footnotetext{
forma separada de cualquier otra información que remita el sujeto obligado (resúmenes de cuenta, boletines informativos, etc.), aun cuando forme parte de la misma remesa- o a su correo electrónico en aquellos casos en que hubiere expresamente aceptado esa forma de notificación. En el cuerpo de estas notificaciones deberá incluirse una leyenda para indicar que en el caso de que el usuario de servicios financieros no acepte la modificación promovida por el sujeto obligado, podrá optar por rescindir el contrato en cualquier momento antes de la entrada en vigencia del cambio y sin cargo alguno, sin perjuicio de que deberá cumplir las obligaciones pendientes a su cargo".

${ }^{623}$ Alterini, Jorge H. (Dir.), Código Civil y Comercial de la Nación..., T. VII, cit., pág. 61.
} 
c.2.4. Imposición de un desembolso inicial.

Algunos autores piensan que "la exigencia de un abono inicial mínimo en las compras a precio aplazado comporta un instrumento de reafianzamiento de la conveniencia, maduración y valoración de la decisión de adquisición de bienes y productos, al que también se apunta como un medio de acreditación inicial de una mínima solvencia”. Consideran que "esta medida actúa, como una mínima barrera psicológica (pues tiene una mayor virtualidad en ese orden, que de obstáculo económico real), que lleva a sopesar y tener una mayor consciencia sobre el deseo, la posibilidad y la necesidad de adquirir un bien o producto $\mathrm{y}$, con ello, a prevenir ciertos fenómenos relacionados con el sobreendeudamiento, como la compra irreflexiva y la compulsiva”. Y entienden que aunque no sea una medida popular, tal exigencia podría "sopesarse en el marco de una política integral de prevención del sobreendeudamiento ${ }^{624}$.

Creemos que imponer este desembolso inicial en -al menos- algunas operaciones de consumo financiado, puede tratarse de una herramienta eficaz para llamar la atención del consumidor sobre las obligaciones asumidas con esa operación.

Hemos señalado ya que la financiación a largo plazo crea una idea de licuación de la deuda contraída puesto que el deudor tiende a reparar en la menor cuantía de la cuota, ignorando el monto total de la deuda contraída; y resulta evidente que esta mirada desenfocada de la realidad no contribuye a la concientización del compromiso de la situación patrimonial del obligado.

Al la fuerza inductiva de la publicidad, que impulsa eficazmente a la contratación, se suma el natural optimismo del consumidor, ilusionado con la adquisición de un producto o la contratación de un servicio en forma financiada, o con la toma de un empréstito que le permitirá acceder a bienes del mercado.

Es frecuente que, a fin de estimular al consumidor, el proveedor ofrezca la contratación, con entrega inmediata del producto o servicio, sin desembolso inicial y con una financiación prolongada del precio. Este anticipo o primer pago, postergado en el tiempo, libera al consumidor de todo sacrificio económico de arranque, despejando obstáculos.

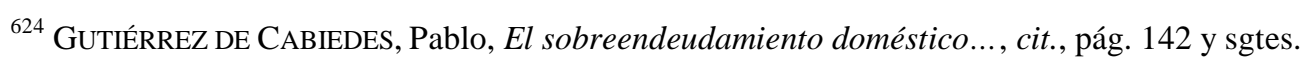


El consumidor motivado a la contratación transita un natural optimismo y suele subestimar la eventualidad de acontecimientos adversos que puedan comprometer el éxito de la operación en la que se embarca o su cuadro de situación patrimonial como consecuencia de dicha contratación. La actual satisfacción es sobrevalorada y los costos futuros tienden a ser minimizados. Ello explica que como estrategia de colocación, se apele a slogans tales como "compre ahora y pague después", "lleve hoy y pague la primera cuota recién a los 90 días". La gratificación inmediata es irresistible para el consumidor y esta postergación del sacrificio que supone el pago de la deuda asumida, muchas veces impide razonarlo para medir sus alcances y derivaciones ${ }^{625}$.

En latitudes donde los consumidores están acostumbrados a transitar situaciones de crisis sistémicas, con escenarios cambiantes e impredecibles, se cae con frecuencia en la trampa de la inmediatez. Y en ese contexto, se hace evidente la tendencia a valorar mucho más un bien si es ofrecido sin dilación temporal que si supone esperar un tiempo con la idea de acceder a otro mejor ${ }^{626}$.

La inexistencia de todo desembolso al momento de contratar desincentiva la reflexión sobre las eventuales desventajas de la operatoria y puede, por tanto, alentar el consumo irresponsable.

En sentido concordante, TrujILlo DIEZ ${ }^{627}$ señala la importancia de imponer un desembolso inicial mínimo en las operaciones con pagos a plazos, como medio de prevenir

\footnotetext{
${ }^{625}$ ANCHÁVAL sostiene que "existen fuerzas del mercado que hacen sumamente difícil la comprensión de muchos fenómenos por parte del consumidor" y de allí que "los individuos incurren en equivocaciones". Explica que los consumidores "enfrentan la información y la racionalidad imperfectas". "Preguntarnos por qué un consumidor se equivoca una y otra vez desestimando la mejor opción racional, puede que no tenga una respuesta sencilla...la respuesta se encuentra en la misperception (la percepción equivocada) que introduce una brecha entre el precio real y el percibido" (ANCHAVAL, Hugo, Insolvencia del consumidor, cit., pág. 52 y sgtes.).

626 "El crédito...no sólo facilita sino que realza, de hecho, la susceptibilidad de los consumidores a la actual tendencia a consumir. El descontar hiperbólico explica (por lo menos en parte) por qué los consumidores supervaloran las ventajas de 'comprar ahora' mientras que minimizan los costos de 'pagar más adelante”" (ANCHAVAL, Hugo, Insolvencia del consumidor, cit., pág. 53).

${ }^{627}$ Trujillo DiEZ, Iván Jesús, El sobrendeudamiento de los consumidores..., cit., pág. 68. El citado autor recuerda el parecer concordante de PASQUAU LIAÑo (PASQUAU LiAÑO, Miguel, "Propuestas para una protección jurídica de los consumidores en materia de créditos de consumo: medidas de prevención y de
} 
el endeudamiento excesivo. Considera que mediante la exigencia de un primer pago al contado, se obliga a realizar una demostración inmediata de cierta solvencia, además de reducirse el importe de la parte aplazada del precio.

\section{c.2.5. Derecho de desistimiento del contrato por parte del consumidor:}

El derecho de arrepentirse -revocando la aceptación antes formulada- es una figura ya conocida en el Derecho comparado ${ }^{628}$ y ha tenido recepción en el ordenamiento jurídico argentino.

En particular, respecto de la operatoria de crédito que nos ocupa, la Directiva 2008/48 de Crédito al Consumo reconoce al tomador, el derecho de arrepentirse y desistir del contrato ya celebrado en el art. $14^{629}$, dispositivo que aporta un remedio eficaz a la prevención del endeudamiento excesivo.

solución de los problemas derivados del sobreendeudamiento”, en Estudios sobre Consumo, núm. 18, 1989, pág. 11-27).

628 Ver Domínguez Luelmo, Andrés, "El derecho de desistimiento", en CÁmara LAPUente, Sergio y ARROYO I AMAYUELAS, Esther (Coord.), La revisión de las normas europeas y nacionales de protección de los consumidores más allá de la Directiva sobre derechos de los consumidores y del Instrumento Opcional sobre un derecho europeo de la compraventa de octubre de 2011,Cívitas, 2012, pág. 209-236. Asimismo, el pormenorizado desarrollo de Álvarez VeGA, María Isabel, Protección jurídica del consumidor..., cit., pág. 330 y sgtes.

${ }^{629}$ Art. 14: "Derecho de desistimiento. 1. El consumidor dispondrá de un plazo de 14 días civiles para desistir del contrato de crédito sin indicar el motivo. Este plazo de desistimiento se iniciará: a) en la fecha de suscripción del contrato de crédito, o bien b) en la fecha en que el consumidor reciba las condiciones contractuales y la información recogida en el artículo 10, si esa fecha fuera posterior a la indicada en la letra a) del presente apartado...3. Si el consumidor ejerce su derecho de desistimiento, deberá: a) para que el desistimiento surta efecto, antes de que expire el plazo previsto en el apartado 1, notificárselo al prestamista ateniéndose a la información facilitada por este último de acuerdo con el artículo 10, apartado 2, letra p), por medios que puedan ser probados de conformidad con la legislación nacional. Se considerará que se ha respetado el plazo si la notificación se ha enviado antes de la expiración del plazo, siempre que haya sido efectuada mediante documento en papel o cualquier otro soporte duradero a disposición del prestamista y accesible para él, y b) pagar al prestamista el capital y el interés acumulado sobre dicho capital entre la fecha de disposición del crédito y la fecha de reembolso del capital, sin ningún retraso indebido a más tardar a los 30 días de haber enviado la notificación de desistimiento al prestamista. Los intereses adeudados se calcularán sobre la base del tipo deudor acordado. El prestamista no tendrá derecho a reclamar al consumidor ninguna 
Por su parte, La Ley 16/2011 de Contratos de Crédito al Consumo española, acoge la figura en el art. 28, conforme el siguiente texto: "Derecho de desistimiento.

1. El derecho de desistimiento de un contrato de crédito es la facultad del consumidor de dejar sin efecto el contrato celebrado, comunicándoselo así a la otra parte contratante en un plazo de catorce días naturales sin necesidad de indicar los motivos y sin penalización alguna.

El plazo para ejercer el derecho de desistimiento se iniciará en la fecha de suscripción del contrato de crédito o bien, si fuera posterior, en la fecha en que el consumidor reciba las condiciones contractuales y la información recogida en el artículo 16.

2. El consumidor que ejerza el derecho de desistimiento tendrá las obligaciones siguientes:

a) Comunicarlo al prestamista antes de que expire el plazo previsto en el apartado 1, ateniéndose a la información facilitada por este último de acuerdo con la letra p) del apartado 2 del artículo 16, por medios que permitan dejar constancia de la notificación de cualquier modo admitido en Derecho.

Se considerará que se ha respetado el plazo si la notificación se ha enviado antes de la expiración del plazo, siempre que haya sido efectuada mediante documento en papel o cualquier otro soporte duradero a disposición del prestamista y accesible para él.

b) Pagar al prestamista el capital y el interés acumulado sobre dicho capital entre la fecha de disposición del crédito y la fecha de reembolso del capital, sin ningún retraso indebido y a más tardar a los treinta días naturales de haber enviado la notificación de desistimiento al prestamista.

Los intereses adeudados se calcularán sobre la base del tipo deudor acordado.

El prestamista no tendrá derecho a reclamar al consumidor ninguna otra compensación en caso de desistimiento, excepto la compensación de los gastos no reembolsables abonados por el prestamista a la Administración Pública.

3. En caso de que un prestamista o un tercero proporcione un servicio accesorio relacionado con el contrato de crédito sobre la base de un acuerdo entre ese tercero y el prestamista, el consumidor dejará de estar vinculado por dicho servicio accesorio si ejerce su derecho de desistimiento respecto del contrato de crédito conforme a lo dispuesto en el presente

otra compensación en caso de desistimiento, excepto la compensación de los gastos no reembolsables abonados por el prestamista a la administración pública....". 
artículo. En caso de que este servicio accesorio sea un contrato de seguro de vida, el derecho de desistimiento se regirá en lo que sea aplicable por lo establecido en el artículo 83.a) de la Ley 50/1980, de 8 de octubre, de Contrato de Seguro, y en el resto de casos, el consumidor tendrá derecho al reembolso de la parte de prima no consumida.....".

La figura del desistimiento del contrato tenía ya acogida -para los contratos de consumo, y en los supuestos y condiciones legalmente previstos- en el régimen protectorio de los consumidores español ${ }^{630}$, que le dedica una pormenorizada regulación en los arts. 68 a $79^{631}$.

${ }^{630}$ Para un análisis pormenorizado de la figura y sus contornos en el régimen español, ver DomínGuEZ Luelmo, Andrés, en Cámara lapuente, Sergio (Dir.), Comentarios a las Normas de Protección de los Consumidores, Colex, Madrid, 2011, pág. 615-695. Asimismo, GARCía ViCEnTE, José Ramón, en BerCovitz Rodríguez-CAno, Rodrigo (Coord.), Comentario del Texto Refundido de la Ley General para la Defensa de los Consumidores y Usuarios y otras leyes complementarias (Real Decreto Legislativo 1/2007), AranzadiThomson Reuters, Madrid, 2009, pág. 845-881.

${ }^{631}$ Art. 68: "Contenido y régimen del derecho de desistimiento. 1. El derecho de desistimiento de un contrato es la facultad del consumidor y usuario de dejar sin efecto el contrato celebrado, notificándoselo así a la otra parte contratante en el plazo establecido para el ejercicio de ese derecho, sin necesidad de justificar su decisión y sin penalización de ninguna clase. Serán nulas de pleno de derecho las cláusulas que impongan al consumidor y usuario una penalización por el ejercicio de su derecho de desistimiento. 2. El consumidor tendrá derecho a desistir del contrato en los supuestos previstos legal o reglamentariamente y cuando así se le reconozca en la oferta, promoción publicidad o en el propio contrato. 3. El derecho de desistimiento atribuido legalmente al consumidor y usuario se regirá en primer término por las disposiciones legales que lo establezcan en cada caso y en su defecto por lo dispuesto en este Título". Art. 69: "Obligación de informar sobre el derecho de desistimiento. 1. Cuando la ley atribuya el derecho de desistimiento al consumidor y usuario, el empresario contratante deberá informarle por escrito en el documento contractual, de manera clara, comprensible y precisa, del derecho de desistir del contrato y de los requisitos y consecuencias de su ejercicio, incluidas las modalidades de restitución del bien o servicio recibido. Deberá entregarle, además, un documento de desistimiento, identificado claramente como tal, que exprese el nombre y dirección de la persona a quien debe enviarse y los datos de identificación del contrato y de los contratantes a que se refiere. 2. Corresponde al empresario probar el cumplimiento de lo dispuesto en el apartado anterior". Art. 70: "Formalidades para el ejercicio del desistimiento. El ejercicio del derecho de desistimiento no estará sujeto a formalidad alguna, bastando que se acredite en cualquier forma admitida en derecho. En todo caso se considerará válidamente ejercitado mediante el envío del documento de desistimiento o mediante la devolución de los productos recibidos". Art. 71: "Plazo para el ejercicio del derecho de desistimiento. 1. El consumidor y usuario dispondrá de un plazo mínimo de catorce días naturales para ejercer el derecho de 
desistimiento. 2. Siempre que el empresario haya cumplido con el deber de información y documentación establecido en el artículo 69.1, el plazo a que se refiere el apartado anterior se computará desde la recepción del bien objeto del contrato o desde la celebración de éste si el objeto del contrato fuera la prestación de servicios. 3. Si el empresario no hubiera cumplido con el deber de información y documentación sobre el derecho de desistimiento, el plazo para su ejercicio finalizará doce meses después de la fecha de expiración del periodo de desistimiento inicial, a contar desde que se entregó el bien contratado o se hubiera celebrado el contrato, si el objeto de éste fuera la prestación de servicios. Si el deber de información y documentación se cumple durante el citado plazo de doce meses, el plazo legalmente previsto para el ejercicio del derecho de desistimiento empezará a contar desde ese momento. 4. Para determinar la observancia del plazo para desistir se tendrá en cuenta la fecha de expedición de la declaración de desistimiento". Art. 72: "Prueba del ejercicio del derecho de desistimiento. Corresponde al consumidor y usuario probar que ha ejercitado su derecho de desistimiento conforme a lo dispuesto en este capítulo". Art. 73: "Gastos vinculados al desistimiento. El ejercicio del derecho de desistimiento no implicará gasto alguno para el consumidor y usuario. A estos efectos se considerará lugar de cumplimiento el lugar donde el consumidor y usuario haya recibido la prestación". Art. 74: "Consecuencias del ejercicio del derecho de desistimiento. 1. Ejercido el derecho de desistimiento, las partes deberán restituirse recíprocamente las prestaciones de acuerdo con lo dispuesto en los artículos 1.303 y 1.308 del Código Civil. 2. El consumidor y usuario no tendrá que rembolsar cantidad alguna por la disminución del valor del bien, que sea consecuencia de su uso conforme a lo pactado o a su naturaleza, o por el uso del servicio. 3. El consumidor y usuario tendrá derecho al rembolso de los gastos necesarios y útiles que hubiera realizado en el bien. 4. En caso de que el usuario incumpla el compromiso de permanencia adquirido con la empresa, la penalización por baja, o cese prematuro de la relación contractual, será proporcional al número de días no efectivos del compromiso de permanencia acordado". Art. 75: "Imposibilidad de devolver la prestación por parte del consumidor y usuario. 1. La imposibilidad de devolver la prestación objeto del contrato por parte del consumidor y usuario por pérdida, destrucción u otra causa no privarán a éste de la posibilidad de ejercer el derecho de desistimiento. En estos casos, cuando la imposibilidad de devolución le sea imputable, el consumidor y usuario responderá del valor de mercado que hubiera tenido la prestación en el momento del ejercicio del derecho de desistimiento, salvo que dicho valor fuera superior al precio de adquisición, en cuyo caso responderá de éste. 2. Cuando el empresario hubiera incumplido el deber de información y documentación sobre el derecho de desistimiento, la imposibilidad de devolución sólo será imputable al consumidor y usuario cuando éste hubiera omitido la diligencia que le es exigible en sus propios asuntos". Art. 76: "Devolución de sumas percibidas por el empresario. Cuando el consumidor y usuario haya ejercido el derecho de desistimiento, el empresario estará obligado a devolver las sumas abonadas por el consumidor y usuario sin retención de gastos. La devolución de estas sumas deberá efectuarse sin demoras indebidas y, en cualquier caso, antes de que hayan transcurrido 14 días naturales desde la fecha en que haya sido informado de la decisión de desistimiento del contrato por el consumidor y usuario. Transcurrido dicho plazo sin que el consumidor y usuario haya recuperado la suma adeudada, tendrá derecho a reclamarla duplicada, sin perjuicio de que además se le indemnicen los daños y perjuicios que se le hayan 
causado en lo que excedan de dicha cantidad. Corresponde al empresario la carga de la prueba sobre el cumplimiento del plazo". Art. 76 bis: "Efectos del ejercicio del derecho de desistimiento en los contratos complementarios. 1. Sin perjuicio de lo dispuesto en el artículo 29 de la Ley 16/2011, de 24 de junio, de contratos de crédito al consumo, el ejercicio, por parte del consumidor y usuario de su derecho de desistimiento conforme a las disposiciones de esta ley, tendrá por efecto la extinción automática y sin coste alguno para el consumidor y usuario de todo contrato complementario, excepto en aquellos casos en que sean complementarios de contratos celebrados a distancia o fuera del establecimiento en los que, sin perjuicio de su extinción automática, el consumidor y usuario deberá asumir los costes previstos en los artículos 107.2 y 108 de esta norma. 2. Ejercido el derecho de desistimiento sobre el contrato principal, las partes deberán restituirse recíprocamente las prestaciones recibidas en virtud del contrato complementario, sin ninguna demora indebida y, en cualquier caso, antes de que hayan transcurrido 14 días naturales desde la fecha en que el consumidor y usuario haya informado al empresario de su decisión de desistir del contrato principal. En el supuesto de que el empresario no reintegre todas las cantidades abonadas en virtud del contrato complementario en el plazo señalado, el consumidor y usuario podrá reclamar que se le pague el doble de la suma adeudada, sin perjuicio a su derecho de ser indemnizado por los daños y perjuicios sufridos en lo que excedan de dicha cantidad. Corresponde al empresario la carga de la prueba sobre el cumplimiento del plazo. El consumidor y usuario tendrá derecho al reembolso de los gastos necesarios y útiles que hubiera realizado en el bien. 3. En caso de que al consumidor y usuario le sea imposible devolver la prestación objeto del contrato complementario por pérdida, destrucción u otra causa que le sea imputable, responderá del valor de mercado que hubiera tenido la prestación en el momento del ejercicio del derecho de desistimiento, salvo que dicho valor fuera superior al precio de adquisición, en cuyo caso responderá de éste. 4. Cuando el empresario hubiera incumplido el deber de información y documentación sobre el derecho de desistimiento del contrato principal, la imposibilidad de devolución sólo será imputable al consumidor y usuario cuando éste hubiera omitido la diligencia que le es exigible en sus propios asuntos. 5. Lo dispuesto en los apartados anteriores será también de aplicación a los contratos complementarios de otros celebrados a distancia o fuera del establecimiento, regulados en el título III del libro II de esta ley". Art. 77: "Desistimiento de un contrato vinculado a financiación al consumidor y usuario. Cuando se ejercite el derecho de desistimiento en los contratos celebrados entre un empresario y un consumidor y usuario, incluidos los contratos a distancia y los celebrados fuera del establecimiento mercantil del empresario, y el precio a abonar por el consumidor y usuario haya sido total o parcialmente financiado mediante un crédito concedido por el empresario contratante o por parte de un tercero, previo acuerdo de éste con el empresario contratante, el ejercicio del derecho de desistimiento implicará al tiempo la resolución del crédito sin penalización alguna para el consumidor y usuario". Art. 78: “Acciones de nulidad o resolución. La falta de ejercicio del derecho de desistimiento en el plazo fijado no será obstáculo para el posterior ejercicio de las acciones de nulidad o resolución del contrato cuando procedan conforme a derecho". Art. 79: "Derecho contractual de desistimiento. A falta de previsiones específicas en la oferta, promoción, publicidad o en el propio contrato el derecho de desistimiento reconocido contractualmente, éste se ajustará a lo previsto en este título. 
En Argentina, la figura tuvo su desembarco en la Ley $\mathrm{N}^{\circ} 24.240$ de Defensa del Consumidor para los supuestos particulares allí establecidos (art. 34) y se incorpora al Código Civil unificado vigente a partir de agosto de 2015, en los arts. 1110 a 1116 emplazados en el capítulo referido a "Modalidades especiales" dentro del Título dedicado a los Contratos del Consumo) ${ }^{632}$.

El consumidor y usuario que ejercite el derecho de desistimiento contractualmente reconocido no tendrá en ningún caso obligación de indemnizar por el desgaste o deterioro del bien o por el uso del servicio debido exclusivamente a su prueba para tomar una decisión sobre su adquisición definitiva. En ningún caso podrá el empresario exigir anticipo de pago o prestación de garantías, incluso la aceptación de efectos que garanticen un eventual resarcimiento en su favor para el caso de que se ejercite el derecho de desistimiento".

${ }^{632}$ Art. 1110: "Revocación. En los contratos celebrados fuera de los establecimientos comerciales y a distancia, el consumidor tiene el derecho irrenunciable de revocar la aceptación dentro de los diez días computados a partir de la celebración del contrato. Si la aceptación es posterior a la entrega del bien, el plazo debe comenzar a correr desde que esta última se produce. Si el plazo vence en día inhábil, se prorroga hasta el primer día hábil siguiente. Las cláusulas, pactos o cualquier modalidad aceptada por el consumidor durante este período que tengan por resultado la imposibilidad de ejercer el derecho de revocación se tienen por no escritos". Art. 1111: "Deber de informar el derecho a la revocación. El proveedor debe informar al consumidor sobre la facultad de revocación mediante su inclusión en caracteres destacados en todo documento que presenta al consumidor en la etapa de negociaciones o en el documento que instrumenta el contrato concluido, ubicada como disposición inmediatamente anterior a la firma del consumidor o usuario. El derecho de revocación no se extingue si el consumidor no ha sido informado debidamente sobre su derecho". Art. 1112: "Forma y plazo para notificar la revocación. La revocación debe ser notificada al proveedor por escrito o medios electrónicos o similares, o mediante la devolución de la cosa dentro del plazo de diez días computados conforme a lo previsto en el artículo 1110". Art. 1113: "Efectos del ejercicio del derecho de revocación. Si el derecho de revocar es ejercido en tiempo y forma por el consumidor, las partes quedan liberadas de sus obligaciones correspectivas y deben restituirse recíproca y simultáneamente las prestaciones que han cumplido". Art. 1114: "Imposibilidad de devolución. La imposibilidad de devolver la prestación objeto del contrato no priva al consumidor de su derecho a revocar. Si la imposibilidad le es imputable, debe pagar al proveedor el valor de mercado que la prestación tiene al momento del ejercicio del derecho a revocar, excepto que dicho valor sea superior al precio de adquisición, en cuyo caso la obligación queda limitada a este último". Art. 1115: "Gastos. El ejercicio del derecho de revocación no debe implicar gasto alguno para el consumidor. En particular, el consumidor no tiene que reembolsar cantidad alguna por la disminución del valor de la cosa que sea consecuencia de su uso conforme a lo pactado o a su propia naturaleza, y tiene derecho al reembolso de los gastos necesarios y útiles que realizó en ella". Art.1116: "Excepciones al derecho de revocar. Excepto pacto en contrario, el derecho de revocar no es aplicable a los siguientes contratos: a) los referidos a productos confeccionados conforme a las especificaciones 
Tal como ha sido regulado el instituto en el ordenamiento argentino, tanto en la ley protectoria de los consumidores como en el nuevo Código Civil ${ }^{633}$, el llamado derecho de arrepentimiento sólo resulta operativo en supuestos de marketing agresivo o de ciertas modalidades especiales de contratos de consumo, esto es, los contratos celebrados fuera de los establecimientos comerciales y a distancia (medios postales, electrónicos, telecomunicaciones, radio, televisión, prensa) ${ }^{634}$, precisamente en atención de los riesgos que tal contexto puede generar para el consumidor.

El remedio previsto se integra de dos medidas complementarias que son ofrecidas al consumidor para neutralizar la amenaza a la que aludimos: el otorgamiento de un plazo de reflexión y el derecho a revocar la aceptación o desistir del contrato. En efecto, configurados los supuestos descriptos por la norma, el sistema ofrece una solución que compensa al consumidor con aquello que el proveedor de bienes y servicios puede haberle negado: el tiempo necesario y la posibilidad de autodeterminarse libremente. El dispositivo ofrece al consumidor un período de enfriamiento ${ }^{635}$ para que pueda pensar, evaluar el acierto o desacierto de su decisión de contratar, revisar su actuación y, eventualmente, volver sobre sus $\operatorname{pasos}^{636}$. Y, como un complemento necesario, se reconoce al consumidor un derecho de arrepentimiento, a revocar la aceptación oportunamente expresada, sin necesidad de expresar causa alguna y sin responsabilidad frente al proveedor.

suministradas por el consumidor o claramente personalizados o que, por su naturaleza, no pueden ser devueltos o puedan deteriorarse con rapidez; b) los de suministro de grabaciones sonoras o de video, de discos y de programas informáticos que han sido decodificados por el consumidor, así como de ficheros informáticos, suministrados por vía electrónica, susceptibles de ser descargados o reproducidos con carácter inmediato para su uso permanente; c) los de suministro de prensa diaria, publicaciones periódicas y revistas".

${ }^{633}$ Para un análisis del régimen legal, ver JAPAZE, María Belén, en RuSCONI, D. (Coord.), Manual de Derecho del Consumidor, cit., pág. 379 y sgtes.

${ }^{634}$ Para el análisis del ámbito de aplicación, ver Alterini, Jorge H. (Dir.), Código Civil y Comercial de la Nación ..., T. V, cit., pág. 891.

${ }^{635}$ Alterini, Jorge H. (Dir.), Código Civil y Comercial de la Nación..., T. V, cit., pág. 892.

${ }^{636}$ Dice DE LORENZO: "Se trata de un mecanismo tendiente a poner el consentimiento en ralenti con el fin de reintegrarle a aquél (al consumidor) la posibilidad de ponderar la conveniencia -con nuevos elementos de juicio- de una contratación que la técnica empleada para concretarla le ha arrebatado” (DE LORENZO, Miguel Federico, “Contrato de consumo y derecho al arrepentimiento", LL 2004-A,790). 
Se ha dicho que esta técnica protectoria consiste en hacer funcionar el consentimiento en ralenti (a marcha lenta) ${ }^{637}$. Es un mecanismo de defensa del libre albedrío del consumidor que se traduce en la exigencia de que transcurra cierto plazo para recién poder tener por configurado el acuerdo y celebrado el contrato de consumo.

Se trata de una herramienta de excepción pues este derecho de arrepentimiento o ius poenitendi confiere la posibilidad de dejar sin efecto un contrato perfeccionado, ya concluido, conforme los principios de la teoría general del contrato. "Se trata de una técnica exorbitante a la tradición liberal del régimen de contratación ideado por Vélez Sarsfield, destinada a proteger a los consumidores de sus propias debilidades" ${ }^{\text {638 }}$. Luce como un instituto de ruptura ${ }^{639}$, en tanto posibilita al consumidor volver sobre su decisión y, bajo ciertas condiciones, desistir unilateralmente de un vínculo negocial ya perfeccionado.

Una regulación del sobreendeudamiento de los consumidores, como la que propiciamos, debería contemplar esta figura pues sumaría una herramienta de eficacia innegable.

Como es evidente, la consagración de este derecho en el marco de la operatoria de crédito, posibilita que el deudor reflexione, revise su comportamiento, evalúe nuevamente la conveniencia de la contratación, "con cierta distancia temporal e incluso física respecto de la oferta y el oferente" y repiense si el compromiso asumido guarda relación con su capacidad económica ${ }^{640}$.

La regulación española de la figura -emplazada en la ley de contratos de crédito para el consumo- que tomamos de modelo, reconoce el derecho a desistir única y exclusivamente al consumidor $^{641}$, que puede llevar adelante su planteamiento por si o por medio de un representante. Se trata de una declaración de voluntad unilateral, de carácter

\footnotetext{
${ }^{637}$ Alterini, Atilio A. - LÓPEZ CABANA, Roberto M., "La formación del consentimiento y la protección del consumidor”, en STIGLITZ, Gabriel A., Derecho del Consumidor, 5, Juris, Rosario, 1994, pág. 3 y sgtes.

${ }^{638}$ CORREA, Giselle, "Daños derivados de las ventas domiciliarias, por correspondencia, telecomunicaciones, electrónico o similares” en Carlos GHERSI (dir.), Tratado de daños reparables, t. II, LL, Buenos Aires, 2008, pág. 171 y sgtes.

${ }^{639}$ DE LorenZO, Miguel Federico, "Contrato de consumo y derecho al arrepentimiento", cit.

${ }^{640}$ Lo explica en términos similares, GutiéRREZ DE CABIEDES, Pablo, El sobreendeudamiento doméstico..., cit., pág. 147.

${ }^{641}$ García Vicente, José Ramón, en MARÍn LóPEZ, Manuel Jesús (Dir.), Comentarios..., cit., pág. 1014.
} 
recepticio, no siendo necesaria, para su operatividad y eficacia, la aceptación de su contraparte. Es un derecho de ejercicio discrecional e irrenunciable ${ }^{642}$.

Se señala con acierto que el ejercicio de este derecho permite al consumidor contrastar la razonabilidad y oportunidad de su decisión de obligarse, sobre todo cuando se trata de contratos de larga duración que le imponen una notable carga económica hacia el futuro $^{643}$.

Conforme la regulación española de la figura, el ejercicio de esta facultad, impone al consumidor restituir el importe del capital dispuesto y el interés pactado entre la fecha de disposición del crédito y la fecha de su reembolso efectivo, a más tardar dentro de los 30 días naturales de haber enviado la notificación del desistimiento al prestamista. Con esta obligación de restitución, no sólo del capital que ha sido previamente entregado sino también de los intereses devengados -que deben ser calculados sobre la base del tipo deudor acordado en el contrato- se evita el desistimiento interesado o un enriquecimiento indebido por parte del consumidor ${ }^{644}$

Se impone profundizar el estudio de esta figura para su aplicación en la operatoria de crédito, tomando como referencia los modelos existentes en los ordenamientos que ya la han implementado ${ }^{645}$. Urge el diseño de una herramienta equivalente en el Derecho

\footnotetext{
${ }^{642}$ ORDÁs AlOnso, Marta, Los contratos de crédito al consumo..., cit., pág. 246 y sgtes. Para un análisis de la terminología utilizada para definir la figura y un desarrollo del debate acerca la naturaleza jurídica del instituto, ver, Domínguez luelmo, Andrés, en CÁMARA LAPUEnTE, Sergio (Dir.), Comentarios..., cit., pág. 618 y sgtes.; asimismo, Álvarez LATA, Natalia, Invalidez e ineficacia en el derecho contractual de consumo español, Aranzadi, Navarra, 2004, pág. 91 y sgtes.

${ }^{643}$ García Vicente, José Ramón, en Marín LóPEZ, Manuel Jesús (Dir.), Comentarios..., cit., pág. 1016; asimismo, García Vicente, José Ramón, en Bercovitz RodríGUEZ-CANo, Rodrigo (Coord.), Comentario del Texto Refundido..., cit, pág. 849.

${ }^{644}$ ORdÁs Alonso, Marta, Los contratos de crédito al consumo..., cit., pág. 259. Asimismo, GARCíA ViCENTE, José Ramón, en MARÍn LóPEZ, Manuel Jesús (Dir.), Comentarios..., cit., pág. 1023.

${ }^{645}$ La normativa sectorial contiene una referencia a la facultad que asiste al usuario de servicios financieros a efectos de desistir del contrato de crédito pero omite precisar los alcances y efectos particulares. La Comunicación A 5460 del BCRA, en su apartado 2.3.1.1 referido a "Requisitos mínimos de los contratos financieros", dispone que "Los contratos como mínimo deben contener:...v) Cláusula de revocación en donde se indique que el usuario de servicios financieros tiene derecho a revocar la aceptación del producto o servicio dentro del plazo de diez (10) días hábiles contados a partir de la fecha de recibido el contrato o de la
} 
argentino, que -con las adecuaciones que corresponda- contribuya al objetivo de prevención del sobreendeudamiento de los consumidores.

\section{c.2.6. Derecho al pago y amortización anticipada}

Con acierto señala Álvarez Vega que "la posibilidad de reembolsar anticipadamente las cantidades debidas se articula como un instrumento que puede resultar útil como remedio a situaciones de sobreendeudamiento, básicamente porque la inexigibilidad de los intereses no devengados por acortamiento del plazo, reduce el montaje de la deuda, adelantándose así a una previsible incapacidad de pago y a sus perjudiciales consecuencias"

Se piensa que "el pago o la devolución de cantidades adeudadas con anterioridad a la fecha convenida por las partes para ello, es una medida que puede servir tanto a los efectos preventivos del sobreendeudamiento, como a los reparadores del mismo: comporta una reducción o eliminación del monto de la deuda y, por ende, en su caso, la correlativa reducción o eliminación del coste del crédito" ${ }^{\prime 647}$.

El dispositivo analizado constituye una "medida innegablemente tuitiva del consumidor $^{648}$, mediante la cual se posibilita que éste no tenga que seguir abonando el precio del préstamo cuando ya no necesita el dinero -porque desapareció la causa que motivaba el empréstito o porque se desistió del gasto que impulsaba el requerimiento de

disponibilidad efectiva del producto o servicio, lo que suceda último, notificando de manera fehaciente o por el mismo medio en que el servicio o producto fue contratado. Para el caso de la contratación a distancia, este plazo se contará a partir de la fecha en la cual el usuario reciba el contrato con la firma del sujeto obligado. Se aclarará en esta misma cláusula que dicha revocación será sin costo ni responsabilidad alguna para el usuario de servicios financieros en la medida que no haya hecho uso del respectivo producto o servicio y que, en el caso de que lo haya utilizado, sólo se le cobrarán las comisiones y cargos previstos para la prestación, proporcionados al tiempo de utilización del servicio o producto. La facultad de revocación debe ser informada al usuario en todo documento que le sea presentado con motivo de la oferta y/o contratación del producto o servicio....".

${ }^{646}$ Álvarez Vega, María Isabel, Protección jurídica del consumidor..., cit., pág. 355 y sgtes.

${ }^{647}$ GuTIÉRREZ DE CABIEDES, Pablo, El sobreendeudamiento doméstico..., cit., pág. 150.

${ }^{648}$ PeÑa LóPEZ, Fernando, en MARÍn LÓPEZ, Manuel Jesús (Dir.), Comentarios a la Ley de Crédito al Consumo, Thomson Reuters-Aranzadi, Pamplona 2014, pág. 1090. 
crédito $^{649}$-, cuando se advierte un desajuste presupuestario en la economía doméstica que justifica abandonar el contrato o cuando existen otras ofertas en el mercado crediticio que hacen ventajoso el cambio de entidad prestamista ${ }^{650}$.

La Directiva 2008/48, en su considerando 39, señala que "debe permitirse al consumidor liquidar sus obligaciones antes de la fecha convenida en el contrato de crédito" reconociendo que "en caso de reembolso anticipado, parcial o íntegro, el prestamista debe tener derecho a una compensación por los gastos directamente derivados del reembolso anticipado, teniéndose en cuenta asimismo los posibles ahorros que tal reembolso suponga para el prestamista". Se deja sentado que "para determinar el método de cálculo de la compensación, es importante respetar varios principios", puntualizando que la determinación de la indemnización "debe ser transparente y comprensible para el consumidor ya desde la fase precontractual, y en cualquier caso durante la ejecución del contrato de crédito" y que "el método de cálculo debe ser fácil de aplicar para el prestamista" y permitir "el control de supervisión por parte de las autoridades responsables".

El art. 16 de la Directiva consagra expresamente este derecho del consumidor y determina el modo de ponerlo en ejercicio y las restricciones que lo condicionan ${ }^{651}$. Y,

\footnotetext{
${ }^{649}$ Piénsese en la toma de un empréstito que se justificaba en una intervención quirúrgica o en tratamiento de alto coste que, por la razón que fuera, no se llevará finalmente adelante; o en la adquisición de una vivienda o en un viaje o en una celebración cuya concreción se frustra luego de acceder al crédito.

${ }^{650}$ Desde esta perspectiva, PEÑA LÓPEZ señala que “con el precepto se consigue, además, intensificar la competencia en el mercado, al permitirse a los consumidores cambiar en cualquier momento de prestamista, dirigiéndose al competidor que ofrezca mejores condiciones" (PEÑA LÓPEZ, Fernando, en MARÍN LÓPEZ, Manuel Jesús (Dir.), Comentarios a la Ley de Crédito al Consumo, cit., pág. 1090). En igual sentido, ALFARO Águila-Real, Jesús, “Observaciones críticas al Proyecto de Ley de Crédito al Consumo”, en Revista de Derecho Bancario y Bursátil, núm. 56, 1994, pág. 1044.

${ }^{651}$ Art. 16: "Reembolso anticipado. 1. El consumidor tendrá derecho a liquidar en todo momento, total o parcialmente, las obligaciones derivadas del contrato de crédito. En tales casos, tendrá derecho a una reducción del coste total del crédito, que comprende los intereses y costes correspondientes a la duración del contrato que quede por transcurrir. 2. En caso de reembolso anticipado del crédito, el prestamista tendrá derecho a una compensación justa y justificada objetivamente por los posibles costes directamente derivados del reembolso anticipado del crédito, siempre que el reembolso anticipado se produzca dentro de un período en el cual el tipo deudor sea fijo.
} 
como debía ser, la Ley 16/2011 de Contratos de Crédito para el Consumo española, incorpora el dispositivo que consagra este derecho y define los contornos de su ejercicio.

$\mathrm{El}$ art. 30 dispone: "Reembolso anticipado.

1. El consumidor podrá liquidar anticipadamente, de forma total o parcial y en cualquier momento, las obligaciones derivadas del contrato de crédito. En tal caso, tendrá derecho a una reducción del coste total del crédito que comprenda los intereses y costes, incluso si éstos hubieran sido ya pagados, correspondientes a la duración del contrato que quede por transcurrir.

2. En caso de reembolso anticipado del crédito, el prestamista tendrá derecho a una compensación justa y justificada objetivamente por los posibles costes directamente derivados del reembolso anticipado del crédito, siempre que el reembolso anticipado se produzca dentro de un período en el cual el tipo deudor sea fijo.

Dicha compensación no podrá ser superior al 1 por 100 del importe del crédito reembolsado anticipadamente si el período restante entre el reembolso anticipado y la terminación

Dicha compensación no podrá ser superior al $1 \%$ del importe del crédito reembolsado anticipadamente si el período transcurrido entre el reembolso anticipado y la terminación acordada del contrato de crédito es superior a un año. Si el período no supera un año, la compensación no podrá ser superior al 0,5\% del importe del crédito reembolsado anticipadamente. 3. No se podrá reclamar compensación alguna por reembolso anticipado: a) si el reembolso se ha efectuado en cumplimiento de un contrato de seguro destinado a garantizar el reembolso del crédito; b) en caso de posibilidad de descubierto, o c) si el reembolso anticipado se produce dentro de un período para el que no se haya fijado el tipo de interés deudor. 4. Los Estados miembros podrán establecer que: a) esta compensación pueda ser reclamada por el prestamista solo bajo la condición de que el importe del reembolso anticipado supere el umbral definido por el Derecho nacional. El umbral no deberá superar los 10000 EUR en un período dado de 12 meses; b) el prestamista pueda reclamar excepcionalmente una compensación más elevada si demuestra que las pérdidas sufridas por el reembolso anticipado superan el importe indicado en el apartado 2. Si la compensación reclamada por el prestamista supera las pérdidas sufridas realmente, el consumidor podrá exigir la reducción correspondiente. En este caso, las pérdidas consistirán en la diferencia entre el tipo de interés acordado inicialmente y el tipo de interés al que el prestamista pueda prestar el importe del reembolso anticipado en el mercado en el momento de dicho reembolso, teniendo asimismo en cuenta el impacto del reembolso anticipado en los gastos administrativos.

5. Ninguna compensación excederá del importe del interés que el consumidor habría pagado durante el período de tiempo comprendido entre el reembolso anticipado y la fecha pactada de finalización del contrato de crédito". 
acordada del contrato de crédito es superior a un año. Si el período no supera un año, la compensación no podrá ser superior al 0,5 por 100 del importe del crédito reembolsado anticipadamente.

3. No podrá reclamarse compensación alguna por reembolso anticipado:

a) Si el reembolso se ha efectuado en cumplimiento de un contrato de seguro destinado a garantizar el reembolso del crédito.

b) En caso de posibilidad de descubierto.

c) Si el reembolso anticipado se produce dentro de un período para el que no se haya fijado el tipo de interés deudor.

4. Si el prestamista demuestra la existencia de pérdidas producidas de forma directa como consecuencia del reembolso anticipado del crédito, podrá reclamar excepcionalmente una compensación más elevada que la establecida en el apartado 2 de este artículo.

Si la compensación reclamada por el prestamista supera las pérdidas sufridas realmente, el consumidor podrá exigir la reducción correspondiente.

En este caso, las pérdidas consistirán en aplicar a la cantidad anticipada la diferencia entre el tipo de interés acordado inicialmente y el tipo de interés al que el prestamista pueda prestar el importe del reembolso anticipado en el mercado en el momento de dicho reembolso, teniendo asimismo en cuenta el impacto del reembolso anticipado en los gastos administrativos. A estos efectos, se considerará como tipo de mercado el Euribor al plazo más cercano a la fecha de vencimiento del préstamo.

5. Ninguna compensación excederá del importe del interés que el consumidor habría pagado durante el período de tiempo comprendido entre el reembolso anticipado y la fecha pactada de finalización del contrato de crédito.

6. El reembolso anticipado de créditos que cuenten con un seguro vinculado a la amortización del crédito o a cuya suscripción se haya condicionado la concesión del crédito o su concesión en las condiciones ofrecidas, dará lugar a la devolución por parte de la entidad aseguradora al consumidor de la parte de prima no consumida".

El ejercicio de la facultad de liquidar anticipadamente la deuda constituye un derecho potestativo, por el cual el consumidor queda legitimado para dar por vencida las 
obligaciones pendientes ${ }^{652}$. La norma entraña una excepción al principio de que el plazo se entiende establecido para ambas partes, favoreciendo al consumidor, que está habilitado a realizar el pago del crédito en cualquier momento, dando por vencida la deuda y extinguiendo el contrato ${ }^{653}$.

Como consecuencia inmediata de la atribución de dicha facultad al consumidor, la negativa del prestamista a admitir dicho reembolso, permitiría considerarlo en situación de mora credendi y el pago anticipado podría efectuarse a través de la consignación de las cantidades correspondientes. Siempre y cuando, obviamente, no medien razones justificativas de dicha actuación"

De conformidad con la amplitud con la que está redactada la norma en la ley española -y resulta saludable que así sea- la facultad de amortización anticipada permite tanto el reembolso de la totalidad del crédito como meras amortizaciones parciales, sin límite alguno. Al consumidor, por consiguiente, se le concede la facultad de pagar el crédito a su mejor conveniencia, pudiendo reducir el importe de lo debido y de los gastos derivados, siempre que lo desee y se lo permita su fortuna ${ }^{655}$.

"Dado el carácter imperativo de la norma, serán nulos, además de los pactos que nieguen el propio derecho, los que señalen fechas concretas para su ejercicio, así como los que limiten las posibilidad de reembolso anticipado parcial a una cuantía mínima determinada" ${ }^{656}$.

El ejercicio de la facultad de reembolso anticipado tiene como natural consecuencia el derecho del consumidor a una reducción del coste total del crédito que comprenda los intereses y costes, incluso si éstos hubieran sido ya pagados, correspondientes a la duración del contrato que quede por transcurrir. El ejercicio de la facultad analizada tiene como derivación necesaria la modificación del término de cumplimiento del contrato de crédito o,

\footnotetext{
${ }^{652}$ Es la posición de VITERI ZUBIA, Ibon, El pago anticipado en las obligaciones a plazo. El derecho al reembolso anticipado en el sector específico del crédito, Tirant lo Blanch, Valencia, 2013, pág. 335.

${ }^{653}$ PeÑA LóPeZ, Fernando, en MARÍn LóPEZ, Manuel Jesús (Dir.), Comentarios..., cit., pág. 1091 y sgtes. Ver el desarrollo del tema en Domínguez Luelmo, Andrés, El cumplimiento anticipado de las obligaciones, Cívitas, Madrid, 1992.

${ }^{654}$ ORdÁs Alonso, Marta, Los contratos de crédito al consumo..., cit., pág. 265.

${ }^{655}$ PeÑA LóPEZ, Fernando, en MARÍn LÓPEZ, Manuel Jesús (Dir.), Comentarios..., cit., pág. 1092.

${ }^{656}$ VITERI ZUBIA, Ibon, El pago anticipado..., cit., pág. 337.
} 
en su caso de amortización parcial -cuando menos- una reducción de la cantidad adeudada. Ambas posibilidades determinan una situación en la que el prestamista y el propio mercado exigirían un precio menor a cambio de la financiación que el pactado originariamente, debido a que el riesgo generado por el crédito es más reducido. El legislador tiene en cuenta ese menor riesgo y ordena que se descuenten del precio total del crédito, todos aquellos intereses y costes que, en el contrato original, se imputaron al consumidor por razón del exceso de duración del negocio (exceso con respecto a la modificación operada con el reembolso anticipado) o de la mayor cantidad originariamente prestada (y reducida con el reembolso).

Debe precisarse que, en cuanto a los intereses, en caso de reembolso anticipado en consumidor no sólo no debe pagar interés alguno que todavía no se haya devengado, sino que, al contrario, todas aquellas cantidades que ya se hubieran abonado por razón de las cantidades adelantadas -lo cual depende del sistema de amortización pactado- también deberán devolverse. En definitiva, se pretende situar al consumidor, tras la amortización, en la misma situación en la que quedaría si el crédito al consumo inicialmente se hubiese pactado en las condiciones generadas como consecuencia del pago anticipado ${ }^{657}$.

El ejercicio del derecho al reembolso anticipado concedido por la ley, "puede generar al prestamista un perjuicio cuyo resarcimiento se admite en cuanto asegura el equilibrio financiero de las partes. No se trata de indemnizar los daños que genera un incumplimiento de la obligación, que en modo alguno tiene lugar cuando se amortiza anticipadamente, sino, más bien de que el acreedor pueda atenuar la pérdida verdaderamente sufrida $^{658}$ como consecuencia del ejercicio de la facultad reconocida al consumidor $^{659}$.

\footnotetext{
${ }^{657}$ PeÑa LóPeZ, Fernando, en MARín LóPEZ, Manuel Jesús (Dir.), Comentarios..., cit., pág. 1093 y sgtes. Lo explica en términos similares, ORDÁs ALONSO, Marta, Los contratos de crédito al consumo..., cit., pág. 266.

${ }^{658}$ VITERI ZUBIA, Ibon, El pago anticipado ..., cit., pág. 339.

${ }^{659}$ Advierte PEÑA LÓPEZ que "la facultad del deudor de reembolsar anticipadamente el crédito puede provocar perjuicios económicos al prestamista. Obviamente el precio del contrato de crédito (los intereses y los costes) es la fuente de la que nace el beneficio que obtiene el prestamista por su actividad. La sujeción obligatoria del prestamista a cambios en el precio pactado en el contrato de crédito al consumo, como consecuencia de la facultad de amortización anticipada del consumidor, es naturalmente susceptible de producir modificaciones a la baja de dicho beneficio. No se trata de algo que necesariamente suceda. Es
} 
La propia ley determina que las pérdidas sufridas como consecuencia del reembolso anticipado del crédito "consistirán en aplicar a la cantidad anticipada la diferencia entre el tipo de interés acordado inicialmente y el tipo de interés al que el prestamista pueda prestar el importe del reembolso anticipado en el mercado en el momento de dicho reembolso, teniendo en cuanta el impacto del reembolso anticipado en los gastos administrativos. A estos efectos se considerará como tipo de mercado el Euribor al plazo más cercano a la fecha de vencimiento del préstamo".

Creemos que el ejercicio de la facultad, analizada en sus líneas centrales a partir del modelo de regulación español, es una herramienta eficaz que debe incorporarse como medida preventiva del sobreendeudamiento de los consumidores. Se impone profundizar el estudio a fin de definir cuál será -en la legislación argentina que esperamos con impaciencia- el ámbito de aplicación, los presupuestos para su ejercicio, la operatividad del derecho reconocido y las consecuencias derivadas ${ }^{660}$.

4.- Medidas de saneamiento del sobreendeudamiento ${ }^{661}$

posible que las condiciones del mercado existentes al momento de la amortización permitan al prestamista invertir el capital recuperado en mejores condiciones que las concertadas en el marco del crédito al consumo amortizado. Sin embargo, también es perfectamente factible lo contrario. Y, en cualquier caso, ...no puede negarse que el prestamista tendrá que hacer frente a determinados gastos de gestión para volver a invertir en el mercado el dinero reembolsado" (PEÑA LÓPEZ, Fernando, en MARín LóPEZ, Manuel Jesús (Dir.), Comentarios..., cit., pág. 1095).

${ }^{660}$ La normativa sectorial contiene una referencia a la facultad que asiste al usuario de servicios financieros a efectos de realizar pagos en forma anticipada pero su campo de aplicación es acotado y la regulación de su alcance y efectos se queda a medio camino. La Comunicación A 5460 del BCRA, en su apartado 2.3.1.1 referido a "Requisitos mínimos de los contratos financieros", dispone que dispone que "Los contratos como mínimo deben contener:... "vi) El derecho del usuario de efectuar, en cualquier momento del plazo del crédito, la precancelación total o precancelaciones parciales con ajuste a lo previsto en el punto 2.3.2.1.”; preceptiva que a su vez establece: "La precancelación total o parcial de financiaciones podrá dar lugar a la aplicación de comisiones. En el caso de precancelación total, no se admitirá la aplicación de comisiones cuando al momento de efectuarla haya transcurrido al menos la cuarta parte del plazo original de la financiación o 180 días corridos desde su otorgamiento, de ambos el mayor. Además, será de aplicación lo previsto en el punto 1.7. de las normas sobre "Tasas de interés en las operaciones de crédito"”.

${ }^{661}$ Los autores que han tratado el tema coinciden, aunque con matices, en la enunciación del catálogo de medidas curativas del endeudamiento. A ellos nos remitimos para un mayor desarrollo. Ver TRUJILLO DíEZ, 
Bajo este título pretendemos analizar cuáles serían las herramientas tendientes a propiciar una solución a la situación de crisis provocada por el sobreendeudamiento del consumidor. Se trata de medidas de superación, reparadoras de los efectos lesivos que provoca el fenómeno analizado.

El objetivo de los dispositivos a diseñar es doble: procurar la mayor satisfacción de los acreedores afectados y la recuperación o rehabilitación de la economía privada del deudor.

a.- Renegociación de la deuda:

La superación de la situación de sobreendeudamiento puede alcanzarse acudiendo a un mecanismo de postulación simple: la renegociación con los acreedores. Pero no se trata de una salida de consenso libre sino marcada por la intervención de quien dirige el procedimiento especial diseñado por el legislador, con reglas propias, ajustadas a la situación problemática que urge superar.

En caso de ser ésta una alternativa posible, el consumidor sobreendeudado debería poder acceder a una instancia de conciliación con sus acreedores $\mathrm{y}$, en ese marco, renegociar el pasivo existente, acordar un plan de pagos serio y cumplirlo en forma satisfactoria.

Este mecanismo impropio de liberación de deudas ${ }^{662}$ conduce al resultado esperado pero de modo indirecto puesto que la exoneración del pasivo pendiente será el corolario de una exitosa etapa de conciliación de intereses, del acuerdo al que se arribe y del cumplimiento satisfactorio del mismo. Es necesario propiciar desde la legislación, un lugar y un tiempo de encuentro para las partes involucradas, ofrecer un escenario favorable al consenso y contar con la participación de un gestor ad-hoc, que permita concretar el

Iván Jesús, El sobreendeudamiento de los consumidores..., cit., pág. 75 y sgtes.; GUTIÉRREZ DE CABIEDES, Pablo, El sobreendeudamiento doméstico..., cit., pág. 153; Álvarez VEGA, María Isabel, Protección jurídica del consumidor..., cit., pág. 340; FERnÁNDEZ CARRón, Clara, El tratamiento de la insolvencia de las personas físicas, cit., pág. 121 y sgtes.

${ }^{662}$ SENENT MARTínEZ, Santiago, Exoneración del pasivo insatisfecho..., cit., pág. 63 y sgtes. 
presupuesto necesario - un convenio y el plan de cumplimiento- para la ulterior liberación del deudor.

La propuesta no parece novedosa. En la totalidad de los ordenamientos que regulan el fenómeno de la insolvencia, se prevén procedimientos -extrajudiciales o judicialesencaminados a lograr convenios de refinanciación, que necesariamente contemplarán plazos de espera, quitas, modificación de las condiciones de pago, etc., acordando un efecto novatorio sobre la deuda originaria.

Ahora bien, la iniciativa -para el caso particular- pasa por redefinir el escenario de actuación y el rol de los actores, aportar un guión propio -sin adaptaciones forzadas de libretos antiguos- y diseñar una dinámica eficiente para su puesta en ejecución. Sólo así la obra en estreno resultará exitosa.

Tradicionalmente, las soluciones de consenso contenidas en los regímenes de insolvencia -renegociación del pasivo y plan de pagos- han ofrecido innegables ventajas como mecanismo indirecto de liberación del pasivo insatisfecho. Por un lado, esta vía de saneamiento contempla en su espectro, supuestos que en otros modelos de exoneración, resultarían excluidos. En estos procedimientos extrajudiciales o judiciales existentes, cualquier deudor accedería a la instancia de negociación con sus acreedores y a la eventual liberación posterior, sin que su buena o mala fe opere como barrera de acceso. Se señala que ante la ausencia de un test de discharge, la posibilidad de arribar a un acuerdo y obtener la exoneración tras el cumplimiento del mismo, no está condicionada a un "especial estándar de conducta del deudor" ${ }^{\text {}} 633$ Tampoco existirán deudas excluidas de la discusión y el convenio, propiciándose su ulterior exoneración.

Aquí y ahora propiciamos una instancia de conciliación para que quien asuma la conducción del procedimiento, convoque a las partes y las inste a participar, facilite las condiciones para el desarrollo de las reuniones y coordine las mismas, estimule el consenso y provea lo necesario para arribar a un acuerdo, sobre la base de un plan de pagos serio y de cumplimiento razonable.

La revisión del pasivo, su renegociación y la elaboración de una propuesta de cumplimiento acordada por las partes, es una posibilidad que debe ser promovida, facilitada, asistida y acompañada. Se impone admitir que la utilidad de la medida estará

${ }^{663}$ SENENT MARTínEZ, Santiago, Exoneración del pasivo insatisfecho..., cit. pág. 486. 
condicionada la factibilidad de reunir a las partes, generar el diálogo y la discusión, acercar posiciones y armonizar los intereses en conflicto. Pero además, como la renegociación de la deuda con los acreedores supone siempre -al menos- refinanciación del pasivo, deberá evaluarse si la prolongación de los plazos de pago de la deuda existente es una medida conveniente o puede significar un agravamiento de la situación de crisis que, en tal caso, deberá ser saneada con otros correctivos.

Este mecanismo de saneamiento del sobreendeudamiento debe ser previsto como una herramienta que el consumidor afectado puede utilizar, en caso de constituir una solución a la realidad de su economía doméstica. Debe ser un procedimiento de tránsito facultativo ${ }^{664}$. Si el deudor carece de todo ingreso (por estar desempleado, enfermo o incapacitado, etc.) o los recursos resultan manifiestamente insuficientes para asumir cualquier compromiso de pago (por precarización de las condiciones laborales, por desaparición de uno de los aportantes al hogar, por cargas y gastos sobrevenidos como consecuencia de la enfermedad de uno de los miembros de la familia o de situaciones imprevistas, etc.), no estará impuesto de peticionar la apertura de esta instancia concreta.

Consideramos, que no obstante tratarse de una herramienta de uso facultativo para el consumidor, la necesidad o la conveniencia de su utilización debe ser aconsejada por quien esté llamado a conducir el procedimiento especial y en cuyo marco podría peticionarse éste $\mathrm{u}$ otro mecanismo de saneamiento.

Requerir el auxilio de los remedios previstos por la ley para la superación de la crisis será un derecho del consumidor sobreendeudado pero su no ejercicio puede eventualmente ser juzgado con reproche cuando no se constate como evidente, la sinrazón de la medida.

En la solicitud de apertura de la instancia de conciliación y renegociación, el deudor deberá ofrecer las precisiones necesarias para constatar la concurrencia de los presupuestos objetivos y subjetivos que habilitan el tránsito por el procedimiento y deberá exhibir su cuadro de situación personal y patrimonial. La normativa debe imponer con claridad el

\footnotetext{
${ }^{664} \mathrm{El}$ anteproyecto de ley elevado por la comisión de juristas designada por el Ministerio de Justicia de la Nación, actualmente analizado en la Secretaría Legal y Técnica de la Nación, prevé en el art. 307 propuesto: "El procedimiento podrá ser solicitado exclusivamente por el deudor, o por apoderado con facultad especial...".
} 
contenido mínimo de esta presentación inicial, explicitando la información a suministrar y la documentación que ha de ser acompañada como respaldo ${ }^{665}$. Se impone evitar dilaciones innecesarias que comprometan la eficacia de un trámite que debe estar caracterizado por la simpleza y la celeridad. Ello no obsta a que, en su caso, quien conduzca el procedimiento esté habilitado a dispensar al deudor del cumplimiento de algún requisito o bien a otorgar un plazo adicional mínimo para completar la información o documentación necesaria ${ }^{666}$.

${ }^{665}$ El art. 308 del Anteproyecto en estudio en Argentina dispone: "Son requisitos formales de la petición de apertura del procedimiento previsto en el presente Capítulo: 1) Suministrar al Juez los datos completos de identificación del deudor, incluyendo su nombre, copia del documento nacional de identidad, fecha y lugar de nacimiento, domicilio, estado civil, actividad o profesión y dirección de correo electrónico, éste último si lo tuviese; 2) Explicar las causas concretas de su situación patrimonial con expresión de la época en que se produjo la situación de sobre endeudamiento, las dificultades económicas o financieras de carácter general o el estado de cesación de pagos - según sea el caso - e identificar y señalar los hechos por los cuales alguna de estas circunstancias se hubieran manifestado; 3) Acompañar, con carácter de declaración jurada, un estado detallado y valorado del activo y pasivo actualizado a la fecha de presentación, con indicación precisa de su composición, los criterios seguidos para su valuación, la ubicación, estado y gravámenes de los bienes y demás datos necesarios para conocer debidamente el patrimonio y la documentación contable que se llevare voluntariamente; 4) Acompañar, con carácter de declaración jurada, la nómina de acreedores, con indicación de sus domicilio, sus direcciones de correo electrónico, montos de los créditos, causas, vencimientos, codeudores, fiadores o terceros obligados o responsables y privilegios, con copia de la documentación sustentatoria de la deuda denunciada, que tuviera en su poder. Debe agregar, en su declaración, el detalle de los procesos judiciales o administrativos de carácter patrimonial en trámite o con condena no cumplida, precisando su radicación; 5) Denunciar la existencia de proceso concursal anterior y justificar, en su caso, que no se encuentra dentro del periodo de inhibición que establece el artículo 59, o el desistimiento del concurso si lo hubiere habido; 6) Acompañar nómina de empleados, si los tuviere, con detalle de domicilio, categoría, antigüedad y última remuneración recibida. Deberá acompañarse también declaración sobre la existencia de deuda laboral y de deuda con los organismos de la seguridad social; 7) Acompañar certificado de su inscripción ante la autoridad tributaria, en caso de existir. El escrito y la documentación agregada deben acompañarse con dos (2) copias firmadas".

${ }^{666}$ Así lo prevé el art 308 in fine del Anteproyecto de ley citado: “...Cuando el deudor lo requiera, o en su caso el juez lo estime necesario, ponderando los requisitos legales con un criterio de razonabilidad, según las circunstancias del deudor, se podrá otorgar un plazo de diez días desde la presentación, para completar la información que se estime necesaria para habilitar el procedimiento pudiendo dispensarse del cumplimiento de algún requisito que el juez no considere pertinente". 
En los ordenamientos que prevén esta herramienta y en la doctrina que así la propicia, la renegociación de la deuda está caracterizada por la intervención de un tercero que, acercando las posiciones de las partes, puede plantear propuestas de solución, e incluso llegar a imponer la solución que estime conveniente y justa para las partes.

Ese tercero imparcial puede ser una autoridad administrativa, como ocurre en el modelo francés, a la que suelen atribuírsele facultades coactivas para llevar adelante su intervención y para propiciar la resolución del conflicto $^{667}$. Sin perjuicio de ello, la renegociación de la deuda puede llevarse a cabo también, en sede judicial sea como una etapa preconcursal o en el trámite del propio proceso concursal. La opción entre un escenario u otro está condicionada a una decisión de política jurídica a cargo del legislador que debe guardar relación con el modelo diseñado y los mecanismos -sustanciales y formales- previstos para ejecutarlo ${ }^{668}$.

Creemos que salvo en aquéllos supuestos en que el propio deudor invoque y acredite el sinsentido de convocar a una renegociación de la deuda, o que la autoridad interviniente advierta la manifiesta ineficacia de la medida, es una instancia que debe ser estimulada.

El éxito de la medida de renegociación dependerá de factores diversos: de la situación personal y patrimonial del deudor y de su grupo familiar (salud, mantenimiento de la fuente de ingresos, etc.), de los recursos existentes y disponibles (salario, bienes o activos en general), de la cantidad y calidad de los acreedores (el Fisco, organismos públicos, entes privados, personas individuales), de la posibilidad de localizarlos en un tiempo razonable y convocarlos de una renegociación, de la factibilidad real de arribar a un acuerdo de este tipo, etc.

Es ineludible ponderar, al momento de decidir la apertura de esta instancia de conciliación y acuerdo, si el tiempo que demande disponer la convocatoria y llevar adelante el procedimiento de renegociación no colocará al consumidor afectado en una situación de

\footnotetext{
${ }^{667}$ GutiÉRREZ DE CABIEDES, Pablo, El sobreendeudamiento doméstico..., cit., pág. 155 y sgtes.

${ }^{668}$ Volveremos sobre el tema al analizar los escenarios de actuación en particular. Adelantamos desde ya que la adopción de un criterio, en relación al punto, dependerá de la filosofía subyacente en el modelo diseñado y de la idiosincrasia del conjunto social en el que se inserta (la confianza que genera cada ámbito de actuación y sus conductores, la adhesión o rechazo a las decisiones que allí se adoptan, etc.).
} 
mayor e irremediable gravedad. La eficacia saneadora del dispositivo legal está directamente vinculada al acierto de esta decisión.

Configurados los presupuestos que definen el ámbito subjetivo y objetivo del procedimiento y habiendo observado el deudor afectado los requisitos formales impuestos a la solicitud de inicio, quien conduzca el trámite deberá dictar una resolución de apertura formal. Consideramos de vital importancia que en el citado pronunciamiento -acto administrativo o sentencia judicial, conforme el escenario de actuación- se hagan explícitos los efectos que del mismo se derivan. La apertura del procedimiento debe provocar consecuencias patrimoniales favorables para el deudor, que contribuyan a crear un clima de encuentro, conciliación y renegociación con los acreedores. En nuestra opinión, se impone impedir el inicio de nuevos reclamos judiciales, suspender -por un plazo razonable- el trámite de todos los juicios de contenido patrimonial en marcha (por deudas de causa o título anterior a la solicitud de inicio del procedimiento). Asimismo, se debe disponer la suspensión del curso de los intereses con excepción de los créditos que el legislador estime necesario excluir. Se propugna, asimismo, dejar sin efecto las medidas cautelares que afecten -como mínimo- el salario y los honorarios que el deudor tuviera por percibir y paralizar cualquier medida que importe el lanzamiento de la vivienda familiar o del lugar en que el deudor desarrolla su oficio o actividad profesional ${ }^{669}$.

\footnotetext{
${ }^{669} \mathrm{El}$ art. 312 del aludido Anteproyecto en estudio, dispone: "La apertura del procedimiento produce los siguientes efectos: 1) La suspensión por noventa (90) días de todos los juicios de contenido patrimonial por causa o título anterior a su presentación, no pudiendo deducirse nuevas acciones con fundamento en tales causas o títulos, incluidas la ejecución de créditos prendarios y/o hipotecarios y desalojos de la vivienda particular del deudor o del lugar donde lleva a cabo su labor profesional. Los expedientes permanecerán en los Juzgados originariamente asignados y los acreedores deberán acreditar su condición con copia certificada a presentar ante el conciliador, cuando sean convocados a los efectos de su reconocimiento; 2) La suspensión de los intereses de los créditos del deudor, con excepción de los créditos garantizados con garantís reales que prosiguen en le medida que alcance el asiento del crédito; 3) Quedan sin efecto todas las medidas cautelares trabadas sobre los bienes y honorarios del deudor, y en especial, los embargos sobre los sueldos, salarios; 4) El conciliador tiene las facultades de contralor de la situación patrimonial del deudor, aplicándose el régimen establecido por los art. 15 y 16 de la presente ley, a cuyo fin el juez puede autorizar para tutela personal del deudor y de su familia el pago de las cuotas correspondientes a las coberturas de salud de obras sociales o empresas de medicina prepaga; 5) La apertura de la etapa de conciliación, la cual se extenderá por noventa
} 
Las medidas enunciadas tienden a fortalecer la posición del deudor, facilitándole el manejo de los escasos recursos disponibles y la elaboración de propuestas a la hora de encarar la renegociación con los acreedores. Como disposición complementaria, cabe aclarar que la apertura del procedimiento en modo alguno debe restringir el ejercicio de la actividad laboral y productiva del deudor ${ }^{670}$. No obstante ello, se impone controlar en esta etapa, el ejercicio de actos de disposición que pongan en riesgo los bienes que pudieran existir y que serán necesarios para afrontar la negociación con los acreedores. Ello explica que se considere conveniente hacer constar en la resolución de apertura del procedimiento, que este acto importa la inhibición general para disponer y gravar bienes registrables del deudor ordenándose su inscripción en el registro pertinente ${ }^{671}$

Efectos como los descriptos, operarán como un llamado de atención para los acreedores que deberán asumir la particular naturaleza del procedimiento al que se los convoca, la finalidad prioritaria del mismo, la cooperación que deberán prestar y las consecuencias de su omisión, el rol de la autoridad interviniente y las consecuencias posibles para su esfera de intereses.

La resolución de apertura del procedimiento deberá determinar quién llevará adelante la instancia de conciliación y renegociación. Consideramos necesario que el director del procedimiento -sea la autoridad administrativa o el juez con competencia para el caso- ponga en manos de un funcionario ad-hoc, la conducción de esta etapa del trámite. Será en encargado de la citación y convocatoria de los acreedores, de determinar provisoriamente el pasivo, de promover el acercamiento de las partes y estimular el acuerdo, asesorar, instar medidas de resguardo patrimonial y extrapatrimonial del deudor y

(90) días desde la última publicación de edictos, en el cual el conciliador tendrá por misión promover y facilitar acuerdos entre el deudor y sus acreedores.

${ }^{670} \mathrm{El}$ art. 313 del Anteproyecto citado hace explícita esta directiva al disponer que "La apertura del proceso no afecta la legitimación del deudor, el que conserva sus facultades para desempeñar tareas artesanales, profesionales o en relación de dependencia, debiendo aplicarse la obligación de residencia reglada en el art. 25 ".

${ }^{671}$ El art. 311 del Anteproyecto, referido a la "Resolución de apertura", dispone: "Cumplidos en debido tiempo los requisitos legales, el juez debe dictar resolución que disponga: ... 4) La inhibición general para disponer y gravar bienes registrables del deudor, la que será anotada en los registros pertinentes”. 
su familia ${ }^{672}$, informar al director del procedimiento, proponer salidas alternativas, coordinar las actuaciones, etc.

El trámite en cuestión requiere experticidad en la conducción. Debe tratarse de un funcionario con formación profesional concreta y capacitación particular en la problemática $^{673}$. Y, principalmente, debe ser un funcionario comprometido con los fines que tuvo en miras el legislador al diseñar este procedimiento, como cauce para la tutela eficaz del consumidor sobreendeudado.

La resolución que disponga la apertura del procedimiento debe, por otra parte, disponer la inmediata convocatoria de los acreedores a efectos de participar de esta instancia de conciliación y renegociación del pasivo. Parece razonable entender que quien asuma la conducción de esta etapa, debe extremar recaudos a fin de ubicar a los acreedores denunciados en sus correspondientes domicilios ${ }^{674}$ y citarlos a efectos de abrir el diálogo y

${ }^{672} \mathrm{Al}$ regular los efectos de la apertura del procedimiento, el art. 312 inc. 4 establece que "el conciliador tiene las facultades de contralor de la situación patrimonial del deudor, aplicándose el régimen establecido por los art. 15 y 16 de la presente ley, a cuyo fin el juez puede autorizar para tutela personal del deudor y de su familia el pago de las cuotas correspondientes a las coberturas de salud de obras sociales o empresas de medicina prepaga".

${ }^{673}$ El modelo al que adhiera el legislador en cada ordenamiento y el emplazamiento del procedimiento determinarán el carácter y el perfil del funcionario que asumirá la tarea de conducir la instancia de conciliación y renegociación. En el modelo de base administrativa, la autoridad con competencia en la materia designará a quien, conforme los cuadros de su estructura, esté llamado a ejercer esa función de conciliación o mediación particular. En el modelo de base judicial, el juez a quien se asigne esta competencia material podrá ordenar que la tramitación de esta instancia se realice con la intervención del funcionario que corresponda, conforme el tipo de proceso de que se trate -concursal u otro proceso especial- y en el marco del mismo (síndico, administrador concursal, mediador, conciliador, etc.). El Anteproyecto de ley en revisión, establece en el art. 311: "Cumplidos en debido tiempo los requisitos legales, el juez debe dictar resolución que disponga: 1) La declaración de apertura del procedimiento, identificando al deudor; 2) La designación de un conciliador de la lista para que intervenga en el procedimiento. Los conciliadores sólo podrán ser abogados o contadores...".

${ }^{674}$ Consideramos oportuno mencionar que los acreedores deberán ser notificados en los domicilios consignados en los instrumentos que formalizan el contrato o en los que, conforme las circunstancias de cada caso, resulten ser sus asientos formales (caso de deudas con el Estado o sus dependencias, entes autárquicos, etc.). Lamentablemente es una práctica frecuente de ciertas empresas, no consignar un domicilio o hacerlo de 
la renegociación, comunicándoles que deberán concurrir a la audiencia establecida en la fecha y la hora fijados, bajo apercibimiento de llevar a cabo la reunión sin su intervención. Ahora bien, en atención a las dificultades que pueda suponer este modo de citación, se ha señalado que la convocatoria y citación de los acreedores debe hacerse en un único acto y de un modo simplificado. En esta línea de razonamiento, se propone la publicación de edictos en el diario de publicaciones legales correspondiente a la jurisdicción de la autoridad interviniente con indicación de las actuaciones de que se trata (expediente administrativo o causa judicial), su radicación, nombre del funcionario a cargo de la conciliación y la citación a los acreedores para que denuncien sus créditos dentro del plazo establecido que deberá computarse desde el último edicto. En consonancia con la naturaleza y fines del procedimiento, deberá dejarse expresamente establecido que la publicación de los edictos pertinentes será gratuita y que su diligenciamiento estará a cargo del deudor. Como corolario de lo expuesto, se ha entendido que si este último incumpliera la carga mencionada, corresponde interpretar que desiste del procedimiento abierto a su requerimiento $^{675}$.

Cabe preguntarse por qué deberían los acreedores acceder a una revisión de sus acuerdos con el deudor y renegociar con éste plazos y condiciones de cumplimiento, concediendo ventajas tales como esperas, quitas, condonación de deudas, etc. Por un lado, es de toda evidencia que si el deudor atraviesa una situación de impotencia patrimonial, el procedimiento propuesto resulta prima facie conveniente para los acreedores pues ofrece la oportunidad de procurarles el cobro de sus créditos. Pero, desde otro enfoque, consideramos que los acreedores deben ser compelidos a participar de esta instancia de renegociación, bajo apercibimiento de soportar las consecuencias desfavorables que les genere su reticencia.

Es indiscutible que el acuerdo celebrado por las partes constituye un programa privado que obtiene su natural satisfacción cuando se observan las obligaciones allí contenidas. Pero no es menos cierto que la morosidad y el incumplimiento son

modo impreciso o incompleto, o remitir a sedes centrales ubicadas en la capital del país, etc., lo que torna imposible o muy dificultoso, ubicarlas a efectos de notificarles diligencias o requerimientos.

${ }^{675}$ Conforme el art. 314 del Anteproyecto citado, "El desistimiento del procedimiento solo se produce si el deudor no cumple con la publicación de edictos...". 
contingencias propias del negocio concertado, de las que las partes suelen ponerse a resguardo, con previsiones particulares ${ }^{676}$. El plan contractual puede verse afectado por causas previsibles o imprevisibles, concomitantes o posteriores a su celebración, provocando la imposibilidad de cumplimiento o serias dificultades de hacerlo; y, para tales supuestos, el sistema general diseñó soluciones orientadas a la revisión o a la extinción del contrato $^{677}$.

FRUSTAGLI y HERNÁNDEZ mencionan que los códigos de fondo han consagrado remedios para corregir las disfunciones que suscita el cambio de circunstancias del negocio oportunamente acordado y recuerdan que el instituto de la revisión tiene tradición jurídica en la teoría general del contrato ${ }^{678}$. Y a propósito de ello, los autores citados señalan que "ese deber de renegociar y/o su consecuente revisión, bien puede ser extrapolado al ámbito del Derecho del Consumidor para hacerlo actuar como instrumento correctivo de la situación de sobreendeudamiento ${ }^{679}$. Se advierte que si el sistema general prevé tal correctivo para el supuesto de incumplimiento de un contrato aislado, frente a la hipótesis de impotencia patrimonial generalizada del deudor, se impone replicar ese dispositivo sustancial, con la natural adaptación.

${ }^{676}$ Cfr. Llamas Pombo, Eugenio-Martínez Rodríguez, Nieves- Toral LaRA, Estrella, en BlancoMorales Limones, Pilar, Medidas de lucha contra la morosidad, La Ley, Madrid, 2011, pág. 97 y sgtes.

${ }^{677}$ LoRenzetTI, Ricardo L., Tratado de los Contrato. Parte General, cit., pág. 505 y sgtes.

${ }^{678}$ Frustagl, Sandra A.-Hernández, Carlos A., "Sobreendeudamiento del consumidor", en LL 2013E,1160.

${ }^{679}$ Frustagli, Sandra A.-HernándeZ, Carlos A., "Sobreendeudamiento del consumidor", cit. Los autores citados consideran que "la renegociación como respuesta jurídica frente al problema del sobreendeudamiento puede resultar útil en algunos supuestos en los cuales se encuentran comprometidos derechos fundamentales del consumidor sobreendeudado de buena fe, y con deudas concentradas en uno o pocos acreedores, puesto que en tal caso, la revisión de tales negocios jurídicos se pone al servicio de la superación de la crisis que compromete el salario -principal, cuando no único, medio de subsistencia-, el patrimonio y la vivienda, conduciendo al grupo familiar del consumidor a la privación de bienes esenciales, y quizás a la exclusión social. En tal contexto parecería irrazonable no reconocerle al consumidor la prerrogativa de solicitar la adecuación o revisión de sus vínculos obligatorios. Esta perspectiva revisora puede incluso ser coherente con futuras soluciones normativas, que puedan llevar a admitir vías prejudiciales de reprogramación del pasivo en supuestos de endeudamiento más extendido". 
Creemos que el proveedor de crédito debe participar activamente en la superación de la problemática asumiendo el deber de cooperación en el procedimiento de saneamiento. La crisis de la economía doméstica del consumidor y el incumplimiento de los compromisos oportunamente contraídos, no le son ajenos. Ese exceso de crédito y la situación de sobreendeudamiento del tomador es un riesgo propio de la actividad que el proveedor despliega de modo profesional. De allí que además de la obligación de cooperar antes mencionada, deberá participar en la distribución de los costes que demande la superación de ese estado de impotencia patrimonial y la consiguiente rehabilitación del sujeto afectado ${ }^{680}$.

Oportuno es reiterar que "la abusiva concesión de crédito comporta un perjuicio de carácter pluriofensivo" ${ }^{\text {681 }}$ pues afecta no sólo el patrimonio del deudor financiado en exceso y el consiguiente interés de los acreedores concurrentes, sino la salud del sistema.

Aún cuando las entidades de crédito soportan en primera persona el riesgo de insolvencia del deudor, la realidad demuestra que acudiendo a mecanismos diversos, logran su externalización, "convirtiendo el riesgo individual en riesgo sistémico" 682 , con descarga del coste en el conjunto social ${ }^{683}$.

Campea la idea de que a la situación de sobreendeudamiento se entra de la mano de quien provee financiación y que para salir de ella, aquella mano no debe serle esquiva ${ }^{684}$. El

${ }^{680}$ Señalábamos a desarrollar el principio de crédito responsable que, desde hace años, organismos especializados vienen propugnando una justa y equitativa distribución del riesgo en los créditos para el consumo. Ello explica que así lo dejara establecido en una de sus reglas, el Consumer Debt Report emitido por el INSOL, al que nos referimos ut supra.

${ }^{681}$ GutIÉRREZ DE CABIEDES, Pablo, El sobreendeudamiento doméstico..., cit., pág. 121.

${ }^{682}$ GALlEGo SÁNCHEZ, Esperanza, "La obligación de evaluar la solvencia del deudor. Consecuencias derivadas de su incumplimiento", en PRAT Albentosa-CuEnA CASAS (Coord.), Préstamo responsable y ficheros de solvencia, Thomson Reuters-Aranzadi, Pamplona, 2014, pág. 207-242.

683 cfr. BALBUENA RiverA, Manuel, “Análisis del riesgo financiero...”, cit., pág. 117-179).

${ }^{684}$ Señala Álvarez LARRONDO: “...Aquí se da una dicotomía enfermiza propia de la sociedad de consumo. Es que esa persona que era invitada a endeudarse por merecer crédito, cuando ve que su capacidad de pago no alcanza a cubrir todas las obligaciones asumidas vuelve a cargar con el mote estigmatizador de deudor, como lo era en los inicios de la historia moderna. En este sentido, también media aquí un trabajo lingüístico imperceptible en pos de cambiar realidades. Es que, en la lógica protestante, deber era pecado. Ser deudor era repudiable, y aún hoy, en el imaginario colectivo, la catalogación como deudor implica un demérito. De allí 
legislador ha de intervenir para proponer una salida del problema, diseñará un procedimiento con un escenario y actores necesarios, convocará a los protagonistas de la operatoria y todos ellos estarán impuestos de subir a escena, cumplir sus roles y aportar el éxito de la obra.

Abierta la instancia de conciliación, notificados los acreedores de la existencia del procedimiento y convocados a fin de acreditar la existencia, cuantía y naturaleza de sus créditos, deben comparecer dentro del plazo establecido observando el requerimiento que les ha sido formulado. Luce razonable que en el primer encuentro, quien lleve adelante la instancia de conciliación, informe sobre la situación del deudor (personal y patrimonial) y las características del trámite (su finalidad, las alternativas existentes, las facultades de la autoridad interviniente para instar y hasta imponer soluciones, así como el ejercicio de atribuciones correctivas para quienes entorpezcan o distorsionen el procedimiento, etc.) ${ }^{685}$.

Seguramente esta reunión de inicio determinará que los acreedores evalúen el estado de su crédito -porción insoluta, existencia y estado de garantías, perspectivas de satisfacción, etc.-, consideren acciones a seguir, fijen posición e impartan instrucciones a sus representantes para la continuación del trámite. Como se dijo, ante el funcionario que subrepticiamente, el sistema capitalista se encargara de modificar la denominación de deuda por la de crédito. Esto es por demás fascinante, dado que la acepción dada por la Real Academia Española al término "deuda" es de por sí lapidaria al conceptualizarla como "Pecado, culpa u ofensa", mientras que algunas de las tantas acepciones del término "crédito" dan una idea diametralmente opuesta al referirse a "Reputación, fama, autoridad" o "Situación económica o condiciones morales que facultan a una persona o entidad para obtener de otra fondos o mercancías". Es decir, que esa persona antes catalogada como "pecadora", con el cambio simplemente del término "deuda" por "crédito", mágicamente pasa a tener condiciones morales elevadas como para merecer la confianza de terceros... La figura del sobreendeudado desenmascara esta realidad, haciendo que la impotencia del sujeto para hacer frente a todas sus obligaciones genere la brutal una nueva conversión del originariamente sujeto de crédito, a la vieja figura vituperada del "deudor"' (ÁLVAREZ LARRONDO, Federico M., "La protección constitucional de los intereses económicos de los consumidores”, en LL 2013-A,395).

${ }^{685}$ El art. 315 del Anteproyecto en estudio está dedicado al llamado "Período de conciliación”. Establece la norma el mismo se extenderá por noventa (90) días desde la última publicación de edictos, etapa durante la cual el conciliador tendrá por misión determinar provisionalmente el pasivo y facilitar acuerdos entre el deudor y sus acreedores. Puntualiza el precepto que "El funcionario designado recibirá la documentación que le presenten los acreedores y corroborará la denuncia del deudor, a los fines de procurar celebrar acuerdos, para la satisfacción de las obligaciones pendientes de cumplimiento". 
interviniente y en el plazo establecido, deberán esgrimir y justificar sus acreencias a efectos de confrontarlas con los créditos denunciados por el deudor y determinar el pasivo existente $^{686}$.

Sería deseable que en la siguiente convocatoria, la autoridad interviniente lograra un avance en el diálogo y arrimar posiciones, armonizando los intereses involucrados. En este esfuerzo, hará saber a los participantes que en el procedimiento abierto con motivo de la petición del deudor, se procurará dar la mayor satisfacción posible a los acreedores pero que el saneamiento y rehabilitación del consumidor es un objetivo prioritario. De allí que resulte necesario advertirles que, en caso de ser necesario, el director del procedimiento podría hasta imponer las soluciones que permitan resolver la situación de crisis del afectado. En esta etapa, y a los fines que la inspiran, el funcionario podrá citar a tantas audiencias como considere necesarias ${ }^{687}$.

Quien lleve adelante esta instancia de conciliación deberá contar con atribuciones para conducir eficazmente la renegociación. Debe estar habilitado para plantear alternativas disponibles: condonación total o parcial de algunas deudas, quitas, esperas, supresión o morigeración de intereses y penalidades, reajuste de prestaciones (monto de alquileres, precios, canon, etc.), modificación de condiciones de contratación (que permitan mejorar las rentas al deudor u obtener ventajas económicas ${ }^{688}$, etc.

\footnotetext{
${ }^{686} \mathrm{El}$ art. 315 del Anteproyecto prevé que en ese período de conciliación, "2) Los acreedores tendrán un plazo de diez (10) días desde la última publicación de edictos para presentarse ante el conciliador a solicitar la verificación de sus créditos" y que "3) Vencido dicho plazo y en igual término, el conciliador deberá informar al juez la nómina detallada de los acreedores cuya verificación o admisibilidad recomienda, como así también de las eventuales exclusiones acompañando la documentación pertinente en sus respectivos legajos". Y agrega que "4) El juez en el plazo de diez (10) días, deberá dictar la sentencia de verificación, con los efectos del art. 36 último párrafo".

${ }^{687}$ Así lo establece expresamente el art 315 en el inc. 5 del mencionado Anteproyecto: “El funcionario promoverá el proceso conciliatorio y podrá celebrar tantas audiencias como considere necesarias, convocando a ellas al deudor y a los acreedores".

${ }^{688}$ Podría ocurrir que en un contrato de locación se hubiera insertado una cláusula que prohibiera al arrendatario la sublocación o alterar el destino de la ocupación; cláusula que en el marco de este procedimiento podría ser modificada, con consentimiento del acreedor propietario, a efectos de propiciar un ingreso adicional al deudor, mejorando su situación patrimonial.
} 
Cualquier comportamiento dilatorio injustificado deberá ser neutralizado mediante el ejercicio de las atribuciones que, a tal efecto, le sean también reconocidas a la autoridad interviniente.

Las condiciones de la propuesta de pago ofrecida por el deudor podrán ser sugeridas por el funcionario a cargo del trámite, que evaluará alternativas y posibilidades, atendiendo a la bipolaridad de los intereses comprometidos pero conforme el objetivo prioritario. Podrá orientar las soluciones, asesorar, aconsejar, plantear objeciones, reconducir las negociaciones.

El vencimiento del plazo establecido para esta etapa de conciliación y renegociación marcará necesariamente el límite del esfuerzo en pos de un acuerdo consensuado entre las partes involucradas. En caso de conciliar intereses y lograr un plan de pagos ${ }^{689}$, el acuerdo deberá observar las formalidades legalmente impuestas y será elevado por el funcionario a cargo de esta instancia para su consideración por el director del procedimiento (la autoridad administrativa o el juez, conforme el modelo adoptado $)^{690}$. Sin que ello demande costes adicionales ni demoras innecesarias ${ }^{691}$, corresponde dar publicidad a la propuesta de acuerdo a fin de permitir su eventual impugnación en el plazo establecido. Vencido el

\footnotetext{
${ }^{689}$ La regulación debe dejar establecidas las reglas para la votación del acuerdo a fin de decidir su aprobación. El inc. 6 del art. 315 del Anteproyecto dispone que "La etapa concluye ... cuando se obtuviere la conformidad de acreedores que representen la mayoría absoluta del capital verificado y declarado admisible, rigiendo el régimen de exclusiones del artículo 45".

${ }^{690} \mathrm{El}$ art. 316 del Anteproyecto al que aludimos, "La forma y contenido del o de los acuerdos quedan sometidos a las siguientes reglas: 1) Se aplica el art. 70 en cuanto el o los acuerdos deben ser otorgados por instrumento firmado por el conciliador debiendo los documento habilitantes de la representación de los acreedores estar debidamente certificados por escribano público o mediante poder otorgado ante el Secretario del Juzgado; 2) Los acuerdos podrán habilitar diversas categorías y ser diferentes respecto de cada acreedor pudiendo pactarse quitas y esperas sin límite temporal, ni cuantitativo, y toda otra fórmula que obtenga la conformidad de los acreedores; 3) Dentro de los dos (2) días de vencido el plazo de conciliación, el conciliador informará al juez sobre los acuerdos, presentándole los convenios a los que se hubiera arribado, con expresa indicación del porcentaje de acreedores y capital de créditos que hubieran conciliado".

${ }^{691}$ En el modelo propuesto para Argentina, conforme el Anteproyecto en estudio, "Presentado los acuerdos en el expediente, el juez hará saber de su existencia mediante resolución que se notificará por ministerio de la ley, momento a partir del cual correrá el plazo previsto en el art. 50 de la ley a los fines de dar cumplimiento a la etapa impugnativa" (art. 317).
} 
término aludido sin cuestionamientos por parte de los acreedores o resueltos los mismos, el director del procedimiento decidirá la homologación o el rechazo de la propuesta de acuerdo, sin más dilaciones ${ }^{692}$.

La razonabilidad de la propuesta final será juzgada por la autoridad administrativa o el juez de la causa que, con los límites que la regulación imponga a su actuación, revisará el acuerdo antes de homologarlo y disponer su ejecutoriedad. Debe tener facultades para disponer, mediante resolución fundada, modificaciones al plan consensuado por las partes en la instancia de conciliación. Oportuno es reiterar que quien dirija este procedimiento, debe ordenar su actuación en pos del saneamiento y superación de la crisis que afecta al consumidor, propiciando la mejor salida para el sujeto afectado y su grupo familiar. Es ésta una de las notas típicas de la vía procesal analizada ${ }^{693}$.

Como se dijo, esta instancia de renegociación del pasivo impone el encuentro del deudor con sus acreedores con el objetivo prioritario de sanear la situación personal y familiar del consumidor sobreendeudado. Los acreedores no podrán eludir su participación y en caso de hacerlo, sabrán que la solución a la que se arribe será de cumplimiento inexorable para ellos. Para transitar el camino y llegar al destino deseado, se confía la conducción a un experto con facultades ordenatorias. El desafío es arribar a una salida consensuada pero ese acuerdo no está librado a la autonomía privada sino marcado por la intervención de quien lleva adelante la instancia de revisión y renegociación en la que ejercerá en plenitud el cúmulo de atribuciones que se le confieran. Todavía más: a falta de

\footnotetext{
${ }^{692}$ A tenor del art. 318 proyectado, "Una vez vencido el plazo previsto en el artículo anterior, ya sea que exista acuerdo entre el deudor y los acreedores o propuesta del conciliador o que se hayan realizado impugnaciones, el juez procederá a realizar el control de legalidad formal y sustancial de los acuerdos, respetando el principio de buena fe y evitando el abuso del derecho en el convenio, previa intervención del Ministerio Público Fiscal. A tal efecto, el juez podrá: 1) Analizar las impugnaciones que pudieran existir, y en su caso, habilitar un nuevo período conciliatorio por treinta (30) días a cuyo fin dará nueva intervención al conciliador, para que intente la superación de los planteos realizados por los acreedores; 2) Homologar el acuerdo en caso que lo estime ajustado a derecho...".

${ }^{693}$ No se trata de ofrecer remedios ya conocidos, propios del régimen general de insolvencia. Para este mal individual y social, precisamos nuevos tratamientos y medicación específica. No se trata de forzar fórmulas adaptativas, ni de reciclar soluciones previstas para otras situaciones problemáticas. En todas las latitudes se han alzado voces reclamando nuevas armas para enfrentar situaciones problemáticas inéditas, admitiendo la ineficacia de los remedios tradicionales. Ése ha sido el desafío del legislador en la materia.
} 
acuerdo, este conciliador puede elevar propuestas de superación para su consideración por el director del procedimiento, que pueden serles finalmente impuestas a las partes involucradas $^{694}$. Y, como señaláramos, aún formalizado el acuerdo bajo la supervisión del funcionario a cargo, la autoridad administrativa o el juez revisará su contenido para adecuarlo y mejorarlo en caso de estimarlo necesario, imponiendo su cumplimiento ${ }^{695}$.

En esa misma línea de razonamiento, ante el fracaso de la conciliación, el funcionario a cargo de la instancia en cuestión, debe estar habilitado para proponer un plan de pagos ajustado a las posibilidades del deudor y someterla a consideración del director del procedimiento ${ }^{696}$. Desde luego, y aún cuando no se hubiera elevado propuesta alguna por parte del funcionario conciliador, la autoridad administrativa o el juez, podrá -ante la falta de consenso- imponer un plan de saneamiento ponderando la situación personal y familiar del deudor, los recursos disponibles y la naturaleza y cuantía del pasivo.

Esta propuesta de superación de la crisis es reveladora del espíritu que inspira al sistema. Tratándose de un procedimiento abierto a instancias de un consumidor sobreendeudado -de buena fe- que peticiona el auxilio de la ley para superar esta situación extrema, deberán agotarse todos los esfuerzos en pos de alcanzar el objetivo. Se señala asimismo, que el plan de saneamiento implementado a instancias del propio director del procedimiento, es un deber ineludible cuando el particular afectado ha exhibido una conducta exenta de reproche antes y durante el procedimiento abierto a su requerimiento ${ }^{697}$.

La homologación del acuerdo producirá consecuencias jurídicas relevantes. El acuerdo homologado por la autoridad interviniente importa la novación de todas las

\footnotetext{
${ }^{694}$ El art. 315 inc. 7 del Anteproyecto citado prevé que "en caso de no lograrse acuerdo, el conciliador propondrá una fórmula de repago y o cualquier otra solución que estime conveniente ante el Juez".

${ }^{695}$ Así lo establece el citado art. 318 del Anteproyecto: “4) En todos los casos, el juez tiene facultades para integrar el acuerdo, mediante resolución fundada, aumentando o reduciendo plazos y adecuando los montos de las cuotas pactadas, en tanto considere pertinente a fin de asegurar el cumplimiento de lo acordado sin afectar subsistencia decorosa del deudor y la de su familia".

${ }^{696} \mathrm{El}$ art. 315 prevé en el inc. 7 que "En caso de no lograrse acuerdo, el conciliador propondrá una fórmula de repago y o cualquier otra solución que estime conveniente ante el Juez".

${ }^{697}$ Conforme el art. 318 proyectado, el juez interviniente, "en el supuesto que no se alcanzara acuerdo alguno, podrá imponer un plan de reorganización que considere razonable, valorando la naturaleza de créditos, origen, el contexto social y familiar del deudor y su conducta, tanto antes como durante el proceso" (inc. 5).
} 
obligaciones con origen o causa anterior al inicio del procedimiento respecto del deudor pero no causa la extinción de las obligaciones respecto del fiador ni de los codeudores solidarios. Sus efectos deben alcanzar a todos los acreedores aunque no hayan participado en el trámite del mismo. En su caso, la regulación deberá establecer las precisiones que correspondan $^{698}$.

El acuerdo que supera la aprobación del director del procedimiento debe ejecutarse conforme los términos allí establecidos. Su estricto cumplimiento habilitará al deudor a peticionar la liberación correspondiente y, en su caso, el levantamiento de las medidas oportunamente dictadas para controlar la disponibilidad de sus bienes. La resolución que se dicte en este sentido deberá hacer explícita la exoneración de las deudas y la rehabilitación del afectado.

Por otra parte, frente al incumplimiento total o parcial del plan de saneamiento, la autoridad interviniente deberá ponderar las causas de tal inobservancia, la imputabilidad de las mismas, la naturaleza y cuantía del pasivo insatisfecho y demás circunstancias relevantes. Consideramos que el director del procedimiento evaluará el cuadro de situación y, en atención a las particularidades del caso, estará habilitado para reconducir el acuerdo cuando la porción insoluta sea menor y pueda ser atendida en un tiempo prudencial- y para disponer la reapertura de la etapa de negociación con los acreedores afectados por un plazo razonable, convocando al funcionario que gestionara la conciliación precedente ${ }^{699}$. De advertirse la inutilidad de la medida, decidirá el cierre del procedimiento previsto para la implementación de esta medida de liberación y rehabilitación del sujeto afectado.

\footnotetext{
${ }^{698}$ En el art. 318 in fine del Anteproyecto, se deja establecido que "el acuerdo tiene los efectos consignados en la Sección III del Capítulo V" de la ley concursal, lo que remite a la preceptiva contenida en los arts. 55 a 50 de la Ley $\mathrm{N}^{\circ} 24.522$ argentina.

${ }^{699} \mathrm{Al}$ regular las cuestiones vinculadas al cumplimiento y vicisitudes del acuerdo homologado, el art. 320 del Anteproyecto mencionado, reza: "Una vez ejecutado el acuerdo el deudor podrá peticionar se declare su cumplimiento y el levantamiento de la inhibición originariamente trabada. Cuando el deudor no cumpla el acuerdo total o parcialmente, a instancia de acreedor interesado, el juez podrá derivar el conflicto al conciliador, a fin de que se intente una nueva negociación conclusiva del asunto. Tal período especia de renegociación no podrá extenderse más de sesenta (60) días desde el requerimiento del acreedor, pero este mecanismo podrá reiterarse en la medida que el juez lo estime razonable".
} 
El fracaso de esta alternativa de superación de la crisis, por cualquiera de los motivos posibles, impondrá la consideración de un escenario diferente, con mecanismos particulares y reglas específicas.

Celebramos que este mecanismo de saneamiento esté previsto en casi todos los ordenamientos que asumen la regulación de la problemática. Creemos que la disposición del deudor a acordar un plan de pagos con sus acreedores debe ser ponderada de forma positiva y que el sistema crear el espacio y el tiempo para ese encuentro, asegurar su realización, asesorar al particular afectado, instar la renegociación, neutralizar los obstáculos y hasta imponer la solución mediante un plan de pagos adecuado a la realidad de la economía doméstica en crisis.

El modelo español plasmado en el Real Decreto-Ley 1/2015 impone como requisito necesario para acceder al beneficio de la exoneración del pasivo insatisfecho, la buena fe del deudor. Ese concepto normativo de buena fe comprende una condición material que ensancha su contenido. Se exige que el deudor “...haya celebrado o, al menos, intentado celebrar un acuerdo extrajudicial de pagos" (art. 178 bis.3.3), interpretándose que "sin duda...el hecho de que un deudor haya iniciado los trámites extrajudiciales previstos en el Título X, pone de manifiesto su buena voluntad inicial, vinculada a su deseo de llegar a un acuerdo con sus principales acreedores". Ahora bien, así como admitimos la valoración positiva de esta iniciativa del deudor, reveladora de la intención de honrar los compromisos asumidos, coincidimos en que este mecanismo de liberación de deuda puede no ser una alternativa posible (en caso de no existir bienes para afrontar la renegociación y un plan de pagos posterior) y forzar su tramitación resulta irrazonable ${ }^{700}$. Desde esta perspectiva, el

\footnotetext{
${ }^{700}$ FERnÁNDEZ SEIJO, José María, La reestructuración..., cit., pág. 240. HERNÁNDEZ RodRíGUEZ considera que "el tenor del art. 187 bis apartado 3 refleja el cambio de criterio del legislador que ha pretendido que todo deudor legitimado para ello intente un acuerdo extrajudicial de pagos de manera previa a acudir a la vía concursal, potenciando con ello la solución alternativa al concurso" pero critica la inclusión de este nuevo requisito común puesto que "el carácter forzado del intento de un acuerdo extrajudicial de pagos genera el riesgo de que sea empleado como un mero cauce formal para una posible exoneración de deudas en un concurso ulterior, especialmente en supuestos en los que la falta de activo haga en la práctica inviable un posible acuerdo con los acreedores por la vía de los arts. 231 y siguientes de la Ley Concursal y les aboque a un concurso que concluya en el momento de su declaración por insuficiencia de la masa activa al amparo del
} 
deudor que omite transitar esta vía de saneamiento no puede ser considerado carente de buena fe.

Alentamos cualquier la previsión de cualquier dispositivo que promueva soluciones de consenso entre el deudor y sus acreedores, aún cuando no pueda predicarse que tales acuerdos expresan el ejercicio de la plena autonomía privada. Propiciamos generar ese escenario de renegociación pero bajo la conducción de un gestor experto, que oriente la salida de la crisis priorizando el saneamiento de la economía doméstica y la rehabilitación del individuo y grupo afectados.

Ahora bien, si este mecanismo resulta inviable, la conclusión no debe ser el abandono del sujeto sobreendeudado y su confinación al régimen general de insolvencia. Precisamente ese subconsumidor endeudado en exceso, de buena fe y sin recursos para afrontar una renegociación y proponer un plan de pagos, es el que debe motivar el mayor esfuerzo de rescate por parte del legislador. La regulación que reclamamos debe ofrecer auxilio a este deudor impotente, que por sí sólo no puede ni podrá superar la situación de crisis terminal por la que atraviesa. La liquidación y extinción del sujeto sobreendeudado no es una opción posible. Se impone acudir a su encuentro con el brazo extendido, proponiéndole una vía de saneamiento alternativa, para que la transite, descargue su deuda y se libere, reinsertándose en el mercado y en la sociedad.

b .- Exoneración del pasivo pendiente de cumplimiento

La exoneración del pasivo pendiente es un beneficio consistente en la liberación de las deudas aún insatisfechas que, por disposición de la ley, se otorgará al deudor que observe los requisitos legalmente previstos, en el marco de un procedimiento judicial o extrajudicial que el legislador diseñe al efecto. Conforme el modelo que se adopte, el beneficio aludido estará precedido por la reestructuración del pasivo y la ejecución de un plan de pagos o se otorgará tras la liquidación de los bienes del deudor o ante falta de activo para liquidar.

art. 176 bis apartado 4” (HERNÁNDEZ RodRíGUEZ, María del Mar, La segunda oportunidad..., cit., pág. 90 y sgtes.). 
En sentido concordante, GUTIÉRREZ DE CABIEDES explica que "esta medida consiste en la exoneración del deudor de la obligación de pago de las deudas pendientes tras la conclusión del concurso (o del procedimiento específico que se establezca de solución de su situación de sobreendeudamiento o insolvencia) o tras un período de tiempo determinado desde aquella conclusión, si se dan determinados presupuestos y se cumplen determinados requisitos. En tales circunstancias, la conclusión del procedimiento de sobreendeudamiento o insolvencia produce el efecto de cancelación forzosa de las deudas que restan por satisfacer al deudor. Es esa nota forzosa la que diferencia esta institución de la condonación, que opera en virtud de la voluntad del acreedor, por lo cual entendemos correcto y preferible hablar de exoneración o liberación, y no de condonación"701.

Cada modelo de liberación de deuda se estructura en reglas que traducen, en dispositivos concretos, los principios propios de la filosofía subyacente.

En el modelo de exoneración denominado discharge, de origen norteamericano ${ }^{702}$, campea la idea de que el deudor en situación de impotencia patrimonial no podrá de ningún modo afrontar el cumplimiento de las obligaciones contraídas ni dar satisfacción a sus acreedores y que, al propiciar la liberación del pasivo insatisfecho, se permitirá -al menosrecomponer la economía doméstica del particular afectado, hacerle superar su status de improductividad y reinsertarlo en el mercado, beneficiando -a la postre- al conjunto social.

${ }^{701}$ GutiérRez De CABIEDES, Pablo, El sobreendeudamiento doméstico..., cit., pág. 202 y sgtes. Allí se destaca que "La condonación opera ex voluntate, es decir, en virtud de la manifestación de voluntad del acreedor, que renuncia a su derecho a exigir el pago y a la acción judicial para la tutela de ese derecho; y está prevista en nuestro ordenamiento como causa de extinción de las obligaciones. La exoneración de deudas restantes opera ex lege, sin necesidad de consentimiento del acreedor o en contra de su voluntad, no estando contemplada en nuestro ordenamiento, aunque aquí aboguemos por ella, en los términos en que veremos, como específica causa de extinción concursal de ciertas deudas".

${ }^{702}$ Este beneficio tiene su origen en la Bankruptcy Act de 1898, del ordenamiento jurídico norteamericano, que reconoció el instituto bajo la expresión discharge. Esta herramienta legal permitía que el juez, en el seno del procedimiento concursal y tras la conclusión del procedimiento de insolvencia allí previsto, despachara una orden de descarga que significaba liberar al deudor persona física de sus deudas no satisfechas. De este modo, el legislador americano ofrecía una segunda oportunidad (second chance), propiciando un nuevo comienzo (fresh start), a ese deudor honesto pero desafortunado (honest but unfortunate debtor), como se dio en llamar al beneficiario de la medida, en aquellas latitudes. 
Desde esta perspectiva, las faltas que eventualmente cometa un deudor honesto, al operar en el mercado de crédito, deben ser dispensadas puesto que de este modo es estimulado a superar las dificultades, su actividad productiva se revitaliza y ello contribuye a la salud de la economía general.

Este modelo de fresh start o nuevo comienzo interpreta que la mala gestión de la economía doméstica y la crisis derivada es un fenómeno que debe ser visualizado con naturalidad, sin estigmatizar a la persona sobreendeudada. Y que frente a esa situación de impotencia patrimonial el sistema debe ofrecer una segunda oportunidad al deudor pues de ese modo es recuperado más rápidamente para el consumo y la producción. Se propone la liquidación inmediata del patrimonio no exento del deudor y la exoneración directa del pasivo pendiente (con excepción de las deudas jurídicamente no exonerables) ${ }^{703}$.

Por otra parte, el modelo de rehabilitación, propiciado mayormente en los países europeos parte de considerar que "el deudor ha cometido una falta y merece ser ayudado, pero no por ello debe ser exonerado pura y simplemente del deber de cumplir sus obligaciones; [...] tendrá que pasar un período de prueba, durante el cual destinará una parte de su renta al reembolso de la deuda restante. Sólo después de eso, y a condición de que haya tenido un comportamiento honesto y de buena fe, podrá beneficiarse de la condonación",704. Se ha señalado que "la visión europea considera inmoral la descarga directa" ${ }^{, 705}$ puesto que beneficia a un sujeto que ha deshonrado los compromisos asumidos

\footnotetext{
${ }^{703}$ Álvarez Vega, María Isabel, Protección jurídica del consumidor..., cit., pág. 102 y sgtes. Desde un punto de vista de filosofía jurídico-económica, la exoneración se funda en la creencia de que debe promoverse "un nuevo comienzo" para el deudor concursado honesto pero desafortunado, alentando su rehabilitación personal, económica y social. Subyace la idea de que el fracaso económico es un fenómeno natural, humanamente comprensible, que no necesariamente conlleva una actuación desaprensiva o dolosa del deudor. Se considera asimismo, que tal instituto permite una mayor eficiencia del régimen concursal, que ha de tener en cuenta la situación personal y patrimonial de los implicados en el proceso de insolvencia (los acreedores, el deudor, sus familiares, los trabajadores de las empresas insolventes y la sociedad en su conjunto), durante el proceso y en el futuro. Se entiende que tal eficiencia exige que el procedimiento concursal no desincentive el espíritu y la capacidad productiva y emprendedora del deudor (vgr. la búsqueda de un nuevo empleo, nuevos proyectos profesionales o empresariales, inversiones futuras). Ver GuTIÉRREZ DE CABIEDES, Pablo, El sobreendeudamiento doméstico..., cit., pág. 204.

${ }^{704}$ Álvarez Vega, María Isabel, Protección jurídica del consumidor..., cit., pág.103.

${ }^{705}$ ANCHAVAL, Hugo, Insolvencia del consumidor, cit., pág. 68.
} 
con sus acreedores. Ello explica que esta concepción proponga condicionar la liberación del deudor a la superación de una instancia en la que purgará su falta. Pero aún más, para sortear con éxito el procedimiento, borrando el reproche moral subyacente, el deudor será sometido a un doble control de buena conducta. Se exigirá su buena fe al momento de acceder al trámite y un comportamiento esmerado durante la ejecución de un plan de pagos necesario. Sólo luego de dar satisfacción a ese pasivo no exonerable, podría liberárselo de pasivo restante. No se trata de un procedimiento de libre acceso ni de asegurar salidas exitosas a quien logra ingresar al mismo. Sólo los deudores merecedores de esta asistencia y que ratifiquen su buena fe observando el programa de cumplimiento al que sean sometido, accederán al beneficio de la liberación del pasivo restante.

Este modelo de rehabilitación, por otra parte, da especial relevancia a la organización de servicios de educación para el consumo y asesoramiento en materia de endeudamiento. Se propicia que el particular sobreendeudado participe, de inicio, en un programa educativo que le permita instruirse, modificar hábitos en materia de consumo y encarar sanamente operatorias de crédito futuras. Estos servicios que el modelo ofrece hacen a la esencia del diseño del procedimiento y responden al fin que lo inspira.

Con acierto se destaca la diversidad paradigmática ${ }^{706}$ de los modelos propuestos para el saneamiento de la situación de sobreendeudamiento del consumidor. Por un lado, como se dijo, un primer criterio de diferenciación refiere a la filosofía que inspira el tratamiento de la problemática ( $\mathrm{y}$, en consecuencia, a los mecanismos diseñados para la superación del endeudamiento excesivo) mientras que, por otra parte, se distinguen en orden a la naturaleza y emplazamiento de los procedimientos previstos para revertir esta crisis de la economía doméstica.

Es ésta la primera decisión de política jurídica que debe asumir el legislador al momento de encarar la regulación del fenómeno. Resulta claro que la adopción de un modelo de gestión y saneamiento del problema depende de la filosofía que lo inspire y que los instrumentos de implementación traducirán en acción, el paradigma que lo sustenta. Decidir cuál es el presupuesto objetivo que impone la intervención reguladora -la situación de sobreendeudamiento-, quién será el destinatario o beneficiario de esta regulación (presupuesto subjetivo), cuál será en escenario en que se emplazará el procedimiento y

\footnotetext{
${ }^{706}$ Álvarez Vega, María Isabel, Protección jurídica del consumidor..., cit., pág.102.
} 
fundamentalmente, cuáles serán las medidas de saneamiento que permitan superar aquella situación crítica.

Sin perjuicio del ideario que nutre a los modelos emblemáticos aquí reseñados y de las líneas centrales sobre las que se estructura el diseño de los mismos, los sistemas normativos vigentes evidencian una mutación de esa matriz originaria y de allí que no pueda predicarse el purismo de las soluciones contenidas en las regulaciones que asumen en la actualidad, el tratamiento y gestión de la problemática. Remitimos al lector interesado, al relevamiento de los sistemas en el Derecho comparado y a las consideraciones desarrolladas en la segunda parte de esta investigación.

Consideramos que el modelo español de reciente aparición, en el afán de recoger las bondades de cada sistema, propone una mixtura interesante, no exenta de observaciones ${ }^{707}$. En lo pertinente ${ }^{708}$, y partiendo de que la buena fe del deudor es un presupuesto de base para acceder al procedimiento, la regulación prevé una descarga de deuda directa -en forma provisional- para determinados supuestos (art. 178 bis. $3,3^{\circ}$ y $4^{\circ}$ de la ley concursal) y el sometimiento a un plan de pagos del pasivo no exonerable, durante cinco años, para la hipótesis restante (art. 178 bis.3,5 $5^{\circ}$, distinguiendo la composición de la deuda exonerable en cada subtipo ${ }^{709}$.

\footnotetext{
707 Hemos analizado con detenimiento el modelo español relevando los dispositivos particulares, con referencias críticas de la doctrina del país. Estos aportes de los especialistas han provocado, en un cortísimo plazo, algunos virajes respecto de la propuesta inicial consagrada por el Real Decreto-Ley 1/2015, retocada luego por el Real Decreto-Ley 27/2015.

${ }^{708}$ Dejamos para los próximos apartados, el análisis de los escenarios en los que pueden emplazarse los procedimientos y la naturaleza de los mismos, y la referencia circunstanciada del modelo español.

709 Señalamos oportunamente la crítica que sobre el punto formula CUENA CASAS, al expresar que la regulación emergente del Real Decreto-Ley 1/2015 propone una diferencia de régimen jurídico respecto de los créditos exonerables y no exonerables conforme los distintos modelos de segunda oportunidad, que "carece de toda justificación”. En efecto, se señala que a diferencia del modelo que prevé el sometimiento al plan de pagos (art. 178 bis. $3.5^{\circ} \mathrm{LC}$ ), si el deudor se acogió a la opción del art. 178 bis. 3.4 LC “no aparece excepcionado de la exoneración, y será por tanto exonerable, el crédito público subordinado y los créditos por alimentos" (CuEna CASAS, Matilde, “A propósito del Real Decreto-Ley 1/2015...”, cit., pág. 10 y sgtes.). Mencionamos asimismo que el documento elaborado en la sesión de debate celebrada el 25 de marzo de 2015 en la Fundación para la Investigación sobre el Derecho y la Empresa (Fide) recoge con espíritu crítico el
} 
La regulación española erige a la buena fe del deudor como un requisito central para acceder al beneficio (art. 178 bis.3), al que dota de un contenido normativo ensanchado, enfatizando más condiciones objetivas que aristas subjetivas ${ }^{710}$. Además, subordina el otorgamiento del beneficio de la liberación definitiva, al transcurso de un plazo de cinco años, durante el cual podrán denunciarse hechos que justifiquen la revocación del beneficio provisorio, en tanto reveladores de la falta de merecimiento del mismo. Asimismo, para el caso en que el saneamiento depende del cumplimiento de un plan de pagos, la regulación prevé que el juez pueda conceder la exoneración definitiva, pese a no haberlo satisfecho en su integridad, siempre que el deudor hubiese desplegado un esfuerzo relevante para cumplirlo, conforme las condiciones allí mencionadas ${ }^{711}$. Creemos que ambas instancias de

desigual tratamiento del pasivo exonerable en función del modelo al que el deudor se acoja (http://www.insolnet.es/wp-content/uploads/2015/04/RDL-1_2015-Segunda-oportunidad.pdf).

${ }^{710}$ Dispone el art. 178 bis.3: "Sólo se admitirá la solicitud de exoneración de pasivo insatisfecho a los deudores de buena fe. Se entenderá que concurre buena fe en el deudor siempre que se cumplan los siguientes requisitos: $1 .^{\circ}$ Que el concurso no haya sido declarado culpable. 2. ${ }^{\circ}$ Que el deudor no haya sido ni condenado en sentencia firme por delitos contra el patrimonio, contra el orden socioeconómico, falsedad documental, contra la Hacienda Pública y la Seguridad Social o contra los derechos de los trabajadores en los 10 años anteriores a la declaración de concurso. Si existiera un proceso penal pendiente, el juez del concurso deberá suspender su decisión respecto a la exoneración del pasivo hasta que exista sentencia penal firme. 3. ${ }^{\circ}$ Que, reuniendo los requisitos establecidos en el artículo 231, haya celebrado o, al menos, intentado celebrar un acuerdo extrajudicial de pagos. 4. ${ }^{\circ}$ Que haya satisfecho en su integridad los créditos contra la masa, y los créditos concursales privilegiados y, si no hubiera intentado un acuerdo extrajudicial de pagos previo, al menos, el 25 por ciento del importe de los créditos concursales ordinarios. 5. ${ }^{\circ}$ Que, alternativamente al número anterior: i) Acepte someterse al plan de pagos previsto en el apartado 6. ii) No haya incumplido las obligaciones de colaboración establecidas en el artículo 42. iii) No haya obtenido este beneficio dentro de los diez últimos años. iv) No haya rechazado dentro de los cuatro años anteriores a la declaración de concurso una oferta de empleo adecuada a su capacidad. v) Acepte de forma expresa, en la solicitud de exoneración de pasivo insatisfecho, que la obtención de este beneficio se hará constar en la sección especial del Registro Público Concursal con posibilidad de acceso público, por un plazo de cinco años".

${ }^{711} \mathrm{El}$ art. 178 bis.7 prevé que "Cualquier acreedor concursal estará legitimado para solicitar del juez del concurso la revocación del beneficio de exoneración del pasivo insatisfecho cuando el deudor, durante los cinco años siguientes a su concesión: a) Incurriese en alguna de las circunstancias que conforme a lo establecido en el apartado 3 hubiera impedido la concesión del beneficio de la exoneración del pasivo insatisfecho. b) En su caso, incumpliese la obligación de pago de las deudas no exoneradas conforme a lo dispuesto en el plan de pagos. c) Mejorase sustancialmente la situación económica del deudor de manera que 
control del merecimiento del beneficio -en el acceso y en el desarrollo del procedimiento- y el reconocimiento expreso de estas facultades al juez interviniente, responden la filosofía subyacente en el modelo europeo originario, aunque no pueda sostenerse que aquella matriz original sea la que define la identidad del modelo español analizado.

Celebramos la consagración del beneficio de la exoneración del pasivo pendiente y que el legislador admita su operatividad frente a la conclusión del concurso por liquidación de los bienes del deudor, extendiéndola al supuesto de clausura por insuficiencia de la masa activa. De este modo, este mecanismo de saneamiento procederá tanto en caso de inexistencia de bienes a liquidar para la distribución del producido entre los acreedores, como cuando la liquidación resulte insuficiente para darles satisfacción. Esta herramienta supone, por tanto, que dispuesta la extinción del proceso concursal por los motivos antes mencionados, el deudor está habilitado a peticionar la liberación de las obligaciones que permanezcan impagas; beneficio que debe serle otorgado cuando se verifiquen los restantes presupuestos y requisitos.

Conforme el modelo diseñado por la legislación española, la petición de exoneración sólo puede ser formulada por el deudor ante el juez del concurso, ${ }^{712}$ en caso de que éste haya concluido por liquidación ó por falta de bienes o insuficiencia de masa activa,

pudiera pagar todas las deudas pendientes sin detrimento de sus obligaciones de alimentos, o d) Se constatase la existencia de ingresos, bienes o derechos ocultados. La solicitud se tramitará conforme a lo establecido en la Ley de Enjuiciamiento Civil para el juicio verbal. En caso de que el Juez acuerde la revocación del beneficio, los acreedores recuperan la plenitud de sus acciones frente al deudor para hacer efectivos los créditos no satisfechos a la conclusión del concurso". En el apartado 8, el art. 178 bis analizado dispone que "Transcurrido el plazo previsto en el apartado anterior sin que se haya revocado el beneficio, el Juez del concurso, a petición del deudor concursado, dictará auto reconociendo con carácter definitivo la exoneración del pasivo insatisfecho en el concurso. También podrá, atendiendo a las circunstancias del caso y previa audiencia de los acreedores, declarar la exoneración definitiva del pasivo insatisfecho del deudor que no hubiese cumplido en su integridad el plan de pagos pero hubiese destinado a su cumplimiento, al menos, la mitad de los ingresos percibidos durante dicho plazo que no tuviesen la consideración de inembargables...”.

${ }^{712}$ Atento a que la regulación del beneficio prevé que se haya tramitado el concurso del deudor y declarado su conclusión por las causas contempladas en el art. 178 bis citado, la remisión de deudas no puede sino peticionarse y obtenerse en ese marco procesal, lo que hace evidente la opción por el escenario judicial y el emplazamiento del beneficio en el proceso concursal. 
quedando pasivo pendiente (conf. art. 178 bis.1 LC) ${ }^{713}$. Se deja claramente establecido que el beneficio presupone acreedores insatisfechos luego del cierre del procedimiento de insolvencia por inexistencia de bienes o insuficiencia de los ya liquidados, con el panorama de impotencia evidente.

Este mecanismo de saneamiento era reclamado enfáticamente los organismos internacionales y la doctrina que asumió la preocupación por la problemática del sobreendeudamiento del consumidor ${ }^{714}$.

Varios ordenamientos europeos admitieron la posibilidad de conceder al deudor el beneficio de exoneración del pasivo restante en el marco de un procedimiento concursal, ya sea como consecuencia de su conclusión por no existir bienes suficientes para satisfacer a todos los acreedores, ya sea por aprobación de un plan de insolvencia entre el deudor y sus acreedores $^{715}$.

Consideramos que la inclusión de una medida como la analizada, sirve de estímulo al deudor a fin de que solicite la apertura del procedimiento diseñado al efecto y lo haga en tiempo oportuno, convencido de las ventajas que éste le ofrece a fin de superar su situación

\footnotetext{
${ }^{713}$ La doctrina ha destacado como un acierto de la nueva regulación, la posibilidad de acceder al beneficio de la remisión del pasivo pendiente no solamente en el supuesto de conclusión del concurso por liquidación sino también en caso de insuficiencia de la masa activa; hipótesis a la que no se refería el art. 178.2 de la ley concursal conforme la reforma introducida por la Ley 14/2013 (HERNÁNDEZ RoDRíGUEZ, María del Mar, "La segunda oportunidad ...”, cit.; asimismo, BenavideZ Velasco, Patricia G., Masa activa del concurso ..., cit, pág. 265.

${ }^{714}$ Pronunciamientos tales como la Guía Legislativa sobre Régimen de Insolvencia de la CNUDMI de 2006, impulsaban la consagración de estos mecanismos de liberación de deudas. El Dictamen del Comité Económico Social Europeo de 2007 sobre "El crédito y la exclusión social en la sociedad de la abundancia", recogía esta propuesta en el punto 6.3.3. En sesión del 29 de abril de 2014, el CESE aprobó un nuevo dictamen sobre "Protección de los consumidores y tratamiento adecuado del sobreendeudamiento para evitar la exclusión social" donde hizo explícita la idea de que el objetivo de los procedimientos de saneamiento debe ser "reintegrar rápidamente al consumidor en la vida económica y social”. Se suma a esta exhortación, la Recomendación de la Comisión Europea de 12 de marzo de 2014 "sobre un nuevo enfoque frente a la insolvencia y el fracaso empresarial" (2014/135/UE).

${ }^{715}$ Estos mecanismos de liberación de deuda han tenido recepción en ordenamientos jurídicos europeos que le han dado acogida en sus reformas concursales como Francia (effacement), Alemania (restschuldbefreiung), Finlandia (yksityishenkilönvelkajärjestely), Portugal (exoneraçao do passivo restante), Italia (endebitazione) y, como se dijo, más recientemente España (Real Decreto-Ley 1/2015 del 27 de febrero), entre otros.
} 
de crisis. En efecto, se afirma que, en ausencia de este estímulo para acudir al concurso, el deudor lo evitaría o lo retrasaría, desplegando actuaciones desesperadas que pueden provocar un mayor endeudamiento; postergación que también resultará perjudicial para los acreedores, en cuanto compromete más aún sus posibilidades de reembolso ${ }^{716}$.

No pocas voces invocan las desventajas derivadas la implementación de mecanismos de exoneración de deudas. De hecho, dado que este beneficio supone admitir una excepción al principio de responsabilidad patrimonial universal, tan arraigado en nuestra cultura jurídica ${ }^{717}$, la reacción adversa ha sido evidente.

Por un lado, se señala que el otorgamiento de este beneficio puede significar un estímulo negativo para el deudor irresponsable, que vea en esta herramienta un camino para endeudarse y luego liberarse de parte de ese pasivo. A ello contestamos que el abordaje de la problemática en estudio impone superar la mirada simplista, anclada en estereotipos binarios y con respuestas prefijadas. En efecto, se nos propone por un lado, la imagen de un consumidor tramposo o de débil moral (que no merece ser asistido) y, por otro, la de un sujeto honesto pero desafortunado (al que hay que ayudar no sin antes hacerle purgar sus culpas). Compartimos la idea de que la masa de consumidores sobreendeudados no se puede caracterizar con descripciones abstractas ${ }^{718}$ para arribar a conclusiones

${ }^{716}$ En el documento comunitario conocido como Guía Legislativa sobre Régimen de Insolvencia de la CNUDMI del año 2006 se hacen interesantes consideraciones sobre el particular.

${ }^{717}$ El art. 1911 del Código Civil español reza: "Del cumplimiento de las obligaciones responde el deudor con todos sus bienes, presentes y futuros”. En paralelo, dispone el art. 743 del nuevo Código Civil y Comercial argentino que "Los bienes presentes y futuros del deudor constituyen la garantía común de sus acreedores....".

718 AnChaval, Hugo A., "El nuevo sujeto concursal", en $L L$ 2010-F,1079. Señala AnCHÁval que "en el corazón de los debates actuales sobre la reforma de la bancarrota están diferentes imágenes o estereotipos, de los contribuyentes del consumidor típico. Por un lado está la imagen del deudor pobre pero honrado que sin culpa se ha quedado tan atrás en sus obligaciones que un nuevo comienzo ... es un recurso apropiado. Por otro lado está la imagen del tramposo o de moral débil que abusa de las buenas intenciones de la ley por alejarse de las deudas que podría pagar. Gran parte del debate en torno a la reforma se apoya abiertamente o implícitamente en estos estereotipos. ...Más allá de esta caracterización simple, lo que se encuentra entre los deudores es como una gran variedad. La masa de los deudores de los consumidores no se puede caracterizar por las descripciones tan excesivamente simples como los estereotipos utilizados con frecuencia en editoriales y eslóganes". 
preestablecidas. La situación de endeudamiento excesivo que motiva nuestro desvelo es un fenómeno complejo y debe se analizado bajo un esquema de razonamiento que contemple el sistema en el que se inserta -el consumo moderno, la operatoria de crédito, el contexto social-, su causalidad diversa, el impacto individual y colectivo y las responsabilidades plurales de los actores económicos y sociales.

Por otra parte, la objeción planteada puede ser replicada señalando que "a la inversa, la inmatizada e ilimitada garantía patrimonial de recobro para los acreedores institucionales o financieros, subsistente aún después de haber liquidado todo el patrimonio del deudor en un proceso colectivo, puede igualmente propiciar prácticas indeseables y nocivas de crédito, y con ellas un sobreendeudamiento de los particulares, promovido por las propias entidades crediticias -con políticas, actuaciones y actitudes igualmente irreflexivas, imprudentes y hasta dolosas, que obvien o sean contrarias a la valoración y asesoramiento sobre la capacidad de pago y cumplimiento del prestatario- ante la expectativa de infalible recuperación ulterior de la totalidad de lo prestado o su garantía, con intereses y costas"

La crítica encaminada a sostener que la liberación de la deuda necesariamente debe estar precedida de un plan de pagos en el que el deudor deje todo de si para dar satisfacción a los acreedores, purgando la culpa del fracaso económico, no está exenta de reparos. Insistir en el sometimiento a un programa de cumplimiento que satisfaga a los acreedores, cuando se trata de un consumidor sin más recursos que su salario y la vivienda familiar porque son sus únicos activos o porque es lo que le queda luego de la liquidación de los demás bienes- resulta casi siempre irrazonable.

Se señala con acierto que en los modelos que proponen esta solución, definir la medida y el tiempo en que debe afectarse la renta futura del consumidor sobreendeudado para destinarla al pago de los créditos y los gastos, "es un problema de diseño legislativo",720. Por un lado, considerar que la falta de activos, justifica el rechazo de la

\footnotetext{
${ }^{719}$ GutiÉRREZ DE CABIEDES, Pablo, El sobreendeudamiento doméstico..., cit., pág. 209.

${ }^{720}$ Señala ANCHÁVAL: "El "cuánto" y "por qué tiempo" debe afectarse la renta futura del quebrado al pago de los créditos y los gastos, es un problema de diseño legislativo...decir que, como su patrimonio (el del deudor) es reducido o insignificante no merece por ello la solución concursal, no es otra cosa que someterlo al endeudamiento eterno por carecer justamente de bienes. Esto sin perjuicio de los deudores de mala fe, que presentan su petición de quiebra unos meses después de haber contraído cuantiosas deudas, frutos de
} 
solución concursal y que sólo imponiéndole un plan de pagos que comprometa sus ingresos futuros merecerá alguna dispensa del sistema, es inadmisible. Implica someter al consumidor al endeudamiento eterno, precisamente por carecer de bienes. De otro lado, mantener embargos de salarios y rentas por largo tiempo importa desincentivar cualquier actividad productiva del afectado e impactar negativamente en el sistema. Distribuir migajas entre los acreedores mientras se confina a un deudor esquilmado, no resulta una salida ajustada al objetivo de la rehabilitación que mueve al modelo analizado. Y, como se dijo, tampoco contribuye a la salud del sistema.

Los organismos internacionales y la doctrina especializada vienen impulsando una limitación temporal de los planes de pago, señalando los efectos adversos de su duración excesiva $^{721}$. Cabe destacar que en el tratamiento de la insolvencia de los consumidores sobreendeudados, la liquidación y reparto de bienes deja de ser una solución prioritaria para la satisfacción de los acreedores -por la inexistencia de activos o su insuficiencia- y donde, en su caso, la mira estará puesta en la afectación de las ganancias futuras del deudor para destinaras al pago del pasivo pendiente. De allí que en la eventual implementación de esta vía de saneamiento, la medida y el tiempo de ese plan de cumplimiento debe ser parte central del debate.

Se ha cuestionado también la eficiencia del beneficio de la exoneración del pasivo insatisfecho desde la perspectiva del análisis económico del derecho, señalando que este enfoque obliga a tener en cuenta y no desentenderse del efecto que la liberación de

diferentes empréstitos tomados para no ser pagados. Tampoco le hace un gran favor ni al deudor, ni al sistema ni menos a la economía sostener el embargo sobre sueldos en el porcentaje legal, por gran tiempo. Repartir miserias y dejar a un agente fuera del circuito económico no parece ser la mejor manera de lograr una rehabilitación, ni al mercado... El sacrificio demasiado alto y demasiado largo produce la falla de los planes, castigando el interés egoísta de los que los imponen..." (ANCHAVAL, Hugo A., "El nuevo sujeto concursal”, cit.).

${ }^{721}$ Conforme el modelo de sometimiento a un plan de pagos previsto en el art. 178 bis. $3.5^{\circ}$ de la ley concursal española (consagrado por el Real Decreto-Ley 1/2015), el pasivo no exonerable debe abonarse durante 5 años. El plazo quinquenal adoptado por el legislador español se aparta de la Recomendación de la Comisión Europea de 12 de marzo de 2014 sobre "Un nuevo enfoque frente a la insolvencia y el fracaso empresarial" donde, al analizar la cuestión, se señala la necesidad de prever la "plena condonación de deudas después de cierto plazo máximo" (Considerando 20) que luego se estima en tres años (apartado IV, referido a "Una segunda oportunidad para los empresarios"). 
responsabilidad del deudor provoca sobre el mercado, especialmente en la disponibilidad y volumen de crédito de una económica determinada y en los costes de autoprotección de los acreedores $^{722}$.

Se señala que cuando los acreedores colocan crédito en el mercado, lo hacen incorporando al valor del mismo, el coste de la insolvencia del deudor conforme las previsiones del ordenamiento que regula la problemática. De allí que se alegue que "el derecho de quiebras no puede defraudarlos ${ }^{723}$ ". Se insiste en que el valor del crédito no depende tanto de su nominal como del volumen de riesgo que incorpora y que "si consideramos al concurso como un instrumento para la maximización del valor de los créditos, lo que ha de hacer es dotar de mecanismos que permitan a los acreedores actuar de forma coordinada, de modo que el concurso no altere los valores de los créditos fijados en

${ }^{722}$ DIÉGUEZ OLIVA, Rocío, "El denominado fresh start español desde la perspectiva del análisis económico del derecho", en http://alacde2015.org/papers/66.pdf (Fecha de consulta: 10/10/2015). La autora citada menciona que "El modelo español participa de rasgos o elementos provenientes de los dos grandes modelos existentes en esta materia: el modelo anglosajón de discharge o fresh start, en el que la exoneración alcanza a todo el pasivo; y los modelos de rehabilitación, en el al deudor de buena que se encuentra en una situación de sobreendeudamiento por circunstancias sobrevenidas (sobreendeudamiento pasivo) o por imprevisión (sobreendeudamiento activo) y en el que durante un periodo de tiempo es observado y analizado su comportamiento económico. Pero la solución adoptada por el legislador en el art. 178 bis LC no responde a criterios de eficiencia. El concurso no es puede transferir el valor de los créditos de un grupo a otros de acreedores, como sucede con el beneficio de exoneración del pasivo insatisfecho sino que debería preservar el contratado. Y sin embargo, el régimen del art. 178 bis LC puede llevar a un encarecimiento del crédito que sufrirán no sólo para los deudores a los que se les hubiera concedido el beneficio de exoneración del pasivo insatisfecho, de los cuales escasa actividad económica puede esperarse como mínimo en cinco años dadas las perspectivas de revocación del beneficio, sino precisamente los demás sujetos que busquen crédito en el mercado. Estamos transfiriendo a otros posibles deudores los costes de la insatisfacción de créditos anteriores a los suyos y en los que no fueron parte. Además aquellos acreedores que no tengan ningún privilegio o que en el momento de contratar no hayan tenido la suficiente capacidad económica para incorporar al coste de su crédito el eventual riesgo de incumplimiento e insolvencia, deberán además asumir nuevos costes si, en caso de concesión del beneficio de exoneración del pasivo insatisfecho, decidieran en el plazo de cinco años, hacer un seguimiento de la situación financiera de su deudor".

${ }^{723}$ DIÉGUEZ OLIVA, Rocío, “El denominado fresh start español...”, cit. La autora desarrolla estas ideas con cita de BERMEJO GUTIÉRREZ. 
la negociación entre las partes en el mundo extraconcursal" ${ }^{, 724}$. Se considera que un mecanismo de liberación de deuda como el propuesto, provocará un necesario encarecimiento del crédito, inconveniente para el propio beneficiario de la medida de exoneración -que procura reinsertarse como agente del mercado- y para los consumidores en general.

Efectivamente, el abordaje del problema de la insolvencia ha sido asumido por el Derecho concursal, con soluciones encaminadas prioritariamente a la tutela del crédito y donde la impotencia patrimonial del deudor debía enfrentarse con resortes inspirados en un principio redistributivo. En la gestión del conflicto suscitado, se consideró necesario socializar el riesgo del quebranto distribuyendo las pérdidas entre los acreedores, en procura de un reparto justo y equitativo del escaso valor del patrimonio restante del deudor $^{725}$.

Pero aún cuando los paradigmas fueron mutando y las soluciones ofrecidas por el Derecho concursal fueron ampliando sus fines ${ }^{726}$, la irrupción del consumidor sobreendeudado como nuevo sujeto del concurso, vino a incomodar, desnudó la impotencia de la regulación existente, hizo impostergable un replanteo.

Oportuno es recordar que no hablamos de la crisis de un deudor cualquiera. Hablamos del sobreendeudamiento de un sujeto que no puede ser liquidado o excluido del sistema por resultar económicamente inviable. El consumidor endeudado en exceso y con un patrimonio impotente "no dejará de funcionar", no podrá ofrecer sus activos a un competidor para superar su situación de quebranto, no puede ser extinguido. Por otra parte,

\footnotetext{
${ }^{724}$ Cfr. PAZ ArES, Cándido, "Principio de eficiencia y derecho privado" en Estudios de Derecho Mercantil en homenaje al profesor Manuel BROSETA PONT, Vol. 3, Valencia, 1995, pág. 2843-2900.

725 Cfr. el desarrollo de estos conceptos en PEINADO GRACIA, Juan Ignacio, "La distribución del riesgo de insolvencia" en Estudios sobre la Ley Concursal. Libro homenaje a Manuel Olivencia, Vol. I, Madrid, 2005, pág. 427-466. Ver, asimismo, PEINADO GRACIA, Juan Ignacio, "Riesgo sistémico, solvencia y riesgo moral. Incidencia en el Derecho privado de los mercados financieros. Un apunte crítico", en Revista de Derecho Bancario y Bursátil, Año no 33, № 134, Valladolid, 2014, pág. 7-34.

${ }^{726}$ Recuerda PEINADO GRACIA que los fines del derecho concursal pueden ser diversos, de modo que se puede configurar, desde una perspectiva liberal como un mecanismo de protección de acreedores, liquidando empresas ineficaces; o, desde un modelo asistencial, garantizando la conservación de la empresa (PEINADO GRACIA, Juan Ignacio, “La distribución del riesgo de insolvencia...”, cit., pág. 431 y sgtes.)
} 
y aunque fuera condenado a pagar todas y cada una de sus deudas -en un proceso individual o en un colectivo- difícilmente satisfaga el interés de los acreedores aunque seguramente quede sometido a un status de exclusión y marginalidad inaceptable por su condición esencial, por tratarse de una persona humana ${ }^{727}$.

La perspectiva propuesta por el análisis económico del derecho es un innegable aporte $^{728}$. No podemos sino adherir al postulado conforme al cual el legislador no debe ni puede desentenderse de los efectos derivados de la regulación que propone cuando asume

${ }^{727}$ Lo explica en términos similares ANCHÁVAL al decir que "El consumidor endeudado, puede ser condenado a pagar todas y cada una de sus deudas. Pero eso no garantizará su efectivo reembolso, como lo demuestra la experiencia en otros países. Pero además ese sujeto —al cual no se le cerrarán sus puertas, ni comprarán sus activos un competidor o en definitiva "se liquidará"— seguirá arrastrando una situación de sobreendeudamiento que definitivamente lo apartará de la vida normal, perjudicando la arista más peculiar que presenta el mismo: su costado humano" (ANCHAVAL, Hugo A., "El nuevo sujeto concursal”, cit.).

${ }^{728}$ Señala LORENZETTI que el análisis económico del derecho no surgió como una dogmática, sino como una perspectiva analítica. Parte de la ciencia económica, porque es la que más rigurosamente ha estudiado la conducta humana, y de allí extrae reglas que la hacen predecible. (LORENZETTI, Ricardo L., "Análisis económico del Derecho: valoración crítica. Hacia una teoría de la acción individual y colectiva en un contexto institucional", en Revista de Derecho Privado y Comunitario, T. 21, Rubinzal Culzoni, Santa Fe, pág. 61). El diálogo entre la ciencia de la Economía y el Derecho es rico, fecundo, beneficioso (cfr. Alterini, Atilio A.LÓPEZ CABANA, Roberto M., "La penetración de la realidad económica en el sistema del Código Civil”, en Derecho de Daños, La Ley, Bs. As., 1.992, pág. 106). “La economía del comportamiento sostiene que el aspecto psicológico es importante para lograr un mayo realismo...logrando de esa manera mejores predicciones de los fenómenos. Incorpora ideas y resultados de la psicología, la sociología, y la antropología, así como la experimentación en laboratorio propia de otras ciencias sociales...Así, numerosas teorías de la economía del comportamiento, tales como la aversión a la pérdida, la regla del ultimátum, la diagonal de retrospección o la maldición del knowledge, son ampliamente utilizadas..." (ANCHAVAL, Hugo A., Insolvencia del consumidor, cit., pág. 51). Resulta disvaliosa, por tanto, la ambición de autosuficiencia cuando se trata de propiciar soluciones para realidades tan complejas (GARRIDO CORDOBERA, Rosa, “Sirve al legislador la teoría económica de la eficiencia?" en Responsabilidad por daños en el tercer milenio. Libro homenaje al Dr. Atilio Aníbal ALterinI, Abeledo Perrot, Buenos Aires, 1.997, pág. 62). Si la norma es regulación de la realidad, todo enfoque científico que coadyuve a su mejor visualización debe ser computado. El análisis económico del Derecho nos ayuda a mirar "lo que es" y contribuye a proyectar el "deber ser" con mayor eficiencia normativa; guiando la conducta hacia los valores que dan el norte al sistema; y en tal sentido, habrán de contemplarse las razones del status imperante, los objetivos del status al que se aspira y las reacciones positivas y negativas que el cambio genere a los sujetos destinatarios de la regulación. 
el tratamiento de una situación problemática ${ }^{729}$. Debe advertirse sin embargo, que el análisis económico del Derecho presenta al hombre como un ser que se mueve en función de su propio interés y procurando maximizar la eficiencia de su acción, ignorando muchas veces otras motivaciones que movilizan la conducta humana. "El hombre no tiene sólo una dimensión de anchura, que es cuantificable; también hay una dimensión de profundidad, que es irreductible a fijaciones exactas; y el campo de lo normativo es especialmente este último aspecto. El Derecho tiene aspiraciones, postula un deber ser, y por ello se vale de la lógica deóntica que no es común a otras ciencias descriptivas"730. "El análisis económico del Derecho debe ser sometido por el jurista a la crítica axiológica, partiendo de los valores fundamentales, humanidad y dignidad, y atendiendo a la justicia, a la equidad, a la seguridad, orden y paz social. Por las razones expresadas, los criterios de eficiencia y maximización de la riqueza, son insuficientes por sí solos para fundar soluciones jurídicas ${ }^{731}$. "El jurista, en su interpretación, está forzado a aplicar el modelo ético y de justicia, y valorar los deberes recíprocos disciplinados por la ley, a diferencia del operador económico que se limita a describir cómo opera el mundo" ${ }^{, 732}$. El sistema jurídico $-\mathrm{y}$ las reglas en que se cristaliza- no puede sino estar anclado en valores; y de allí que las más modernas tendencias en materia de regulación privatista, hagan explícita la necesidad de

\footnotetext{
${ }^{729}$ Cfr. LORENZETTI, Ricardo L., Las normas fundamentales..., cit., pág. 173 y sgtes.

${ }^{730}$ LORENZETTI, Ricardo L., “Análisis económico del Derecho..., cit., pág. 63. Oportuno es reiterar la opinión de BouRGOIGNIE: "Se trata de orientar a los consumidores a reencontrar el rol y la influencia que la teoría económica tradicional les ha dado, sin duda, pero que el entorno socio económico real de la sociedad moderna les ha hecho perder. Tal política no limitará sus preocupaciones a reencontrar los imperativos de cualidades, de eficacia y de racionalidad exigidas por el sistema económico. Buscará, especialmente, corrigiendo las lagunas e insuficiencias que afectan al buen funcionamiento del mercado, restablecer un cierto equilibrio entre los recursos y los poderes respectivos de los actores que participan del sistema; devolver al consumidor su poder sobre el proceso de consumo, disminuyendo las coacciones que rodean el ejercicio de la función de consumir" (BoURGOIGNIE, Thierry, "El año del consumo”, cit., pág. 4-35).

${ }^{731}$ Conclusiones de las XIII ${ }^{\circ}$ Jornadas Nacionales de Derecho Civil (Bs. As., Septiembre de 1.991) elaboradas por la Comisión N 9, sobre “Economía y Derecho", punto I. 6.

${ }^{732}$ Recomendaciones de las IV ${ }^{\circ}$ Jornadas Sanjuaninas de Derecho Civil” (San Juan, 1.989), Comisión N 4 sobre "Interpretación económica del contrato", puntos 3 y 5.
} 
coordinar los derechos contractuales y la propiedad individual con los demás derechos e intereses involucrados en las relaciones del mercado, evitando distorsiones ${ }^{733}$.

No se trata de sustituir un paradigma de regulación por otro, ni de desechar un modelo -con sus principios estructurales y reglas concretas- por otro diferente. Creemos que si las medidas de saneamiento han de emplazarse en el régimen general de insolvencia, el legislador debe fragmentar el elemento subjetivo -diferenciando categorías de sujetos habilitados a transitar el proceso concursal- y establecer procedimientos alternativos con mecanismos particulares y distintos, para cada uno ${ }^{734}$. Dicho de otro modo: si la decisión metodológica es concentrar el tratamiento de la problemática en el régimen general de la insolvencia, bajo el postulado "unidad en la diversidad", la ley concursal deberá proponer para los diferentes subtipos en la fattispecie, trámites diferenciados con mecanismos de saneamiento ajustados a cada realidad.

El estado de insolvencia de la empresa con una actividad económica de envergadura presenta caracteres distintos de los que definen la situación de crisis en una pequeña empresa o la de un profesional; y todavía más marcadas resultan las diferencias cuando nos referimos a la impotencia patrimonial de un consumidor persona física. El impacto de esta situación crítica se proyecta de modo muy distinto en la actividad productiva de cada sujeto, en los bienes que integran su patrimonio, en su actuación como agentes del mercado y en su esfera de relaciones económicas y sociales. Y al consumidor se le añade un coste no

\footnotetext{
${ }^{733}$ LORENZETTI, Ricardo L., "Entra en vigencia el Código Civil y Comercial de la Nación", en La Ley, $3 / 8 / 2015$,

http://www.laleyonline.com.ar/maf/app/documentVM?\&src=laley\&srguid=i0ad81816000001508aa632884e1 36093\&docguid=i6CB71850C4AA0E655793F7E9D955EAB1\&hitguid=i6CB71850C4AA0E655793F7E9D9 $\underline{55 \mathrm{EAB} 1 \& \text { spos }=2 \& \text { epos }=2 \& \mathrm{td}=91 \& \mathrm{ao}=0.10 \mathrm{ADFAB} 87 \mathrm{AF} 31 \mathrm{C} 98881 \mathrm{AF} 32 \mathrm{BE} 7421 \mathrm{AC} 4 \mathrm{E} \& \text { searchFrom }=\& \text { sav }}$ edSearch=false \&context=12\&crumb-action=append (Fecha de consulta: 10/10/2015).

${ }^{734}$ La ley concursal argentina prevé un proceso general y los llamados "pequeños concursos" para atender a situaciones de insolvencia especial, que merecían un tratamiento diferenciado por la estructura y menor envergadura económica del sujeto afectado (pequeñas empresas o empresarios individuales, profesionales, consumidores) y por el cuadro de situación particular (composición del patrimonio, cargas, etc.). La reforma encarada por la Comisión de Juristas a requerimiento del Ministerio de Justicia de la Nación en Argentina, prevé la tan reclamada adecuación del capítulo referido a los "pequeños concursos", que mencionaremos al cierre de esta investigación y donde remitimos
} 
patrimonial añadido, que exhibe dramatismo y gravedad: la confinación a un status de marginalidad y exclusión social que arrastra al individuo y al grupo familiar directo.

No tenemos dudas: la exoneración del pasivo pendiente es un dispositivo de contenido sustancial que debe coronar el procedimiento diseñado para el saneamiento de la situación crítica por la que atraviesa un consumidor sobreendeudado ${ }^{735}$.

Celebramos el acogimiento de la figura en la legislación española y estamos persuadidos de que su implementación y ejecución permitirá hacer los ajustes que fueran necesarios para su mejor implementación. Tenemos presente que la preocupación del legislador estuvo principalmente focalizada en la crisis y el endeudamiento del sector empresario aunque como derivación necesaria, dio a luz varias de las herramientas que venían siendo reclamadas para tutelar especialmente a los consumidores sobreendeudados. El camino transitado por España revela una sucesión de esfuerzos por dar respuestas al fenómeno del endeudamiento excesivo. Hemos constatado que en ese incansable derrotero, muchos de esos dispositivos jurídicos se muestran como normas de emergencia -con sus notas de excepcionalidad y transitoriedad- mientras que otros desembarcaron con vocación de permanencia, para aportar a la reconstrucción del sistema general.

\footnotetext{
${ }^{735}$ En el Anteproyecto de ley que se encuentra en estudio actualmente, la "descarga de deuda" es receptada como corolario del procedimiento especial que se incorporaría en el nuevo Capítulo V de la ley concursal, titulado "Del concurso de las personas humanas que no realizan actividad económica organizada y otros sujetos". En el trámite particular previsto para ese procedimiento, luego de haber transitado el período de conciliación y ante el fracaso del mismo -por falta de acuerdo o imposibilidad de cumplir otra medida de saneamiento- el juez debe abrir la etapa liquidatoria a fin de que el funcionario encargado, lleve adelante la realización de los bienes del deudor, presente el proyecto de distribución y proceda a su reparto o prorrateo entre los acreedores reconocidos (conforme los arts. 322 a 326 del citado Anteproyecto). Precisamente para el supuesto de de insuficiencia del producido, es que el art. 327 proyectado, consagra la liberación del deudor o descarga de deuda. Lo dispone en los siguientes términos: “Art. 327.- Una vez realizados los bienes , si el producido del activo no alcanzare para pagar los créditos se procederá al prorrateo de los fondos debiendo abonarse en primer lugar los gastos de justicia y el saldo entre los acreedores reconocidos, respetando en su caso el régimen de privilegios dispuesto en la presente ley. Una vez distribuido el resultado, el juez dictará una resolución en la que declarará extinguidas todas las deudas que tuviese el deudor vinculadas con el proceso, salvo los gastos de justicia, las obligaciones alimentarias, y los que constituyan créditos originados en daños a la persona humana por daño moral y por daño material derivado de lesiones a la integridad psicofísica, no pudiendo ningún acreedor reclamar en el futuro saldo insoluto alguno....”.
} 
Al formular nuestra propuesta para una futura legislación en Argentina, señalamos cuáles serían los presupuestos para la procedencia de la medida de saneamiento en estudio. Remitimos al lector a las consideraciones allí desarrolladas.

Para sintetizar, recordaremos que, en nuestra opinión, este beneficio de excepción debe preverse para superar la situación de sobreendeudamiento del consumidor persona física, de buena fe (presupuesto subjetivo) ${ }^{736}$. Tratándose de un mecanismo de saneamiento excepcional, que supone apartarse del principio de responsabilidad patrimonial universal (art. 1911 del Código Civil español y art. 743 del Código Civil argentino), acudiremos a él para atender un supuesto de endeudamiento excesivo de justificación evidente, por el tipo de sujeto de que se trata, por el impacto que provoca en el grupo familiar involucrado y por los efectos patrimoniales y no patrimoniales que urge revertir. Todo ello en el convencimiento de que se impone, efectivamente, la adecuación del procedimiento especial diseñado bajo el título "pequeños concursos" dotándolo de un trámite eficaz, con dispositivos ajustados a la problemática particular de las empresas de estructura y patrimonio acotado, a las características de los emprendimientos de profesionales y cuentapropistas, etc. ${ }^{737}$, tal como lo propone el Anteproyecto de ley en estudio.

El requisito de la buena fe impuesto al consumidor sobreendeudado supone la evaluación de su actuación -pasada y presente- y de los motivos de su situación de crisis económica. Cobra relevancia el concepto de sobreendeudamiento y su clasificación en activo y pasivo, reiterando la perspectiva de análisis propiciada al analizar los presupuestos subjetivos u objetivos de la regulación que reclamamos. La justificación de esta medida

\footnotetext{
${ }^{736}$ El Anteproyecto de ley aludido establece en el art. 305 que "Pueden acceder voluntariamente al procedimiento previsto en este Capítulo las personas humanas que: 1) No realicen una actividad económica organizada ni resulten titulares de una empresa o establecimiento comercial, industrial, agropecuario o de servicios; 2) Realicen una actividad como empleados públicos o privados en relación de dependencia; 3) Ejerzan una profesión liberal no organizada bajo forma de empresa; 4) Realicen una actividad autónoma e independiente no organizada bajo la forma de empresa. La circunstancia de que dichas personas humanas se encuentren inscriptas como empleadores y tengan personal en relación de dependencia en número no mayor a tres (3) trabajadores, no obstará a su inclusión dentro del régimen regulado por el presente capítulo".

${ }^{737}$ Hemos mencionado en detalle la crítica que se ha formulado a la regulación existente en los arts. 288 y 289 de la ley concursal, al analizar los instrumentos legales con los que cuenta al día de la fecha, el ordenamiento argentino y a esas consideraciones y referencias doctrinales nos remitimos.
} 
particular de saneamiento debe ponderarse a la luz de la complejidad del fenómeno, de la multiplicidad de factores que condicionan y desencadenan el endeudamiento excesivo y apreciando la conducta del consumidor conforme la vulnerabilidad que le es propia, agravada más aún en casos particulares. Insistimos en que, la buena fe que debe calificar la conducta del sujeto beneficiario, debe entenderse como ausencia de mala fe; y que admitiremos el merecimiento de la exoneración del pasivo pendiente, siempre que no pueda imputársele al peticionante mala fe o ejercicio abusivo de sus derechos.

Dado que la propuesta pasa por liberar al particular afectado del pasivo pendiente, luego de transitar el procedimiento diseñado al efecto, se impone fijar posición respecto de las deudas exonerables, explicitando cuáles son las excluidas del beneficio en examen. El legislador adoptará un criterio en relación al punto precisando qué obligaciones imponen un cumplimiento que no puede ser dispensado.

Consideramos que por su naturaleza o carácter, las deudas por alimentos constituyen un supuesto de pasivo no exonerable. En atención al bien jurídico tutelado, tampoco será liberado el deudor de cumplir el pago de indemnizaciones por daño a la integridad psicofísica y espiritual de la persona ${ }^{738}$. En el modelo propuesto por la legislación española, se prevé la exclusión del crédito público, que resulta por tanto "no exonerable" y de cumplimiento estricto (art. 178 bis. $5,1^{\circ}$ ); previsión que ha despertado las críticas que apuntáramos y a las cuales adherimos ${ }^{739}$.

\footnotetext{
${ }^{738}$ En el Anteproyecto de ley antes mencionado, la norma que recepta el mecanismo de liberación de deuda, exceptúa del pasivo exonerable a las obligaciones alimentarias y a las que deriven de daños a la persona humana (daño material derivado de lesiones a la integridad psicofísica y daño moral).

739 "Es cierto que los créditos de derecho público han gozado tradicionalmente de un tratamiento privilegiado. Tal carácter se justifica por el destino en el que se emplean los mismos: la realización de los fines públicos, siempre que se trate de créditos tributarios vencidos y que no deriven de actividad contractual de la Administración Pública. Esta solución del legislador español ha sido criticada por la doctrina española por razones de ineficiencia a la hora de conceder el beneficio de exoneración del pasivo insatisfecho, al constituir en ocasiones la mayor partida en el pasivo del deudor y haber sido de los inicialmente impagados, por lo que suelen estar incrementados por multas y recargos; así como por alejar aún más la verdadera finalidad que se supone que persigue el beneficio de exoneración del pasivo insatisfecho. El incumplimiento del plan de pagos, en el que el legislador considera incluido no sólo el plan de pagos con respecto a los créditos no exonerables distintos del derecho público sino los fraccionamientos y aplazamientos de los de derecho público que haya concedido la Administración permite que cualquiera de los acreedores concursales pueda
} 
La exoneración del pasivo pendiente, sea que se conceda tras la liquidación o luego de someter al sujeto afectado a un plan de pagos (con cesión de rentas o afectación de su salario durante un tiempo determinado), debe estar prolijamente previsto en la regulación que reclamamos. Insistimos en el diseño de un procedimiento caracterizado por la simpleza, la celeridad y el mínimo coste de tramitación.

En orden a la legitimación para peticionar el beneficio, consideramos que la solicitud de exoneración debería ser promovida siempre por el interesado, sin perjuicio de que la autoridad interviniente -el juez o el funcionario que resulte competente en el ámbito de la administración- advierta o aconseje al deudor sobre la facultad de instar el trámite correspondiente.

Dado el rol relevante que asume el conductor del procedimiento y la inmediatez que debería caracterizar al trámite, se impone que una vez deducida la petición, practique un análisis liminar de la misma, de conformidad a los presupuestos y requisitos legalmente impuestos y decida la procedencia o improcedencia del beneficio solicitado.

Si conforme el modelo adoptado, el beneficio es una derivación necesaria luego de la liquidación de los bienes o ante inexistencia de bienes a liquidar, el juez podría despachar la resolución sin más trámite, otorgando la liberación del pasivo pendiente con carácter provisional. Eventualmente, los acreedores estarán habilitados a presentarse e invocar los hechos que, conforme la regulación, autoricen la revocación del beneficio en cuestión. En ocasiones se estima conveniente que antes de disponer la liberación del deudor, el conductor del procedimiento convoque a los acreedores y previa audiencia, concluya

solicitar la revocación del beneficio" (DIÉGUEZ OLIVA, Rocío, "El denominado fresh start español..., cit.). Se denuncia que "la demagogia del legislador se reduce a predicar y no dar trigo" puesto que las deudas públicas "no se perdonan ni antes (cfr. nuevos arts. 231.5 II y 235.2.a) II), ni después de abierto y cerrado el concurso (cfr. art. 178 bis.3.4 y 178bis.5.1)" (CARRASCO PERERA, Ángel, "El mecanismo de segunda oportunidad ...", cit.), con lo cual el modelo adoptado "incumple de forma flagrante las recomendaciones del FMI" y se aparta de la posición fijada por el Banco Mundial, cuando sostiene que "el Estado debe soportar el mismo tratamiento que los demás acreedores para así apoyar el sistema de tratamiento de la insolvencia" (CUENA CASAS, Matilde, “A propósito del Real Decreto-Ley 1/2015...”, cit., pág. 10 y sgtes.). 
respecto de la concurrencia de los presupuestos y requisitos impuestos a la procedencia del beneficio peticionado para decidir en consecuencia ${ }^{740}$.

Si el modelo adoptado condiciona la exoneración de las deudas pendientes a un programa de cumplimiento complementario, con cesión de rentas o afectación de ingresos futuros, el beneficio podría concederse igualmente en forma provisoria, postergándose el pronunciamiento definitivo sobre el mismo hasta tanto se constate el efectivo cumplimiento de las obligaciones impuestas durante el plazo estipulado. Culminado el término impuesto al plan de pagos, cumplidas las obligaciones impuestas al deudor, y previa audiencia de las partes, procedería dictar la resolución que disponga la concesión definitiva de la exoneración. En su caso, el incumplimiento del deudor, denunciado y debatido en una convocatoria al efecto, habilitaría a dar por concluido el procedimiento, restableciéndose la exigibilidad del pasivo pendiente.

Habiéndose otorgado el beneficio con carácter provisorio (luego de la liquidación de los bienes o ante la inexistencia de bienes liquidables) y habiendo transcurrido el plazo preclusivo sin que los acreedores legitimados peticionaran la revocación del mismo, o como se dijo- luego de vencido el plazo para el cumplimiento del programa de pagos complementarios sin alegación de inobservancia por los acreedores, el interesado podría solicitar el reconocimiento de esa liberación con carácter definitivo, que debería ser concedido sin más trámite.

Consideramos un acierto que en caso de someterse al deudor a un plan de pagos y plazo de buena conducta, el juez o la autoridad administrativa tengan atribuciones para merituar la entidad del eventual incumplimiento y el esfuerzo desplegado para observarlo, y

\footnotetext{
${ }^{740}$ Así lo prevé el art. 178 bis.4 de la ley concursal española: "De la solicitud del deudor se dará traslado por el Secretario Judicial a la Administración concursal y a los acreedores personados por un plazo de cinco días para que aleguen cuanto estimen oportuno en relación a la concesión del beneficio. Si la Administración concursal y los acreedores personados muestran su conformidad a la petición del deudor o no se oponen a la misma, el Juez del concurso concederá, con carácter provisional, el beneficio de la exoneración del pasivo insatisfecho en la resolución declarando la conclusión del concurso por fin de la fase de liquidación. La oposición solo podrá fundarse en la inobservancia de alguno o algunos de los requisitos del apartado 3 y se le dará el trámite del incidente concursal. No podrá dictarse auto de conclusión del concurso hasta que gane firmeza la resolución que recaiga en el incidente reconociendo o denegando el beneficio".
} 
disponer la reconducción del plan o la liberación definitiva, no obstante aquella contingencia ${ }^{741}$.

c.- Escenarios de actuación y vías para la instrumentación de las medidas de saneamiento

Como ya lo señaláramos, el escenario en el que estas medidas pueden ser solicitadas, tramitadas y resueltas, puede ser diverso. En atención a la naturaleza del órgano ante quien se insten estos procedimientos, las alternativas posibles son el ámbito administrativo o la sede judicial.

La primera decisión a adoptar por el legislador es la vinculada al escenario en el que se emplazará el procedimiento encaminado al saneamiento de la situación de sobreendeudamiento y a la rehabilitación de sujeto afectado. No es una resolución simple pues supone fijar posición y definir un diseño estratégico. Se trata de una decisión de política jurídica.

"Desde un punto de vista puramente competencial material, a favor de una solución extrajudicial obraría la sobrecarga de trabajo que pesa sobre los Juzgados [...], que se han visto desbordados y cercanos al colapso ante el vertiginoso crecimiento del número de solicitudes de concurso formuladas ante ellos, como consecuencia precisamente de la crisis financiera y económica general que vivimos en estos momentos, hasta el punto que de pudiera dudarse de la conveniencia de atribuir (cargar y distraer) a estos órganos judiciales con el cometido de resolver crisis que cabría considerar como menores, sencillas, pero que pueden multiplicarse en un número elevado de procedimientos. A favor de la solución judicial, en cambio, se encontraría la falta de una estructura de órganos que tengan la debida experiencia y medios para desarrollar esa competencia, en contraposición a la judicial, que la viene ya desempeñando, ${ }^{, 742}$.

\footnotetext{
${ }^{741}$ Así lo prevé el art. 178 bis.8, segundo párrafo de la ley concursal española: “...También podrá (el juez), atendiendo a las circunstancias del caso y previa audiencia de los acreedores, declarar la exoneración definitiva del pasivo insatisfecho del deudor que no hubiese cumplido en su integridad el plan de pagos pero hubiese destinado a su cumplimiento, al menos, la mitad de los ingresos percibidos durante dicho plazo que no tuviesen la consideración de inembargables....".

${ }^{742}$ GutiÉRREZ DE CABIEDES, Pablo, El sobreendeudamiento doméstico..., cit., pág. 160.
} 


\section{c.1.- Procedimiento extrajudicial}

Se menciona, por un lado, el modelo de base administrativa, aunque también se mira con simpatía el diseño de un procedimiento extrajudicial no administrativo (de mediación o conciliación previa al eventual proceso judicial, emplazado en ámbitos diversos).

Se preguntan algunos si el particular afectado por un endeudamiento excesivo puede razonablemente obtener una solución a instancias suya, por vía privada, sin intervención de terceros ajenos a la crisis. Resulta lógico pensar que frente a una situación de sobreendeudamiento, el deudor procure abordar las medidas de saneamiento de modo convencional, privado, mediante una solución extrajudicial con sus acreedores.

Se dice que si los acreedores están legitimados para poner fin a un procedimiento concursal a través de un convenio judicial, no tiene por qué existir inconveniente en que esos mismos acreedores eviten la iniciación de un procedimiento concursal en virtud de un acuerdo libremente consentido ${ }^{743}$.

En esta línea de razonamiento, como el acuerdo al que eventualmente se arribe -en tanto contrato- sólo enlaza y obliga a las partes que lo suscribieron, si al mismo han concurrido todos los acreedores, la cuestión parecer sencilla. "A su respecto, la cuestión queda definida y el cumplimiento de lo acordado resulta inexorable; y de ello se sigue que si los titulares de los créditos transaccionados deciden acudir ulteriormente al procedimiento concursal, [...] estarían incurriendo en incumplimiento contractual. Evidentemente, la cuestión se complica cuando sólo parte de los acreedores suscriben el acuerdo extrajudicial con el deudor. En este caso, la dificultad práctica se hace patente, ya que cualquiera de los no suscribientes estaría perfectamente legitimado para actuar aisladamente contra el deudor ejercitando la acción concursal simultánea o posterior" ${ }^{\text {,744 }}$.

Se advierte que el escenario de renegociación de la deuda (donde habrá de discutirse la composición del pasivo, donde habrán de reclamarse eventuales quitas, donde se procurará la refinanciación de la deuda con la consiguiente prórroga de los plazos de pago, etc.) es complejo, arduo y de eficacia condicionada. En el mejor (o peor) de los casos, la renegociación concluirá con un acuerdo de nuevo crédito, a ciencia cierta encarecido, que

\footnotetext{
743 Álvarez Vega, María Isabel, Protección jurídica del consumidor..., cit., pág. 342 y sgtes.

744 Álvarez Vega, María Isabel, Protección jurídica del consumidor..., cit., pág. 342 y sgtes.
} 
puede agravar la situación de endeudamiento del consumidor. De allí que la solución privada, puramente convencional, puede no ser el camino adecuado cuando la situación de sobreendeudamiento está ya planteada.

La doctrina especializada considera que resulta conveniente, en estos casos, acudir a otras soluciones colectivas, institucionalizadas, extrajudiciales o judiciales, que ofrezcan resguardo a los intereses del consumidor afectado y no pongan en riesgo las buenas prácticas que deben ser alentadas en la operatoria de crédito ${ }^{745}$.

La propuesta de una vía administrativa plantea la tramitación de un procedimiento que procure el saneamiento de la situación económica del deudor particular mediante la formalización de un acuerdo que permita una reconducción convencional del status crítico existente entre el deudor y sus acreedores.

Este tipo de solución descansa en la idea de desjudicialización, según la cual la solución privada o extraconcursal (por acuerdo libre o facilitado por un tercero) de estas situaciones de crisis económica, es superior en términos de eficiencia económica a la judicial $^{746}$.

En lo que hace a los sujetos, este procedimiento se tramitaría ante un órgano que desempeñara funciones de mediación y, en su caso, de arbitraje.

Una utilización funcional de los órganos ya existentes en el ámbito de la protección del consumidor (que mire a la economía organizativa y de costes) ha hecho que se haya aconsejado que tal función fuera desarrollada por las juntas arbitrales de consumo ${ }^{747}$. Su composición estaría dada por la presencia de representantes de los sectores socioeconómicos implicados (un miembro perteneciente al ámbito de las entidades financieras,

\footnotetext{
745 Trujillo DíEZ, Iván Jesús, El sobreendeudamiento de los consumidores..., cit., pág. 76 y sgtes.; GutiÉRrez de CABIEDES, Pablo, El sobreendeudamiento doméstico..., cit., pág. 154 y sgtes.; AlvÁREZ VEGA, María Isabel, Protección jurídica del consumidor..., cit., pág. 342 y sgtes.; entre otros; FERNÁNDEZ CARRÓN, Clara, El tratamiento de la insolvencia de las personas físicas, cit., pág. 122 y sgtes.

746 Seguimos en este tema, el desarrollo de GuTIÉRREZ DE CABIEDES, Pablo, El sobreendeudamiento doméstico..., cit., pág. 163.

${ }^{747}$ La doctrina española destaca que en su país, al igual que en Argentina, no existe una arraigada costumbre ni tradición de sometimiento a arbitraje, y menos en esta materia, por lo que cabe ser escéptico en cuanto al predicamento práctico que pudiera tener esta previsión (a diferencia de otros países como Francia, con una preferencia tradicional más acusada a soluciones administrativizadas, como la existente en este ámbito).
} 
comerciantes o de crédito; otro, de las organizaciones de consumidores y usuarios; y otro, de la Autoridad Administrativa de Aplicación en materia de Defensa del Consumidor).

La regulación del procedimiento debe prever la legitimación para instar el trámite, los requisitos de forma de la solicitud de inicio y el contenido que la misma habría de cumplir. Sería conveniente aprobar un modelo estandarizado en el que el deudor haga constar sus datos, los de sus acreedores y una memoria simple donde describa su situación personal y patrimonial (de su activo y pasivo: ingresos, patrimonial y deudas y gastos). Debería imponerse la obligación de acompañar los documentos justificativos de los extremos aludidos (documentación que acredita identidad, estado civil y de familia, sentencia de separación o divorcio, en su caso; títulos de propiedad de sus bienes, declaraciones tributarias, estado de cuentas bancarias; créditos contratados, gastos ordinarios y extraordinarios, etc.).

La admisibilidad de la petición sería verificada por el órgano competente que, por decisión motivada, se pronunciará sobre el particular, con indicación de los presupuestos o requisitos que eventualmente incumplidos y la posibilidad de subsanarlos para proseguir el trámite.

Admitida la solicitud de trámite, el órgano mediador determinará un primer estado de la situación del particular. Inmediatamente procederá a convocar a los acreedores, por el medio más rápido y efectivo posible, poniendo en su conocimiento las actuaciones cumplidas y concediéndoles un plazo para que, en caso de desacuerdo, presentan las alegaciones y justificantes que consideren convenientes.

En el marco de la negociación, el deudor podrá peticionar quita, espera o una combinación de ambas. Se procurará arribar a un acuerdo sobre la base de la propuesta de reembolso de razonable cumplimiento. Quien conduzca el trámite debe asumir un rol protagónico en la búsqueda de la solución de dicha solución consensuada, sin perder de vista que el objetivo prioritario es el saneamiento de la situación de sobreendeudamiento que afecta del consumidor que acude a este procedimiento.

Consideramos imprescindible destacar la necesidad de contar con funcionarios altamente capacitados. Sería deseable que quienes accedan a estas competencias tengan formación y solvencia técnica pero por sobre todo, un firme compromiso con el ejercicio de la función encomendada. 
Quienes impulsan esta vía de superación del sobreendeudamiento, señalan que el procedimiento culminará por rechazo del concordato ofrecido o por aprobación del mismo, dictándose la resolución correspondiente. No obstante ello, propugnan valorizar el esfuerzo realizado en ese escenario y asignar virtualidad al consenso al que se hubiera eventualmente arribado. Se piensa que el juez, en una instancia judicial posterior, puede considerar aquel plan de reembolso y tomarlo como base de una nueva propuesta, estimulando el tránsito de la instancia extrajudicial.

\section{c.2.- Procedimiento judicial}

Si el modelo de regulación opta por emplazar las medidas de saneamiento en sede judicial, se impone diseñar un procedimiento ajustado a los requerimientos de la situación problemática que se procura superar.

La discusión parece estar centrada en un paralelo con el debate vinculado al emplazamiento de la regulación. ¿Ha de tratarse de un procedimiento particular, distinto del proceso concursal regulado, por una ley especial? ¿Será un procedimiento particular dentro del espectro de opciones diseñado en el régimen general de insolvencia?

Dados los reclamos que han motivado la insuficiencia e inadecuación del procedimiento y los mecanismos previstos en la ley concursal ${ }^{748}$ se impone adoptar un

\footnotetext{
748 AlEgríA, Héctor, "Los llamados pequeños concursos...", cit.; FARHI DE MONTALVÁN, Diana, "La insolvencia del consumidor: un problema social globalizado que debe preocupar a la comunidad", Ponencia presentada en el $\mathrm{IV}^{\circ}$ Congreso Iberoamericano sobre Insolvencia; BARREIRO, Marcelo, "Una aproximación al fenómeno del sobreendeudamiento del consumidor y su necesaria regulación”, Ponencia presentada en el $\mathrm{IV}^{\circ}$ Congreso Iberoamericano de Derecho Concursal sobre Crisis económica mundial y la concursalidad; TRUfFAT, E. Daniel, "Pequeños concursos: lineamientos para la regulación del concurso pequeñísimo (y en especial, el concurso del consumidor)”, Ponencia presentada en el IV $^{\circ}$ Congreso Iberoamericano de Derecho Concursal sobre Crisis económica mundial y la concursalidad; BARREIRO, Marcelo-LORENTE, JAVIER A.TrufFAT, E. Daniel, "Del traje de confección al de medida: los procesos concursales deben tener una regulación diversa según su magnitud”, Ponencia presentada en el $\mathrm{IV}^{\circ}$ Congreso Iberoamericano de Derecho Concursal.; BARREIRO, Rafael, "Precisiones acerca de concursos pequeños, crisis sistémicas y consumidores endeudados en demasía", en Truffat, Daniel-BARreiro, Marcelo-AnTONi PiosseK, Carlos RobertoNiCAStro, Ramón Vicente (Coord.), Libro Homenaje al Doctor Osvaldo Maffía, Lerner Editora, Córdoba, 2008, pág. 567 y sgtes.; JUNYENT BAS, Francisco, "El empleado público sobreendeudado y la pérdida de la fuente de trabajo", en LL 2010-B,1264; JUNYENT BAS, Francisco-IZQUIERDO, Silvina, "El consumidor
} 
nuevo modelo con dispositivos de contenido sustancial e instrumental que de modo específico, realista y adecuado, ofrezcan una respuesta a las múltiples aristas que plantea la problemática del sobreendeudamiento del consumidor ${ }^{749}$.

Creemos que pese a las críticas que se plantean respecto de funcionamiento del servicio de justicia, en la idiosincrasia argentina, se sigue apostando a los jueces a la hora de someter un conflicto a la decisión de un tercero imparcial. Se acude a la autoridad del magistrado porque se lo respeta, se confía en él. La decisión final respecto de cualquier controversia la tiene el juez y a ella se está. No se trata de una cuestión menor puesto que será en ese escenario donde habrá de dirimirse la suerte final de los créditos que reclaman los acreedores y donde eventualmente se concederá un beneficio de excepción al deudor, liberándolo del pasivo pendiente de cumplimiento.

Debería ser un procedimiento especial, de trámite ágil, sencillo y económico. Se reclama un verdadero concurso doméstico, capaz de dispensar el debido tratamiento y atención a las situaciones de impotencia patrimonial de las economías particulares, como opuestas -desde lo conceptual- a la crisis que afronta una empresa sobreendeudada.

Una temática a abordar y resolver es la vinculada a la competencia materia para conocer en este concurso doméstico o procedimiento especial de insolvencia del consumidor. En jurisdicciones donde existe un fuero residual civil y comercial unificado, la dificultad parece no existir; mas, cuando ello no es así, se impone determinar si será el juez en lo comercial (que lleva adelante los concursos y quiebras del régimen general de

sobreendeudado y el derecho a quebrar. A propósito de la búsqueda de la rehabilitación y la limpieza del pasivo preexistente", Semanario Jurídico $N^{\circ} 1734$ del 26/11/2009, pág. 757; CRISTÓFARO, Giovana E., "procedimiento especial para el sobreendeudamiento de personas físicas con ingresos fijos", Ponencia presentada en el $\mathrm{V}^{\circ}$ Congreso Iberoamericano sobre Insolvencia; entre muchos otros.

${ }^{749}$ Por su relevancia, invitamos a compulsar las conclusiones y propuestas de regulación contenidas en Kemelmajer de CARluCCI, Aída-Roitman, Horacio (Dir.), "El sobreendeudamiento de la persona física en el ámbito del Poder Judicial de la Provincia de Córdoba con relación a las causas judiciales iniciadas entre el año 2006 y 2010 en el fuero de concursos y quiebras y penal económico. Consecuencias normativas, procesales e institucionales", en Investigaciones aplicadas en el ámbito del Poder Judicial de Córdoba 8, Colección Investigaciones y Ensayos, Córdoba, 2011, pág. 97-145, https://www.justiciacordoba.gob.ar/JusticiaCordoba/files/libros/Investigaciones\%20y\%20Ensayos\%20n\%C2 \%BA\%208.pdf (Fecha de consulta: 9/7/2015). 
insolvencia), quien entenderá asimismo en los procesos de sobreendeudamiento de consumidores, o si deberá asignarse esa competencia al juez en lo civil.

Una cuestión relevante, a nuestro criterio, está relacionada con el rol del juez-como director del proceso- y de los funcionarios que asuman la conducción de las instancias que integren el trámite procesal (la conciliación y renegociación, la liquidación y distribución, la supervisión del plan de pagos complementario si lo hubiera, etc.). Se impone destacar el protagonismo que ha de alcanzar la actuación del juez en este tipo de procedimiento, su activismo. Del mismo modo, los auxiliares a quienes la regulación asigne las funciones antes mencionadas -conciliadores, administradores, enajenadores, etc.-, deben desplegar un esfuerzo comprometido con el objetivo del procedimiento.

Resueltas estas cuestiones, el gran tema es el procedimiento.

En Argentina, la doctrina ha elaborado propuestas. El aporte de los especialistas es de innegable valor ${ }^{750}$. En general, y tal como resulta de confrontar proyectos e iniciativas, las propuestas pasan por abreviar los plazos de publicación de edictos, o restringir el número de edictos a publicar, simplificar la verificación, eliminar la verificación tardía y el recurso de revisión, eliminar la sindicatura, restringir aún más la apelabilidad o disponer que todas las apelaciones planteadas sean resueltas en forma conjunta y en contadas oportunidades que la ley debe determinar, prever que la clausura del procedimiento produzca la caducidad de todas las deudas anteriores cuyos titulares no se hubiesen presentado a verificar, que la clausura pueda disponerse aún cuando no se haga distribución alguna, etc." 751 .

Se impone profundizar el estudio de la problemática. Los modelos implementados por otros ordenamientos han de servirnos de experiencia. Podemos abrevar en ella pero sin

\footnotetext{
${ }^{750}$ ALEGRÍA, Héctor, "Los llamados pequeños concursos...”, cit.; RIVERA, Julio César, "Insolvencia de las personas físicas...", cit; TRUfFAT, E. Daniel, "Pequeños concursos: lineamientos para la regulación del concurso pequeñísimo (y en especial, el concurso del consumidor)", Ponencia presentada en el IV $^{\circ}$ Congreso Iberoamericano de Derecho Concursal sobre Crisis económica mundial y la concursalidad, cit.; BARREIRO, Marcelo-LOREnTE, JaVIER A.-Truffat, E. Daniel, "Del traje de confección...”, cit; BARREIRO, Rafael, "Precisiones acerca de concursos pequeños...", cit., pág. 567 y sgtes.; entre otros.

${ }^{751}$ Con cita de los autores que formulan esas propuestas, lo expresa KEMELMAJER DE CARLUCCI, Aída, "El sobreendeudamiento del consumidor...", cit.
} 
olvidar que el éxito no está en la imitación sino en la adopción de fórmulas adaptativas respecto de medidas y correctivos de acreditada eficacia.

\section{c.3.- Los proyectos de ley presentados al Congreso en Argentina:}

Varios han sido los proyectos de ley presentados en el Congreso de la Nación, encaminados a proponer soluciones normativas al fenómeno del sobreendeudamiento de los consumidores.

En la Cámara de Diputados, ingresó el Proyecto de la Diputada Gladys Esther González bajo el título "Sobreendeudamiento familiar pasivo" "752, que propone el dictado de una ley especial con una regulación particular de la problemática.

$\mathrm{Al}$ referirse al objeto de la ley, el art. 1 dispone: "La presente Ley tiene por objeto garantizar la protección administrativa y judicial de las personas físicas usuarias de servicios financieros y crediticios, que se encontraren en una situación de sobreendeudamiento pasivo. Establecer un procedimiento administrativo y judicial que les permita celebrar un acuerdo de pago con sus acreedores y cumplir así con sus obligaciones pecuniarias pendientes de naturaleza no comercial. Están exceptuadas de la aplicación de la presente Ley, las deudas alimentarias, los procesos ejecutivos de las mismas y las deudas de carácter empresarial.

Conforme el art. 2, "La finalidad de la presente Ley es, sobre la base de la buena fe de las relaciones financieras y comerciales, prevenir las situaciones de insolvencia familiar que puedan devenir de un estado de sobreendeudamiento pasivo producto de alguna de las causales enumeradas en el artículo 6 de la presente Ley. Asimismo, busca promover la recuperación de la economía familiar, normalizar su situación financiera, y evitar cualquier situación de exclusión social o laboral persiguiendo el desarrollo de una cultura de consumo y acceso al crédito responsable. Son objetivos de la presente Ley:

a) Proporcionar una instancia administrativa de conciliación a los fines de evitar la judicialización del caso.

\footnotetext{
${ }^{752}$ El citado proyecto de ley ha sido identificado como Expediente $N^{\circ}$ 7482-D-2010. Luego fue reproducido como Expediente $\mathrm{N}^{\circ}$ 324-D-12.
} 
b) Proporcionar un procedimiento judicial especial, en los casos en los que haya fracasado la instancia administrativa a la que hace referencia el inc. a).

c) Crear, promover y ejecutar programas de educación financiera y administración personal de las finanzas y la utilización reflexiva de los distintos servicios o productos crediticios.

d) Procurar que los proveedores de servicios crediticios y financieros cobren la deuda contraída por el usuario, en los términos que se acuerden.

Al definir el ámbito de aplicación subjetivo, el art. 3 dispone: “Alcance. Quedan comprendidas en la presente Ley, las personas físicas usuarias de servicios financieros y crediticios que habiten el territorio nacional de la República Argentina, y los proveedores de dichos servicios que desarrollen su actividad comercial y financiera dentro del país”.

Como medidas de carácter preventivo, el Capítulo III del proyecto organiza cuatro normas:

-El art. 7 dispone: "Las entidades que oferten créditos deberán cumplir con los requisitos del artículo 36 de la Ley 24.240, Título VIII "de las operaciones financieras y de crédito para el consumo".

-El art. 8 establece: "Las entidades financieras que oferten créditos deberán proporcionar en forma gratuita al deudor la información detallada según lo dispone el artículo 36 de la Ley 24.240 de Defensa al Consumidor".

-El art. 9 reza: "Las entidades financieras deberán dar a conocer al deudor, por escrito en forma clara y detallada, el saldo de cancelación total de la deuda a una fecha determinada".

-El art. 10 prevé que "Las entidades financieras tendrán la obligación de entregar copia del contrato y sus anexos. Cualquier modificación al contrato sin el consentimiento del consumidor está prohibida".

El citado proyecto de ley deja establecido en el art. 11 que "La autoridad de aplicación nacional de la presente Ley será la Unidad de Conciliaciones de Sobreendeudamiento Pasivo (UCSP), la cual será creada a tal efecto, dependiente de la Secretaría de Comercio Interior en el ámbito del Ministerio de Economía. La Ciudad Autónoma de Buenos Aires y las Provincias actuarán como autoridades locales de 
aplicación ejerciendo el control, vigilancia y juzgamiento en el cumplimiento de esta Ley y de sus normas reglamentarias".

El restablecimiento del particular sobreendeudado se proyecta en un doble escenario.

El Título II, Capítulo I está dedicado al procedimiento administrativo, que se encamina a propiciar la renegociación del pasivo con los acreedores, con la asistencia de la autoridad de aplicación y bajo los principios que inspiran la regulación. El trámite previsto es descripto entre los arts. 14 a $26^{753}$.

753 Conforme el art. 14, y a efectos de dar inicio al procedimiento administrativo, "La persona deudora deberá solicitar por escrito de manera personal o vía Internet, la posibilidad de acogerse al procedimiento administrativo que establece la presente Ley cuando se encuentre ante una situación de sobreendeudamiento pasivo. Dicha solicitud deberá contener una descripción clara y precisa de los ingresos y patrimonio personales y/o de la familia; gastos mensuales personales y/o de la familia; créditos contraídos, acreedores y montos adeudados a éstos; información necesaria y documentación que respalde las causales de sobreendeudamiento pasivo, los datos personales; domicilio legal donde se realizarán las notificaciones”. El art. 15 prevé que "Recibida la solicitud, la UCSP evaluará su procedencia dentro del plazo de 5 (cinco) días hábiles de recibida la misma. Para el análisis de la procedencia se verificará que el o los acreedores sean entidades debidamente habilitadas". Conforme el art. 16, "Determinada la procedencia, la UCSP notificará de manera fehaciente al acreedor o acreedores sobre la solicitud interpuesta y comunicará fecha, horario y domicilio en la que pondrán presentar sus apreciaciones frente a la UCSP, fecha que no deberá superar el plazo de 5 (cinco) días hábiles de emitida tal notificación". En virtud del art. 17, "Cumplido el plazo para realizar las apreciaciones frente a la UCSP se abrirá una etapa de prueba de 10 (diez) días hábiles, a efecto de lograr una adecuada apreciación de la situación económica y financiera de la persona deudora. Dentro de la etapa de prueba, las partes podrán presentar por sí o a petición de la UCSP los elementos probatorios que estimen pertinentes". A renglón seguido, el art. 18 dispone: "Finalizada la fase probatoria, el equipo técnico de la UCSP contará con 5 (cinco) días hábiles para ratificar o confirmar la procedencia de la petición o disponer el archivo de la misma, decisión que deberá notificarse dentro del plazo de tres días corridos. La decisión de archivar la solicitud deberá fundamentarse de forma fehaciente y consistente, precisando que la situación de sobreendeudamiento pasivo de la persona deudora no se adecua a lo preceptuado en el artículo 6 de esta ley". Por su parte, el art. 19 establece: "Efectos. Confirmada la procedencia, quedará sin efecto y se suspenderán todas las causas extrajudiciales o judiciales existentes o de acción posterior que de alguna manera empeoren la situación patrimonial del deudor. Asimismo, el deudor una vez iniciado el procedimiento, quedará imposibilitado de adquirir nuevos préstamos o créditos que afecten su patrimonio sin previa autorización de la UCSP. En caso que el deudor adquiera nuevos préstamos una vez iniciado el procedimiento, el expediente será archivado, salvo que la persona justifique su proceder de forma debida ante 
El Título III, Capítulo I, contiene la preceptiva del procedimiento judicial. Del art. 27 surge que "una vez agotada la vía administrativa establecida en la presente Ley sin alcanzar acuerdo conciliatorio alguno, la UCSP remitirá todo lo actuado al juzgado de primera instancia con competencia en lo civil y/o comercial".

Conforme el art. 28, "Una vez designado el Juez competente, éste citará a las partes a una única audiencia en la que intentará buscar que las mismas arriben a un acuerdo en base a lo actuado en sede administrativa, siempre asegurando la consecución de los objetivos preceptuados en el plan de saneamiento económico contenido en el dictamen emitido por la UCSP".

"En caso de no existir acuerdo entre las partes o de ausencia de una de ellas en la audiencia citada por el Juez, éste deberá pronunciarse sobre la situación de la UCSP y ésta determine la continuación del procedimiento”. Así, el art. 20 agrega: “ Novación. En todos los casos, el procedimiento concedido importa la novación de todas las obligaciones con origen o causa anterior a la solicitud del mismo". El art. 21 prevé que "Una vez confeccionado el dictamen técnico, la UCSP sorteará de la nómina del Registro, el conciliador correspondiente que llevará a cabo la etapa de negociación de la actuación administrativa pertinente". El art. 22 propicia la celebración de la audiencia, al establecer que "El conciliador sorteado notificará a las partes la fecha, horario y domicilio en que se llevará a cabo la audiencia de negociación, la que deberá realizarse en un plazo no mayor de 10 (diez) días hábiles de su designación. En la audiencia, el conciliador designado realizará un análisis de las consideraciones expuestas por las partes, y elaborará un plan de reprogramación de pagos acorde a los ingresos de la persona deudora, teniendo en cuenta lo estipulado en el artículo 2 de la presenta Ley, y agotando todas las vías de negociación posible para que las partes lleguen a un acuerdo en la misma audiencia. Dichos acuerdos podrán contener, entre otros: suspensión de intereses o reducción de los mismos; quita o condonación parcial de la deuda; reformulación de los plazos de pago; unificación de deudas". En caso de acuerdo, sus efectos están previstos en el art. 23 que reza: "El acuerdo alcanzado tendrá fuerza ejecutiva y será plasmado en un acta labrada por el conciliador, la cual deberá contener por lo menos los siguientes datos: fecha de celebración, monto total de la deuda, términos del acuerdo. El acuerdo alcanzado no podrá estipular plazos de pago superiores a 5 años”. Atento a los términos del art. 24, "En caso que el o los acreedores no comparecieran a la audiencia de negociación, se fijará una nueva audiencia en una fecha no mayor a los 10 (diez) días de celebrada la primera" y "si el acreedor no compareciera a la segunda audiencia se fijará una multa según lo establecido en el artículo 47 de la Ley 24.240 de Defensa del Consumidor (art. 25). Cierra el capítulo del procedimiento administrativo, el art. 26, conforme al cual, "cuando el conciliador haya agotado toda instancia de negociación y las partes no hubieren llegado a ningún acuerdo dentro de las audiencias previstas en los artículos 22 y 24 de la presente Ley, quedará expedita la vía judicial”. 
sobreendeudamiento pasivo del deudor y la forma en la que responderá a las obligaciones contraídas con el acreedor o los acreedores dentro del plazo de 5 (cinco) días hábiles desde la fecha en que fue o debió ser celebrada la audiencia establecida en el artículo precedente. La resolución del Juez competente podrá comprender: suspensión de intereses o reducción de los mismos de acuerdo a la tasa de interés activa del Banco de la Nación, quita o condonación parcial de la deuda, reformulación de los plazos de pago, unificación de deudas. El Juez tiene la facultad de homologar el dictamen elaborado en sede administrativa por parte de la UCSP” (art. 29). Puntualiza el art. 30 que "el Juez en su resolución valorará entre otras las siguientes circunstancias con respecto a la persona deudora: a) La voluntad mostrada para cumplir con sus obligaciones; b) $\mathrm{Su}$ historial crediticio antes de la situación de sobreendeudamiento pasivo; c) La veracidad y gravedad de la situación argumentada respecto de las causas de dicho sobreendeudamiento pasivo; d) Prácticas de consumo sustentable" (art. 30).

El art. 33 prevé que "Cuando la persona deudora incumpliese, por causas imputables a su persona, el programa de pagos dictado por la UCSP, ya sea en sede administrativa o judicial, se procederá de conformidad al Juicio Ejecutivo Civil, sin que pueda invocar nuevamente los procedimientos establecidos en esta Ley por las mismas deudas. Si el incumplimiento se debe a causas no imputables a la persona deudora, la instancia competente podrá revisar el programa de pagos".

Tiempo atrás había ingresado también a la Cámara de Diputados, un proyecto de ley de los Diputados Vilma Lidia Ibarra, Alejandro Luis Rossi y Luis Francisco Jorge Cignona $^{754}$ que proponía la regulación de la problemática del sobreendeudamiento (de algunas de sus aristas) pero a partir de una modificación de la ley de concursos y quiebras.

Este proyecto de ley impulsaba una reforma a la ley concursal, incorporando la figura del concurso mínimo, con un procedimiento que se estimaba ajustado a los requerimientos del caso. La propuesta legislativa se asentaba sobre la base del diseño de un trámite particular, que superara las deficiencias que la aplicación de los "pequeños

\footnotetext{
${ }^{754}$ El citado proyecto de ley ha sido identificado como Expediente No $6605-\mathrm{D}-2008$.
} 
concursos" (arts. 288 y 289 de la Ley $N^{o}$ 24.522) exhibía para la insolvencia de los consumidores $^{755}$.

${ }^{755}$ El Proyecto aludido era el siguiente: "Art. $1^{\circ}$.- CONCURSO MINIMO. APLICACIÓN. Al decidir la apertura de un concurso preventivo, o la conversión de quiebra en concurso preventivo, el juez debe disponer la aplicación del procedimiento estatuido en esta ley; si el pasivo denunciado es inferior a Pesos CIEN MIL (\$ 100.000) y el deudor es: a) una persona física, sea o no comerciante; b) una sociedad de hecho; c) una sociedad civil, o una asociación civil; d) una cooperativa, mutual o fundación. El juez también puede ordenar, mediante resolución fundada, la aplicación de este trámite cuando la escasa significación económica del proceso concursal así lo justifique, aún cuando exceda el tope establecido en el párrafo anterior. La decisión de aplicar el procedimiento de concurso mínimo es irrecurrible. Art. 2.- CONVERSION DEL CONCURSO MINIMO. Si durante el trámite de un concurso mínimo se determina que el pasivo resulta mucho más significativo que el tenido en cuenta al decidirse su aplicación, o si la relevancia de los activos así lo aconsejara, el juez puede: a) convertir el procedimiento en el de concurso preventivo previsto en la ley 24.522. En tal caso dicta una resolución ordenatoria a dichos efectos, mediante la cual otorgará el plazo previsto en el art. 11 último párrafo de la ley 24.522 para que el sujeto concursado cumpla con los recaudos faltantes; o b) pronunciar la quiebra en los términos del art. 3, último párrafo de la presente ley. En este caso en la resolución en la que se determine la declaración de quiebra, dictará las medidas de adecuación que resulten pertinentes. El decreto de quiebra es apelable en los términos de lo dispuesto por el art. 273 inc. 4 de la ley 24.522. Art. 3.- PETICION DE CONCURSAMIENTO COMO "CONCURSO MINIMO". ADECUACIÓN DE PETICIÓN EN LOS TÉRMINOS DEL ART. 11 DE LA LEY 24.522. El peticionante de concursamiento como concurso mínimo debe: a) aportar todos los datos de identificación personal que correspondan, para evitar confusiones con homónimos o parónimos, en caso de tratarse de una persona física; b) acompañar la documentación prevista en los arts. 6 y 11 inc. 1ro. de la ley 24.522, en caso de tratarse de una de las personas jurídicas referidas en el art. 1 de la presente ley; c) acompañar un listado de activos, indicando si existen sobre los mismos gravámenes o embargos y señalando su valor probable de realización conforme parámetros de mercado; d) acompañar legajos de cada uno de sus créditos concurrentes, declarando bajo juramento la existencia de tales deudas y la inexistencia de cualquier otra. Deberá detallar también todos los juicios de contenido patrimonial que lo registren como demandado. Tal declaración valdrá como confesión, e) informar sobre sus ingresos en los últimos dos años y efectuar una proyección de ingresos por igual plazo futuro; f) formular una propuesta de pago a sus acreedores concurrentes quirografarios en función de los ingresos proyectados, o indicando qué bienes del activo se liquidarán para ello; g) formular una propuesta de pago a sus acreedores privilegiados; h) indicar precisa y documentadamente él o los hechos que causaron su estado de cesación de pagos; i) adjuntar una denuncia de los activos de los que el deudor hubiere ido titular durante el término de dos (2) años anteriores a la fecha de petición de su concurso mínimo, y que ya no integraren su acervo. El cumplimiento de los recaudos de este artículo se hará mediante un Formulario que elaborarán, dentro de los treinta días de entrada en vigencia de la presente ley, las Cámaras de 
Apelaciones con competencia en lo concursal de cada jurisdicción. Los datos que el deudor consigna en el Formulario de Iniciación del Concurso Mínimo tienen carácter de declaración jurada, y su inexactitud, sea producto de dolo o culpa, ya sea que surja de los pedidos de explicaciones en la Audiencia Preliminar, que sea informado por el conciliador dentro de 72 horas de aceptado el cargo, o que sea objeto de manifestación ulterior de éste dentro de los cuarenta días de negociación del acuerdo, autoriza al juez a dar por concluido el trámite de concurso mínimo, decretando la quiebra -salvo cuando el interés de los acreedores o la preservación de la fuente de trabajo, justificaran la conversión prevista en el último párrafo del art. 2, apartado a). En la elaboración del Formulario el deudor deber recurrir a la asistencia de un abogado que lo asesore y patrocine en la presentación de su concurso mínimo; así como durante su tramitación. El Formulario debe ser suscripto por ambos, siendo el profesional pasible de las sanciones que prevea la normativa local para el abogado que hubiera patrocinado presentaciones maliciosas o temerarias. El deudor puede recurrir, además, a la asistencia de un contador público que certifique que según libros, la denuncia de activos y pasivos es correcta. Art. 4.- SUSPENSION AUTOMATICA DE TODAS LAS ACCIONES DE CONTENIDO PATRIMONIAL CONTRA EL DEUDOR. La mera presentación del Formulario de Iniciación del Concurso Mínimo por el deudor, importa automáticamente la suspensión temporaria por un término de 90 días hábiles judiciales de todas las acciones de contenido patrimonial contra el deudor, por cualquier causa y en cualquier jurisdicción. La suspensión mencionada en el párrafo anterior no opera cuando a criterio del Juez, el deudor no reúne prima facie los requisitos previstos en la presente ley, o dudare de su veracidad. La elaboración y tramitación de las comunicaciones u oficios haciendo saber la suspensión temporaria del trámite a los juzgados o tribunales donde tramiten las causas de contenido patrimonial contra el deudor es responsabilidad de éste. Art. 5.- CITACION A LA AUDIENCIA PRELIMINAR. NOTIFICACION. Dentro de los cinco días de producida la presentación del Formulario de Iniciación del Concurso Mínimo por el deudor, excepto cuando éste no reúna los requisitos previstos en el art. 3 de la presente ley, o el Juez dude fundadamente de su veracidad, el Tribunal interviniente dicta una resolución mediante la cual fija una Audiencia Preliminar que se celebra con el deudor y con los acreedores que concurran, en un plazo que no puede exceder de los 20 días. El día, hora y lugar de celebración de la Audiencia Preliminar debe ser notificado a todos los acreedores denunciados por el deudor, como así también a los accionantes en los juicios en trámite denunciados, mediante cédula, por Carta Documento u otro mecanismo de notificación fehaciente. También se debe publicar, por un día, edicto en el diario de publicaciones oficiales. El envío de las notificaciones y la publicación del edicto son responsabilidad del deudor, quien debe acreditar la satisfacción de tales extremos dentro de los 10 días de notificado por nota de la resolución que fija la Audiencia Preliminar. Art. 6.CELEBRACION DE LA AUDIENCIA PRELIMINAR. La Audiencia Preliminar se celebra con presencia del Juez. En la misma jornada pueden tener lugar diversas audiencias preliminares. El juez recibe a los peticionarios en forma sucesiva y en el orden de presentación de sus pedidos de concurso mínimo. En la Audiencia Preliminar el peticionario de concursamiento sometido al procedimiento de concurso mínimo aporta los datos que no son exigidos por el art. 11 de la ley 24.522 y que establece el artículo 3 de la presente ley y, especialmente, confiere valor de declaración jurada al informe sobre pasivos. En todos los casos el juez 
pide las explicaciones o requiere la información complementaria que juzgue menester. Puede prorrogar la audiencia hasta siete días si fuera indispensable. Durante la Audiencia Preliminar los acreedores presentes pueden hacer las manifestaciones que crean útiles para la mejor marcha del proceso concursal, y tanto éstos como el Juez pueden requerir al deudor las más amplias explicaciones sobre su situación patrimonial presente y pasada. Rendidas tales explicaciones o aportada la información complementaria, el juez declara abierto el concurso y, en el mismo acto, procede al sorteo de conciliador. Los acreedores presentes en la Audiencia Preliminar, como así también todos aquellos denunciados como acreedores y/o accionantes en los términos del inciso "d" del art. 3 tienen derecho a cuestionar la declaración jurada de pasivos y a impugnar la denuncia de pasivos dentro de quinto día de concluida la misma. Si no se produjeren cuestionamientos ni impugnaciones o, aún habiéndolas, el tribunal las juzgare insuficientes, el Juez resuelve sobre la base de la información rendida por el concursado y el solo control del conciliador, quien deberá emitir un informe sobre la observaciones realizadas contra la denuncia de créditos, dentro de los cinco días posteriores al plazo referido en el párrafo anterior. Dicha resolución debe dictarse sobre los pasivos denunciados determinando su existencia, magnitud y graduación, en un plazo no mayor a los cinco días a contar del informe del conciliador o del vencimiento del plazo para que este se presente. Esta resolución será irrecurrible a los fines del cómputo de las mayorías. Art. $7^{\circ}$.- RECHAZO DEL CONCURSO MINIMO. El juez, en caso de considerar absolutamente inviable la solución preventiva, rechaza el pedido y, por sentencia separada, decreta la quiebra. El rechazo de la apertura de concurso mínimo es apelable en los términos de lo dispuesto por el art. 273 inc. 4to. de la ley 24.522. La quiebra decretada en simultáneo no puede liquidar activos, salvo que fueran perecederos, hasta que dicha sentencia quede firme. Art. 8.- CONCILIADOR. CONTROL DE ACTIVOS Y PASIVOS. El conciliador se sortea a partir de las listas de Sindicatura "B" hoy existentes. En lo sucesivo las Cámaras de Apelaciones confeccionarán listas de Síndicos Clase "A", Clase "B" y "Conciliadores". Debe aceptar el cargo dentro de las 24 horas de notificado del mismo. Una vez aceptado el cargo por el conciliador, éste deberá, en un plazo de 72 horas; analizar los libros del deudor o las constancias que llevare, presentar informe ante el juez, sobre la exactitud de los activos y pasivos denunciados por el deudor, sin perjuicio del informe que deberá presentar sobre las observaciones a los mismos en el plazo previsto en el artículo $6^{\circ}$. Asimismo, el Conciliador, tendrá un plazo de cuarenta días para, asistiendo al deudor negociar la propuesta efectuada -u otra de cumplimiento factible en función de los ingresos proyectados-. Si el conciliador advierte diferencias groseras en la información presentada por el deudor, antes del vencimiento del plazo de cuarenta días, las debe informar al juez. El juez, en tal caso, puede dar por concluido el concurso mínimo y decretar, por auto separado la quiebra, conforme lo establecido en el artículo 7 de la presente. Art. 9.- PROPUESTA. Pueden ofrecerse como propuestas todas las previstas en el art. 43 de la ley 24.522, así como cualquier otra que no resulte incursa en la previsión del art. 52 inc. 4to. de la misma norma, elaboradas con asistencia del conciliador quien debe controlar que las mismas no sean arbitrarias o que no importan manipulación de mayorías, para lo cual adjuntará un dictamen fundado en el momento de incorporarse las propuestas al expediente. A los fines de ofrecer propuestas diferenciadas puede dividirse a los acreedores en categorías. Dentro del plazo de cuarenta días determinado en el artículo anterior, se acompaña/n la/s propuesta/s, y si 
En la Cámara de Senadores, por su parte, ingresó un proyecto de ley de la Senadora Liliana Negre de Alonso en el cual proponía también el dictado de una ley especial Régimen de Sobreendeudamiento para Pequeños Deudores- que asumiera el abordaje de esta problemática con perspectiva particular ${ }^{756}$.

El ámbito de aplicación se definía en el art. 2, conforme al cual "Serán sujetos comprendidos en esta ley toda persona física que tenga domicilio en el territorio nacional". A los efectos de esta ley, se entenderá por pequeño deudor a aquella persona física cuyos ingresos mensuales no superen los veinte salarios mínimos vitales y móviles, y sus pasivos no superen el trescientos por ciento de sus ingresos mensuales, normales y habituales. También podrá ser solicitado por un comerciante cuyo pasivo denunciado no alcance la suma equivalente a los treinta salarios mínimos, vitales y móviles”.

Este proyecto prevé procedimientos de saneamiento siguiendo los lineamientos del modelo francés, aunque con adaptaciones.

El art. 3 reza: "Estado de sobreendeudamiento. Solicitud. El proceso se inicia a instancia del deudor, solicitando se le aplique el régimen de la presente ley por ante el juez competente para todas aquellas deudas exigibles y a vencer originadas, pero no limitadas, por el consumo individual o familiar, obligaciones fiscales $\mathrm{u}$ obligaciones asumidas como, garante o deudor solidario. En todos los casos el deudor deberá ser de buena fe". El art. 4 prevé que este procedimiento tramitará ante el juez en lo comercial que corresponda al domicilio del deudor.

hubiera/n reunido las mayorías del art. 45 de la ley 24.522 y se ajustara/n a las pautas del art. 52, inc. 4 de dicha ley, el juez la homologa. Art. 10.- QUIEBRA MINIMA. La quiebra mínima es la que resulta como consecuencia de haberse rechazado la apertura de un concurso mínimo, de haberse decretado la quiebra en cualquiera de las hipótesis que la presente ley prevé durante un proceso de concurso mínimo; o cuando, decretada la quiebra a pedido del propio deudor, éste solicitó la aplicación de este procedimiento y suscribió el Formulario de Iniciación. Art. $11^{\circ}$.- REHABILITACION AL AÑO DE DICTADA LA SENTENCIA DE QUIEBRA MINIMA. Si se detectan inexactitudes u ocultamientos, sean estos por culpa o dolo, en la información rendida por el deudor en su Formulario de Iniciación de Quiebra Mínima, el Juez puede extender por períodos de un año y hasta un máximo de 5 años, la inhabilitación del deudor, y obligarlo a que mientras dure su inhabilitación, todos los ingresos o activos que obtenga y adquiera que excedan de lo necesario para su manutención propia y familiar, sean aplicados al pago de las deudas falenciales. Art. 12.- APLICACIÓN SUPLETORIA. La ley 24.522 será de aplicación supletoria a la presente ley”.

${ }^{756}$ El citado proyecto de ley ha sido identificado como Expediente S-1422/13. 
A renglón seguido, se da intervención al síndico $^{757}$ pues del resultado de su actuación dependerán los escenarios de actuación y medidas sucesivas.

Conforme el art. 5, "A los fines de determinación del procedimiento a seguir, producida la solicitud y aceptado el cargo por parte del síndico, el Juez pedirá la opinión de este último.

A. Si el síndico estimare que el deudor posee activos de conveniente realización o su situación económica y financiera es remediable, procederá a solicitar al juez la inmediata apertura del procedimiento de conciliación extrajudicial, continuando su actuación hasta la homologación del acuerdo o de la propuesta propiciada por ella, de corresponder. En la resolución que dicte el juez declarando la procedencia del procedimiento de conciliación extrajudicial, deberá fijar, además, las fechas en las que el síndico deberá reunirse con el deudor y los acreedores denunciados para intentar un acuerdo entre ellos, como así también

${ }^{757}$ El Título V del proyecto de ley está dedicado a la Sindicatura. Así: Art. 18.- "Elección del síndico. Recibida la solicitud por parte del deudor, el juez procederá a fijar audiencia dentro de los próximos tres días para sortear al síndico. Éste deberá manifestar si acepta o no el cargo dentro de los dos días de efectuada dicha audiencia". Art. 19.- "Funciones. El síndico tendrá las siguientes funciones específicas: A. Citar a los acreedores denunciados por el deudor para que denuncien los datos relativos a sus créditos dentro del plazo de diez días antes de la reunión conciliatoria con el deudor fijada en la resolución judicial del artículo 8 de esta ley. Si no denunciaren tal información en la fecha fijada, el crédito se tomará tal cual lo denunció el deudor; B. Invitar a que las partes, en la reunión conciliatoria fijada en el artículo 8 de la presente ley, logren un acuerdo sobre el modo de afrontar la situación de sobreendeudamiento del deudor. Cuando la situación lo amerite, podrá disponer de cuartos intermedios, los que no podrán exceder de 2 días entre cada uno, siendo el máximo cuatro cuartos intermedios; C. Fijar una suma estimada para que el deudor pueda afrontar los gastos corrientes familiares, tales como gastos de electricidad, gas, agua, alimentos, escolaridad y seguro de salud. Deberá reservar una suma razonable en concepto de pago de honorarios a los profesionales intervinientes del deudor; D. Escuchar a toda persona que aporte datos útiles para el trámite, siempre que intervenga gratuitamente; E. Citar a los garantes del deudor o codeudores, si los hubiere; F. Solicitar fundadamente al juez competente que suspenda todos los procedimientos de ejecución contra el deudor, salvo los iniciados por créditos alimentarios. Si el juez estuviere de acuerdo, dictará aquella suspensión dentro de las 48 horas de presentado el pedido, por un término máximo de 9 meses; G. Realizar y confeccionar un plan de medidas para paliar el sobreendeudamiento del deudor cuando las partes no arribaren a una conciliación entre ellas. Este plan de medidas será vinculante; H. Remitir las actuaciones al juez competente, y emitir todo tipo de opinión que el juez le requiera para llevar a cabo los fines establecidos en la presente ley". 
la fecha en la que se debe presentar el acuerdo extrajudicial o el plan de medidas propuesta por el síndico, si correspondiere, para su eventual homologación.

B. Si el síndico estimara que el deudor tuviere pocos activos realizables, o su realización fuese antieconómica, o se encuentre en una situación económica irremediablemente comprometida de seguir cualquier medida que disponga el síndico deberá emitir una opinión fundada y razonada al juez competente en la que establecerá los motivos por los cuales se recomienda que el juez aplique al deudor el trámite de restablecimiento personal regulado en la presente ley. La opinión del síndico podrá estar sujeta a revisión a pedido del propio deudor ante el mismo, pero en caso de ser rechazado su pedido, éste será irrecurrible.

La misma norma prevé que "en todos los casos, el síndico deberá pronunciarse acerca del grado de responsabilidad en que, directa o indirectamente, los acreedores incurrieron para que el deudor se halle en la situación económico financiero que origino la aplicación de la presente ley. Cuando la responsabilidad del acreedor haya contribuido en forma significativa y determinante a la situación del deudor anteriormente mencionada, el juez podrá disminuir proporcionalmente el crédito según el grado de responsabilidad que determine el síndico".

El proyecto dedica el art. 6, al procedimiento de conciliación extrajudicial: "Cuando el deudor se halle en una situación en la que sus activos denunciados sean económicamente convenientes de realizar y su situación económica y financiera sea remediable, a criterio del juez, se seguirá el procedimiento de conciliación extrajudicial, en el que intervendrán como parte el síndico, el deudor y los acreedores denunciados".

Por su parte, el art. 7 establece: "Restablecimiento Personal. El deudor que se encuentre en una situación irremediablemente comprometida caracterizada por la imposibilidad manifiesta de cumplir cualquier medida de saneamiento, seguirá el trámite de restablecimiento personal regido en la presente ley".

Atento al trámite diseñado en el art. 8 de este proyecto de ley, "Dentro de los 10 días de pronunciado el síndico, el juez dictará una resolución en la que fijará el procedimiento a seguir, y se notificará lo resuelto al deudor, al síndico, a los acreedores denunciados y mandará a publicar por 1 (un) día en el diario de mayor circulación local, y 
edictos por 2 (dos) días, en el que se individualizará y detallará las partes intervinientes, el juez y el procedimiento resuelto".

La misma norma prevé que "la buena fe del deudor se presumirá, a no ser que sea desvirtuada por quien la niegue, siempre que sea parte del proceso o quien demuestre que tenga un interés legítimo, y podrán hacerlo en cualquier etapa del proceso, hasta la homologación del acuerdo. Dicha presentación no interrumpirá ni paralizará las actuaciones que hubiese fijado el síndico para llevar a cabo la conciliación extrajudicial, estando condicionado el eventual acuerdo con acreedores o propuesta del síndico que no se declare la mala fe del deudor. El juez decidirá mediante resolución fundada dentro de las 72 horas de presentado el pedido y su decisión podrá ser recurrida en los 3 días siguientes, debiendo, de así proceder, otorgarse en relación y con efecto devolutivo. Declarada la mala fe del deudor, el juez ordenará el cierre del procedimiento y mandará a archivar las actuaciones".

El procedimiento de conciliación extrajudicial está regulado en el art. 9 que dispone: "Reunión Conciliatoria. En la fecha fijada para la reunión conciliatoria entre el deudor y sus acreedores, se negociará y elaborará un plan de pagos, el que no podrá postergar el pago de la deuda por un plazo superior a los siete años. La negociación deberá llevarse a cabo a la luz del principio de buena fe".

Allí se establece que "El contenido del plan podrá ser fijado libremente por las partes, con la estricta vigilancia del síndico, pero deberá contener siempre una regulación de honorarios de los letrados intervinientes del deudor. El síndico podrá, en todo momento, opinar acerca de la conveniencia o no de las propuestas realizadas".

El art. 10 se refiere al llamado "Plan de medidas". Consigna la norma que "si no se llegara a un acuerdo en la reunión conciliatoria, el síndico deberá realizar un plan de medidas de saneamiento dentro de los cinco días posteriores al fracaso de la reunión, las que exclusivamente consistirán en: quita; espera; ejecución por subasta de bienes gravados o no; otorgamiento de garantías; venta o entrega de bienes; refinanciación con un plazo no superior a 7 años y reducción de la tasa de interés. El juez podrá controlar la regularidad del plan de medidas al momento de homologar. El deudor o los acreedores podrán recurrir dicho plan de medidas al juez dentro de los cinco días de su notificación. En caso de proceder la ejecución por subasta de bienes o venta o entrega de bienes, se aplicará la forma de realización establecida en el artículo 15 y siguientes, en lo pertinente. 
De conformidad al art. 11, "si hubiere logrado un acuerdo en la reunión conciliatoria, o fracasada ésta y hecho el plan de medidas correspondiente por el síndico, este último deberá en todos los casos remitir inmediatamente las actuaciones correspondientes al juez que interviene a los fines de homologación. Si el juez homologare el plan de medidas, éstas serán oponibles al deudor y todos los acreedores cuyos créditos fueron incluidos en la negociación, hayan o no asistido a ella. Homologado el acuerdo o el plan de medidas, en su caso, el juez regulará los honorarios”.

"El cumplimiento del acuerdo o del plan de medidas será declarado por resolución emanada del juez que intervino en el proceso de sobreendeudamiento, a instancia del deudor y previa vista al síndico" (art. 12).

Como una nota propia de la iniciativa legal, se destaca el art. 13 que reza: "A todos los efectos de este título, el trámite no podrá durar más de 6 meses. En el caso en que durase más, el juez podrá imponer, previa petición de parte, una multa del $0.5 \%$ del pasivo denunciado por cada día de retardo a la parte culpable. Si fuere algún acreedor, se le descontará de su crédito y se le imputará al capital. Si fuere el deudor, dicho porcentaje generará un crédito a favor de entidades no lucrativas que tengan por fin la promoción de la educación en los pueblos rurales. Y si fuese imputable al síndico, será excluido de la lista de síndicos por el término de dos años".

El trámite del "Restablecimiento Personal" está previsto a partir del art. 14. Dispone la citada preceptiva que "El procedimiento de restablecimiento personal del deudor se sigue únicamente en los estrados del juez interviniente". Allí se prevé que "recibida la opinión del síndico y habiendo dictado la resolución a la que se refiere el artículo 8 de la presente ley, el juez procederá a citar al deudor y a los acreedores denunciados y presentados, en su caso, a los efectos de hacerles saber la apertura del proceso y de que comparezcan ante él a los cinco días de notificada dicha citación. En esta oportunidad el juez, o el funcionario judicial que aquel designe, recibirá la información que los acreedores le faciliten sobre la existencia, monto y cuantía de su crédito, y oirá al deudor sobre las causas que dieron origen a su desnivel económico-financiero. El juez deberá designar un enajenador para que lo asista en las tareas pertinentes, siendo su opinión previa requisito necesario para la elección del método de realización. El juez podrá apartarse de aquella opinión sólo cuando 
por circunstancias excepcionales el método elegido por el enajenador resultare inútil o antieconómico para la realización de los bienes en su caso particular.

El art. 15 se refiere a la enajenación de Bienes: "A los diez días de realizada la citación del artículo 14 de esta ley, el juez ordenará la enajenación de los bienes del deudor, con excepción de los inembargables, los de antieconómica enajenación, la sede de su actividad, los resguardados por leyes especiales, y el inmueble del deudor cuando constituya su única vivienda u hogar. El método de enajenación será el que mejor considere el enajenador luego de los tres días de aceptado el cargo, según las circunstancias especiales de cada caso y sin perjuicio de lo establecido en el último párrafo del artículo 14 de esta ley".

"Efectuadas las enajenaciones correspondientes, se procederá a depositar el producido, luego de haber hecho una reserva para los gastos de enajenación y honorarios de los profesionales del deudor, en el banco de depósitos judiciales a nombre del juez interviniente. Acreditados dichos extremos, el juez procederá a ordenar el pago de los créditos denunciados y presentados. Si luego de haber pagado todas las deudas, honorarios y gastos, existiere algún remanente, dicho producido será entregado inmediatamente al deudor (art. 16).

Conforme el art. 17, "Si del producido de los activos no alcanzare para pagar los créditos contra el deudor, se procederá al prorrateo en el siguiente orden:

1. Se deberán pagar los gastos del proceso y los honorarios del abogado del deudor, del síndico y enajenador;

2. El saldo se dividirá por la cantidad de acreedores denunciados y presentados. En caso de existir créditos con privilegios, se aplicará lo dispuesto en el régimen de privilegios de la ley 24.522 de Concursos y Quiebras y sus modificatorias.

Hechas las divisiones anteriores y pagadas las deudas, el juez dictará una resolución en la que declarará extinguidas todas las deudas que tuviese el deudor, salvo las originadas por créditos alimentarios, reparaciones pecuniarias y multas fijadas judicialmente, no pudiendo ningún acreedor reclamar en el futuro todo o parte de su crédito impago, sean créditos de fecha anteriores a la promoción del proceso".

El art. 22 establece: "Período de inhibición. El deudor no podrá presentar una nueva petición para el sometimiento al régimen de esta ley hasta después de haber 
transcurrido el plazo de tres años contados a partir de la fecha de cumplimiento del acuerdo o plan de medidas, o cierre del proceso de restablecimiento personal o rechazo de solicitud por mala fe del deudor".

Una medida de gran interés es la prevista en el art. 23 del proyecto de ley analizado. Dispone la norma proyectada: "Registro Nacional. Créase un Registro Nacional de Personas Sobreendeudadas, a fin de tomar nota de los procedimientos reglados por la presente ley que tramiten ante los magistrados de cualquier jurisdicción, nacional o provincial, los cuales remitirán a éste dentro de los tres días de conocida la causa la información, como así también las modificaciones relevantes que se produjeran con posterioridad, conforme las especificaciones que requiera la reglamentación".

En el Senado de la Nación ingresó otro proyecto de ley, suscripto por Eugenio J. Artaza, José Manuel Cano, Mario J. Cimadevilla, Luis Carlos Petcoff, Alfredo A. Martínez, Juan Carlos marino, Gerardo R. Morales, Norma B. Morandini, Blanca Monllau y Jaime Linares ${ }^{758}$.

El art. 1 de este proyecto de ley expresa: "El objeto de la presente ley es establecer un procedimiento administrativo y judicial que permita a los usuarios de productos y servicios financieros que se encuentren en situación de insolvencia celebrar un acuerdo de pago con sus acreedores y cumplir así con sus obligaciones pecuniarias pendientes de naturaleza no comercial. Asimismo, busca promover la recuperación de la economía familiar o personal, normalizar su situación financiera, y evitar cualquier situación de exclusión social o laboral persiguiendo el desarrollo de una cultura de acceso al crédito responsable, a través de la información y la educación financiera.

Al definir el ámbito de aplicación subjetivo, el art. 2, dispone: "Quedan comprendidas por la presente ley las personas físicas usuarias de servicios financieros que habiten en el territorio nacional, y los proveedores de dichos productos o servicios que desarrollen su actividad comercial y financiera dentro del país. Lo anterior no obsta a que se consideren dentro del procedimiento aquellas acreencias generadas por la utilización de productos o servicios de carácter internacional como la línea de crédito en moneda extranjera para su disposición en otro país".

\footnotetext{
${ }^{758}$ El citado proyecto de ley ha sido identificado como Expediente S-586/12.
} 
El presupuesto objetivo queda establecido en el art. 3: "Quedan comprendidos en el procedimiento establecido en la presente ley todos los créditos que se hayan originado por causa o título anterior a la solicitud. Están exceptuadas de la aplicación de la presente ley, las deudas alimentarias, los procesos ejecutivos de las mismas y las deudas de carácter empresarial. No obstante lo anterior, respecto de las alimentarias, se tendrá a la vista para efectos de presupuestar los pagos que deberá cumplir el deudor en el acuerdo con sus acreedores".

El art. 4 hace explícitas algunas notas particulares de la propuesta legislativa. Reza la norma aludida: "Esta ley estará basada en los principios de buena fe, simplicidad, transparencia y gratuidad, y los trámites del procedimiento establecido serán regidos por los principios de celeridad, economía, sencillez y oralidad".

El proyecto dedica un título a las obligaciones que deben observar las entidades financieras, teniendo en miras la tutela preventiva. El art. 7 dispone que "Las entidades financieras que oferten créditos deberán proporcionar en forma gratuita al usuario de productos y servicios financieros información detallada sobre el producto ofrecido, en los términos y con los alcances establecidos en la ley de defensa del consumidor $\mathrm{N}^{\mathrm{o}} 24.240$, y otras leyes conexas y supletorias". El art. 8 agrega que "Las entidades financieras deberán dar a conocer al usuario de servicios financieros, por escrito, en forma clara y detallada, el saldo de cancelación total de la deuda a una fecha determinada”. Por su parte, el art. 9 establece: "Las entidades financieras tendrán la obligación de entregar al usuario de servicios financieros una copia del contrato y sus anexos de forma previa a la firma del mismo".

Conforme el art. 10, "la autoridad de aplicación de la presente Ley será la Unidad de Conciliaciones de Sobreendeudamiento (UCS), la cual será creada a tal efecto, dependiente de la máxima autoridad en materia de defensa del consumidor, ejerciendo el control, vigilancia y administración del procedimiento, en el cumplimiento de esta ley y de sus normas reglamentarias"

\footnotetext{
${ }^{759} \mathrm{Al}$ referirse a la autoridad de aplicación, el proyecto dispone en el Art. 11: "La Unidad de Conciliaciones de Sobrendeudamiento estará conformada por un coordinador quien tendrá a su cargo la administración del registro de conciliadores que se crea por la presente en el ámbito de la autoridad de aplicación. Dicho coordinador será responsable del equipo técnico especializado que entenderá en las solicitudes presentadas, y
} 
La propuesta legislativa diseña un procedimiento administrativo cuyo trámite se regula en los arts. 13 a 22 .

Reza el art. 13: "La UCS será la instancia responsable de garantizar a las personas usuarias de productos y servicios financieros un procedimiento simple, breve, gratuito y confidencial".

"La persona insolvente deberá presentar por escrito, personalmente o por medio de una asociación de consumidores, la solicitud de inicio del procedimiento administrativo establecido por la presente ley. En dicho escrito inicial deberá: a) Informar sobre sus datos personales, los motivos de su solicitud, y fijar domicilio en el cual recibirá todas las notificaciones; b) Describir de forma clara y precisa los ingresos, el patrimonio, los gastos mensuales personales y de su familia, en su caso. c) Señalar el mínimo de vida necesario del grupo familiar; d) Señalar los créditos contraídos y otros elementos necesarios y pertinentes que den certeza de su situación económica-financiera; e) Detallar los datos de sus acreedores, con los montos adeudados a cada uno, respectivamente; f) Presentar la documentación que respalde la información proporcionada; La declaración patrimonial indicada en el escrito inicial tendrá carácter de declaración jurada. Recibida la documentación por la UCS, la misma será girada al equipo técnico, el que estudiará y verificará la información proporcionada para determinar la suficiencia de la información proporcionada" (art. 14).

Se prevé que "La UCS notificará al acreedor o acreedores del solicitante sobre la solicitud interpuesta, con la finalidad que realicen en forma escrita sus

coordinará las políticas al efecto". En el art. 12 se consagran las funciones a cumplir: "Funciones de la Unidad de Conciliaciones de Sobrendeudamiento: serán funciones de la UCS: a) Garantizar a los usuarios de productos y servicios financieros o crediticios que se encuentren en una situación de sobreendeudamiento, un procedimiento simple, breve, confidencial y gratuito. b) Elaborar los planes de saneamiento económico para cada caso. c) Conformar y administrar el Registro de Conciliadores. d) Regular, impulsar y desarrollar el proceso administrativo estipulado por la presente ley. e) Dar inicio al procedimiento judicial remitiendo las actuaciones administrativas, en los casos en los que en éstas haya fracasado la conciliación. f) Autorizar a los usuarios de servicios financieros que se acojan al procedimiento establecido por esta ley a la adquisición de nuevos préstamos y créditos de acuerdo a las particularidades de cada caso. g) Crear y diseñar programas de educación financiera y administración personal de las finanzas; que incluyan campañas en los diferentes medios de comunicación". 
presentaciones, dentro del plazo de tres días siguientes al de la notificación" (art. 15) y que "Vencido el plazo indicado en el artículo 15, el equipo técnico evaluará el caso, a efectos de lograr una adecuada apreciación de la situación económica y financiera del solicitante. Durante el plazo de evaluación, las partes podrán presentar los elementos probatorios que estimen pertinentes o que sean solicitados por el equipo técnico. El equipo técnico deberá resolver la procedencia de la petición o el archivo de la misma, decisión que deberá ser notificada a las partes. La decisión de archivar la solicitud deberá ser fundada" (art. 16).

Conforme el art. 17, "El dictamen técnico que declare la procedencia de la solicitud deberá contener el plan de saneamiento económico, el cual será presentado a las partes en la audiencia de conciliación. El plan de saneamiento económico tendrá los siguientes objetivos con respecto a la persona deudora: a) Recuperar su economía familiar; b) Restablecer su situación financiera; c) Garantizar su subsistencia y de las personas que dependan económicamente de ella a través de un monto mínimo existencial de vida colegido de los ingresos familiares; d) Evitarle cualquier situación de exclusión social e inestabilidad psicológica".

"Iniciado el procedimiento, se suspenderá cualquier causa judicial o extrajudicial existente o de acción posterior que pueda afectar el patrimonio del deudor o de sus codeudores solidarios. Asimismo, iniciado el procedimiento el solicitante no podrá asumir nuevos préstamos u obligarse con cualquier tipo de carga que afecte su patrimonio, bajo apercibimiento de ordenarse el inmediato archivo del expediente, salvo que exista autorización previa de la UCS, la que será concedida sólo si el solicitante logra justificar su proceder de forma suficiente y válida ante ella. Las entidades especializadas en información crediticia deberán suspender el acceso y el intercambio de la información personal y crediticia del solicitante de forma inmediata al momento de recibir la notificación correspondiente por parte de la UCS. En caso que se constatare que las entidades especializadas en información crediticia han incumplido con lo establecido en el anterior inciso, serán pasibles de una sanción” (art. 18).

Conforme el art. 19, "El coordinador de la UCS deberá designar un conciliador del Registro de Conciliadores, quien estará a cargo de la audiencia a celebrarse. El referido dictamen técnico y cualquier decisión adoptada por el equipo técnico de insolvencia deberán ser fundamentados o motivados". 
"La UCS citará al solicitante y al acreedor o acreedores, a efecto de celebrar la audiencia de conciliación. La audiencia se celebrará con las partes que concurran a la misma, y en ella se debatirá el contenido del dictamen técnico. Las partes podrán realizar durante la audiencia las aclaraciones y observaciones que consideren necesarias y proponer soluciones alternas. El conciliador tratará de acercar posiciones, siempre asegurando la consecución de los objetivos preceptuados del plan de saneamiento económico elaborado, y asegurando siempre el mínimo de vida. Si de la audiencia surgiera un acuerdo entre las partes, el mismo será volcado en un acta, la que contendrá los términos del acuerdo al que se ha arribado, y será suscripta por las partes presentes en la audiencia y por el conciliador. La misma será, posteriormente, refrendada y homologada por el coordinador de la UCS. La certificación del acta, expedida por la UCS en la cual conste el acuerdo conciliatorio producirá los efectos de una transacción y sólo tendrá fuerza ejecutiva cuando así lo declare un juez" (art. 20).

Dispone el art. 21 que "La UCS, en base al informe del equipo técnico, resolverá si la persona deudora deberá inscribirse en los programas de educación financiera que dicte en las oficinas creadas para tal fin en el ámbito de la autoridad de aplicación de la presente ley".

Se prevé que "Cuando en el procedimiento administrativo no se lograse un acuerdo conciliatorio, o en el caso de que no fuere exitosa la conciliación con uno o más acreedores, la persona usuaria de servicios financieros podrá requerir la intervención del juez competente, a los efectos de que éste establezca un plan de saneamiento económico del deudor" (art. 23).

El trámite del procedimiento judicial se regula en los arts. 24 a 39.

Conforme el art. 24, "El solicitante realizará su petición ante la UCS, la que deberá remitir el expediente administrativo al juzgado competente de turno. El Estado deberá garantizar un sistema de asistencia técnica gratuita, que garantice la ayuda contable, jurídica y financiera a los deudores que requieran de aquella. El procedimiento judicial establecido por esta ley será gratuito para el deudor".

"Recibido el expediente administrativo, el juez competente citará al deudor para que ratifique la solicitud. Dicha ratificación tendrá el valor de juramento legal para todos lo efectos. Al ser admitida la demanda, ésta suspenderá todos los plazos procesales de las 
causas judiciales que se hubieran incoado contra el deudor, al igual que el curso de los intereses legales y moratorios que corrieran en perjuicio de aquel, declarándose de igual forma la indisponibilidad patrimonial del mismo. Admitida la demanda, el juez ratificará la suspensión del acceso e intercambio de la información personal y crediticia relacionada al deudor por parte de las entidades administradoras de registro de historial o de información de crédito" (art. 25).

Dispone el art. 26 que "el juez ordenará la notificación del acreedor o los acreedores, los que podrán exponer sus observaciones, dentro del plazo de cinco (5) días. Asimismo dispondrá que se fije un edicto o anotación judicial por cinco (5) días en los estrados del juzgado, conteniendo un extracto del auto que admitió el expediente, emplazando a todas las personas o instituciones que tengan interés en el proceso. Si el juzgado mantuviere una página de Internet deberá colocar en ella la noticia del inicio del expediente, a los mismos fines que los establecidos en el párrafo anterior".

"Vencido el plazo, el juez señalará una fecha y hora para la realización de una audiencia, a la que citará al deudor y a el o los acreedores, los que podrán, hasta ese momento, acercar al expediente todos los documentos probatorios que estuvieren en su poder, y que consideren relevantes para la resolución del mismo" (art. 27).

Se prevé que "El deudor podrá presentar una propuesta de pago, la que será debatida en la audiencia. En la misma, las partes podrán hacer las alegaciones y consideraciones que estimen convenientes. El juez podrá suspender momentáneamente la audiencia por un máximo de tiempo no mayor de dos (2) horas, a fin de que el acreedor o acreedores realicen las verificaciones técnicas que estimen pertinentes" (art. 28).

"El juez podrá hacer todas las consultas que estime pertinentes a fin de arribar un acuerdo entre las partes en relación a la propuesta de pago. Las opiniones del juez en esta etapa procesal no le inhabilitarán para continuar conociendo la causa (art. 29).

Dispone el art. 30 que "En caso de que no sea posible un acuerdo entre el deudor y el acreedor o acreedores, el juez procederá a declarar la conclusión de esta etapa preliminar, pasando de manera inmediata a escuchar los argumentos a favor o en contra del trámite de reestructuración judicial del estado de insolvencia o de deuda". 
"El juez podrá disponer de todos los medios probatorios para alcanzar la verdad en torno de los elementos materiales vinculados a la situación económica o financiera del deudor" (art. 31).

El art. 32 prevé que "analizada toda la situación económica, jurídica, crediticia y financiera del deudor, el juez dictará sentencia, en la que se señalará:

a) El plan de reestructuración de deuda, con el objetivo de restablecer la situación financiera del deudor, permitiéndole la satisfacción de sus deudas, y garantizándole simultáneamente el bienestar de su familia y el mantenimiento de un nivel digno de existencia (monto del mínimo de vida);

b) La suspensión o la extinción de los procesos judiciales en desarrollo;

c) La suspensión de los intereses por mora resultantes;

d) La anotación correspondiente de la situación jurídica que se genere, dentro de los registros de historial crediticio que provean o administren los organismos administradores de esta clase de información; y

e) Toda otra cuestión que estime relevante".

Conforme el art. 33, "el juez en su resolución valorará, entre otras, las siguientes circunstancias con respecto al consumidor deudor: a) La voluntad mostrada para cumplir con sus obligaciones; b) Su historial crediticio antes de la situación de insolvencia; c) La veracidad de lo argumentado; y d) El ejercicio cierto de prácticas de consumo responsable".

"El plan de reestructuración de deuda no podrá establecer para su cumplimiento un plazo superior a los 5 (cinco) años y podrá contener medidas de contemporización o reescalonamiento del pago de las deudas, de remisión de las mismas, de reducción o de supresión de la tasa de interés, de consolidación, de creación o de sustitución de las garantías, entre otras medidas indispensables para adecuar el pasivo a las posibilidades de cumplimiento efectivo del deudor en cuestión. El plan deberá observar la reserva del mínimo existencial, de modo que su ejecución no venga a perjudicar la manutención y existencia económica básica del consumidor y de su familia, o el pago de los gastos corrientes de sobrevivencia, incluidos entre estos los servicios públicos domiciliarios; no siendo secuestrables o embargables los bienes, salarios o fondos que se le asignen al deudor, salvo orden en contrario emitida por el juez. El plan deberá subordinar estas medidas al compromiso asumido por el deudor, que lleven a facilitar o a garantizar el pago 
de sus deudas o compromisos. El juez examinará las condiciones, compromisos, situaciones o elementos impuestos al deudor" (art. 34).

"La sentencia podrá ser apelada con efectos suspensivos" (art. 35).

De conformidad al art.36, "El procedimiento se extinguirá cuando: a) El deudor deje de comparecer, injustificadamente, a cualquiera de las audiencias o etapas del proceso; b) El juez rechazare la admisibilidad del procedimiento, en los términos entendidos en esta ley, por ser inconducente, improcedente o no llenar el cometido y alcance exigido en esta clase de procesos; c) La actuación del deudor genere un fraude procesal, o la alguna motivación dolosa en su accionar, en claro perjuicio de un acreedor o acreedores; La constatación de alguna de las conductas descritas previamente dará lugar, además, a la imposición de multas o sanciones al deudor".

Advierte el art. 37 que "Queda vedado al deudor la obtención del beneficio legal de la reestructuración judicial de deudas, asegurada en esta ley, cuando haya sido beneficiado anteriormente de los efectos de esta regulación en un plazo inferior a los dos (2) años de haber concluido un procedimiento similar. La prohibición del párrafo anterior no se considerará si comprobadamente dejare de pagar o de cumplir con los acuerdos o sentencia emitidos en el contexto de este procedimiento, por causas estrictamente comprobadas de caso fortuito o fuerza mayor, declarado así por el juez interviniente".

A tenor del art. 38, "la inconducta del deudor generará el vencimiento anticipado de las deudas contempladas en el acuerdo, sentencia ejecutoriada o plan de reestructuración de deudas. Serán causales de inconducta: a) Presentar declaraciones falsas o producir documentos inexactos con el objetivo de utilizar los beneficios del procedimiento fijado en esta ley; b) Disimular o desviar, o intentar disimular o desviar la totalidad o una parte de sus bienes con idéntico objetivo; c) Agravar su situación de endeudamiento mediante la obtención de nuevos préstamos o practicar actos de disposición de su patrimonio no avalados judicialmente durante el curso del procedimiento o durante la ejecución del plan o del acuerdo resultante de conciliación".

"Se reputa litigante de mala fe el acreedor que presente reclamaciones falsas o exageradas; o incidiese negativamente en la ejecución reiterada de actos dilatorios tendientes a la generación o aumento de la mora existente en el proceso de resolución final 
de esta clase de trámites judiciales. Dicha conducta judicialmente comprobada por parte del juez llevará a la imposición inmediata de sanciones o multas para dicho acreedor" (art. 39).

Resulta de interés, la previsión contenida en el art. 40 conforme la cual "Se creará un Fondo Estatal para Resolución de Insolvencias que estará formado por las multas civiles y administrativas que impongan los jueces o la administración, que conozcan de las infracciones generadas durante el trámite de estos procesos, ya sea en su instancia administrativa o jurisdiccional. Dicho fondo será administrado por la autoridad de aplicación de la presente ley".

El proyecto dedica una norma particular a la prevención del fenómeno, de gran relevancia. El art. 41 dispone: "El Estado propiciará el establecimiento de programas educativos destinados a la capacitación de la población en aspectos relacionados con los servicios financieros. Dichos programas abarcarán la enseñanza primaria y media. También se establecerán programas de educación financiera para aquellos consumidores que, voluntariamente, quieran capacitarse en la materia, los que serán obligatorios para todos aquellos que hayan solicitado la intervención administrativa o judicial que establece la presente ley".

Lamentablemente, todas estas iniciativas han perdido estado parlamentario, debido al tiempo transcurrido sin registrar avances en el trámite legislativo. De ello se sigue que ninguna de las propuestas de regulación -ni las que proponían el dictado de una ley especial ni las que impulsaban una reforma a la ley de concursos y quiebras- ha llegado al debate en el Congreso Nacional, como para avizorar la tensión entre el consenso y los disensos.

La problemática del sobreendeudamiento del consumidor está en la agenda política y desde el Ministerio de Justicia de la Nación, que un anteproyecto de ley que propone la regulación del tema y el diseño de un procedimiento especial en la ley concursal ${ }^{760}$. La

${ }^{760}$ Por Resolución N ${ }^{\circ} 1163$ del Ministerio de Justicia de la Nación de fecha 22 de mayo de 2015, se creó la Comisión de Reforma de la Ley 24.522 (art. 1) encomendándole la adecuación del régimen concursal aplicable a los "pequeños procesos" y proveer la necesaria reforma a la ley de concursos y quiebras N²4.522 a fin de incorporar el sobreendeudamiento del consumidor y la microempresa" (art. 2). A tal fin, se impuso a la Comisión un plazo de treinta días corridos a partir de la fecha de su constitución para elevar un anteproyecto (art. 3), integrándose la misma con los juristas Héctor Osvaldo CHOMER, Daniel Roque VíTOLO, Juan Carlos VeIgA, Francisco JunYent BAS, Alejandra Noemí TÉvEZ, Emiliano GARCía CuERva y Marcelo 
iniciativa contempla su presentación en el Congreso Nacional para su debate y aprobación en el año en curso.

Lamentamos que el mandato sea reformar el régimen de insolvencia y no el dictado de una ley especial que regule la problemática de modo integral y sistemático; y que el objetivo sea el saneamiento de una situación de sobreendeudamiento ya consumado y no la prevención del fenómeno. Pero alentamos el avance. Confiamos en que el proyecto ofrezca remedios eficaces para superar el endeudamiento excesivo del consumidor y permitir la recuperación del deudor y su grupo familiar.

El Anteproyecto, propone, por un lado, reformar el capítulo de los denominados "De los pequeños concursos y quiebras" (Capítulo IV de la ley concursal), para adecuarlos a los requerimientos que la doctrina venía formulando desde hace tiempo.

El anteproyecto define la figura en el remozado art. 288: "A los efectos de esta ley se consideran pequeños concursos y quiebras aquellos en los cuales ese presente, en forma indistinta, cualquiera de estas circunstancias: 1) Que el pasivo denunciado no alcance la suma equivalente a cincuenta (50) veces el monto correspondiente a la facturación anual de la categoría i) de prestación de servicios de la inscripción tributaria en el monotríbuto ante la Administración Federal de Ingresos Públicos; 2) Que el deudor no posea una facturación anual bruta superior a cincuenta (50) veces el monto de la facturación anual correspondiente a la categoría i) de prestación de servicios de la inscripción tributaria en el monotributo ante la Administración Federal de Ingresos Públicos; o 3) Que el deudor no posea más de quince (15) trabajadores en relación de dependencia”.

Dedica a estos pequeños concursos y quiebras un régimen particular que mejora, en nuestra modesta opinión, el trámite originario. Al establecimiento de las nuevas reglas del procedimiento se destina el art. 289 que dispone: "En los presentes procesos: 1) No serán necesarios los dictámenes previstos en el artículo 11, inciso 3 y 5; 2) No se constituirán los comités de acreedores, ni el comité de control; 3) No regirá el régimen de supuestos especiales previstos en los artículos 48 y 48 bis; 4) El contralor del cumplimiento del acuerdo estará a cargo del sindico y los honorarios por su labor en esta etapa serán del 1\%

Eduardo HAISSINER (art. 4). La Comisión presentó en el tiempo señalado el Anteproyecto de ley elaborado al Ministerio de Justicia que, según entendemos, lo derivó a la Secretaría Legal y Técnica de la Presidencia de la Nación para su consideración, donde se encuentra a la fecha. 
(uno por ciento) de lo pagado a los acreedores; 5) El plazo fijado en el art. 13 será de tres (3) días; 6) La publicación de edictos fijada en los art. 27 y 28 se dispondrá y efectuará sólo en el diario de publicaciones oficiales y por el plazo de dos (2) días; 7) $\quad$ La fecha prevista en el art. 14, inc. 3) se establecerá entre diez (10) y quince (15) días; 8) No se fijará ni se llevará a cabo la audiencia informativa prevista en los art. 14 inc. 10 y 45; 9) El plazo previsto en el art. 34 se fija en tres (3) días; y el plazo previsto en el art. 35, párrafo $1^{\circ}$, se fija en diez (10) días; 10) El plazo previsto en el art. 36, se fija en tres (3) días; 11) El plazo fijado en el art. 41 se fija en tres (3) días; 12) El plazo fijado en el art. 39, se fija en tres (3) días; 13) Los plazos fijados en el art. 43 párrafo $1^{\circ}$, se fijan en sesenta (60) días y quince (15 días), respectivamente; 14) El plazo fijado en el art. 40 se fija en tres (3) días; 15) El plazo fijado en el art. 42 se fija en tres (3) días".

Para el supuesto de acuerdo, el art. 290 prevé: "Finalizado el período de exclusividad, el juez, deberá dictar resolución declarando la existencia o inexistencia del cuerdo. Si no se hubieran logrado las mayorías de ley, el juez igualmente puede declarar la existencia del acuerdo siempre que resulte reunida la totalidad de los siguientes requisitos: 1) La conformidad de por lo menos el cincuenta y cinco por ciento (55\%) del capital quirografario; 2) Que no se haya efectuado discriminación alguna en contra de los acreedores disidentes; 3) Que el pago resultante del acuerdo impuesto equivalga a un dividendo no menor al que eventualmente obtendrían en la quiebra los acreedores disidentes teniendo en cuenta el valor del activo realizable conforme a lo señalado por el síndico en el informe general"

El art. 300 contempla la mediación previa a la declaración de quiebra y dispone: "Declarada la inexistencia del acuerdo, o denegada que fuera la homologación del acuerdo existente, el juez, antes de declarar la quiebra del deudor, dispondrá abrir una etapa de mediación obligatoria por un término de noventa (90) días entre los acreedores verificados y declarados admisibles y el deudor, con el objeto de intentar superar las diferencias existentes y obtener un acuerdo. En esta etapa intervendrá un mediador habilitado, y el plazo comenzará a contarse a partir del momento en que el mediador designado acepte el cargo. 
El trámite posterior está previsto en el art. 301 que establece: "Obtenido que fuera el acuerdo en el procedimiento de mediación previsto en el artículo 300, se aplicará el artículo 290 en lo pertinente o se homologará el acuerdo, según sea el caso".

El art. 302 está destinado al trámite de la quiebra: "Declarada la quiebra, la liquidación se realizará conforme a las normas previstas en la presente ley pudiendo el juez, en función de la relevancia de los bienes a ser realizados, disponer según su criterio las vías más idóneas para el mejor resultado del proceso liquidatorio". Por su parte, el art. 303 prevé la necesidad de despachar medidas tales como la suspensión de remates y medidas precautorias para supuestos particulares que así lo imponen. Reza el citado precepto: "En caso de necesidad y urgencia evidentes para el concurso, y con el criterio del artículo 16, párrafo final, el juez puede ordenar la suspensión temporaria de la subasta y de las medidas precautorias que impidan el uso por, el deudor, de la cosa gravada en la ejecución judicial o extrajudicial de créditos con garantía prendaria o hipotecaria. Los servicios de intereses posteriores a la suspensión son pagados, como los gastos del concurso, si resultare insuficiente el producido del bien gravado. Esta suspensión no puede exceder de ciento ochenta días (180). Sin perjuicio de ello, el juez deberá convocar a una audiencia con propósitos conciliatorios al deudor, el acreedor ejecutante, y al síndico con veinte (20) días de anticipación al vencimiento del plazo por el cual se dispuso la suspensión. Las ejecuciones suspendida no podrán reanudarse sin la previa celebración de esta audiencia, salvo que la misma hubiere fracasado por ausencia del deudor. La resolución es apelable al solo efecto devolutivo por el acreedor, el deudor y el síndico”.

La gran novedad de la reforma impulsada en este Anteproyecto, es la incorporación del Capítulo V, dedicado al "Concurso de las personas humanas que no realizan actividad económica organizada y otros sujetos".

El art. 304 define el presupuesto objetivo: "Es presupuesto para la apertura del proceso regulado en el presente capítulo que el sujeto peticionante se encuentre: 1) En estado de cesación de pagos; 2) En dificultades económicas o financieras de carácter general; o 3) Sobreendeudado.

A efectos de este artículo se entenderá por sujeto sobre endeudado a aquel que presente, en su patrimonio, un desequilibrio significativo entre su activo ejecutable y las obligaciones por las cuales dicho activo deba responder". 
Por su parte, el art. 305 precisa quiénes son los destinatarios de esta regulación particular, tomando posición respecto del presupuesto subjetivo, siempre controvertido. Establece la norma citada que "Pueden acceder voluntariamente al procedimiento previsto en este Capítulo las personas humanas que: 1) No realicen una actividad económica organizada ni resulten titulares de una empresa o establecimiento comercial, industrial, agropecuario o de servicios; 2) Realicen una actividad como empleados públicos o privados en relación de dependencia; 3) Ejerzan una profesión liberal no organizada bajo forma de empresa; 4) Realicen una actividad autónoma e independiente no organizada bajo la forma de empresa. La circunstancia de que dichas personas humanas se encuentren inscriptas como empleadores y tengan personal en relación de dependencia en número no mayor a tres (3) trabajadores, no obstará a su inclusión dentro del régimen regulado por el presente capítulo".

El art. 306 define el juez competente, al disponer que "Corresponde intervenir en el presente procedimiento al juez con competencia ordinaria del lugar del domicilio del deudor, entendiendo por tal al lugar de residencia habitual o donde desempeña su actividad profesional, en los términos de los arts. 73 y 76 del Código Civil y Comercial de la Nación”.

En orden a la legitimación activa, el art. 307 establece que "El procedimiento podrá ser solicitado exclusivamente por el deudor, o por apoderado con facultad especial, mientras no haya sido declarado en quiebra. Declarada la quiebra, el deudor podrá hacer uso de la facultad prevista en el art. 90, con el objeto de convertir el trámite en el procedimiento previsto en el presente Capítulo, en el mismo plazo, y con los efectos y alcances fijados en el art. 91”. Por su parte, los requisitos de la solicitud de inicio del trámite están previstos en el art. 308: "Son requisitos formales de la petición de apertura del procedimiento previsto en el presente Capítulo: 1) Suministrar al Juez los datos completos de identificación del deudor, incluyendo su nombre, copia del documento nacional de identidad, fecha y lugar de nacimiento, domicilio, estado civil, actividad o profesión y dirección de correo electrónico, éste último si lo tuviese. 2) Explicar las causas concretas de su situación patrimonial con expresión de la época en que se produjo la situación de sobre endeudamiento, las dificultades económicas o financieras de carácter general o el estado de cesación de pagos - según sea el caso - e identificar y señalar los hechos por los cuales 
alguna de estas circunstancias se hubieran manifestado. 3) Acompañar, con carácter de declaración jurada, un estado detallado y valorado del activo y pasivo actualizado a la fecha de prese4ntación, con indicación precisa de su composición, los criterios seguidos para su valuación, la ubicación, estado y gravámenes de los bienes y demás datos necesarios para conocer debidamente el patrimonio y la documentación contable que se llevare voluntariamente.

4) Acompañar, con carácter de declaración jurada, la nómina de acreedores, con indicación de sus domicilio, sus direcciones de correo electrónico, montos de los créditos, causas, vencimientos, codeudores, fiadores o terceros obligados o responsables y privilegios, con copia de la documentación sustentatoria de la deuda denunciada, que tuviera en su poder. Debe agregar, en su declaración, el detalle de los procesos judiciales o administrativos de carácter patrimonial en trámite o con condena no cumplida, precisando su radicación. 5)

Denunciar la existencia de proceso concursal anterior y justificar, en su caso, que no se encuentra dentro del periodo de inhibición que establece el artículo 59, o el desistimiento del concurso si lo hubiere habido. 6) Acompañar nómina de empleados, si los tuviere, con detalle de domicilio, categoría, antigüedad y última remuneración recibida. Deberá acompañarse también declaración sobre la existencia de deuda laboral y de deuda con los organismos de la seguridad social. 7) Acompañar certificado de su inscripción ante la autoridad tributaria, en caso de existir. El escrito y la documentación agregada deben acompañarse con dos (2) copias firmadas. Cuando el deudor lo requiera, o en su caso el juez lo estime necesario, ponderando los requisitos legales con un criterio de razonabilidad, según las circunstancias del deudor, se podrá otorgar un plazo de diez días desde la presentación, para completar la información que se estime necesaria para habilitar el procedimiento pudiendo dispensarse del cumplimiento de algún requisito que el juez no considere pertinente".

Respecto del domicilio procesal y a fin de imprimir celeridad al trámite, establece el art. 309: "Se aplica la norma contenida en el art. 12 en lo pertinente. El presentante deberá constituir domicilio electrónico y denunciar un teléfono de contacto en los que el conciliador pueda efectuar válidamente las comunicaciones necesarias".

El plazo para resolver la suerte de la petición y los motivos de su eventual rechazo están contemplados en el art. 310, conforme al cual "presentado el pedido o, en su caso, 
vencido el plazo que acuerde el juez, conforme el art. 308, último párrafo, éste se debe pronunciar dentro del término fijado en el art. 13. Puede rechazar la petición, cuando el deudor: 1) No sea sujeto susceptible de acceder al procedimiento regulado en el presente capítulo; 2) Si no se ha dado cumplimiento al artículo 308; 3) Si se encuentra dentro del período de inhibición que establecen los artículos 59 y 314, o 4) Cuando la causa no sea de su competencia. La resolución es apelable”.

La resolución de apertura, su contenido y las diligencias a cumplir con motivo del inicio de la misma se regulan en el art. 311, de gran relevancia, que dispone: "Cumplidos en debido tiempo los requisitos legales, el juez debe dictar resolución que disponga: 1) La declaración de apertura del procedimiento, identificando al deudor. 2) La designación de un conciliador de la lista para que intervenga en el procedimiento. Los conciliadores sólo podrán ser abogados o contadores. Se aplicará el art. 253 a los efectos de la inscripción, selección y designación y, en cuanto sea pertinente, , rigen los arts. 255, 256 y 258. 3) La orden de publicar edictos durante dos (2) días en el diario de publicaciones legales de la jurisdicción del juzgado, los que deberán contener los datos referentes a la identificación del deudor, los del juicio y su radicación ; el nombre y domicilio del conciliador, y la citación a los acreedores para que formulen sus pedidos de verificación de sus créditos ante el conciliador dentro de los diez (10) días de la fecha de publicación del último edicto observando las disposiciones contenidas en el art. 32. 4) La inhibición general para disponer y gravar bienes registrables del deudor, la que será anotada en los registros pertinentes. La publicación de edictos será gratuita; debiendo llevarse a cabo dentro de los cinco (5) días desde la aceptación del cargo del conciliador, y su diligenciamiento estará a cargo del deudor".

El art. 312 está dedicado a los efectos de la apertura del procedimiento. Dispone la norma que "La apertura del procedimiento produce los siguientes efectos: 1) La suspensión por noventa (90) días de todos los juicios de contenido patrimonial por causa o título anterior a su presentación, no pudiendo deducirse nuevas acciones con fundamento en tales causas o títulos, incluidas la ejecución de créditos prendarios y/o hipotecarios y desalojos de la vivienda particular del deudor o del lugar donde lleva a cabo su labor profesional. Los expedientes permanecerán en los Juzgados originariamente asignados y los acreedores deberán acreditar su condición con copia certificada a presentar ante el conciliador, cuando 
sean convocados a los efectos de su reconocimiento. 2) La suspensión de los intereses de los créditos del deudor, con excepción de los créditos garantizados con garantís reales que prosiguen en le medida que alcance el asiento del crédito. 3) Quedan sin efecto todas las medidas cautelares trabadas sobre los bienes y honorarios del deudor, y en especial, los embargos sobre los sueldos, salarios. 4) El conciliador tiene las facultades de contralor de la situación patrimonial del deudor, aplicándose el régimen establecido por los art. 15 y 16 de la presente ley, a cuyo fin el juez puede autorizar para tutela personal del deudor y de su familia el pago de las cuotas correspondientes a las coberturas de salud de obras sociales o empresas de medicina prepaga. 5) La apertura de la etapa de conciliación, la cual se extenderá por noventa (90) días desde la última publicación de edictos, en el cual el conciliador tendrá por misión promover y facilitar acuerdos entre el deudor y sus acreedores".

El art. 313 deja expresa constancia de las facultades que conserva el deudor, al establecer que "La apertura del proceso no afecta la legitimación del deudor, el que conserva sus facultades para desempeñar tareas artesanales, profesionales o en relación de dependencia, debiendo aplicarse la obligación de residencia reglada en el art. 25".

A fin de comprometer al particular afectado con el trámite del procedimiento abierto a instancias suyas, el art. 314, dispone: "El desistimiento del procedimiento solo se produce si el deudor no cumple con la publicación de edictos pero el plazo de inhibición previsto en el art. 31 último párrafo, se reduce a seis (6) meses".

De gran interés, resulta la previsión de un período de conciliación en el art. 315: "El período de conciliación se extenderá por noventa (90) días desde la última publicación de edictos, etapa durante la cual el conciliador tendrá por misión determinar provisionalmente el pasivo y facilitar acuerdos entre el deudor y sus acreedores. Durante el período de conciliación se llevarán a cabo las siguientes gestiones: 1) El funcionario designado recibirá la documentación que le presenten los acreedores y corroborará la denuncia del deudor, a los fines de procurar celebrar acuerdos, para la satisfacción de las obligaciones pendientes de cumplimiento. 2) Los acreedores tendrán un plazo de diez (10) días desde la última publicación de edictos para presentarse ante el conciliador a solicitar la verificación de sus créditos. 3) Vencido dicho plazo y en igual término, el conciliador deberá informar al juez la nómina detallada de los acreedores cuya verificación o admisibilidad recomienda, como 
así también de las eventuales exclusiones acompañando la documentación pertinente en sus respectivos legajos.

4) El juez en el plazo de diez (10) días, deberá dictar la sentencia de verificación, con los efectos del art. 36 último párrafo. 5) El funcionario promoverá el proceso conciliatorio y podrá celebrar tantas audiencias como considere necesarias, convocando a ellas al deudor y a los acreedores. 6) La etapa concluye por el vencimiento del plazo o cuando se obtuviere la conformidad de acreedores que representen la mayoría absoluta del capital verificado y declarado admisible, rigiendo el régimen de exclusiones del artículo 45. 7) En caso de no lograrse acuerdo, el conciliador propondrá una fórmula de repago y o cualquier otra solución que estime conveniente ante el Juez".

La forma y contenido del acuerdo al que pudiera arribarse están regulados en el art. 316, que dispone: "La forma y contenido del o de los acuerdos quedan sometidos a las siguientes reglas: 1) Se aplica el art. 70 en cuanto el o los acuerdos deben ser otorgados por instrumento firmado por el conciliador debiendo los documento habilitantes de la representación de los acreedores estar debidamente certificados por escribano público o mediante poder otorgado ante el Secretario del Juzgado. 2)Los acuerdos podrán habilitar diversas categorías y ser diferentes respecto de cada acreedor pudiendo pactarse quitas y esperas sin límite temporal, ni cuantitativo, y toda otra fórmula que obtenga la conformidad de los acreedores. 3) Dentro de los dos (2) días de vencido el plazo de conciliación, el conciliador informará al juez sobre los acuerdos, presentándole los convenios a los que se hubiera arribado, con expresa indicación del porcentaje de acreedores y capital de créditos que hubieran conciliado".

La impugnación del acuerdo es una contingencia prevista en el art. 317, que establece: "Presentado los acuerdos en el expediente, el juez hará saber de su existencia mediante resolución que se notificará por ministerio de la ley, momento a partir del cual correrá el plazo previsto en el art. 50 de la ley a los fines de dar cumplimiento a la etapa impugnativa".

La resolución vinculada al acuerdo y su eventual impugnación es motivo de regulación en el art. 318 que dispone: "Una vez vencido el plazo previsto en el artículo anterior, ya sea que exista acuerdo entre el deudor y los acreedores o propuesta del conciliador o que se hayan realizado impugnaciones, el juez procederá a realizar el control 
de legalidad formal y sustancial de los acuerdos, respetando el principio de buena fe y evitando el abuso del derecho en el convenio, previa intervención del Ministerio Público Fiscal. A tal efecto, el juez podrá: 1) Analizar las impugnaciones que pudieran existir, y en su caso, habilitar un nuevo período conciliatorio por treinta (30) días a cuyo fin dará nueva intervención al conciliador, para que intente la superación de los planteos realizados por los acreedores; 2) Homologar el acuerdo en caso que lo estime ajustado a derecho 3) En el supuesto que no se alcanzara acuerdo alguno, podrá imponer un plan de reorganización que considere razonable, valorando la naturaleza de créditos, origen, el contexto social y familiar del deudor y su conducta, tanto antes como durante el proceso. 4) En todos los casos, el juez tiene facultades para integrar el acuerdo, mediante resolución fundada, aumentando o reduciendo plazos y adecuando los montos de las cuotas pactadas, en tanto considere pertinente a fin de asegurar el cumplimiento de lo acordado sin afectar subsistencia decorosa del deudor y la de su familia. El acuerdo tiene los efectos consignados en la Sección III del Capítulo V”.

El art. 319 está dedica a la problemática de los acreedores no admitidos. Establece la norma que "Los acreedores y el deudor, en su caso, podrán presentarse al juez en un plazo de diez (10) días a fin de solicitar la revisión de la declaración de admisibilidad o inadmisibilidad de los créditos dispuesta por el juez. A esos fines, en el plazo de cinco (5) días el juez designará una audiencia, la que se llevará a cabo con la participación del conciliador, el acreedor y el deudor y donde se receptará toda la prueba ofrecida, oportunidad en la que invitará a las partes a conciliar.

La audiencia será pública y el procedimiento oral. La prueba será producida en la misma audiencia y, sólo en casos excepcionales, el juez podrá fijar una nueva audiencia para producir la prueba pendiente, la que deberá celebrarse en un pazo máximo e improrrogable de diez (10) días.

Una vez concluido el procedimiento, el tribunal resolverá la incidencia en el plazo de cinco (5) días. Los acreedores que no se hubieren presentado tempestivamente tendrán la posibilidad de formular su pedido de verificación tardía hasta la conclusión del período conciliatorio, el que tramitará según el procedimiento pautado en el párrafo precedente. La resolución que admita al acreedor y su crédito deberá además indicar como, cuanto y cuándo deberá el deudor pagar el monto admitido. Firme la decisión que desestima la 
pretensión del acreedor, o transcurrido el plazo previsto en el párrafo quinto, el crédito pierde toda exigibilidad. Ambas decisiones son apelables".

El cumplimiento del acuerdo, por una parte, y las vicisitudes que puedan afectarlo, por otra, están previstos en el art. 320. Allí se deja establecido que "una vez ejecutado el acuerdo el deudor podrá peticionar se declare su cumplimiento y el levantamiento de la inhibición originariamente trabada. Cuando el deudor no cumpla el acuerdo total o parcialmente, a instancia de acreedor interesado, el juez podrá derivar el conflicto al conciliador, a fin de que se intente una nueva negociación conclusiva del asunto. Tal período especia de renegociación no podrá extenderse más de sesenta (60) días desde el requerimiento del acreedor, pero este mecanismo podrá reiterarse en la medida que el juez lo estime razonable".

En el art. 321 se advierte que "el deudor no podrá presentar una nueva petición para el sometimiento al régimen de este capítulo, hasta después de haber transcurrido 1(un) año, contando a partir de la fecha de cumplimiento del acuerdo o del plan de reorganización impuesto por el tribunal, o de la clausura del proceso liquidatorio".

La liquidación de los bienes del deudor ante la frustración de la conciliación es regulada en el art. 322. La norma dispone que "en caso de que la conciliación fracasará, ante la imposibilidad de cumplir cualquier medida de saneamiento, el juez mediante resolución fundada abrirá el proceso liquidatorio, disponiendo la realización de los bienes parte del enajenador que designe, habilitando las vías más idóneas para el mejor resultado del proceso liquidatorio y el restablecimiento del deudor. Asimismo, ordenará la conciliador que presente el informe general que prevé el art. 324”. Por su parte, el art. 323 establece que "la apertura del proceso liquidatorio implica el desapoderamiento de los bienes del deudor existentes a la fecha de la resolución del juez, sin perjuicio de lo cual, el deudor conserva facultades y legitimación para desempeñar tareas artesanales, profesionales o en relación de dependencia". El art. 324 prevé que "el conciliador deberá presentar en el plazo de treinta (30) días de iniciada la liquidación un informe general con el contenido del art. 39 en lo que fuere pertinente, en especial los incisos 1, 2, 3, 6 y 8. Además, deberá pronunciarse sobre la eventual procedencia de eventuales acciones de responsabilidad patrimonial”. 
De conformidad al art. 326, "una vez efectuadas las realizaciones e ingresados los fondos, el conciliador deberá presentar el informe final sobre el producido de los bienes y el respectivo proyecto de distribución. A esos fines se seguirá el siguiente procedimiento: 1) Una vez presentado en el expediente el informe final y el proyecto de distribución, quedarán a disposición de los acreedores por un plazo de cinco (5) días para que éstos formulen las observaciones pertinentes 2) El proyecto deberá contener una reserva para la regulación de honorarios del conciliador y demás funcionarios intervinientes, teniendo en cuanta las pautas establecidas en el presente proceso. 3) Una vez resueltas las impugnaciones, el juez resolverá la reformulación del proyecto o su aprobación, y en su caso la correspondiente distribución de fondos. 4) El proyecto de distribución se notificará a casa acreedor a los domicilios electrónicos, o en su defecto, podrá ser consultado en la página de internet correspondiente o en el expediente. 5) Los fondos quedarán disponibles en el banco de depósitos judiciales luego de los cinco (5) días de la última comunicación. 6) Se aplicarán los artículos 228 a 233, en cuanto corresponda".

Sin duda ninguna, la novedad de la regulación propuesta es la recepción del mecanismo de liberación del deudor o descarga de deuda, consagrado en el art. 327.

La norma prevé que "una vez realizados los bienes, si el producido del activo no alcanzare para pagar los créditos se procederá al prorrateo de los fondos debiendo abonarse en primer lugar los gastos de justicia y el saldo entre los acreedores reconocidos, respetando en su caso el régimen de privilegios dispuesto en la presente ley. Una vez distribuido el resultado, el juez dictará una resolución en la que declarará extinguidas todas las deudas que tuviese el deudor vinculadas con el proceso, salvo los gastos de justicia, las obligaciones alimentarias, y los que constituyan créditos originados en daños a la persona humana por daño moral y por daño material derivado de lesiones a la integridad psicofísica, no pudiendo ningún acreedor reclamar en el futuro saldo insoluto alguno. El juez podrá imponer al deudor la realización de cursos dirigidos a la educación para el consumo con la finalidad de orientarlo y prevenir los riesgos que pudieran derivarse del consumo de productos o de la utilización de servicios, como así también ayudarlo a evaluar alternativas y emplear los recursos en forma eficiente, con el objeto de evitar que puedan producirse situaciones futuras que 1 coloquen nuevamente bajo los presupuestos señalados en el art. $304 "$. 
Las normas aplicables a este trámite procesal particular, son precisadas en el art. 328. Allí se deja establecido que "en el presente trámite son aplicables las normas procesales generales contenidas en el art. 273, en lo que sea pertinente, y el juez atendiendo a la debida protección de los intereses de éste procedimiento y el interés general, podrá aplicar las normas que resulten análogas".

La temática de los honorarios de los letrados de las partes y funcionarios intervinientes es tratada en el art. 329, que reza: “La regulación de honorarios del letrado del deudor, de los conciliadores y demás funcionarios se regirá por el presente artículo que tiene carácter de orden público. A esos fines, la regulación de honorarios en la etapa conciliatoria se establecerá entre el 3 y el $6 \%$ del pasivo verificado, y el juez tiene facultades para distribuir los porcentajes que corresponda a cada uno de los profesionales intervinientes. A todo evento, se establece un piso regulatorio de 4 salarios mínimos vitales y móviles. En caso de liquidación judicial, la escala será del 5 al 8\% del activo realizado y/o el pasivo verificado, el que sea mayor, con idéntico piso mínimo. Las costas en el proceso conciliatorio están a cargo del deudor, el que podrá enfrentarlas en cuotas, de conformidad a lo que resuelva el juez al homologar el acuerdo. En el caso de liquidación judicial, al no extinguirse los gastos de justicia, las sumas que queden adeudadas en concepto de honorarios deberán abonarse por el deudor, pudiendo a esos fines solicitar un régimen de cuotas al tribunal, el que previa vista a los funcionarios resolverá en definitiva el modo de pago, pudiendo aplicar el art. 271".

La norma transitoria del art. 330 prevé que "hasta tanto las Cámaras de Apelaciones con competencia concursal formalicen la lista de conciliadores, con abogados o contadores con cinco años de antigüedad en la profesión y donde podrán anotarse también, individualmente quienes integren estudios de la sindicatura categoría "A" y síndicos categoría "B", actuarán en su remplazo los síndicos categoría "B”, que serán desinsaculados por el tribunal en la forma prevista en los artículos 253 y siguientes”.

Conforme el art. 331, "el nuevo régimen de conciliación y liquidación reglado en el presente capítulo comenzará a regir a los sesenta (60) días de su publicación y para las causas que se inicien a partir de dicha fecha”.

El Anteproyecto de reforma a la ley concursal preé la incorporación de un Capítulo VI a la Ley 24.522. Bajo el título "Disposiciones transitorias y complementarias", el art. 
332 dispone que "Dentro del plazo de "TREINTA (30) días contados a partir de la publicación de la presente ley, las Cámaras de Apelaciones con competencia en la materia procederán a la apertura de los registros previstos en los artículos 253, 261 y 262”. Por su parte, el art. 333 prevé que "a partir de la entrada en vigor de la presente ley se aplicarán las normas que en materia de regulación de honorarios ella prevé a los concursos y quiebras en trámite, salvo en lo que se refiere a los honorarios contemplados en el art. 291, inciso 1, de la Ley 19.551".

De particular relevancia es la norma contenida en el art. 347 que a efectos de visibilizar el abordaje sistémico de la problemática, establece que "La presente ley se incorpora como norma complementaria del Código Civil y Comercial de la Nación”.

Como norma de cierre, el art. 335 dispone: "Créase el REGISTRO NACIONAL DE CONCURSOS Y QUIEBRAS a fin de tomar nota de los procedimientos reglados por a presente ley que tramiten ante los magistrados de cualquier jurisdicción, nacional o provincial, los cuales remitirán a éste dentro de los CINCO (5) días de conocida la causa la información, como así también las modificaciones que requiera la reglamentación”. Por vía del art. 336 se faculta al Poder Ejecutivo Nacional a reglamentar el funcionamiento y organización del mencionado Registro. 


\section{CONCLUSIONES:}

1.- Necesidad de una regulación del fenómeno del sobreendeudamiento del consumidor La complejidad de la fenómeno del sobreendeudamiento del consumidor -por la condición de los sujetos involucrados, por la naturaleza de los bienes y derechos involucrados y por el impacto que ese endeudamiento excesivo provoca en su esfera personal y familiar, así como en el regular funcionamiento del mercado- impone la intervención del legislador. Admitimos que la problemática en estudio no se puede gestionar ni resolver con el dictado y la puesta en marcha de un dispositivo legislativo pero es un punto de partida necesario. La ley a dictarse debe ser la traducción de un modelo regulatorio, diseñado para implementar políticas públicas, en coherencia con el sistema general y a la luz de los principios y valores sobre los que el mismo está construido.

\section{2.- Dónde emplazar la regulación}

El emplazamiento de la regulación que propugnamos tiene gran importancia pues el diseño de dispositivos orientados a la prevención y saneamiento del sobreendeudamiento de los consumidores estará inspirado en el paradigma del sistema en el que se inserte. Pero creemos también, que dicho emplazamiento no es dirimente. Lo relevante es elaborar un cortejo de herramientas eficaces, sustanciales y procedimentales, de naturaleza preventiva y reparadora de la situación de sobreendeudamiento. Sea que la regulación reclamada se incorpore al régimen general de insolvencia, a la ley de defensa del consumidor o sea motivo de una ley especial, lo decisivo es dar respuesta eficaz a una problemática de tratamiento impostergable. En nuestra opinión, el dictado de una ley especial resulta apropiado para el abordaje esta temática compleja y de gran dinamismo. Ese emplazamiento facilitaría las modificaciones que fueran necesarias para adecuar las herramientas y los procedimientos cuando su puesta a prueba y evaluación así lo demande. Permite asimismo, el diseño de un capítulo particular dedicado a la prevención del fenómeno con abordaje de aspectos tales como la educación para el consumo en el mercado de crédito, la publicidad, el marketing crediticio y sus técnicas, el control de ciertas prácticas, el deber de información y de asesoramiento, el control de la abusividad 
contractual en la operatoria de crédito, etc., que exceden el objetivo del régimen de insolvencia.

\section{3.- Cómo regular}

3.a.- Ámbito de aplicación de la regulación:

El presupuesto objetivo debe considerarse definido por una situación de grave dificultad para afrontar el cumplimiento de las obligaciones contraídas y en situación de pronta exigibilidad, aunque no necesariamente deudas vencidas. Este criterio permite ampliar el catálogo de hipótesis aprehendidas en la noción de endeudamiento excesivo, ensanchando el campo de aplicación de la regulación. La exigencia del carácter de obligaciones vencidas, restringe injustificadamente la configuración del presupuesto propiciando un agravamiento de la situación del deudor que, de lo contrario, podría reclamar la aplicación de los mecanismos preventivos y de saneamiento previstos en la regulación.

Propugnamos que el modelo regulatorio argentino tenga como destinatario al consumidor persona física. Es quien precisa de un régimen particular de saneamiento -que incluya el reconocimiento de una segunda oportunidad- para superar su situación de sobreendeudamiento excesivo. Sin perjuicio de admitir la necesidad de una reforma del estatuto particular, entendemos que la persona jurídica y el empresario individual, pueden acudir a la regulación concursal vigente y encontrar allí el cauce para superar su situación de impotencia patrimonial. El concepto de consumidor tiene tradición jurídica, proporciona el bagaje conceptual, inspira el paradigma protectorio de la regulación que propiciamos y marca un estándar de tutela. Este criterio permite revalorizar la categoría de los subconsumidores, admitida por todos los ordenamientos, aunque no siempre visualizada con la relevancia que merece.

Al acotar el presupuesto subjetivo al sobreendeudamiento del consumidor persona física con exclusión del empresario individual- se restringe el alegado impacto de las medidas de saneamiento (el encarecimiento del crédito por la previsión generalizada de resguardos antes la eventual insolvencia, por parte de los dadores de crédito).

Concurriendo los presupuestos objetivo y subjetivo, la buena fe del consumidor sobreendeudado debe presumirse. Los beneficios derivados de las medidas de saneamiento reconocidas por el modelo regulatorio resultarán justificado en todos aquellos supuestos en 
los que no pueda formularse un juicio de reproche a la conducta del particular afectado. Acudir al crédito sin asesoramiento, endeudarse en exceso y en condiciones de contratación poco favorables no puede calificarse per se, como carente de la debida diligencia. El merecimiento de la segunda oportunidad estará justificado, en muchos casos, en la lógica de la operatoria de crédito, en las asimetrías que le son propias, en las particularidades del mercado de que se trata, en el juego de balances y en el paradigma protectorio que debe inspirar la solución de los derechos e intereses en tensión.

\section{3.b.- Contenido de la regulación: Principios}

Los dispositivos contenidos en la regulación del sobreendeudamiento de los consumidores deben estar inspirados en la idea de centralidad de la persona humana y en la llamada ética de los vulnerables, tal como se recogen en la reciente unificación del Derecho privado argentino (Código Civil y Comercial vignte desde el 1 de agosto de 2015). Al sistema general habrá de integrarse en diálogo con las demás fuentes, participando de sus principios y valores.

La prevención y el saneamiento del sobreendeudamiento deben estar también inspirados en la tutela de la confianza. Por una parte, el quiebre de este valor importa la minar las bases de la operatoria de crédito y el sustrato de la relación proveedor-consumidor, imponiéndose neutralizar este riesgo por razones de mercado y por razones humanitarias. Por otro lado, la distribución del coste de la insolvencia será una manifestación más de la responsabilidad que pueda corresponder al dador de crédito en tanto no se trata de un riesgo ajeno a la actividad y donde la confianza depositada en el sistema y en sus operadores, ocupa un lugar central como factor de imputación.

El principio de préstamo responsable debe tener consagración expresa en la regulación a dictarse, mediante la imposición de deberes en cabeza de las entidades de crédito. El deber de indagar acerca de las necesidades concretas del tomador del crédito y su capacidad de reembolso, de asesorar adecuadamente la toma del empréstito, de evaluar la solvencia patrimonial, de informar el resultado de esa evaluación al interesado y de decidir con responsabilidad el otorgamiento o la denegatoria, serán de cumplimiento necesario. No debe consentirse la externalización del coste de la insolvencia, que hace del riesgo individual, un riesgo sistémico. Por otra parte, sólo haciendo al acreedor parcialmente 
responsable del sobreendeudamiento del consumidor, se le incentivará a prácticas serias, implicadas con los sujetos afectados.

\section{4.- Medidas preventivas del sobreendeudamiento del consumidor}

4.a.- Sin perjuicio de distinguir objetivos y herramientas para alcanzarlos, la regulación integral de la problemática impone no excluir situaciones de endeudamiento excesivo en función de las causas que las generan. El resguardo de las buenas prácticas en el mercado es de interés prioritario y las desviaciones que se detecten en el comportamiento o actividad de cualquiera de los actores (proveedores y consumidores) debe ser objeto de análisis y abordaje. El criterio de clasificación binario del endeudamiento -activo y pasivo- simplifica el esquema causal sin reparar en que el consumidor cae, con mucha frecuencia, en esa situación de exceso de deuda por una retroalimentación entre ambos subtipos.

El tratamiento diferenciado de las herramientas legales -aperturista para las medidas preventivas y con requisitos para las medidas de saneamiento- permite un doble efecto benéfico. Por un lado, la regulación aportaría a la prevención el fenómeno, procurando neutralizar las causas del sobreendeudamiento y, por otra parte, se dejarían a resguardo los estímulos de conducta responsable, que es dable esperar de los protagonistas del intercambio. Las soluciones preventivas se imponen con carácter prioritario, por razones éticas, económicas y jurídicas.

4.b.- Ciertas medidas preventivas dependen del diseño de políticas públicas y su implementación corresponde al ámbito de la gestión, como lo referido a programas de educación para el consumo de crédito y el control de los agentes en la operatoria de crédito. Existen deudas pendientes en este plano que deben ser motivo de urgente abordaje.

4.c.- Se impone seguir el modelo de regulación española que, en materia de crédito al consumo, consagra un catálogo de derechos al consumidor con los correlativos deberes para el dador de crédito, que merece ser replicado en Argentina. Muchos de estos remedios de corte preventivo no tenían previsión concreta en el ordenamiento argentino o se trataba de dispositivos aislados, contenidos en la ley de defensa del consumidor o en normas sectoriales. Con la entrada en vigencia del nuevo Código Civil y Comercial unificado, 
varias de las medidas preventivas aquí propuestas, desembarcan en el Derecho argentino y las ya existentes se revigorizan con la fuerza del sistema general (el control de la actividad publicitaria, el deber de información y asesoramiento, la imposición de formalidades al contrato de consumo en general y de crédito en particular, el contenido mínimo, el control de incorporación y de las cláusulas abusivas en la contratación, el derecho de revocación, etc.).

4.d.- La regulación en el nuevo Código Civil de numerosos aspectos vinculados a los contratos de consumo, en general, y a la operatoria de crédito con consumidores, en particular, ratifica el postulado vinculado a la necesaria intervención del legislador en la materia. Celebramos su previsión en el corpus iusprivatista y somos conscientes de lo que ello implica. Insistimos en la necesidad de contemplar algunos dispositivos de carácter preventivo que consideramos eficaces: la imposición de un desembolso inicial al tomador del crédito, el derecho al pago y amortización anticipada y el derecho a desistir del contrato, con regulación concreta del ejercicio de esta facultad y sus efectos en la operatoria de crédito.

5.- Medidas de saneamiento del sobreendeudamiento:

5.a.- La renegociación del pasivo es un mecanismo indirecto de saneamiento puesto que la liberación del deudor será el corolario de una exitosa etapa de conciliación de intereses, del acuerdo al que se arribe y del cumplimiento satisfactorio del plan de pagos allí acordado. $\mathrm{Si}$ bien la propuesta no parece novedosa pues en la totalidad de los ordenamientos que regulan el fenómeno de la insolvencia, se prevén procedimientos -extrajudiciales o judicialesencaminados a lograr convenios de refinanciación, la iniciativa pasa por redefinir el escenario de actuación y el rol de los actores, aportar un guión propio -sin adaptaciones forzadas de libretos antiguos- y diseñar una dinámica eficiente para su puesta en ejecución. Sólo así la obra en estreno resultará exitosa. Esta instancia de renegociación debe ser promovida, facilitada, asistida y acompañada cuando resulte una salida eficiente (por la factibilidad de reunir a las partes, generar el diálogo y la discusión, acercar posiciones y armonizar los intereses en conflicto y lo justifique la realidad de la economía doméstica en crisis). La apertura del procedimiento debe propiciar el bloqueo de nuevas ejecuciones y la 
paralización de las que se encuentren en trámite, la suspensión del curso de los intereses y la no ejecutoriedad de las cautelares ya despachadas. Este mecanismo requiere experticidad en la conducción y compromiso con los fines que inspiran el diseño de este procedimiento. El funcionario a cargo debe contar con atribuciones para instar y orientar la renegociación y estimulando el acuerdo. La razonabilidad de la propuesta final será juzgada por el director del procedimiento -la autoridad administrativa o el juez- que revisará el acuerdo antes de homologarlo y disponer su ejecutoriedad propiciando la mejor salida para el sujeto afectado y su grupo familiar. Debe ser un trámite caracterizado por la simplicidad, celeridad y coste mínimo. La homologación del acuerdo producirá la novación de las obligaciones y el cumplimiento del plan de pagos habilitará al deudor a peticionar la liberación. Por otra parte, frente al incumplimiento total o parcial del plan de saneamiento, la autoridad interviniente deberá ponderar las causas de tal inobservancia, la imputabilidad de las mismas, la naturaleza y cuantía del pasivo insatisfecho y demás circunstancias relevantes, para así reconducir el acuerdo o decidir el cierre del procedimiento.

5.b.- La exoneración del pasivo pendiente es beneficio que debe ser acogido por la regulación, como mecanismo de saneamiento necesario para la situación de sobreendeudamiento del consumidor. La recepción del instituto sirve de estímulo al deudor a fin de que solicite la apertura del procedimiento diseñado al efecto y lo haga en tiempo oportuno, convencido de las ventajas que éste le ofrece a fin de superar su situación de crisis.

5.c.- El legislador debe diseñar un modelo regulatorio conforme la perspectiva analítica a la que adhiere el sistema jurídico en el que se emplace.

5.d.- Dado que se trata de consagrar un beneficio que hace excepción al principio de responsabilidad patrimonial universal, propiciamos restringir el presupuesto subjetivo reconociendo como beneficiario eventual del mismo, al consumidor persona física sobreendeudado, de buena fe. Cuando se regula en situación de crisis generalizada y se persiguen fines plurales y distintos (además, del saneamiento de la crisis en la economía 
doméstica y la rehabilitación del consumidor), se explica el ensanchamiento de la masa de beneficiarios; pero no lo proponemos para Argentina.

5.e.- El beneficio consistirá en la liberación de las deudas aún insatisfechas que, por disposición de la ley, se otorgará al deudor que observe los requisitos legalmente previstos, en el marco de un procedimiento judicial o extrajudicial que el legislador diseñe al efecto y que, puede estar precedido por la ejecución de un plan de pagos o por la liquidación de los bienes del deudor o ante falta de activo para liquidar.

5.f.- Rechazamos el argumento conforme al cual el otorgamiento de este beneficio puede significar un estímulo negativo para el deudor irresponsable, que vea en esta herramienta un camino para endeudarse y luego liberarse de parte de ese pasivo. El abordaje de la problemática en estudio impone superar la mirada simplista, anclada en estereotipos binarios y con respuestas prefijadas. No se trata de confrontar la imagen de un consumidor de débil moral (que no merece ser asistido), con la un sujeto honesto pero desafortunado (al que hay que ayudar no sin antes hacerle purgar sus culpas). El colectivo de consumidores sobreendeudados no se puede caracterizar con descripciones abstractas para arribar a conclusiones preestablecidas. Estamos frente a un fenómeno complejo que debe ser analizado bajo un esquema de razonamiento que contemple el sistema en el que se inserta el consumo moderno, la operatoria de crédito, el contexto social-, su causalidad diversa, el impacto individual y colectivo y las responsabilidades plurales de los actores económicos y sociales.

5.g.- Insistir en el sometimiento a un programa de cumplimiento que satisfaga a los acreedores, cuando se trata de un consumidor sin más recursos que su salario y la vivienda familiar -porque son sus únicos activos o porque es lo que le queda luego de la liquidación de los demás bienes- resulta irrazonable. Decidir la medida y el tiempo en que se afectarán las escasas rentas futuras del consumidor sobreendeudado, para destinarla al pago de los créditos y los gastos, es un problema de difícil resolución. 
5.h.- Rechazamos de plano la idea de que la falta de activos, impide acceder al beneficio de la exoneración del pasivo insatisfecho en forma directa. Una solución contraria, implica someter al consumidor al endeudamiento eterno, precisamente por carecer de bienes. Mantener embargos de salarios y rentas por largo tiempo, lleva a desincentivar cualquier actividad productiva del afectado e impactar negativamente en el sistema.

5.i.- No compartimos la descalificación del beneficio de la exoneración del pasivo insatisfecho formulada con fundamento en el análisis económico del derecho. No ignoramos que una medida como la propuesta, impacta negativamente en quien esgrime la titularidad del crédito y que los costes de autoprotección pueden traducirse en un encarecimiento del crédito. Pero ni este argumento, ni alegada frustración de los remedios concursales tradicionales alcanzan para restar validez a la propuesta de regulación. Las soluciones ofrecidas por el Derecho concursal fueron ampliando sus fines pero la irrupción del consumidor sobreendeudado, como nuevo sujeto del concurso, desnuda la impotencia de la regulación existente y hace impostergable un replanteo. No hablamos de la crisis de un deudor cualquiera. Hablamos del sobreendeudamiento de un sujeto que no puede ser liquidado o excluido del sistema por resultar económicamente inviable. Aunque fuera condenado a pagar todas y cada una de sus deudas -en un proceso individual o en un colectivo- difícilmente el consumidor satisfaga el interés de los acreedores, pero seguramente sí quede sometido a un status de exclusión y marginalidad inaceptable.

5.j.- No se trata de sustituir un paradigma de regulación por otro, ni de desechar un modelo -con sus principios estructurales y reglas concretas- por otro diferente. Creemos que si las medidas de saneamiento han de emplazarse en el régimen general de insolvencia, el legislador debe fragmentar el elemento subjetivo -diferenciando categorías de sujetos habilitados a transitar el proceso concursal- y establecer procedimientos alternativos con mecanismos particulares y distintos para los diferentes subtipos.

5.k.- Dado que la propuesta pasa por liberar al particular afectado del pasivo pendiente luego de transitar el procedimiento diseñado al efecto, se impone fijar posición respecto de las deudas exonerables, explicitando cuáles son las excluidas del beneficio en examen. 
Consideramos que por su naturaleza o carácter, las deudas por alimentos constituyen un supuesto de pasivo no exonerable. En atención al bien jurídico tutelado, tampoco será liberado el deudor de cumplir el pago de indemnizaciones por daño a la integridad psicofísica y espiritual de la persona.

5.1.- Habiéndose otorgado el beneficio con carácter provisorio (luego de la liquidación de los bienes o ante la inexistencia de bienes liquidables) y habiendo transcurrido el plazo preclusivo sin que los acreedores legitimados peticionaran la revocación del mismo, o luego de vencido el plazo para el cumplimiento del programa de pagos complementarios sin alegación de inobservancia por los acreedores, el interesado podría solicitar el reconocimiento de esa liberación con carácter definitivo, que debería ser concedido sin más trámite. Consideramos un acierto que en caso de someterse al deudor a un plan de pagos y plazo de buena conducta, el juez o la autoridad administrativa tengan atribuciones para merituar la entidad del eventual incumplimiento y el esfuerzo desplegado para observarlo, y disponer la reconducción del plan o la liberación definitiva, no obstante aquella contingencia.

5.m.- La primera decisión a adoptar por el legislador es la vinculada al escenario en el que se emplazará el procedimiento encaminado al saneamiento de la situación de sobreendeudamiento y a la rehabilitación de sujeto afectado. No es una resolución simple pues supone fijar posición y definir un diseño estratégico. Pese a las críticas que se plantean respecto de funcionamiento del servicio de justicia, en la idiosincrasia argentina, se sigue apostando a los jueces a la hora de someter un conflicto a la decisión de un tercero imparcial. No se trata de una cuestión menor puesto que será en ese escenario donde habrá de dirimirse la suerte final de los créditos que reclaman los acreedores y donde eventualmente se concederá un beneficio de excepción al deudor, liberándolo del pasivo pendiente de cumplimiento.

5.n.- Se impone el diseño de un procedimiento especial, de trámite ágil, sencillo y económico. Se reclama un verdadero concurso doméstico, capaz de dispensar el debido tratamiento y atención a las situaciones de impotencia patrimonial de las economías 
particulares, como opuestas -desde lo conceptual- a la crisis que afronta una empresa sobreendeudada. 


\section{BIBLIOGRAFÍA}

-ABDALA, Martín, "El consumidor en el mercado de capitales", en LORENZETTI - SCHOTZ (Directores), Derecho del consumidor, Abaco de Rodolfo Depalma-Universidad Austral, Buenos Aires, 2003, pág. 205-227.

-ALEGRíA, Héctor, “Aspectos humanos no patrimoniales en la insolvencia”, $L L$ 2008-F, 1134.

-ALEGRíA, Héctor, "Diálogo de Economía y Derecho y convergencias culturales en la insolvencia”, en LL 2007-C,900.

-ALEgríA, Héctor, "Los llamados pequeños concursos. Concursos de personas físicas, consumidores, patrimonios reducidos", LL 2005-E,1353.

-Alfaro Águila-Real, Jesús, "Observaciones críticas al Proyecto de Ley de Crédito al Consumo”, en Revista de Derecho Bancario y Bursátil, núm. 56, 1994, pág. 1030-1053.

-Alonso, Daniel, "El sobreendeudamiento de la persona física no comerciante frente a los procesos concursales", Ponencia presentada en el $\mathrm{V}^{\circ}$ Congreso Iberoamericano sobre la Insolvencia y el $\mathrm{VII}^{\circ}$ Congreso Argentino de Derecho Concursal realizados en Mendoza entre el 4 y el 7 de octubre de 2009.

-Alonso Ledesma, Carmen, "Endeudamiento del consumidor e insolvencia familiar: propuestas de regulación en el procedimiento concursal", en CUENA CASAS, MatildeColino Mediavilla, José Luis (Coord.), Endeudamiento del consumidor e insolvencia familiar, Cívitas, Pamplona, 2009, pág. 459-271.

-Alterini, Atilio A., Contratos Civiles, Comerciales, de Consumo, Abeledo Perrot, Buenos Aires, 1998.

-Alterini, Atilio A., "Control de la publicidad y comercialización”, en STIGLITZ, Gabriel A., Derecho del Consumidor, 5, Juris, Rosario, 1993, pág. 23 y sgtes.

-Alterini, Atilio A., "Responsabilidad objetiva derivada de la generación de confianza", en Temas de responsabilidad civil, Ediciones Ciudad Argentina, Buenos Aires, 1995, pág. 243-255.

-Alterini, Atilio A.-Ameal, Oscar-LóPez Cabana, Roberto M., Derecho de Obligaciones, Abeledo Perrot, Buenos Aires, 1998. 
-Alterini, Atilio A.-LÓPEz CABANA, Roberto M., "La penetración de la realidad económica en el sistema del Código Civil”, en Derecho de Daños, La Ley, Bs. As., 1.992, pág. 105-113.

-ALterini, Atilio A.-LÓPEZ CABANA, Roberto M., "La debilidad jurídica en la contratación contemporánea”, en Derecho de Daños, Ed. La Ley, Buenos Aires, 1992, pág. 85-103.

-Alterini, Atilio A.- LóPEz CABANA, Roberto M., "La formación del consentimiento y la protección del consumidor", en STIGLITZ, Gabriel A., Derecho del Consumidor, Juris, Rosario, 1994, pág. 3 y sgtes.

-Alterini, Jorge H. (Dir.), Código Civil y Comercial de la Nación Comentado. Tratado exegético, La Ley, Buenos Aires, 2015.

-Álvarez Larrondo, Federico M., "La protección constitucional de los intereses económicos de los consumidores", en LL 2013-A,395.

-Álvarez Lata, Natalia, en Bercovitz RodríGuez-CANo, Rodrigo (Coord.), Comentario del Texto Refundido de la Ley General para la Defensa de los Consumidores y Usuarios y otras leyes complementarias (Real Decreto Legislativo 1/2007), Aranzadi-Thomson Reuters, Madrid, 2009, pág. 226-250.

-Álvarez Lata, Natalia, en Marín LóPez, Manuel Jesús (Dir.), Comentarios a la Ley de Crédito al Consumo, Thomson Reuters-Aranzadi, Pamplona 2014, pág. 522-549.

-Álvarez Lata, Natalia, Invalidez e ineficacia en el derecho contractual de consumo español, Aranzadi, Navarra, 2004.

-Alvarez Martínez, Georgina Ivón, Los grupos de contratos en el crédito al consumo, texto de la tesis doctoral de la autora, publicada en La Coruña, 2008.

-Alvarez Olalla, Pilar, “Crédito al consumo”, en Bercovitz, Rodrigo (Coord.), Tratado de Contratos, T. II, Valencia, Tirant lo Blanch, 2009.

-Alvarez Rubio, Julio, "Algunas reflexiones en torno a la reforma del fresh start del consumidor en USA", Anuario de Derecho Concursal, Nº. 14, 2008, pág. 233-259

-Alvarez Vega, M. I., Protección jurídica del consumidor sobreendeudado e insolvente, Cívitas, Pamplona, 2010.

-Alvarez VegA, Isabel, "El concurso del consumidor en España”, en Tomillo UrbinA, Jorge (Dir.)-Alvarez Rubio, Julio (Coord.), El futuro de la protección jurídica de los consumidores, Thomson-Cívitas, Pamplona, 2008, pág. 299-321. 
AnCHAVAL, Hugo A., Insolvencia del consumidor, Astrea, Buenos Aires, 2011.

-ANChaval, Hugo A., "El nuevo sujeto concursal", en LL 2010-F,1079.

-ANCHAVAL, Hugo A., "Sobreendeudamiento de consumidores y responsabilidades subyacentes", en Truffat, D.-BARreiro, M.-Antoni Piossek, C.- Nicastro, R. (Coord.), Libro Homenaje al Doctor Osvaldo Maffía, Lerner Editora, Córdoba, 2008, pág. 619-627. -Aravena, P.- Herrera, V.- Poblete, P.- Vera, D., "Consumo patológico: compra impulsiva y compulsiva”, Documento presentado para la asignatura Psicologia Económica a cargo Doctora Marianel Denegri, de la Universidad de LA Frontera, Chile, 2008 (inédito). -ARIAS CAU, Esteban - BAROCELli, Sebastián, "Sobreendeudamiento y adicción al consumo", Ponencia presentada en las $\mathrm{XXIV}^{\circ}$ Jornadas Nacionales de Derecho Civil celebradas en la Facultad de Derecho de la Universidad de Buenos Aires entre los días 21 y 23 de setiembre de 2013.

-Arroyo Amayuelas, Esther, en Marín LóPez, Manuel Jesús (Dir.), Comentarios a la Ley de Crédito al Consumo, Thomson Reuters-Aranzadi, Pamplona 2014, pág. 643-682.

-AZNAR DINER, Eduardo, Refinancianción de deuda, acuerdos extrajudiciales de pago y concurso de acreedores, Tirant lo Blanch, Valencia, 2014.

-BALbuena Rivera, Manuel, "Análisis del riesgo financiero de las personas físicas y su impacto en el coste crediticio", en Prat Albentosa-Cuena Casas (Coord.), Préstamo responsable y ficheros de solvencia, Thomson Reuters-Aranzadi, Pamplona, 2014, pág. 117-179.

-BARACAT, Edgar J..- MiCELLI, María I., "La crisis del sistema ante la desnaturalización del proceso falencial”, Ponencia presentada al $\mathrm{VI}^{\circ}$ Congreso Argentino de Derecho Concursal y $\mathrm{IV}^{\circ}$ Congreso Iberoamericano sobre la Insolvencia, Rosario, Libro de Ponencias, T. I, Moralización en los procesos concursales, pág. 81 y sgtes.

-BARreiro, Marcelo.-LOREnTE, Javier. A.-Truffat, E. Daniel., "Del traje de confección al de medida: los procesos concursales deben tener una regulación diversa según su magnitud”, Ponencia presentada en $\mathrm{el} \mathrm{IV}^{\circ}$ Congreso Iberoamericano de Derecho Concursal. -BArreiro, Marcelo-LOREnTE, JAVIER A.-Truffat, E. Daniel, "Proyecto de ley que regula el concurso mínimo", Ponencia presentada en el $\mathrm{IV}^{\circ}$ Congreso Iberoamericano de Derecho Concursal. En esta línea, el VII ${ }^{\circ}$ Congreso Nacional de Derecho Concursal y V Congreso Iberamericano de la Insolvencia desarrollado en octubre de 2009 en Mendoza. 
-BARREIRO, Marcelo, "Una aproximación al fenómeno del sobreendeudamiento del consumidor y su necesaria regulación", Ponencia presentada en el $\mathrm{IV}^{\circ}$ Congreso Iberoamericano de Derecho Concursal sobre Crisis económica mundial y la concursalidad. -BARREIRO, Marcelo, "Sobre la prevención del sobre consumo", Ponencia presentada en el $\mathrm{V}^{\circ}$ Congreso Iberoamericano sobre la Insolvencia y el $\mathrm{VII}^{\circ}$ Congreso Argentino de Derecho Concursal realizados en Mendoza entre el 4 y el 7 de octubre de 2009.

-BARREIRO, Rafael F., "Precisiones acerca de concursos pequeños, crisis sistémicas y consumidores endeudados en demasía”, en Truffat, D.-BARreiro, M.-ANTONi Piossek, C.- Nicastro, R. (Coord.), Libro Homenaje al Doctor Osvaldo Maffía, Lerner Editora, Córdoba, 2008, pág. 567-576.

-Belluscio, Augusto (Dir.)-Zannoni, Eduardo (Coord.), Código Civil y Leyes Complementarias, T. IV, Astrea, Buenos Aires, 1988.

-BELTRÁN SÁNCHEZ, Emilio, "El concurso de acreedores del consumidor", en CUENA Casas, Matilde-Colino Mediavilla, José Luis (Coord.), Endeudamiento del consumidor e insolvencia familiar, Cívitas, Pamplona, 2009, pág. 119-130.

-BELTRÁN SÁNCHEZ, Emilio, "Insolvencia de las familias en la ley concursal española”, en Tomillo Urbina, Jorge (Dir.)-Álvarez RuBio, Julio (Coord.), El futuro de la protección jurídica de los consumidores, Thomson-Civitas, Pamplona, 2008, pág. 199-135.

-Benavides Velasco, Patricia G., Masa activa del concurso y bienes gananciales, Monografía asociada a la Revista de Derecho Concursal y Paraconcursal, Wolters Kluver La Ley, Madrid, 2015.

-Bercovitz RodríGuez-CANo, Alberto, "El presupuesto subjetivo del concurso. En particular, el problema del sobreendeudamiento de los consumidores”, en QUINTANA Carlo, I.-Bonet Navarro, Á.- García Cruces-González (Dir.), Las claves de la ley concursal, Thomson-Aranzadi, Madrid, 2005 pp. 17-23.

-Bercovitz Rodríguez-CAno, Rodrigo (Coord.), Comentario del Texto Refundido de la Ley General para la Defensa de los Consumidores y Usuarios y otras leyes complementarias (Real Decreto Legislativo 1/2007), Aranzadi-Thomson Reuters, Madrid, 2009.

-Bergel, Salvador D., y Paolantonio, Martín R., Responsabilidad civil de las entidades financieras en las operaciones de crédito al consumo, cit., pág. 281; BERGEL, Salvador D., 
y PaOlantonio, Martín R., "Las letras de consumo y su problemática jurídica”, en RDCO, T. 1991-B,7.

-Bernal Del Castillo, Ángel, "La Ley 7/1995, de 23 de marzo, de Crédito de Consumo", en De León ARCE, Alicia (Dir.), Derechos de los consumidores y usuarios”, Tirant lo Blanch, Madrid, 2007, pág. 404-444.

-BERSTEN, Horacio L., "La regulación del sobreendeudamiento de los consumidores", en LL Suplemento Actualidad, del 30/08/2011, pág. 1.

-Bohoslavsky, Juan Pablo, Créditos abusivos. Sobreendeudamiento de Estados, empresas y consumidores, Editorial Ábaco de Rodolfo Depalma, Buenos Aires, 2009.

-BonHOMME, Regine, "La responsabilidad por concesión abusiva de crédito conforme la ley 2005-845 de 26 de julio de 2005. El art. L. 650-1 del CCom”, en Revista de Derecho Concursal y Paraconcursal, $N^{\circ}$ 5, Sección Reseña legislativa española y comparada, Segundo semestre de 2006, pág. 349-352.

-BordA, Guillermo A., Tratado de Derecho Civil-Parte General, Tomo II, , Ed. La Ley, Buenos Aires, 2008.

-Borgarello, Luisa, "El concurso del consumidor: algunas reflexiones", Ponencia presentada en el $\mathrm{V}^{\circ}$ Congreso Iberoamericano sobre la Insolvencia y el VII ${ }^{\circ}$ Congreso Argentino de Derecho Concursal realizados en Mendoza entre el 4 y el 7 de octubre de 2009.

-BouRgoIGNIE, Thierry, "Seguridad del consumidor y vigilancia de mercado: estrategias y herramientas legales", en Tomillo Urbina, Jorge (Dir.)-Álvarez Rubio, Julio (Coord.), La protección de los consumidores como motor de desarrollo económico, Civitas-Thomson Reuters, Pamplona, 2011, pág. 93-110.

-Bourgoignie, Thierry, "El año del consumo", en Revista de Política del Consumidor, vol. 13, editado por Thierry Bourgoignie y Guy Delvax, Bruselas, pág. 4-35.

-BRÚ, Jorge M., "Educación y formación del consumidor (reflexiones sobre la conciencia del consumidor)", en Stiglitz, Gabriel A. (Dir.), Manual de Defensa del Consumidor, Editorial Juris, Rosario, 2004, pág. 19-51.

-Bueres, Alberto J. (Dir.)-Highton, Elena, Código Civil y Normas Complementarias, t. II B, Hammurabi-José Luis Depalma Editor, Buenos Aires, 1998. 
-CABANAS TREJo, Ricardo, "El nuevo régimen legal de la exoneración del pasivo concursal y del acuerdo extrajudicial de pagos (Real Decreto-Ley 1/2015, de 27 de febrero)" en Diario La Ley, $N^{o}$ 8505, Sección Doctrina, 23 de Marzo de 2015, Ref. D-111, Editorial La Ley).

-CABANILlas SÁNCHEZ, Antonio, Las cargas del acreedor en el derecho civil y mercantil, Editorial Montecorvo, Madrid, 1988.

-CÁmara Lapuente, Sergio (Dir.), Comentarios a las Normas de Protección de los Consumidores, Colex, Madrid, 2011.

-CARrasco PERERA, Ángel, "El mecanismo de segunda oportunidad para consumidores insolventes en el RDL 1/2015: realidad y mito", en http://www.uclm.es/centro/cesco/pdf/trabajos/mecanismosegundaoportunidad.pdf

-CASTÁN VAZQuez, José María, "El favor debitoris en el Derecho Español", Anuario de Derecho Civil, 1961-IV, pág. 835.

-CASTElls, Manuel, La era de la información. Economía, sociedad y cultura.: Vol. I: La sociedad red, Siglo XXI, Buenos Aires, 2005.

-CELENTANi, Marco, "El intercambio de información y el funcionamiento del mercado de crédito", en Prat Albentosa-Cuena Casas (Coord.), Préstamo responsable y ficheros de solvencia, Thomson Reuters-Aranzadi, Pamplona, 2014, pág. 93-115.

-Cifuentes, Santos (Dir.)-Sagarna, Fernando (Coord,), Código Civil Comentado, t. I, Ed. La ley, Buenos Aires, 2003.

-Ciuro CALDANI, Miguel Ángel, "Desde la protección del propietario a la protección del consumidor y el usuario", en E.D. T. 159, pág. 1022 y sgtes.

-Colino Mediavilla, José Luis, "Concurso de consumidor", en Convergencias y paralelismos en el Derecho de Sociedades y en el Derecho Concursal en el marco Estados Unidos-Unión Europea. III Seminario Harvard-Complutense de Derecho de los negocios, 2007, pág. 375-388, http://eprints.ucm.es/7848/1/conccons2007-publicHarv2006EPRINT.pdf (fecha de consulta 3/7/2015).

-Colino Mediavilla, José Luis, "Tratamiento de la crisis patrimonial del consumidor: ¿Procedimiento colectivo extrajudicial preconcursal, procedimiento colectivo preventivo, o procedimiento concursal especial?", en CuEna CASAS, Matilde-Colino MEDiAVILLA, José 
Luis (Coord.), Endeudamiento del consumidor e insolvencia familiar, Civitas, Pamplona, 2009, pág. 429-445.

-CORDERO, Encarna, "La adjudicación al acreedor hipotecario extingue la deuda restante. Auto de la A.P. de Navarra de 17 diciembre 2010", Notas Jurisprudenciales, Centro de Estudios de Consumo, en https://www.uclm.es/centro/cesco/pdf/notasJurisprudencia/financiacion/23.pdf (Fecha de consulta: 20/4/2015).

-CORREA, Griselda, "Daños derivados de las ventas domiciliarias, por correspondencia, telecomunicaciones, electrónico o similares", Tratado de daños reparables, GHERSI, C. (Dir.), T. II., La Ley, Buenos Aires, 2008, pág. 171-193.

-CRISTÓFARO, Giovanna. E., "La conveniencia del uso de técnicas de resolución alternativa de conflictos por las pymes, los consumidores y los concursados", en ANTONI PIOSSEK, Carlos Roberto (Dir.), Resoluciones alternativas de conflictos en la crisis de la empresa y el consumidor. Libro homenaje al Doctor Francisco Junyent Bas, Lerner Editora, Córdoba, 2010, pág. 113-129.

-CRISTÓFARO, Giovanna E., "Procedimiento especial para el sobreendeudamiento de personas físicas con ingresos fijos", Ponencia presentada en el $V^{\circ}$ Congreso Iberoamericano sobre Insolvencia.

-Cuena Casas, Matilde, “A propósito del Real Decreto-Ley 1/2015 ¿Un régimen de segunda oportunidad?" en El Notario del Siglo XXI, № 60, marzo/abril 2015, pág. 10 y sgtes.).

-CUENA CASAS, Matilde, "Una segunda oportunidad para la persona física insolvente: cambios de última hora", en http://www.legaltoday.com/practica-juridica/mercantil/concursal/unasegunda-oportunidad-para-la-persona-fisica-insolvente-cambios-de-ultima-hora (Fecha de consulta: 27/9/2015).

-CUENA CASAS, Matilde, "Fresh start y mercado crediticio" en http://www.raco.cat/index.php/InDret/article/viewFile/247092/330974 (fecha de consulta 1/7/2015).

-Cuena Casas, Matilde, "Conclusión del concurso de acreedores de persona física y exoneración del pasivo pendiente (a propósito del auto del Juzgado Mercantil $\mathrm{N}^{\circ} 3$ de Barcelona de 26 del octubre de 2010)", Revista de Derecho Bancario y Bursátil, $\mathrm{N}^{\circ} 125$, Enero-Marzo, 2012, pág. 289 y sgtes. 
-Cuena Casas, Matilde, "Insolvencia de la persona física y sobreendeudamiento hipotecario", en Revista de Derecho Concursal y Paraconcursal, N $^{\circ}$ 17, Sección Varia, Segundo semestre de 2012, pág. 97 y sgtes.

-CuEna CASAS, Matilde, "Conclusión del concurso del consumidor y pasivo insatisfecho", en http://eprints.ucm.es/23521/1/Cuena_conclusi\%C3\%B3n_concurso_E-prints.pdf (fecha de consulta 25/4/2015)

-Cuena CASAS, Matilde, "Algunas deficiencias de la ley concursal ante la insolvencia de la persona física” en http://www.derechocivil.net/esp/Comunicaci\%F3n\%20Ponencia\%20II.\%20D.\%AA\%20Matilde\%20Cuena\% 20Casas.pdf (fecha de consulta: 13/8/2014).

-Cuena CASAs, Matilde, "Una segunda oportunidad para la persona física insolvente: cambios de última hora", en http://www.legaltoday.com/practica-juridica/mercantil/concursal/unasegunda-oportunidad-para-la-persona-fisica-insolvente-cambios-de-ultima-hora (Fecha de consulta: 27/9/2015)

-Cuena Casas, Matilde, "Préstamo responsable, información crediticia y protección de datos personales", en Revista de Derecho Concursal y Paraconcursal, $N^{\circ} 20$, Sección Estudios, Segundo semestre de 2013, pág. 161-185.

-Cuena CASAs, Matilde, "El sobreendeudamiento privado como causa de la crisis financiera y su necesario enfoque multidisciplinar", en PRAT AlBENTOSA-CUENA CASAS (Coord.), Préstamo responsable y ficheros de solvencia, Thomson Reuters-Aranzadi, Pamplona, 2014, pág. 27-89.

-De Castro Portugal Carneiro da Frada, Manuel Antonio, Teoría da confíanca e responsabilidade civil, Ed. Almedina, Coimbra, 2004.

-De la Cuesta Rute, José María, “Persona física y consumidor”, Ponencia presentada al I Congreso Internacional Sobreendeudamiento del consumidor e insolvencia familiar, celebrado en la Facultad de Derecho UCM en noviembre de 2008. http://eprints.ucm.es/8761/1/06.04.09.Persona_f\%C3\%ADsica_y_consumidor.pdf (fecha de consulta: 7/7/2015).

-De LAS Morenas, Gabriel Alejandro, "Reciente legislación de Mendoza sobre las consecuencias de la quiebra en los empleos públicos”, LLGran Cuyo, 2010 (julio), 503. 
-De las Morenas, Gabriel Alejandro, "Rechazo de quiebra voluntaria por ausencia de activos. Una polémica vigente. ¿Existe un derecho a quebrar? ¿Es ejercitable ese derecho por las personas de escasos recursos?", Suplemento Concursos y Quiebras, 2008 (octubre), 34; LL 2008-E, 1346.

-DE LoREnZo, Miguel Federico, "Contrato de consumo y derecho al arrepentimiento", $L L$ 2004-A, 790 .

-Del Fierro Elgart, Alfonso, "El Derecho de la insolvencia de los consumidores: una reforma pendiente en el Derecho Concursal chileno", Boletín Jurídico/Publicación $\mathrm{N}^{\circ} 3$, http://www.superir.gob.cl/wp-content/uploads/2014/09/boletin-juridico-publicacion-n3-1.pdf (fecha de consulta 1/7/2015).

-Delgado ZegarRa, Jaime, "Técnicas de comercialización y publicidad" en, Stiglitz, Gabriel A., Derecho del Consumidor, 5, Juris, Rosario, 1993, pág. 151 y sgtes.

-DESPOUY, Leandro, "Informe final sobre los derechos humanos y la extrema pobreza" presentado ante la Comisión de Derechos Humanos del Consejo Económico y Social de las Naciones

Unidas

(file:///C:/Documents\%20and\%20Settings/Belen/Escritorio/DERECHOS\%20HUMANOS. pdf) Fecha de consulta 6/7/2015).

-DíAz AlABART, Silvia, "La forma ad luciditatem en la contratación con consumidores" en López Cabana, R.-Ameal, O. (Dir.), Obligaciones y contratos en los albores del siglo XXI. Buenos Aires, Abeledo Perrot, Buenos Aires, 1997, pág. 635-639.

-DíAZ EchegARAY, José Luis, Los acuerdos de refinanciación, Cívitas-Thomson Reuters, 2015.

-DiÉGueZ Oliva, Rocío, "El denominado fresh start español desde la perspectiva del análisis económico del derecho", en http://alacde2015.org/papers/66.pdf (Fecha de consulta: 10/10/2015).

-DíEZ- PiCAZo, Luis, Fundamentos del Derecho Civil Patrimonial, II, Cívitas, Madrid, 1996.

-Di LELLA, Nicolás J., "El fenómeno de las llamadas 'quiebras sin activo' y su tratamiento en la jurisprudencia actual", La Ley Online, AR/DOC/1805/2013.

-Domínguez luelmo, Andrés, en Cámara lapuente, Sergio (Dir.), Comentarios a las Normas de Protección de los Consumidores, Colex, Madrid, 2011, pág. 615-695. 
-Domínguez Luelmo, Andrés, "El derecho de desistimiento", en CÁmara LaPuente, Sergio y ARROYO I AMAYUELAS, Esther (Coord.), La revisión de las normas europeas y nacionales de protección de los consumidores más allá de la Directiva sobre derechos de los consumidores y del Instrumento Opcional sobre un derecho europeo de la compraventa de octubre de 2011,Cívitas, 2012, pág. 209-236.

- Domínguez Luelmo, Andrés, El cumplimiento anticipado de las obligaciones, Cívitas, Madrid, 1992.

-ESCUIN IBÁÑEZ, Irene, Las adquisiciones financiadas en el crédito al consumo, Comares, Granada 2002.

-FARHI DE Montalván, Diana, "La insolvencia del consumidor: un problema social globalizado que debe preocupar a la comunidad”, Ponencia presentada en el $\mathrm{IV}^{\circ}$ Congreso Iberoamericano sobre Insolvencia (inédito).

-FARINA, Juan M., Defensa del consumidor y del usuario. Comentario exegético de la ley 24.240 y del decreto reglamentario 1798/94, Astrea, Buenos Aires, 2008.

-FERnÁNDEZ CARRón, Clara, El tratamiento de la insolvencia de las personas físicas, Thomson-Aranzadi, Pamplona, 2008.

-FERnÁndez SeIJo, José María, La reestructuración de las deudas en la ley de segunda oportunidad, Bosch, Wolters Kluver, Barcelona, 2015.

-Fernández SeIJo, José María, "Concurso de personas físicas: sobreendeudamiento familiar y situación de los consumidores en el marco del procedimiento concursal", en Tomillo Urbina, Jorge (Dir.)-Álvarez Rubio, Julio (Coord.), El futuro de la protección jurídica de los consumidores, Thomson-Civitas, Pamplona, 2008, pág. 257-270.

-FERRÉ, Juan, La liberación de deudas en el concurso del consumidor (un apunte de derecho alemán)», Anuario de Derecho Comercial, núm. 7, Aranzadi, 2006, p. 205 y sgtes. -Fragapane, H.R.-GAMES, F.G., "Juguemos a los concursos”, en TrufFAt, D.-BARREIRO, M.-Antoni Piossek, C.- Nicastro, R. (Coord.), Libro Homenaje al Doctor Osvaldo Maffía, Lerner, Córdoba, 2008, pág. 597-608.

-Frustagli, Sandra-Hernández, Carlos A., "El concepto de consumidor. Proyecciones actuales en el Derecho argentino", en LL 2011-F,992.

-Frustagli, Sandra-HeRnándeZ, Carlos A., "Sobreendeudamiento del consumidor", en $L L$ 2013-E,1160. 
-GALlego SÁnchez, Esperanza, "La obligación de evaluar la solvencia del deudor. Consecuencias derivadas de su incumplimiento", en Prat Albentosa-Cuena Casas (Coord.), Préstamo responsable y ficheros de solvencia, Thomson Reuters-Aranzadi, Pamplona, 2014, pág. 207-242.

-GARAguSO, Horacio- GARAGUSO, Guillermo H., "Las pequeñas quiebras que avergüenzan a algunos juristas y jueces son necesarias para el deudor y sus acreedores”, ponencia presentada en las Jornadas Nacionales de Institutos de Derecho Comercial celebradas en San Nicolás en el año 2008, en Libro de Ponencias, Fundación para la Investigación y el Desarrollo de las Ciencias Jurídicas, pág. 408 y sgtes.

-García Vicente, José Ramón, en Bercovitz Rodríguez-Cano, Rodrigo (Coord.), Comentario del Texto Refundido de la Ley General para la Defensa de los Consumidores y Usuarios y otras leyes complementarias (Real Decreto Legislativo 1/2007), AranzadiThomson Reuters, Madrid, 2009, pág. 845-881.

-García Vicente, José Ramón, en Marín LóPez, Manuel Jesús (Dir.), Comentarios a la Ley de Crédito al Consumo, Thomson Reuters-Aranzadi, Pamplona 2014, pág. 1005-1026. -García-Villarrubia, Manuel, "La conclusión del concurso por inexistencia de bienes y el 1lamado concurso express", en El Derecho, Revista de Derecho Mercantil, $\mathrm{N}^{\circ} 4$, en http://www.uria.com/es/publicaciones/buscador-publicaciones.html?id=3645\&pub=Publicacion $\quad$ Fecha de consulta 20/4/2015)

-GARrido Cordobera, Rosa, “Sirve al legislador la teoría económica de la eficiencia?” en Responsabilidad por daños en el tercer milenio. Libro homenaje al Dr. Atilio Aníbal Alterini, Abeledo Perrot, Buenos Aires, 1.997, pág. 61-66.

-GAVIDIA SÁNCHEZ, Julio V., El crédito al consumo (cesión y contratos vinculados), Tirant lo Blanch, Valencia, 1996.

-Gelpi, Rosa M.-LabruYere, Julien, Historia del crédito al consumo. Doctrinas y practicas, Península, Barcelona, 1998.

-Gelcich, Marcelo G.- García Villareal, Antonio-PASSARElla, Julián Emmanuel, “La información y el crédito en la sociedad de riesgos", LL Litoral, 2010 (noviembre), 1081.

-Gerscovich, Carlos G., Consumidores bancarios, Abeledo Perrot, Buenos Aires, 2011.

-GHERSI, Carlos A., "Endeudamiento y sobreendeudamiento desde el análisis económico del derecho", LL 2015-B, diario del 20/3/2015. 
-GHERsi, Carlos Alberto, "La dignidad como principio general del derecho", LL 2014-D, 1054.

-Ghersi, Carlos-Weingarten, Celia (Dir.), Tratado Jurisprudencial y Doctrinario. Defensa del Consumidor, T. I, La Ley, Buenos Aires, 2011.

-Ghersi, Carlos-Weingarten, Celia (Dir.), Manual de los Derechos de los Consumidores y Usuarios, La Ley, Buenos Aires, 2011.

-GonzÁlez Pecanowsa, Isabel, en en Bercovitz Rodríguez-Cano, Rodrigo (Coord.), Comentario del Texto Refundido de la Ley General para la Defensa de los Consumidores y Usuarios y otras leyes complementarias (Real Decreto Legislativo 1/2007), AranzadiThomson Reuters, Madrid, 2009, pág. 995-1180.

-GozAlo LóPEZ, Vicente Gonzalo, "La protección de los consumidores en el procedimiento concursal”, en Tomillo URBINA, Jorge (Dir.)-Álvarez Rubio, Julio (Coord.), El futuro de la protección jurídica de los consumidores, Thomson-Cívitas, Pamplona, 2008, pág. 283-294.

-Gross, Karen, "La insolvencia de los consumidores en el Derecho de los Estados Unidos”, en Tomillo Urbina, Jorge (Dir.)-Álvarez Rubio, Julio (Coord.), El futuro de la protección jurídica de los consumidores, Thomson-Civitas, Pamplona, 2008, pág. 229 y sgtes.

-Guastavino, Elías, Derecho de Familia-Bien de Familia (3era. Edición actualizada por Eduardo Molina Quiroga con la colaboración de S. Fodor, L.E. Guastavino y G. Guastavino), La Ley, Buenos Aires, 2010.

-GutiÉRreZ DE CABIEDES, Pablo, El sobreendeudamiento doméstico: prevención y solución. Crisis económica, crédito, familias y concurso, Arazadi, Pamplona, 2009.

-GutiÉRreZ De CABIEDES, Pablo, "El Real Decreto-Ley 27/2012, de 15 de noviembre, de medidas urgentes para reforzar la protección a los deudores hipotecarios", en Revista de Derecho Concursal y Paraconcursal, № 18, 2013, pág. 479 y sgtes.

-Hernández, Carlos A., en LoRenzetti, Ricardo L. (Dir.), Código Civil y Comercial de la Nación Comentado, T. VI, Rubinzal-Culzoni, Santa Fe, 2015, pág.153-162.

-Hernández, Carlos A., "Reflexiones sobre el Derecho del consumidor (a propósito de algunos aportes del Doctor Miguel Ángel Ciuro Caldani)" en, ALTERINI, Atilio-NiCOLAU, Noemí (Dir.), El Derecho Privado ante la internacionalización, la integración y la 
globalización. Homenaje al profesor Miguel Ángel Ciuro Caldani (texto facilitado por el autor).

-HERNÁNDEZ PAULSEN, Gabriel, La obligación precontractual de la entidad de crédito de informar al cliente en los servicios bancarios y de inversión, Marcial Pons, Madrid, 2014. -Hernández Rodríguez, María del Mar, "La segunda oportunidad en el Real DecretoLey 1/2015, publicación del 1 de abril de 2015, http://www.elderecho.com/tribuna/mercantil/segunda-oportunidad-Real-Decreto-Ley_11_790930003.html (Fecha de consulta: 20/4/2015).

-HERnández RodríGuez, María del Mar, La segunda oportunidad. La superación de las crisis de insolvencia, Lefebvre-El Derecho, Madrid, 2015.

-IRIARTe IbARguren, Ainoa, "Las 10 claves sobre la Segunda Oportunidad, Reducción de la Carga Financiera y Otras Medidas de Orden Social (Real Decreto Ley 1/2015, de 27 de febrero BOE de 28 de febrero de 2015)", Redacción Wolters Kluwer, http://lighthouse9901news.blogspot.com.ar/2015/03/las-10-claves-sobre-la-segunda.html (Fecha de consulta: 24/5/2015).

-IZUZQUIZA, Ignacio, Introducción a LUHMANN, Niklas, Sociedad y sistema: la ambición de la teoría, Paidos -I.C.E.-Universidad Autónoma de Barcelona, Barcelona, 1997.

-JABIF, Hernán M. - PASTORE, Augusto O., "Relación de consumo: cajeros automáticos”, en DJ 2007-2,1037.

-JACOBY, Melissa B., "Perspectivas Empíricas y de política jurídica sobre el concurso de los consumidores en los Estados Unidos", en Cuena CASAS- Colino Mediavilla (Coord.), Endeudamiento del consumidor e insolvencia familiar, Cívitas, Pamplona, 2009, pág. 381-399.

-JACOBY, Melissa-WARD, George R., "Perspectivas empíricas y de política jurídica sobre el concurso de los consumidores en los Estados Unidos", en Cuena Casas, Matilde-Colino MediaviLla, José Luis (Coord.), Endeudamiento del consumidor e insolvencia familiar, Cívitas, Pamplona, 2009, pág. 381-399.

-JAPAZE, María Belén, "La protección del consumidor sobreendeudado", en PiCASSO, S.VÁzQUEZ FERREYRA, R. (Dir.), Ley de Defensa del Consumidor comentada y anotada, Ed. La Ley, Buenos Aires, 2009, pág. 735-788. 
-JAPAZE, María Belén, "El deber de información”, Capítulo V, en RusCONI, D. (Coord.), Manual de Derecho del Consumidor, Abeledo Perrot, Buenos Aires, 2015, pág. 221-267. -JAPAZE, María Belén, "Publicidad y prácticas comerciales", Capítulo VII, en RUSCONI, D. (Coord.), Manual de Derecho del Consumidor, Abeledo Perrot, Buenos Aires, 2015, pág. 307-390.

-JAPAZE, María Belén, “Crédito al consumo y protección del consumidor. La impostergable necesidad de una regulación protectoria”, en JA 2010-IV, Revista del 3/11/2010.

-JAPAZE, María Belén, "El Derecho del Consumo y el replanteo de algunas antinomias tradicionales", en Revista Crítica de Derecho Privado, № 5, Montevideo, 2008, pág. 693713.

-JUNYENT BAS, Francisco, "El empleado público sobreendeudado y la pérdida de la fuente de trabajo", en LL 2010-B,1264.

-JunYENT BAS, Francisco-IZQUiERdo, Silvina., "El consumidor sobreendeudado y el derecho a quebrar. A propósito de la búsqueda de la rehabilitación y la limpieza del pasivo preexistente", Semanario Jurídico $N^{\circ} 1734$ del 26/11/2009, pág. 757-766.

-JUNYENT BAS, Francisco-IZQUIERDO, Silvina., "El consumidor sobreendeudado y el derecho

quebrar,

https://www.google.com.ar/?gws rd=ssl\#q=Junyent+Bas+Izquierdo+sobreendeudamiento+ del+consumidor+e+el+derecho+a+quebrar (Fecha de consulta 9/7/2015).

-JUnYENT BAS, Francisco A. - IZQUIERDO, Silvina, “¿Decoctor ergo fraudator? La quiebra de los consumidores”, en Suplemento Concursos y Quiebras, 2009 (octubre), 1; LL 2009F, 991.

-Junyent Bas, Francisco-Molina Sandoval, Carlos A., Facultades del juez concursal, Advocatus, Córdoba, 2004.

-Kabas de Martorell, María Elisa- Martorell, Ernesto E., "Fraudes y escándalos bancarios internacionales. Experiencias para la realidad argentina”, La Ley 2013-B,1151.

-KemElmajer DE CARLuCCI, Aída "El sobreendeudamiento del consumidor y la respuesta del legislador francés", en Anales, año LIII, segunda época, N 46, La Ley- Academia Nacional de Derecho y Ciencias Sociales de Buenos Aires, Junio/2008.

-Kemelmajer DE Carlucci, Aída, "El consumidor. Concepto. Modificaciones introducidas por la Ley 26.361", en ANTONi PiosseK, Carlos Roberto (Dir.), Resoluciones 
alternativas de conflictos en la crisis de la empresa y el consumidor. Libro homenaje al Doctor Francisco Junyent Bas, Lerner, Córdoba, 2010, pág. 233 y sgtes.

-Kemelmajer de CARlucci, Aída-Roitman, Horacio (Dir.), "El sobreendeudamiento de la persona física en el ámbito del Poder Judicial de la Provincia de Córdoba con relación a las causas judiciales iniciadas entre el año 2006 y 2010 en el fuero de concursos y quiebras y penal económico. Consecuencias normativas, procesales e institucionales", en Investigaciones aplicadas en el ámbito del Poder Judicial de Córdoba 8, Colección Investigaciones y Ensayos, Córdoba, 2011, pág. 97-145, https://www.justiciacordoba.gob.ar/JusticiaCordoba/files/libros/Investigaciones\%20y\%20E nsayos\%20n\%C2\%BA\%208.pdf (Fecha de consulta: 9/7/2015).

-Kemelmajer Del Carlucci, Aída, "Publicidad y consumidores" en Revista de Derecho Privado y Comunitario, 5, Rubinzal Culzoni, Santa Fe, Santa Fe, 1994, pág. 63 y sgtes.

-KOHTE, Wolfhard, "Las proyectadas modificaciones de la normativa concursal alemana sobre consumidores", en Revista de Derecho Concursal y Paraconcursal, Anales de doctrina, praxis, jurisprudencia y legislación, Nº 19, 2013, pág. 415-416.

-Lacruz Mantecón, Miguel L., "La moderna dación en pago", en Revista de Derecho Civil, vol. I, núm. 3 (julio-septiembre, 2014), Ensayos, pág. 89 y sgtes. http://nreg.es/ojs/index.php/RDC (Fecha de consulta: 20/4/2015).

-LAGUinge, Esteban, Los contratos de crédito ante la ley de defensa del consumidor, Ábaco, Buenos Aires, 2001.

-LAwLESS, Robert, "La Ley concursal estadounidense de 2005. Cómo llegamos a ella y hacia dónde vamos", Revista de Derecho Concursal y Paraconcursal, 2008, pág. 99-111. -LAWLESS, Robert, y WARREN, Elizabeth., "Los cambios de la normativa concursal estadounidense en 2005: reduciendo parte de la red de seguridad", Revista de Derecho Concursal y Paraconcursal, nº 6, 2007, pág. 405-412.

-Lima Marques, Claudia- Lunardelli Cavallazi, Rossalva., Direitos do consumidor endividado. Superrendividamento e crédito, Biblioteca de Direito do Consumidor, 29, Editora Revista Dos Tribunais, Sao Paulo, 2006, pág.p. 23-38.

-LóPez Cabana, Roberto M., "Defensa jurídica de los más débiles", en Revista de Direito do Consumidor $\mathrm{N}^{\circ}$ 28, Editora Revista dos Tribunais, San Paulo, 1998, pág. 7-21. 
-LÓPEZ CABANA, Roberto M., "La información en los contratos de consumo”, en J.A. 1995IV-800.

-LorenZetTI, Ricardo L., Consumidores, Rubinzal Culzoni, Santa Fe, 2009.

-LoRenZetTI, Ricardo L., Tratado de los Contrato. Parte General, Rubinzal Culzoni, Santa Fe, 2004.

-LORENZETTI, Ricardo L., Las normas fundamentales de Derecho Privado, Rubinzal Culzoni, Santa Fe, 2005.

-LorenzeTti, Ricardo L., "Entra en vigencia el Código Civil y Comercial de la Nación”, en Revista La Ley del día 3/8/2015, pág. 1.

-LORENZETTI, Ricardo L., "Redes contractuales: conceptualización jurídica, relaciones internas de colaboración, efectos frente a terceros”, en Revista de Direito do Consumidor N²8, Editora Revista dos Tribunais, San Paulo, 1998, pág. 22-29.

-LORENZETTI, Ricardo L., "La oferta como apariencia y la aceptación basada en la confianza”, LL 2000-D, 1155.

-LORENZETTI, Ricardo L., “¿Cuál es el cemento que une las redes de consumidores, de distribuidores o de paquetes de negocios? (aproximación a la conexidad contractual como fundamento imputativo)", LL 1995-E,1013.

-LORENZETTI, Ricardo L., "Redes Contractuales, contratos conexos y responsabilidad"; en Revista de Derecho Privado y Comunitario, № 17, Rubinzal-Culzoni, Santa Fe, 1998, pág. 207-261.

-LORENZETTI, Ricardo L., "Situaciones jurídicas abusivas lesivas de libertades del consumidor", en STIGLiTZ, Gabriel (Dir.), Derecho del Consumidor, $\mathrm{N}^{\circ}$ 7, Editorial Juris, Rosario, 1996, pág. 9-16.

-LORENZETTI, Ricardo L. "El Derecho Privado como protección del individuo particular", en Revista de Derecho Privado y Comunitario, $\mathrm{N}^{\circ} 7$, Derecho Privado en la reforma constitucional, Rubinzal-Culzoni, Santa Fé, 1994, pág. 53-86.

-LOREnZETTI, Ricardo L., "Tratamiento de las cláusulas abusivas en la Ley de Defensa del Consumidor", en Revista de Derecho Privado y Comunitario, $\mathrm{N}^{\circ} 5$, Consumidores, Rubinzal-Culzoni, Santa Fe, 1994, pág. 172-194.

-LoREnZETTI, Ricardo L., "Nuevos paradigmas en el Derecho privado: el acceso a los bienes", en LL 1994-E,990. 
-LORENZETTI, Ricardo L., “Análisis económico del Derecho: valoración crítica. Hacia una teoría de la acción individual y colectiva en un contexto institucional", en Revista de Derecho Privado y Comunitario, T. 21, Rubinzal Culzoni, Santa Fe, pág. 61-90.

-Lovece, Graciela, "Contrato de publicidad” en Ghersi, Carlos A.- WeIngarten, Celia (dirs), Tratado de los contratos civiles, comerciales, laborales, administrativos y de consumo, T. II, La Ley, Buenos Aires, 2010, pág. 55-91.

-Lowenrosen, Flavio, Derecho del Consumidor. Teoría y práctica, 1, Ediciones Jurídicas, Buenos Aires, 2008.

-Llamas Pombo, Eugenio, La compraventa, Editorial La Ley, Madrid, 2014.

-Llamas Pombo, Eugenio, Cumplimiento por equivalente y resarcimiento de daños al acreedor, Entre la aestimatio rei y el id quod interest, Trivium, Madrid, 1999.

-Llamas Pombo, Eugenio (Coord.), Ley General para la Defensa de los Consumidores y Usuarios. Comentarios y jurisprudencia de la ley veinte años después, La Ley, Madrid, 2005.

-Llamas Pombo, Eugenio-Martínez Rodríguez, Nieves- Toral Lara, Estrella, en Blanco-Morales Limones, Pilar, Medidas de lucha contra la morosidad, La Ley, Madrid, 2011, pág. 97-205.

-Llambías, Jorge J., Tratado de Derecho Civil-Parte General, T. II, Abeledo Perrot, Buenos Aires, 1997.

-Llobet i Aguado, Joseph, El deber de información en la formación de los contratos, Marcial Pons, Madrid, 1996.

-MAFFIA, Osvaldo. J., La ley de concursos comentada, T. II, LNBA, Buenos Aires, 2002.

-MARín LóPEZ, Manuel J., La compraventa financiada de bienes de consumo, Aranzadi, Elcano, 2000.

-MARÍN LÓPEZ, Manuel Jesús, "El crédito al consumidor", en http://www.ubo.cl/icsyc/wpcontent/uploads/2011/09/4-Mar\%C3\%ADn.pdf (fecha de consulta 11/7/2015).

-MARÍn LÓPEZ, Manuel Jesús, “Obligación de asesoramiento, obligación de evaluar la solvencia del consumidor y otras obligaciones precontractuales del prestamista. Su regulación en el Proyecto de Ley de Contratos de Crédito al Consumo", en www.uclm.es/centro/cesco/pdf/trabajos/6/2011/6-2011-8.pdf (Fecha de consulta: 15/7/2015). 
-MARÍn LóPEZ, Manuel Jesús, "Protección del consumidor y crédito al consumo. Análisis del proyecto de ley de contratos de crédito al consumo", en Revista de Derecho Privado ${ }^{\circ}$ 95, marzo-abril, Edersa, Madrid, 2011.

-MÁRqueZ, José Fernando, texto de la conferencia pronunciada en el $V^{o}$ Congreso Internacional de Derecho Privado organizado por el Núcleo de Derecho Civil, Punta del Este, Octubre de 2008).

-MARTínEZ RodríGUEZ, Nieves, "Protección del consumidor a crédito frente al financiador", en Revista Actualidad Civil, $\mathrm{N}^{\circ}$ 17, Madrid, 1era. Quincena de octubre de 2004, pág. 2005-2032.

-MARTORELl, Ernesto E., "Nuevos paradigmas que agravan la responsabilidad de los bancos", La Ley, revista del 26/03/2015.

-MicelLI, María I., "Un límite necesario al uso antifuncional de la quiebra voluntaria”, en LLLitoral, 2007 (diciembre), 1135.

-MoRCECIÁN, Rubén y GACIO, Marisa, "Sobreendeudamiento del consumidor. Mecanismos para su solución en sede administrativa", Ponencia presentada en el $\mathrm{V}^{\circ}$ Congreso Iberoamericano sobre la Insolvencia y el VII ${ }^{\circ}$ Congreso Argentino de Derecho Concursal realizados en Mendoza entre el 4 y el 7 de octubre de 2009.

-Morello, Augusto M. - Stiglitz, Rubén S. - Stiglitz, Gabriel A., "Información al consumidor y contenido del contrato", en STIGLiTz, Gabriel A., Derecho del Consumidor, 5, Juris, Rosario, 1993, pág. 151 y sgtes.

-Mosset ItURRASPE, Jorge, Contratos Conexos, Grupos y redes contractuales, Rubinzal Culzoni, Santa Fe, 1999.

-Mosset IturRaspe, Jorge-Wajntraub, Javier H., Ley de Defensa del Consumidor. Ley 24.240, Rubinzal Culzoni, Santa Fé, 2008.

-Mosset Iturraspe, Jorge-Piedecasas, Miguel A. (Dir.), Código Civil Comentado, Contratos-Parte General, Rubinzal Culzoni, Santa Fe, 2007.

-NICOLAU, Noemí, texto de la conferencia pronunciada en el Seminario sobre "Impacto de la crisis económica en las instituciones del Derecho privado" organizado por la Maestría en Derecho Privado con motivo de su $10^{\circ}$ aniversario, Rosario, 2008, (inédito). 
-Nicolau, Noemí, "La teoría de la confianza en el Derecho civil actual", en file:///D:/Mis\%20documentos/Downloads/nicolau__confianza.pdf (Fecha de consulta 20/7/2015).

-NIEMI-KIESILÄINEN, Johanna, “Construcciones de acreedores y deudores en la quiebra del consumidor" La quiebra del consumidor en perspectiva global, Hart Publishing, 2003.

-Nigro, Alessandro, "La insolvencia de las familias en el Derecho italiano", en TomiLlo Urbina, Jorge (Dir.)-Álvarez Rubio, Julio (Coord.), El futuro de la protección jurídica de los consumidores, Thomson-Civitas, Pamplona, 2008, pág. 211-221.

-ORdás Alonso, Marta, Los contratos de crédito al consumo en la Ley 16/2011 de 24 de junio. Cuadernos de Aranzadi, Thomson Reuters-Aranzadi, Pamplona, 2013.

-ORduña Moreno, Francisco Javier-TAMAYo Haya, Silvia, La protección patrimonial del crédito, T. I, Aranzadi, Cizur Menor, 2006.

-ORti VAllejo, Antonio, “Derecho a la información” en BerCovitz, Rodrigo - SAlas, Javier, Comentarios a la ley para la defensa de los consumidores y usuarios, Civitas, Madrid, 1992, pág. 403-425.

-Ossola, Federico- VAllespinos, Gustavo., La obligación de informar, Advocatus, Córdoba, 2001.

-PAISANT, Gilles, "La insolvencia de los consumidores en el Derecho francés", en TomiLlo Urbina, Jorge (Dir.)-ÁlvareZ Rubio, Julio (Coord.), El futuro de la protección jurídica de los consumidores, Thomson-Civitas, Pamplona, 2008, pág. 237-243.

-PARDUCCI, Diego Martín, “Contratos bancarios con consumidores y usuarios", Suplemento Especial Nuevo Código Civil y Comercial de la Nación. Contratos en particular, 2015 (abril), pág. 214.

-PARra LuCÁn, María Ángeles, en CÁMara Lapuente, Sergio (Dir.), Comentarios a las Normas de Protección de los Consumidores, Colex, Madrid, 2011, pág. 258-270.

-PASQUAU LIAÑO, Miguel, "Propuestas para una protección jurídica de los consumidores en materia de créditos de consumo: medidas de prevención y de solución de los problemas derivados del sobreendeudamiento", en Estudios sobre Consumo, núm. 18, 1989, pág. 1127. 
-PAz ARES, Cándido., "Principio de eficiencia y derecho privado" en Estudios de Derecho Mercantil en homenaje al profesor Manuel Broseta Pont, Vol. 3, Valencia, 1995, pág. 2843-2900.

-PeÑAs Moyano, Benjamín, "Concurso de consumidores" en Revista de Derecho Concursal y Paraconcursal, № 8, Sección Comunicaciones, Primer semestre de 2008, pág. 229.

-PEINADO GRACIA, Juan Ignacio, "Riesgo sistémico, solvencia y riesgo moral. Incidencia en el Derecho privado de los mercados financieros. Un apunte crítico”, en Revista de Derecho Bancario y Bursátil, Año n ${ }^{\circ} 33, \mathrm{~N}^{\circ}$ 134, Valladolid, 2014, pág. 7-34.

-PeinAdo Gracia, Juan Ignacio, "Cooperación y pillaje en el concurso”, ADC, Madrid, 2006, pág. 231-257.

-Peinado Gracia, Juan Ignacio, "La distribución del riesgo de insolvencia" en Estudios sobre la Ley Concursal. Libro homenaje a Manuel Olivencia, Vol. I, Madrid, 2005, pág. 427-466.

-PeÑa LóPez, Fernando, en MARÍn LóPez, Manuel Jesús (Dir.), Comentarios a la Ley de Crédito al Consumo, Thomson Reuters-Aranzadi, Pamplona 2014, pág. 1088-1106.

-Pereyra, Alicia, "Los procesos concursales en los que el deudor manifiesta no poseer activos liquidables: sólo cuenta con su sueldo", en Revista de Derecho Concursal, Zeus, T VI, pág. 221.

-PÉREZ BENíTEZ, Jacinto José, “La nueva regulación de los acuerdos de refinanciación”, en http://www.elderecho.com/tribuna/mercantil/acuerdos_de_refinanciacion_11_685180006.h $\underline{\mathrm{tml}}$

-PÉREz GARCíA, Pedro A., La información en la contratación privada. En torno al deber de informar en la Ley general de Defensa de los Consumidores y Usuarios, Ministerio de Sanidad y Consumo de España, Ed. Instituto Nacional de Consumo, Colección Estudios, Madrid, 1990, pág. 26-39.

-Pertíñez Vílchez, Francisco en CÁMARa Lapuente, Sergio (Dir.), Comentarios a las Normas de Protección de los Consumidores, Colex, Madrid, 2011, pág. 788-938.

-Pertíñez Vílchez, Francisco, "Falta de transparencia y carácter abusivo de la cláusula suelo en los contratos de préstamo hipotecario", en http://www.indret.com/pdf/995.pdf (Fecha de consulta: $1 / 10 / 2015)$. 
-PizArro, Ramón D.- Stiglitz, Rubén S. "la Publicidad como fuente heterónoma de integración del contrato", LL 2009-E, 1082.

-PORTHÉ, Luis Ignacio, "Responsabilidad de las entidades bancarias frente al consumidor", en http://www.derecho.uba.ar/publicaciones/lye/revistas/84/09-winitzky-porthe.pdf (Fecha de consulta 15/7/2015).

-PotTow, John A. E., "Un primer estudio de los cambios de la ley concursal estadounidense de 2005", Revista de Derecho Concursal y Paraconcursal, Anales de doctrina, praxis, jurisprudencia y legislación, $N^{\circ} 3,2005$, pág. 355-363.

-Prat Albentosa, Lorenzo, Préstamo de consumo. Crédito al consumo, Tirant lo Blanch, Valencia, 2001.

-Prat Albentosa, Lorenzo, "Régimen jurídico de los ficheros de solvencia", en Prat Albentosa-Cuena CASAs (Coord.), Préstamo responsable y ficheros de solvencia, Thomson Reuters-Aranzadi, Pamplona, 2014, pág. 363-406.

-Puertas Villavicencio, María José, "La importancia de educar para consumidor: el Indecopi como ente protector y de promoción de los derechos de los consumidores peruanos”, en Tomillo UrbinA, Jorge (Dir.)-ÁlvareZ Rubio, Julio (Coord.), La protección de los consumidores como motor de desarrollo económico, Civitas-Thomson Reuters, Pamplona, 2011, pág. 149-159.

-Pulgar EzQuerra, Juana, "Concurso y consumidores en el marco del Estado Social del Bienestar" en Revista de Derecho Concursal y Paraconcursal, N $^{\circ}$ 9, Sección Estudios, segundo semestre de 2007, pág. 43 y sgtes.

-PUlgar EZQUerRA, Juana, "La responsabilidad de las entidades financieras por concesión abusiva de crédito en Derecho español”, en PUlgar EzQUERRA (Dir.), AAVV: tendencias actuales en torno al mercado del crédito, Marcial Pons, 2010, págs. 111-141.

-Pulgar EzQuerRA, Juana, "Refinanciación de deuda, emprendedores y segunda oportunidad", en Diario La Ley, No 8141, Sección Doctrina, 4 Sep. 2013, Año XXXIV, Editorial La Ley.

-PULGAR EZQUERRA, Juana, "El nuevo paradigma concursal europeo y su incorporación al Derecho español", en Estudios de Derecho Empresario, en http://revistas.unc.edu.ar/index.php/esdeem/article/view/8812 (fecha de consulta: 10/2/2015). 
-Pulgar EzQuerra, Juana, Preconcursalidad y acuerdos de refinanciación. Adaptado a la Ley 38/2011 de 10 de octubre de 2011 de reforma a la ley concursal, Ed. La Ley, Madrid, 2012.

-Pulgar EzQuerra, Juana, “Acuerdos de refinanciación, escudos protectores y garantías reales",

en

http://www.mjusticia.gob.es/cs/Satellite/Portal/1292347817007?blobheader=application\%2 Fpdf\&blobheadername1=Content-

isposition\&blobheadervalue $1=$ attachment\%3B+filename\%3DPonencia_de_Juana_del_Pulg ar_Ezquerra.PDF. (fecha de consulta: 21/4/2015).

-QuiJAno GonZÁLEZ, Jesús, "El sobreendeudamiento de los particulares y del consumidor. Sistemas jurídicos europeos a debate", Revista de Derecho Concursal y Paraconcursal, $\mathrm{N}^{\circ}$ 22, Sección Recensión, segundo semestre de 2014, Editorial La Ley; asimismo, en http://www.academia.edu/5851665/_EUROPE_El_sobreendeudamiento_de_los_particulares_y_del_consumi dor._Sistemas_jur\%C3\%ADdicos_europeos_a_debate (fecha de consulta 1/7/2015).

-Quintana CARlo, Ignacio., "El sobreendeudamiento de los consumidores", en TOMILlO Urbina, J. (Dir.)-Álvarez Rubio, J. (Coord.), El futuro de la protección jurídica de los consumidores, Thomson-Cívitas, Pamplona, 2008, pág. 2257-2269.

-ReYes LóPEZ, María J., "La ley de crédito al consumo”, en Derecho de consumo, Tirant lo Blanch, Valencia, 2000.

-RIVERA, Julio César, "Insolvencia de las personas físicas (especialmente de los consumidores)", en Revista de Derecho Comercial del Consumidor y de la Empresa, Año 1, N², La Ley, noviembre de 2010, pág. 3-7.

-Rivera, Julio César-Medina, Graciela (Dir.), Código Civil Comentado, Rubinzal Culzoni, Santa Fe, 2007.

-Roca Guillamón, Juan, "Los contratos de crédito al consumo. Forma y contenido, reembolso anticipado y cobros indebidos (Ley 7/1995, de 23 de Marzo)", en NIETO CAROL, Ubaldo (Dir), Crédito al Consumo y transparencia bancaria, Civitas, Madrid, 1998, pág. 192-218.

-Rogel VIDE, Carlos, Favor debitoris. Análisis crítico, Editorial Zavalía, Buenos Aires, 2010. 
-Rojo FERNÁNDEZ-Río, Ángel, "Problemas y cuestiones en torno al sobreendeudamiento e insolvencia de las familias españolas, en Tomillo URBINA, J. (Dir.)-Álvarez Rubio, J. (Coord.), El futuro de la protección jurídica de los consumidores, Thomson-Cívitas, Pamplona, 2008, pág. 251-273.

-Rubio Vicente, Pedro J., "Concesión abusiva de crédito y concurso", en Revista de Derecho Concursal y Paraconcursal, $\mathrm{N}^{\circ}$ 8, Sección Comunicaciones, Primer semestre de 2008, pág. 247-274.

-RusConi, Dante (Coord.), Manual de Derecho del Consumidor, Abeledo Perrot, Buenos Aires, 2015.

-SÁENZ, Luis R, “Comentario al art. 60 de la Ley de Defensa del Consumidor”, en PiCASSO, Sebastián-VÁZQUEZ FERREYRA, Roberto (Dir.), Ley de Defensa del Consumidor comentada y anotada, Ed. La Ley, Buenos Aires, 2009, pág.729-735.

-SAINT-AlARY-Houin, Corinne, "El tratamiento de las dificultades financieras de los particulares en Francia", en Cuena Casas, Matilde-Colino Mediavilla, José Luis (Coord.), Endeudamiento del consumidor e insolvencia familiar, Cívitas, Pamplona, 2009.

-SANCHEZ-CALERO Guilarte, Juan, "Segunda oportunidad I" en http://jsanchezcalero.blogspot.com/2015/05/segunda-oportunidad-i_4.html (fecha de consulta: 29/6/2015).

-SAntarelli, Fulvio G., Comentario al art. 1, en PicAsso, Sebastián.-VÁzQuez Ferreyra, Roberto (Dir.), Ley de Defensa del Consumidor comentada y anotada, T.I, La Ley, Buenos Aires, 2009, pág. 26-33.

-SAntarelli, Fulvio G., Comentario al art. 7, en PiCAsso, Sebastián-VÁzQuez Ferreyra, Roberto (Dir.), Ley de Defensa del Consumidor Comentada y Anotada, T. I, La Ley, Buenos Aires, 2009, pág. 97-99.

-SANTARELli, Fulvio Germán, "De la debilidad, sistema y paradigmas", en RCyS 2014-II, tapa.

-SAnTORO, Vittorio, "La liberación de deudas ("esdebitazione") en el Derecho italiano", Revista de Derecho concursal y Paraconcursal, 2010, pág. 411-424.

-SARCIAT, Alberto D.”La asimetría de la información”, LL 2008-C. 616. 
-SauX, Edgardo I.-Muller, Enrique C., en Picasso, S.-VÁzquez Ferreyra, R. (Dir.), Ley de Defensa del Consumidor comentada y anotada, Ed. La Ley, Buenos Aires, 2009, pág. 425-439.

-SCHIAVI, María Virginia, “Abordaje jurídico del vínculo entre la publicidad y el consumidor", LL 2011-E,678.

-SCHMIDT, Karsten, "El Derecho alemán. Una comedia de equivocaciones", en CuENA Casas, Matilde-Colino Mediavilla, José Luis (Coord.), Endeudamiento del consumidor e insolvencia familiar, Cívitas, Pamplona, 2009, pág. 417-425.

-SEguí, Adela M., "Prevención de los daños y tutela inhibitoria en el Derecho del Consumo", PiCAsso, Sebastián - VÁzQuez Ferreyra, Roberto A., (dirs.), Ley de Defensa del Consumidor comentada y anotada, T. II, La Ley, Buenos Aires, 2009, pág. 661-696.

-SEnEnt Martínez, Santiago, Exoneración del pasivo insatisfecho y concurso de acreedores, tesis doctoral inédita, Universidad Complutense de Madrid, http://eprints.ucm.es/28133/1/T35661.pdf (Fecha de consulta: 20/4/2015).

-Senent Martínez, Santiago, "Concurso sin masa y protección de los consumidores", en Revista de Derecho Concursal y Paraconcursal, N ${ }^{\circ}$ 15, Sección Ponencias, Segundo semestre de 2011, pág. 133 y sgtes.

-Serrano de Nicolás, Ángel, en MARÍn LóPeZ, Manuel Jesús (Dir.), Comentarios a la Ley de Crédito al Consumo, Thomson Reuters-Aranzadi, Pamplona 2014, pág. 415-474.

-SosA, Lucía- LóPEz, Erica- CHAvEz, Verónica, "Regulación de la insolvencia: abordaje desde la realidad", Ponencia presentada en Ponencia presentada en el $V^{\circ}$ Congreso Iberoamericano sobre la Insolvencia y el VII ${ }^{\circ}$ Congreso Argentino de Derecho Concursal realizados en Mendoza entre el 4 y el 7 de octubre de 2009.

-Sotillo MARTí, Antonio, "Segunda oportunidad y Derecho Concursal", Seminario Interdisciplinar Facultad de Derecho celebrado el 30 de octubre de 2013 en Valencia, http://www.uv.es/seminaridret/sesiones2013/concursal/ponenciasotillo.pdf (fecha de consulta 1/7/2015). -Sozzo, Gonzalo, "Introducción. Derecho y gobierno de los riesgos", en Sozzo, Gonzalo (Coord.), El Gobierno de los riesgos, UNL Ediciones, Santa Fe, 2007, pág. 11 y sgtes.

-Sozzo, Gonzalo, "Interpretación y otros efectos de la complejidad negocial (¿Para qué puede servir vincular los contratos?", en Revista de Derecho Privado y Comunitario, 20072., Rubinzal Culzoni, Santa Fé, 2007, pp. 311-337. 
-SPINA, María Laura, MusaCchio, Carolina y ARdOY, Victoria: ¿Están las Provincias Argentinas constitucionalmente habilitadas para dictar una ley que regule un procedimiento ante el sobreendeudamiento de los consumidores o insolvencia familiar?, Ponencia presentada en el $\mathrm{V}^{\circ}$ Congreso Iberoamericano sobre la Insolvencia y el VII ${ }^{\circ}$ Congreso Argentino de Derecho Concursal realizados en Mendoza entre el 4 y el 7 de octubre de 2009.

-STIGLitZ, Gabriel A., La defensa del consumidor en Argentina. 30 años de derecho, sin políticas, Rubinzal Culzoni, Santa fe, 2012.

-STiglitZ, Gabriel A., Reglas para la defensa de los consumidores y usuarios, Juris, Santa Fe, 1998.

-Stiglitz, Rubén S., en Lorenzetti, Ricardo L. (Dir.), Código Civil y Comercial de la Nación Comentado, T. V, Rubinzal-Culzoni, Santa Fe, 2015.

-STIGLITZ, Rubén S., Responsabilidad Civil-Doctrinas Esenciales, t. I, 1073

-STigLiTZ, Rubén S., "El deber de información y los vicios del consentimiento" en $L L$ 2005-C, 1444.

-Stiglitz, Rubén S.-Stiglitz, Gabriel A., Contratos por adhesión, cláusulas abusivas y protección del consumidor, 2da. edición actualizada y ampliada con la Ley 24.240 y el proyecto de Código Civil y Comercial de la Nación, La Ley, Buenos Aires 2012.

-Stiglitz, Rubén S.- Stiglitz, Gabriel A., Responsabilidad precontractual, Abeledo Perrot, Buenos Aires, 1992.

-TAMAYo Haya, S., "El sobreendeudamiento de los consumidores", en Tomillo Urbina, J. (Dir.)-Álvarez Rubio, J. (Coord.), El futuro de la protección jurídica de los consumidores, Thomson-Cívitas, Pamplona, 2008, pp. 346-350.

-ToBíAs, José W., "Persona y mercado", en LL 2012-B, 632.

-Tobías, José. W.- De Lorenzo, Federico., “Complejo de negocios unidos por un nexo (el ligamen negocial)", $L L-\mathrm{D}, 1387$.

-TORRES GARCíA, Teodora F., "Protección del consumidor y derecho de la contratación", en Separata del Libro homenaje a ldelfonso Sánchez Mera, Europa Notario-Consejo General del Notariado, Madrid, 2002, pág. 881-906.

-Trigo Represas, Alberto-Compagnucci DE CASo, Rubén (Dir.), Código Civil Comentado, T. II, Rubinzal Culzoni, Santa Fe, 2007. 
-TRuffat, E. D., "Pequeños concursos: lineamientos para la regulación del concurso pequeñísimo (y en especial, el concurso del consumidor)", Ponencia presentada en el IV $^{\circ}$ Congreso Iberoamericano de Derecho Concursal sobre Crisis económica mundial y la concursalidad.

-TRujILlo DiEz, Iván Jesús, El sobrendeudamiento de los consumidores (Estudio jurídico en el marco de la colaboración entre la Direccion General de Consumo de la Junta de Comunidades de Castilla-La Marcha y el Centro de Estudios de Consumo de la Universidad de Castilla- La Marcha), Comares, Granada, 2003.

-Vicente-AlmazÁn Pérez de Petinto, Miguel, "Normas de transparencia en la contratación bancaria de préstamos y créditos”, en La protección de consumidores y usuarios en la contratación bancaria. Cuadernos de Derecho y Comercio, Consejo General del Notariado, Madrid, 2014.

-VIGO, Rodolfo Luis, "Del Estado de Derecho Legal al Estado de Derecho Constitucional”, Suplemento de Derecho Constitucional, La Ley, 2010 (febrero), pág. 1; LL 2010-A,1165).

-VITERI ZUBIA, Ibon, El pago anticipado en las obligaciones a plazo. El derecho al reembolso anticipado en el sector específico del crédito, Tirant lo Blanch, Valencia, 2013.

-Vítolo, Daniel R., La insolvencia del consumidor, Ad Hoc, Buenos Aires, 2012.

-Vítolo, Daniel Roque: "Debe legislarse en forma particular un régimen de reestructuración extrajudicial y judicial de pasivos para personas físicas no comerciantes", ponencia presentada en el $\mathrm{V}^{\circ}$ Congreso Iberoamericano sobre la Insolvencia y el $\mathrm{VII}^{\circ}$ Congreso Argentino de Derecho Concursal realizados en Mendoza entre el 4 y el 7 de octubre de 2009.

-Wajntraub, J. H., "La noción de consumidor", en Revista de Responsabilidad Civil y Seguros, Año IX, N 3, Mayo 2007.

-Wajntraub, Javier H., en LoRenzetti, Ricardo L. (Dir.), Código Civil y Comercial de la Nación Comentado, T. VI, Rubinzal-Culzoni, Santa Fe, 2015, pág. 227-318.

-Weingarten, Celia.-GHERsi, Carlos A., "Los contratos conexados”, en LL 1997-F-1348.

-WAYAR, Ernesto C., Derecho Civil-Obligaciones, Lexis Nexis, Buenos Aires, 2002.

-Zabaleta Díaz, Marta, El concurso del consumidor, Anuario Facultad de Derecho, Universidad de Alcalá III, Alcalá de Henares, 2010, pág. 301-331. 
-Zabaleta DíAz, Marta, "La condonación de las deudas pendientes en el Derecho concursal alemán", en Estudios sobre la Ley Concursal. Libro Homenaje a Manuel Olivencia, T. I, Madrid, 2005, pág. 885 y sgtes.

-ZABAlETA DíAZ, Marta, "El derecho concursal de la crisis. Tendencias de reforma de las normativas concursales, Anuario de derecho concursal, No $.30,2013$, pág. 195 y sgtes.

-Zentner, Diego H., "Contratos de Consumo”, Capítulo VIII, en Rusconi, Dante (Coord.), Manual de Derecho del Consumidor, Abeledo Perrot, Buenos Aires, 2015, pág. 391-455.

-ZENTNER, Diego H., "Operaciones de crédito al consumo”, Derecho del Consumidor, № 7, pág. 87, Juris, Santa Fé, 1996.

-ZoLo, Danilo, Democracia y Complejidad (Un enfoque realista), Nueva Visión, Buenos Aires, 1994. 